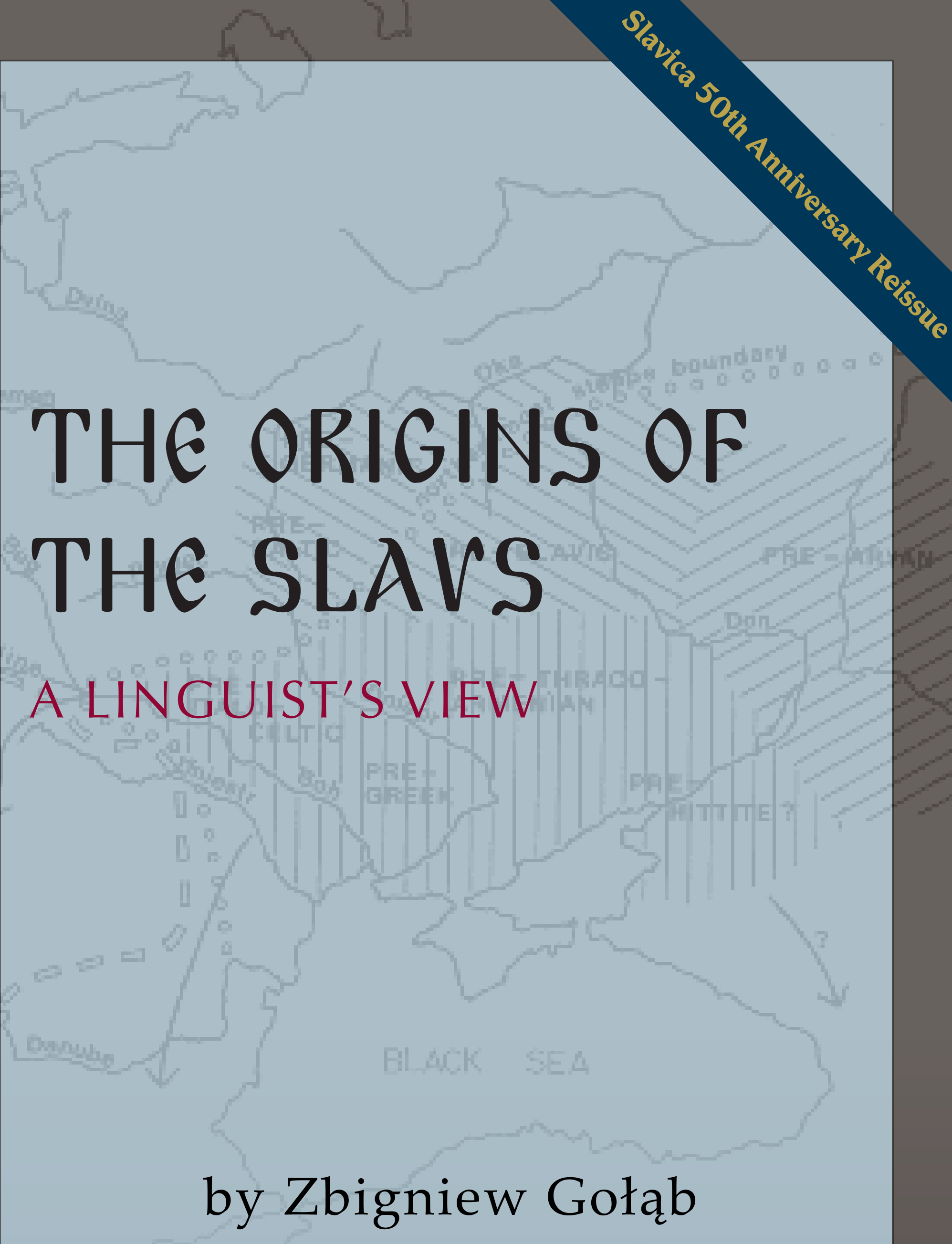




\section{From the Publisher}

This book represents the fourth in a series of reprints of notable titles published by Slavica and long out of print. We are restoring these titles to print and making them available as free downloads from our web site, slavica.indiana.edu, in honor of Slavica's fiftieth anniversary. Yes, we are officially middle-aged. Founded by four graduate students at Harvard in 1966, Slavica published its first book in 1968, Studies Presented to Professor Roman Jakobson by His Students. To celebrate Slavica's jubilee, we are releasing in .pdf format, no strings attached, scans of twelve older titles that have been requested over the years. Enjoy these books, tell your friends, and feel free to share them with colleagues and students.

The Origins of the Slavs: A Linguist's View is a deep philological investigation into the identification of the original homeland where the Slavic languages and ethnicities coalesced as distinct from other Indo-European peoples. Zbigniew Gołą, Professor of Slavic Linguistics at the University of Chicago, surveys a huge range of data and contributes numerous original analytical points of his own. And as a personal note, let me mention that when I was a graduate student at Chicago in the early 1980s, I typed the majority of this remarkably difficult manuscript twice on an IBM Selectric III typewriter, changing the typing element repeatedly in switching from one language or alphabet to another. The book itself was subsequently computer typeset by someone else, and thank God for that!

Slavica would like to express its sincere thanks to the late author's wife Janina Gołąbowa. We welcome comments on this and other forthcoming titles to be released in this series.

George Fowler

Director, Slavica Publishers

Bloomington, Indiana

13 April 2016 


\section{THE ORIGINS OF THE SLAVS A LINGUIST'S VIEW}




\section{THE ORIGINS OF THE SLAVS \\ A LINGUIST'S VIEW}

\section{Zbigniew Gołąb}

Slavica Publishers, Inc. 
Slavica publishes a wide variety of scholarly books and textbooks on the languages, peoples, literatures, cultures, history, etc. of the USSR and Eastern Europe. For a complete catalog of books and journals from Slavica, with prices and ordering information, write to:

\author{
Slavica Publishers, Inc. \\ PO Box 14388 \\ Columbus, Ohio 43214
}

ISBN: 0-89357-224-1.

Copyright (C) 1991 by Zbigniew Gołąb. All rights reserved. This book was published in 1992.

Excerpts from The Persian Wars by Herodotus, translated by George Rawlinson. Copyright 1942 by Random House, Inc. Reprinted by permission of the publisher.

All statements of fact or opinion are those of the authors and do not necessarily agree with those of the publisher, which takes no responsibility for them.

Printed in the United States of America. 
To the memory of Tadeusz Lehr-Spławiński whose intellectual inspiration has been the main source of this book. 


\section{Acknowledgements}

The author would like to thank his former students Masha Belyavski-Frank, George Fowler, and Victor Lychyk, who found time and patience to read the manuscript, correct its English and type it. For their indispensable help the author is deeply grateful.

\section{A Note from the Publisher}

Due to circumstances beyond our control, the publication of this book has been greatly delayed. We wish to express our profound regret and apologies to the author. 


\section{CONTENTS}

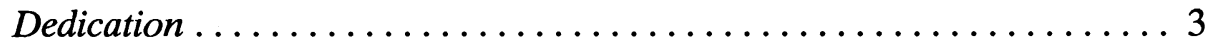

Acknowledgements ......................... 4

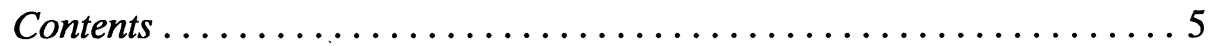

Abbreviations of Languages and Dialects ................ 6

Chapter 1: Introduction $\ldots \ldots \ldots \ldots \ldots \ldots \ldots \ldots \ldots \ldots \ldots$

Chapter 2: Slavic (Proto-Slavic) within the Indo-European Linguistic Family .................. 35

Chapter 3: The Stratification of Proto-Slavic Vocabulary ......... . 76

Chapter 4: The Problem of the Primary Habitat of the Indo-Europeans ................. 187

Chapter 5: The Primary Habitat of the Slavs The Testimony of Hydronymy, Dendronymy, and Ethnonymy . . . . 236

Chapter 6: The Slavs and the Neighboring Peoples (the Problem of Foreign Loanwords in Proto-Slavic) . . . . . . . 310

Chapter 7: Conclusions ...................... 415

Notes ............................ 420

Bibliography ............................. 439 


\section{Abbreviations of Languages and Dialects}

\begin{tabular}{|c|c|c|c|}
\hline Alb. & Albanian & OCS & Old Church Slavonic \\
\hline Alem. & Alemanic & $\mathrm{OCz}$. & Old Czech \\
\hline Arm. & Armenian & $\mathrm{OE}$ & Old English \\
\hline Av. & Avestan & $\mathrm{OHG}$ & Old High German \\
\hline Balt. & Baltic & OI & Old Indic \\
\hline Balto-Slav. & Balto-Slavic & OIc. & Old Icelandic \\
\hline Bulg. & Bulgarian & OIr. & Old Irish \\
\hline BRuss. & Byelo-Russian & OIran. & Old Iranian \\
\hline $\mathrm{CS}$ & Church Slavonic & OLG & Old Low German \\
\hline Cymr. & Cymric (Welsh) & OLith. & Old Lithuanian \\
\hline $\mathrm{Cz}$. & Czech & OLus. & Old Lusatian \\
\hline EIE & East Indo-European & OPers. & Old Persian \\
\hline Eng. & English & OPol. & Old Polish \\
\hline Fr. & French & OPruss. & Old Prussian \\
\hline Gallo-Rom. & Gallo-Romance & ORuss. & Old Russian \\
\hline Germc. & Germanic & OSax & Old Saxon \\
\hline Goth. & Gothic & OSerb. & Old Serbian \\
\hline Gr. & Greek & Osm. & Osmanli (Turkish) \\
\hline Hitt. & Hittite & OSwed. & Old Swedish \\
\hline Hung. & Hungarian & PGermc. & Proto-Germanic \\
\hline IE & Indo-European & PIE & Proto-Indo-European \\
\hline Indo-Iran. & Indo-Iranian & Pol. & Polish \\
\hline Ir. & Irish & Polab. & Polabian \\
\hline Ital. & Italic & Pruss. & Prussian (Old Pr.) \\
\hline Kajk. & $\begin{array}{l}\text { Kajkavian (a Cro- } \\
\text { atian dialect) }\end{array}$ & $\begin{array}{l}\text { PSlav., PSl. } \\
\text { Rhaeto-Illyr. }\end{array}$ & $\begin{array}{l}\text { Proto-Slavic } \\
\text { Rhaeto-Illyrian }\end{array}$ \\
\hline Kash. & $\begin{array}{l}\text { Kashubian (a Pol- } \\
\text { ish dialect) }\end{array}$ & $\begin{array}{l}\text { Rum. } \\
\text { Russ. }\end{array}$ & $\begin{array}{l}\text { Rumanian } \\
\text { Russian }\end{array}$ \\
\hline Lat. & Latin & Slav. & Slavic \\
\hline Latv. & Latvian & $\mathrm{S}-\mathrm{C}$ & Serbo-Croatian \\
\hline Lith. & Lithuanian & Sloven. & Slovenian \\
\hline LLus. & Lower Lusatian & Span. & Spanish \\
\hline LG & Low German & Swed. & Swedish \\
\hline MHG & Middle High German & Thrac. & Thracian \\
\hline MGr. & Modern Greek & Toch. & Tocharian \\
\hline MLG & Middle Low German & Ukr. & Ukrainian \\
\hline MIr. & Middle Irish & ULus. & Upper Lusatian \\
\hline $\begin{array}{l}\text { MPers. } \\
\text { NCz. }\end{array}$ & $\begin{array}{l}\text { Middle Persian } \\
\text { New Czech }\end{array}$ & Vot. & Votyak (a Finnic \\
\hline NHG & New High German & Zyr. & Zyrian (a Finnic \\
\hline NLith. & New Lithuanian & & language) \\
\hline Norw. & Norwegian & Žem. & Žemaitian (Śamogit- \\
\hline NPers. & New Persian & & ulal.) \\
\hline
\end{tabular}




\section{Chapter 1}

\section{Introduction}

The subject of the present book is the origins of the Slavs, the most numerous group of peoples in Europe. The question immediately arises, why the Slavs should be separated out from the other Europeans. Anybody even superficially acquainted with the history of Europe knows that the Slavs do not represent any racial, cultural, or linguistic entity. And even today, although their majority is included directly or indirectly in the Soviet block (the only exception is the Slavs of Yugoslavia), they do not represent any such unity. To speak about the "Slavic race" (in terms of physical anthropology) is as obvious a nonsense as to speak about, for example, a Germanic, Romance, or other race, referring to groups based primarily upon criteria of historical-comparative linguistics. Equally empty is the term "Slavic culture." There is no such thing in the sense of a set of beliefs, values, customs, habits, etc., common to all the present-day Slavic peoples. And it is also doubtful whether such a common culture could be discernibly posited even for earlier periods in the history of the Slavs, at least on the level of the upper classes. So the cultural "community" of the Slavs seems to be a phenomenon that belongs to their prehistory, and only its vestiges can be traced in the folklore of the historical Slavic peoples. Thus we are left with language as the only objective feature which can be used for the definition and identification of the Slavs among other peoples. Of course, there is no longer one Slavic language, just as there is no one Germanic, Romance (neo-Latin), Celtic, etc., language. But there is an obvious genetic relationship between the present-day Slavic languages, which strikes any person acquainted with one or more of them who is trying to learn and understand others. Such an obvious genetic relationship between languages (for some examples, see p. 12) proves their common origin and ultimately the common origin of their respective societies (ethnic groups), which use these languages, although we must be aware that the historical continuity and identity of a language does not necessarily imply the historical continuity and identity of the original speakers of that language. A language can spread from its original speakers to the original speakers of other languages, and after a period of bilingualism it can ultimately be 
adopted by the latter as their only language. This relative "autonomy" of language with respect to its original (native) speakers is a very significant socio-cultural fact, which accounts for the lack of coincidence between language and physical race, and also, to a lesser extent, between language and culture.

These general remarks are indispensable in order to understand the problem of ethnos and ethnicity. For it is language, culture, and race that are relevant for the determination of ethnos as a separate category among other social categories (such as classes, religious organizations, etc.). There is no doubt that the separation of the Slavs from other European peoples rests ultimately upon their historically distinct ethnicity. To grasp this distinctive ethnicity of the primary, i.e., prehistorical and early historical, Slavs is the main task of the present book. But first we should attempt to determine, if not define, the differentia specifica of ethnos among other social categories. The task is not easy, as is no task concerning not purely abstract concepts but concrete historical phenomena. It even seems paradoxical that this question still remains open to discussion and final definition, despite, or perhaps because of an impressive revival of ethnicity which has been taking place in recent times, i.e., after the second world war. ${ }^{1}$

There is a time-honored intellectual tradition that whenever we wish to understand more profoundly the meaning of a concept, we examine the origin and primary signification of the corresponding term, i.e., we simply reach for its etymology. In our case, then, we should examine the

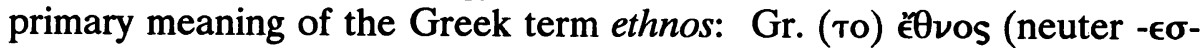
stem) means according to Chantraine (1970: II,315) 'groupe plus ou moins permanent d'individus, soldats, animaux' $\rightarrow$ 'nation, classe, caste,

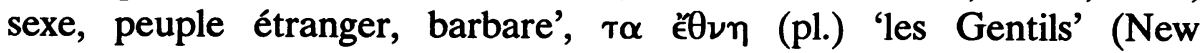
Testament). Its derivative is $\mathrm{Gr}$. ỏ $\theta \nu \in \hat{\imath}$ os 'étranger'; “le sens originel est appartenant a l' é $\theta \nu$ os par opposition au yévos, donc proprement 'étranger a la famille'."

From among the above meanings, that of a separate people, especially foreign people, 'tribe', seems to prevail. So there is no doubt that the

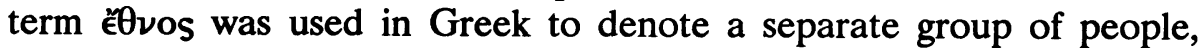
connected internally by close ties which were easily identifiable to external observers. The biblical use of $\dot{\epsilon} \theta \nu \eta$ is instructive in this connection. Now, what is the etymology of the word $\theta \nu 0 s$ in Greek? Without entering into the details of the historical phonology of Greek, we can simple state that the word represents a prehistorical form *suedhnos, a neuter noun derived from the PIE adjective *suedho- 'one's own' (actually its primary meaning was 'one's own affine'). The existence of such an adjective is supported by, among others, OI svadhá (f.) 'Eigenart, 
Gewohnheit, Heimstätte' (notice especially the last meaning!); for details see Chantraine, loc. cit., and Pokorny, 883. Here we can only mention that from a similar adjective *suebho-, with the -bho- suffix, some IE ethnica, like *Svoběne $\geq$ Slověne 'Slavs' and Suëbi 'Swabians', have been derived (see the discussion of these ethnica on p. 293). One is entitled to reconstruct for Proto-Indo-European two adjectives: *suedho- and *suebho- 'one's affine', both derived from the same basic PIE radical element * $s(u) e$ - 'apart, aside', etc. (for details see again p. 294).

All this would indicate that the primary meaning of ethnos (PIE *suedhnos), the meaning present in the minds of the speakers of prehistorical Greek, was 'community of (one's own) affines', i.e., 'the community of people tied by intermarriages'. Now it is quite well known to anthropologists that besides consanguinity ties, those of affinity are the oldest and the most basic ties underlying any human society. Actually no human society is imaginable without a system of affinity ties whose "node" is constituted by marriage, which in its turn is based upon an "exchange of women" between men (cf. Levy-Strauss). In view of this, any further research into the problem of the primary meaning of ethnos raises the following question: what are the conditions which enable people to enter affinity relations (through exchange of women for marriage, and eventually through subsequent reciprocal obligations between two families entering into such a relationship)? It seems to be obvious that the first and fundamental condition is the ability to communicate in the same language, i.e., there must be a common language used by the respective parties. (The question whether this is always the same language as is used in the everyday life of the respective parties does not interest us at this point.) The second condition is the very concept of marriage, and of consanguinity and affinity stemming from it and from its main product, the progeny. Of course, the institutions of marriage and family, the phenomena of birth and maturation, the practices of initiation preparing young generations of the two sexes for mature life and its duties, etc., all that constitutes the essence of any organized social life and culture, require a common set of more or less clear ideas in the minds of the people who are involved in the respective social activities and relations. In modern terms we could say that a set of common cultural values is necessary for the functioning of basic affinity and consanguinity relations. There is no need to elaborate here on the religious aspect (in a very broad sense of the word) of all the above socio-cultural phenomena and their sometimes quite rich symbolism. Both in the minds and behavior of the persons involved, this symbolism represents a kind of common "language" used and understood by the members of a given group within which the basic affinity and 
consanguinity relations hold. So the ethnos (*suedhnos), conceived as a community tied by affinity relations (actual or potential), usually implies a common language and a common set of cultural values. Among the latter, those referring to basic duties and rights of affinity and consanguinity and to corresponding religious ideas and symbols seem to be indispensable. In other words, ethnos was an organic social group characterized by a common language, a common kinship system, and a common spiritual culture. As we see, such external aspects of social groups as biological race and material culture are not important here. This does not mean that they should be neglected: ethnography and history know numerous instances of ethnic groups which are distinctly characterized by a determinate biological race and original material culture. But the former, as an automatic result of sexual relations and heredity, is independent of human consciousness, and the latter, as a set of technical devices, spreads easily across the boundaries of languages and spiritual cultures, so they seem to play only a secondary, additional role in the maintenance and transmission of ethnic identity, i.e., the identity of language, basic social structure, and spiritual culture, is the crucial problem here. This transmission requires the participation of the consciousness and will of those involved, whereas the transmission of racial (biological) features is independent of consciousness and will. ${ }^{2}$ This is the reason why language and culture groups do not overlap with biological-racial groups, although relatively isolated and stabilized societies (ethnic groups) usually manifest well-definable biological (racial) features, i.e., they represent characteristic types of populations which can be distinguished from others at least by a different ratio of the same (common) racial elements.

The above considerations, which started from the etymological meaning of the Gr. é $\theta \nu o s$ ( ${ }^{*}$ suedhnos), enable us to establish the essential components of ethnos: language and spiritual culture, the latter connected with a determinate social structure. These components seem to be relevant at any stage of the cultural development of ethnic groups. On the lowest level we are dealing with the kinship system and the respective religious-mythological symbols, plus concomitant rituals; on a higher level the appearance of statehood and universal religions causes additional complication. But the two essential features of any ethnic group, a separate language (or dialect) and a characteristic spiritual culture, seem to be present in the overwhelming majority of cases. To be sure, we can find ethnic groups which do not speak a separate language or dialect of their own, but such cases are rare and rather exceptional, and even then a historical study usually reveals an earlier period in the life of a given ethnic group when it used its own separate language or 
dialect (e.g., Hebrew in the case of the Jews, Cakavian in the case of the Croatians, Irish [Gaelic] in the case of the Irish, etc.). This close connection between language and spiritual culture is obvious: language is a system of conventional (i.e., socially established) signs, through which the communication (transmission of information) between individuals within a social group takes place. A central part in the transmission of information is played by the transmission of traditional knowledge (in the broadest sense of the word), which represents the experience accumulated by the previous generations and which allows for the continuity of society and culture. The most essential values of that traditional knowledge are transmitted in the language used in the everyday life of the family (whatever its size and structure). The practice of the Catholic Church was symptomatic: in spite of the preservation of Latin as the language of liturgy and theological literature, the ethnic languages have been used since the first missions for creed, confession, and prayer, i.e., in order to transmit the most basic values of the religion.

Of course, the analysis of the basic meaning of ethnos, which has elicited the essential features of ethnicity, does not suffice to answer all the complex questions concerning larger ethnic groups, especially those resulting from federations of nuclear tribes and from state organization. Here one can only mention the distinction between "nationality" and "nation", to which I will devote some remarks in the following paragraphs. In any case, the phenomenon of ethnos strikes the student of the history of Europe as probably its most stable feature. In order to obtain an idea about this phenomenon, one need only take a look at the ethnic map of Europe a thousand years ago and now: the ethnic boundaries have not changed radically, in most cases they have preserved their basic lines from the tenth century A.D. with some insignificant shifts. And we should remember that during the last thousand years Europe experienced great political changes and upheavals, especially in its main continental bulk, having witnessed the birth and fall of great empires.

This phenomenon of the amazing permanence of ethnic groups and boundaries in Europe, the fact that it is ethnicity that since the romantic cult of nationality has become the universally recognized principle of international politics (experiencing its apogee as "national selfdetermination" at the peace conference in Versailles in 1919, but undoubtedly declining at the Potsdam conference in 1945)-should be sufficient reason for scholars to investigate the origins of the historical ethnic groups in Europe.

For the purpose of more general classification, the numerous and diversified ethnic groups of Europe can be combined into higher entities 
on a historical-linguistic basis; in this way the basic intuition about the role of language in the determination of ethnic identity is obviously manifested. The most numerous ethno-linguistic group of Europe is the Slavs. There is no question as to their common linguistic origin (the problem of biological race is irrelevant here) and ultimately as to the common origin of their oldest pre-Christian cultural traditions. The obvious kinship of the present-day Slavic languages strikes everybody, not just the professional linguist. One can say that the Slavic languages are much more conservative (i.e., slower in their historical change) than other languages of Europe, e.g., Germanic. Some examples should suffice:

\begin{tabular}{cccccc} 
Pol. człowiek & $\sim$ & Russ. čelovék & $\sim$ & S-C čovek & 'man' \\
(pl) ludzie & $\sim$ & ljúdi & $\sim$ & ljudi & \\
gtowa & $\sim$ & golová & $\sim$ & glava & 'head' \\
ręka & $\sim$ & ruká & $\sim$ & ruka & 'hand' \\
żyć & $\sim$ & žit' & $\sim$ & živeti & 'live' \\
umrzeć & $\sim$ & umerét' & $\sim$ & umreti & 'die' \\
& \multicolumn{4}{c}{ etc. }
\end{tabular}

$\begin{array}{lll}\text { Eng. } \text { man } & \sim \text { Germ. Mensch, Mann 'male person' } \\ \text { (pl) people } & \sim & \text { Leute } \\ \text { head } & \sim & \text { Kopf (etymologically: Haupt) } \\ \text { hand } & \sim & \text { Hand } \\ \text { live } & \sim & \text { leben } \\ \text { die } & \sim & \text { sterben (etymologically=Eng. starve) }\end{array}$

But the very fact of the obvious linguistic kinship of the Slavic peoples in Europe provides only a very general and broad framework within which a great diversity can be observed, reflecting the quite complex ethno-linguistic differentiation of these peoples as a result of their history, at least during the last millennium.

Let us take a brief look at the contemporary Slavic peoples in Europe. In order to obtain a clear picture with sharp contours, I will apply the following criteria in the presentation and classification of the present-day Slavic peoples: statehood, religion, alphabet, and literary language. The problem of statehood (present and/or past) seems to be particularly significant, because the awareness of even a short period of political independence plays an important role in the formation of national identity, i.e., in the formation of modern ethnicity par excellence.

The present-day Slavic peoples are usually divided into the three following groups: West Slavic, East Slavic, and South Slavic. This 
division has both linguistic and historico-geographical justification, in the sense that on the one hand the respective Slavic languages show some old features which unite them into the above three groups, and on the other hand the pre- and early historical migrations of the respective Slavic peoples distributed them geographically in just this way. Of course, the later political and cultural history of the Slavs very often strengthened the primary division. But this problem does not lie within the scope of our considerations.

I will start this survey with the West Slavic group, then move down to South Slavic, and complete the review with the East Slavic group. This sequence tends to reflect the West European geographic-cultural point of view, since it is the Western Slavs, rather than the two other groups, who have been intimately related to West European cultural history, and it was the Southern Slavs who first came into contact with the Christian civilization of the Byzantine empire.

\section{A. The Western Slavs.}

The most numerous West Slavic nationality - the third most numerous among the Slavs in general and the second most numerous among those Slavs who have a long tradition of statehood (i.e., after the Russians and Ukrainians, or the Russians, respectively)-is the Poles (Polacy). According to the 1977 census they number 34,527,900. ${ }^{3}$ Of course, this amount does not reflect the sum total of Poles in the world, i.e., those living abroad, in diaspora, e.g., in the adjacent countries like the U.S.S.R., where according to official statistics (1970) the number of Poles was $1,167,000$ (almost half of them in the Wilno region, divided between Soviet Lithuania and Soviet Byelorussia), or in the United States, where they number about $3,000,000$, etc. The geographical region which has been continuously occupied by the Poles overlaps with the Vistula and Odra (Oder) basins in Central Europe, the geopolitical core of historical Poland. The independent Polish state has existed since 966 A.D. (the year of christianization), with a gap between 1795 and 1918. Since 1945, i.e., since the Soviet victory in World War II, Poland has been a Soviet satellite. Ninety-five percent of Poles are Roman Catholics; they use the Latin alphabet, adjusted, of course, to their native language, and have an unbroken literary tradition stemming from the fourteenth century. In Polish some of the best works of Slavic poetry have been written by Jan Kochanowski in the sixteenth century and by Adam Mickiewicz in the nineteenth century. In connection with the Polish Lithuanian Union (Rzeczpospolita Obojga Narodów, 1569-1795), which encompassed vast East Slavic territories (i.e., White Ruthenia [Byelorussia] and the Ukraine), Polish became the language of the upper classes and higher 
civilization in that part of Europe, and obvious proof of its influence can still be seen in Ukrainian and White Ruthenian (Byelorussian).

The second West Slavic nationality is the Czechs (Č eši-9,655,000 according to the 1977 census). Their original habitat represents the most congenial geographical region an ethnic group can dream of: the so-called "Bohemian Basin", enclosed by the Sudetes, the Ore Mountains, the Bohemian Forest, and the Moravian Heights, with the inclusion of the transitional region of the Morava River in the east. This geographical location has acted as a stronghold during the turbulent history of the Czech people, surrounded on three sides by the gradually expanding German element. The beginnings of the Czech state go back to the year 895 (?), with a gap from 1620 to 1918. It should be emphasized, however, that for most of its history the kingdom of Bohemia constituted a part of the so-called Roman Empire (of the German Nation), and in the fourteenth century it was even the flourishing center of that loose political body. After 1918 the Czechs formed a common state with the Slovaks (and the Sub-Carpathian Ruthenians), Czechoslovakia. After World War II Czechoslovakia became another Soviet satellite in Central Europe.

Since the last quarter of the ninth century (874?) the Czechs have been Roman Catholics. As a result of Hussitism (the religious-national movement initiated by Jan Hus at the beginning of the fifteenth century) and the Reformation, a significant percentage of the Czechs became Protestants. The Czechs use the Latin alphabet. Since the orthographic reform introduced by Hus, a variety of this alphabet with characteristic diacritical marks adjusted to the needs of the language has been in use. The literary language began in the thirteenth century, flourished in the fifteenth, and after the decline between 1620 and the beginning of the nineteenth century it experienced an impressive renascence.

The Slovaks (Slováci-4,564,000 according to the 1977 census) inhabit the mountainous region between the Western Carpathians and the middle Danube River in Central Europe. They have never had their own state (except for a brief period between 1939 and 1945, when they separated from Czechoslovakia and became a satellite state of Hitler's Germany). From the beginning of the tenth century until 1918 Slovakia was a part of Hungary, with whose history it is closely linked. After 1918 the Slovaks joined the Czechs in a common state called Czechoslovakia, which was restituted after World War II. Most Slovaks are Roman Catholics, their christianization being connected with the Moravian mission of Cyril and Methodius (863-885); they use the Latin alphabet. Since the middle of the nineteenth century they have had their separate Slovak (slovenský) literary language. 
The smallest West Slavic nationality is that of the Lusatian Sorbs (Serbja), or simply Lusatians (from the name of the country, Łužica [Lusatia]). Their numbers in 1961 were estimated at 120,000, but in 1976 at only 50,000. They still dwell in the Spree River basin, extending north of the Sudetes parallel to the border between East Germany and Poland. Their main center is the city of Bautzen (Budyšin). The Lusatians do not have any statehood tradition; since the tenth century they have belonged to Germany (to Saxony; their northern branch, the Lower Lusatians, belonged to Brandenburg). Christianized at the end of the ninth century, they were, of course, Roman Catholics until the Reformation; now most of them are Protestants. They use the Latin alphabet and have, in spite of their insignificant numbers, two different literary languages based upon two different dialects: Upper Lusatian and Lower Lusatian (the primary center of the latter is the city of Cottbus [Chośebuz]). These literary traditions reach back to the sixteenth and the seventeenth centuries for Lower and Upper Lusatian, respectively.

\section{B. The Southern Slavs.}

The Southern Slavs are the most diversified group among the Slavic nationalities; this situation reflects the very complicated and turbulent history of Southeastern Europe.

Ahead of the rest one should mention the Serbs (Srbi), the most numerous and politically the most active South Slavic nationality $(8,652,089$ according to the 1971 census). Their main bulk inhabits the Morava River basin south of the Danube-Sava confluence, with enclaves stretching north towards the Pannonian plain and west towards the Adriatic, reaching the coast in Montenegro. From 1189 they had their own state, the kingdom of Serbia, which lasted until the ultimate Turkish conquest in 1459. In 1816, after three national uprisings in the preceding years, Serbia regained political independence, first as a principality and then as a kingdom under her own dynasty. Since 1918 the Serbs have lived in a common state, called Yugoslavia, with the Croatians, Slovenians, and the nationally unrecognized (until 1944) Macedonians. After World War II Yugoslavia was transformed, under Communist rule, from a monarchy into a federal republic. The Serbs have been Orthodox Christians since the end of the ninth century. They use the Cyrillic alphabet and have quite a long and complex literary tradition. At the time of the Old Serbian kingdom they used Old Serbian, based upon Church Slavonic. Since the middle of the nineteenth century they have used a new literary language based upon the Stokavian dialect common to the Serbs and to the majority of the Croats (hence the language is called Serbo-Croation [srpskohrvatski]). In discussing the literary 
traditions of the Serbs, one cannot neglect to mention their oral epic poetry, a unique phenomenon in the Slavic world. This poetry, concentrated on the theme of the fatal battle with the Turks on Kosovo Polje (1389), stimulated the popular imagination and feelings for centuries and contributed significantly to the preservation and development of national awareness.

The Croatians, or Croats (Hrvati), the second largest national group in Yugoslavia (4,526,782 according to the 1971 census), are by language and origin closely related to the Serbs, but by their history and culture they are far from them. They inhabit two quite different, although geographically connected regions: the Dalmatian coast of the Adriatic as far south as Boka Kotorska (Bocca di Cattaro), and the region between the Sava and Drava rivers, called Slavonia, as far east as the Fruška Gora mountains, with some enclaves in western Bosnia and Hercegovina. The Croatians have a very old tradition of statehood: between 925 and 1102 a separate kingdom of Croatia existed with native kings, which was eventually incorporated into Hungary. But it should be emphasized that within Hungary the Croatians enjoyed a kind of provincial autonomy. Since 1918 Croatia as a part of Yugoslavia has shared the fate of that state.

The Croatians, christianized during the second half of the ninth century, partly in connection with the Moravian mission of Cyril and Methodius, are Roman Catholics. Since the fifteenth century they have used the Latin alphabet. Originally, however, under the influence of Church Slavonic they used the Glagolitic alphabet, which is the script of the oldest Croatian documents. Their literary tradition is very old, reaching back to the twelfth century. Between the twelfth and the sixteenth centuries a separate Croatian literary language based upon the Cakavian coastal dialect developed, in which some of the best works of Slavic Renaissance literature were written in the sixteenth century. Later on, after a period of disunity of the literary language when various dialects were used, the Croatians accepted a common literary language with the Serbs called Serbo-Croatian (see above). But it should be noted that the unity of this common language is not absolute. Not only is the external graphic form different (the Croatians use the Latin alphabet, the Serbs the Cyrillic), but there are also significant differences in vocabulary and phraseology between the two national varieties of Serbo-Croatian (or Croato-Serbian), which reflect different cultural traditions, that of Belgrade, the capital of nineteenth century Serbia, and that of Zagreb, the capital of Croatia.

Besides the Orthodox Serbs and the Roman Catholic Croatians, there is another ethnic group in Yugoslavia which uses Serbo-Croatian as its 
literary language: these are the so-called Bosnian "Muslims" (Muslimani), treated after World War II officially as a separate nationality. They number 1,729,932 (according to the 1971 census) and dwell compactly in Bosnia and Hercegovina, i.e., geographically in the basins of the Bosna, Vrbas, and Una rivers, in the very center of Yugoslavia. Their separate ethnic character and status is a result of the history of the region. Namely, from the end of the twelfth century until the Turkish conquest in 1463 there existed a separate Bosnian state (Kingdom of Bosnia). The allegiance of its population to Christianity was undermined by the influential Bogomil (Slavic Manichean) heresy, and after the Turkish conquest the Slavic nobility of the country accepted Islam. Since 1918 Bosnia and Hercegovina have been a part of Yugoslavia. The Bosnian Muslims now use the Latin alphabet and the Croatian, rather than the Serbian, variety of Serbo-Croatian.

The Slovenians (Slovenci-1,678,032 according to the 1971 census), the third South Slavic nationality officially recognized in the kingdom of Yugoslavia (1918-1945), inhabit the Upper Sava and Upper Drava basins in the Eastern Alps and Northern Istria, with some enclaves extending across the Yugoslav-Italian border westward (the vicinity of Trieste) and across the Yugoslav-Austrian border northward (the vicinity of Klagenfurt). They do not have any tradition of separate statehood, having constituted a part of Austria all through their history until 1918. In that year their mountainous country, Slovenia, became a part of Yugoslavia, and since then the Slovenians have also shared the fate of this state. They were christianized in the second half of the ninth century, to some extent in connection with the Moravian mission, and are Roman Catholics. They use the Latin alphabet and their literary tradition reaches back to the sixteenth century.

The Macedonians (Makedonci-1,194,784 according to the 1971 census), officially the youngest South Slavic nationality, since they were recognized only as recently as 1944, inhabit the Vardar Macedonia region, i.e., the Vardar River basin in the very center of the Balkan Peninsula, with some enclaves stretching south to Greece (the vicinity of Kastoria and Florina). In their origin and language they are closely related to the Bulgarians, although the history of their country very early detached them from political ties with medieval Bulgaria. They do not, however, have a tradition of separate statehood, except for the period of the so-called "Samuil's Tsardom", also known as the "West-Bulgarian Tsardom", at the turn of the tenth and eleventh centuries. The Macedonian Slavs, undoubtedly the oldest Slavic stratum in the Balkans, also remained for the longest time under Turkish dominion (until 1912). In 1918 Vardar Macedonia was incorporated into Yugoslavia, but the 
Macedonians were not recognized as a separate nationality. Official recognition came only in 1944, by the Yugoslav Communists, and since that time Macedonia has constituted an autonomous republic within Yugoslavia.

The Macedonians have been Orthodox Christians since the end of the ninth century. They use the Cyrillic alphabet. Their primary literary language was Old Church Slavonic, based upon the dialect of the Macedonian Slavs from the vicinity of Salonika in Northern Greece and codified for ecclesiastic use by the Slavic apostles Cyril and Methodius (862). An impressive religious literature flourished in this language using the primary Slavic alphabet, the Glagolica (Glagolitic), invented by St. Cyril, during the tenth and eleventh centuries in Macedonia, with its center in the city of Ohrid. However, Modern Literary Macedonian, codified ultimately after 1945, is based upon the west Macedonian living folk dialect and has nothing in common with the tradition of Old Church Slavonic.

The Bulgarians (Bzlgari ${ }^{4}-8,727,771$ according to the 1975 census) are the only South Slavic nationality whose very origins are connected with the conquest of the Lower Danube region of the country by the Turkic Bulgars (also called the Proto-Bulgarians). This happened in the second part of the seventh century and brought about the organization of the Old Bulgarian State (679). Thus the Slavic Bulgarians owe the beginnings of statehood and their ethnic name to a foreign Altaic tribe. But it should be emphasized that the Turkic Bulgars, not very numerous from the beginning, were soon slavicized, and the Old Bulgarian Tsardom, which in the ninth and tenth centuries controlled most of the Balkan Peninsula north of Greece, was ethnically a Slavic state. The Bulgarians occupy the northeastern half of the Balkan Peninsula, i.e., the plain between the Lower Danube and the Balkan Mountains, the Marica River basin and the Rodope Mountains south of the Balkan range, and the Struma River basin in the west-roughly the territory of ancient Thracia. They no longer reach the Aegean Sea. Having the oldest statehood tradition among the Southern Slavs, they were also the first to succumb to the Ottoman Turkish onslaught at the end of the fourteenth century. After five hundred years of the Turkish yoke, under which the Bulgarians were reduced to the peasant class, they regained independence as a result of the Russian-Turkish war in 1877-1878, and since that time have existed politically first as the Kingdom of Bulgaria (until 1945) and then as a People's Republic, a satellite of the Soviet Union.

The Bulgarians were christianized in the ninth century. They are Orthodox Christians and use the Cyrillic alphabet. Their primary literary 
language was Old Church Slavonic (see above) in its eastern Old Bulgarian variety. The capital of the Old Bulgarian Tsardom, Preslav, was a very important center of ecclesiastic-literary activity in the tenth century. It is there that the Cyrillic alphabet, i.e., the Greek alphabet adjusted to the needs of Old Church Slavonic, was introduced and replaced the Glagolitic alphabet. Modern Literary Bulgarian, which is typologically far removed from Old Church Slavonic, was codified in the second part of the nineteenth century.

\section{The Eastern Slavs.}

The three East Slavic nationalities, the Russians, the Ukrainians, and the White Ruthenians (this term is preferable to the misleading "Byelorussians"), are relatively more uniform linguistically and culturally than the other Slavic groups. This stems from the fact that their ethnic differentiation came about rather late compared to that of the Western and Southern Slavs. It did not take a discernible shape until after the fall of the Old Kievan Rus' caused by the Mongol (Tartar) invasion in the first half of the thirteenth century. Thus, when the other Slavs were already politically and culturally differentiated, i.e., between the tenth and the thirteenth centuries, the Eastern Slavs still remained in a kind of political-cultural and linguistic unity, which delayed their ethnic differentiation. This accounts for the fact that until the end of the nineteenth century the simple folk (peasants) of these three already separate nationalities called their respective languages "russkij", with an adjective derived from the collective Rus' (=Kievan Rus'). This adjective is misleadingly translated as "Russian", causing, of course, a great deal of confusion in the understanding and interpretation of historical documents.

The Russians (Russkie - 129,015,000 according to the 1970 census) inhabit vast spaces of the East European plain from the Gulf of Finland in the west to the Ural Mountains in the east, from the White Sea in the north to the Sea of Azov, Caucasus, and the Caspian Sea in the south, concentrating in the Volga and Don basins. They transcend the Ural Mountains into Siberia and along its southern belt reach the Pacific Ocean. It should be noticed, however, that in the regions between the Volga River and the Ural Mountains the Russian population is quite densely interspersed with Uralic and Altaic peoples. The beginnings of Russian statehood are connected with the Kievan Rus', which was organized in the middle of the ninth century (856-860) by Scandinvian merchant-warriors (Varangians or Rus') along the waterway joining the Gulf of Finland southward along the Volkhov and Dniepr rivers with the Black Sea. This impressive although not very cohesive political organism 
unified all the Eastern Slavs, and its center, Kiev, was located in what was later to become the Ukraine.

The Mongol invasion in the first half of the thirteenth century destroyed the Kievan Rus' and created conditions for two historical phenomena decisive in the further development of the Eastern Slavs: on the one hand the Grand Duchy of Muscovy, primarily a colonial peripheral principality within the late Kievan Rus', began to grow rapidly in spite of Tartar control, until the ultimate overthrow of this control (officially in 1480), while on the other hand the Polish-Lithuanian federation managed to incorporate most of the territory of the primary Kievan Rus' (i.e., the whole Dniepr basin or in other words White Ruthenia [Byelorussia] and the Ukraine). This latter fact had to entail an inevitable conflict between the Grand Duchy of Muscovy (later the Russian Tsardom) and the Polish-Lithuanian Commonwealth (Rzeczpospolita), since Muscovy considered itself the only legitimate successor to the heritage of the Kievan Rus'. But before this long conflict, which lasted for about three centuries, ended with the fall of the Polish Commonwealth in 1795, the Eastern Slavs of the Ukraine and White Ruthenia-living within the political institutions of the Rzeczpospolita and under the strong influence of western culture represented by the prevailingly Roman Catholic Polish and polonized gentry-began to develop into two separate nationalities: the Ukrainians in the south and the White Ruthenians in the north. It is necessary to underline the fact that this dichotomy reflects the internal division of the Rzeczpospolita into the so-called Polish Crown and the Great Duchy of Lithuania as the two components of the Union.

The Russians have been Orthodox Christians since the official christianization of the Kievan Rus' under Vladimir the Great in 988. After the fall of Constantinople, Muscovy even considered itself the spiritual and political center of Orthodox Christianity, the "third Rome". It should be noted that two generations of Communist rule, in spite of the ideological and administrative fight against religion, have not eliminated Orthodox Christianity from the life of the Russian people. In connection with the Orthodox Christianity adopted by the Kievan Rus' in its Church Slavonic form, the Russians use the Cyrillic alphabet. The beginnings of their literary language reach back to the Kievan period, whose greatest work is the Primary Russian Chronicle ("The Tale of Bygone Years") compiled at the beginning of the twelfth century. It should be noted that the literary language of that period, common to all Eastern Slavs, was based upon Old Church Slavonic, and was only gradually impregnated with original East Slavic features and elements. This intimate symbiosis of the two types of elements has ultimately brought about the 
predominance of the native Russian element and produced Modern Literary Russian. In Russian some of the greatest works of world literature were written in the nineteenth century (e.g., by Leo Tolstoy, Fyodor Dostoyevsky, etc.).

The Ukrainians (Ukrajinci-40,753,000 according to the 1970 census) inhabit the Lower Dniepr basin roughly south of the Prypet'-Desna Line, most of the Dniestr basin, and Sub-Carpathian Ruthenia, located at the southern foothills of the Eastern Carpathians. The term "Ukraine" ('borderland') was primarily a geographic designation and referred to the eastern part of the country, i.e., east of the Boh River. It was extended to include all the regions occupied by the Ukrainian people only in this century, as was the ethnic term "Ukrainian" itself. Before the twentieth century the Ukrainians called themselves Rusyny (Ruthenians), especially in the west, in Galicia, the cradle of modern Ukrainian nationalism. The Ukrainians did not succeed in forming and maintaining their own statehood, except during the brief period of the Duchy of Galicia (Halycyna) in the thirteenth and the first half of the fourteenth century on the southwestern outskirts of the Ukrainian territory, and also during the turbulent Cossack war period in the second half of the seventeenth century, when the political center of the Ukraine was in the Dniepr region. The history of the Ukraine is closely related to the history of Poland (see p. 13), and the development of modern Ukrainian national awareness cannot be understood except against the background of Polish-Ukrainian and Russian-Ukrainian relations.

Stemming from the Kievan Rus', the Ukrainians were Orthodox Christians until the end of the sixteenth century, when the so-called Brześc Union was constituted and the East Slavic Uniate Church (popularly called "Greco-Catholic") was founded. The Union, however, only split the Ukrainians into two parts, the Uniate (Catholic) and the Orthodox. In the nineteenth and twentieth centuries the Uniates were basically the Western Ukrainians (in Poland). The incorporation of the West Ukraine (Galicia) into the Soviet Union in 1945 destroyed the Ukrainian Uniate Church. In connection with their religion, the Ukrainians retained the Cyrillic alphabet. As far as the tradition of their literary language is concerned, the Ukrainians have every right to claim the Kievan Rus' period, even more than the Russians do, for simple geographic reasons. The limited use of a kind of literary Ukrainian never ceased, even during the prolonged period of Polish cultural and linguistic domination. Modern Literary Ukrainian, however, was codified only in the nineteenth century on the basis of the Poltava dialect in the East Ukraine (the so-called left-bank Ukraine, i.e., beyond the Dniepr). In comparison with Literary Russian, Literary Ukrainian is free of 
traditional Church Slavonicisms.

The White Ruthenians (Belarusy -9,052,000 according to the 1970 census) inhabit the Upper Dniepr basin and the adjacent Upper Dvina and Upper Niemen basins, i.e., historical White Ruthenia (Belarus'). They do not have any tradition of separate statehood, although it should be noted that the Grand Duchy of Lithuania, which formed a close Union with Poland in 1569 (see p. 13), was ethnically White Ruthenian, the Lithuanian ethno-linguistic element there being an insignificant minority. Thus, indirectly, up until its polonization ${ }^{5}$ in the seventeenth and eighteenth centuries, the Grand Duchy can be considered a White Ruthenian state.

The White Ruthenians, who gradually crystallized into a separate ethnos only after the fall of the Kievan Rus' within the political organism of the Grand Duchy of Lithuania, were primarily Orthodox Christians, but later, after the Brześc Union (see above), most of them became Uniates. When after the fall of the Polish Commonwealth at the end of the eighteenth century the territory of the Grand Duchy of Lithuania was incorporated into Russia, the russificatory czarist policy cancelled the Church Union and forced the White Ruthenian population back to the Russian Orthodox Church. But a significant number of the White Ruthenians preferred to switch to Roman Catholicism, especially in the western part of the country (Minsk), which in most cases brought about their linguistic polonization. It should be emphasized, however, that there are Roman Catholic White Ruthenians who maintain their White Ruthenian national awareness. In connection with the primary Orthodox or secondary Uniate Christianity, the White Ruthenians use the Cyrillic alphabet. In the nineteenth and the beginning of the twentieth century the Catholic White Ruthenians also used the Latin alphabet.

The literary tradition of White Ruthenian extends back to the thirteenth century. A kind of semi-artificial White Ruthenian chancellary language was used until the end of the seventeenth century as the official language of administrative and legal documents in the Grand Duchy of Lithuania. Being virtually a mixture of Church Slavonic and White Ruthenian, with a constantly increasing number of Polish elements, it could not become the basis of Modern Literary White Ruthenian. The latter, based upon the living vernacular, began in the middle of the nineteenth century and was ultimately codified only in this century. In its vocabulary and phraseology it shows the strong influence of Polish, a fact which distinguishes it sharply from Russian.

As language is an essential component of ethnic identity, the classification of languages cannot be without significance for the 
classification of ethnic groups. It is necessary to make some clear distinctions, since not all linguistic classifications are relevant here. Only genetic linguistics provides us with useful criteria for the classification of ethnic groups. In order to understand the essence of these criteria and to be somehow prepared for a productive reading of this book, the reader should become familiar with some basic concepts of comparative-historical (i.e., genetic) linguistics which underlie the genetic classification of languages.

The languages of the world can be compared in two different respects: either phonemic similarities (more or less perceivable) between their vocabularies (in a broader sense, i.e., including also morphemic components of words) attract our attention, or the similarities between their abstract grammatical categories and rules organizing the elements of their vocabularies into higher entities (phrases and sentences) do so. In the former case, one can say, we are interested in the "lexical substance" of languages, and in the latter in their "grammatical form" ("entelechy"). The former approach creates comparative-historical or genetic linguistics, the latter-typological linguistics. These two kinds of linguistics have different objectives and different methods, and should not be confused; especially their cognitive results should be understood as belonging to two different levels of the phenomenon "language".

Needless to say, only the first kind of linguistics, comparative-historical (or genetic) is relevant for ethnic studies. There is an obvious logical connection here: ethnic groups are ultimately creations of history, which means that their study and understanding requires historical research. Consequently, only comparative-historical study and research into their languages can tell us something about their origins and past development, whereas typological linguistics, being ex definitione ahistorical, is in this respect useless.

But let us ponder for a while the most important concepts of comparative-historical linguistics. In a logical sequence reflecting the discovery procedures of comparative-historical linguistics, we should start from the notion of regular phonemic correspondences between the languages compared; this is the fundamental concept upon which the whole structure of phonetic laws (Lautgesetze), linguistic kinship, and linguistic family has been built. These correspondences do not even have to represent easily perceivable phonetic similarities, but they must be regular, i.e., repeated in a sufficient number of cases where the conditions of the phonemic environment are the same, e.g., Eng. two $\sim$ Pol. dwa, Eng. ten $\sim$ Pol. dziesięć, etc. In the first case we have the correspondence $t \sim d$, in the second $t \sim \xi$ (written $d z i$-): this difference is conditioned by the fact that in the second case the primary Slavic $d$-, followed by the 
front vowel $e$, was palatalized into $\xi$. Of course, as the above examples indicate, we compare words (or morphemes) which are still comparable semantically, although the relations may be quite loose, due to the sometimes radical semantic changes that words undergo in the history of languages. It is important to realize that the phonemic correspondences between the languages compared become more obvious, i.e., represent quite easily perceivable phonetic similarities, the older (earlier) the stage of the respective languages. Thus, there is more similarity between Gothic (4th century A.D.) and Old Church Slavonic (9th century A.D.) than between New English and Polish; compare, e.g., Goth. taihun 'ten' and OCS desętb. The regular phonemic correspondences between the lexical elements of compared languages cannot be accidental, provided that they are represented by a sufficient number of basic words and grammatical morphemes, such as declensional and conjugational suffixes or desinences, etc. So the idea of a common origin of the respective languages suggests itself quite obviously. Such regular phonemic correspondences enable us to posit and to reconstruct a common source, the "protoforms" from which the historically attested forms of the compared languages have developed. In this way the idea of a common prehistorical language, the "protolanguage" (Ursprache, langue commune, Russ. prajazyk, etc.), whose descendants are the languages compared, has originated. Only the languages for which such a protolanguage can be reconstructed are genetically related and form a "linguistic family". As long as linguistics is unable to reconstruct a protolanguage, the respective languages, despite some correspondences, cannot be treated as belonging to one and the same family, i.e., as stemming from a common prehistorical source. This point is very important because of linguistic (lexical) borrowings, which always take place between languages of different origins if there is any kind of contact between them. If there are a great many borrowings from language $A$ in language $B$, this may create the impression that both are genetically related, i.e., that they belong to the same family. But a closer historical-comparative scrutiny is usully able to distinguish between the lexical elements really inherited by the two languages from a common protolanguage ("mother-tongue") and those which have been borrowed from one to the other.

A classical example can be taken from English. As is well-known, English belongs genetically to the Indo-European languages, within which its direct ancestor (its "mother", not its "grandmother", as it were) is represented by Proto-Germanic. On the other hand, Latin also belongs to Indo-European. So between English and Latin there are many regular phonemic correspondences which occur in words and morphemes inherited by both langugages from their ultimate common source, 
Proto-Indo-European. For example, Lat. unus, duo, tres, etc. $\sim$ Eng. one, two, three, etc.; Lat. pater, mäter, fräter, soror, etc. Eng. father, mother, brother, sister, etc.; Lat. ager, ovis, etc. $\sim$ Eng. acre, ewe, etc. But on the other hand we have a multitude of words in English which show a striking similarity, sometimes almost identity, with some Latin words, but which do not represent the correspondences established above for Latin and English, e.g., paternal, maternal, fraternal, etc. Their original English correspondences are fatherly, motherly, brotherly, etc. These words are borrowings from bookish Latin, which has never ceased to influence the English language since the introduction of Christianity to England. The number of Latin borrowings in some styles of English (e.g., philosophical and scientific) is so impressive, that if one were restricted only to the lexical material contained in such texts, one could get the impression that English is a neo-Latin, i.e., Romance language. Take for example such a sentence:

Comparative-historical linguistics involves numerous complex questions related to the origins and evolution of individual members of respective linguistic families.

In Latin (for etymological purposes):

Linguistica comparativa et historica involvit numerosas complexas quaestiones relatas ad origines et evolutionem individualium membrorum respectivarum familiarum linguistiarum.

As we see in the above English sentence, all the "full words", i.e., those referring to definable phenomena of reality, are of Latin origin. Only the grammatical morphemes (e.g., the plural endings of nouns, personal endings of verbs, etc.) and "empty (function) words", i.e., prepositions and conjunctions, are of Anglo-Saxon (Germanic) origin. The latter have been directly inherited from Proto-Germanic, the mother-tongue of English, whereas the former represent loanwords acquired by English during its history from bookish Latin, a language which, although remotely cognate to Anglo-Saxon, was basically foreign to the native speakers of primary English. The above genetic relationship between the analyzed vocabularies could be presented thus:

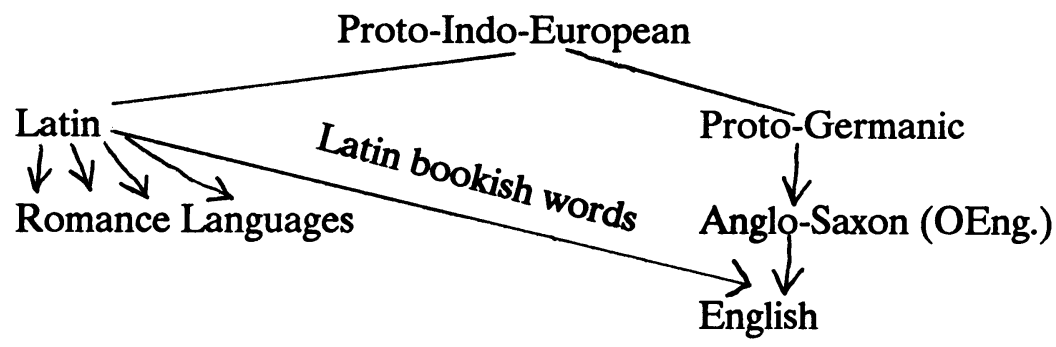


The above examples taken from the history of English vocabulary, in which the grammatical elements, i.e., endings and empty words, show their Anglo-Saxon (Germanic) origin, whereas the full words represent loanwords from Latin, are important and instructive because they prove that the genetic identity of a language, in our case the Germanic character of English, is established on the basis of the etymology of the grammatical elements of the language. Consequently, there may be languages whose genetic ties can be proven almost exclusively by their grammatical elements showing common origins, whereas their vocabularies, i.e., full words, may be overwhelmingly of various and foreign origins, i.e., not stemming from the same common source (protolanguage) as the respective grammatical elements. This fact is very significant: it proves the closeness of grammar (as a finite set of morphemes and empty words) as opposed to the openness of lexicon (as an infinite set of full words). Of course, the comparative-historical study of languages takes account of the fact that in spite of the openness of lexicon and its susceptibility to foreign influences (borrowings), one can establish a layer, a core of lexicon, which in most languages manifests a remarkable immunity to foreign "pressure", remaining genetically unchanged. Numerals, pronouns, basic kinship terms, verbs denoting basic activities of the human body, etc., belong here, although it is not easy to give a universal list, since the history of languages, reflecting the history of peoples, is full of special and sometimes rare events and accidents; e.g., the impregnation of English with Romance, i.e., French elements, as the result of a very special historical event, the Norman conquest, and its political, social, and linguistic consequences. Without that conquest English would undoubtedly have remained more Germanic in its vocabulary and would resemble German in this respect.

Regular phonemic correspondences between the grammatical and lexical morphemes (in that order of significance) of the compared languages become, as we have seen, the basis for the reconstruction of an earlier common stage of these languages, the protolanguage. The procedure of reconstruction is not always simple, since we may lack some intermediary stages or an entire language of the family that disappeared without leaving any vestiges. So in the process of reconstruction we also take into consideration some suggestions of general phonetics and linguistic insights acquired through the study of historical languages. These suggestions and insights guard us against unjustifiable hypotheses and allow us to posit "protoforms" which have a high degree of historical probability. For example, for Eng. father, Lat. pater, Gr. $\pi \alpha \tau \dot{\eta} \rho$, and Sanskr. pitá (the stem pitar-), the PIE form * pater or ${ }^{*}$ pHtêr (where $H=\mathbf{a}$ laryngeal consonant) has been established; for Eng. ten (Goth. taihun), 


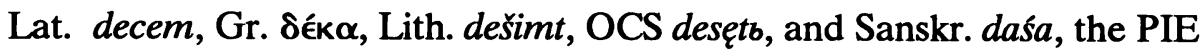

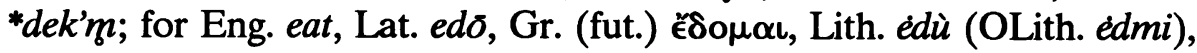
OCS -ěmb (3.pl. -ědętz), and Sanskr. ádmi, the PIE *edmi 'I eat', etc.

Having established a sufficient number of protoforms from which the forms of historical languages can be derived, we trace "vertically" the changes which in prehistorical times took place between the reconstructed forms of a protolanguage and those of historical languages, and in this way we arrive at the formulation of the historical laws of phonemic change (the Lautgesetze of nineteenth century linguistics). The "laws", as their very attribute "historical" clearly indicates, are not universal (thus in this respect they should not be confused with the laws of natural sciences!); their validity is limited in space and time, since they refer not just to certain languages, but to these languages at a determinate period of time. That they may reflect some universal tendencies of human language as such is a different problem, which does not undermine their basic historicity. Some examples should suffice to illustrate the point. One of the best is the palatalization of velar consonants $(k, g, h / x)$ before front vowels (i.e., the vowels of the $i$-e type). Observing the respective linguistic facts, one can say that the change of velars into corresponding palatals in this position (i.e., $k, g, x \geq \check{c}$, $\check{z}, \check{s}$ ), well conditioned by the articulatory movements of our speech organs and reflecting phonetic adjustment (assimilation between speech sounds), represents a universal tendency of human language phonetics. But this tendency is manifested only in certain languages and at certain times. For example, the primary sequences of the $k+i / e$ type underwent palatalization into $\check{c}+i / e$ in English (i.e., in Old English), but they remained unchanged in German; cf. Eng. chin Germ. Kinn, Eng. churl (OEng. ćeorl) Germ. Kerl, etc. A similar relationship can be observed between Slavic and Lithuanian, cf. Russ. četýre Lith. keturi 'four', Russ. čeredá, 'row, herd' Lith. kerdžius 'shepherd', etc. The palatalization of velars into the corresponding palatals before primary front vowels in English and Slavic affects, however, only older words, i.e., those inherited from Proto-Germanic or Proto-Slavic, respectively, or borrowed from foreign languages at a very early historical period. Later sequences of the $k+i / e$ type, whatever their origin (e.g., with secondary front vowels), remain unchanged, however, cf. Eng. keep, kick as opposed to cheap, chicken, etc., Russ. kerosin 'kerosine', kefir 'kefir' as opposed to čelovék 'man', čest' 'honor', etc.

Schematically, the Lautgesetze operating within a linguistic family can be presented in the following way: 


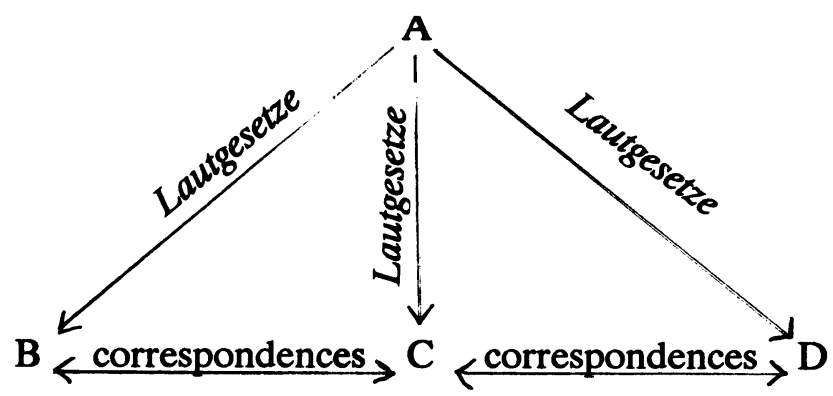

It should be emphasized that the Lautgesetze are virtually without exceptions, i.e., that the phoneme $a$ of language $A$ becomes the phoneme $b$ of language $B$ in all the inherited morphemes or words in which the phonetic conditions (environment, stress, etc.) are the same. The alleged exceptions are usually accounted for either as borrowings from other dialects or languages in which a given phonemic change did not happen, i.e., for which different Lautgesetze hold, or they are the results of so-called morphological analogy, which took place in a given language after the phonemic change represented by the respective Lautgesetz ceased to act. For example, a morphological analogy representing the "uniformization" or "levelling" of the noun-stem accounts for the removal of the consonants $c, z, s$, stemming from the second PSl. palatalizaion of velars, in the Russ. paradigms ruká $\sim$ ruké, nogá nogé, muxá $\sim$ muxé, etc., instead of ORuss. ruka rucě, noga $\sim$ nozě, and muxa $\sim$ musě, etc.

Having reconstructed a protolanguage for a group of historical (attested or documented) languages, i.e., having proven their genetic relationship (linguistic family), we are entitled to raise the following question: what is the ontological status of such a reconstructed protolanguage, e.g., Proto-Indo-European in the case of IE languages? This question is not without serious epistemological implications: ultimately the whole study of IE antiquities, or the antiquities of any ethno-linguistic group conceived as a linguistic family, depends on the answer to this question. Here at the very beginning I must state clearly-and this also obviously follows from the very title of the book-that I take a decisively realistic approach to the problem of protolanguage and reject the idealistic concept, according to which the reconstructed forms are only convenient and economical symbols or graphic devices which represent in a synthetic abbreviation regular phonemic correspondences between the respective languages. So, for example, the reconstructed PIE form *k'mtóm 'hundred' would represent only a synthetic abstract formula expressing a whole set of regular 


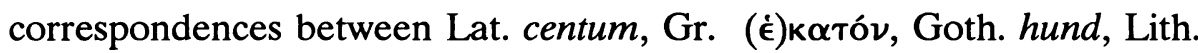
šimtas, OCS szto (with an irregular $z$ instead of ${ }^{*} e$ ), Avestic satam, Sanskr. satam, etc. Of course, such a minimalistic concept of reconstructed forms is ultimately agnostic, since it renounces any realistic interpretation of the remarkable fact of regular phonemic correspondences between the compared languages, and transforms historical-comparative linguistics into a formal game. But on the other hand, the assumption that the reconstructed forms represent a kind of prehistorical reality must be accepted with the caveat that they are only approximations open to corrections suggested by new discoveries or by deeper insights into the language provided by general linguistics. In this respect the history of the development of IE comparative linguistics in the nineteenth century can by quoted as an interesting and instructive example (see H. Pedersen: The Discovery of Language).

The above statement that the reconstructed forms appoximate prehistorical reality should be understood as saying that at a period of prehistorical time there was a language, in this case a protolanguage of some linguistic family, whose forms could be imagined with the help of the reconstructed forms. This imagination has, however, an abstract intellectual character; we reconstruct only the most relevant features, the distinctive ones, which somehow played a role in the later development of the individual languages of the given family. This means that the reconstruction of a concrete linguistic substance, i.e., the phonic substance, is impossible and even irrelevant. For example, we do not know what the phonetic realization of the PIE voiced aspirate stops (the mediae aspiratae) ${ }^{*} b h,{ }^{*} d h,{ }^{*} g^{\prime} h,{ }^{*} g h$ (or ${ }^{*} g h$ ) was, but we mark their voiced character (i.e., $b, d, g, g$ ) because this feature is relevant in the further development of many historical IE languages, such as Sanskrit, Avestic, Baltic, Slavic, Germanic, etc., (cf. *bheró 'I carry': Sanskr. bharämi, Lith. beriù, OCS berq, Goth. baíra, etc.) and it accounts best for the respective phonemic correspondences between the IE languages (e.g., Sanskr. bharāmi Gr. ф́́ $\rho \omega \sim$ Lat. ferō $\sim$ Goth. baíra Slav. berq, etc.)

If a reconstucted protolanguage was a highly probable prehistorical fact, actually the only reasonable hypothesis to explain the regular phonemic correspondences observed between certain historical languages, then it could not exist in a socio-geographical vacuum. It must have been spoken by a certain group of people at a certain time and place. In this connection the problem of a proto-ethnos and its primary habitat (Urvolk and Urheimat) arises and acquires a legitimate place within the historical human sciences.

We cannot get involved in the methodological discussion of these problems here in the introduction. It is the aim of this book to analyze 
and explain these problems concretely with respect to the Slavic languages and peoples. However, in order to avoid misunderstandings, one aspect of the relation language people should be emphasized: these terms are relatively independent, in the sense that people can deliberately and consciously change their primary inherited language and replace it with another, foreign, learned one, i.e., they can stop using their own and adopt the foreign one. Such a change usually takes place through the intermediary of bilingualism. As a simplified example, take a situation where of three generations, the oldest still speaks only its native language $\mathrm{A}$, the middle generation is bilingual, speaking the native language $\mathrm{A}$ and a foreign language $\mathrm{B}$, but the youngest generation deliberately abandons language $A$ and speaks only language $B$. In this way in the span of three generations of a social (or ethnic) group we witness a change of language. For the time being the concrete social and cultural conditions under which such a change of language takes place are irrelevant, although they must exist for the switch of language to occur. Now, when reconstructing the linguistic prehistory of a people, only very rarely can we obtain any indirect indications that something like a switch of the primary language took place. These are the cases when we speak about a foreign substratum (see p. 60) in the history of a linguistic family. So the ways in which a linguistic tradition was transmitted in the prehistorical past may sometimes be quite complicated. We must take into account two fundamentally different possibilities: either there is an uninterrupted transmission of a language from generation to generation within a given community without the interference of a foreign language, i.e., without bilingualism; or a given language is first learned and used as a secondary language within a community with another native language, and then during some generation it becomes the only one and is further transmitted as such, subsequently acquiring the status of a native language.

In this way we can formulate the phenomenon of linguistic inheritance, which has nothing to do with biological inheritance. For the former the flow of linguistic substance is determined by the consciousness of the speakers, who can reject the original native language of their community and adopt a foreign one primarily belonging to another community; for the latter the flow of the biological substance is independent of the consciousness of those involved, since it is an automatic result of their sexual life. Of course, the transmission of culture has basically the same features as the transmission of language. When speaking about the linguistic ancestors of a group of people who use a certain language, we have in mind those people whose linguistic substance ("core" lexicon and grammatical morphemes) still prevails in the language of this group, 
regardless of any biological (racial) or even cultural ties between the two groups of people. So, for example, the English and the Bengalis have remote common linguistic ancestors.

Any research into the origins of the Slavs must start with the statement of their obvious membership in the IE linguistic family. This very fact immediately suggests the main direction of ethnogenetic studies, namely that the Slavs should be considered in the framework of other peoples which speak IE languages, and their historical ties with these peoples should be traced. But how do we know that the Slavic languages are Indo-European? Linguistic kinship is not always obvious; sometimes it takes quite complicated and difficult historical-comparative analysis to prove that a given language belongs to a certain family. Consider, for example, the story of Armenian within Indo-European. In the case of Slavic languages, however, we are very lucky. In the first place, they are all so obviously related to each other that they could even be treated as various dialects of one "Slavic" language, were it not for sharp historical, political, and cultural differences among the Slavic peoples, which have conditioned the crystallization of separate national Slavic languages on the basis of dialectal entities. Furthermore, because of the rather conservative character of these languages they provide simple material for comparison with other IE languages. Some examples should suffice. (Contrary to the scholarly practice which compares the oldest philologically attested forms of cognate languages, here for the sake of a popular presentation and in order to illustrate the above statements, the following present-day IE languages of Europe will be compared: from Slavic-Polish, from the other IE languages-English and Italian, three languages which occupy quite remote positions from each other on the European continent).

$\begin{array}{lll}\text { Polish } & \text { English } & \text { Italian } \\ \text { dwa } & \text { two } & \text { due } \\ \text { trzy [tšsy] } & \text { three } & \text { tre } \\ \text { dziesięć [ร́eśeńć] } & \text { ten } & \text { dieci }\end{array}$

Other numerals are less recognizable as cognate elements, although they stem from the same IE source, e.g., cztery four quattro, etc.

$\begin{array}{lll}\text { matka (OPol. macierz) } & \begin{array}{l}\text { mother } \\ \text { brother }\end{array} & \text { madre } \\ \text { siostra } & \text { sister } & \text { fratello } \\ \text { sorella }\end{array}$

Other kinship terms are also related, although their identification is not so obvious, e.g., Pol. córka Eng. daughter. The corresponding word is lacking in Italian, which continues another Latin element, figlia, from Lat. 
filia, etc.

\begin{tabular}{|c|c|c|}
\hline oko & eye & occhio \\
\hline ucho & ear & orecchio \\
\hline nos & nose & naso \\
\hline $\begin{array}{c}\text { serce (simplified from } \\
\text { *serdce) }^{\text {sere }}\end{array}$ & heart & cuore \\
\hline $\begin{array}{l}\text { stać (pres. stoję, etc.) } \\
\text { siedzieć }\end{array}$ & $\begin{array}{l}\text { stand } \\
\text { sit }\end{array}$ & $\begin{array}{l}\text { stare } \\
\text { sedere }\end{array}$ \\
\hline
\end{tabular}

Compare also the suppletion of the two roots in the verb 'be':

$$
\text { jest 'is' : byt 'was' is : be (subjunctive) è 'is' : fu 'was' }
$$

Even if there was no other IE language preserved in the world and if we knew nothing about the history of the above languages, examples like those quoted above would suffice to hypothesize a genetic relationship between Polish, English, and Italian, and to attempt to formulate some phonemic correspondences, e.g., Pol. $d / d z \sim$ Eng. $t \sim$ Ital. $d$, as illustrated

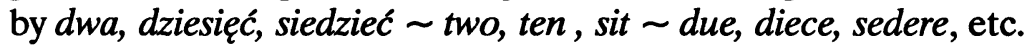

But as I mentioned earlier, in order to prove genetic relations convincingly, we must use as much as possible the oldest attested material, i.e., the oldest texts, since languages evolve (develop, change) with time and their earlier stages are obviously closer to their common source (protolanguage) than their later stages. Thus, instead of Polish, English, and Italian, we should use the corresponding examples from Old Church Slavonic, Gothic, and Latin, all of which represent the oldest philologically attested languages of the respective IE branches: Slavic, Germanic, and Italic. If we do this, we will see that the degree of similarity between the compared languages is much greater, and that the regular phonemic correspondences which have been blurred in the modern languages are much easier to recognize at that older stage. The corresponding examples are as follows:

\begin{tabular}{|c|c|c|}
\hline OCS & Gothic & Latin \\
\hline$d z v a$ & twai & $d u o$ \\
\hline trije & preis $[\theta r i \bar{s}]$ & tres \\
\hline desętb & taihun [tæhun] & decem \\
\hline četyre & fidwōr & quattuor \\
\hline mati (mater-) & $\begin{array}{l}\text { the corresponding word } \\
\text { unused, replaced by aipei }\end{array}$ & mater \\
\hline bratrb & bröpar & frater \\
\hline
\end{tabular}




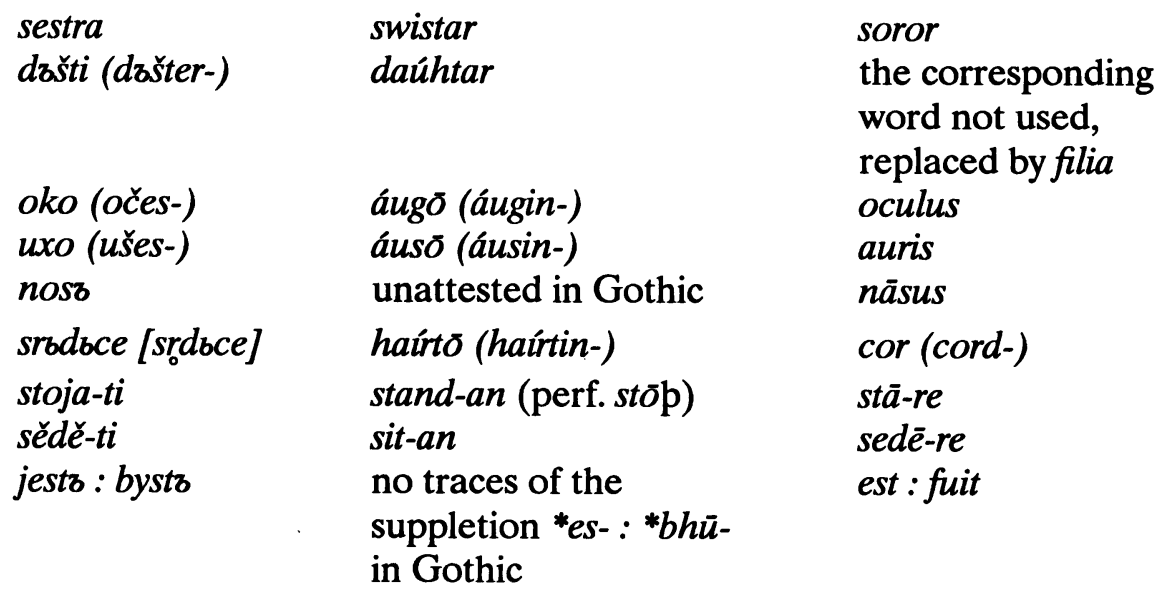

But the above examples also show that in spite of the relatively early chronology of the linguistic material compared, there already occur in it some cases of specific lexical changes, e.g., the replacement of the undoubtedly Com. Germc. *mōðar (IE *mäter-) by áipei in Gothic, or that of IE *dhug(h)ater- by filia in Latin. Such examples are instructive since they prove that linguistic change is a universal phenomenon and the only thing which varies in this respect is its relative speed and extent.

So there is no doubt that the Slavic languages can be shown to be members of the IE linguistic family without any complicated methodological procedures. Of course it is not enough to state this fact in general terms. Any scientific study of the comparative grammar of Slavic against the IE background requires more detailed and precise analysis and an explanation of all the aspects of the genetic relationship which holds between Slavic and its ultimate prehistorical source, Proto-Indo-European. This is, however, a complex task involving the reconstruction of gradual prehistorical stages through which Slavic developed before it appeared in its early historical form, Old Church Slavonic. I will discuss some aspects of this prehistorical evolution in later chapters of this book, when tracing the gradual crystallization of the Slavs within the IE family of languages and peoples.

Studying the history of the Slavs, we are struck by their relatively late appearance on the historical stage, practically in the sixth century A.D., when they invaded the Balkan provinces of the East Roman (Byzantine) Empire en masse. At that time they were clearly identified by Byzantine authors as a separate and uniform ethnic group, Sclaveni in Latin and $\Sigma_{\kappa} \lambda \alpha \beta \eta \nu o i$ in Greek. The question is to what extent they were still ethnically and linguistically uniform, i.e., undifferentiated, and where were their early historical strongholds, from which they expanded. 
Everything indicates that the impressive sixth century expansion of the Slavs, not only southward to the Balkans, but also westward to Central Europe (they reached the Elbe- $€ a b a$ by the year 600 A.D.), started from the regions located north of the Carpathians, roughly speaking on the territory of present-day Poland, and the adjacent western half of the Ukraine. It is there that we should look for their late prehistorical habitat, which, of course, does not say that this was their oldest primary abode, where they were formed as a separate ethno-linguistic entity. But this is the first step in our retrograde investigation into the prehistorical location of the Slavs. It is significant that at least the ancestors of the Southern Slavs, who undoubtedly expanded to the Balkans from Pannonia and Dacia (i.e., the central Danubian basin), seem to have followed the route which was most probably taken by the ancestors of the Hellens (Greeks) twenty-five centuries ago. The main routes of ethnic migrations and expansions in the Old World have not changed for millennia. This fact also indicates that the Slavs seem to be the youngest group of IE peoples, in the sense that they must have remained longer than any other IE group near the primary habitat of the Indo-Europeans. These circumstances explain the relatively conservative character of Slavic, although, as we will see, they are not the only conditions supporting linguistic conservatism in the IE world. These circumstances can also be used as a strong argument for the Indo-European character of Slavic, in that Slavic preserves many essential features of primary Indo-European better than other IE languages of Europe, with the exception of Baltic, particularly Lithuanian.

So we can formulate the three questions which will direct our investigation in the following chapters: when, where, and under what conditions did the Slavs form a separate ethnos within the IE peoples? This is the main topic of this book, which I will attempt to elaborate, first using linguistic data and methods, and then, if possible, supporting them with historical data and methods. Archaelogy and physical anthropology are deliberately excluded from the following considerations. 


\section{Chapter 2}

\section{Slavic (Proto-Slavic) within the Indo-European Linguistic Family}

Having established the membership of Slavic in the IE linguistic family, we should now determine its position within this family more precisely. As any linguistic family, IE can be traced back to a prehistorical period for which a kind of common language, in this case Proto-Indo-European, is reconstructed. But the concept of a protolanguage is a historical concept, i.e., it should be treated dynamically as the period of prehistorical development preceding the appearance of the historically attested individual languages of a given family. In other words, between the remote time of a real linguistic unity, in our case early PIE, and the time of the first separate historical languages, in our case Hittite, Vedic Sanskrit, Avestan, Homeric Greek, Latin, Gothic, Old Church Slavonic, Lithuanian, etc., we should posit a prehistorical period of gradual dialectal differentiation of PIE, which ultimately brought about those attested early historical IE languages. Dialectal differentiation is a well known process in the history of any language occupying a large territory, and late PIE was no exception in this respect. That it must have been quite extended geographically is best shown by the wide range of early historical IE languages, reaching from India in the East to Britain in the West. Now, in view of the above we should pose the following question: what was the dialectal differentiation of late PIE, or what was the geographic and historical pattern of the dissolution of the primary PIE linguistic unity. This question is motivated by the fact that between some early IE languages there are closer ties, i.e., phonemic, morphemic, and lexical correspondences, than between others, which indicates that they stem from some prehistorical IE dialects. So for the late PIE period we can try to establish characteristic dialectal differences which continued in early historical IE languages.

As is well known, the problem of genetic relations between groups of separate IE languages has a long history. The first model proposed for the presentation of these relations was the Stammbaumtheorie (the 
theory of the genealogical tree), formulated by A. Schleicher in the 1860's under the spell of the biological sciences. This model, or rather metaphor, presented the genetic relations between languages in the same way as the genetic relations between human beings coming from the same common ancestors are usually presented, e.g.: (see Chart 1 on page 37.)

However, there is no doubt that the actual relations between these languages were more complicated than this schematic tree shows. The Schleicherian Stammbaumtheorie was critized by linguistic geographers who studied the territorial differentiation of living languages. They noticed relations between the dialects of national languages which could not be accounted for as simply the specific continuation of common protoforms. Rather they had to be regarded as the result of the geographic spread of linguistic innovations which had originated at a point within a given linguistic territory and then expanded, owing to an ethno-linguistic continuum existing on this territory.

The experience of dialectology suggested a new interpretative model of the genetic relations between languages, the Wellentheorie ('wave theory') formulated by J. Schmidt. According to this model, linguistic innovations in a language or group of closely related dialects which cover a larger territory spread from a central point like the waves in a pool aroused by throwing a stone: the farther from the original center, the weaker they are, and they die out on the periphery. This fact explains the peripheral archaisms of a linguistic territory. Of course, we can have different "innovation centers" on a linguistic territory simultaneously or successively, which means that the waves of linguistic change arising from them may cross each other (or intersect), bringing about quite a complicated net of isoglosses. In view of this the separation of individual territorial dialects as linguistic facts must be based upon clear bundles of isoglosses. The wave-theory proved to be very useful in linguistic geography and dialectology but it is not sufficient in historical-comparative linguistics because it neglects such important social and historical facts as migrations, conquests, demographic shifts (such as those connected with the history of colonization), etc., which complicate the simple mechanics of the linguistic waves.

So the only realistic approach seems to be a combination of the two interpretative models (or rather models of presentation), the Stammbaum-model and the wave-model. This means that on the one hand we derive common features of related languages from a common prehistorical source (the "ancestor", mother-tongue, etc.), and on the other hand we accept secondary territorial ties and reciprocal interference between dialects and languages which are not directly related. In the first case the Stammbaum-model can be applied, and in 


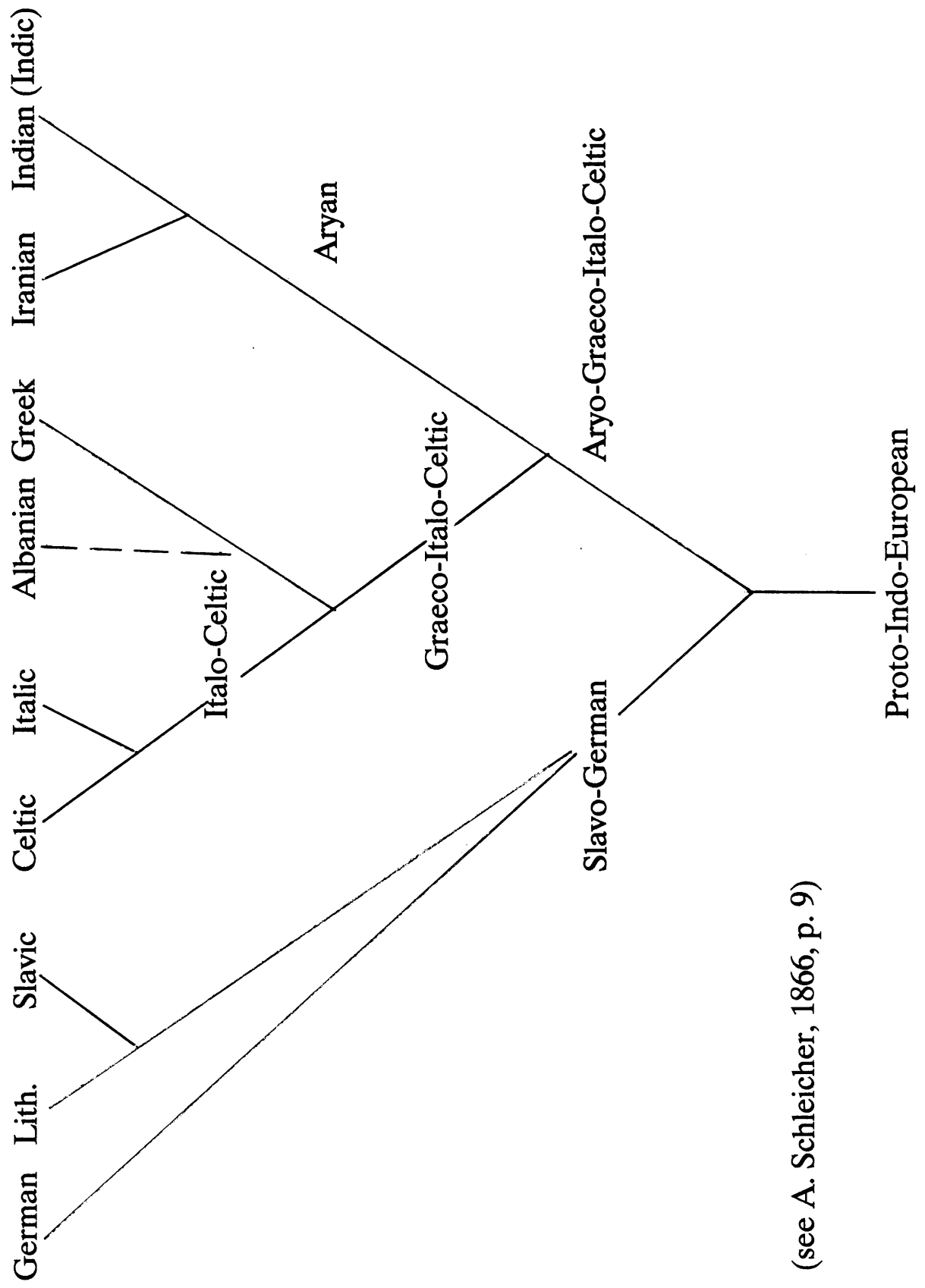


the second the wave-model. A kind of synthetic approach and presentation was applied by T. Milewski (1968:42-43, 51-53). Since Milewski condenses his views clearly, I will simply quote appropriate paragraphs from his essay with corresponding diagram:

Von dem so umrissenen Ausgangsgebiet erfolgten neue indo-europäische Expansionen in allen Richtungen, was zur weiteren sprachlichen Differenzierung führte. In diesem Prozeß kann man eine bestimmte Gesetzmäßigkeit feststellen, die auf dem Gegensatz zwischen Randgebiet und Zentrum beruhte. Dieser Gegensatz hatte zwei Aspekte.

Einerseits lagerten sich die Dialekte der Randgebiete auf den neueroberten Kolonialgebieten der nichtindoeuropäischen Bevölkerung auf, die in diesen bei der Übernahme der Sprache der Eroberer weitgehende Veränderungen durchführte. Im Bereich der Phonetik war die Lautverschiebung am bezeichnendsten. Die nichtindoeuropäische Bevölkerung beseitigte die in ihrer eigenen Sprache nicht vorhandene Opposition stimmhaft : stimmlos in den übernommenen Dialekten oder ersetzte sie durch die Opposition stark : schwach, wie schon oben gesagt wurde. Im Bereich der Morphologie erfolgten weitgehende Vereinfachungen, der Verlust selten gebrauchter und komplizierter Kategorien. Im Bereich des Wortschatzes war die massenhafte Übernahme von Ausdrücken des Substrats kennzeichnend. Typisch hierfür ist das Hethitische der Keilschrifttexte, in denen von 1500 Grundwörtern nur 20\% der Wörter indoeuropäischer Herkunft, dagegen $80 \%$ Entlehnungen aus den Sprachen des asianitischen Substrates sind. Außerdem sind fast alle von den Hethitern gebrauchten geographischen. Namen und Personennamen ebenfalls nichtindoeuropäischer Herkunft.

Der Gegensatz zwischen Zentrum und Randgebiet beschränkt sich jedoch nicht ausschließlich auf die Einwirkungen des Substrats. Er geht tiefer. Die vom Zentrum ausgehenden Prozesse sprachlicher Neuerungen werden in den Randgebieten und den noch weiter entfernten Kolonialgebieten teilweise oder ganz gehemmt und erreichen nicht mehr die Grenzen der Sprachfamilie. Während das Zentrum den eigentlichen Typus der Sprachfamilie weiter entwickelt und in dieser Hinsicht progressiv ist, bleiben die Randgebiete hinter dieser Entwicklung zurück und bewahren auf diese Weise einen weit älteren, archaischen Zustand. 
Dieser Gegensatz ist im indo-europäischen Raum im Bereich der Phonetik und Morphologie deutlich sichtbar.

(Milewski, 1968, 42-43)

Die Ergebnisse unserer Erwägungen lassen sich schematisch folgendermaßen zusammenfassen.

NÖRDLICHES RANDGEBIET

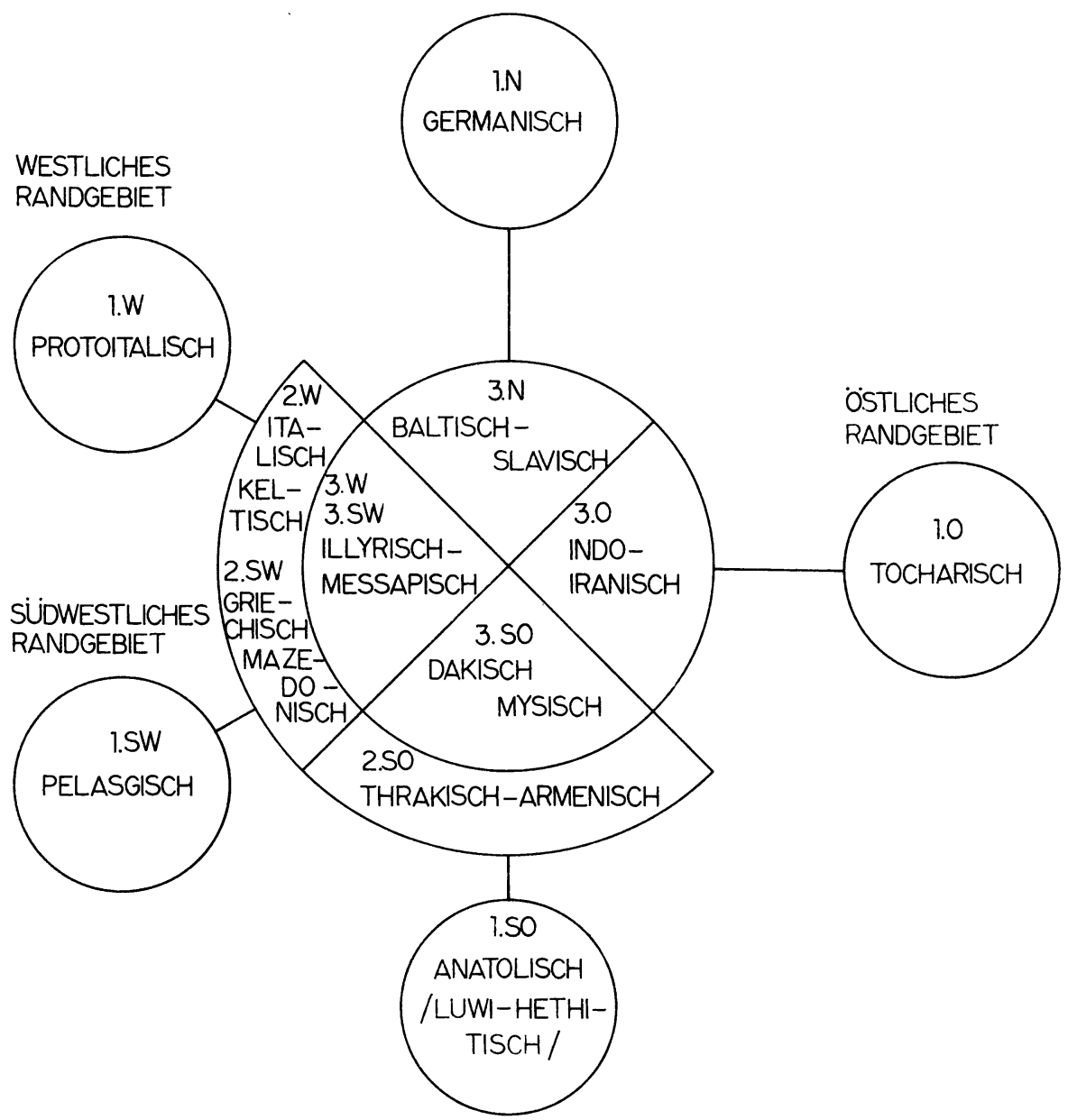


Alle fünf Sprachgruppen der ersten Welle (1), und zwar die germanische im nördlichen Randgebiet $(\mathrm{N})$, die tocharische im östlichen Rangebiet $(\mathrm{O})$, die anatolische (luwi-hethitische) im südöstlichen Randgebiet (SO), die pelasgische (vorgriechische) im südwestlichen Randgebiet (SW) und schließlich die protoitalische im westlichen Randgebiet (W) führten die Lautverschiebung durch und gehören zum Kentumtypus. Bei der Einordnung der pelasgischen Gruppe gehen die Meinungen auseinander. Manche rechnen sie zum Satem-, andere-was mir wahrscheinlicher scheint-zum Kentumtypus. Die Lautverschiebung tritt in den genannten Sprachen in zweierlei Gestalt auf. Im Tocharischen und Protoitalischen führte sie zum gänzlichen Schwund der Opposition stimmhaft : stimmlos, in den übrigen Gruppen wurde diese Opposition durch die Opposition schwach : stark (b: $\mathrm{p} \geq p: P)$ ersetzt. In der anatolischen Gruppe blieb diese neue Opposition unverändert, im Pelasgischen ging sie in die Opposition nichtaspiriert : aspiriert $(p: P \geq p: p h)$ über, im Germanischen nahm sie die Gestalt der Opposition Verschlußlaut : Reibelaut $(p: P \geq p: p h \geq p: f)$ an. Im Germanischen tritt außerdem die Lenierung (Vernersches Gesetz), die das zweite Stadium der Lautverschiebung darstellt, auf. Die Gruppen der zentralen Sprachen (3) dagegen, und zwar die nördliche baltisch-slawische $(\mathrm{N})$, die östliche indoiranische $(\mathrm{O})$, südöstliche dakisch-mysische (SO), westliche illyrisch-messapische (W) Gruppe, weisen absolut keine Spuren einer Lautverschiebung auf und gehören-mit Ausnahme der illyrisch-messapischen-zum Satemtypus.

Die Sprachgruppen der zweiten Welle (2), und zwar die thrakisch-armenische auf dem südöstlichen (SO), die griechisch-mazedonische auf dem südlichen (S) und die italisch-keltische auf dem westlichen (W) Randgebiet nehmen eine Mittelstellung zwischen den Sprachgruppen der ersten Welle, auf die sie sich auflagerten, und den zentralen Gruppen ein. Die thrakisch-armenische Gruppe führte zwar die Lautverschiebung wie die Randgebietssprachen durch, gehört aber gleichzeitig dem Satemtypus - wie die zentralen Sprachen - an. Die griechisch-mazedonische Gruppe gehört zu den Kentumsprachen wie die Randgebietssprachen, im Griechischen erfolgte außerdem der Übergang der uride. 
stimmhaften Aspiraten $b h, d h, g h$-durch Beseitigung der Stimmhaftigkeit - in $p h, t h, k h$, was eine Erscheinung ist, die der Lautverschiebung ähnelt, die jedoch-wie in den zentralen Sprachen - nicht durchgeführt wurde. Gemeinsam ist der italisch-keltischen Gruppe und den Randgebietssprachen die Zugehörigkeit zur Kentumgruppe und eine Reihe von Erscheinungen, die im Zusammenhang mit der Lautverschiebung stehen, wie der Schwund von $p$ im Keltischen und die Lenierung im Keltischen und Italischen. Dem Zentralgebiet nähert sie sich in Hinblick auf das Fehlen einer vollen Lautverschiebung.

(Milewski, 1968, 51-53)

As we see, Milewski's scheme represents not so much the actual dialectal differentiation of primary IE (PIE), but rather the process of the prehistorical split (dissolution) of primary IE, entailed by population movements (migrations, conquests, etc.). Of course, this process continued and deepened previously existing prehistorical dialectal differences. But, as stated above, we are interested in the dialectal differentiation of PIE prior to the ultimate split of the PIE unity, i.e., somewhere about the year 3000 B.C., if we agree with those scholars (e.g., Milewski) who consider the third millenium B.C. the period of the dissolution of PIE.

So we should try to establish or reconstruct the oldest dialectal differentiation of PIE prior to the period of its dissolution, which was undoubtedly connected with a great expansion of the Indo-Europeans. Here I would like to remind the reader that the main dialectal differences usually consist of phonetic, phonemic, and lexical phenomena. The grammatical phenomena play a rather marginal role, since too many grammatical (i.e., morphological and syntactic) deviations break the linguistic unity of dialects and create serious problems in communication. In such a case we could speak about the boundaries between individual languages, rather than between dialects of the same language.

In this connection I would like to use another scheme of the PIE dialectal differentiation, which was proposed, quite incidentally, by Kuryłowicz in his L'apophonie en l'indoeuropéen (1956: 166-7). According to this view the oldest dialectal isoglosses dividing the PIE linguistic territory are, in the order of relative chronology, as follows:

1.) Kentum : satem, i.e., $k, g, g h$, and $k, \underline{u}, g, g, g h$ in the West are opposed to $k^{\prime}, g^{\prime}, g^{\prime} h$ and $k, g, g h$ in the East. Actually, the geographical distribution of the two dialect-groups is somewhat simplified since Tocharian, geographically the most eastern IE language in historical 
times, and Hittite, the most southeastern, both belong to the kentum group. For our purposes, however, we can neglect this fact and the prehistorical background of migrations and demographic shifts which caused the peripheral position of Tocharian and Hittite.

2.) European : Asian (i.e., Aryan) vocabulary is reflected first of all in the innovative agricultural terminology of the European branch (Tocharian and Hittite are included here!), whereas the Aryan branch either completely lacks the correspondences or has them represented on an archaic preagricultural (pastoral?) semantic level.

3.) North European undifferentiated vocalism $\breve{\bar{o}}$ (rather $\check{\bar{J}}$ ) : South European differentiated vocalism $\check{\bar{a}}$ : $\check{\bar{o}}$. Since the dialectal development of PIE vocalism is closely related to the fall of the laryngeals (a or $H$ ), we must make some indispensable clarifying remarks here.

Namely, Kuryłowicz proposes the following primary PIE vowel system, existing in the laryngeal epoch:

(i)

$\check{\bar{e}}$ (u)

ö (rather $\check{\check{J}}$ )

Then in connection with the fall of laryngeals, which took place after the separation of Aryan (or Pre-Aryan), we have the following subsequent differentiation:

a.) European (except Hittite) $H$, i.e., $a$, merged with $H_{2,4}+\check{o}(\breve{\jmath})$ :

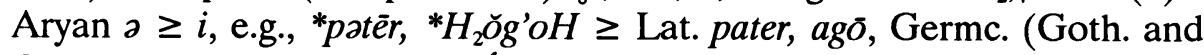
OIc.) faðar, akan : Sanskr. pitâ, ájati, etc.

b.) North European a merged with $H_{2,4}+\check{o}(\breve{\jmath})$ and with $\check{o}(\breve{\jmath})$,

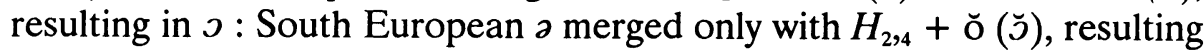
in $a$, but the primary $\check{o}$ remained as $\check{o}$, e.g., Germc. (Goth. and OIc.)

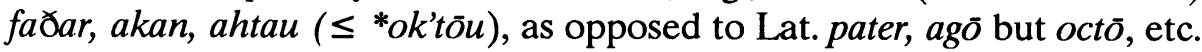
It should be added that in South European the long $\bar{a}$ vocalism appeared also from $H_{2,4}+\bar{o}$ and from the contraction of $\check{o}+H_{2,4} 1$ before consonants and in word-final position. Thus the appearance of the vocalism $\check{\bar{a}}$ characterizes the South European dialects of PIE in contradistinction to North European, where the fall of the laryngeals did not entail the differentiation of the primary $\breve{\bar{o}}(\overline{\bar{J}})$ into $\check{o}: \check{\bar{a}}$. In view of this, after the fall of the laryngeals in North European we ultimately have:

a $\left.) H_{2,4}+\check{o}\right\rceil \check{o} \geq \check{J}$ and $\left.H_{2,4}+\bar{o}\right\rceil \check{o}+H_{2,4} \backslash \bar{o} \geq \bar{\jmath}$

i.e., the system:

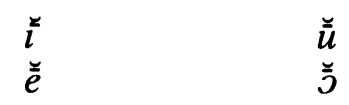

which obviously underlies the historical development of Germanic and 
Slavic, whereas for Baltic (Lithuanian and Latvian) we must accept a prehistorical differentiation between $\bar{a}: \delta$ (where $\delta$ continued the primary PIE $\delta, o+H_{1}$, and $e+H_{3}$ in archaic lexicalized examples); cf., e.g., Goth. bröpar, dōms (=Eng. doom), OIc. sót $\mathrm{n}$. (=Eng. soot) and Lith. brólis, broterẽlis but dúona 'bread', súodžiai 'soot', all from PIE *bhro $H_{2} t e \bar{r}$,

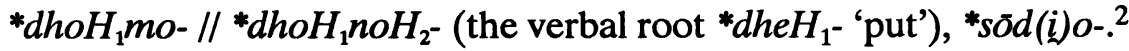

These changes, including also the disappearance of $a$ in word-middle and word-final syllables, entailed characteristic North European transformations of the primary IE apophony, particularly of the old relation full grade zero grade (cf. J. Kuryłowicz, 1956: Chapter V, § 24). Completing this digression I should also emphasize that by the satem group I understand (after J. Kuryłowicz, 1956: 356-64) those PIE dialects in which the primary system of the so-called gutturals, consisting of the palato-velar series $k^{\prime}, g^{\prime}, g^{\prime} h$ and the velar series $k, g, g h$, has been preserved, whereas in the kentum group it underwent a transformation

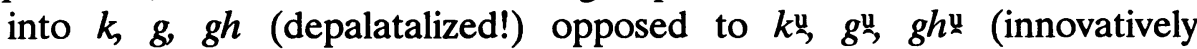
labialized!). Thus the relatively later assibilation, etc., of the palato-velars in the satem languages, e.g., Lith. šintas, žañbas, Slav. što, zqbъ, OI satám, jámbha-, etc., is a secondary change, which only indirectly proves the primary situation.

Below are some typical examples of the satem $\sim$ kentum differentiation. (See Chart 3 on the next page)

After all the above remarks I can now present the PIE dialectal differentiation according to Kuryłowicz in the following diagram:

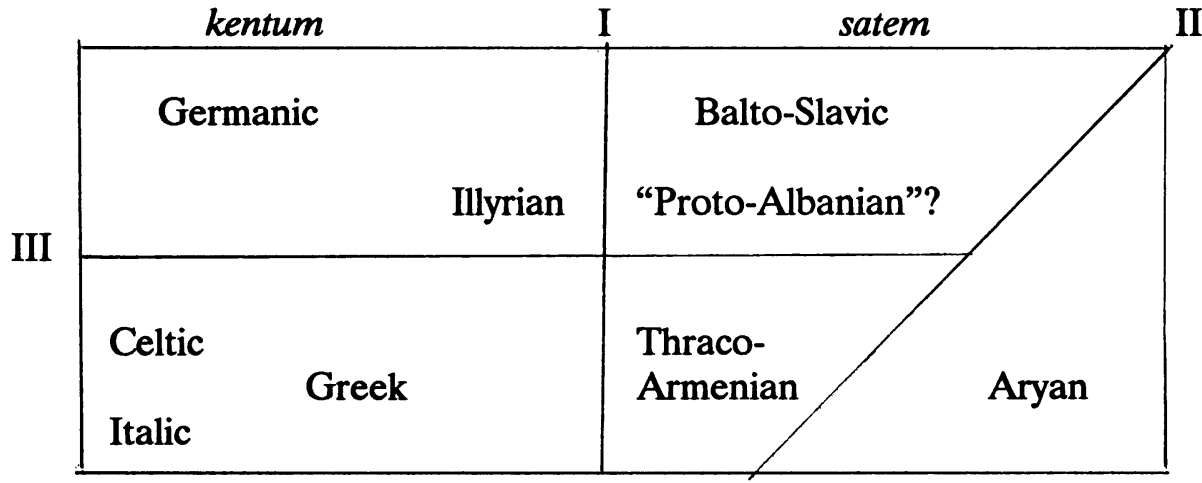



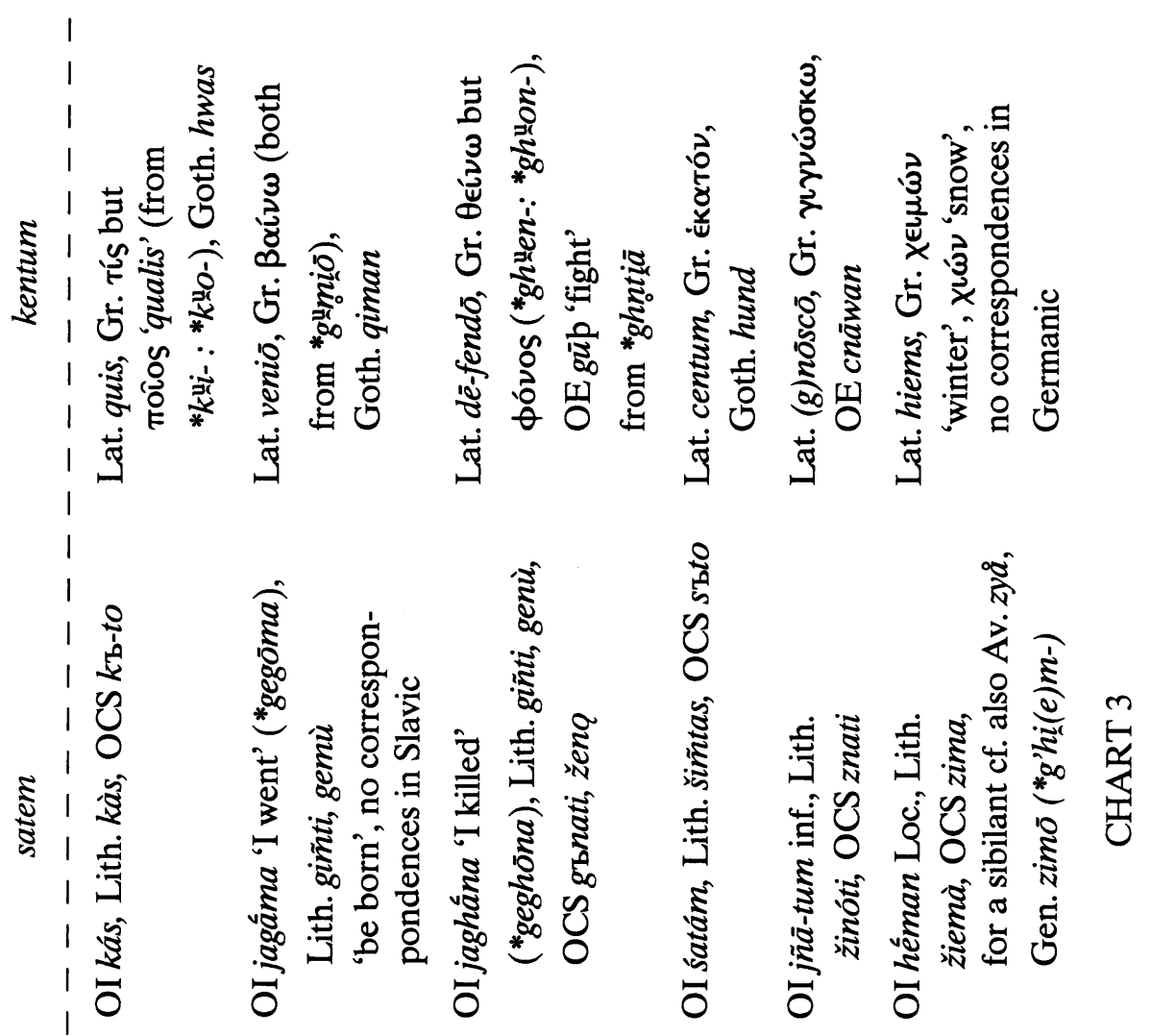

떨 $1 \frac{1}{3}$

1

\%

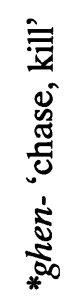

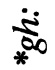

공

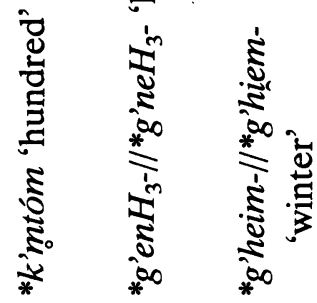

華获范 
Note that in the above diagram Hittite and Tokharian have been omitted since they are irrelevant in our discussion.

The above diagram can be supplemented by other isoglosses representing some morphological (e.g., North European case desinences with $-m$ as opposed to those with $-b h$ - in other PIE dialects) and lexical phenomena. I will devote to this problem the following paragraphs of this chapter. Here it suffices to state that the diagram based upon Kuryłowicz's presentation has significant advantages over the previous ones. It undoubtedly reflects the oldest dialectal differentiation of PIE, and it can easily be projected on the map of Eastern Europe, if we agree that it is somewhere there that we should look for the oldest habitat of the Indo-Europeans.

The position of Slavic within Indo-European is shown clearly in the above diagram. Exactly speaking, as long as we have in mind the situation of the primary IE dialects about the year 3000 B.C., we should rather speak about Pre-Slavic, i.e., that PIE dialect from which in the course of time the later Proto-Slavic (Common Slavic) and subsequently the historical Slavic languages developed. As we see, Pre-Slavic, closely connected with Pre-Baltic (Balto-Slavic on our diagram)-about this connection we will speak later on-belongs to the North European dialectal group, within which it has as its neighbor or "partner" Pre-Germanic. Pre-Illyrian and Pre-Albanian we can neglect in this context because about the former we do not know enough and about the latter our knowledge is quite controversial, although recent contributions of E. Hamp prove its close relations to Balto-Slavic. So the main problem seems to be the substantiation of the membership of Slavic in the North European dialectal group or zone within late PIE. Of course, this zone was from the very beginning divided into the kentum (western) area and the satem (eastern) area. Postponing the analysis of common North European lexical elements (innovations?) to the next chapter, let us nevertheless list some phonological and morphological features which could be assigned to the Germanic-Baltic-Slavic dialectal zone (cf. Lehr-Spławiński, 1946: 32-33, and Kuryłowicz, 1957: 74-81).

1.) The metathesis of the syllabic function of sonorants in the primary clusters -rn-, e.g., Goth. drunkum, 'we drank', OCS kręnqti (*krint-) 'deflectare', Lith. krintù idem $\leq{ }^{*} \mathrm{Crn} n C$ but OI krnntati etc. $\leq{ }^{*} C r n C$.

2.) The case desinences with $-m$ - as opposed to those with $-b h$ - in other IE languages, e.g., the dative pl. Goth. nahtim (= NHG Nächten), Lith. naktìms, OCS noštımı but OI naktibhyah, Lat. noctibus; of course, the same element appears in the instr. pl. and sg., cf., e.g., OCS noštımi :

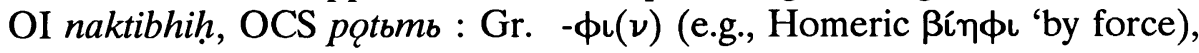
etc. 
3.) The demonstrative pronoun based upon the particle ${ }^{*} k i$, e.g., Goth. Dat. sg. himma (daga) = Germ. heute 'today', OCS sb, si, se, Lith. šìs, šì.

4.) The numerals 10-100 represent a syntactic construction consisting of the names of units and tens, e.g., Goth. preis tigjus, Lith. trýs dẽšimtys, OCS trije desęte / tri desęti ' 30 ', etc., whereas in other IE languages these

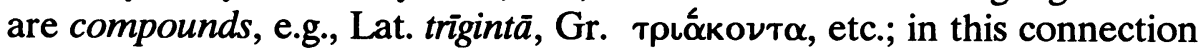
the North European innovation for the numeral '1000' - *tüsk'mitīa should be mentioned (see below).

5.) A parallel formation of the intransitive verbs in -ne- and the transitive (causative) ones in -ei-, which is found only in Germanic and Slavic, e.g., Goth. usgeisnan 'sich entsetzen' usgaisjan, its causative, OCS užasnoti sę idem užasiti, etc. There are also some special derivational correspondences between Germanic and Baltic, such as the common formation of the numerals '11', '12' (Goth. ainlif, twalif $\sim$ Lith. vienúolika, dvýlika), which, however, we can omit in this connection. Special North IE lexical correspondences will be discussed in the next chapter.

This view about the close dialectal relations between Pre-Balto-Slavic and Pre-Germanic is corroborated among others by W. Porzig in his synthesis "Die Gliederung des indogermanischen Sprachgebiets" (1954), where he clearly states:

Die Beziehungen des Germanischen zum baltisch-slavischen Raum bewegen sich im allgemeinen auf dem Gebiete der natürlichen Umwelt und einfachster Wirtschaftsformen. Nur die gemeinsamen Wörter für 'Gold', 'tausend', 'herrschen' bekunden eine höhere Entwicklung des wirtschaftlichen und staatlichen (sic!) Lebens. Sie gehören alle drei in den gemeinsamen Neuerungen des Germanischen, des Baltischen und des Slavischen. Es war eben eine Auswirkung der mehr entwickelten Wirtschaft, daß sich solche Wörter einheitlich über ein größeres Gebiet verbreiteten.

Alle Nachbarschaft zwischen dem germanischen, dem baltischen und dem slavischen Sprachgebiet und sprachlicher Austausch unter ihnen steht trotz namentlich von Hirt geäußertem Zweifel fest. Das Germanische hat engere Beziehungen zum Baltischen und Slavischen als zu irgendeiner anderen Sprache außerhalb der Westgruppe. Nur dem Lateinischen steht es offensichtlich näher. Es unterscheidet sich demnach von den anderen Angehörigen der Westgruppe, die alle nur geringe spezielle Beziehungen 
zu östlichen Sprachen haben.

(Porzig, 1954: 147)

The above views of $\mathrm{W}$. Porzig, written seventeen years before a special monograph by $\mathrm{Ch}$. Stang devoted to Germanic-Balto-Slavic lexical correspondences (see below), coincide with the views of the latter. Thus the prehistorical North European dialectal zone within late PIE (whatever its precise chronology) seems to be well substantiated.

Now we should pass to the highly controversial problem of the so-called prehistorical Balto-Slavic linguistic unity. First, before answering the question of whether such a "unity" - a kind of Common Balto-Slavic as an intermediary proto-dialect from which the historical Baltic and Slavic languages developed-existed at all, let us objectively enumerate all the prehistorical linguistic changes which are shared by Baltic and Slavic but are unknown in other IE languages, and which can therefore be treated as common Balto-Slavic innovations, originating in a prehistorical epoch when the linguistic ancestors of the Balts and Slavs maintained close socio-linguistic contacts after having broken their ties with the other IE dialects (sometime between 2500-1000 B.C.?). We should emphasize here the phenomenon of common linguistic innovations, not the common preservation of linguistic archaisms inherited from the PIE epoch, because only the former prove a period of common dialectal Balto-Slavic development. And as historical dialectology instructs us, the spread of common innovations in a linguistic territory requires a demographic continuum and an easy socio-cultural exchange between the respective population groups. So, depending on the kind and quantity of the prehistorical Balto-Slavic linguistic innovations, we can reconstruct the character of the social ties between these two ethno-linguistic groups in prehistorical times. The list of common Balto-Slavic innovations is arranged in the order of relative chronology (see Szemerényi, 1957: 97-121; Kuryłowicz, 1957: 79-113; Stang, 1966: 17-21).

1.) The palatalization of all the consonants by $i: C+i+V \geq C^{\prime}+V$ (for details see Kuryłowicz, 1957: 88-91). ${ }^{3}$

2.) The split of PIE $r, l, m, n$ into the sequences $i r / u r, i l / u l, i m / u m, ~ i n / u n$ with the vocalism $u$ primarily only after velars, e.g., OPrus. curwis 'ox', PSl. *karvz (cf. Pol. karw) related to B-S *käruāa-, i.e., Lith. kárve, PSl. *korva (cf. Pol. krowa, Russ. koróva, S-C kräva, etc.); the phonetically conditioned distribution of ir/ur etc. was later, already in the prehistorical epoch, obscured by secondary morphological levellings so that ultimately in the same morpheme we can have ir $\sim u r$, the former being a regular, morphologically productive treatment, the latter occurring only in 
derivationally isolated (unproductive) formations, e.g., PIE *grHtó- $\geq \mathrm{B}-\mathrm{S}$ *gïrta-, from which Lith. gìrtas 'drunk', PSl. *žbrtz (cf. OCS požrbtz, Pol. zarty, etc.) 'devoured', an old past passive participle $\sim$ PIE ${ }^{*}$ grH-dhlo/dhro/tlo- $\geq \mathrm{B}-\mathrm{S}{ }^{*}$ gürdla- and *gürtla-, from which PSl. *gordlo (cf. S-C grlo, Pol. gardło, Russ. górlo, etc.) 'throat' and Lith. gurklỹs

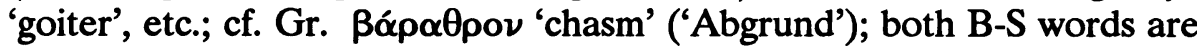
derived from the PIE verbal root *gerH- 'swallow, attested among others by Lith. geriù, gérti 'drink', PSl. *žbrq, *žerti (cf. OCS požbro, požrěti, Pol. pożrę, pożreć, Russ. požrú, požrát', etc.) 'devour', OI giráti, grnáti 'swallow',

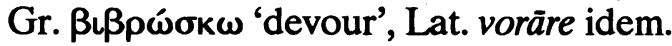

3.) The development of long diphthongs (diphthongs with a long first component) as a result of the fall of the laryngeals in PIE and early B-S sequences of the type $V R H+C(V R a+C)$, thus $V R H C \geq \bar{V} R C$ (where $R$ $=\dot{b}, \underline{u}, r, l, m, n$, and $H=$ laryngeal). For example, PIE * g'enH-to/ti- B-S žēnta-//žênti- from which Lith. žéntas 'son-in-law', Slav. zętı idem (cf. Pol. zięć, Russ. zjat', S-C zềt, etc.); PIE *bherHg'oH ${ }_{2}-\geq$ B-S bēržā-, from which Latv. bērza, Lith. béržas (m.!), Slav. *berza (cf. Russ. berëza, Cz. břža, S-C brèza, Pol. brzoza, etc.) 'birch'; for comparative IE material see Trautmann, 370, 32.

4.) The B-S retraction of the primary IE stress from word-middle short vowels onto the preceding long vowels and as the result of this retraction - the appearance of a pitch distinction (long rising : long falling) within initial syllable containing long vowels; then the shortening of the primary long diphthongs, i.e., the passage of $* \bar{V} R C \geq V R C$. These changes ultimately produced-also through morphological analogy - pitch distinctions of the following type:

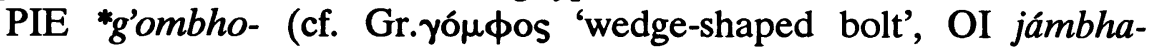
'tooth') $\geq$ B-S *žamba- from which Lith. žam̃bas 'edge', PSl. *zōbs 'tooth'

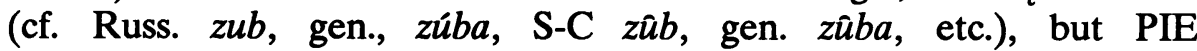

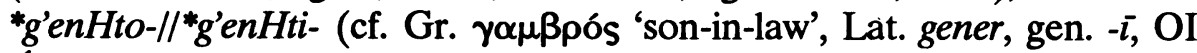
jâmatar- idem, although the connections are not regular since the B-S word undoubtedly underwent the influence of the verb * ${ }^{*}$ 'enH $_{3^{-}}$'to know') $\geq$ B-S žênta-//*̌̌ênti-, from which Lith. žéntas 'son-in-law', PSl. "zęttb idem (cf. Russ. zjat', gen. zjátja, S-C zềt, gen. zèta, etc.). ${ }^{4}$

Other examples: PIE (kentum) *ghordho- (cf. Pokorny, 444 s.v. g'herdh- 'umfassen, umzäunen, umgürten') $\geq$ B-S *garda- from which Lith. gar̃das 'pen, corral', PSl. *gõrds 'fort, town' (e.g., Russ. górod, gen. góroda, S-C grâd, gen. grâda, etc.), but PIE (kentum) *korHuno- (cf. Gr.

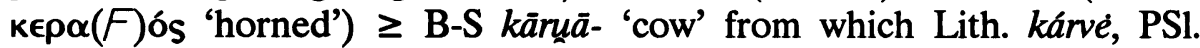
*kórva (e.g., Russ. koróva, S-C krâva, etc.).

5.) Common B-S changes in vocalic apophony (vowel gradation), especially the lengthening of the PIE $\emptyset$-grade (represented in B-S by $i / u$ in 
the primary diphthongal roots), thus B-S $i / u \rightarrow \bar{\imath} / \bar{u}$, e.g. PIE *dhus-, *kup-, *uid- lengthened into B-S dūs-, küp-, üid- in *dūsētei, *küpētei, *uìdētei, from which Lith. dūséti Slav. dyšati, Lith. küpéti Slav. kypěti, Lith. pa-vydéti 'envy' Slav. vidéti (see Kuryłowicz 1957: 96-97); then the lengthening of the root vowel (open syllable!) in the iterative verbs with the B-S suffix -äje, e.g., Lith. súpoju, súpoti 'rock' Slav. sypajq, sypati 'pour' from the basic durative B-S *supo, *supti, etc., and ultimately the lengthening of the root vowel ${ }^{5}$ in the primary athematic verbs ${ }^{*} b h e g$ 'run', *ed- 'eat', *sed- 'sit', *sek- 'cut': thus B-S bēgmi, èdmi, sēdmi, sēkmi, etc., from which Lith. bégu, bégti Slav. *běgq (Russ. begú), *běkti (Russ. dial. beč’, Pol. biec, etc.); Lith. édu (+émi), èsti Slav. (OCS) jamb, -ěmb, jasti, -ěsti; Lith. sédu, sésti Slav. (OCS) sędo, sěsti; Lith. ìsékti 'engrave', išsékti 'carve' Slav. (OCS) sěkg, sěšti; for comparative IE material see Kuryłowicz, 1957: 106-107.

The above phonemic and morphophonemic innovations of Balto-Slavic are arranged in the order of their relative chronology. This point is relevant because the relative chronological ordering enables us to determine the beginnings of the prehistorical common Balto-Slavic development, i.e., the separation of Balto-Slavic from the other IE dialects. As the above list indicates (suggests), that development began at the time when the PIE dialects still preserved laryngeals, i.e., undoubtedly before the year 2500 B.C., terminus ad quem we can speak about a relative unity of PIE dialects. The most obvious proof of this chronology is the development of ${ }^{*} R H C \geq \bar{i} / \bar{u} R C$ and $* V R H C \geq \bar{V} R C$ in Balto-Slavic. So the separation of Balto-Slavic from the other PIE dialects started before the ultimate dissolution of the PIE linguistic unity and continued after the year 2500 B.C. in the later period of the relative isolation of Balto-Slavic from the other IE dialects or languages (2500-1000 B.C.?). How long that common B-S period or dialect lasted is difficult to say. Some clues could be provided by the comparative analysis of Baltic and Slavic vocabularies, about which see Chapter 3.

Now we should move on to the list of common Balto-Slavic innovations in morphology, including both derivation and inflection. In this connection, however, I would like to quote a statement by Kuryłowicz (1957: 112-113) in which this outstanding indo-europeanist evaluates the relative significance of phonological and morphological evidence for prehistorical relationship (i.e., genetic relations) between languages: "Therefore we are inclined to consider the changes discussed under II-IV [i.e., all the above changes $1-5$ in my presentation] the strongest arguments for the B-S linguistic unity. First of all the palatalization of all the consonants (by $i$ ) and the characteristic change of accentuation can be regarded as those innovations which clearly 
separated both linguistic groups from the neighboring IE languages, much as the so-called "consonant shift" did for the Germanic group. The agreement in the semantic change of this or that morpheme, the extension or limitation (including disappearance) of the use of some morphemes, common formation of new suffixes through the integration of the old ones-are, undoubtedly, also desirable and useful arguments, supporting the thesis about the B-S unity, but their importance recedes before that of the points presented above."

What follows is simply a list of Balto-Slavic morphological innovations repeated after Stang (1966: 18-20, 10-12).

1.) The suffix -ima- (i.e., PIE -imo-) in verbal-abstracta, e.g., Lith. piešimas 'drawing' Slav. pisbmo 'writing', etc.

2.) The suffix - -̌ba in abstract nouns, e.g., Lith. ganýba 'Hüten, Weiden', Latv. draudziba 'Gemeinschaft, Freundschaft' $\sim$ Slav. *gonbba (cf. Russ. gon'bá 'Jagd, Galopp'), družbba, etc. This suffix is highly productive in Balto-Slavic.

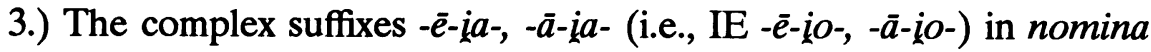
agentis, e.g., Lith. artójas 'tiller' $\sim$ Slav. *ortajb (cf. OCS ratajb) idem,

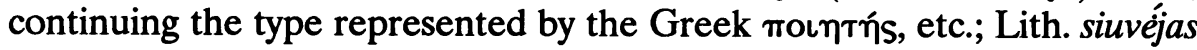
'Schneider' Slav. *̌̌bvějb (cf. ORuss. švěj) idem, etc.

4.) The suffix -ika- (i.e., IE -iko-) also in nomina agentis, e.g., Lith. siuvikas 'Schuster' Slav. *šbvbcb (cf. Russ. švec, Pol. szewc, etc.) idem, etc.

5.) The suffix -ït(i)ia- (i.e., IE -ït(i)io-) expressing 'belonging to' and 'diminutiveness', e.g., Lith. sūnýtis 'little son' Slav. *otročitjb 'little boy' (cf. OCS otročištb), etc.

6.) The suffixes: Lith. dial. -inỹkas, Slav. -bnikz, e.g., Lith dial. arklinȳkas 'stableman' OCS dlъžbnikъ 'debtor', etc., correspond to each other semantically, but because of the standard Lith. -ininkas and Latv. -nieks in the same function the formal correspondences are not completely clear.

7.) The verbal type in *auie- in the present tense and *aūa- in the past (or infinitive), e.g., Lith. keliáuja 'he travels' : keliãvo 'he travelled' S-C kùpujē : küpovā (i.e., PSl. kupujetz 'he buys' : kupova 'he bought'), etc.

8.) The past tense (praeteritum) in *-a, e.g., Lith. pirko 'he bought' (pres. perka) Slav. aor. pbsa (pres. pišetz), etc.; this type of past is more productive in Baltic than in Slavic.

9.) The praeteritum in ${ }^{*}-\bar{e}$, which in Baltic completely replaced the primary $s$-aorist, and in Slavic is found in the imperfect forms of the type vedé-axz from vede-tz, etc., e.g., Lith. vẽdé (pres. vẽda), etc.

Actually we can speak about a common Balto-Slavic pattern of present 
versus preterit stem dichotomy with the utilization in the latter stem of the same suffixes $(-\bar{a},-\bar{e})$. In this case the Slav. imperfect of the bura-axz type should be compared with the Lith. past of the pirko type, like vedè-axb with vẽde, etc. Of course, that common B-S preterit later underwent a secondary morphological transformation in Slavic toward the imperfect or aorist, cf., e.g.,aorist bbra : imperf. bbra-aše, etc. (cf. A. Vaillant, 1966: 46-47, 66-67).

10.) The innovative form of the oblique cases of the pronoun 'I'-*me/an- (IE *me/on-) generalized from the genitive, e.g., Lith. gen. manęs, dat. mán, acc. manè, instr. manimi, loc. manyjè Slav. mene, dat.-loc. mъně , instr. mъnojq; here also the innovative gen. pl. of 'we' *nōsōm can be quoted: Lith. músu (instead of *núsų or rather *núosu) Slav. nass, etc.

To the above morphological B-S innovations we can also add some listed by Szemerényi (1957: 97-123), namely:

11.) The compound declension of the definite adjective utilizing the same IE pronoun *io- as a kind of postpositive article, e.g., Lith. gẽras : geràs-is, gerà : geró-ji Slav. dobrı : dobrъ-jb, dobro : dobro-je, dobra : dobra-ja, etc.

12.) The extension of the oblique cases of participles (present active and past active masculine and neuter) by the stem suffix - $i a-$ (IE - io-), e.g., Lith. gen. sg. nẽšančio, acc. sg. nẽšanti, etc. OCS gen. sg. nesošta, acc. sg. nesqštb, etc., both from B-S nešantịa-; Lith. gen. sg. nẽšusio, acc. sg. $\quad$ ẽšusį OCS gen. sg. nesъša, acc. sg. nesъšb, etc., both from B-S nešusia-, etc.

13.) The formation of the comparative with the complex suffix *-ēiōs-, e.g., Lith. geriáus-ias ${ }^{6}$ (actually the superlative) from gẽras $\sim$ Slav. starějb (neuter starěje, oblique and feminine starějbš-) from starı (as the OCS example shows, Slavic has generalized the zero vocalism of the suffix: -ẹ̌ibš- from IE *-ęios-).

14.) The replacement of the PIE demonstrative pronominal nominatives ${ }^{*} s o / /{ }^{*} s \bar{a}$ by ${ }^{*} t o s / / *^{*} a \bar{a}$, e.g., Lith. tàs//tà $\sim$ Slav. tż//ta.

Common B-S innovations in the vocabulary are treated in Chapter 3.

In the above survey I have omitted innovations affecting either only one lexical item (although semantically important), such as the characteristic transformation of the present tense of the verb

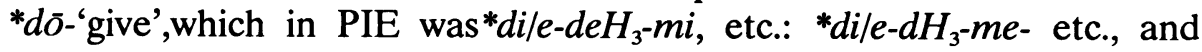
which in Balto-Slavic shows the paradigm ${ }^{*} d \bar{o}(d) m i,{ }^{*} d \overline{s i}$, ${ }^{*} d \bar{s} t i$, *do $(d) m e,{ }^{*}$ doste, *dodinti (cf. OLith. duosti OCS dastz, etc.) - and innovations common only to Slavic and to a part of the Baltic languages, such as the often quoted replacement of the primary IE genitive sg. of the $o$-stems by the form of the ablative, which connects only Slavic and 
East Baltic (Lithuanian and Latvian), e.g., Lith. diẽvo (nom. sg. diẽvas) Slav. diva (nom. sg. divz, attested in ORuss.); but OPruss. preserves the primary IE desinence *-s(i)o, e.g., OPruss. gen. sg. deiwas (nom. sg. deiws, deywis): for the primary situation cf. OI gen. devasya: abl. devāt, etc.

Stang considers these (partial) agreements between Slavic and only East Baltic or West Baltic (Old Prussian) older than common Balto-Slavic innovations, i.e., innovations including all the Baltic languages. I do not see any convincing argument for this view (cf. Stang 1966:12). In any case one point is worth emphasizing here: the special, characteristic innovative correspondences between Slavic and East Baltic (Lithuanian and Latvian) are more numerous than those between Slavic and Old Prussian. Prussian seems to take a peripheral (western) position within Balto-Slavic (cf. its vocabulary with Germanic connections, Stang, 1966: 12-13).

The rich evidence of common B-S innovations presented above strongly supports, I think, the hypothesis about a prehistorical B-S dialectal period or zone. This practically boils down to the acceptance of a kind of prehistorical B-S dialect from which both the historical Baltic and Slavic languages can be derived. Of course, that prehistorical B-S dialect was never completely uniform, as is the case with all larger dialects, i.e., those which cover a large territory. Then we should also remember that already in the prehistorical epoch Balto-Slavic underwent a split into the Baltic (internally quite differentiated: West-East) and Slavic halves, i.e., Proto-Baltic and Proto-Slavic. When that split occurred is difficult to say, since we have no extralinguistic historical evidence about the life and development of the respective tribes. The linguistic evidence drawn from the old differences between the Common Baltic and Common Slavic cultural vocabularies, which seems to suggest quite an early split between the Balts and the Slavs (i.e., the Proto-Balts and the Proto-Slavs), will be discussed later. As far as historical evidence is concerned, I would call the reader's attention to the Scythian invasion of the Pontic steppes (i.e., the southern part of the present-day Ukraine) about the year 700 B.C. This important historical event undoubtedly caused great demographic shifts in the adjacent (northern and western) territories, comparable to those triggered in the thirteenth century A.D. by the Mongols. Thus I am inclined to see in the Scythian invasion and the subsequent population movements on the Balto-Slavic territory the cause of the ultimate split between the Proto-Balts (or Eastern Balts?) and the Proto-Slavs. The former started moving westward towards the Baltic Sea along the Dvina and Niemen rivers; the latter also began to move in the westerly direction, but following a more southern route, across Wolynia toward the Vistula basin. In this way the two groups, or 
rather the main bulks of the Balts and the Slavs, were separated from each other by the Prypeć marshes.

After all that I subscribe to the following statement by Szemerényi (1957: 120, §24): "In spite of the strictures just quoted, I feel that the reader would like to see at the end of this long survey a catalogue raisonné of those features which, in my view, decide the question in favour of the theory of BS unity, and against Meillet and his present-day followers. The most important innovations, which cannot be ascribed to chance or "parallel" development and thus prove a period of common language and life [author's emphasis], are as follows..." (The known list of fourteen innovations, with all the lexical innovations quoted under one point [sic!], follows.)

Anybody who has an opportunity to study Lithuanian and Old Church Slavonic against the comparative background of other older IE languages (such as Latin, Greek, Gothic, Avestan, Sanskrit, etc.) is undoubtedly impressed by the high degree of "conservatism" of these two languages. This linguistic conservatism consists in the preservation of the essential features of PIE phonology and the essential features of PIE morphology, not to mention the preservation of the basic IE vocabulary. Limiting our examples to the North European dialectal group, i.e., Germanic-Baltic-Slavic, we can substantiate the above statement with the following selected facts:

1.) The preservation of the PIE opposition between voiceless and voiced obstruents with the elimination only of aspirates, i.e., PIE ${ }^{*} p,{ }^{*} b$, ${ }^{*} b h,{ }^{*} t,{ }^{*} d,{ }^{*} d h,{ }^{*} k^{\prime},{ }^{*}{ }^{\prime},{ }^{*} g h,{ }^{*} k,{ }^{*} g,{ }^{*} g h \geq \mathrm{B}-\mathrm{S} p, b, t, d, \check{s}, \check{z}, k, g$. This situation is sharply opposed to that of Germanic, where owing to the so-called Lautverschiebung the PIE pattern ${ }^{*} p:{ }^{*} b:{ }^{*} b h$, etc., was replaced by $f: p: b$, etc., e.g.,

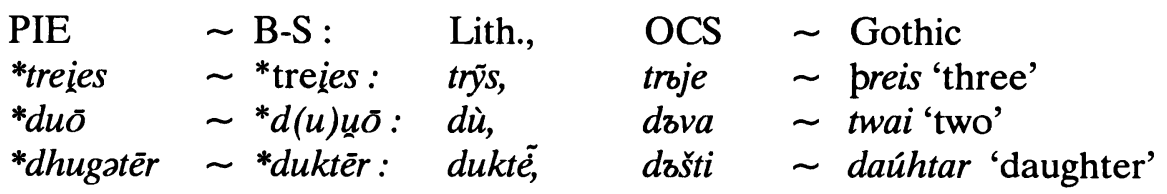

This fact is very important: together with the preservation of PIE *s, which only under some conditions passes into $\check{s}$ in Lith. and $x \sim \check{s}$ in Slav., it accounts for the survival of the primary IE consonantal skeleton of words and derivational suffixes in B-S, e.g., PIE *nebhos, gen. *nebheses 'cloud', etc. (cf. skr. nabhah, gen. nabhasah, etc.) OCS nebo 'sky', gen. nebese, etc. $\sim$ Lith. debesis (with the shifting of this type of stem to the

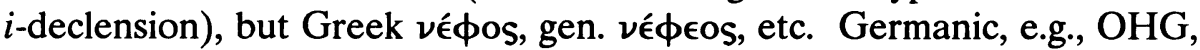
preserved the traces of the -es stems only in the plural: lamb-ir 'lambs', where $-i r \leq *_{-}$es-a, etc. Thus OCS nom. pl. nebesa, Russ. nebesá, Pol. 
niebiosa, etc., preserve the PIE consonantal skeleton of the stem with only slight changes: *nebhes- $\bar{a}$, etc., whereas Greek already shows a more altered shape: $\nu \in ́ \phi \in \alpha, \nu \in ́ \phi \eta$, etc.

2.) In order to realize the conservatism of B-S morphology, it is sufficient to take a look at some nominal paradigms, e.g., the stems in $-u$ (the noun *sūnus 'son'):

$\begin{array}{lllll} & \text { PIE } & \text { Lith. } & \text { OCS } & \text { Goth. } \\ \mathrm{N} & \text { sūnus } & \text { sūnùs } & \text { synz } & \text { sunus } \\ \mathrm{A} & \text { sūnum } & \text { súnù } & \text { synz } & \text { sunu } \\ \mathrm{G} & \text { sūnous } & \text { sūnaũs } & \text { synu } & \text { sunaus } \\ \mathrm{D} & \text { sūnoùei } & \text { súnui } & \text { synovi } & \text { sunau } \\ \mathrm{I} & \text { sūnumi (dial.) } & \text { sūnumì } & \text { synzmb } & \emptyset \\ \mathrm{L} & \text { sūnōu } & \text { sūnūjè } & \text { synu } & \emptyset \\ \mathrm{V} & \text { sūnou } & \text { sūnaũ } & \text { synu } & \text { sun }(a) u\end{array}$

Notice the number of cases in B-S: besides the so-called "grammatical" cases (the first four) there are still the instrumental and locative, lacking, e.g., in Gothic (the remnants of the instrumental are still attested in OHG, OSax., and OE).

The conservatism of Balto-Slavic within the IE linguistic family has been noticed and emphasized by many scholars, e.g., in the well-known book Kultur, Ausbreitung und Herkunft der Indogermanen (1913) S. Feist clearly states: "Manche ihrer Sprachgebilde stimmen mit den erschlossenen indogerm. Grundformen genau überein: lit. gývas 'lebend', ẽsti 'ist', russ. pekú 'koche', sěmená, 'Saaten', nová 'Neuigkeit' [sic!], usw. Einzig unter allen indogerm. Sprachen hat die baltisch-slavische Gruppe den indogerm. Wortakzent häufig an der ursprünglichen Stelle und (im Litauischen) in seiner alten Gestalt (als musikalischen Akzent...) erhalten. Der Wortschatz ist zum größten Teil in beiden Sprachgruppen identisch und auch die Entlehnungen aus fremden Sprachen (vornehmlich dem Germanischen) sind zumeist dieselben. Nennenswerte Neuerungen hat weder die slavische noch die baltische Gruppe eingeführt: sie sind die konservativsten aller indogerm. Sprachen...." (S. Feist, 1913: 454).

The above statement, even with all due corrections and attenuations, nevertheless reflects the basic truth about B-S, which cannot be denied.

Of course, there is a clear difference between the degrees of conservatism of Baltic and Slavic (if we compare, for example, Lithuanian with Old Church Slavonic). The relatively more conservative character of Lithuanian phonology is recognizable at first glance, e.g., in the vowels the preservation of $i, u \sim$ whereas in Slavic we already have the 'jers' ( $b$, z); the preservation of $\bar{u} \sim$ Slav. $y$; the preservation of the sequences $e N$, 
$i N, a N, u N$ before stops $\sim$ Slav. $\varepsilon, Q$; the preservation of the primary sequences $e r / l, a r / l+C \sim$ Slav. metathesis and/or polnoglasie, etc.; and the most important for the reconstruction of the primary B-S inflectional morphology - the preservation of word-final $-s$, dropped in Slavic in the prehistorical epoch. All these archaic features of Baltic (as illustrated by Lithuanian) allow us to interpret historically, i.e., to derive Slavic forms from Baltic, not vice versa, which led the two Russian scholars V. V. Ivanov and V. N. Toporov (1961) to a simplified statement that Slavic (Proto-Slavic) could be treated as a descendant of Proto-Baltic.

The problem of a relative evolutionary conservatism of separate dialects or languages within a given linguistic family, which emerges in connection with the position of Balto-Slavic within Indo-European, is very important: it concerns not only the linguistic history of the given language family, but also its ethnic history (including prehistory), and particularly the genesis of separate ethnic groups within a given linguistic family. Methodologically, however, we should clearly distinguish two different aspects of "linguistic conservatism" as opposed to "linguistic innovatism". These two aspects reflect two different aspects of language as such, namely: the lexical substance and the grammatical form. By the former, as was formulated in Chapter 1, I understand the whole inventory of morphemes, both lexical and grammatical (e.g., PSl. *ortajb, OCS ratajb, etc. 'tiller', divided into the root or-, cf. orjo, orati, etc. 'till', the suffix -taj-, the desinence $-\mathbf{b}$, etc.). By the latter I understand the system (i.e., closed set) of grammatical categories and the system of formal techniques applied to express these categories (e.g., the nominal cases expressed by desinences, etc.). Now, it is obvious that a language may be conservative or innovative either with respect to its lexical substance or its grammatical form, or with respect to both. The substantial conservatism or innovatism, which ultimately consist in the amount of phonemic change which the main bulk of morphemes undergoes (including here also the preservation or elimination of a significant portion of basic vocabulary), I propose to call "genetic" conservatism or innovatism. The formal conservatism or innovatism, which ultimately consist in the preservation or transformation (including elimination) of primary grammatical categories and the formal techniques of their expression, I propose to call "typological" conservatism or innovatism. When discussing the conservatism of Balto-Slavic in comparison with other IE languages, and that of Slavic in comparison with Baltic, we should specify what kind of conservatism we have in mind. For a language (of course always with respect to other languages of the same family and their common source, Ursprache) may be genetically very conservative and typologically innovative, or vice versa, genetically very innovative but typologically 
conservative; a language may also be conservative or innovative in both respects. These distinctions are essential for the understanding of linguistic evolution and for any extralinguistic inferences, especially those concerning ethnic prehistory, we can make on the basis of linguistic facts.

Of course, in order to characterize a concrete IE language from the standpoint of conservatism or innovatism as defined above, we must know (i.e., reconstruct) not only the set of basic lexical and grammatical morphemes of PIE (Ursprache) but also the set of PIE grammatical categories, i.e., the linguistic type which PIE represented. The latter task is not easy, since there is the inherent danger of a vicious circle in the whole procedure. But if the main ancient IE languages, such as Greek (Homeric), Latin (archaic), Sanskrit (Vedic), Avestan (older) agree on a grammatical point, e.g., the use of cases, we can be relatively sure that such an agreement reflects the situation prevailing at least in late PIE.

As we have seen, the linguistic conservatism of Balto-Slavic, especially with respect to Germanic, has chiefly a genetic character, i.e., it concerns first of all the preservation of the phonemic shape of the primary IE morphemes with only slight changes. On the other hand, Slavic (i.e., Proto-Slavic in its later period) shows a striking degree of genetic innovatism with respect to Baltic. The question is whether Slavic is also typologically innovative with respect to Baltic. The answer to this question would require a detailed grammatical study, calling for a separate book. Here I will mention only some phenomena which indicate that the problem is not so simple. In the system of verbal tenses, for example, Slavic (e.g., OCS) seems to be more conservative than Baltic (e.g., Lithuanian) since it preserves the old IE aorist (both asigmatic and sigmatic) and continues in a remodeled form both the old IE category of the imperfect (influenced clearly by the sigmatic aorist) and that of the resultative perfect (e.g., from vedo we have OCS asigmatic aorist vedz, sigmatic věsz, remodeled imperfect veděaxz, remodeled compound perfect velz jesmb, etc.). Baltic (Lithuanian), however, seems to have simplified the primary IE (i.e., late PIE) past tense system, showing only the so-called Baltic praeteritum, which as a whole is substantially a Baltic innovation, although it can be treated functionally as the continuation of the PIE aorist. Besides that, Baltic (only Lithuanian) also has a relatively young formation of praeteritum frequentativum (denoting habitual actions in the past), which can be treated functionally as a continuation of the $\mathrm{PIE}$ imperfect. In the words of J. Otrębski, "Present and future have been preserved, but IE imperfect, aorist, perfect and pluperfect have been lost and the corresponding forms have been replaced by a peculiar Baltic "praeteritum", and a "praeteritum frequentativum" so characteristic of Lithuanian has been introduced" (Otrębski, 1956: III, 179), e.g., from 
the verb vedù we have in Lith. the praeteritum vedžiaũ (the stem vẽde $=$ Slav. vedě- in vedě-axz, etc.) and the praeteritum frequentativum vèsdavau, etc.

But in the nominal system, Baltic seems to be typologically more conservative than Slavic. I mean here the syntactic use of the cases, especially the use of the genitive and prepositionless locative. But against a deeper comparative-historical background the above impression proves to be illusory. From the standpoint of historical IE linguistics the use of an adnominal genitive as a relational modifier (among other things as possessive, etc.) instead of a denominal adjective (the latter being so characteristic of an older stage of Slavic, in OCS), is an innovation, not an archaism in Lithuanian. Thus OCS cěsarbstvbje nebesbskoje is typologically

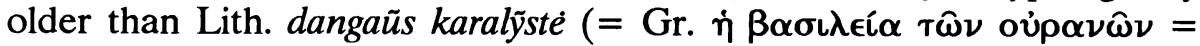
Lat. regnum coelorum = Eng. the kingdom of heaven); for the whole problem see E. Fraenkel, 1928: 89-102, and J. Wackernagel, 1908: 137-146.

The prepositionless use of the locative can also be treated as such only from a synchronical standpoint; historically the Lithuanian locative represents in most cases a coalescence of the primary locative with the postposition *en 'in'. This means that Lithuanian used primarily the postpositional phrase locative + 'in', not a pure locative (for details see Ch. Stang, 1966: 175-232). The problem of the new Lith. locative coming from the coalescence with the postposition *en is closely related with the emergence in the Baltic languages (Lith., Latv.) of the so-called localistic cases, which represent the primary pattern Noun + postposition. According to Stang (1966: 228-229) the following system of these cases can be established for older Lithuanian:

$\begin{array}{lll} & \text { Allative } & \text { Adessive } \\ \text { e.g., } & \text { Illative } & \text { Locative } \\ & \text { galvõsp }(i) & \text { galváip }(i) \\ & \text { galvõn } & \text { galvojè }\end{array}$

which etymologically represent: Allative-Gen. $+p i$, Adessive-Loc. + $p i$, Illative - Acc. $+n(a)$, Locative-Loc. $+{ }^{*} e n$. It seems highly probable that this innovative system of localistic cases in Lithuanian (and in Latvian) was copied from the Finnic languages ${ }^{7}$, although in these languages the system is more consistent, since it contains also the negative counterparts of the above cases, e.g., in Suomi-Finnish there are: Ablative with respect to Allative, Abessive with respect to Adessive, and Elative with respect to Illative. In view of the above remarks about the relative conservatism or innovatism of Baltic and Slavic within the IE languages, we should rather formulate a cautious statement on this point, 
namely: the notorious conservatism of Baltic (especially Lithuanian) is best reflected in its phonemic system or development, which renders the phonemic shape of Baltic (Lithuanian) morphemes very archaic, closer to the posited PIE than the shape of the corresponding Slavic (OCS) morphemes. This fact, however, does not mean that Baltic (Lithuanian) is also conservative in other respects. For example, the use of the genitive and the development of localistic cases are undoubtedly innovative features of nominal morphology in this language, in comparison with Slavic (OCS), which in this respect shows rather a striking conservatism.

But in this way we reach a point at which we should ask an important and difficult question: what are the reasons for linguistic conservatism or innovatism in the history of the IE languages? Of course, we should remember that it is not sufficient to speak about the conservatism or innovatism of a language in general terms; we must always specify in what respect a given language is conservative or innovative (as was proposed above). For example, the development of localistic cases, belonging to the grammatical form of a language, suggests a foreign influence in Lithuanian, namely that of the Finnic languages. It is also probable that the early elimination of relational (denominal) adjectives and their replacement by nominal genitives in the function of adnominal modifiers (cf. contemporary Lith. Lietuviu kalbos žodžiu daryba ${ }^{8}$, etc.) could be traced to the same foreign influence (Finnic). I would include here also the use of the genitive of personal pronouns instead of the corresponding possessive pronouns (e.g., mano namas 'my house', literally 'house of mine', musu tievyne, 'our fatherland', literally 'the fatherland of ours', cf. Slav. mojb domz, naše otbčbstvo, etc.). Briefly, I would like to raise here the problem of a foreign linguistic substratum as a frequent cause of structural, typological changes in languages. It is understandable that we are allowed to resort to the substratum hypothesis only under two conditions: 1.) if the typological changes in a given langage cannot be explained satisfactorily in terms of its independent internal development; and 2.) if we have either sufficient historical and philological information about a foreign language acting as a substratum, or we can at least presuppose it indirectly on the basis of prehistorical facts, etc.

The substratum hypothesis has been used to explain the diversification of IE languages, i.e., the historical split of Proto-Indo-European, by many scholars. One of the most typical examples in this respect is the hypothesis of Sigmund Feist about the origin of Germanic (1924: 88-89 and 91) in a chapter with the characteristic title: "Das Germanische keine direkte Fortsetzung des Indogermanischen", from which the following statements deserve quotation: 
Das Germanische steht zu Beginn seiner Überlieferung in einem so weit entwickelten Stadium, wie es die indischen und iranischen Dialekte oder das Griechische erst im Laufe vieler Jahrhunderte ihres Sprachlebens erreicht haben, als Rassenmischung oder Ausbreitung der Sprache über weite Gebiete ein schnelleres Tempo in ihre Entwicklung gebracht hatte. Dieser Zustand wäre bei den Germanen schwer zu erklären, wenn die indogermanische Grundsprache bei ihnen eine ungestörte Fortentwicklung ohne eine Kulturumwälzung oder eine Rassenmischung bis zur Zeit der Völkerwanderung genommen haben sollte. Und noch ein Unterschied bliebe bei dieser Sachlage auffallend. Im Germanischen gibt es eine ganze Anzahl Wörter, die keinerlei etymologische Verknüpfung mit dem indogermanischen Sprachgut finden, das uns aus den Schwestersprachen bekannt ist. Schätzungsweise habe ich den Umfang des nicht etymologisierbaren deutschen Sprachguts auf ein Drittel des gesamten Wortschatzes berechnet. Besonders auffällig ist, daß sich ein großer Teil der germanischen Ausdrücke für das Seewesen und damit Zusammenhängendes in den anderen indogermanischen Sprachen nicht wiederfindet:

See, Segel, Nachen, Kahn, Kiel, Spant, Bord, Brise, Hafen, Damm, Reede, Ebbe, Sturm, Zeit (Gezeiten), Fels, Klippe, Strand, Geest, Laich, Netz, Reuse, schwimmen, Stange, Steuer, usw.

Ebenso haben fast alle Fischnamen (mit Ausnahme von Lachs und vielleicht $\mathrm{Wal}$ ) keine auswärtigen Entsprechungen. Isoliert sind innerhalb des Germanischen zahlreiche Pflanzen-, Vogel- und Tiernamen.... Man braucht eines der etymologischen deutschen Wörterbücher neueren Datums (Fr. Kluge, H. Hirt-Weigand, R. Loewe) aufzuschlagen, um auf jeder Seite solche nicht etymologisierbare Wörter zu treffen.

(S. Feist, 1924: 88-89)

and then:

Wir können aus allen angeführten Gründen (Akzentwechsel, Verfall der Flexion, fremder Einschlag im Wortschatz) einer solchen Annahme nicht zustimmen [i.e., that "das Germanische der Nachkomme des Indogermanischen in seiner Urheimat wäre und die Germanen als reine Indogermanen angesehen werden müßten"]. Wir werden uns 
für die genügend begründete Ansicht entscheiden, daß die Prägermanen in vorgeschichtlicher Zeit eine indogermanische Mundart übernommen, sie mit einem bedeutenden Einschlag ihres einheimischen Sprachguts durchsetzt und den freien musikalischen Akzent der Ursprache durch ihren eigenen, an die erste Wortsilbe gebundenen Starkton ersetzt haben. ${ }^{9}$

(S. Feist, 1924: 91)

In my opinion the non- or pre-IE substratum in Germanic could be the megalithic culture of the North Sea (i.e., its people!).

In this connection see also Feist's earlier remarks (1913: 480-485), where the so-called first Germanic consonant shift (Lautverschiebung) is also listed among the changes due to a foreign non-Indo-European substratum. Closer to our times Ernst Pulgram (1957: 239-252) emphasized the role of a substratum in the diversification of IE languages. But it should be noted that we do not need to limit the concept of substratum to a foreign non-IE language (or languages): we may also deal with an IE substratum, i.e., an older IE language or dialect influencing a younger one which supersedes it in the concrete historical development of a country or region (e.g., Celtic and Latin in Gaul, etc.). Since, however, the term "substratum" is sometimes used quite vaguely, I will attempt to define it more precisely in a way useful for the understanding of corresponding linguistic processes.

Thus in the following, by a linguistic substratum $A$ I understand a language that has been spoken in a country or region since before the arrival of another language $B$ (superstratum). This means that two different ethnic groups are involved here, one native, another immigrant or, as seems to be more common in such cases, conqueror. The result of the coexistence of the two ethnic groups and their languages is usually bilingualism: the speakers of language $A$ endeavor to speak language $B$ and vice versa. If for political, social, or cultural reasons the primary population ultimately abandons their native language $A$ and switches to language $B$, learned practically in the course of everyday contacts, then we usually observe some characteristic changes in the new variant of $B$ used by the descendants of the native speakers of $A$. These changes are caused by the transfer to language $B$ (superstratum) of some structural patterns of language $A$ (substratum), which is an inevitable phenomenon connected with bilingualism. The whole process could be presented in 
the following formula:

$$
A a) B b \geq B a
$$

where: $A=$ the lexical substance of $A$ (substratum)

$a=$ the grammatical form of $A$

$B=$ the lexical substance of $B$ (superstratum)

$b=$ the grammatical form of $B$

In the above formula the phonemic features of the two interacting (interfering) languages are neglected, although in this respect we also observe some influence of $A$ upon $B$, expressing itself, for example, in the elimination or reinterpretation of the phonemic oppositions characteristic of $B$ according to the patterns prevailing in $A$, etc.

As we see, the basic condition for the structural influence of $A$ (substratum) upon $B$ (superstratum) is bilingualism, and the vehicle of this influence is calques linguistiques in the field of grammar (morphology and syntax). In this process, which is ultimately a psycholinguistic phenomenon that takes place in the minds of the speakers of $A$ who are trying to speak $B$, language $A$ (substratum) turns out to be structurally dominant, and language $B$ (superstratum)-structurally recessive. What remains from the latter is its basic lexical substance, but its grammatical form undergoes a change as it is adjusted to the structural patterns of the substratum. Thus, we have the preservation of the genetic substance and the genetic identity of $B$ but a change, sometimes radical, of its typological identity. In this way the diversification within a linguistic family proceeds.

Of course, the external, socio-cultural, and political circumstances which bring about the abandonment of $A$ on behalf of $B$ by the primary population of the native speakers of $A$, and the numerical relations between the two groups of native speakers are of great importance for the understanding of the above processes. Unfortunately, for the prehistorical period we have no direct data concerning the basic social context of the relation substratum : superstratum. But much can be inferred by analogy with some historical instances of the substratum : superstratum relationship.

Limiting ourselves to the field of Slavic languages we can call attention to the undeniable fact of a Balkan-Romance substratum in the southeastern branch of the South Slavic languages (Bulgarian, Macedonian, and the Serbian dialects of the Prizren-Timok region, the so-called Sop or Torlak dialects). As is well-known, this substratum, which should be identified with an earlier stage of Rumanian (including here Arumanian as well), has acted for centuries upon those Slavic languages and dialects, gradually transforming their grammatical form in such a way that now they only genetically belong to Slavic; typologically, 
however, they join Rumanian and, to a lesser degree, also other languages of the so-called Balkan linguistic league (Sprachbund). This gradual process of the "balkanization" (or rather "romanization") of Bulgarian, Macedonian, and southeastern Serbian dialects was caused by the slavicization of large groups of the autochthonous Balkan-Romance population, which the Slavs had encountered south of the Danube after their invasion of the Balkan Peninsula. Simply, the natives of the land gradually learned Slavic and through the process of bilingualism impregnated it with the structural features of their original Romance dialect. So the Slavic (Bulgarian, Macedonian, and southeastern Serbian) used by them became qualitatively different from the Slavic used by the primary invaders and settlers. Everything seems to indicate that this process of balkano-romanization of the respective South Slavic dialects and languages was completed by the sixteenth century. This means that if we consider OCS of the tenth-eleventh centuries as the model of the primary Slavic linguistic type, then the above process of typological transformation caused by the slavicization of the Balkan-Romance population took at most about five hundred years. It is, however, striking that in spite of the significant and deep structural influences (e.g., the characteristic limitation or complete loss of nominal declension, the postpositive article, the replacement of the infinitive by subjunctive clauses with $d a$, the reduplication of the oblique cases of personal pronouns and of definite nominal objects by pronominal clitics, etc.), the lexical influences of Balkan-Romance in the southeastern branch of South Slavic are insignificant: some terms connected with sheep breeding and landscape.

This puzzling phenomenon could be explained by the relatively low level of culture represented by the Balkan-Romance population with whom the Slavs came in contact after their invasion of the Balkans. The old Roman city and villa life was destroyed; the survivors of the Latin-speaking population (descendants of old Roman veterans!) withdrew to inaccessible mountain regions, where they experienced an economic and cultural regression, switching from agriculture to pastoralism, etc.; all this created conditions under which the Balkan-Romance rural population did not have anything culturally attractive to offer the Slavic newcomers and settlers. So the number of lexical borrowings from Balkan-Romance could not be large. It is interesting that the opposite situation can be observed in Rumanian (Daco-Rumanian), which in its turn underwent, especially in Walachia, a strong influence of Slavic substratum. Here not only were some characteristic features of Slavic grammatical form, especially in the system of compound verbal tenses and moods, introduced into the Rumanian 
language, but also whole lexical microstructures such as agricultural terminology (see Z. Gołąb, 1970: 5-18 and 1976: 297-309; S. B. Bernštejn, 1948: 80-127, E. Seidel, 1958: 141-173; G. Mihailă, 1958: 52-62).

I have elaborated on this point because it seems to provide quite an instructive model for the reconstruction and understanding of the prehistorical phenomena of substratum, bilingualism, and subsequent structural changes in the languages of ethno-linguistic superstrata, which ultimately can account for the historical diversification of a linguistic family. I would like also to emphasize the importance of the analogy of the Slavic expansion in the early medieval epoch (500-800 A.D.) for the reconstruction and understanding of the IE expansion in prehistorical times: both linguistic expansions represented infiltration and migration (cf. Pulgram, 1956: 411-417) and both proceeded in general from the east towards the west and south (as far as Europe is concerned). Taking into account the unchangeability of the natural routes of migration and the unchangeability of the primitive means of transportation (foot, ox-cart, horse) for thousands of years, we can imagine the prehistorical expansion of the IE dialects, mutatis mutandis, analogically to the expansion of the Slavic peoples and dialects between 500-800 A.D. This point to my knowledge has not been raised by scholars studying the expansion and differentiation of the prehistorical IE dialects in Europe, and it deserves serious attention since the Slavs, being the last IE peoples who expanded into Central and Southeastern Europe in the historical epoch, provide us with the only verifiable analogy and model for the reconstruction of similar ethnic and linguistic movements in the prehistorical past. Thus it would be illuminative to try to compare the early historical differentiation of the Slavic peoples and dialects, conditioned by their migration and geographical spread, with the hypothetical differentiation of the prehistorical IE dialects, conditioned by their geographical spread. I will come back to this problem later after a discussion of the lexical connections between Proto-Slavic and other IE dialects.

Now, returning to the problem of non-IE substrata as causes for the prehistorical differentiation of PIE, and limiting ourselves to the North European branch of PIE (Germanic-Balto-Slavic), we can make the following statements: The western part of the North European dialectal group (Germanic) seems to have undergone the influence of a non-IE ethno-linguistic substratum in the new country: Southern Scandinavia, Jutland, and the adjacent coastal regions of continental Europe. The eastern part of that dialectal group, Baltic, seems to have undergone some influence of a Finnic ethno-linguistic substratum in the regions adjacent to the Baltic Sea after its split with Slavic. The rest of the North European dialectal group, Slavic, which in the primary geographical 
distribution of the group occupied a more southern position (for details see below) seems to be relatively free from any influences of a prehistorical non-IE substratum. On the contrary, many facts indicate that in Proto-Slavic we should rather take into account a secondary influence of an IE substratum, which among other things strengthened some archaic IE features, especially in Slavic conjugation. This is a hypothesis which I will try to substantiate in the following pages.

The observation of relatively recent historical developments in South Slavic (Bulgarian, Macedonian, and the Torlak dialects of Serbian) has shown that the verbal system (conjugation) of these languages has been particularly sensitive and receptive to the structural interference of the Balkan-Romance substratum. On the one hand we have the preservation of the old past tenses (aorist and imperfect) in these langauges, and on the other hand the development of a new perfect with the auxiliary 'have' (Mac. imam) + the (formally) passive participle, exactly according to the Romance model: dixi : dicebam : habeo dictum (cf. Arum. zašu : zaceám ${ }^{\mathbf{u}}$ : am zása). So in Macedonian, which is the most balkanized South Slavic language in this respect (the only one with the category of the new resultative perfect imam kažano = habeo dictum, etc.), we have the following system of past tenses (if we neglect the category of "auditive"): aorist kažav, $3 \mathrm{sg}$. kaža; imperfect kažuvav, $3 \mathrm{sg}$. kažuvaše; perfect imam kažano, etc. Besides that the future tense is expressed by a very old calque linguistique of Balkan-Romance and/or (colloquial) Byzantine Greek: k'e kažam, which indirectly continues the OCS xošto kazati (literally 'I want to say' $\rightarrow$ 'I will say'), a construction known not only in these South Slavic languages, but also in literary Serbo-Croatian and in all Balkan languages (Albanian, Modern Greek, and Rumanian). These are the facts which can be easily traced in their gradual development during the historical period, ushered in by the settlement of the Slavs in the Balkans and the subsequent Slavo-Romance, etc.; bilingualism. What I want to emphasize here is the cumulation of substratum influence in the verbal system of the respective South Slavic languages. This influence, as we have seen, worked in two directions: toward the preservation of those categories which were common to Slavic and Balkan Romance, and toward the development of new categories, which had existed in Balkan Romance but were unknown to Slavic.

Now, using the South Slavic phenomena as a historical parallel we turn to the prehistorical past, to the period when the linguistic ancestors of the Slavs (Pre-Slavs) within the late PIE dialectal community (2500-1500 B.C.?) were gradually moving towards their early historical settlements (western Ukraine, see p. 183), loosening more and more their contacts with the Balts. We can justifiably raise the following question: 
what IE dialects or languages of the East European area could possibly influence the Pre-Slavic verbal system in such a way that it became quite different from that of Baltic? As mentioned above, Baltic (Lithuanian) shows no traces of the IE asigmatic (thematic) or sigmatic aorist, whereas Slavic not only does, but proves that in an earlier prehistorical epoch (at the stage of Pre-Slavic?) the sigmatic aorist must have even been quite productive in it, since the aoristic element $-s-\geq-x$ - was used in the formation of a new Slavic imperfect (aorist byxz $\sim$ běxъ : imperfect běaxz, etc., see the excursus below!). This is undoubtedly a conservative feature of Proto-Slavic, which distinguishes it sharply from Baltic and also from Germanic (that is, from the remaining North IE dialects!) and brings it closer to those IE languages which have preserved the sigmatic aorist: Latin (in the so-called $s$-perfect) veho $\rightarrow v e \bar{x} i$, Greek $\lambda \epsilon ́ \gamma \omega \rightarrow \dot{\epsilon} \lambda \epsilon \xi \alpha$, Avestan vaz- $\rightarrow$ vaš- [cf. Bartholomae, 1961: 1386], Sanskrit vah- $\rightarrow$ áväkşam, Tokharian [in the so-called s-perfect] camp 'pouvoir' $\rightarrow 3 \mathrm{rd} \mathrm{sg}$. perf. campäs (see van Windekens, 1944: 272).

On the other hand, the PIE perfect has been lost in Slavic completely (like in Baltic but unlike in Germanic) and replaced by a periphrastic construction consisting of the PIE verbal adjective in -lo- + the auxiliary

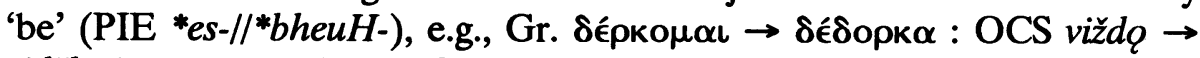
vidělı jesmb, etc. This PSl. morphological innovation must have been relatively early, since the so-called $l$-participle (resultative) already in Old Church Slavonic functions only as a predicative within the compound verbal forms (perfect, pluperfect, conditional, and futurum exactum), although in Proto-Indo-European, being an adjective, it could and should function also as an attribute (cf. the traces of this situation in the Com. Slav. deverbal adjectives sъmělı 'daring', teplъ//toplъ 'warm', ob(v)ilъ 'abundant', zbrělı 'ripe', etc.). But what is relevant in this connection is the fact that besides Slavic only three other IE languages have made use of this verbal adjective in creating new compound verbal forms: Armenian with its perfect consisting of the past participle in -eal and the auxiliary 'be', e.g., cneal em 'je suis né' (cf. Slav. rodilb sę jesmb), Umbrian (an Italic dialect) with its futurum exactum consisting of the participle in $-l u+$ the auxiliary 'be', e.g., apelust 'impenderit', entelust 'intenderit', 'imposuerit' ( ${ }^{*}$ apendlo-esti, *entendlo-esti), see W. Thomas, 1952: 9, and K. Trost, 1972: 46, and Tokharian with its verbal adjective in $-l$ or -lle used mostly with the auxiliary 'be' and showing modal functions either of "necessity" or "possibility", which depends on the underlying inflectional stem of the verb: present or conjunctive (for details and examples see W. Thomas, 1952: 12). It should, however, be noted that whereas in Armenian the PIE lo-adjective has been transformed into a perfect participle (with passive meaning in the case of transitive verbs), in 
Tokharian it still remains an adjective, but is so closely connected with the verb that it takes over the verbal syntax and shows predominantly passive meaning. Especially significant is the use of the second $l$-participle (i.e., derived from the conjunctive stem) + the present copula as future (cf. the situation in Umbrian!), with the conjunctive copula as the conjunctive mood and with the imperfect copula as irrealis (i.e., conditional); for details see W. Thomas, 1952: 28.

Of course, the most striking similarity exists between the Slav. and Arm. periphrastic perfect. But there is also an important difference in the syntactic pattern of the transitive perfect between Slavic and Armenian: the Slav. form is active and personal, whereas the Arm. construction is possessive and impersonal (see E. Benveniste, 1966: 176-186), e.g., $z$-gorc gorceal $\bar{e}$ nora 'he has accomplished a work', literally 'operam factum est eius', where the agent is conceived as possessor and consistently expressed by the genitive (nora), but the patient appears as a regular direct object (accusative with the preposition $z$-). This construction of the perfect in Armenian stems from the passive meaning of the participle in -eal and has probably developed from the passive type of periphrastic perfect similar to the Latin hostis mihi occisus est instead of hostem occidi. The syntactic transitivization of that older passive type in Armenian has been entailed by the regular transitive construction of the primary IE synthetic perfect. The whole development is perfectly explicable in terms of inherent IE constructions, i.e., we do not need here any Caucasian influences, once we realize that the resultative perfect is conceived as "possession" and uses regular possessive constructions (in Armenian the type aliquid est mei 'something is mine', etc.).

I have elaborated on the subject of the Armenian perfect because etymologically, though not syntactically, it is so closely related to the Slavic perfect. The fact that the participle in $-l$ - is active in Slavic but passive in Armenian may be conditioned by the preservation of the IE verbal adjectives in -to-, -no- with passive meaning (the opposition neslo : nesenz, jęlı : jętъ, etc.) in Slavic, whereas in Armenian those verbal adjectives disappeared and the formal opposition active : passive within participles has not developed.

The etymological identity of Slavic and Armenian periphrastic perfects is not the only old common feature in the verbal systems of these two languages. If we keep in mind the starting point of our discussion, namely the basic difference in the system of past tenses between Baltic and Slavic, of course against an IE background, then a general pattern of the development, including here the identity of substantial elements (concrete morphemes and inflectional types), will again bring Slavic closer to Armenian. Namely Armenian has: an aorist, imperfect, and perfect (+ 
pluperfect). Of these the aorist represents two types: radical and with the formant -c-; the radical type continues the PIE thematic aorist or imperfect just like the Slavic asigmatic aorist (e.g., Arm. elik $\sim$ Gr. Ė $\lambda_{\iota \pi \epsilon} \leq{ }^{*} e$-lik ${ }^{\mathrm{u}}$ et $\sim$ Slav. čbte $\leq{ }^{*}$ kitet, etc.). In this connection it is worthwhile to quote Meillet: "En effet l'arménien, ayant constitué un imparfait indepéndent de l'imparfait indo-européen, a pu affecter à l'emploi d'aoriste les anciennes formes d'imparfait; c'est ce qui s'est passé en slave où, un imparfait nouveau ayant été créé, l'imparfait padŭ d'un verbe padö ${ }^{10}$, pasti 'tomber' a pris l'emploi d'aoriste" (Meillet, 1936: 114). The Arm. imperfect is a characteristic innovation of this language. But here again we observe interesting parallels (or etymological identity?) with the Slavic imperfect. The inflection of the Armenian imperfect suggests that it is a compound form consisting of the present tense stem + the imperfect of the verb 'be'. Meillet writes: "Mais ce qui appelle l'attention, c'est le $-i$ qui se retrouve presque à toutes les personnes: bere-i 'je portais' a l'aspect d'une forme composée comme l'imparfait vieux slave nesě-axъ 'je portais'; si l'on se souvient que le subjonctif beriçem a, au moins en apparence, l'aspect d'un composé (v. §90), on est tenté de voir dans -i, -ir, etc., des formes d'un prétérit de 'être'; * $i$ répondrait à homerique $\hat{\eta} \alpha, \mathrm{skr}$. ása, c'est-à-dire a l'ancien parfait [but cf. G. Klingenschmitt: Das altarmenische Verbum, L. Reichert Verlag, Wiesbaden, 1982, p. 15 - ZG]; la $3^{\mathrm{me}}$ personne ${ }^{*}-y-r$ aurait un aspect particulier parce qu'elle reposerait sur une ancienne forme monosyllabique d'imparfait *ēst, cf. skr. áh, gr. ทิs). L'emploi du thème du présent avant un ancien prétérit du verbe être est un fait qu'on constate, mais qu'il est malaisé d'expliquer, à peu près comme les premiers termes des formes composées analogues des autres langues, lat. legē-bam, v. sl. nesě-axz, got. nasi-da, etc.” (A. Meillet, 1936: 126).

In view of the above we can suspect that the Armenian imperfect (whatever the exact primary pattern of its construction) and the Slavic imperfect represent the same or a very similar prehistorical archetype, a kind of compound with the imperfect of the verb 'be' as the second component. To be sure, the origin of the Slavic imperfect: brra-aše, vidě-aše, vedě-aše, mol'a-aše (*moljě-aše) is disputable. Some scholars, such as Meillet above, see in it an old compound with an imperfect of the verb 'be' (e.g., T. Lehr-Spławiński, 1959: 83), others see a synthetic, specifically Slavic formation (e.g., J. Kuryłowicz, 1950: 119-125, and A. Vaillant, 1966: 66-68). I think that the parallels of Armenian and Latin (legébat, amäbat, etc.) support rather the former view. In this connection one could imagine the development of the Slavic imperfect in the following way:

a.) The PIE imperfect of the verb *es- 'be' with the syllabic augment, 
i.e., *ēsm, ēss, ēst, etc. (see O. Szemerényi, 1970: 289) was preserved in Proto-Slavic (or Pre-Slavic as that part of Balto-Slavic from which Proto-Slavic later developed). Incidentally, it is well-known that the verb 'be' used as an auxiliary very often preserves an exceptional archaic form, cf., e.g., Pol. dial. bych, bychmy, etc., with the aoristic -x-instead of the Standard Pol. bym, byśmy, etc. This PIE imperfect underwent the influence of a thematic imperfect of the PIE type *uedhe-t, preserved in Slavic as the asigmatic aorist (OCS vede, etc.): so instead of the primary PIE *ēsm, *ēss, *ēst, etc., early Proto-Slavic introduced the forms of the type *ēsom, *ēses, *ēset, etc.

b.) From the period of Balto-Slavic dialectal innovations, Proto-Slavic inherited the preterits in $-\bar{a},-\bar{e}$ : $b b r a$, vide $(2-3$ persons sg.) which on the one hand were influenced by the old sigmatic aorists of the type daxz, děxb (*do-s-om, *dhe-s-om, etc.), becoming themselves aorists, but on the other hand were combined with the imperfect of the *esom, etc., type (transformed in Proto-Slavic regularly into *jaxz, with an analogical $s \rightarrow$ $x)$ to create primarily a kind of iterative preterit: bıra + jaše, vidě + jaše, etc. ${ }^{11}$ After "univerbation" and establishment of the imperfect function through opposition to the aorist function of the forms bura, vidě, etc., these new agglutinated imperfects bbraaše, viděaše (1.sg. bbraaxъ ${ }^{2}$ vidéaxz), etc., provided a model for the derivation of the imperfect from any verb, e.g., OCS xoždaaše, mol'aaše, i.e., *xodj-ěaše, *modlj-ěaše, etc. This whole hypothetical development suggests that the verbal (tense) system of early Proto-Slavic (or Pre-Slavic) was quite complicated and rather heterogeneous. So, for example, from a verb like ved, , vedeši, vest $i$ we have the following old IE tense formations: the sigmatic aorist věsı ( $\left.{ }^{*} u \bar{e} d h-s-m\right)$, the asigmatic-thematic aorist (old IE imperfect) vedz (2-3 sg. vede) from *uedhom, etc., a new Slavic imperfect vedě-axz, etc., based upon an older Balto-Slavic preterit *vedě ("uedē-t) combined with the thematized IE imperfect of the verb *es- : *ésom, etc:

Such a situation suggests rather a transitional dialect, developing along a linguistic boundary in which two different systems are combined in a characteristic way. It looks as if a Proto-Balto-Slavic dialect moved south and was learned by a population speaking another IE dialect with the preservation of the IE sigmatic aorist, the IE asigmatic-thematic aorist or the imperfect, and with an iterative compound preterit using the imperfect of the verb *es-. Perhaps also the new periphrastic perfect based upon the lo- participle was used there. It is highly probable that a remote prehistorical ancestor of Armenian or a dialect close to it could be suggested.

As is well-known, Armenian belongs genetically (together with Thracian) to the South European branch of the satem languages. Of 
course, it split from the rest of the IE dialects of Europe very early, and having migrated to Asia Minor, underwent there a very strong influence of non-IE languages (Caucasian?). This is first of all reflected in its vocabulary, which contains only 743 words of IE origin (see G. R. Solta, 1960: 9, footnote 2). But in spite of the "substantially" so remote character of Armenian, even more striking are the traces of its prehistorical dialectal contacts with the North IE languages (Germanic/Baltic-Slavic). In this connection it is worth quoting the results of the monograph by G.R. Solta, 1960, devoted to the etymological analysis of the IE stratum in the Armenian vocabulary from the standpoint of its relations to separate groups (prehistorical dialects) of IE languages. The list of words shared by Armenian with Baltic and Slavic:

A.) Armenian-Baltic:

Arm. gort 'Frosch' Latv. warde

last 'Nachen' Lith. lazdà 'Stecken'

ezr 'Rand, Grenze' Lith. ežé 'Feldrain'

varem 'zünde an' Lith. vìrti, OCS vbrěti 'kochen'

gatt 'heimlich' Latv. wilt 'betrügen'

aud 'Schuh' Lith. aũtas (cf. S-C òbuća)

$k^{\prime}$ 'eni 'Schwester der Frau' Lith. svainé

es 'ich' Latv., OPruss. es

B.) Armenian-Balto-Slavic:

Arm. gišer 'Nacht' Lith. vãkaras, OCS večerı

glux 'Kopf' Lith. galvà, OCS glava

olok' 'Schienbein' Lith. ùolektis, OCS lakztb

getjk' 'Drüse' East Lith. gẽležuonas, OCS žlěza

lakem 'lecke' Lith. lakù, CS ločq

C.) Armenian-Slavic:

Arm. argand 'Mutterleib' OCS grodb 'Brust'

eri 'Bug der Tiere' OCS ritb

gēr 'fettleibig, plump' OCS žir 'Weide', Russ. žir 'Fett'

kotr 'Zweig, Stamm' CS golbja

etevin 'Zeder' Russ. jalovec 'Wacholder'

isk 'wahr, wirklich; 'aber' OCS isto 'wirklich, echt'

tartam 'langsam' (also 'schläfrig') Slav. drěmati 'schlafen'

("interesantes Parallelismus")

trtum 'traurig' Slav. *dbrměti 'traurig sein' (in S-C dial.

drmljeti, Berneker, 1924: 256)

ut 'Weg' Slav. ulica

(cf. Solta, 1960: 469-471). 
The above facts, plus a recent analysis of Armenian within Indo-European, enabled E. A. Makaev to formulate the following statement about the position of Armenian: "The amount of exclusively Armenian isoglosses is significantly smaller than that of 'group isoglosses' encompassing it, which speaks clearly about the central location of Armenian among remaining IE languages" (È.G. Tumanjan, 1971: 8).

My hypothesis about the movement of Pre-Slavic (as a part of the Proto-Balto-Slavic dialectal group) in a southerly direction, or rather southwesterly as we will see later, is clearly supported by the etymological analysis of the different dialectal strata of the IE vocabulary in Proto-Slavic. To this problem the next chapter of this book has been devoted. However, before getting involved in the analysis of the very rich lexical material, I would like to emphasize some more general points which usually escape the attention of those Slavists who are too much oriented towards the historical development of the Slavic languages, i.e., towards the historical differentiation of the primary Common Slavic linguistic unity. In this respect it has been customary among Slavists to start from the conventionally reconstructed Common Slavic forms which, for example, in the vocalic system actually reflect the stage of OCS (except for the non-metathesized sequences *ort-, *olt-, *tort, *tolt, *tert, *telt); so, of course, instead of the OCS razumb, lakomz, gradz, glava, srěda, mlěko the forms *orzumъ, *olkomъ, etc., have been reconstructed. Such a procedure is somehow justified only if we are interested in the historical development of the Slavic languages. But if we want to understand the prehistorical development of Slavic, i.e., its gradual emergence from Common Indo-European (PIE) with all the implications of this development for the ethnic prehistory of the Slavs, we must be aware that Proto-Slavic also had its own history, which means that we can and should reconstruct different and successive stages of Proto-Slavic. A great achievement in this respect is the book by G. Shevelov (1965). The realization of different stages in the development of Proto-Slavic, the very fact that we can speak about Proto-Slavic as a separate IE dialect or language only at a determinate and rather late time, is important and sometimes decisive for the solution of problems concerning prehistorical contacts (e.g., borrowings, etc.) between individual IE dialects or languages. So in my further discussion I will often be obliged to speak about different stages or epochs in the development of Proto-Slavic. Here, for the purpose of a general orientation I will distinguish the following three epochs in the prehistory of Slavic, using as a criterion purely linguistic (internal) changes within the PSI. phonemic system:

I.) Early Proto-Slavic (which could also be called "dialectal Balto-Slavic", meaning here that dialectal branch of Balto-Slavic from 
which Proto-Slavic developed); this is the period before the monophthongization of the diphthongs with a simple quadrangular vowel system:

$$
\begin{array}{ll}
\check{l} & \check{u} \\
\dddot{\check{l}} & \check{\jmath}
\end{array}
$$

(Note that the purely Baltic system at that time must have had an asymmetrical structure:

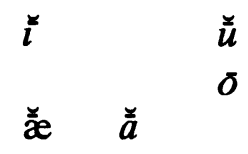

because it made a distinction between $\bar{a}: \bar{o}$, Lith. móte $:$ dúoti, etc.) This is also the period before the first palatalization of the velars by the following front vowels (but not by $j$ : this latter seems to have palatalized all the consonants already in Balto-Slavic, cf. Kuryłowicz's hypothesis above). So for that Early Proto-Slavic period we should reconstruct forms like ${ }^{*} k æ l o u s i k o s=$ Late Proto-Slavic čelověkz, ${ }^{*} g æ n \bar{~}=\check{z} e n a$, ${ }^{*} x i d l o s={ }^{*}$ šbdls, etc. Of course, word-final consonants at that stage were still preserved.

II.) Middle Proto-Slavic (which from a purely linguistic standpoint, i.e., as far as the internal linguistic changes are concerned, represents already a "Slavic" stage par excellence, separate from Baltic): this is the period characterized by the monophthongization of the diphthongs and its consequences, the appearance of the nasal vowels and the

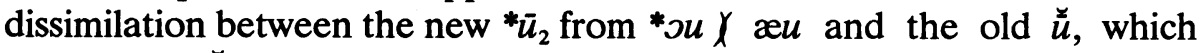

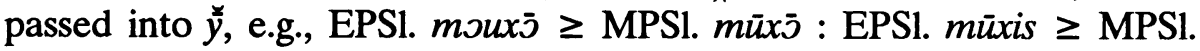
$m \bar{y}$ ši, etc. Among the consonants the first, the "third", and ultimately the "second" palatalizations of velars took place and the morphophonemic alternations $k \sim \check{c} \sim \mathrm{c}, \mathrm{g} \sim \check{\mathrm{z}} \sim 3, x \sim \check{\mathrm{s}} \sim \mathrm{s}^{\prime 12}$ were established. The Middle Proto-Slavic period was rather short compared with the preceding period, but it was very unstable, loaded with rapid changes, which condition was undoubtedly related to the extensive migratory movements of the Slavic tribes during and after the great migration of peoples (400-600 A.D.).

III.) Late Proto-Slavic (some changes of this period are still Common Slavic, i.e., their results are identical in all Slavic languages, but some already have a dialectal character, i.e., their results are different in different groups of Slavic languages): this is the period of the ultimate qualitative differentiation of vowels previously differentiated only

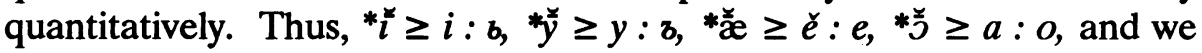


obtain the system which is familiar to us through OCS. This is the period of the elimination of the sequences *ort-, *olt-, *tort, *tolt, *tert, *telt (in traditional presentation, although for the sake of exactness we should reconstruct rather $*^{*}$ ort-, $*^{*}$ slt- and $*^{*}$ tort, ${ }^{*}$ tolt, etc.; certainly the latter situation should be reconstructed for South Slavic and Czecho-Slovak ${ }^{*}$ gordy $\geq$ gradz, ${ }^{*}$ golvj $\geq$ glava, etc.). These sequences, the last strongholds of closed syllables in Proto-Slavic, were changed by metathesis or polnoglasie, resulting in a clear dialectal division of Late Proto-Slavic into the two and three dialectal zones: South : North (in connection with the development of word-initial *ort-, *olt-), and South + Central : North-West : East (in connection with the development of the groups *tort, *tolt, etc.).

As can be seen from the above sketchy presentation of the three stages in the development of Proto-Slavic, the Early PSl. lasted very long, probably until the first centuries of the Christian era. Such an absolute chronology can be established on the basis of the Germanic loanwords in Proto-Slavic, strictly speaking on the basis of their phonetic treatment in Proto-Slavic. Most of these loanwords are of Gothic origin, and we know from historical sources (Jordanis, etc.) that the Goths reached the prehistorical Slavic territory, or rather the lower Vistula basin, about the birth of Christ. More extensive contacts between them and the prehistorical Slavs and subsequent linguistic exchange (reciprocal borrowings) began undoubtedly a little later, when the main bulk of the Gothic population moved southeast across the Slavic territory towards the Black Sea: this migration took place in the second half of the second century A.D. Of course, there were earlier contacts between the Proto-Slavs and other East Germanic tribes pouring from Scandinavia across the Baltic Sea towards the Odra basin; first of all we should mention the Burgundians and Vandals ${ }^{13}$, who settled for a time in what is now Pomorania, Great Poland (Wielkopolska), and Silesia. But the number of pre-Gothic loanwords in Proto-Slavic is much smaller than that of Gothic words.

The most striking phenomenon in the treatment of the Germanic loanwords in Proto-Slavic, with respect to our periodization of Proto-Slavic, is the palatalization of the Germanic sequences $K+E$ (velars plus front vowels) and $i(n) K[i(n)+$ velars] according to the three Proto-Slavic palatalizations: e.g., Germ. *geldan $\geq$ LPSI. *želdo, *želsti (OCS žlědo, žlěsti 'pay off'), Germ. *helma- (Goth. hilms) $\geq$ LPSl. *šelmъ (OCS šlěmz) 'helmet', Goth. kaisar $\geq$ LPSl. cěsar̂̀ (idem in OCS) 'emperor', Goth. gabigs $\geq$ LPSl. gobbzb (idem in OCS) 'abundant, rich',

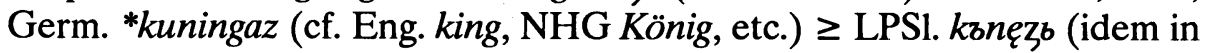
OCS) 'prince, ruler', etc. Especially important are the cases like *želd $q$, 
*šelms, since they prove that at the time of their borrowing the first Proto-Slavic palatalization of velars was just acting.

So everything indicates that about the birth of Christ and still in the first and second centuries A.D. Proto-Slavic (actually Early Proto-Slavic) represented a very conservative IE dialect with a phonology that was still Balto-Slavic in its basic features. Only in morphology (inflection) and vocabulary can we assume differences which already distinguished the Proto-Slavic of that time clearly from Baltic (or prehistorical Baltic dialects). It would be rewarding and illuminating to reconstruct the concrete PSI. forms of that epoch. Such reconstruction would help us to understand the possibility of easy linguistic contacts and exchange between, for example, Early Proto-Slavic and the Iranian dialects of the Scythians and Sarmatians, with whom the Proto-Slavs were coterminous for at least a thousand years (700 B.C.-300 A.D.). This last point is especially important because, as we will see later, the number of common Slavic-Iranian elements in vocabulary (whatever their origin and interpretation) is impressive.

In order to illustrate the relative ease of switching - in that ancient epoch - from Proto-Slavic to Iranian and vice versa, almost as from one dialect to another, I will quote some typical words and paradigms which can be reconstructed for Proto-Slavic and Iranian (North Iranian) of that time, about 500 B.C., i.e., the time when Nevpoí, undoubtedly a Proto-Slavic tribe (see below), dwelt in the Western Ukraine and were in a federation with the Scythians (cf. Herodotus).

PIE *bheudh- 'be awake'

EPSl.

Present

*bæudj̄m(i) 1 'watch'

*bæudæxæi

*bæudæti

*bæudæmos

*bæudætæ

*bæudonti

Aorist (Sigmatic)

*bæu $(t) \operatorname{som}^{2}$

*bæu(t)ss

*bæu $(t) s t$

*bæu $(t) \operatorname{som}>(s)$

*bæu(t)stæ

*bæu(t)sint
Avesta

Present

baodāmi 'sentio'

baodahi

baodati

baodāmahi

baoda $\theta \bar{a}$

baodanti

$\quad$ Aorist (Sigmatic)
${ }^{*}$ bao $(t)$ sam
${ }^{*}$ bao $(t) s$
${ }^{*}$ bao $(t)$ st
${ }^{*}$ bao $(t) s(a) m a$
${ }^{*}$ bao $(t) s t \bar{a}$
*bao(t)sat


1.) OCS bljudo, etc.

2.) OCS bljusz, etc.

We could further add here a primary IE imperfect derived from the present stem which in Slavic became the asigmatic (thematic) aorist in opposition to the new compound imperfect (see my remarks above), e.g.,

PIE *ueg'h- 'transport by vehicle'

EPSI.

*uæzom (OCS *vezъ)

*uæzæs (OCS veze)

*uæzæt (OCS veze)

*uæzomo(s) (OCS *vezomz)

*uæzætæ (OCS *vezete)

*uæzont (OCS *vezq)
Avesta

*vazam

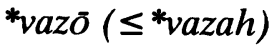

*vazat

*vazāma

*vazatā

*vazan

It should be noted that in connection with some phonemic changes many PIE phonemes became identical in (Balto-)Slavic and Iranian, e.g., the voiced aspirates lost their aspiration and became plain voiced $(b h, d h$, $g h \geq b, d, g)$, the primary satem palatals became dentals $\left({ }^{*} k,{ }^{*} g,{ }^{*} g\right.$ ' through the intermediary of $*_{s}$, $*_{\check{z}}$, $*_{\check{z}} h \geq s, z$ ), etc., which brought about very similar or identical phonemic shapes for many words; e.g., EPSl. *-üæżm(i), OCS vezQ Avesta vazämi, EPSl. *snoigæiti, or later *snoižæiti, OCS sněžitz Avesta snaēžati, EPSl. *zovj̄m(i), OCS zovq Av. zavāmi, etc.

Let us now compare a nominal paradigm, e.g., an o-stem masculine noun:

\section{PIE *bhago- 'alloter'}

EPSI.

Singular

N. bogos 'God'

A. bogom

G. =Abl.

D. boḡ̄ $i$

I. bogomi

L. bวgoi

Abl. boḡ̄t

V. bogæ!
Avesta

\begin{tabular}{ll} 
& \multicolumn{1}{c}{ Singular } \\
N. & bagō (*bagah) 'God' \\
A. & bagàm \\
G. & bagahyā \\
D. & bagāi \\
I. & bagāa \\
L. & bagaya \\
Abl. & bagāt \\
V. & baga!
\end{tabular}

The Avestan examples are quoted after Reichelt, 1909, and Bartholomae, 1961, 2nd ed. 
So, as we see, there was a high degree of phonetic and grammatical similarity between Early Proto-Slavic and the North Iranian dialects of the Scythians, which we can somehow imagine or reconstruct using the language of Avesta as a model. About the lexical similarity between Slavic and Iranian there will be a special exposition in the next chapter. The above remarks have been presented in order to enable the reader to realize that in the Early Proto-Slavic period, before most of the characteristic phonemic changes of Slavic took place (i.e., those of the Middle Proto-Slavic and the Late Proto-Slavic periods), we can still treat Slavic as a conservative IE dialect, somehow taking an intermediary position between Baltic and Iranian probably not only linguistically, but also geographically. 


\section{Chapter III}

\section{The Stratification of Proto-Slavic Vocabulary}

After having established the position of Slavic within Indo-European on the basis of its phonemic and grammatical features, we can raise a legitimate question about the relations which connect the Slavic vocabulary with the vocabularies of other IE languages. Of course, what is relevant are the correspondences that can be established between the inherited IE elements of the Slavic lexicon (which means that obvious prehistorical loanwords from adjacent IE languages are excluded) and such elements of other IE languages. In other words, we face here the problem of different Proto-Indo-European dialectal elements of the Proto-Slavic vocabulary which reflect different prehistorical contacts and ties between the linguistic ancestors of the Slavs and their IE neighbors. The term stratification used in the title of this chapter thus has both a geographical and a historical character. For there is no doubt that what we call Proto-Indo-European represents a long period of a prehistorical development starting with a relatively uniform linguistic system, which in the course of time through gradual dialectal differentiation resulted in the historically attested deeply differentiated IE languages of the ancient epoch (ca the year 2000 B.C.). Now, the problem is whether the successive prehistorical dialectal changes and corresponding dialectal zones concerning the PIE vocabulary were reflected in the inherited IE vocabulary of Proto-Slavic. A careful comparative analysis of the Slavic vocabulary against the IE background provides an affirmative answer to this question. This answer also contributes to the precision of the position of Proto-Slavic within the IE linguistic family or, if we approach it dynamically, to the understanding of the crystallization of Proto-Slavic within Indo-European. It also bears on the controversial question of the oldest prehistorical habitat of the Slavs.

The experience of historical-comparative linguistics indicates that the lexical substance of a language is a relatively unstable element which easily undergoes exchange with or replacement by the lexical substance of other languages. This is especially true about more peripheral parts of 
the lexicon, but there is always a core in the vocabulary of every language which virtually resists foreign influences, since at this point the very identity of the language and its ethnos seems to be at stake. Here belong: basic kinship terms (concerning the nuclear family), names of body parts, pronouns, numerals, prepositions, names of the main elements and phenomena of nature, names of the main processes of the human organism, and so forth. But we should also remember that reciprocal borrowings between genetically related dialects whose speakers understand each other without special difficulties are more frequent than between really foreign languages, i.e., whose speakers do not understand each other without learning the other's language. This latter point is essential for an understanding of the prehistorical dialectal isoglosses within late Proto-Indo-European.

So, in the following pages an attempt will be made to reconstruct different IE dialectal layers in the Proto-Slavic vocabulary and to translate the spatial relations into chronological ones.

The first layer which we can reconstruct is connected with the oldest dialectal differentiation of Proto-Indo-European, namely the division into the kentum and satem dialects. In order to avoid any misunderstanding, I would like to remind the reader that the kentum : satem division is interpreted here in accordance with Kuryłowicz's presentation (see the preceding chapter). The satem dialects are viewed as conservative, i.e., preserving the primary PIE distinction between the palatal set $k^{\prime}, g^{\prime}, g^{\prime} h$, and the velar set $k, g, g h$ with a subsequent assibilation of the former set, whereas the kentum dialects are viewed as innovative, i.e., depalatalizing the palatal set and adding labialization to the velar set, thus: $k^{\prime}, g^{\prime}, g^{\prime} h \geq$ $k, g, g h$ and $k, g, g h \geq k \stackrel{\mathrm{u}}{g} g^{\mathrm{u}}, g h \stackrel{\mathrm{u}}{\text {. }}$

There is no doubt that Proto-Slavic basically belongs to the satem branch of Indo-European, in spite of numerous kentum elements in its vocabulary which come from prehistorical times. The evidence for the original satem character of Proto-Slavic is provided by the most conservative parts of its vocabulary: pronouns, numerals, names of body parts, etc. As an illustration some examples can be quoted here: PIE ${ }^{*} k$ 'm tom $\geq$ PSl. soto (instead of the expected *sęto, cf. Lith. šintas), PIE *dek'm $\geq$ PSl. desętb (extended by the -t- suffix), PIE *ok'tō $(u) \geq$ PSI. osmb (transformed according to the ordinal osmb, which in its turn is based on sedmъ 'the seventh'), PIE *eg'hom 'I' $\geq$ PSl. azъ (cf. Lith. às, etc.), PIE *k'ei- 'this' $\geq$ PSl. sb, si, se (cf. Lith. šis, šì, etc.), PIE *k'rd'heart' $\geq$ PSl. *sbrdbce (cf. Lith. širdis, etc.), PIE *g'ombho- 'cutter' $\geq$ PSl.

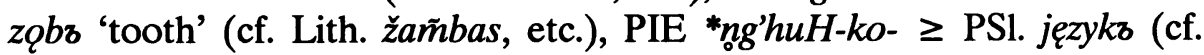
OPrus. insuwis, etc.). Also very instructive are the examples like koza 'goat' and its derivatives: koža 'skin', kožuxz, 'fur-coat', *azbno (in ORuss. 
jazbno) 'skin, fur' (primarily 'goat's skin), all of them representing ultimately PIE *ag'á 'goat' (cf. OI ajá 'goat', OIr. ag 'he-goat', etc.) and showing a regular satem treatment of the primary ${ }^{*} g$ ', as opposed to *korva (Lith. kárvè) 'cow', *kъrvz 'ox' (in OPol. karw and OPruss. kurwis) from PIE *k'orHua $-/ /{ }^{*} k^{\prime} \zeta H u o$ - with an obvious kentum treatment of the primary ${ }^{*} k^{\prime}$. In view of the very archaic character of goat breeding (the goat was probably domesticated earlier than the cow), such examples further support the membership of Proto-Slavic as originally in the satem group.

The problem is whether, in addition to "regular" satem-forms, i.e., with $s, z$ from ${ }^{*} k^{\prime},{ }^{*} g^{\prime} l * g^{\prime} h$, there can be found in Slavic forms which show the kentum treatment of the corresponding IE palatals, i.e., with $k$ (or later $\check{c} / c$ ), $g$ (or later $\check{z} / \bar{l}$ ) from ${ }^{*} k^{\prime},{ }^{*} g^{\prime}{ }^{*} g^{\prime} h$. Such forms, if not explicable by special phonetic laws, must be treated as loan-words from some prehistorical kentum dialects with which the linguistic ancestors of the Proto-Slavs were in contact. I have devoted a special article to this problem (Gołąb: 1972), the results of which I will simply summarize here. In that article I presented 47 words with the kentum treatment of PIE $k$, $g^{\prime}, g^{\prime} h$ for which there is positive evidence in other satem languages, chiefly in Aryan (but sometimes we have also kentum : satem doublets in Slavic!). Of course the above list of satem words could be easily extended. For example, a quick look at some basic words I took for the sake of testing resulted in 61 obvious satem items. So everything seems to indicate that the oldest (deepest) layer of Slavic words clearly represents a satem dialect of PIE. Only among later layers does one discover kentum borrowings. This would prove that the linguistic ancestors of the Slavs belonged primarily to the eastern, i.e., satem zone of PIE. Such an assumption harmonizes well with the old correspondences between Slavic and Aryan. A later shift of the Pre-Slavs westward brought them into closer contact with the PIE kentum dialects. This hypothetical fact can be illustrated by such lexical pairs as: *zordz : *gordz; zętb : svekry, svekrz; koza : *korva, etc. (for more examples, see below)

Before I proceed with the presentation of the respective material, I would like to mention further steps which will be taken in this chapter. Namely, after presenting the so-called old kentum elements in Proto-Slavic, I will discuss the very controversial problem of the old lexical connections (correspondences) between Proto-Slavic and Iranian, or in a broader framework: between Balto-Slavic and Indo-Iranian (Aryan). The old ties of Slavic with (Indo-)Iranian can be considered as proof of the more eastern orientation of the original Proto-Slavic vocabulary. As we will see, the problem is open to discussion. The next point under consideration will be the so-called North-West 
Indo-European vocabulary (established by A. Meillet) which encompasses Italo-Celtic, Germanic and Balto-Slavic. In this field some new data will be quoted, showing old lexical connections of Slavic with Italic (Latin). Then we will move to the problem of the North European vocabulary common to Germanic and Balto-Slavic, or Baltic and Slavic separately. Here again some new data will be quoted. The last point of our discussion will be represented by the Balto-Slavic innovative vocabulary, which, of course, can only be attended to without any pretense of its exhaustive treatment. At the end of our survey, an attempt will be made to point out some typical Proto-Slavic lexical innovations which prove already purely Slavic linguistic creativity. At the end of each particular paragraph, I will try to draw from the semantic analysis of respective words some extralinguistic conclusions concerning the social and cultural prehistory of the Slavs, and their probable geographical location at a given time.

Let us start with the kentum elements in Slavic. Words will be quoted in the Proto-Slavic form (according to the traditionally accepted late Proto-Slavic shape one finds in the etymological dictionaries of Berneker, Machek, Sławski, Sadnik-Aitzetmüller, and Vasmer). If a given form is identical with an attested OCS word no asterisk is used. In order not to repeat dictionaries the exemplification is quoted very sparsely, the reader being referred to appropriate sources.

1.) *bergq, *berkti 'guard, preserve', e.g. OCS brěgQ, brěšti (attested only with the negation ne), Russ. beregú, beréc', etc. (cf. Bern. 49, Vasm. I. 153): Pokorny 145 derives this verb from the root *bherg'h-from which also *bergz (see below) is derived.

2.) *bergz 'shore, slope', e.g. OCS brěgz, Russ. béreg, Pol. brzeg, etc. (cf. Shev. 143) - Arm. berj (satem form) 'height'; for details see Pokorny 140.

3.) *borgz 'the roof on four poles covering a stack', e.g., Pol. bróg, Ukr. oboríh, gen. oboróha, etc. (cf. Bern. 73, Vasm. I. 153): an old apophonic derivative from *bergq; cf. also Gallo-Rom. (Rhaeto-Illyr.) barga 'gedeckte Strohhütte.'

4.) braga 'malt, thin beer' (Bern. 80, Vasm. I. 205), attested only in East Slavic; for details, see Gołąb 1972: 64 and Pokorny 137.

5.) *brokati : *brssati 'throw, etc.' (the form with the satem $s$ means basically 'scrape', except for Russ., e.g., Russ. brokát', brosát', etc., cf. Bern. 93); for discussion see Shev. 142 and Gołąb 1972: 55-56 where as Proto-Slavic, the forms *broknqti; *brbsnoti are posited.

6.) *bbrgz 'den, cottage, tent' attested only in Czech: brh (cf. Bern. 49 under *bergq and Vasm. I. 153 under beregú); an old apophonic derivative of *bergo, with an exact correspondence in Germanic: *burgs e.g., Goth. baúrgs f. cons. stem 'city', etc. 
7.) cěva/cěvb (*koiuä/koiuis) 'tube, pipe' (cf. Shev. 143, Bern. 128), e.g. OCS cěvbnica ' $\lambda u ́ p \alpha$, fistula', Pol. cewa 'tube, pipe', etc. - Lith. šeivà, šaivà, Latv. saiva, satem forms (cf. Traut. 301, Pok. 919-920).

8.) čerda ( $\left.{ }^{*} k e r d h a \overline{)}\right)$, 'row, herd', e.g. OCS črěda, Russ. čeredá, Pol. trzoda (from czrzoda), etc. - OI śardha- m., śardhas- n. 'Herde, Schar', Av. sarada- n. 'Art, Gattung', etc. (for details, see Gołąb 1972: 53).

9.) *čermъ/uxa 'bird cherry' or 'wild garlic', e.g., Russ. čerëmuxa, Pol. dial. trzemcha (from czrzemcha), etc. (see Shev. 142) - *sermъ/uxa, e.g., S-C srêmuš, Sloven. srêmša, etc.; a similar variation between kentum and satem forms occurs also in Baltic (cf. Traut. 128-9).

10.) češǫ, česati (*kesjo, *kesati) 'scrape, comb' (cf. Bern. 151-2, Sław. I, 120, Vasm. IV 349) attested in all Slavic languages, e.g., Russ. češú, česát', Pol. czeszę, czesać, etc. For the discussion about the derivation of the verb in question from *k'es- (cf. Pok. 586), see Gołąb, 1972: 64.

11.) gladzks 'smooth' (cf. Shev. 142 quoted in connection with *žbltz), attested in all Slavic languages; derived from the same root *g'hel(a)- (cf. Pok. 429) as the verb *ględjo, *ględéti (see below).

12.) 'ględjo, 'ględěti 'look', e.g., Russ. gljadét', in OCS only the iterative ględati is attested, similarly in Pol.: -gladać, etc.; the palatal ${ }^{*} g$ 'h is well attested, e.g., Lith. želiù, žélti 'grow green' (the primary meaning of the root is 'glänzen, schimmern' or as an adjective 'gelb, grün, grau' etc. (see Pok. 429); for a detailed discussion, see Gołąb, 1972: 57.

13.) gnbjo, gniti 'rot, decay', attested in all Slavic languages (cf. Bern. 413) - *znějo, *zněti 'smolder, rot', e.g., Russ. dial. znét', znéju (cf. Vasm. II 101); Brückner mentions Russ. znijat' (SEJP 655 under znój). If these are really two dialectal kentum and satem variants of the same root, then we should posit PIE *g'hen-, with the extended form * ${ }^{\prime}$ 'hnei-, *g'hneiH(?) (cf. Pok. 437).

14.) gnojb 'dung', attested in all Slavic languages (cf. Bern 314) - znojb 'heat, sweat', also in all Slavic languages (cf. Vasm. II 101); old apophonic derivatives from the above verbs.

15.) golobb 'pigeon', attested in all Slavic languages (cf. Bern. 322, Vasm. I. 432-3): the word belongs to the IE root * $g$ 'hel(a)- treated above under ględjo, etc.

16.) *gorditi 'fence in, build' (cf. Bern. 330), e.g., OCS graditi 'build', Russ. gorodit' 'fence in', Pol. grodzić idem; an old derivative from *gordb (see below).

17.) *gordja f. (*gordjb m.) 'fence, wall; building material' (cf. Bern. 330), e.g., OCS graždb m. ' Hürde, stabulum', Russ. goróža 'Zaun', Pol. gródza 'Damm', Cz. hráze 'Lehmwand, Gartenmauer, Damm', etc.; an old derivative from *gords (see below).

18.) *gords 'fortified, fenced-in settlement' (cf. Shev. 142), attested in 
all Slavic languages, e.g., OCS gradъ 'town, city', Russ. górod 'town, city', Pol. gród 'castle', etc. - *zordz 'kind of wooden construction', known only in Russ. and Byeloruss., e.g., Russ. dial. zoród (old-acute!). The identical variation between kentum and satem forms occurs in Baltic: Lith. gar̃das 'corral' : žárdas 'kind of wooden construction'; for a detailed discussion, see Gołąb, 1972: 57-8.

19.) gosb 'goose' (cf. Shev. 143), attested in all Slavic languages, e.g., Pol. gęs f., Russ. gus' m., etc. - In Baltic there are only satem forms, e.g., Lith. žqusis idem; but there is also Ukr. dial. interjection dzus' (see Rudnyćkyj, 773-4).

20.) *guězda 'star' (cf. Shev. 143), attested in all Slavic languages, e.g., Pol. gwiazda, OCS zvězda, Russ. zvezdá, etc. - Baltic correspondences show the satem form: Lith. žvaigzdẽ, žvaigždẽ, etc.; cf. Gr. фoîßos 'shining' and Osset. ævzist//ævzestæ 'silver' $\leq$ OOsset. ${ }^{*}$ zvestæ (see Vasm. II, 85-86).

21.) *gybljo//gybajo, gybati iterative from *gz[b]noti 'bend' (cf. Bern. 373), e.g., OCS prě-gybajo, -gybati 'beugen', Russ. gybát' iter. 'biegen', Pol. dial. gibać idem, etc. - zybati 'rock, swing' (cf. Sad.-Aitz. 338, § 1150 and Vasm. II 109), only in OCS and East Slavic, undoubtedly two kentum and satem variants from the PIE root ${ }^{*} g^{\prime} h e u b(h)$ (cf. Pok. 450 under g'heub(h)- 'biegen, bücken, bewegen').

22.) *jbgzla ( $\leq$ *igulā) 'needle' (cf. Bern. 423, Vasm. II 115), attested in all Slavic languages, e.g., OCS in the derivative igzlinz adj., Russ. iglá, Cz. jehla, etc. - Pokorny (15) posits *ăik'-// $\breve{l k}$ ', *aig'u-; a regular satem form of the root is represented in Baltic, e.g., Lith. iẽšmas 'Bratspiess' (*aik'mo-), etc.; see Gołąb, 1972: 65.

23.) kamy, gen. kamene 'stone' (Shev. 143), attested in all Slavic languages, e.g., OCS kamy, gen. kamene, Russ. kámen', Pol. kamień, etc. - In Baltic, there are two forms (kentum and satem), e.g., Lith. akmuõ 'stone': ãšmenys 'edge'; in Indo-Iran. only satem forms, e.g., OI áśman'block of rock', Av. asman- 'rock'.

24.) katz 'hangman' (primarily 'killer, enemy'), West Slavic only, e.g., Pol. kat; probably an old vrddhi derivative from kotiti (see below). ${ }^{1}$

25.) klětb 'closet', etc. (Shev. 143), attested in all Slavic languages, e.g., OCS klětb 'Kammer, Zelle, Behausung', Russ. klet' 'store-room', etc. Baltic *šlitā- 'aus liegenden Hölzern gemachter Zaun', e.g., Lith. 16th cent. šlités plur. f. 'ladder', etc. (cf. Traut. 309); many correspondences in kentum languages, e.g., Gr. к $\lambda \iota \sigma i \alpha$ 'Hütte', Gallo-Rom. clēta 'Hürde', etc. (cf. Pok. 601); for details, see Gołąb, 1972: 59.

26.) klęčo, klęčati (klęknoti) 'kneel' (cf. Bern. 514, Vasm. II 259 under kljakat'), attested in all Slavic languages, - *slęčo, *slęčati (*slęknoti), in West Slavic only (?), e.g., Pol. ślęczeć (3 sing. ślęczy) 'pore (over)', Cz. 
dial. slečet 'bother somebody with request, wait for a gift, long for something; derived from the same PIE *k'lei- as klbno (sę) klęti (sę) (see below); for details, see Gołąb, 1972: 65.

27.) kloniti 'bend' (Shev. 142), attested in all Slavic languages, e.g., OCS klonjo, kloniti 'neigen, beugen', Russ. klonjú klonit' idem, Pol. kłonię, kłonić idem, etc. - sloniti 'lean', e.g., Church Slav. slonjo sę, sloniti sę 'acclinari', Russ. slonjú, slonit' 'lean', Pol. stonić się idem, etc.; for a detailed discussion see Gołąb, 1972: 60. We are undoubtedly dealing here with the PIE *k'lei-, from which the basic klbng (sę), klęti sę is derived (see 28).

28.) klbno (sę), klęti (sę) 'swear' (the primary meaning is 'to bow to the ground and touch it with the hand when swearing'), attested in all Slavic languages (cf. Bern. 525, Vasm. II 259), e.g., OCS klbng, klęti 'fluchen', klbnq sę, klęti sę 'schwören', Russ. kljanú(s'), kljast'(sja) (with a secondary orthographic -ja- in the present) idem, Pol. klnę (się), klqć (się) idem, etc. - Baltic *šleị̄o//šleinō (?), 'lehne an', e.g., Lith. šliejù, šliêti, Latv. sleju and slienu (sic!), sliet, etc. (see Traut. 308).

29.) koljo, *kolti 'stab and split' (Bern. 551, Vasm. II 296), attested in all Slavic languages, e.g., OCS koljg, klati 'stechen, schlachten', Russ. koljú, kolót' 'stechen, schlachten;spalten, hacken', Pol. kolę, kłóć // kłuję, khuć 'prick, sting', etc. Baltic also shows a kentum form, e.g., Lith. kalù, kálti 'schlagen' (mit Hammer, Axt), schmieden', etc. (cf. Traut. 114). To be sure, the satem correspondences of this basic verb are not attested, but judging from the lack of labialization in kentum languages, e.g., Lat.

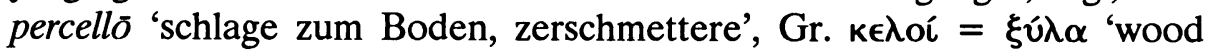
ready for use', etc., which is expected in the primary *kel- according to Kuryłowicz's theory - we can posit here an *k'el-, etc. (cf. Pok. 545); for a detailed discussion see Gołąb, 1972: 66. The root * $k^{\prime} e l(H)-$, etc. is very productive in Balto-Slavic: *kólda, *koltiti, (?), *kols, *kolsz, *kzltati,

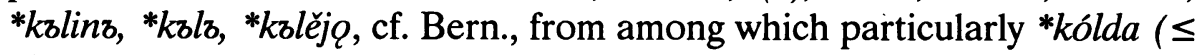
*kolHdā) 'trunk' is an old formation.

30.) kopýto 'hoof' (Bern. 565, Vasm. II 320), attested in all Slavic languages - OI śaphá-, Av. safa- idem; the details of word formation are not clear.

31.) *kórva 'cow' (Shev. 143), attested in all Slavic languages, e.g., Church Slav. krava, Russ. koróva, Pol. krowa, etc. - Pruss. sirwis m. 'Reh'; etymologically 'horned' ( $k$ '(e)rHuo-, etc.; cf. Pok. 574-6); this is a classical example of a kentum word in Balto-Slavic: Lith. kárve 'cow'.

32.) *korvajb 'horn-shaped ritual wedding cake' (cf. Bern. 577, Vasm. II 332), unknown in West Slavic, e.g., Russ. korováj, S-C kràvaj, gen. kravája, etc. - an old derivative from the same basis as *kórva.

33.) kosá I 'scythe' (Shev. 143), attested in all Slavic languages - OI 
śasati 'cut', śastrá- n. 'knife, dagger' (cf. Pok. 586 under *k'es-).

34.) kosá II 'head-hair' (Bern. 580, Vasm. II 344), attested in all Slavic languages, an old apophonic derivative from češo, česati (see above).

35.) kosnoti 'touch' (Bern. 581, Vasm. II 346), unknown in West Slavic if we abstract from its probable expressive derivative koxati (sę); etymologically connected with češo, česati (see above).

36.) kotiti 'throw down, overthrow' (Bern. 591, Vasm. II 209 under katát'), e.g., Russ. kačú, katít' (with a secondary $a$ from the iterative katát'), 'wältzen, rollen', Sloven. prekotiti 'umwältzen, umstossen', Cz. kotiti 'umwerfen', etc., etymologically identical with PSl. kotiti sę 'Junge werfen' (see Bern. 583 under kotz 2) - OI sátáyati 'haut zusammen, wirft nieder': PIE * k'at- (cf. Pok. 534) whose meaning should be posited not as 'fight', but rather 'throw' (a boomerang, spear, etc.); for a detailed discussion, see Gołąb, 1972: 67.

37.) kotora/kotera 'discord, fight' (Shev. 143), the word is known only in OCS and East Slavic, e.g., Russ. dial. kotorá, etc. OCS also has the derivative kotorati sę 'streiten, kämpfen', etc. Nominal formations are known in other IE languages, e.g., Cymr. cadr (*katro-) 'stark', MHG hader 'Zank, Streit', and a clear satem form in OI: sátru- 'Besieger, Feind' (Pok. 534); cf. kotiti.

38.) kropz 'boiling water' (cf. Bern. 623), attested in all Slavic languages (often with the prefixes $u$-, $o$-); it probably belongs to the root represented by OI śrapáyati 'kocht, brät, röstet', in other IE languages,

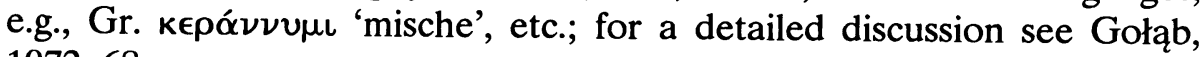
1972: 68.

39.) kropiti 'sprinkle', attested in all Slavic languages - OI śrapáyati, etc. (cf. above): the semantic development would be "stir a liquid when cooking it' $\rightarrow$ 'sprinkle', etc. Perhaps we should include here *kropiva//*kopriva 'nettle' (cf. Vasm. II 366 under krapíva).

40.) *kotja 'cottage, house', only South Slavic and Ukr., e.g., OCS kqšta 'Hütte, Zelt', S-C küća 'House', Sloven. kóča idem, Ukr. kúča 'Schweinestall, Koben', etc., undoubtedly derived from kqtz (see below) as an old vrddhi formation, primarily denoting a house with corner poles (?).

41.) kqtz 'corner' (Bern. 602, Vasm. II 422, Sław. II 2 (1961) under kqt), attested in all Slavic languages, e.g., Pol. kat, gen. kqta, Russ. kut,

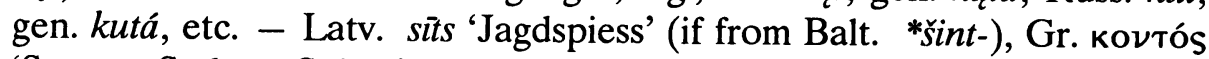
'Stange, Staken, Spiess', etc. (cf. Pok. 567 under *k'ent-): the primary meaning of Slav. kotz might be 'a pole used for construction', etc.

42.) kuna *'bitch' $\rightarrow$ 'marten' (Bern. 644 and esp. Mosz., 1957:19), the primary meaning 'bitch' is preserved in the Kashubian kuna; attested in all Slavic languages, e.g., Russ. kuná, S-C kúna, etc. Lith. has kiáunè, 
Latv. caûne, OPruss. caune (Baltic *kaunjā//keunjā, cf. Traut. 122). It is probably an old vrddhi derivative from * $k$ 'un- 'dog' according to the following pattern: *k'un- 'dog' $\rightarrow$ *k'ouná 'dog's, canine' like *diu- 'sky' $\rightarrow$ *deiúós 'celestial, god' (cf. Kuryłowicz, 1956: 151); for the regular satem treatment of * $k^{\prime} u n$ - in Baltic, cf. Lith. suõ ( $\left.\leq{ }^{*} k^{\prime} u \delta n\right)$, etc.

43.) *kury (kurbv-a) 'whore' (Bern. 651, Vasm. II 423, Mach. 249), in the latter form attested in all Slavic languages, already in Serb. Church Slav. kurbva. The best etymology seems to be the one proposed by Martynov (1963: 208-9), who compares the word with Gr. kúpıos 'powerful, lord', OI súra- 'strong, hero', Av. süra- idem, all from *k'euH'swellen, etc.' (cf. Pok. 592). In this connection *kury ("kourüs) would simply mean 'mature, grown up woman'; for details see Gołąb, 1972: 69.

44.) květz 'flower', attested in all Slavic languages (in the South and East cvětz), e.g., OCS cvětz, Pol. kwiat, etc.: an old apophonic derivative ( ${ }^{* k u o i t o-)}$ from the verb *kvbto, *kvisti (see below) - světz 'light', attested in all Slavic languages, e.g., OCS světz, 'light', Pol. świat 'world', etc., represents a satem variant of the former, i.e., PIE *k'uoito-; see also the basic verb svbtěti, svb(t)nqti, quoted in 45 below.

45.) *kvbto, *kvisti (*kvbtěti) 'bloom' (Bern. 657, Vasm. IV 292, Mach. 251, Sad.-Aitz. $221 \S 97$ ), attested in all Slavic languages, usually in different, secondary forms, e.g., OCS pro-cvbto, -cvisti, Russ. cvetú, cvestí, OPol. 3. sing. kwcie, kwiść, etc.; a clear kentum variant of the PIE root *k'uei-t- 'leuchten, hell, weiss' (cf. Pok. 628); Baltic shows a similar variation between the kentum and satem forms: Latv. kvitu, kvitêt 'flimmern, glänzen': Lith. švitěti 'fortgesetzt hell glänzen', etc. (Traut. 147, 310) - svbtěti svb(t)nqti 'shine', e.g., OCS svbtěti (sę), Russ. Church Slav. (12th cent.) svbnuti, etc.; a satem variant of the root *k'uei-t-.

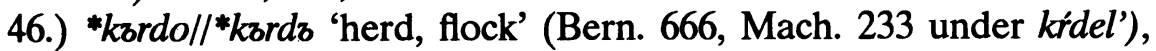
known only in S-C, Slovenian, and Slovak, and from there in the Ukr. and Pol. Carpathian dialects, e.g., S-C kr̈d/lkrd, older krdo, etc.: a reduced grade of *cerda (see above).

47.) *karms 'food, forage' (Shev. 143, Bern. 668), attested in all Slavic languages, e.g., OCS kroma//kromlja, Russ. korm, gen. kórma, etc. - Lith. has the basic verb with a clear satem treatment: šeriù, šérti 'feed' (Traut. 302-3); a nominal derivative with the suffix -men attested in Arm. $\operatorname{serm}(n)$ 'Same' and Lith. ̌̌ermens//šermenys m. plur. 'Begräbnismahl', etc. (cf. Pok. 577); here also belongs an obvious derivative *krrmiti 'feed', known in all Slavic languages.

48.) *krrvz 'ox', attested only in OPol. and Pol. dial. karw, and in OPruss. kurwis: a derivative from the same basic root as korva (cf. above); a clear kentum satem variation is represented in OPruss.: kurwis 'ox' sirwis 'roe' (cf. Shev. 142). 
49.) *melko 'milk' (Bern. II 33, Vasm. II 645, Sad.-Aitz. 269 § 527), attested in all Slavic languages, e.g., OCS mlěko, Russ. molokó, Pol. mleko, etc. - *melzivo 'beestings, colostrum', e.g., Slovenian mlézivo, Russ. molózivo, etc. (cf. Vasm. l.c.) and the basic verb ${ }^{*} m_{b} l z q,{ }^{*} m e l s t i$ 'milk', e.g., Russ. Church Slav. mъlzu, mlěsti, S-C múzem, müsti, etc. (cf. Vasm. 1.c.) show a clear satem treatment of the primary PIE *melg'-//melk'-; for a detailed discussion see Gołąb, 1972: 70.

50.) mogQ, 'mokti 'can' (Bern. II 67, Vasm. II 635, Sad.-Aitz. $270 § 531$, Mach. 303), attested in all Slavic languages, e.g., OCS mogq, mošti, Russ. mogú, moc', Pol. mogę, móc, etc. - probably an old perfect from PIE *meg'(h)- 'big' ('powerful'?), cf. Walde-Pokorny II, 258, e.g., Av. mazant-, OI mahánt-, Alb. math, madhi, etc.; for a detailed discussion see Gołąb, 1972: 70-2, and also Stang, 1972: 37-8.

51.) *moktb 'power', attested in all Slavic languages, e.g., OCS moštb, Russ. moc', Pol. moc; an obvious derivative from the above verb.

52.) *molka 'swampy ground', etc. (Bern. II 72, Vasm. II 645); this form seems to be South Slavic and Slovak, e.g., S-C mläka, etc.; but related derivatives are known also in North Slavic, e.g., ORuss. molokita, etc.; probably related to *melko (see above).

53.) *praskurz//praščrı 'great-great-grandfather, forefather, ancestor' (cf. Trub., 1959: 72-3), e.g., ORuss. praščur 'great-great-grandfather' but also 'great-great-grandson', OPol. praskurze (sic!), praszczur 'great-great-grandson', MPol. praszczur 'ancestor', OCS prašturı 'pronepotis filius', prašture idem. If from PIE *prös-k'euHro- (cf. Gr. кúpıos 'lord', OI śávīra-, 'strong' śüra- 'hero', etc. see Pok. 592), then we would have a clear kentum treatment of the $k^{\prime}$ - as opposed to the regular satem treatment of similar sequences in other cases, namely:

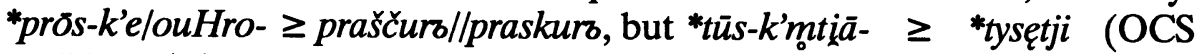
tysęšti, etc.) 'thousand'. This word would be derived from the same basis as *kury (cf. above).

54.) puga 'the wide end of an egg' (Shev. 142), attested only in Russ. and Ukr. - púzo 'belly', attested in Russ., Byeloruss. and Ukr.; there is also Pol. pyza 'big dumpling'; for details see Gołąb, 1972: 61-2.

55.) svek(z)ro 'husband's father' (Shev. 143, attested in all Slavic languages, e.g., Russ. svëkor, gen. svëkra, etc.; Trautmann (295) reconstructs a kentum form *suekura- opposed by a satem treatment in Lith. ร̌ěšuras, OI śvásura-, Av. $x^{\mathrm{v}}$ asura- idem., PIE *suek'uro- 'lord of the opposite moiety' (?) (cf. also Mach. 487).

56.) svekry 'husband's mother' (Shev. 143), attested in all Slavic languages, e.g., OCS svekry, Russ. dial. svekrý, Russ. svekróv', OPol. swiekry, S-C svekriva, etc.: "suek'rū- 'lady of the opposite moiety' (?) satem treatment in OI śvaśrū-, Arm. skesur, etc. (cf. Traut. 296); the same 
etymology as svek(z)ro.

57.) žely, gen. želzve 'turtle' (Vasm. II 41 under želvák, Mach. 593 under želva), attested in most Slavic languages, e.g., Russ. Church Slav. žely, gen. -ъve, S-C žêllva, Pol. żótw, gen. żótwia, OPol. gen. żótwi, etc. -

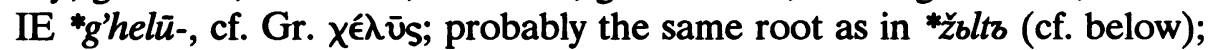
there is also an isolated Russ. Church Slav. satem (?) form zelvb (sic!).

58.) *žbltz 'yellow' (Shev. 142), attested in all Slavic languages, e.g., Church Slav. žlztz, Russ. žëltyj, Pol. żótty, etc. - the same root is represented by a regular satem form zelenı 'green', cf. Lith. želiù, žélti 'grow green', etc.; see ględěti, etc. in 12 above.

59.) 'žbrdb 'perch' (Shev. 142), attested in most Slavic languages, e.g., OCS žrbdb, Russ. dial. žéred', Pol. żerdź, etc.: a zero-grade form of the PIE base *'herdh- treated under *gordz.

As we see, there are 59 words which can be considered kentum elements with a high degree of probability, i.e., old borrowings from kentum dialects in early Proto-Slavic or even Balto-Slavic, since most of them also have correspondences in Baltic. From among these 59 words some 14 should be eliminated: they have close correspondences only in the North-West IE languages (Italo-Celtic and Germanic), therefore they can represent a later stratum of either North-West IE or even North IE vocabulary (cf. below). These 14 words are as follows: *berge, *bergz, *borgz (?), *braga, *brıkati (?), *bırgъ, gladъkъ, ględěti, kamy, *melko, ${ }^{*}$ mogg, *moktb, *molka, puga. So we are left with 45 old kentum words in Proto-Slavic.

Now it will be interesting to establish some semantic groups to which the above kentum words belong, because in this way we can obtain insight into the cultural (and ethnic?) prehistory of the Slavs. First of all we have some terms referring to cattle breeding: *čerda, *kopyto, *korva, *kotiti sę, ${ }^{*} k b r d o,{ }^{*} k b r m ъ / a,{ }^{*} k b r m i t i,{ }^{*} k b r v z ;$ then some terms referring to wooden constructions: *gordz, *gorditi, *gordja, klětb, kqtъ, *kqtja, *žbrdb; there are also some names of tools: cěva, *jogzla, kosa, and some social terms: *kury (kurъva), praskurъ//praščurъ, svekry svek(ъ)rъ; in the latter we can also include: klęti (sę) and kotora. It should be remembered that in the above list mainly the kentum words which cannot be suspected of belonging to a later North-West IE stratum have been quoted.

The fact that $40 \%$ of these kentum words represent important cultural words seems to suggest close socio-cultural relationships between the two ethnic layers of the early Proto-Slavs: a kentum and a satem tribe. The former could be considered as substratum, the latter as superstratum. We can imagine that the satem superstratum (moving from the east?) ultimately absorbed the kentum substratum, but as is the case in such 
situations, the language or dialect of the ethnic superstratum was impregnated with some elements of the substratum language or dialect. An instructive example of a similar phenomenon in relatively recent times is provided by the Polish language of the rural gentry and the urban class which was developing since the sixteenth century east of the Bug and San rivers on original Ukrainian territory: it absorbed many words of the Ukrainian substratum with their phonemic characteristics, and transmitted them to Standard Polish (e.g., the words with typical East Slav. polnoglasie like czereda, czerep, czeremcha, etc., or with $h$ instead of $g$ like hotota, hulać, hoży, the latter even with the East Slav. $\check{z}$ instead of the West Slav. $d z$, etc.). So it is probable that a kentum tribe was absorbed by the satem core of the early Proto-Slavs, most probably moving from the east. As the semantics of the words analyzed above indicates, that kentum tribe lived by cattle breeding and farming, dwelt in fenced-in or fortified settlements ( ${ }^{*}$ gord $\left.\mathrm{s}\right)$ with highly developed wooden architecture, etc. Such a situation would correspond well to the so-called Lusatian culture which flourished on the present-day Polish territory between $1300-600$ B.C., although I think that in many cases this chronology of kentum elements in Proto-Slavic would be too late.

In this connection we can also ask the following question: does the internal linguistic reconstruction allow us to establish a relative chronology of the kentum elements in Proto-Slavic? In the article mentioned above, I suggested three chronological strata for these elements in (Balto-)Slavic, namely:

1.) The oldest from the period of the PIE ethno-linguistic unity (?) or close dialectal ties: the most imporatant evidence would be the presence of a given kentum word in Indo-Iranian. This case seems to be represented by a B-S *gardas and PSl. *žbrdb (from *girdis) with their Slav. derivatives and by Indo-Iran. * $g(h) r d h a-$ (cf. OI grhá- 'Haus, Wohnstätte', Av. garađa- 'Höhle als Behausung daevischer Wesen', an older meaning "Haus, Wohnung' attested in Finno-Ugric loanwords from Iranian, e.g., Vot. gurt, Zyr. gort, etc.). Other cases which can be included here with some reservations are: česati, kosa II, kosnqti, perhaps mogQ, *moktb, if really from *meg'h-. Another piece of evidence would be the presence of a given word in Baltic: here, e.g., may belong *kärua $\bar{a}_{-},{ }^{*} k e r d a-,{ }^{*} k u r u a-$, *kurda-, i.e., PSl. *korva, *čerda, *kъrvъ, *kъrdz.

2.) The middle stratum from the period of that North West European dialectal formation or zone comprising Italic, Celtic, Germanic, and Balto-Slavic, which is represented by a set of characteristic lexical elements (see below). That transitional dialectal zone may have lasted until the first part of the second millennium B.C. It is difficult to decide which of the kentum elements in Proto-Slavic belong to that period. An 
indication would be an exact correspondence between a Slavic word and an Italo-Celtic one. See the fourteen words quoted above on p. 86.

3.) The latest from the period of the PSl. migration towards the west, which most probably started from the Middle Dniepr basin and gradually occupied the Vistula and Odra basins. The time of this prehistorical migration, or rather this gradual expansion should be connected with the appearance of the Scythians in the Pontic steppes (the back wave of the North Iranians?). Historical data indicate that the invasion of the Scythians took place somewhere around the year 700 B.C. In my opinion it was an important event which caused a large demographic upheaval in Eastern Europe (like the invasion of the Huns later). Consequently, the ethno-linguistic ties between the Proto-Slavs and the Proto-Balts were ultimately broken, the former moving more to the west and starting to occupy the Vistula basin, the latter moving more to the northwest and occupying the Niemen and Dvina basins. This newly acquired PSI. territory located in the Vistula and most probably Upper Odra basins was not empty. It was quite well populated by an agricultural population, the bearers of the so-called Lusation culture. Everything seems to indicate that they were not Germanic tribes. The alternative is that they belonged or were quite closely related to the Italo-Celtic group. Some scholars, e.g., W. Porzig (1954), would see in them Illyrians or rather their ancestors, others the so-called prehistorical Veneti. In any case, they spoke a kentum dialect with obvious western lexical innovations. I think that many kentum words in Proto-Slavic are due to this substratum. ${ }^{2}$

But the most convincing internal evidence of the high antiquity of some kentum elements in Proto-Slavic (and Baltic) is the continuation of B-S long diphthongs coming either from the PIE sequence $V R H+C^{3}$ or from $\bar{V} R C$ with a morphological (vrddhi) lengthening which, if accented, appear with the so-called old acute (rising) pitch, e.g., *korHū $\geq \mathrm{B}-\mathrm{S}$ *kāruā: Lith. kárvè, PSl. *kórva, (Russ. koróva, S-C krâva, Cz. kráva); ${ }^{*} k r H m a ̈ \geq$ PSI. 1. *kūrm̄̄, 2. *kźrma (the old acute seems to be indicated by Russ. kórmlja, S-C coll. krmad 'die Schweine', krime 'Schwein', Sloven. k'ma; the PIE root is *k'erH-); *bhōrghos $\geq$ PSl. *bórgz (the old acute seems to be indicated by Ukr. o-boríh, g. o-boróha); ${ }^{*} m o ̄ l k a \bar{a} \geq$ PSl. ${ }^{*}$ mólka (the old acute seems to be indicated by S-C mlâka, Sloven. mláka, Slovak and Cz. mláka); *kōntịa $\geq$ PSl. *kọt'a (the old acute seems to be indicated by S-C küca, Sloven. kóča; it is a derivative from *kontos $\geq$ PSl. kqtz, etc.).

Cases like the above prove that the words in question come from the B-S period, i.e., from that prehistorical stage in the development of Baltic and Slavic when the two linguistic groups were not yet separated and formed a kind of closer dialectal area after the dissolution of 
Proto-Indo-European somewhere in the third and second millennium B.C. Thus some kentum elements in Balto-Slavic or in Slavic only must have been borrowed from a kentum dialect practically still in the late PIE period. Such a hypothesis seems to be plausible if we agree that the kentum : satem differentiation (i.e. $K^{\mathbf{}}: K$ opposed to $K: K^{\prime} \geq K: \check{S} / S$, etc.) was the oldest dialectal differentiation of Proto-Indo-European and divided the primary IE territory into the West (kentum) and the East (satem) leaving aside of course the peripheral kentum dialects: Hittite and Tokharian. In this connection the linguistic ancestors of the Balts and the Slavs, i.e., those PIE satem tribes whose dialects developed later into Balto-Slavic, etc., could represent a relatively younger wave of migration moving from the east in the wake of other IE migrations undertaken by earlier kentum tribes, i.e. by the linguistic ancestors of the Celts, Italics, Teutons, etc. It is highly probable that some of those earlier IE tribes settled down on their way westward and were subsequently absorbed by a new satem wave coming from the east. In this way they acted as a kentum substratum with respect to the satem superstratum represented by the newcomers from the east. I venture the hypothesis that the population of the late Tripolye culture ${ }^{4}$ in the western Ukraine (the end of the third millennium B.C.) was a kentum substratum absorbed by the satem ancestors of the Slavs. I emphasize here the satem ancestors of the Slavs rather than those of the Balto-Slavs because first, the number of kentum elements is higher in Slavic than in Baltic (cf. Shevelov, 1965: 144), and secondly, the undoubtedly more conservative or archaic character of Baltic in comparison with Slavic seems to prove the lack of any significant earlier IE substratum in the linguistic prehistory of the Balts. Such an hypothesis is also well supported by the geographical distribution of the Slavs and the Balts in the late prehistorical and early historical periods. The Proto-Slavs most probably occupied primarily the Middle Dniepr basin, from whence they expanded quite early westward across the Bug river to the Vistula basin, whereas the Proto-Balts occupied primarily the Upper Dniepr basin, from whence they also expanded at a quite early period towards the Baltic Sea. Of course, this geographical distribution of both the ethno-linguistic groups will be discussed and substantiated in one of the following chapters. For the time being, we can hypothesize that the Proto-Slavs seem to be the descendants of a satemized earlier kentum population of the northern half of the so-called Tripolye culture. That earlier kentum agricultural population could in its turn represent some indoeuropeanized descendants of the oldest non-IE ethnic layer of the primary Tripolye culture. This "double" IE stratification (or even triple, if we agree with the already expressed hypothesis about a "Pre-Armenian" substratum in 
Proto-Slavic) of Slavic in contradistinction to a rather "monolithic" character of Baltic is reflected also in the sharp differences concerning the agricultural terminology of these two languages (which will be discussed at a later point in this chapter).

In connection with the above facts and considerations concerning the problem of kentum elements in Proto-Slavic, it is appropriate to quote the views of two outstanding Polish scholars who devoted special books to the problem of the ethnogenesis of the Slavs: they are T. Lehr-Spławiński with his book $O$ pochodzeniu $i$ praojczyźnie Stowian (On the Origins and Primary Habitat of the Slavs - 1946), and K. Moszyński with his book Pierwotny zasiag języka prasłowiańskiego (The Primary Geographic Scope of Proto-Slavic - 1957). Regardless of deep differences between these two authors (the former a linguist, and the latter an ethnologist) concerning their methods and ultimate results, they both emphasize the mixed character of Proto-Slavic in the sense of two different IE strata that are retrievable in that language. Lehr-Spławiński (1.c. 100) presents the hypothetical expansion of the so-called "Lusatian" culture carried by the prehistorical Veneti eastward to the Vistula basin:

But since the Lusatian culture did not reach further east into the territories which later constituted the core of settlements of the Baltic tribes, a simple conclusion follows: that the linguistic transformation caused by the "Lusatian" invasion of the western half of the old Pre-Balto-Slavic (i.e. undifferentiated Balto-Slavic) complex was tantamount to the splitting of this complex, and to the separation of the Proto-Slavic linguistic group. The remaining half of the earlier Pre-Balto-Slavs, untouched by this invasion, afterwards developed separately along previously marked out lines and formed a separate Proto-Baltic linguistic group, which in the course of time split into several smaller subgroups corresponding to the individual Baltic peoples... This lack of a second IE linguistic "admixture" explains the much more conservative character of Baltic linguistic development compared to Slavic and the closer connection (compared to Proto-Slavic) between the general type of the Proto-Baltic linguistic structure and that of PIE. We can also relate to that period the beginnings of a separate Baltic toponymy in the territories extending from the Narew River eastward into the Oka basin. On the other hand, in the western part of the old Pre-Balto-Slavic (i.e. undifferentiated Balto-Slavic) territory, which was encompassed by the "Lusatian" expansion, the toponyms defined by us above as 
"Venetic" began to appear at that time.

Moszyński (1.c. 18, etc.) devotes a whole chapter to the "mixed" character of Proto-Slavic and refers to a later formulation of the problem by Lehr-Spławiński in which the latter mentions the kentum elements in Slavic as evidence of an additional IE stratum in Proto-Slavic:

The Slavic languages, which are heterogeneous in character, contain among others a number of elements stemming from the kentum stratum of this mixture, which was obviously much thinner than the satem stratum.... Thus, first of all, the above stratum of kentum lexical ingredients in the vocabularies of the Slavs and the Balts being clearly non-Germanic in its character, indicate that there existed at one time in the vicinity of the Slavs and Balts an IE non-Germanic language which eventually died out. Since, however, the death of a language (except for completely small and primitive tribes) is most frequently tantamount to its assimilation (absorption) by another language, we also can assume that this kentum non-Germanic language, which was neighbor of the Slavs at one time, was eventually assimilated. (1.c. 20)

Now we can move to the eastern part of the PIE dialectal zone, to the satem languages par excellence, i.e. the Aryan or Indo-Iranian group. From the very fact that Slavic manifests its basic satem character, we can draw a hypothetical conclusion that it will also show many old lexical ties with Aryan, or al least with the Iranian branch of the Aryan languages. Such an hypothesis was ventured quite a few years ago; in the books by $\mathrm{T}$. Lehr-Spławiński and K. Moszyński mentioned above in that respect we actually find some interesting facts.

First of all, Lehr-Spławiński attempted to establish the number of old lexical correspondences (in terms of PIE dialectology) between (Balto-)Slavic and the other dialectal groups of Proto-Indo-European, mainly Germanic on the one hand and Aryan on the other. Using the comparative dictionary of IE languages by Walde, be obtained the following results: Slavic-Germanic correspondences - 187, Slavic-Aryan correspondences - 100. But Moszyński questions the conclusions which are drawn directly from these statistics. Namely, in his opinion, the Germanic vocabulary is much better known, and in Walde's dictionary the Germanic word index fills sixty-five pages, whereas the Aryan vocabulary is less well-known (especially the Iranian), and in Walde's dictionary takes up only twenty-seven pages. Against this statistical background, we should indeed wonder that the number of Slavic-Aryan correspondences is so high. Undoubtedly a better knowledge of Iranian 
vocabulary would increase the number of Slavic-Iranian correspondences, which, incidentally speaking, seems to have taken place recently. In this connection it is characteristic that Moszyński devotes an entire chapter of his book to this statistical interpretation (1.c. 77-81). Consequently we venture the hypothesis that the actual number of Slavic-Aryan correspondences at least equaled, if not surpassed, the number of Slavic-Germanic correspondences.

The problem of Slavic-Aryan, and particularly Slavic-Iranian lexical correspondences, has been discussed by many scholars during this century. As one of the first, J. Rozwadowski with his article written in 1908, and published in 1914-15 can be mentioned. One of the recent scholars, O. N. Trubačev with his critical essay of 1967 is worthy of special note.

Following is a condensed, critical review of all the relevant examples found in the pertinent literature. The data-core has been taken from a very useful article by A. A. Zaliznjak (1962), and supplemented on the one hand by an older source, namely $\mathrm{H}$. Arntz (1933), (whose valuable contribution is not included in Zaliznjak's bibliography), and on the other by recent publications (O. N. Trubačev, 1967; E. Benveniste, 1967; Z. Gołąb, 1969, 1972, 1975). The list of words in question is, of course, critically checked against the comparative IE background provided by $\mathrm{J}$. Pokorny's dictionary.

However, before quoting the relevant examples, it is necessary once again to emphasize that we should attempt to make a clear distinction between words which represent prehistorical dialectal Slavic-Aryan or Slavic-Iranian correspondences and those which can be treated as prehistorical borrowings from Aryan (chiefly Iranian) to Slavic, although in individual cases judgment may be difficult. Especially in cases when we deal with seemingly purely semantic calques linguistiques of Iranian in Slavic a difficulty appears. Nonetheless, obvious or quite transparent borrowings, such as those which show phonemic and/or morphological features of Aryan (mainly Iranian), are treated in a separate chapter of this book. Therefore, in order to realize the entire scope of prehistorical Slavic-Aryan, and especially Slavic-Iranian contacts, both in the sense of prehistorical dialectal relations within late Proto-Indo-European and in the sense of prehistorical relations between already individualized ethno-linguistic groups, one should compare the results of this paragraph with the results of the appropriate paragraph in the chapter on the reciprocal lexical borrowings between Proto-Slavic and the neighboring languages.

The words which are listed and analyzed below are tentatively divided into the four following groups: 1 . words common to Balto-Slavic and Aryan; 2. words common only to Slavic and Aryan; 3 . words common to 
Baltic, Slavic and Iranian; 4. words common only to Slavic and Iranian (schematically: BS-A, S-A, BS-I, S-I). Such a distribution seems to reflect a different relative chronology of the prehistorical linguistic contacts between the respective ethno-linguistic groups. ${ }^{5}$ It is obvious that the first group of words (common to Balto-Slavic and Indo-Iranian) represents the oldest stratum from the period of the PIE dialectal community in Eastern Europe, i.e. before the separation of the Aryan tribes and their gradual movement across the Caucasus and around the Caspian Sea (?) to Asia. The last group of words (common only to Slavic and Iranian) represents the youngest stratum from the period of the split of the PIE dialectal community in Eastern Europe, probably when the already loosened linguistic contacts between the ancestors of the Indians and the Iranians enabled the latter to develop some characteristic features of their own. Or maybe it is even from a relatively later epoch when a "back-wave" of the Iranians, namely the Scythians, appeared in the Pontic steppes, and again entered into close relations with the Proto-Slavs. It is from that time (starting about 700 B.C.?) that some semantic borrowings (calques linguistiques) most probably came into Slavic from Iranian, e.g., bogz, divz, nebo, slovo, etc., and of course, the obvious lexical ("material") borrowings which are treated in a separate chapter.

Group 1: Aryan Balto-Slavic

1.) avě adv., e.g. OCS (j)avě 'kund, deutlich, offenbar', and its derivative (j)aviti 'zeigen, offenbaren', known in all Slavic languages (cf. Bern. 34) - Lith. ovyje 'im Wachen' (Traut. s.v. äuii-), OI ãvís adv., Av. āviš adv. 'offenbar, vor Augen' (cf. Pok. 78 s.v. au-, auēi- 'sinnlich wahrnehmen, auffassen' and Zal. 36).

2.) (j)azbno 'skin, leather' attested in Church Slavonic azno, jaz(b)no 'corium detractum' (cf. Sławski 1974: 167) - Lith. ožinis adj. 'goat's, OI ajina- n. 'Fell', all derivatives from PIE *ag'- 'Ziegenbock, Ziege, cf. OI ajá- m. etc. known only in EIE (cf. Arntz 37, Bern. 35, Traut. 22 s.v. äžla äžina-, Pok. 6-7).

3.) bez(z) prep. with gen. 'without', e.g. OCS bez with gen. 'ohne,' known in all Slavic languages (cf. recently Sławski, 1974: 218-219) Latv. bez prep. with gen. and nominal prefix 'ohne', Lith. bè idem, OPruss. bhe prep. with acc. idem, OI bahih(-s) adv. 'draussen, von aussen, ausserhalb von' (with abl.), cf. Arntz 33, Traut. 28, Pok. 112-113, s.v. b(h)eg'h-.

4.) cadz//kadz 'smoke' and čaditi//kaditi causative verb, the first variant attested in all Slavic languages, e.g. Russ. čad, gen. čáda, Pol. czad usually with the meaning 'smell of burning', S-C čâd m. 'smoke, steam,' etc. (cf. Sławski, 1976: 105-106) - OPruss. accodis (*at-codis) 'Rauchloch', OI 
kadru- 'brown', other sure correspondences are unknown (cf. Bern. 133, 467, Arntz 36, Pok. 537 s.v. ked- 'rauchen, russen'; Trubačev, 1977: 9 considers kadz the primary form and $\check{c} a d z$ the result of an expressive palatalization).

5.) *čbrnz 'black', e.g. OCS črbns 'schwarz' known in all Slavic languages (cf. Bern. 169-170) - OPruss. kirsnan idem, OI krşna'schwarz' (cf. Traut. 134, Pok.583, Porzig 167).

6.) čbto, čisti 'count'; 'read'; 'regard, esteem,' e.g. OCS čbto, čisti 'zählen, lesen; ehren, verehren', known in all Slavic languages, usually in the primarily iterative form čitati, čitajo (cf. Bern. 174 and Sławski, 1976: 206-208) - Balt. forms with the initial mobile $s$-: Latv. šk'ietu, šk'ist 'meinen', skàitu, skàitît 'zählen', Lith. skaitaũ, skaitýti 'zählen, lesen' (the two latter forms representing the primary iterative have an exact correspondence in Ukr. dial citátysja 'bother, ponder for a prolonged period'), OI cétati(*keite-ti) 'hat acht auf etwas, nimmt wahr', Av. čiki denkend, überlegend': only Balto-Slav. and Aryan show the extension - $t$ in this root (Traut. 135, Pok. 637, Zal. 36).

7.) griva 'mane', e.g. Church Slav. griva, Russ. griva, S-C grìva, etc., known in all Slavic languages (cf. Bern. 352) - Latv. griva 'Delta, Flussmündung', a clearly metaphoric meaning, OI grivaá- f. 'Hinterhals, Nacken', Av. griv̄ā- f. 'Nacken' (Traut. 98-99, Pok. 475, Porzig 167).

8.) *klěsno, klěsnqti 'clench, clasp' (with tongs, pincers, etc.) and old derivatives of this root: *klěša, klěšča (i.e. *klěstja) 'tong', *klěšč m. 'tick', e.g. Cz. s-klesnúti, s-klesnouti 'zusammendrücken, -legen' (ústa, zuby), Russ. dial. klestí (*klěstí) 'drücken, pressen'; etc., Church Slav. klěšta f. 'Zange', Russ. klešči plur. 'Zange, Kummetholz; Vorderzähne der Tiere', etc., the noun is known in all Slavic languages; Russ. klešč m., Ukr. klišč, Pol. kleszcz, etc. 'Zecke' (cf. Bern. 516-517) - Lith. klišé f. 'Krebsscheren', OI kliśnáti 'quält, belästigt', klísyatē 'wird gequält, leidet', kléśa- m. 'Schmerz, Leiden, Beschwerde'; the PIE verbal root *kleik'- is Aryan and Balto-Slav. only (cf. Pok. 602, Traut. 137 and Arntz 35).

9.) *kyša $\rightarrow$ *kyšbka 'stomach, belly' $\rightarrow$ 'gut', North Slavic (?) dialectism, e.g. Polab. k'oisa (t'áisa) 'Niere', Russ. Church Slav. kišbka 'stomach', Russ. kišká 'gut', Pol. kiszka idem, etc. (cf. Bern. 679, Sławski, II, 2, 174-175, Vasm. II 242) - Lith. küšỹs, Latv. küsis, küsa 'weibliche Schamhaare' ( *kük'i- or kük'si-), Lith. kiaũšis 'Ei, Hode', káušas 'grosser Schöpflöffel', Latv. kaûss 'Schüssel, Kochlöffel', OI kukşí- m. 'Bauch, Mutterleib, Höhlung', kôśa- m. 'Behälter, Schatzkammer, Scheide'; most probably Balto-Slav. archetype *kük'siāala- (cf. Arntz 40, Pok. 953 s.v. (s)keu-k'-).

10.) *kzrnz 'mutilated' (especially about ears, nose, limbs), attested in most Slavic languages, e.g. Church Slav. krъnъ 'verstümmelt am Ohr, an 
der Nase', Russ. kórnyj 'von kleinem Wuchs, kurz', S-C krn, f. kína 'splitterig', Cz. krniti 'verschneiden', etc.; this adjective seems to have played an important role in animal husbandry terminology (cf. examples in Bern. 669 and Vasm. II 330) - Latv. dial. kuorns 'taub', besides Latv. kurls, Lith. kur̃cias, kurlas idem (Balto-Slav. *kurna-, cf. Traut. 146), OI kirnáa- 'verletzt', karná- 'stutzohrig', Av. karəna- 'taub', Osset. kur-, kul-, $k^{6} u l$ - in words denoting handicaps (cf. Slav. compounds with *kzrno-!) e.g. kur-æf-cæg 'having a short neck', etc. (cf. Zal. 38 and Pok. 938 s.v. (s)ker(a)- 'schneiden' where the PIE *kj̄-nó- 'abgeschnitten' is reconstructed, the archetype underlying Slavic, Baltic and Aryan forms).

11.) otz-lěkъ 'remnant', attested in OCS otzlěkъ 'das Übrige, der Rest' and olěkろ from *otlěkß attested in ORuss. olěkろ dial. Russ. ólek 'upper part of bort', i.e. wild bees' nest', Ukr. olik, BRuss. olëk - Lith. ãt-laikas 'Rest', OI atiréka- m. 'Überbleibsel', all of the above words are derivationally and semantically identical: ${ }^{*}$ et(i)-loik ${ }^{\mathrm{u} o}{ }_{-}{ }^{6}$ although the root and the type of noun are common PIE (cf. Bern. 710, Vasm. III 134, Traut. 155, Pok. 669-670, and Porzig 167).

12.) 'paža//*paxa//*paxy (paxzv-) 'armpit', attested in Cz. paže 'arm', Slovak podpažie 'armpit', ULus. podpaža idem, and in Russ. paxá 'armpit', Ukr. paxál/paxvá, BRuss. paxvá, Pol. pacha idem; in other Slavic languages and in Russ. also paxъ m. - Latv. paksis 'Hausecke' (sic!), OI pákşa- m. 'Schulter, Flügel', pakșas- n. 'Seite, Achsel, Hälfte', pãjasya- n. 'Bauchgegend, Weichen'; whether Lat. pectus n. 'Brust' belongs here is disputable (cf. Meillet 745), but there is a correspondence in Tokharian; Pok. 792 reconstructs * ${ }^{*} \check{o g}$-, ${ }^{*} p \check{p} k$-s- (cf. Vasm. III 220 and Arntz 38).

13.) paz-duxa 'armpit' in this form (with - $d$-) is preserved only in Sloven. pâzduha, in all other Slavic languages there is continuation of a simplified pazuxa, e.g. OCS pazuxa 'Achselhöhle, der gekrümmte Arm', Russ. pázuxa, Pol. pazucha, etc. - East Latv. pazuse from *paduse under the influence of borrowed pazuka (?), OI dōş- n., m., gen. dōşnáh 'Vorderarm, Arm, unterer Teil des Vorderfusses bei Tieren', Av. daoš- m. 'Oberarm, Schulter'; the Balto-Slav. words contain the prefix * $p \check{o}(s)$ - 'at, with' (cf. Vasm. III 186-187, Traut. 64, Pok. 226, s.v. dous-).

14.) *pbrsb 'breast', used normally in the dual *pbrsi and attested in all Slavic languages, e.g., OCS prbsi, Russ. plur. pérsi, Pol. pierś, piersi, etc. Lith. (Žem.) pirřys plur. 'anterior pars pectoris equini', OI párśu- f. 'Rippe, gebogenes Messer', Av. parasu- f. 'Rippe', parasu- m. 'Rippe, Seite', Osset. fars 'Seite, Strich, Gegend' (Vasm. III 245, Traut. 220, Pok. 820, Zal. 38).

15.) sivz 'gray', attested in all Slavic languages, e.g. Russ. Church Slav. sivz 'dunkelgrau' (referring to horses), Russ. sivyj 'bläulich grau', etc. (cf. Vasmer III 617) - Lith. šyvas 'weiss, schimmelicht' (mostly referring to 
horses), OPruss. sijwan 'grau', OI śyāvá- 'schwarzbraun, dunkel' (especially about horses), Av. syāva- 'schwarz': PIE archetype *k'üuo-//*k'iēuo- (cf. Traut. 306, Pok. 541, and Porzig 166).

16.) "szčetb f. 'bristle', the continuation of this form or its derivative *szčetina known in all Slavic languages, e.g. Polab. sacét, Russ. ščet', f. šcetína, Sloven. ščet f. 'Bürste', etc. (cf. Vasmer IV 505) - Lith. šùkos f. plur. 'Kamm', Latv. suka 'Bürste, Pferdestriegel; Hechel', etc. (cf. Traut. 309-310 s.v. šukā-),OI śüka- m., n. 'Stachel eines Insekts, Granne des Getreides', Av. sūkā- f. 'Nadel' (cf. Pok. 626 s.v. k'ü- 'spitz, Spiess' under which, however, Balto-Slav. words are not quoted; cf. also Arntz 37, who derives Aryan and Balto-Slavic words from the root of OI sváñcatē 'öffinet sich, tut sich auf', i.e. from PIE *k'uek//*k'uenk-//*k'uk- according to Pok. 629; the derivatives of the latter, e.g. OI ucchvanka- $\mathrm{m}$. have the meaning 'das Aufklaffen, Lücke, Scherbe' etc.; here the Slav. sъčetb is quoted by Pokorny).

17.) *tžšč (i.e. *tzskjo-) 'empty', attested in all Slavic languages, e.g. OCS tžštb 'leer, nichtig, eitel', Russ. tóščij 'leer, nüchtern; mager, hager, dünn', Pol. czczy (OPol. tszczy) 'leer, nüchtern, eitel', etc. (cf. Vasm. IV 31) - Lith. tùščias 'leer', Latv. tukš, tukša f. 'leer, ledig, arm, nüchtern' (Balto-Slav. *tuštia- according to Traut. 333 from PIE *tus-sk'-tio-) OI tucchá-, tucchyá- ('tus-sk'o-, tus-sk'-io-) 'leer, öde, nichtig,' Afghan taš 'leer' (cf. Pok. 1085 s.v. teus- 'leeren,' tus-sk'o-, -sk'-io- 'leer': the underlying verb of the *tus-sk'o type attested by Av. tusan 'sie verlieren die Fassung' and Baluchi tusag, etc. 'verlassen werden' seems to be continued by Slav. *tzsknqti, e.g. Church Slav. sztzsnqti si 'to feel irritation', etc. Cz. stesknouti se impers. 'to feel melancholy', stesknouti si 'to complain', 'to pine for (something or someone); cf. also Arntz 36).

Group 2: Aryan-Slavic

1.) *bъrz $(d) z$ 'fast, rapid', known in all Slavic languages, e.g. OCS brzzo adv. 'rasch, schnell', Russ. bórzyj 'schnell, rasch', etc.; borzój idem, type of dog, Pol. bardzo adv. 'sehr', dial. 'schnell', etc. The forms with -d( $\left.{ }^{*} b z r z d z\right)$ are attested in ORuss. borzdyj, borzdo, BRuss. bórzdy and in S-C derivative brzdica = brzica 'Stromschnelle' (for details, see Bern. 109-110, Vasm. I, 194, Traut. 40 s.v. burzdu-, Sławski, 1974: 427, Trubačev, 1976: $135,137-138)$. The etymology for this word is highly controversial; the closest correspondence seems to be Lith. burzdùs//bruzdùs 'beweglich' which Pokorny quotes under *bheres- 'schnell', and compares it among others with Lat. festino 'beeile mich, beschleunige', a denominal from 'ferstiō(n)- 'Eile', etc. (Pok. 143). But the simplest correspondence (formally) would be Arm. barjr 'hoch' ('bhrg'hu-), Av. baraz- 'hoch' as the first component of compounds, otherwise barazant- idem, OI brhánt- 
'gross, hoch, erhaben, hehr'; there are, however, also Celtic and Germanic correspondences. In view of the fact that the latter have their Slavic counterparts showing a kentum $g$ (from PIE * ${ }^{\prime} h$ ), e.g. ${ }^{*} b b r g z$ (quoted in the preceding paragraph), the equation PSI ${ }^{*} b z r z b=$ PIE *bhrg'hu-, supported by Aryan and Armenian, would indicate here a regular satem continuation of the PIE word in Slavic having close, although not exclusive ties with the Aryan East; the semantic passage 'high' > 'rapid' was probably conditioned by the application of the adjective ${ }^{*} b h g g ' h u$ - to river rapids (where the water runs down from a grade, $\mathrm{cf}$. in this connection S-C brzica 'rapids'). In such a case, of course, the forms with $-d$ - and their Baltic correspondences should be kept apart; their eventual contamination with *bbrzb would be a later process. In connection with all of the above, ${ }^{*} b z r z b$ cannot be considered as a special case of Slavic-Aryan lexical ties, although it deserves mention in this context (for IE material, see Pok. 140, for the Aryan correspondences, Zal. 36). It is also worth mentioning that Fraenkel, I, 57 s.v. briaũgzti, briauzgiù suggests the derivation of Lith. burzdùs//bruzdùs and Slav. *brrz(d)z from PIE *bhreus- 'brausen, wallen, rauschen, hervorquellen', cf. Pok. 171).

2.) čbstb 'reverence, honor', known in all Slavic languages, e.g. OCS čbstb 'Ehre, Verehrung, Rang, Stand, Feier', Russ. čest' 'Ehre', Pol. cześć idem, etc. (cf. Bern. 173) - OI čitti- f. 'Denken, Einsicht', Av. čisti- idem: an obvious old derivative from the verb čbto, čisti quoted in the first group (of Aryan Balto-Slav. correspondences); Zal. 36.

3.) gajo, gajati 'shout', only in ORuss. gaju, gajati 'caw, croak' - OI gáyati/lgáti 'singt'; cf. also Toch. A. kāk, B kāka (reduplicated from * ${ }^{\prime} \bar{a}-$ ) 'er rief' (Pok. 355 s.v. gē(i)-: gö(i): gī- 'singen, rufen, schreien'; cf. Zal. 37).

4.) gatajo, gatati 'divine, tell fortunes,' attested in South Slavic e.g. Church Slav. gataju, gatati 'dunkel in Rätseln sprechen, wahrsagen', Bulg. gátam 'divine, tell fortunes', gátkam se 'gebe ein Rätsel auf', S-C gâtam, gátati 'wahrsagen, hexen,' etc. and in OPol. gatać 'converse, deliberate' the etymological basis of this verb seems to be Aryan *gāthä- f., i.e. OI gáthā- 'Gesang, Vers', Av. gā $\bar{a} \bar{a}-$ 'Lied religiösen Inhalts', which is derived from gáya-ti 'singt' (see above); the Slavic verb seems to share with the Aryan noun a characteristic religious-magical connotation (cf. Bern. 296, Trubačev, 1979: 105, Pok. 355, and Zal. 37).

5.) 'goldz 'hunger', attested in all Slavic languages, e.g. OCS gladz, Russ. gólod, Pol. głód, etc.: an old o-grade derivative from *žblděti (see below) - OI gárdha- 'Gier', Av. garađa- adj. 'gierig', hastig' (the latter corresponding to OI grdhra-idem, not to the noun gárdha- as Pok. 434 seems to suggest and Zal. 37 repeats; there is a different etymology in Trubačev, 1979: 199-200; cf. Bern. 320, Pok. 434, and Zal. 37). 
6.) xudz 'meager; bad; poor', attested in all Slavic languages, e.g. OCS xudz 'klein, gering, dürftig, schlecht, mässig', Russ. xudój 'schlecht, schlimm, übel; mager, hager', Pol. chudy 'mager, hager; armselig', etc. (cf. Bern. 405) - OI kşodh-uka- 'hungrig', an obvious derivative from kşudhyati 'hungert' (cf. Machek, 164, Pok. 625) or OI kşudrá- 'klein; niedrig, gemein', comparative kşódiyas- from the verb kșódati 'stampft, zermalmt' (Pok. ibid. and Arntz 37).

7.) $x y b a$ 'error, lack, deficiency' and its derivatives xybiti and $x y b a t i$ 'err, miss', etc., attested im most Slavic languages, e.g. Ukr. $x y ́ b a$ 'Mangel, Fehler', xybýty, xybáty 'mangeln, fehlen, irren', but the latter also 'zweifeln, unschlüssig sein', Sloven. híba 'Gebrechen, Fehler', híbati 'tadeln', Cz. chyba 'Zweifel', chybati 'zweifeln, schwanken', chybiti 'nicht treffen, fehlen', Pol. chyba 'Fehler, Mangel, chybać 'schaukeln; sich rühren, bewegen', chybic 'fehlen, verfehlen; missraten', etc. - OI kșúbhyati, kşóbhyatē 'schwankt, zittert, kşóbha- 'Schwanken, Erschütterung', Av. x̌aob- 'in Aufregung geraten' (cf. Bern. 412, Pok. 625, Zal. 37: the PSl. noun represents the archetype $\left.{ }^{*} k s \bar{u} b h \bar{a}\right)$.

8.) jędr 'strong' and its derivative jędró 'nucleus, kern', in plur. 'testicles', attested in most Slavic languages, e.g. OCS jędro adv. 'schnell' (secondarily from 'strongly'), Bulg. édar kräftig, tüchtig, kernig', S-C jédar 'voll, kräftig, stark', Russ. dial. u-jadrét' 'stark werden, sich kräftigen', etc.; Russ. Church Slav. jadro 'nucleaus, testiculus', Russ. jadró 'Kern, Kugel, Granate', Pol. jqdro 'Kern', plur. jqdra 'Hoden', etc. (cf. Bern. 455-456) OI indra- 'stark', Indra-, Av. Indra-, the name of one of the trinity-gods, cf. also OI indriyá- n. 'Kraft, Vermögen' and 'semen virile' (for the latter, see Slav. jędra 'testicules'): the stem with a nasal infix, *i-n-dro-, is known only in Aryan, Slavic and in Baltic hydronyms (cf. Pok. 774 under *oid 'schwellen' and Zal. 37).

9.) $k z(n)$ prep. with dative 'towards', attested in all Slavic languages, e.g. OCS $k b$ ' $z u$ ', Russ. $k(o)$, S-C $k(a)$, Pol. $k$, $k u$, etc. - OI kam after personal datives as dativus commodi, after abstract datives as dativus finalis, similarly in Av. kam (cf. Bern. 568, Pok. 515 and Zal. 34); but there is a different interpretation in Etymologický slovník jazyku slovanských I (1973), p. 105, where $k b$ is derived from $k b$-de 'where'.

10.) Mara 'demon of death', attested in Ukrainian, Bulgarian, Polish, and Czech folklore, e.g. Ukr. Mará, Bulg. Mára, Pol. Marzana, Cz. Mařena, etc. (cf. Moszyński, 1957: 87 and Gołąb, 1967: 779-780) - OI māra- m. 'death, pestilence' Māra- 'Death personified, demon of darkness and evil'; a common Aryan-Slavic vrddhi derivative from *moro- 'death' (cf. Porzig, 166, and Pok. 735).

11.) niščb ("nistịo-) 'poor', attested in OCS ništb 'arm, niedrig', Russ. níščij, Ukr. nyščyj, S-C ništ and OPol. niszczotny - OI nisstya- 'foreign' 
derived from nih 'outside' (cf. Vasm. III, 77).

12.) -nbznq, -nbznqti and nižq, nizati 'pierce' (with nail or needle, etc.), attested in most Slavic languages, e.g. OCS pro-nbznoti 'durchbohren', vъnbsti//vъnbznǫti '(hin)einstecken', OCz. pronznúti, venznúti, Russ. (morphologically transformed) pronzit', vonzit', -nžú, etc. and Russ. nizát', nižú 'thread, string', S-C nizati, nužem idem, Pol. nizać, niżę idem, etc. OI níksati 'durchbohrt', Av. naèza- 'Spitze', i.e. *neig'- (?) (cf. Arntz 40, Sadnik, 275, § 580, Machek, 329 s.v. nưž, Vasm. III, 73, 80). PSl. nožb 'dagger' > 'knife' is most probably connected with the above verb.

13.) ovz, ova, ovo 'this', known in most Slavic languages, e.g. OCS ovz 'dieser', ORuss. ovyj = ètot, tot, Pol. ów, owa, owo, 'that', S-C dvaj, òva, dvo 'this', etc. - OI, Av., OPers. ava- 'jener' (cf. Vasm. III, 116, Pok. 73 and Zal. 33).

14.) pěsъkъ 'sand', attested in all Slavic languages, e.g. OCS pěsъkъ 'Sand, feiner Kies', Russ. pesók, Pol. piasek, etc. - OI pāmsú-, pāmsuká'Staub, Sand', Av. pqsnu- idem, i.e. PIE *pē(n)s- (cf. Vasm. III 249-250, Pok. 824 and Zal. 37).

15.) piskz 'germ of a feather' (on a nestling), only in Czech pisk (cf. Machek 368), a possible connection with *pisklę, e.g. Pol. piskle, Cz. piskle, Russ. pisklënok 'nestling', although the influence of the verb "piščati//piskati 'squeal' is obvious in the latter; - OI picchá- $\mathrm{n}$. 'Schwantzfeder', PIE * $p(e) i s k ' o$ - (?) (cf. Arntz 38, after Walde-Pokorny II, 11).

16.) *pbrkajo, *psrkati//*pzrkajo, *pъrkati 'rut' (especially referring to goats) and its derivative * pbrčb//*pzrks 'he-goat', attested in S-C prcati se (with a secondary $c$ according to the third palatalization of velars, or expressive) 'coitum appetere', Sloven. prkati 'sich begatten', Bulg. parca se 3rd sing. idem, Cz. prkati 'to smell like a he-goat'; S-C prěc, gen. prča 'he-goat', also 'ram': known in all South Slavic languages from which it penetrated into Rum., Alb., and MGr. (cf. Skok, III 28); indirectly in the derivative ${ }^{*}$ pb/zrčiti se, e.g. Cz. prčiti se, Ukr. pérčyty sja, and *pb/ъrk-ot, *pb/zrk-ot-ina, e.g. Pol. park, parkot, Cz. prk, prkotina 'goat's odor', etc. (cf. Brückner, 396, Machek, 392); probably an old pastoral term; - OI upa-parcana- n. 'Begattung' (Arntz 42).

17.) sanz ( $u$-stem!) 'dignity', attested only in OCS and ORuss. - OI sánu- n. 'Gipfel, Oberfläche, Höhe'; this is questionable because of the limited spread of the word, more probable (?) is a Proto-Bulgarian (Turkic) origin (cf. Sadnik-Aitzetmüller, 297, §784, Traut. 250, Vasmer III, 555, and Arntz 37).

18.) šibajo, šibati 'throw, whip', attested in most Slavic languages, e.g. OCS šibati, -ajQ 'geiseln', Russ. šibát' 'throw, beat', šíbkij 'fast', S-C šibati, š̉bam 'whip', etc., Pol. szybki 'fast', etc. - OI kssipáti 'wirft, schleudert,' 
caus. kşēpáyati, kşiprá- 'schnell' (cf. *šibъkъ in Russ. šíbkij, Pol. szybki), Av. xšviwra- 'schnell', flink, geläugig' = OI kşiprá-, i.e. PIE *kseip/b- 'werfen, schwingend schleudern' (cf. Vasm. IV, 435, Pok. 625, Bartholomae 563, and Arntz 37).

19.) šujb 'left', attested in OCS šujb 'link', ORuss. šujb idem, Sloven. šûj, f. šúja idem; elsewhere in the derivatives: e.g. Ukr. šújbič (*šujb-bočb) 'on the left side', S-C šùvak 'lefthanded person', etc. - OI savyá- 'link', Av. haoya- idem (cf. Vasm. IV, 484, Pok. 915, Arntz 36 and Zal. 37); it is worth noticing that the adj. 'left' and 'left-handed' (cf. OCS šujica) play a very important role in magical, religious, and legal symbolism.

20.) *šurbjb 'wife's brother', attested in most Slavic languages, e.g. CS šurb, šurinz, Russ. šúrin, plur. šur’já, Bulg. šúrej, S-C šûra, šùr(j)ak, plur. sürevi, OPol. szurzy, etc. (for the reconstruction of the primary form *šurbjb, see Vaillant, II (1958:71). It is usually compared with OI syāla'Bruder der Frau' and both are derived from PIE *siē $(u) r(i) o-(?)$, cf. Vasm. IV, 488, Traut. 261, Pok. 915, and Arntz 37. If the above etymology is true, then *sieuro- could be treated as a derivative of the verbal root *siēu-, *sīu- 'sew, i.e. bind' (cf. Pok. 915 s.v. sìü-) and a

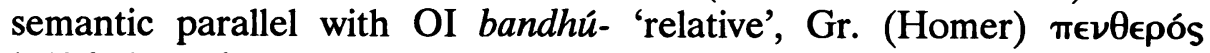
'wife's father', later also 'son-in-law, brother-in-law', both words from PIE *bhendh- 'bind', will be obvious (cf. Buck, 124). There are, however, some doubts concerning this etymology. Namely: if we accept Vaillant's convincing reconstruction of this noun as an old -iịo- stem, i.e. a primary adjective, then šurbjb could be interpreted as parallel to Germanic *swēhura- (OHG swäger, NHG Schwager) - a vrddhi adjective from *swihura- (Goth. swaihra, OHG swëhur, NHG Schwäher) - also as a $v$ rddhi derivative *k'ēurijo- from *k'ūro- 'lord'. The only distinction would be in the older type of vrddhi in the latter case (cf. Kuryłowicz, L'apophonie...152), so: *k'üro- (or *k'uHro-) 'lord' (respectful title of future father-in-law) > *k'éuriīo- (or 'k'euHriio-) 'lord's (son)'; in connection with the latter, notice the old acute in the PSl. šúrbjb!

21.) 'tzlkb 'interpreter' and its derivative *tzlkujq, -ovati 'interpret', attested only in East Slavic and Macedo-Bulgarian, e.g. OCS tlokb 'Dolmetscher', tlıkovanije 'Erklärung, Interpretation', ORuss. tolkъ 'interpretation' and 'interpreter', Russ. tolk 'sense', tolkovát' 'interpret, explain', Bulg. tzlkúvam idem, etc. - OI tarkáyati 'vermutet, sinnt nach', tarka- m. 'Vermutung'; other connections are uncertain (cf. Vasm. IV, 71, Sadnik-Aitzetmüller, 319, §976 and Arntz 39).

22.) *vertenz//*verten'b 'a measure of length' (applied to land, etc.), attested only in BRuss. dial. verećen, Ukr. dial. vereten', Bulg. (N. Gerov) vrěten and OSerb. vreten - Mitanni-Aryan aika-vartana 'eine Runde (der Rennbahn)’, OI vartana- n. ‘das Drehen’ (cf. Moszyński, 1957: 95-97, Pok. 
1156).

23.) *ver(t)meq *'turn' > 'time', attested in most Slavic languages, e.g. OCS vrěmę, ORuss. veremja Russ. vrémja (from OCS), Ukr. véremje 'good weather', S-C vrijème, OPol. wrzemię, etc. - OI vártman- n. 'Radspur, Bahn' (also metaphorically); for an interesting semantic analysis of Slav. *vertmę OI vártman- cf. Moszyński, 1957: 95-97 (cf. Vasmer I, 361, Pok. 1156 and $\mathrm{Zal} 37)$.

24.) 'žbldjo, -iši, žblděti 'be thirsty, thirst for, desire', attested in Serb. Church Slav. žlbděti, Russ. Church Slav. žblděti, S-C žúdjeti 'desire, strive' (cf. Vasm. I, 430 s.v. gólod) - OI g'́dhyati 'ist gierig, verlangt heftig' (cf. Pok. 434 and Zal. 37); see also *golds 'hunger', quoted above.

Group 3: Iranian Balto-Slavic

1.) čarı m.//čara f. 'magic, sorcery, witchcraft', attested in all Slavic languages, e.g. OCS plur. m. čari 'Zauber' (cf. čaro-dějb 'Zauberer'), Russ. Church Slav. čarß m., čara f. 'Zauber', Russ. čáry plur. f. idem, Pol. czar, usually in plur. czary idem, Cz. čár m., čára f., usually in plur. čáry idem, $\mathrm{S}-\mathrm{C}$ čâr f., Sloven. čára f. idem - Lith. kẽras m. 'Zauber' and Av. čārā- f. 'Mittel, Hilfsmittel', NPers. čãra 'Mittel, Hilfe, List' from the root kar'machen' (cf. Bartholomae 444), with a quite frequent semantic development 'action' > 'magic action', etc. (see Pok. 642). Because of the phonemic (long $\bar{e}$ ) and morphemic ( $\bar{a}$-stem) identity of Slavic and Iranian forms, the relation between them is closer than between the Slavic and Lithuanian forms. (Bern. 136, Vasm. IV, 317, Traut. 127, Pok. 641-642).

2.) kupa//kups 'heap', attested in all Slavic languages, e.g. OCS kupz 'Haufen', Russ. kúpa idem, Pol. kupa idem, S-C küp 'Haufen, Schober; Versammlung', kúpa//küpa 'Haufen', etc.; in ULus. and LLus. kupa means 'Hügel' (!) (cf. Bern. 646) - Lith. kaũpas 'Haufe', kúopa 'Gruppe, Haufen (Volkes)', Latv. kuops m. kuõpa f. 'Haufe'; OPers. kaufa-, Av. kaofa- m. 'Bergrücken, Höhenzug' (*koupho-); in this form and meaning attested only in Iranian and Balto-Slavic, but for the latter two Baltic forms should be reconstructed: *kaupa- m. and *koupa- m.//*köupā- f. (cf. Traut. 138, Pok. 591 s.v. *keu-p- b. and Zal. 38).

3.) město 'place, dwelling place (?)', attested in all Slavic languages, e.g. OCS město 'Ort', Russ. mésto idem, but ORuss. město among others 'settlement', Pol. miasto 'Stadt', this secondary meaning being a loan-translation from German, similarly Cz. město 'Stadt': místo 'Ort', S-C mjềsto 'Ort', etc. - Lith. maĩstas ' 'Nahrung', undoubtedly a secondary meaning with respect to the basic verb: Balt. *mintō 'wohne' (cf. Traut. 185), Av. maë日ana- n. 'Aufenthaltsort für Menschen und Götter, Wohnung, Haus' (cf. Bern. II, 51, Vasm. II, 608, Pok. 715 and Zal. 38). 
4,5.) nikzto, ničbto 'nobody, nothing', e.g. in OCS, ORuss. also nikz, Sloven. nic, etc.: attested in all Slavic languages - Lith. niêkas 'niemand, nichts', Latv. niẽks 'nichts', Av. naēčiš 'keiner', naēčit 'nichts': this compound with the particle ${ }^{*}$ nei- is only Balto-Slav. Iranian (cf. Vasm. III, 75, Traut. 195, Zal. 34, Arntz 35 and Pok. 757).

6.) ritb f. 'podex', attested in ORuss. ritb 'hoof' (?), Serb. Church Slav. ritb, S-C rüt, gen. rüti, Cz. rit', Pol. rzyć - Lith. ríetas m. 'Oberschenkel, Dickbein; Lende (des Menschen); Schweineschinken', Latv. rieta f. 'Bein', Pehl. rit 'podex'; but also Arm. eri, gen. ervoy 'Bug, Schulter von Tieren' (Vasm. III 486, Traut. 242 s.v. rëita-, Arntz. 39, Pok. 863 and Zal. 38). In South Slavic rititi sę (perf.), ritati sę (imperf.), 'kick' (about animals) which would indicate the primary meaning of the noun as 'rump, crupper' (cf. Skok III, 147).

7.) sir 'orphan', attested in all Slavic languages, at least in the derivative sirota, e.g. OCS sirz, adj. 'verwaist', Russ. síryj, sirotá, Pol. sierota, etc. - Lith. šeirỹs m. 'Wittwer', šeirẽ f. 'Wittwe', Av. saē 'verwaist, Waise', according to Bartholomae 1547, "kein selbständiges Wort. Es ist aus einem Komp. losgeschält, wo saē... sich zu Ksl. sirŭ verhält wie darazizu darazra-." Notice that the continuation of PIE *orbho- 'orphan', i.e. PSl. *orbz, means in Slavic 'serf' (Vasm. III, 627, Traut. 301 and Zal. 38).

8.) svęţ 'sacred, holy, saint', attested in all Slavic languages, e.g. OCS svętz, Russ. svjatój, Pol. święty, etc. - Lith. šveñtas idem, with many derivatives, e.g. švęsti, švenčiù, -čiaũ 'heilig-feiern; (ein)weihen, opfern, widmen', OPruss. Swente- in toponyms and Av. spanta- 'heilig, sanctus'. This important magical-religious term represents a common element of the two groups of languages and is a derivative of the verbal root ${ }^{*} k$ 'eu$(H)$ - 'schwellen', extended by -(e)n-: *k'uen-: so *k'uento- would have primarily the meaning 'exubérant, gonflé de force' (according to Benveniste, 1969: II 183-4), then specialized in the religious sense. Latvian has preserved the basic verb svinêt, svinu, -ẽju 'feiern', with many derivatives, e.g. svinibas plur. 'Feier,' etc., but not the corresponding adjective: Latv. svęts is borrowed from Russ. svjat-ój. The meaning of Latv. svinêt is, of course, secondary. A semantic parallel to its development can be provided by Lat. magnifico,, -äre (from magnificus) 'to prize highly, esteem greatly' (Plaut), 'glorify' (in ecclesiastic Latin) and Pol. wielbic (from *wielba 'power') 'worship'. The primary, non-religious meaning of svętı is preserved in the Slavic personal names *Svęto-pzlkz (Pol. Świętopetk, Russ. Svjatopolk), *Svęto-vitz ("Svantevitus", a deity of the pagan Baltic Slavs on the island Rugia - Rügen). The connection between spanta-, svętı and šventas on the one hand and the Germanic *hunsla-, e.g. Goth. hunsl 'Opfer', on the other is disputable (for the details, see Vasm. III, 585, Fraenkel, II, 1041-1042, Benveniste, 1969: II, 
183-4, and Pok. 592: the latter unnecessarily posits a separate *k'uen'feiern, heilig(en), p. 630, where the Iranian and Balto-Slavic words are quoted; Zal. 38).

9.) věţ 'council' and its derivatives *větje 'diet', větiti 'deliberate' (?), attested at least by the derivatives in most Slavic languages, e.g. ORuss.

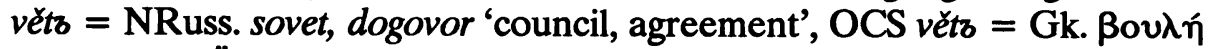
'Beschluss, Übereinkunft, Pakt', věšte 'Versammlung (um zu beraten)', ORuss. věče idem, Pol. wiec, OPol. wiece idem, etc. OCS věštati -ajo 'sprechen, verkünden', Russ. otvétit', otvečát' 'answer', Pol. obiecać 'promise', etc. - Lith. dial. vaitenù 'richte, bestimme', OPruss. waitiāt 'reden, sprechen', Av. vaēe- 'gerichtlich feststellen', vaē $\theta \bar{a}-$ f. 'gerichtliche Feststellung' (Vasm. I, 305, Traut. 339, Zal. 38).

Group 4: Iranian Slavic

1.) bogz 'God', attested in all Slavic languages - OPers. baga- m., younger Avesta baya- m. idem, in older Avesta baya- n. 'Anteil, Los', especially 'günstiges Los, Glück'; for a detailed discussion of this most important Slavic-Iranian correspondence undoubtedly representing a calque linguistique of Iranian upon Slavic, which assigned a new, special meaning 'God' to the old inherited Slav. bogz 'good fortune', see Trubačev, Étimologija 1965, 25-28; for other IE parallels of the semantic development 'alloter' > 'God', cf. V. Pisani: Der Gott als 'Verteiler' und armenisch astuac, in Lingue e Culture, 1969, $257-269$ (Vasm. I, 181-182, Zal. 34).

2.) *bolgz 'good, blessed, blissful', attested in all Slavic languages, e.g. OCS blagz, ORuss. and dial. bólogo adv., Pol. błogi, etc.; a very important term in Church Slavic religious terminology which usually renders Greek $\epsilon \dot{u}-$; besides that, the derivatives *bolžiti, *bolgati, e.g. OCS blažiti 'selig preisen', S-C blážiti 'besänftigen', Cz. blahati 'lobpreisen; from the latter Pol. błagać, instead of a rare OPol. błogać 'flehen', etc. - Usually compared with Av. barag- 'willkommen heissen; huldigen' (Bartholomae 945), barag- f. 'religiöser Brauch, religiöse Form, Ritus' (ibidem 957) whose IE etymology is uncertain. The comparison with OI B̧̆has-páti'lord of prayer or devotion', name of a deity in whom Piety and Religion are personified' (cf. Monier-Williams 737) is disputable; perhaps we are dealing here with the PIE base *bheleg- 'glänzen' (cf. Pok. 124), but in such a case the OI form would not belong here. Pokorny does not mention these Aryan words in his dictionary at all, but he quotes Slav. *bolgz under *bheleg-. If we accept that PIE *bhel-(e)g- 'shine', etc., as the source of the above Slavic and Iranian (not Old Indian!) words, then the semantic development could be imagined as follows: *bholgo- 'shiny, bright' (cf. OI bhárgas- 'strahlender Glanz', Latv. balgans 'weisslich') 
changed to 'good' because of the opposition to 'dark' > 'bad, evil' (the latter semantic change is quite common); the religious meaning of the verbs *bolžiti, *bolgati would be already derived from the secondary meaning of the adjective 'good', etc., and would mean primarily 'placate' (a deity, supernatural power, etc.); for the latter, cf. Pol. udobruchać (from dobry 'good') 'coax into a good temper', etc. In this whole semantic development 'shiny, bright' > 'good', etc. as opposed to 'dark' > 'bad, evil', etc. - the old dualistic "world-view", so characteristic of Mazdeism, seems to be expressed. (Bern. 69, Vasm. I, 188, Pok. 124, Zal. 34).

3.) brbjo, briti 'trim, shave', attested in most Slavic languages, e.g. Russ. Church Slav. briju, briti 'scheren', Russ. bréju, brit', S-C brïjem, brijati, Cz. briju, bríti 'shave', etc. - Av. bräy-, only with the prefix pairi-: 3rd plur. pairi-brinanti 'ringsum schneiden, be-, verschneiden', OI bhrīnánti 'sie

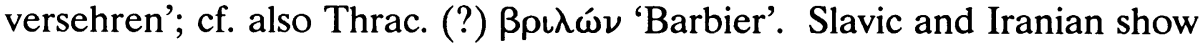
semantic identity, in other IE languages the meanings of the verbs derived from this root (*bhrëi-, ${ }^{*} b h r_{i}$-) are more remote (cf. Bern. 94, Vasm. I, 213, Pok. 166, Zal. 34).

4.) divz 'demon', directly attested only in ORuss. divs and Ukr. dyv, but as the first component of the compounds divo-žena, etc., it occurs also in other Slavic languages (cf. Z. Gołąb, 1975: 151-159); its derivative divbjb 'wild' (from the primary meaning 'belonging to the realm of demon(s)', cf. Gołąb l.c.) is Com. Slav. - Av. daèva-, OPers. daiva- 'Dämon, Unhold, Teufel': a specific Iranian semantic change of the PIE *deiuo- 'God', which together with baga- = Slav. bogz "revolutionized" the inherited PIE religious terminology in Slavic (Bern. 202, Vasm. I, 512, 513, Sławski, 1979, III, 225-226, Trubačev, ÈSSJa, V, 35, Zal. 34).

5.) *dbržq, -iši, *dbržati 'hold', attested in all Slavic languages, e.g. OCS drъžati, Russ. deržát', Pol. dzierżeć, etc. - Av. dražaite 'hält, hat an sich, mit sich; führt'; in other IE languages the forms derived from this base, i.e. *dheregh-, are different (cf. Bern. 258, Vasm. I, 503, Trubačev, ÈSSJa, V, 230-231, Pok. 254, Zal. 34).

6.) gojb 'state of peace and prosperity' (as opposed to that of war and death), attested in ORuss. goj 'pax, fides, amicitia', Old S-C gôj, gen. gôja 'Friede' (usually in the expression mir i goj), Sloven. gòj, gen. gója 'Pflege' and OCz. hoj 'Fülle, Überfluss', i.e. NCz. 'dostatek, blahobyt' (cf. Machek 136) - Av. gaya- m. 'Leben, Lebenszeit, Lebensführung' and OI gáya'Haus und Hof, Hauswesen'; the OIran. meaning seems to be closer to the Slavic than to the OIndian one; in addition, the noun, whose archetype is PIE *gólo- 'life' from the verbal root *gei $(H)$ - (traditionally ${ }^{*} g^{\mathrm{u}} e \mathrm{i}(\mathrm{\partial})-$ ), is not attested outside Slavic and Aryan (Bern. 319, Vasm. I, 427, Machek 136, Pok. 467-468, Zal. 38).

7.) kajo (sę), kajati (sę) 'punish, make someone repent; repent 
(reflexive)', attested in all Slavic languages, e.g. OCS kajati sę 'repent', Russ. kájat'sja idem, Pol. kajać się idem, but Russ. okájat' 'blame, reproach', S-C käjati 'revenge', Sloven. kájati 'blame, reproach', etc. Av. kāy- 'vergelten, büssen' also 'rächen, strafen', depending on syntactic constructions (cf. Bartholomae 464); the verbal root ${ }^{*} k e i$ - (according to Pokorny 636) is known in many IE languages, but in the above case, the forms and meanings of the respective verbs correspond exactly to each other only in Slavic and Iranian (Bern. 469, Vasm. II, 216, Pok. 636-637, Zal. 35).

8.) kotz, kotbcb 'a kind of wooden shelter', etc. attested, especially the derivative, in most Slavic languages, e.g. Church Slav. kotbcb 'cella', Russ. kotý, kotcý plur. m. 'Fischwehr, Fischzaun, Gatterfang', Pol. kojec, old kociec, gen. kojca, old koćca 'Hühnerkäfig; Abteilung im Stall', Cz. kot, kotec 'Bude, Kram', S-C dial. kôt, gen. kòta 'ein kleiner Stall für Lämmer, Zicklein, Hühner', etc. - Av. kata- m. 'Kammer. Vorratskammer; Keller', NPers. kad 'Haus' (Bern. 588, Vasm. II 351, Zal. 35). But it also might be an Iranian loanword in Slavic (see Chapter 6).

9.) nebo, gen. nebese 'sky; heaven', attested in all Slavic languages, e.g. OCS nebo, gen. nebese 'Himmel', Russ. nébo, plur. nebesá (borrowed from OCS), dial. nëbo idem, Pol. niebo, plur. niebiosa idem, etc. - Av. nabah- n. 'Himmel', plur. 'Luftraum': the semantic development of PIE *nebhos- 'cloud' > 'sky' is characteristic of Slavic, Iranian and Hittite (nepiš = nebis?) only (Vasm. III, 53, Pok. 315, Zal. 35).

10.) *ob-aciti 'watch, see', a West PSl. dialectism, preserved only in Pol. obaczyć, baczyć 'see, watch' - Iran. *abi-äxšaya-, e.g. Av. aiwyāxšayafrom PIE *obhi- 'around' and *ok- 'eye' (Trubačev, Etimologija 1965: 45-46).

11.) *pitvajo, *pitvati 'cut with a blunt knife', a West PSlav. dialectism, e.g. Pol. dial. pitwać 'cut with a blunt knife', etc. - Av. poïiwa-, intensive of "paiOwa- 'crush' (Trubačev, Ėtimologija 1965, 62-63).

12.) pišo, -eši, pbsati 'write', attested in all Slavic languages with the same meaning, e.g. OCS pbsati, pišo, -eši, Russ. pisát', pišú, píšeš, Pol. pisać, piszę, -esz, etc.; Lith. piešiù, piẽšti 'mit Kohle Linien ziehen, zeichnen, malen, schreiben', OPruss. peisāi 'sie schreiben' (probably a semantic borrowing from Polish) - OPers. ni-pišta- 'niedergeschrieben', ni-pištaniy inf. 'schreiben'; the semantic development of the PIE *peik''paint' > 'write' is restricted to Slavic, Iranian and Tokharian, but the primary meaning is still preserved in Polish pisanki 'painted Easter eggs' (Vasm. III, 266, Pok. 794, Traut. 210-211, Zal. 38).

13.) radi postposition after genitive 'because of', attested in East and South Slavic, e.g. OCS radi and radbma: ovogo radi, Russ. rádi: čegó rádi, $\mathrm{S}-\mathrm{C}$ râdi: radi čega (the latter word order is innovative), etc. - OPers. 
rádiy (loc. sing. of an $i$-stem) idem and in the same construction: avahya rädiy = ovogo radi 'because of this'; here both linguistic groups use the noun *röhi- in the same way; for the etymological connections in Slavic and other IE languages, see the verb raditi//roditi 'take care of' etc. in OCS and ráditi 'do' in S-C (Vasm. III, 430 under radét', Pok. 59, Zal. 31).

14.) slovo, gen. slovese 'word', attested in all Slavic languages, e.g. OCS slovo, gen. slovese, Russ. slóvo, gen. slóva, Pol. stowo, gen. stowa, etc. the exact semantic correspondence found only in Av. sravah-, whereas in other IE languages PIE * $k^{\prime} l e u o s$ has preserved its primary meaning

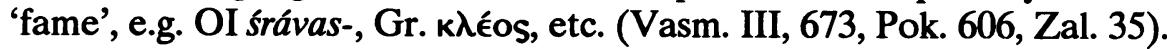

15.) *sormb 'shame', attested in most Slavic languages, e.g. OCS srams, Russ. sórom, OPol. srom, etc. - Av. fšarama- m. 'Scham(gefühl vor)', Pehl., NPers. šarm, Osset. æfsarm idem; Iranian correspondences are semantically identical with Slavic, whereas Germc. forms, e.g. OIc. harmr 'Betrübnis, Kummer, Harm, Kränkung' are remote (Vasm. III, 724, Pok. 615, Zal. 35).

16.) stepb 'steppe', only East Slavic, e.g. Russ. step' f. - Iran. tap- 'flat', cf. Osset. (Digor.) tæpæn: PIE *(s)tep- 'to be flat, even, low' (Trubačev, Ėtimologija 1965: 39).

17.) *szdorvo 'healthy' (etymologically 'like a good oak'), attested in all Slavic languages, e.g. OCS szdravz, Russ. zdoróvyj, Pol. zdrowy, etc. OPers. duruva-, Av. dr(u)va- 'gesund, heil': the same semantic development in Slavic and Iranian of the derivatives from PIE *deru'oak' > 'tree'; cf. also OI su-drú- $h$ 'gutes Holz' suggesting the PIE nominal base *su-doru- for the PSl. adjective (vrddhi) (Vasm. II, 20, Pok. 214, Zal. 36).

18.) tajo, -eši, tajati 'melt' (intrans.), attested in most Slavic languages, e.g. ORuss. tajati, taju, S-C tâjati, tâje (3rd sing.), Pol. tajać, taję, etc. Osset. t'ajun idem (Vasm. IV, 30, Pok. 1053, Zal. 36).

19.) tęgnqti 'pull' and the causative tqžiti 'make pull' > 'make heavy', etc., the basic verb attested in all Slavic languages, e.g. OCS -tegnqti in sъ-tęgnoti 'zusammenschnürren', etc., ş-tožiti 'bedrücken, bedrängen', tqžiti 'zagen, sich ängstigen, bedrückt sein' (the meanings of the two latter verbs are obviously secondary), Russ. tjanút' 'pull', tužít' I = OCS tqžiti, túžit' II = natjagivat', Pol. ciqgnq̨ć 'pull', etc. - Av. causative Oanjaya(Өang-) 'ziehen, Bogen spannen', Osset. t'yndzyn 'ausdehnen': Iranian represents the closest semantic and formal correspondences of Slavic (Vasm. IV, 139, 115, Pok. 1067, Zal. 36).

20.) *trzvajo, *trъvati 'last, endure', only West Slavic, e.g. Pol. trwać, trwam, etc. - Av. taurvaya- 'überwinden, bewältigen' (from Iran. *ţ̄va-) and OI túrvati 'überwältigt, besiegt': a common PIE base in -u, i.e. *teru-, as opposed to ${ }^{*} \operatorname{ter}(a)$-, *trā- connects here West Slavic with Iranian (for 
geographic reasons, OI túrvati can be omitted); in other Slavic languages, the root trä- is used, e.g. S-C trâjati, etc. (Pok. 1074, Trubačev, Étimologija 1965: 58-60).

21.) 'volsъ 'hair', attested in all Slavic languages, e.g. OCS vlasъ, Russ. vólos, Pol. włos, etc. - Av. varasa- m., n. 'Haar der Menschen und Tiere, meist Kopfhaar', MPers. vars idem (Vasm. I, 342, Pok. 1139, Zal. 36).

22.) 'voržiti 'augur, divine; cast spells (?)', attested in most Slavic languages, e.g. Russ. vorožít', Pol. wróżyć, Sloven. vražíti 'do harm by magic', etc. - Ormuri waž ( $\leq$ *warz-) 'cast spells', cf. Osset. warz- 'to love': this correspondence is questionable because of the continuation of two different "gutturals" in the root: PSl. $g \geq \check{z}$ from PIE ${ }^{*} g(h)$ and Iranian $z$ from PIE * $g^{\prime}(h)$. In addition, the PIE source is uncertain (perhaps *uer-g-//*uer-g'h- 'drehen', or *uerg'- 'wirken, tun', etc. (cf. Pok. 1154 and 1168, Vasm. I, 353, and Zal. 36).

23.) zzlb adj. 'bad, evil' (the moral connotation seems to be basic), attested in all Slavic languages, e.g. OCS zъlz, -a,-o, Russ. zloj, zlája, zlóe, Pol. zły, zła, złe, etc. - Av. zürah- n. 'Unrecht, Trug', OPers. zürah idem, NPers. $z \bar{u} r$ 'falsch; Lüge', Osset. $z \bar{u} l$ 'crooked, wry', ævzær 'bad'; there are also correspondences in Baltic: Lith. atžúlas, atžúlus 'schroff, hart, unhöfflich, unbarmherzig, etc., jžúlas 'lästig, unverschämt, grob' (Trautmann 372 reconstructs Balto-Slav. žula- 'schief; böse'), but they seem to be deprived of a clear moral connotation so characteristic of the Slavic and Iranian forms (Vasm. II, 99, Pok. 489, Zal. 36).

24.) *želdb, *želdica 'freezing rain, etc.', attested in OCS žlédica 'gefrorener Regen', Sloven. žlệd f. 'Glatteis', Ukr. oželéda 'Regen mit Schnee, Eis auf Bäumen', Pol. żłódź f. 'Schneeregen, Glatteis' - NPers. žăla ( $\leq$ *žalda) 'Hagel, Reif'; there is also a correspondence in Homeric Gr. $\chi \alpha$ '́ $\lambda \alpha \zeta \alpha$ 'Hagel', but it represents another (reduced) vocalic grade ( ${ }^{*}$ ghlad-), see Pok. 435 s.v. *ghelad- and Zal. 36.

25.) 'žbrq, 'žbrti 'sacrifice', attested in OCS and ORuss. only: OCS žbrq, žrbti, ORuss. žbrq, žereti; the Baltic correspondences show an older meaning 'praise', e.g. OPruss. girtwei 'loben', Lith. giriù, girti 'loben, rühmen', Latv. dziruôs, dzir̂tiês 'sich rühmen' - Av. gar-, in the present tense only with prefixes: aibi-garante 'preisen, lobend einstimmen', OI grnāti, grnite 'singt, lobt, preist, kündigt an', etc.; in Slavic and Aryan this root seems to have been used especially with a religious connotation, $c f$. e.g. Av. gar- f. 'Lob, Preis; Loblied' (Bartholomae 512-513), Osset. Digor. argawun 'hold a church service', etc. (cf. V.I. Abaev, Istoriko-ètimologičeskij slovar' osetinskogo jazyka, I (1958), 65); in this connection the Slavic-Aryan, and especially the Slavic-Iranian semantic correspondence, acquires significance (Vasm. II, 63 s.v. žrec, Pok. 478, Zal. 36).

The above presentation of the old special lexical correspondences 
between (Balto-)Slavic and (Indo-)Iranian requires additional remarks and some general, hypothetical conclusions. First, the statistics: as we are aware, common Balto-Slav. and Aryan correspondences are represented by 17 words among which we cannot find any important social or cultural term, excepting perhaps Slav. čbto, čisti 'count' > 'read'. Common Slavic and Aryan correspondences amount to 24 words among which there are already several socially and culturally important entities: čbstb 'honor', gatati 'divine', Mara 'demon of death', niščb 'poor', šujb 'left' (also used symbolically and magically), šurbjb (?) 'wife's brother', tzlkz 'interpreter', *vertenz, *ver(t)mę both of these primarily measures of length (?). Common Balto-Slavic and Iranian correspondences are represented by only 9 words, among which one should underline the following socio-cultural terms: čarı 'magic', sir̋ 'orphan', svętъ 'holy, sacred', větz 'council'. Finally, common Slavic-Iranian correspondences amount to 25 words, among which the number of important socio-cultural terms is impressive: bogz 'God', bolgz 'good, blessed', divz 'demon', gojb 'state of peace and prosperity', kajati 'punish', pbsati 'write' (?), *sorms 'shame', $z$ zlъ 'bad, evil', *žbrti 'sacrifice'. The sum total of the above correspondences is 75 (including some questionable ones); among them those excluding Baltic are represented by 49 words (24 Slavic-Aryan, 25 Slavic-Iranian). Against these statistics, the 26 correspondences with Aryan (17 with Indo-Iranian, 9 with Iranian only) in which Baltic participates (always in the company of Slavic) seem to have an obvious significance. Of course, here we can add several special lexical correspondences between Baltic and Iranian noted by Trubačev (ל̇timologija 1965: 12-15), i.e. those which do not include Slavic. There are 10 such words (counting only the convincing examples), which will bring the number of all the Baltic-Indo-Iranian correspondences to 36 (17 Balto-Slavic Indo-Iranian, 9 Balto-Slavic Iranian, 10 Baltic Iranian): thus we obtain the ratio 75: 36 . It should also be emphasized that among the examples of special Baltic Iranian correspondences quoted by Trubačev, one cannot find any significant socio-cultural terms, although among them there are such important words as Lith. miežys 'barley' Iran. maiz- 'to sow seed' (rather questionable etymology), Lith. dúona 'bread' Iran. dāna- 'grain' (OI dhānā- idem), Lith. svíestas 'butter' $\sim$ Av. xšvid- 'milk'. These facts would indicate that there were some prehistorical direct contacts between Baltic and Iranian, but they seem to have been rather limited in time and space, and basically independent of the contacts between Slavic and Iranian. Trubačev even suggests the region where such contacts could have taken place: the Sejm river basin, since it is there that some (probably) Iranian and Baltic hydronyms are found in close proximity (cf. V. N. Toporov and O. N. 
Trubačev, 1962: 231 and maps 2 and 3). ${ }^{8}$

Trubačev's great merit (in the quoted essay in Ėtimologija 1965) undoubtedly lies in his calling our attention to those Baltic-Iranian correspondences - and in general, to the possibility of direct prehistorical contacts between Baltic and Iranian (or rather betwen the linguistic ancestors of these two IE groups). But I cannot subscribe to his radical critique of the most special Slavic-Iranian correspondences accepted in traditional linguistic literature and presented above. He simply rejects most of them, retaining only bogz, kotz (interpreted as a borrowing), obaciti, pitvati, stepb, trovati. The justification for this purge is that the discarded words have correspondences outside of Slavic and Iranian (the author does not say whether he means cognates in Baltic and Old Indian only, or in other IE groups as well, and does not analyze each item separately). From among the remaining (Balto-)Slavic Indo-Iranian correspondences he rejects: avě, čbto,//čisti, gajati, gatati, *goldz, jędrz, pěsъkb, šujb, *ver(t)mę on the same basis. He even rejects such a characteristic Slavic-Iranian correspondence as radi, trying to argue that it is an independent PSl. innovation well substantiated by Slavic lexical material, and by the semantic-syntactic parallel dělja 'because of': dělo, dělati, etc. I should confess that Trubačev's arguments do not convince me. So I have preserved the words which he eliminated, leaving for a future discussion their ultimate fate (cf. Trubačev, 1.c. 21-24).

So, as the facts seem to suggest, we cannot doubt the special relations between Slavic and Indo-Iranian in prehistorical times. It is difficult to tell what was the concrete socio-cultural background of these relations, since the only cue we have is the semantics of the words in question. Let us again take a look at their semantics, trying to arrange the words in question into respective semantic groups.

A. Religion and magic
1. bogs
4. divz
7. nebo
10. *voržiti
2. ${ }^{*}$ bolg
5. gatati
8. svęto
11. *žbrti
3. carb
6. Mara
9. šujb

B. Morality, law, social relations and functions
1. čbstb
6. sirb
2. gojb
7. *sormb
3. kajati sę
8. surbjb (?)
4. niščb
9. věts
5. sanz (?)
10. zßls 
1. ${ }^{*} b z r z b$

2. * golds

3. $x u d s$

4. *jędrs

5. ${ }^{*} k b r n b$

6. kyšbka

7. pažal/paxa

C. Health, parts of the body, some organic features and functions

As we can see, there are thirty-four words belonging to three important semantic spheres; they represent $45 \%$ of all Slavic (Indo-)Iranian correspondences. Such a ratio proves that there were undoubtedly close social and cultural ties between the linguistic ancestors of the Slavs and those of the Aryans or Iranians. Whether these ties could be interpreted as a federation or alliance between the respective tribes is open to discussion. In any case, the semantic character of Slavic $\sim$ (Indo-)Iranian lexical correspondences is striking, and more indicative of the cultural prehistory of the Slavs within the IE peoples than the later (younger?) correspondences between (Balto-)Slavic and Germanic (see below).

Now, as far as the number of kentum elements on the one hand, and that of common Slavic (Indo-)Iranian on the other is concerned, they seem not to be far apart (59 or (45): 75 including Baltic, but 49 excluding it). But we should remember Moszyński's opinion quoted above: the number of Slavic-Iranian correspondences which is so high being based on our present knowledge of the Iranian vocabulary would undoubtedly increase if we knew this vocabulary better. The ratio between kentum elements and Slavic (Indo-)Iranian correspondences (59/47: 75/49) seems to reflect very well the geographic position of the IE dialect from which subsequently Balto-Slavic and later on Proto-Slavic developed, namely: that IE dialect occupied a rather central position near the old isogloss which split the primary IE territory into the satem East and the kentum West, and in this connection at the very beginning of its existence, the dialect under discussion absorbed some kentum elements.

Having reviewed the prehistorical ties (correspondences) between Slavic and (Indo-)Iranian vocabularies, which seem to prove the deep "rootedness" of Slavic in the eastern, satem subgroup of the old IE dialects, let us now turn westward, to the IE North-West. This dialectal zone was established by A. Meillet (1908) on the basis of some old lexical correspondences connecting Italic, Celtic, Germanic, Baltic, and Slavic but not found in Indo-Iranian, Armenian, or Greek. It is worth mentioning that this North-West IE lexical area recently has been 
supported by the Italic $\sim$ Celtic $\sim$ Germanic $\sim$ Balto-Slavic core of PIE tree names (cf. P. Friedrich, 1971).

What follows is a list of such words attested in Slavic. In order to indicate their western character, I shall limit myself to quoting only the Latin or Celtic correspondences of these words - simply repeating Meillet's material, which the author has grouped into several semantic categories.

\section{Agricultural terms}

1. OCS sěti Lat. serere (sēvī) 'sow'

2. OCS sěmę Lat. sēmen 'seed'

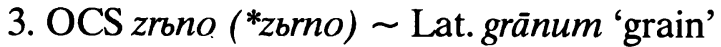

4. OCS brašıno (*boršbno) Lat. far (farris), farina, Umbr. farsio, 'cereal-derived food'

5. OCS lěxa Lat. lìra 'furrow'

6. OCS ablıko malifera Abella (a city name in Campania) 'apple'

7. OCS prasę (*porsę) Lat. porcus 'pig'

8. OCS bobs Lat. faba 'bean'

9. OCS mzxz Lat. muscus 'moss'

10. OCS bodo Lat. fodiō 'dig' (in Slav. 'pierce')

11. OCS ovbsz (cf. Russ. ovës) Lat. avēna 'oats'

12. To these agricultural terms listed by Meillet we can add PSl. *polsa 'strip of arable land' as attested, e.g. by Russ. polosá, Church Slav. plasa, S-C (Čakavian) plasâ and Pol. płosa; it has an exact correspondence in MLG falge, OE fealg $=\mathrm{NE}$ fallow etc., i.e. PGermc. ${ }^{*}$ falgō, and in Gallic olca 'Pflugland' (from which French ouche 'gutes Ackerland'): all these words presuppose NW Indo-European *polkä//polk'a belonging to the same stratum as Meillet's examples above. The lack of correspondence in Lithuanian is characteristic (Vasmer III, 315 and Pokorny 850 and 807).

Names of birds and insects

13. OCS drozdz (*trozdz) Lat. turdus 'thrush'

14. OCS osa Lat. vespa 'wasp'

15. OCS srbšenb $\left({ }^{*}\right.$ sbršenb $) \sim$ Lat. crābrō $\left({ }^{*} k^{\prime} r H s r o n-\right.$ Pok. 576) 'hornet'

16. OCS gnězdo Lat. nïdus ("nizdo-) 'nest'

Names of trees

17. OCS jelbxa (but Pol. olcha) Lat. alnus 'alder' 
18. Com. Slav. *ilbmъ/*ilıma, e.g. Russ. ílem, gen. íl'ma, etc. (Vasm. II 126, Bern. 424) Lat. ulmus 'elm'

19. OCS iva 'kind of willow' Ir. eo 'yew'

Technical terms

20. OCS kujg 'forge' and its derivative kyjb 'hammer' Lat. cūdō 'pound', incūs, gen. incūdis 'anvil'

21. OCS sěkq 'cut' and its old derivative sekyra 'axe' $\sim$ Lat. secō, secūris idem

22. OCS pleto Lat. plecto 'plait, braid'

23. OCS štitz (*ščitz) Lat. scūtum (*scoitom) 'shield'

Words for social relations

24. OCS gostb 'guest' Lat. hostis 'stranger, enemy' (we should also include here Slav. gospodb and Lat. hospes, gen. hospitis from IE *ghost(i)-pot(i)s? 'host')

25. OCS dlzgz OIr. dliged 'debt' (cf. Stang, 1972: 69)

26. OCS vlado ("voldo) 'rule' Lat. valeo 'be strong'

Miscellaneous

27. OCS brada (*borda) Lat. barba 'beard'

28. OCS gladъkъ Lat. glaber 'polished, smooth' (Eng. glad belongs here; cf. kentum elements above)

29. OCS golotb, žlědica ("želdica) Lat. gelu and glaciēs 'ice' (but see *želdb among Slavic-Iranian correspondences above): this correspondence is illusory and should be eliminated (see Pok. 365-366 s.v. gel(a)- 'kalt, frieren').

30. OCS trudz 'Mühe, Anstrengung' Lat. trudō 'push'

31. OCS sěverı 'north' Lat. caurus ( ${ }^{*} k$ 'è/ōuero-, Pok. 597) 'north wind'

32. OCS verra 'faith' Lat. vērus 'true'

33. OCS mъnogъ 'numerous' Ir. menicc 'abundant'

34. OCS morje Lat. mare (plur. maria) 'sea' (Eng. moor belongs here).

(The actual number is 35 since we eliminate golotb, etc. but count separately sekyra and gospodb.)

To the above list compiled by Meillet we can now add the following words proposed by J. Safarewicz (1967, actually in 1964), and Trubačev (1966). I am quoting only certain examples, having rejected typical cases of Wurzeletymologie and controversial cases. J. Safarewicz concentrates on verbs common to Slavic and Italic (Latin), which in most instances also include Baltic and Germanic correspondences. These verbs are not 
always attested in all the languages under consideration, but they can be easily retrieved by a correct etymological analysis of the nouns and adjectives derived from them.

1. OCS imq, jęti (*jbmq, etc.) 'take' Lat. emō, emere 'buy', but the primary meaning 'take' is still preserved in the compounds: ad-imere 'take away', ex-imere 'take out' (Safar. 268).

2. OCS slabs 'weak' Lat. lābor, lābì, etc. 'glide, slide, fall down' (Safar. 268).

3. ORuss. skoblb m. 'scraper' Lat. scabere 'scratch', cf. also Trub., 1966: 156 (Safar. 269).

4. OCS po-vrbzQ, -vrěsti, (*-vbrzQ, *-versti) 'tie up' Lat. urgēre 'push, press, drive', Stang, 1962: 63 doubts this because of semantic discrepancies (Safar. 269).

5. OCS steljo, stblati 'spread' Lat. lātus 'wide', arch. stlatta (sic!) $\leq$ *stlāta 'genus navigii latum magis quam altum a latitudine sic appellatum' (Safar. 269).

6. -OCS na-čbng, -čęti 'begin' Lat. recēns, gen. recentis 'newly coming, fresh', an old nomen agentis re-cen-t-s; no correspondences in Baltic and Germanic; but see OI kanin- 'jung, Av. kaine, kaini-, kainin-

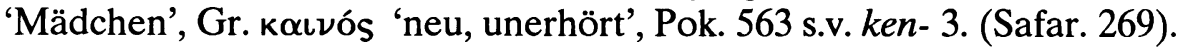

7. Pol. tracić 'knock, jostle', Rus. trutit 'strangle, knock', etc. (cf. Vasm. IV, 111) Lat. truncus subst. 'the stem or trunk of a tree', as an adj. 'maimed, mutilated, cut short'; as the Lith. correspondences indicate, namely: trenkiù, treñkti 'hit with a resounding blow', iterat. trankaũ, trankýti, the Slav. verb is derived from *tronkto- $\geq$ trqtı (cf. OCS trotz 'Wache, Schar', ORuss. trutz 'multitude' with obviously secondary meanings), Safar. 269.

Trubačev has analyzed the old handicraft terminology in Slavic, i.e. terms referring to weaving, carpentry, pottery and smithery, against the IE background and has arrived at some very important conclusions. Before I quote these conclusions, I shall list all the words for which membership in the so-called North-Western vocabulary has been convincingly demonstrated in his book.

1.) *brbvb ( $\leq * b r b v b)$, e.g. Cz. brev, gen. břvi 'gang plank, footbridge' but ORuss. bervb 'fence', etc., and the derivative brbvbno, e.g. OCS brbvbno 'Balken', Pol. bierwiono idem, etc. (cf. Vasm. I, 209 s.v. brevnó) Germc. *bruwjō 'bridge', e.g. OIc. brū, OE. bruggia, OHG. brucka, etc., Gaul. briva $\left({ }^{*} b h r \bar{e} u \bar{a}\right)$. In spite of some difficulties in the reconstruction of the PSI. form, we seem to have here an old technical term with the basic meaning 'beam', and a secondary meaning 'footbridge' (cf. Pok. 173), Trub. 159.

2.) *dely//dbly, gen. *delsve//dblave, attested only in Russ. Church Slav. delva//delvb//dbly//dzly, gen. dolve 'kind of barrel', etc., and in Bulg. délva 
'big earthen jug' Lat. dolium 'large earthen vessel', OE tala 'pot'; according to Trubačev (see his long discussion 1.c. 241-251) ultimately from PIE *del(a)-, i.e. *del(H)-, whose primary meaning 'spalten, snitzen, kunstvoll behauen' (cf. Pok. 194) developed into 'plait, wreath' from which a further specialization occurred in the terminology of pottery (Trub. 241-243).

3.) 'gъrnz, e.g. in its primary meaning 'kiln' used in all East Slav. languages (Russ. gorn, etc.) Lat. furnus 'baking oven' (in other IE languages the primary meaning 'glow, fire' is preserved, e.g. OIc. gorn 'fire', etc.); Trub. 195.

4.) 'gъrnidlo, e.g. Russ. Church Slav. gærnilo, Russ. gornilo 'furnace' Vulg. Lat. *furniculum, reconstructed on the basis of Ital. fornello 'oven, kiln,' Span. hornillo idem, French fourneau idem, etc.; ultimately dial. IE *guhrnitlo- (Trub. 195).

5.) *gzrnbcb, a derivative of ${ }^{*} g r m b$, e.g. Pol. garniec, Cz. hrnec, etc. 'pot'; cf. also the derivative of the latter *gzrnbčar'b Lat. fornix, gen. fornicis 'arch, vault'; the primary meaning 'vault of pots' in connection with a primitive kiln technique; ultimately dial. IE * $g h$ urnik(o)- ? (for details see Trub. 197-199).

6.) "gъrnbčar'b, derived from *gъrnbcb, e.g. ORuss. gъrnbčarz, Russ. gončár, Pol. garncarz, Cz. hrnčír, S-C dial. grnčar, etc. 'potterer' Lat. fornicarius, derived from fornix, whose medieval meaning 'debauchee' is secondary, influenced by fornix 'vault' > 'cave of debauchery', etc. (for details see Trub. 200).

7.) kladivo 'small hammer', e.g. Cz. kladivo, Sloven. kládivo, S-C (Kajk.) klädivo, only Czech-Slovak-Slovene Lat. gladium 'short sword' $\leq$ *kladiuom (for *kl- $\geq$ gl- cf. clousia $\geq$ glöria), both from dial. IE *klădiuorelated to Slav. *kolda, Lat. clädēs (the latter from PIE *kel(a)-, *klä(d)'schlagen, hauen' according to Pok. 545), Trub. 361-365.

8.) kostra//*kostro, e.g. Russ. kostrá 'rough bark used for spinning' and kostër 'pile of firewood', with many derivatives in other Slav. languages Lat. castrum (usually in the plural castra 'military camp') whose primary meaning seems to have been not 'dugout' (i.e. shelter), etc. as Trubačev speculates (starting wrongly from PIE *kes- 'kratzen, kämmen', cf. Pok. 585), but since both words (Slav. and Lat.) are obviously derived from PIE * $k$ 'es- 'schneiden' (cf. Pok. 586) castrum would mean primarily 'abgeschnittenes Stück Land'; for a similar semantic development see East Slav. sěčb, namely Russ. seč' f., Ukr. sič f. 'fortified camp of Zaporožee Cossacks', also as Ukr. place name Sič, from sěko, *sěkti 'cut' (cf. Vasm. III, 615): therefore dial. IE *kostro- (notice kentum form in Slavic!) could originally mean 'result of cutting', etc.; no correspondences in Baltic and Germanic (Trub. 83-85). 
9.) košb//košel'b (not *koslb as reconstructed by Trubačev), e.g. Russ. koš, košél', gen. košeljá, etc.: košb is known in all Slav. languages, the forms with -(e)l- limited $\sim$ Lat. quälus ( $\leq{ }^{*}$ quas-lo-, cf. dimin. quasillus) idem; no correspondences in Baltic and Germanic (Trub. 163-164).

10.) *moltz, e.g. OCS mlatz 'hammer', Russ. mólot, Pol. młot idem, etc.; the primary meaning 'flail', as an old derivative of this noun, *moltiti 'thresh', indicates Lat. malleus 'hammer, mallet', especially 'the axe used for slaying animals offered as a sacrifice', marculus 'hammer': the former from *mal-to-(?), the latter from *mal-tlo-; both the Slav. and Lat. words represent a dial. IE derivative of *(s)mel(a)- 'zermalmen, schlagen, mahlen' (cf. Pok. 716); no correspondences in Baltic and Germanic (Trub. 357-360).

11.) pazъ and its derivative pažb, e.g.: Russ. paz 'groove', Pol. paz, Sloven. pâz idem, besides Sloven. pâž m. 'wooden wall', etc. $\sim$ Lat. com-pāgēs f. 'joint' and many correspondences in Germanic, e.g. OHG fuoga, NHG Fuge, etc.: all from PIE *păg'-//*pang'- 'festmachen', cf. Lat. pango, etc. (Pok. 787-8); the special technical meaning connected with carpentry seems to be characteristic of North West IE vocabulary (Trub. 158).

12.) sěčivo, e.g. ORuss. 'tool for cutting or chopping' (Vasm. III, 615 'topor', i.e. 'hatchet') known in South Slavic, e.g. S-C sjêcivo 'hammer' (sic!), etc. unknown in West Slavic Lat. secivum libum est, quod secespita secatur ${ }^{99}$; in view of the productivity in Latin and Slavic of the suffix -üuo-, and in connection with the whole set of parallel derivatives of *sěk- (sěkq secō, sekyra securis, sěčivo secivum) the above correspondence between Slavic and Latin is significant; no correspondences of this noun are found in Baltic and Germanic (Trub. 151).

13.) *stativz, primarily an adjective, secondarily substantivized, e.g. Pol. staciwa n. plur. 'frame of a loom', Ukr. statýva idem, S-C dial. stative $\mathrm{f}$. plur. 'loom', etc. Lat. statīus adj. 'standing (still)', stativa n. plur. 'permanent camp'; no correspondences in Baltic and Germanic (Trub. 123).

14.) teslál/tesló, e.g. Russ. teslá, tesló 'carpenter's adze', known in all Slavic languages Lat. tēlum 'missile, dart, javelin', etc., OHG dehsala 'Queraxt', OIc. pexla f. idem, OIr. tāl ( $\leq^{*}$ tokslo-) 'axe'; we are dealing here with a dial. North West IE *tekslo/ä-//*tek'slo/ā- 'carpenter's axe' (cf. Pok. 1058 s.v. tek'p-), Trub. 152.

The above lexical correspondences between Proto-Slavic and the North-Western IE languages (Italic, Celtic, Germanic), and particularly those between Proto-Slavic and Italic have recently been corroborated and supplemented by the very illuminating research of V. V. Martynov (1978). Since Martynov's methodology represents a significant 
improvement and the results of his research are an important contribution to the problem of the ethnolinguistic prehistory of the Slavs (i.e. their ethnogenesis), I consider it worthwhile to quote some of his statements, and to present his list of examples. However, this does not mean that I subscribe to the tenor of his extralinguistic, i.e., prehistorical, conclusions.

But first let us start with Martynov's working hypothesis and methodology:

So we consider Slavic-Italic linguistic relations in the context of Slavic glottogenesis, which is presented in the following way. As a result of the invasion by the Italic peoples into the western area of the "Proto-Baltic" (i.e. Balto-Slavic, Z.G.) linguistic massive about 1200 B.C., with the appearance of (the so-called) Lusatian culture in this region, the Proto-Slavic language began to crystallize as a separate entity. One should separate its formative process into two periods: before the beginning of Slavic-Iranian lexical relations, and after. When we speak of the prehistorical Slavic-Iranian linguistic relations, we have in mind the invasion by the Scythians in the fifth century B.C. into the region where Proto-Slavic was being formed. Consequently, the first period of this formation of Proto-Slavic encompasses approximately the time from 1200 to 500 B.C. In the second period of the formation of Proto-Slavic (i.e. after 500 B.C.), Slavic-Germanic linguistic contacts began. (Martynov, 1.c. 8)

It is obvious that the whole hypothesis concerning the prehistorical formation of Proto-Slavic has been borrowed from T. Lehr-Spławiński (1946), as Martynov clearly acknowledges himself. Doubtless from the standpoint adopted in this book, we see a clear case of circulus vitiosus. Linguistically we are unable to decide whether there was any invasion of the Italic peoples (perhaps a better term would be Pre-Italic peoples) into the early Proto-Slavic (or rather Pre-Slavic) linguistic territory, or whether the linguistic contacts in question were the result of the close proximity of the two ethno-linguistic groups. What ultimately matters is that the methodology of the author has proven successful. In essence, this method can be boiled down to the following statement by the author himself:

If it is true that the glottogenesis of the Slavs was determined by the Italic migration into the Western 
Balto-Slavic area, then consequently we should expect the appearance of Balto-Italic synonymous pairs in the PSI. vocabulary, similarly (analogically), as there exist in English pairs of synonyms of Anglo-Saxon and Old French origin. In these cases when one of the synonyms does not oust the other, a kind of semantic correlation is established between them of the type of English sheep (Anglo-Sax. scéap) ... mutton (OFrench mouton) ... (... sheepskin but mutton chop ...).

A close scrutiny of PSl. vocabulary should reveal Baltic and Italic ingredients between which a similar semantic correlation exists. A Slavic synonymous pair is considered to be a maximally satisfactory criterion for Baltic and Italic ingredients if one of its components has obligatorily Baltic and, possibly, other IE parallels (correspondences, Z. G.), and the other - only an exact Italic parallel (correspondence, Z. G.) (Martynov, l.c. 9)

Now, operating with the above "working hypothesis" and method, Martynov was able to identify the following synonymous pairs in the PSI. vocabulary whose first components represent old common Balto-Slav. elements, whereas the second components stem from Italic. From among his thirty-two examples, I will quote only the twenty-one that he considers maximally certain:

1.) *bernъ *dètъ 'child', the former attested indirectly, e.g. in S-C brèna 'pregnant', zabrénjiti 'become pregnant' (referring to ewes), has an exact correspondence in Lith. bérnas 'Jüngling, Knecht', etc. (but there is also Goth. barn n. 'Kind'!), the latter commonly attested in all Slavic languages in the secondary forms *dětę (e.g. Pol. dziecię, Russ. ditjá, S-C déte, etc.) can, however, be reconstructed on the basis of such collective forms as Russ. detva, Pol. dziatwa, etc. as a primary $u$-stem which corresponds exactly to Lat. fêtus, gen. -üs 'bearing, bringing forth; offspring, brood' (Martynov, 1.c. 12).

2.) brrna * *ydlo 'snout', the former attested only in South Slavic and Slovak, e.g. Bulg. bzrna 'lip', etc., has an exact correspondence in Lith. burnà 'lip', etc., the latter attested in most Slavic languages, e.g. Russ. rýlo, S-C rilo, ULus. rydto, according to Martynov is, against the accepted etymology, not a derivative of $r y t i$ 'dig' + the suffix $-d l o$, but has a correspondence in Lat. rōstrum 'snout, pig's snout' ( ${ }^{*}$ rōd-tro- $m \leq$ rōdere 'gnaw'): Italic *rōd-tro- $m$ was borrowed by the early Proto-Slavs as ${ }^{*}$ rüdlo, i.e. later rydlo, with replacement of the West IE suffix -tro- by the PSI. - dlo and of Italic long closed $o$ by early PSI. $\bar{u}$, i.e. historical $y$. (For 
details, see Martynov, 1.c. 11-12, where, however, there is some confusion concerning the suffix.)

3.) desn $\sim$ pravs 'right', the former, attested in OCS and in all South Slavic languages, has exact correspondences in Lith. dẽšinas, OI dákșinaand OIran. dašina-, the latter, known in all Slavic languages, (in the south with the meaning 'straight'), has an exact correspondence in Lat. prāvus 'crooked; perverse, wrong', whose negative meaning in Latin is a result of the influence of the "inverse" semantic system of the augurs, in which the primary Italic pair *prāuos 'right, straight, etc.': *laiuos 'left, crooked, etc.' acquired the opposite meanings. According to Martynov, the primary, i.e. early PSl., pair desnz : krivz confronted the new Italic pair *prāuos : *laiuos (pravъ : lěvъ), which entailed subsequent lexical changes in Slavic (for details, see Martynov, 1.c. 15-16). But in the whole process of semantic changes of that microsystem, no mention is made of PSl. šujb 'left', which as we know has old connections with Indo-Iranian. ${ }^{10}$

4.) gqsb gosers 'goose', the former attested directly or indirectly in all Slavic languages, e.g. Pol. gęs f., Russ. gus', etc., is an old kentum element in Slavic (cf. Lith. žqusis), otherwise known in appropriate forms in most of the old IE languages, the latter, attested in Pol. gasior, Cz. houser, Sloven. gosẹrr, Bulg. gźser 'gander', has an exact correspondence in Lat. (h)anser 'goose' (PIE *g'hansero-) and represents an Italic element in Early Proto-Slavic. It is possible that Italic *ghansero- entering into a regular semantic correlation with the inherited Balto-Slavic *zaansi- (note the vestige of this noun in the Ukr. goose-call $d z u s^{\prime}, d z u s$ ') caused the generalization of the kentum word-initial $g$ - in PSl. gqsb (for details, see Martynov, l.c. 17-18).

5.) gъnati//goniti pasti 'make graze', the former attested in all Slavic languages, e.g. OCS gъnati, ženq, -eši and its iterative goniti, etc. 'drive,' represents an inherited PIE verb and has exact correspondences in Baltic, e.g. Lith. giñti 'drive', but the iterative ganýti 'make graze', the latter, attested also in all Slavic languages, e.g. OCS pasti, paso, -eši 'make graze', etc., has an exact correspondence in Lat. pāscō, -ere. Martynov, on the basis of some vestiges of the pastoral meaning of goniti in Slavic assumes that it was ousted later by the Italic pāscō. In this connection, he interprets Slav. pastyr'b (as in OCS) 'shepherd' as an old Italic element exactly corresponding to Lat. pāstōr (Martynov, 1.c. 18-9).

6.) *gardlica golobb 'pigeon', the former attested in most Slavic languages, e.g. OCS grolica, Russ. górlica, Pol. gardlica, etc. 'columba turtur', has an obvious etymology (a derivative of *gzrdlo 'throat' or perhaps 'goiter' as the Lith. correspondence gurklÿs indicates), the latter, known in all Slavic languages, e.g. OCS golqbb, Russ. gólub', Pol. gotab, gen. gotębia, etc., 'pigeon' has the only correspondence in Lat. columbus, 
columba, which as a word formation is well rooted in that language (see palumbus, palumba, palumbis, palumbès 'wild pigeon'). In this connection, golqbb is most probably an old Italic element in Slavic (Martynov, 1.c. 19).

7.) ${ }^{*} g$ grdlo glbts 'throat', the former attested in all Slavic languages, e.g. OCS grolo, Russ. górlo, Pol. gardło, etc. 'throat', is an old derivative from žsrq, *žerti 'swallow' > 'devour' and has an obvious correspondence in Baltic, e.g. Lith. gurklỹs 'goiter', gurklẽ f. 'throat', etc.; the latter, attested e.g. in S-C gût 'throat,' Sloven. gôlt idem, Bulg. góltzk//glátka, Russ. glot, glotók, Cz. hlt, Slovak hlt 'gulp', has an almost exact correspondence in Lat. glūtus 1. 'throat' (?), 2. 'gulp' (the only difference is in the quantity of the root-vowel: Slavic is short $z \leq{ }^{*} \breve{u}$, Latin long, but the primary shortness can be reconstructed for Italic). In Slavic and Latin there are also corresponding verbs derived from the above noun: PSI. glstati, glıtiti, poglztiti (e.g. OCS poglъštati, -ajo 'swallow up', ORuss. glätati, S-C gùtati, etc. Lat. glūtiō, -ïre idem), Martynov, 1.c. 20.

8.) jara lěto 'favorable season, time of crops, late spring, summer', the former also found in the variant jarb and others attested in most Slavic languages, e.g. Russ. Church Slav. jara and Bulg. jara 'spring, S-C jära 'summer heat', Ukr. jar' 'spring', OCz. jěr idem, etc., has correspondences in Lith. jöré 'spring greenery'11 and in many other IE languages,

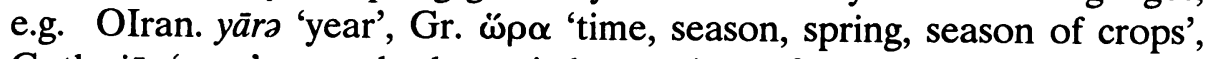
Goth. jerr 'year', etc.; the latter is known in all Slavic languages with the meaning 'summer', and has an exact correspondence only in Lat. laetus adj. 'abundant' (referring to crops), 'favorable' (referring to natural phenomena), 'beautiful'; see also laetitia 'abundance of crops' (these meanings quoted by Martynov seem to be archaic in Classical Latin). In this connection, Martynov interprets PSl. *lěto vermę 'favorable season, season of crops'. This attractive etymology, however, represents some difficulties: lěto shows the primary acute (see S-C ljêto, Cz. léto, Russ. immobile stress léto), which in the case of its provenience from Italic *laitos is inexplicable (see Pok. 652). In my opinion, lěto comes rather from PIE *löi-to-m 'profit (from the land)' > 'harvest' > 'time of harvest', etc., for which see OIc. lōd f., n. 'Ertrag des Bodens', läd n., OE lǣed n. 'Grundbesitz', etc. (Pok. 665 s.v. lè(i)- 'gewähren, Besitz', medium 'erwerben, gewinnen'); Martynov, l.c. 21-22.

9.) *jars agns 'lamb', the former is reconstructed for Proto-Slavic from such words as Russ. jarka, Pol. jarka, Sloven. jârka 'young ewe', etc. and seems to have an exact correspondence in Lith. jëras 'lamb', Latv. jêrs idem (although Baltic obviously represents PIE *ēro- 'lamb', see Traut. 70 and Pok. 326, whereas Slavic shows a contamination between *ēro- and *iōrā 'spring, summer' treated above); the latter, reconstructed from such 
words as OCS agnbcb, Bulg. agnec, S-C jägnjac, Cz. jehnec, etc. 'lamb', has a transparent correspondence in Lat. agnus and Gr. $\dot{\alpha} \mu \nu o ́ s$ (*’̉ßvós) 'lamb'. It seems that the Italic word ousted the inherited Balto-Slav. *jarb, restricting it to secondary uses (for details, see Martynov, 1.c. 22 and Berneker 446-447).

10.) komonb kobyla 'horse', the former attested e.g. in ORuss. komonb, Cz. komoň, and indirectly in OPol. komonika and North Slavic komonica, is ingeniously interpreted by Martynov as representing a condensation of Balto-Slav. *kamanas ašvas 'bridled horse' (cf. Lith. kãmanos 'bridle', kãmanoti, kamanúoti 'to bridle' and ašvà 'mare'); the latter, known in all Slavic languages in the meaning 'mare,' according to Martynov, comes from Italic kabō (cf. Lat. cabō, gen. -önis 'horse') extended by the suffix -la in Proto-Slavic (Italic long closed $o$ is treated in early Proto-Slavic as $\bar{u} \geq y$, cf. pāstōr > pastyr'b, etc.); Martynov, 1.c. 24 .

The above treatment of $c a b \bar{o}$ by Martynov as an old Italic word is mistaken. Ernout and Meillet (1939 edition) have cabō, -ōnis m. 'cheval hongre' (sic!) and clearly indicate that it is a glossary word, most probably a contamination of caballus and capo//capus 'capon'. But caballus itself is of unknown foreign origin in Latin and in Greek (Hesychius: $\alpha \alpha \beta \alpha \lambda^{\prime} \lambda \eta \varsigma^{*}$

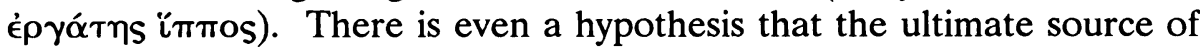
caballus may have been an ethnicon referring to some East European people known for their skill in horse breeding and especially horse gelding (see Fr. cheval hongre, i.e. literally 'Hungarian horse' and Pol. watach 'gelded horse', literally 'Walachian', etc.). Whether Slav. kobyla is somehow connected with caballus remains doubtful. So the above Slavic-Italic correspondence does not have sufficient historical justification, and should be removed from the list (but cf. p. 168).

11.) $k$ gq $\sim$ qgzls 'nook, corner', the former, attested in its respective forms in all Slavic languages, e.g. Pol. kqt, gen. kqta, Russ. kut, gen. kutá, etc., is, perhaps, genetically connected with OPruss. pokūnst 'cover, protect'12; the latter, also attested in its respective forms in all Slavic languages, e.g. OCS ggъlı, Pol. węgieł, gen. węgła, Russ. úgol, gen. uglá, etc., has the closest correspondence in Lat. angulus, and is most probably an Italic element in Proto-Slavic (Martynov, 1.c. 25-26).

12.) ${ }^{*} k b l k b \sim$ bedro 'hip', the former, attested in South Slavic, e.g. Bulg. kzlk, S-C kük, Sloven. kolk 'hip,' has correspondences in Baltic, e.g. Lith. kùlšè (*kulkšè), kùlšis (*kulkšis), but according to Trautmann 145 from PIE * $k l k / /{ }^{*} k l k^{\prime}-;$ the latter, known in all Slavic languages, has a close correspondence in Lat. femen, femur, gen. feminis, femoris 'hip', and supposes a transformation of the primary Italic heteroclitic stem in $n / r$ (*bhed-men/er-) in early Proto-Slavic (cf. e.g. Berneker 47-48, Martynov, l.c. 26-27). 
13.) kyjb *molts 'hammer', the former, attested in all Slavic languages, usually with the meaning 'stick, club', although the meaning 'hammer' is known in Russian, Bulgarian and Slovenian, has an exact correspondence in Baltic, e.g. Lith. kújis 'hammer', which allows the reconstruction of the latter meaning as primary Balto-Slavic; the latter (i.e. *moltz), which has been discussed on page 115 of this chapter, has a correspondence in Lat. malleus ("malteus), and represents an Italic element (according to Martynov) in early Proto-Slavic (cf. Martynov, l.c. 28).

14.) mësęcb luna 'moon', the former, attested in all Slavic languages, e.g OCS mësęcb, Russ. mésjac, Pol. miesiqc, etc., ultimately represents the PIE name of this celestial body, see Lith. mënuo, gen. mënesio, mernesies, Gr. $\mu \eta \dot{\eta}$, Lat. mēnsis, OI mäs, etc.; the latter (luna) known in most Slavic languages, e.g. OCS luna, Russ. luná, Pol. tuna, etc. also in the meaning 'light, reflection of light in the sky', although the meaning 'moon' is well attested in OCS, Russ., Bulg, S-C, OCz. and OPol., has its exact correspondence in Lat. lūna 'moon' and undoubtedly represents an Italic element in early Proto-Slavic (*louksnā $\geq$ luna), Martynov, 1.c. 30. (The regular PSl. form from PIE *louksnā would be *luxna, cf. daxnoti from *dhusnou-tei, since the noun was known in Baltic, cf. OPruss. lauxnos plur. 'stars' (cf. Traut. 152), but the lack of $k s \geq x$, etc. seems to be additional evidence of the Italic origin of this word in Proto-Slavic).

15.) moka *boršbno 'flour', the former, attested in most Slavic languages, e.g. OCS mqka, Russ. muká, Pol. mqka, etc., has very close correspondences in Baltic, e.g. Lith. minkle 'dough' (from minkyti 'knead' which also underlies PSI. mqka, i.e. *monk-ā), and in other IE languages, but not in Italic; the latter, known in South and East Slavic (but also in Lusatian), e.g. OCS brašbno 'food', Russ. bórošno 'rye flour', etc. has an obvious correspondence in Lat. farina ( $\leq$ *farsina) 'flour', and is an Italic element in Proto-Slavic, which in a characteristic way has competed with its older synonym mqka (for details, see Martynov, l.c. 31-32).

16.) 'pbrstz *palbcb 'finger', the former, attested in most Slavic languages, e.g. OCS prbstz 'finger', Russ. perst, Cz. prst, has exact correspondences in Baltic, e.g. Lith. piřstas 'finger', and seems to be an old Balto-Slav. innovation; the latter, known in all Slavic languages, e.g. Russ. pálec, Pol. palec, S-C pålac, etc., with the more specialized meaning 'thumb' in Czech, Slovak and South Slavic, which should be reconstructed as the primary PSl. meaning of this word, has an exact correspondence in Lat. pollex, gen. pollicis ( ${ }^{*}$ polik-), and is an old Italic element in early Proto-Slavic (Martynov, 1.c. 34-35).

17.) soxa *vidla 'pitchfork', the former with the primary meaning 'type of pitchfork' attested in all Slavic languages, e.g. OCS soxa, although 
in North Slavic it occurs as well with the meaning 'primitive wooden plough', has old correspondences in Baltic, e.g. Lith. šakà 'forked branch', šãke 'pitchfork', and other IE languages, e.g. Goth. höha 'plough', OI sakhā 'branch'; the latter known in its respective forms, frequently in the plural, in all Slavic languages, e.g. ORuss. vila, plur., Russ. víly, Pol. widly, S-C vile, etc., should be reconstructed as plurale tantum *vi-dla 'hooks' and related through Italic *uidlā (*uei-dhlā) to Lat. fibula 'buckle, clasp', especially 'an iron clasp fastening beams together' (Martynov, l.c. 35).

18.) starb mator 'old, mature', the former, attested in all Slavic languages, has an obvious correspondence in Lith. stóras 'thick, big, strong' and Germanic, e.g. OIc. stórr 'big, strong', etc., which would indicate the primary meaning in Proto-Slavic 'big, strong'; the latter, also attested in most Slavic languages, e.g. OCS mator 'old', Bulg. mator 'healthy, strong, mature, old', Russ. matëryj 'big, strong', OCz. matorný 'mature', etc. with meanings hesitating between 'big, strong' and 'mature, old', has almost an exact correspondence in Lat. mätūrus 'ripe', and is most probably an Italic element in early Proto-Slavic (Italic *mätoros $\geq$ PSI. matorz), which brought about the semantic shift of starb : 'big, strong' $>$ 'old' (Martynov, 1.c. 36).

19.) tesla sekyra 'hatchet', both words are known in all Slavic languages, the former also with neuter gender: tesló (e.g. Russ. tesló, Sloven, téslo, etc.), with a clear specification of tesla//teslo as 'carpenter's adz', and have been discussed above under the North West IE lexical stratum in Proto-Slavic (p. 112 and 115 of this chapter), but according to Martynov, the former is an IE archaism with correspondences in Baltic, e.g. Latv. teslis, Lith. tašiklis, and other IE languages as a derivative from PIE *tek'p- 'das Holzwerk des geflochtenen Hauses zusammenfügen' (Pok. 1058); the latter, however, because of the exact correspondence in Lat. secūris (note: Slavic sekyra with the primary $e$ but sěko, etc. with the secondary $\check{e}$ ) is an Italic element in early Proto-Slavic (Martynov, 1.c. 36-37).

20.) voditi snubiti 'to marry a woman', the former, known in all Slavic languages in the expression voditi žen (or rather vesti ženq) has the meaning 'to marry a woman' (cf. Lat. uxorem ducere) and is an IE archaism with exact correspondences in Baltic, e.g. Lith. vèsti (a woman) 'to marry', etc. and in other IE languages, also showing such characteristic derivatives as Lith. vedỹs 'bridegroom', OI vadhû- 'bride, young wife', etc.; the latter, attested in most Slavic languages, e.g. ORuss. snubiti, S-C snúbiti, Cz. snoubiti, OPol. snębić in the meaning 'to betroth' has an exact correspondence only in Italic, e.g. Lat. nūbō, nübere 'to marry, to be married to' (referring to a bride), 'to give in marriage', with many 
derivatives. The primary early Italic form *snoubho should have resulted in Slavic *snubq, *snuti, the actual form snubiti seems to be an iterative or rather a denominal verb, perhaps derived from an Italic noun of the type of Lat. pronūbus, pronūba 'matchmaker' (cf. OPol. dziewo-stab dissimilated from *dziewo-snąb and this from *dèvo-snubz). Anyway, this Slavic-Italic correspondence seems to support Martynov's hypothesis about the Italic origin of the word in early Proto-Slavic (Martynov, 1.c. 37-38).

21.) $z b d z \sim g z r n b$ 'oven, hearth' (primarily 'potterer's kiln'), the former, reconstructed from its vestiges in Slavic languages, e.g. OCS $z b d b$ 'dwelling, roof' (Sadnik-Aitzetmüller: 'Mauer, Dach'), S-C zâd, gen. $z d a$ m. 'stone-wall', ORuss. zbdb 'clay', etc. (derivatives from *zidjo, zbdati, OCS ziždq, zbdati 'build'), has correspondences in Baltic, e.g. Lith. židinỹs 'hearth', etc., which indicate that the noun was connected primarily with pottery. The latter, which is known in most Slavic languages (directly or through its derivatives), e.g. Russ. gorn 'kiln', etc. (see the discussion of PSl. pottery terminology on page 114 of this chapter) has an exact formal and semantic correspondence only in Lat. fornus//furnus and, as Trubačev has proven, represents the prehistorical Slavic-Italic ties, which in this case are interpreted by Martynov in terms of the Italic penetration into the early Proto-Slavic territory (Martynov, 1.c. 39-40).

The above list of maximally certain Italic elements in Proto-Slavic is truly significant, although it should be kept in mind that some of them have been noticed previously as evidence of prehistorical dialectal contacts between early Proto-Slavic and Italic (e.g. *boršsno, golǫbb, *gzrn and its derivatives, *moltz, sekyra). What distinguishes Martynov's approach is his insistence on the synonymous pairs composed of an old Balto-Slav. element and a new Italic one with subsequent semantic changes caused by the confrontation of these elements. The other distinctive feature of Martynov's approach is his hypothesis that the lexical elements representing special Slavic-Italic correspondences are simply the result of the penetration of Italic words into early Proto-Slavic, or rather Pre-Slavic (in the sense of the western zone of the common prehistorical Balto-Slavic dialect). This point, which practically boils down to prehistorical borrowings from Italic is in some cases well substantiated phonemically, e.g. the substitution of early PSl. $\bar{u}(\geq y)$ for Italic $\delta[\bar{Q}]:$ pāstōr > pastyr'b, *ródtrom > *rydlo, etc. But in other cases we can only state a correspondence in terms of prehistorical IE dialectology. In summation, however, Martynov's hypothesis regarding the penetration of Italic lexical elements into early Proto-Slavic (or Pre-Slavic) seems convincing, and combined with Trubačev's views on the special, old ties between PSI. (excluding here Baltic!) and Italic technical 
(handicraft) terminologies compels us to reconsider the traditional views which bind too closely Slavic to the eastern zone of the PIE dialects (i.e. Baltic and Indo-Iranian). But, Martynov's extra-linguistic hypothesis that the Italic elements in Slavic which distinguish it so sharply from Baltic are due to the conquest of the Pre-Slavic tribes by some Italic tribes cannot be proven by linguistic arguments. This hypothesis has been borrowed from archeology (the appearance and 'expansion' of the so-called Lusatian culture), in which, however, the very direction and chronolgy of the expansion of the so-called prehistorical cultures is a matter for controversy. In view of a general prehistorical movement of the IE peoples from Eastern Europe west and southward, it is more plausible that the Italic elements (e.g. kentum elements) penetrated early Proto-Slavic from the dialects of those Italic tribes which in their movement to Italy "slowed" their migration somewhere in Central Europe and were found there by the early Proto-Slavs who were moving gradually from the east. We may be dealing here with a rather banal case of lexical borrowing in the contact (border) zone of two neighboring peoples. We can quite easily imagine the following process: some tribes of primary Balto-Slavic origin ("Proto-Baltic" in Lehr-Spławiński's and Martynov's terminology) moving from the east to the west, e.g. from the central Dniepr basin towards the Vistula basin, most probably along the park-land zone, came into contact with some Italic tribes concentrated in the Vistula and Odra basins. This contact led first of all to a cultural-linguistic exchange, and later, perhaps, to the ultimate absorption of the Italic tribes by the expanding Proto-Slavic tribes. The traces of these ethno-linguistic processes are represented, among others, by those elements of PSI. vocabulary which have correspondences in Italic, but lack them in Baltic. The ethnogenic process presented in this way cannot be forced into a simple scheme of the relationship between a superstratum and a substratum. History, as we know it, is by definition always richer than any sociological scheme. The spread of a prehistorical culture does not necessarily prove the migration and expansion of its original founders. In the border zones we constantly observe borrowings and imitations, which in their turn spread towards the center of a given area if only the social contacts between its inhabitants are sufficiently close and frequent. Moreover, whatever may have been the social conditions under which a gradual socio-cultural and linguistic integration of the primary early Proto-Slavic element (moving from the east) with the Italic element (in the second millennium B.C. still remaining in the Vistula basin) developed - the linguistic results of this process are clearly visible in the PSI. vocabulary. They provide one of the important arguments for a relatively early split of the so-called Balto-Slavic linguistic 
unity, i.e. for the differentiation of the primary Balto-Slavic complex into Proto-Baltic and Proto-Slavic.

The sum total of Slavic words belonging to the so-called (North-) West [North in parentheses since not all of the words discussed have correspondences in Germanic] IE vocabulary is, as we see, seventy-six. However, from this number we should deduct those words which have been quoted twice under various headings, namely *boršbno, *gbrnz, *moltz, and the kentum-elements gladzkb, golobb mentioned at the beginning of this chapter; thus we obtain $76-5=71$. This number is close to the sum-total of Slavic (Indo-)Iranian correspondences (75 including Baltic/49 excluding it). I think that this fact should be emphasized. Of course, the semantic significance of Slavic $\sim$ (North-) West correspondences seems to be lesser than that of the correspondences between Slavic and (Indo-)Iranian. Most of the former are technical terms related to material culture: there are no religious terms among them. From among social terms we can quote only six: ${ }^{*} d z \lg$ 'debt', gospodb 'lord', gostb 'stranger, guest', pravb 'right' (in connection with its juridical significance), snubiti 'betroth', *volde 'rule' (but we must also remember that the relationship of the latter to Lat. valeo is rather doubtful). This situation seems to indicate that the contacts between the IE ancestors of the Slavs and the North-West IE tribes (or dialects) - in Meillet's terminology - were, to be sure, old but rather external, consisting probably of economic exchanges. In this connection, I shall quote the conclusions drawn by Trubacev from his comparative-etymological analysis of PSl. handicraft terminology. One should add that these conclusions are based not only on Slavic North-West IE correspondences, especially Slavic-Latin ones, but also on very specific Slavic-Germanic correspondences, which will be discussed in a separate paragraph below. Trubačev's conclusions (1.c. 392-393) read as follows:

Emphasizing that the etymological parallels or identities presented above are considered in principle as representative of a lexicon which goes back to the epoch of dialectal Proto-Indo-European, i.e. which reflects to a significant degree early Proto-Slavic and Pre-Slavic relations, we assume, moreover, that the facts presented here speak for themselves. The number of common, old Balto-Slav. innovations (neologisms) is minimal, based, as we have explained, on a sufficiently large corpus of old terminological groups... . We hope that this material will attract the attention of linguists who periodically return to the 
Balto-Slav. problem. Refraining from further classifications, we will only repeat that this material indicates in itself the probability of an old orientation of the Slavs, not towards contacts with the Balts, but towards the more western Indo-Europeans. The linguistic community with the latter in the domain of terminology is so intensive and serious that we are compelled to admit the existence of an old Central-European cultural zone which comprised prehistorical Germanic, Italic, and Slavic dialects (or a part of the latter) but did not include Baltic dialects; community with the latter might have taken place later. A later inclusion of the Slavs in the zone under consideration (let us say, after Balto-Slav. union), is, in our opinion, less probable. ${ }^{13}$ This is also contradicted by the formation of terminology in Baltic which developed along paths completely different from Slavic in the corresponding thematic groups.

In the final section of this chapter, I will try to show that Trubačev's idea (hypothesis) about a Central-European cultural zone derives additional support from the old dialectal (including lexical) isoglosses and from the geographical distribution of the corresponding ethnographic facts on the Polish linguistic territory (and partly on the Ukrainian territory as well). This is the phenomenon of the so-called rubiez etnograficzna established by K. Moszyński. But before that we should still discuss the problem of the North IE vocabulary as reflected by Germanic, Baltic, and Slavic correspondences.

In the preceding chapter we mentioned some phonemic and morphemic features which characterize the prehistorical North-European dialectal zone of Proto-Indo-European, i.e. the zone including later (historical) Germanic, Baltic, and Slavic languages. But, as usually is the case with dialectal phenomena, we can also find in this zone many common prehistorical lexical phenomena, the so-called North-European lexical dialectisms. ${ }^{14}$ Most of these lexical dialectisms undoubtedly come from a time when the linguistic ancestors of the Slavs, Balts, and Teutons dwelt close to each other, as a group of neighboring tribes somewhere in Eastern Europe, probably in the third millenium B.C. So we may be dealing here with the so-called areal phenomena: a word formed in one dialect, let us say, in Pre-Germanic or Pre-Balto-Slavic, could penetrate other dialects of the zone because social contacts (e.g. barter trade between the respective tribes) made this possible.

The problem of the North European lexical dialectisms in question has been recently treated in a special study by Chr. Stang (1972). What 
follows is a critical survey of Stang's material with supplements from Cemodanov (1962) and Trubačev (1966) whose books did not reach Stang's attention. Facts of Slavic will often be illustrated with additional data from Berneker's, Vasmer's, and other dictionaries.

The special lexical correspondences among Germanic, Baltic, and Slavic (henceforth Germc. Balto-Slav.) should be divided into three subgroups: 1. Germc. Balto-Slav., i.e. words common to all three linguistic groups; 2. Germc. $\sim$ Baltic, i.e. words common to Germanic and Baltic only; 3. Germc. Slavic, i.e. words common to Germanic and Slavic only. It is obvious that for our purposes the second subgroup is not important, and can be omitted. So we shall review words common to all three linguistic groups, and those common to Germc. and Slavic only.

\section{Germc. $\sim$ Balto-Slavic}

1.) *oldi(ji) 'boat', attested in all Slavic languages, e.g. OCS al(z)di(ji)//ladi(ji), ORuss. lodıja, Cz. lod'//lodí, S-C lâđa, etc. - Lith. aldijà/leldijà 'Einbaum, Kahn', Norw. dial. olda 'grosser Trog, oft aus einem ausgehöhlten Baumstamm', etc. $\leq$ PGermc. *aldon (Stang, 13).

2.) blějo, blějati 'bleat', attested in East and South Slavic, e.g. Russ. Church Slav. blěju, blějati, Russ. bleját', S-C bléjim, bléjati, etc. - Latv. blëju, blēt, MLG blǣjen idem (Stang 15).

3.) blędq, blęsti 'err' and its old derivatives: bloditi iterative, blodz 'mistake, error', attested in all Slavic languages, e.g. OCS blędq, blęsti 'irren, Hurerei treiben', bloditi 'irren', blods 'Hurereri', Russ. bludit' 'irren, schweifen', blud 'Unzucht', OCz. blésti 'faseln', Cz. bluditi 'irren', blud 'Irrtum', Pol. btqdzic 'irre gehen', błqd, gen. błędu 'Irrtum', etc. Lith. blǐsti//blęstis 'trübe, dunkel werden', blandýti(s) 'umherschweifen; sich verfinstern', blandùs 'unrein, trüb, dünster, dunkel', etc., Goth. blandan sik 'sich vermischen', blinds 'blind', etc.; correspondences in other Germc. languages, e.g. Eng. blend, blind, blunder, etc.; the basic meaning of the causative verb was probably 'zusammenrühren, trüben, unklar machen' (Stang 15).

4.) *blbščq, -iši, *blb̌̌čati and its derivatives: bliskati//bliscati and blbs(k)nqti 'shine, gleam', attested in most Slavic languages, e.g. OCS blbšto, -iši, blb̌̌tati and iterative bliscajo, bliscati sę 'glänzen'; Russ. Church Slav. blb̌̌cu, blbščati (sja) and blbsnuti (sja) 'glänzen, blitzen'; Russ. bleščú, blestét'; blistát'; blesnút' 'glänzen strahlen; blitzen'; OCz. blšču sě, blščieti sě 'glänzen, blitzen', Cz. blesknouti 'blitzen', etc. - Lith. blyškěti 'funkeln, schimmern, glänzen' and blykštù, blyškaũ, blỹkšti 'bleich werden', OIc. blikja, 'blinken, glänzen', OE blícan, OHG blihhan idem, etc.; PIE *bhleig'-, *bhleig'-sk'e- (cf. Bern. 63, Traut. 34 s.v. blaiška-, Palome, 1972: 
51, etc., Cemodanov, 84).

5.) *bolzbno, *bolzina 'thick board, beam', attested only in Russ. dial. bólozno 'dickes Brett', Sloven. blazína 'Dachbalken, Querbaum des Schlittens, Rungstock' but also 'Kissen, Matratze, Brettpfühl' and Kash. błozno 'das die Schlitten verbindende Querholz' - Lith. balžíena(s) 'Längsbalken an der Egge, am Wagen'; 'biegsame Querstange zur Verbindung des Aufsatzes auf dem Schlitten, Krummholz, etc.', correspondences also in Latvian and Old Prussian; OHG balko 'Balken', OIc. bljalki 'Balken', etc.; PIE *bholg'-, in Balto-Slavic contaminated with *bholg'h- 'Balg' (for details, see Stang 14 and Bern. 70).

6.) cělъ 'whole, healthy' attested in all Slavic languages, e.g. OCS cělz 'heil, gesund; ganz, unversehrt', Russ. celyj, Pol. caly, etc. - OPruss. kails 'heil!', kailūstiskan 'Gesundheit', Goth. háils, OIc. heill, OHG heil, OE hál 'heil, ganz, gesund'; correspondences in other IE languages show remote

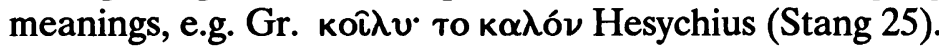

7.) čemerı 'Nieswurz', attested in all Slavic languages, e.g. ORuss. čemerb//čemerb 'Nieswurz', Russ. čémer 'Kopfschmerzen', čemeríca 'Nieswurz', S-C čêmer 'Gift, Teufel', OPol. and dial. czemier, czemierzyca 'Nieswurz', etc. - Lith. plur. kemerai 'Alpkraut, Wasserdost' (not mentioned by Stang and Trautmann, but attested by Berneker 142), OHG hemera, NHG dial. hemern 'Niewswurz' (Stang 16).

8.) *čbmel'b 'humblebee', attested in most Slavic languages, e.g. Russ. dial. čmel' (standard Russ. šmel'), gen. čmeljá 'Hummel, Erdbiene, Pol. czmiel, trzmiel idem, Sloven. čmêlj idem, etc. - Lith. kamãné 'Mooshummel', correspondences in other Baltic languages, e.g. OPruss. camus 'Hummel', OHG humbal, Norw. dial. and Swed. humla; cf. also Eng. humble-bee ${ }^{15}$ (Stang 26).

9.) *dbrgajo, *dbrgati 'pluck', attested in most Slavic languages, e.g. Russ. dërgat' 'zupfen, reissen', Pol. dziergać, dzierzgać 'klöppeln, schlingen, knüpfen; benähen, besticken; riffeln', S-C drgati 'reiben, wetzen, würgen' (but Berneker quotes this as Sloven.!) - Lith. dirginti 'bewegen, rütteln, erregen, aufbringen, reizen', MLG tergen, targen 'reissen, zerren', MHG zergen 'ziehen, zerren, ärgern, quälen', OE tergan 'zerren' (Stang 19).

10.) doba 'opportunity' (?), attested in all Slavic languages, except for OCS where there are only derivatives based on a secondary verb podobiti 'passend, gleich machen', e.g. podoba 'Zier', etc.; Russ. dóba 'Zeit, Stunde', Pol. doba 'Zeitpunkt, rechte Zeit; voller Tag von 24 Stunden', etc. (for details see Berneker 203-204) - Lith. dabà 'Natur, Art und Weise, Charakter'; the same in Latvian, Goth. gadaban 'passen', actually 'sich ereignen, eintreffen' (Pok. 233 s.v. *dhabh- 'passend fügen, passend'); correspondences in other Germc. languages, e.g. OE gedēfe ('ga-dōbja) 'passend, mild', etc. (Stang 17). 
11.) dregz 'club, stick', attested only in South and West Slavic, e.g. OCS drggz 'Holz, Knüttel, Stock', Pol. drag 'Stange, Stab, Stock, etc.; Lith. drãngas 'dicke Stange', OIc. drangr 'spitzer, aufrecht stehender Stein', drengr 'edler und tüchtiger Mensch, Junger, unverheirateter Mann, Diener' (cf. Pol. chłop jak drag!); Stock, Stange', etc. (Stang 19).

12.) drugz 'companion', also as the pronominal adjective 'other', attested in all Slavic languages, e.g. OCS drugz 'Freund, Gefährte', as pron. adj. 'anderer, zweiter', Russ. drug, plur. druz'já and drugój, S-C drûg and drügi, etc. - Lith. draũgas 'Freund, Kamerad', known also in Latvian and Old Prussian; in Germanic the basic verb is preserved: Goth. driugan 'Kriegsdienst leisten, zu Felde ziehen', but OE dréogan 'ausführen, aushalten', etc.; the military meaning of the verb in Gothic is secondary, according to Stang, the primary meaning was 'eine harte kollektive Arbeit ausführen'; Balto-Slav. *draugas is an obvious old derivative of the verb preserved in Germanic (Stang 19-20).

13.) *dblbo, *del(b)ti//*dbl(b)ti, 'delve, carve', attested in most Slavic languages (often in the secondary form ${ }^{*}$ dblbajo//*dblbljo, *dblbati), e.g. S-C dúbem, dúpsti 'aushöhlen', Russ. dolbáju, dolbát' and dolbljú, dolbít' 'meisseln, stemmen, hacken', Pol. dtubię, dłubać 'meisseln, höhlen, stochern', etc.; there is also a PSl. derivative of this verb: *del(b)tó//*dol(b)tó, attested e.g. in S-C dlijèto 'Meissel', Russ. dolotó and Russ. Church Slav. dlato idem, Pol. dłóto idem, etc. - OPruss. dalbtan 'Durchschlag' = PSl. *dol(b)to, OHG bi-telban 'begraben', OE delfan 'graben', etc.; here also can be included Lith. delbti 'die Augen niederschlagen' (Stang 17 and Berneker 250-251).

14.) gads 'reptile', attested in all Slavic languages, often in the secondary meaning 'vermin', e.g. OCS gadz 'Kriechtier, Gewürm', Russ. gad 'Reptil, Amphibie, ekelhafter Mensch', Pol. gad 'Reptil', dial. 'Schlange, Gewürm, Läuse', etc.; cf. also the Pol. verb żadzić się 'Ekel empfinden', with the primary vocalism * $\bar{e}-$ Lith. géda 'Schande', OPruss. gidan 'Scham', MHG quāt 'böse', OE cwēd 'schlimm, böse', NHG Kat, Kot 'Unrat, Schmutz', etc. (Stang 21 and Berneker 289).

15.) *gležo, * ${ }^{*}$ gleziti, attested only in Bulg. glézja (perf. participle glezíl) 'verziehe, verzärtele', i.e. 'coddle, pamper' - Lith. gležnus 'zart, schwächlich', OIc. $k l ø k k r$ 'soft, flexible, LG klinker 'weak': Palomé 1972: 51 etc. reconstructs PGermc. *klenkwan- from PIE *gleg'-//*gleng'(Cemodanov 84).

16.) globiti 'join by wedge' (?), attested in South and West Slavic, e.g. S-C uglòbiti 'einfügen, einstecken', zglòbiti 'zusammenlegen, fügen', Pol. dial. głobić 'ein Fass mit Reifen beschlagen; einen Keil einschlagen', old 'drücken, zusammenfügen', etc.; Trubačev in Ėtimologičeskij slovar' slav. jaz. 6, 131 s.v. globa among others 'a kind of pole', treats the noun as 
primary, derived from a reconstructed verb *glebo, *gle(b)ti 'dig, press', although globiti may be simply an old iterative (cf. ved $q>$ voditi, etc.) Lith. glěbti 'umarmen, in die ausgebreiteten Arme nehmen', there are correspondences in Latvian and Old Prussian; OIc. klafi 'Kloben, Joch für Kühe', OHG klättra = NHG Klafter 'wood cord'; Stang reconstructs *gle/obh- with long vocalism $\bar{e}$ in Baltic and Germanic (Stang 22, Berneker 305, Trubačev Etimolog. slov. slav. jaz. 6, 131-134).

17.) grebo, *gre(b)ti 'dig', attested in all Slavic languages, e.g. OCS grebo, greti 'rudern, graben' (the first meaning is obviously secondary, conditioned by the primitive method of rowing, cf. Vasmer I, 454), Russ. grebú, grestí 'rake; row', OPol. grzebę, grześć, NPol. grzebię, grzebać 'graben, wühlen, scharren', etc. - Latv. grebju, grebt 'schrapen, aushöhlen, mit dem Grabstichel eingraben', Goth. graban 'graben', OHG graban = NHG graben, etc. (Stang 24). It is worth noting that an old derivative grobs 'grave' is common to Slavic and Germanic, cf. OIc. grof 'Höhle, Grab', OHG grab, NHG Grab, etc.

18.) gręda 'bar, beam', attested in all Slavic languages, e.g. Russ. Church Slav. grjada 'Balken', Russ. grjadá 'Beet; Gang, Reihe, Streifen' (secondary meanings!), S-C gréda (acc. grêdu) 'Balken', Pol. grzęda 'Stange, Hühnerstangte; Beet', etc. - Lith. grindì f. 'Dielenbrett; Bretterbeleg des Fussbodens, Fussboden', correspondences are also found in Latvian and Old Prussian; OIc. grind 'Heck, Rahmen, Gestell, Gitterwerk', OHG grintil 'Riegen, Balken, Deichsel', OE grindel 'Stange, Stab, Riegel' (Stang 24).

19.) grqbs 'crude, coarse', attested in most Slavic languages (with various secondary meanings), e.g. OCS grobs 'Idiot, ungelehrt, ungebildet', Russ. grúbyj 'rasch, roh, grob', Pol. dial. gręby 'runzelig, herb, rauh, widrig' but Standard Pol. gruby 'dick, stark, grob', etc. - Lith. grùbti (3rd sing. pres. grum̃ba) 'erstarren, steif, rauh, uneben, holperig werden' and grubùs 'rauh, steif, uneven, holperig', OHG grob (Stang 24).

20.) gruda 'clod of earth', attested in most Slavic languages, e.g. Church Slav. gruda 'Erdscholle', Russ. grúda 'Haufen (Steine), Stoss (Holz)', S-C grüda 'Klumpen, Schneeball', Pol. gruda 'Klumpen, Scholle', etc. - Lith. grústi (3rd. sing. pres. grúdžia,-da, 3rd. sing. past -dè, -do) 'stampfen, zerstossen, drängen, hineinpressen', grúdas 'Korn', Latv. grûst (1st. sing. pres. -žu, past -du) 'stossen, stampfen', grûds//graûds 'Korn', OIc. grautr 'Brei, Grütze', grjót 'Gestein', OHG grioz = NHG Griess; here, of course, belongs Eng. grout(s). The basic Balto-Slav meaning was probably 'lump, clod', in the verb 'make lumps, clods' (Stang 24-25).

21.) (j)esenb 'autumn', attested in most Slavic languages, e.g. S-C jèsen, Russ. ósen', Pol. jesień, etc. - OPruss. assanis 'Herbst' (according to Berneker and Trautmann may represent esenis), Goth. asans 'Erntezeit', 
OHG aran, arn, arnôt 'Ernte', OIc. qnn 'Arbeit, Bemühung, etc. (Stang 25 who, however, does not quote OPruss. assanis); but see also another etymological interpretation of (j)esenb, etc. by Martynov in the sixth chapter of this book, in the paragraph discussing PSI. loanwords in Germanic: so the example is questionable.

22.) (j)u(že) 'already' (Germ. 'schon'), attested in all Slavic languages, e.g. OCS (j)uže 'schon; noch', but also a simpler form without the particle že: (j)u: ne (j)u 'noch nicht', Russ. užé, Pol. już idem, etc. - Lith. jaũ 'schon', Latv. jàu idem, Goth. ju idem (for details, see Stang 25 and Vasmer IV, 151).

23.) klado, klasti 'put, lay', attested in all Slavic languages, e.g. OCS klado, klasti 'laden, legen', Russ. kladú, klast' 'legen', Pol. kładę, kłaść idem, etc. - Lith. klóti, 3rd sing. pres. klója 'hinbreiten, ausbreiten überdecken', known in Latvian, Goth. afhlapan 'beladen', OHG, OE hladan = NHG laden, NE lade, etc.: the three linguistic families share the common PIE basis ${ }^{*} k l a \bar{a}-/ /{ }^{*} k l a-\left(i . e .{ }^{*} k_{l e H}-/ /{ }^{*} k l a-\right)$; cf. Stang 29-30.

24.) kliknqti > klicati (klič , etc.) 'shout', attested in most Slavic languages, e.g. OCS kliknoti (perf.) and klicati, kličo, etc. (imperf.) 'schreien, rufen', Russ. klíknut', klíkat', klícu idem, OCz. klícěti, kliču 'schreien' Lith. klýkti, 3rd. sing. pres. klýkia, past klýké besides klikti, 3rd. sing. pres. $k l i n ̃ k a$, the former 'kreischen, laut schreien', the latter 'plötzlich aufkreischen' (cf. Trautmann 136), OE hli 'zuschreien', MLG li(h)en 'sagen, melden' (Stang 29).

25.) *kl'uk-, i.e. *kl'učb 'key, hook' and its derivatives, e.g. kl'učiti, etc., attested in all Slavic languages, e.g. OCS kl'učb m. 'Schlüssel', kl'učiti 'schliessen', kl'učiti sę 'zusammenpassen, übereinkommen, sich ereignen', Russ. ključ, gen. ključá 'Schlüssel', za-ključít' 'verschliessen', Pol. klucz 'Schlüssel', etc. - There are verbal root correspondences in Baltic and Germanic, e.g. Lith. kliúti (3rd. sing. pres. kliựva, past kliùvo) 'hängen bleiben, anstossen an' and many secondary meanings, kliáutis 'sich zusammenfügen, aufeinanderpassen...dicht anschliessen, etc.', with dental extensions of the root: kliudýti 'anstossen, treffen, anhaken, hindern', correspondences in Latvian, OIc. hljóta (hlaut, hlotinn) 'als seinen Teil, Anteil bekommen, etc.', OE hléotan 'cast lots, obtain by lots, get a share, etc.', OHG hliozan = MHG losen, 'erlosen, zaubern', etc.; the basic meaning of the root *kleu- was probably 'das Anhaken, Anschliessen' or 'Umschliessen', then 'Hängenbleiben', etc. (for details, see Stang 29).

26.) kuča 'heap', attested only in East and West Slavic, e.g. Russ. kúča 'Haufen, Heuschober', Pol. kuczki (plur.) 'kleine Haufen', etc. - Lith. kaũkas 'Kobold, zwerghafter Erd- or Hausgeist, Beule, Geschwür', with correspondences in Latvian and Prussian, Goth. hauhs 'hoch', OIc. hár 
'hoch', haugr 'Anhöhe, Hügel', OHG hoh, OE héah = NHG hoch, NE high, etc. (for details, see Stang 27).

27.) *kupr 'rump', attested only in East and West Slavic, e.g. Russ. kupér//kupr 'Bürzel' (but Vasmer II, 420 also gives the meaning 'small hill'), Pol. kup(e)r 'Bürzel; Hinterer', etc. - Lith. kuprà 'Höcker, Buckel, gekrümmter Rücken', kaũpras 'Hügel, Berg', OE hofar 'Höcker, Schwellung: a common feature of the above languages is the extension -ro/a of the root *koup- known elsewhere (cf. Slav. kupa discussed under the Slavic-Iranian correspondences), Stang 31.

28.) lapa 'paw', attested only in East Slavic, Polish and Slovenian, e.g. Russ. lápa 'Pfote, Tatze', Pol. tapa 'Klaue, Tatze', etc. - Lith. lópa 'Pfote, Tatze, Klaue', Latv. lẽpa//lãpa 'Pfote', Goth. lofa 'flache Hand', OIc. lófi 'Innerseite der flachen Hand'; from lapa > lopata 'shovel', etc. (Stang 23).

29.) *lěviti 'give way, yield, etc.', attested only in Ukrainian and Czech: Ukr. livýty 'nachgeben, nachlassen', Cz. leviti 'nachlassen, lindern' - Lith. liáuti(s), 1st. sing. pres. liáuju, liáujuos 'aufhören', Latv. l'aũt 1st. sing. pres. l'auju/ll'aũnu (Trautmann 161) 'erlauben, gestatten, zulassen, einräumen', l'aũtiês 'aufhören, nachgeben, sich hingeben', with a correspondence in Prussian, Goth. lëwjan 'verraten', galēwjan 'hingeben, überlasen, verraten', OE láwan 'verraten'; the primary, basic meaning was probably 'lassen, fahren lassen', etc. (Stang 32).

30). lězo, lěsti 'crawl', attested in all Slavic languages, often with secondary meanings, e.g. OCS vъzlězQ, -lěsti 'hinaufgehen, besteigen', Russ. lézu, lezt' 'kriechen', S-C ù-ljezem, -ljesti 'hineingehen', Pol. colloq. lezę, leźć 'shuffle, lumber', etc. - Pruss. lïse 'kriecht', Latv. lēžat 'rutschen', lēzētiês 'mit einem Schlittchen vom Berge fahren', more remote correspondences in Lithuanian (cf. Trautmann 161), OIc. lágr 'low', MHG læge 'flat', etc. (Čemodanov 84, Palome, 1972: 52-53, Pokorny 660 s.v. *lëg'h-//*lag'h- 'am Boden kriechen, niedrig' and Vasmer II, 476-477 where also Gr. $\lambda \alpha \chi$ v́s 'low' is quoted!).

31.) *lęčb 'string, running knot', attested only in Cz. léc 'Netz, Schlinge', Polab. lqc 'Krümme' and indirectly in S-C (sixteenth century glagolitic text) lečka 'Schlinge', Sloven. lęçka idem: an obvious derivative from PSl. *lękg, *lękti 'bend and stretch', attested in most Slavic languages, e.g. OCS ş-lękg, -lęšti 'krümmen, niederbeugen', na-lękg, -lęšti 'spannen (den Bogen)', etc. - In Baltic only the verb has correspondences, e.g. Lith. lenkiù, leñkti 'beugen, neigen, biegen', etc. (cf. Trautmann 159), but in Germanic there are close correspondences of the noun lęčb: OIc. lengja f. 'Riemen', OE lóh (*lanha-) idem (Čemodanov 82). So this example would qualify rather for the Slavic-Germc. correspondences. 
32.) *lędo//*lęda 'clearing, fallow piece of land' (?), attested in most Slavic languages, e.g. Russ. ljadá 'Neubruch, Rodeland', BRuss. ljádo 'Neuland', Bulg. léda 'Aue, Bergwiese', Cz. lada//lado 'Brache', etc. Pruss. lindan 'Tal', Goth. land 'Land, Gegend', common in Germc. languages, cf. also Swed. dial. linda 'Brachfeld' (for details, see Stang 33).

33.) libivs 'meager, lean', attested, with some secondary meanings, in all Slavic languages, e.g. Church Slav. libivъ (liběvz) ' $\lambda \in \pi \tau o ́ s, ~ g r a c i l i s '$, Russ. dial. libívyj 'schwach', OCz. libivý//liběvý 'mager', etc. - Lith. liebas 'mager, dünn', láibas 'schlank, hager, dünn', OE léf, OSax. lêf (gen. lêbes) 'schwank, schwächlich, krank, matt' (PIE *lëibho-), Stang 32, but see also Berneker 716 and Trautmann 154.

34.) lomiti 'break', attested in most Slavic languages, e.g. OCS lomiti 'brechen', Russ. lomit', S-C lòmiti, OPol. tomić idem, etc. - Lith. limti, 3rd. sing. pres. limsta intrans. 'einknicken, brechen', laminti 'zerknüllen, zerknittern', but also 'zähmen, zureiten (Pferde)', lémti 'bestimmen, bescheiden, bescheren', correspondences in Latvian and Prussian, OHG lemmen 'lähmen, schlagen', OE lemian idem, 'zähmen (ein Pferd)' [cf. Lith. meanings], OIc. lemia 'schlagen; hindern', etc.; in addition, not "umlauted" Germc. *lam-: OHG lam= NHG lahm, OE lame = NE lame, etc.; the traces of $e$-vocalism in ULus. lemic 'brechen', $\check{e}$-vocalism in S-C lijèmati 'schlagen' (Stang 33, for details, Trautmann 162, Berneker 731 and Pokorny 674).

35.) *lotz 'linden bast', attested only in East Slavic and Polish, e.g. Russ. dial. lut 'Bast, Lindenrinde', Pol. tęt 'Gerte', etc. - Lith. lentà 'Brett, Tafel, Platte' (the connection is questionable), OHG linte 'Linde, Schild', OE, OIc. lind 'Linde', cf. also NHG dial. lind 'Bast' (Stang 34-35, see also Pokorny 677).

36.) l'udbje plur., l'uds collect., attested in all Slavic languages, e.g. OCS ljudbje 'Menschen, Leute' (actually 'simple folk', cf. ljudins 'Mann aus dem Volke, Laie'), ljudъ 'Volk', Russ. ljúdi 'Menschen, Leute, Gesinde', ljud 'Volk', Pol. ludzie 'Menschen, Leute; Dienstboten', lud 'Volk', etc. - Lith. liáudis '(gewöhnliches) Volk', Latv. l'àudis m. plur. 'Leute, Menschen', OHG liut m. 'Volk', liuti 'Leute', OE léode 'Menschen', OIc. lýrr (plur. in -ir!) 'Volk': in all three linguistic groups the same form of the plur. is found: *leudheies (Stang 32).

37.) a) *mъrgajo, *mbrgati 'twinkle, blink', attested only in East Slavic and Polish, e.g. Russ. morgát', -áju 'blinzeln, zuchen', Pol. mrugać (sic!) idem, but murga 'lout, boor', etc. - Lith. mirgéti 3rd. sing. pres. mirga, past. -ějo 'aufleuchten und wieder erlöschen, funkeln, glitzern, blinken', with a correspondence in Latvian, OIc. myrkr 'dunkel' (Eng. murky belongs here); notice that in Balto-Slavic ir//ur (PSl. br/or) represent PIE *r. 
b) *mbrknqti 'grow dusky, dark', attested in all Slavic languages, e.g. OCS mrıknoti 'dunkel werden', Russ. mérknut' idem, S-C mr̈knuti idem, Pol. zmierzchnqú się (with a secondary $c h$ ) 'grow dusky, dark', etc.; besides this basic verb there is also an old nominal derivative *morkz 'darkness': OCS mrakz, Russ. dial. mórok, Pol. mrok, etc. - Lith. mérkti, 3rd. sing. pres. mérkia, past $-\dot{e}$ 'die Augen schliessen', etc.; in Germanic Goth. maúrgins, OIc. morginn, myrginn, OHG morgen, etc. 'Morgen' most probably belong here. (Stang 36-37; Pokorny 734 s.v. *mer(a)gü- quotes not only Balto-Slav. and Germc., but also Greek and Albanian correspondences, e.g. Gr. $\dot{\alpha} \mu o \rho \beta o ́ s ~ ' d u n k e l '$, i.e. for PSl. *mbrg-, and 733 s.v. ${ }^{*} m e r(a) k$-, i.e. for PSl. ${ }^{*} m b r k$ - he reconstructs the following meanings: 'flimmern, vor den Augen flimmern; sich verdunkeln; Zwielicht').

38.) navb 'dead', attested in Church Slav. and ORuss. navb 'der Tote' (traces in Russ. dialects: nav'//náv'e//návej, cf. Vasmer III, 35), OCz. náv, gen. návi 'Hölle, Jenseits', Sloven. nâvje n. 'Seelen der ungetauften Kinder' - Lith. nõve 'Bedrückung, Qual, Tod', Latv. nâve 'Tod', Pruss. nowis 'Rumpf', Goth. naus, nom. plur. naweis 'Toter', OIc. nár 'toter Mensch, toter Körper' (Stang 39).

39.) ols 'kind of beer', attested in Russ. Church Slav. and ORuss. ols

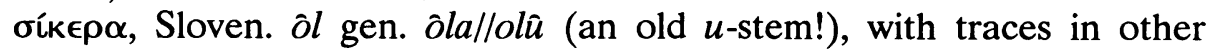
Slavic languages, e.g. Bulg. olovína 'malt' (?), etc. - Lith. alùs 'Bier', correspondences in Latvian and Prussian, OIc. ol (dat. $q l v i)$ 'Bier', OE ealu (oblique eoloð) 'Bier, Schmauss' (Stang 13).

40.) osa > osina, osika 'aspen', attested in the basic form in Pol. osa, Cz. dial. osa, ULus. wosa, LLus. wosa//wósa, elsewhere the derivatives in -ina, -ika - Lith. ãpušél/ẽpuše 'Espe', Latv. apse, Pruss. abse (primary Balto-Slav. *apsā-, cf. Trautmann 11), OHG aspa 'Espe', OIc. osp with an obvious metathesis of $p s>s p$ (of course Eng. aspen belongs here) Stang 13.

41.) pęstb 'fist', attested in most Slavic languages, e.g. Church Slav. pęstb 'Faust', Russ. pjast' 'flache Hand, Mittelhand', S-C pèst//pêst 'Faust', Pol. pięść idem, etc. - OHG füst, OE fyst (PGermc. *funsti-) 'fist'; a possible Balt. correspondence is Lith. kùmste, Latv. kumste idem through metathesis from *punkstē: the ultimate source of all these words is PIE *pn $k$ usti- a derivative of the numeral *penk ${ }^{\mathrm{u}} e$ 'five' (Stang 42).

42.) prędo, pręsti 'spin', attested in all Slavic languages, e.g. OCS prędo, pręsti 'spinnen', Russ. prjadú, prjast', Pol. przędę, przq̨ść idem, etc. - Lith. sprésti, 3rd. sing. pres. spréndžia, past -dè '(Finger) spreizen, spannen’ (and many secondary meanings), Latv. spriêst, 1st. sing. pres. -žu, past -du 'strecken, spannen, messen, etc.', OE sprindel 'Vogelschlinge, Spannhaken' (no traces of the basic verb in Germanic, but the noun has an exact correspondence in PSl. *prędlo 'jenny'(?), e.g. Cz. přádlo, Sloven. 
prelo, etc., even semantically, since its technical meaning according to Trubačev 1.c. 92-94 is prjalka 'spinning jenny'; Stang 54 and Trubačev l.c.).

43.) pręgo, "prękti 'stretch' > 'harness', attested in all Slavic languages, e.g. OCS vъ-pręgg, -pręšti 'anspannen, anschirren', Russ. prjagú, prjač' 'vorspannen, spannen', S-C sprêgnem, spréci 'spanne zusammen', Pol. s-, za-przęgnę, -przqc 'harness together, harness', etc. - Lith. spreñgti '...in einen engen Zwischenraum pressen, drängen, drücken, (ein)klemmen, ...spannen, (einen) Riemen anziehen', etc. with correspondences in Latvian, OHG springan 'hervorspringen, hervorspriessen', etc., OE springan 'laufen; hervorbrechen, etc.', OIc. springa 'springen, bersten, hervorspringen, etc.'; to the intransitive meaning of the Germc. verbs see S-C prézati se ("pręzati sę) 'vom Schlaf aufspringen'; to the meaning of the Balto-Slav. *sprengo 'spanne' (Trautmann 278), see also OHG springa 'Falle' (Stang 43 s.v. progz and 53 s.v. spreñgti).

44.) puga 'blizzard', attested only in Russ. dial. pugá 'Schneesturm' but with close correspondences in Latv. püga 'stossweiser Wind, Windstoss', Lith. pūgà 'Schneestrum, -gestöber', which however may be a Russ. loanword, and in OIc. fjúka 'treiben, stieben' (the basic verb!), snjá-fok 'Schneegestöber' (Stang 43).

45.) rъž̌b 'rye', attested in all Slavic languages, e.g. ORuss. rъžzb, Russ. rož', gen. rži, OPol. reż, gen. rży, S-C râž, gen. răži, etc. - Lith. rugiaĩ plur. m., Latv. rudzi plur. m., Pruss. rugis 'Roggen', (Baltic stem *rugia-, Slav. *rugi-), OIc. rugr ( $i$-stem), OE ryze, OSax. roggo = NHG Roggen (Stang 46).

46.) *sadja 'soot', attested in most Slavic languages, e.g. OCS sažda (according to Vasmer III, 544), Russ. sáža, Pol. sadza, etc. - Lith. súodys m. sing., súodžiai m. plur. 'Russ' (but there is a fem. plur. súodžios corresponding to Slav. fem. in -a, Trautmann 273), OIc. sót, OE sót = NE soot, etc. 'Russ' (Stang 56).

47.) *skrebo, *skre(b)ti//*skrobl'Q, *skrobati 'scrape', attested in most Slavic languages (in West Slavic the vocalism skrob- prevails), e.g. Church Slav. oskrebq, Russ. skrebú, skrestí 'schaben, kratzen', Pol. skrobię, skrobać idem, etc. - Latv. skrebêt 'kratzen', skrabt 'meisseln, schaben, striegeln, schrapen', Lith. skrebëti, 3rd. sing. pres. skrëba 'rauschen, rasseln' (obviously secondary meanings), OIc. skrapa 'kratzen, schaben', OE screpan 'kratzen' (NE scrape from Scandinavian), MHG schrapfen 'striegeln' (Stang 49).

48.) 'skubo, *sku(b)ti 'pluck', attested in all Slavic languages, e.g. Church Slav. skubo, skupsti, 'vellere', Russ. dial. skubú, skust'//skupstí 'zause, rupfe', Pol. older and dial. skubę, skusśc and skubię, skubać 'pluck', S-C skúbem, skúpsti 'rupfen', etc. - Lith. skùbti, 3rd. sing. pres. skum̃ba, past skùbo 'anfangen sich zu beeilen, etc.', skùbinti 'beschleunigen', Latv. 
skubinât, 'antreiben', Goth. af-skiuban 'verstossen', OHG scioban = NHG schieben, OIc. skúfa 'schieben, stossen, (of course Eng. shove belongs here); for the semantic shift 'shove' > 'scrub, rub', which seems to characterize Slavic, see Norw. skubba 'reiben, scheuern' from the same root, Pokorny 955 (Stang 50).

49.) slabs 'weak', attested in all Slavic languages, e.g. OCS slabs 'schwach', Russ. slábyj, Pol. słaby idem, etc. - Lith. slàbti, 3rd. sing. pres. slam̃ba 'schwach werden', släbnas//slöbnas 'schwach, kraftlos', OHG slaf = NHG schlaff, OIc. slappi 'schwacher Mensch'; basic verbs in Goth. slëpan = NHG schlafen and in OE slápan = NE sleep, etc.; but see also North West IE vocabulary (Stang 50).

50.) smagajo, smagati 'whip', attested only in East Slavic and Polish, e.g. Russ. smagáju, smagát' 'schlagen, peitschen', Pol. smagam, smagać 'peitschen, geisseln', etc. - Lith. smõgti, 3rd. sing. pres. smãgia 'peitschen, schlagen, (etwas schweres) werfen, etc.', OE smacian 'streicheln, klopfen', Swed. smacka 'mit dem Munde schnalzen', dial. 'schlagen, werfen' (Stang 51).

51.) smola 'pitch', attested in all Slavic languages, e.g. Serb. Church Slav. smola ö $\sigma \phi \alpha \lambda \tau o s$, Russ. smola 'Harz, Pech, Teer', Pol. smoła idem, etc. - Latv. smęli 'Kien, Harz', Lith. smélti, 3rd. sing. pres. -lsta, past -lo 'sich beschmieren, trübe, matt werden', LG smelen 'langsam und rauchend brennen', etc. (Eng. smell obviously belongs here); there is also the Slav. verb smaliti (an old causative?), e.g. Russ. smálit' 'ansengen, Übelriechendes verbrennen', Pol. smalić 'versengen' (Stang 51, but see also Pokorny 969 where MIr. smäl, smöl, smüal f. 'Feuer, Glut, Asche' is quoted).

52.) smykajo, smykati (sę) 'whisk' trans., 'crawl, creep' intrans, attested in most Slavic languages, e.g. OCS smykati sę (-ajq) 'sich dahinschleppen', Russ. smykát'sja 'kriechen', Pol. smykać się 'sich schleppen' (but smykać 'pluck, whisk'); there is also Slav. smukati, e.g. Pol. smukać 'streifen', Sloven. smúkati intrans. 'whisk' (i.e. move rapidly here and there) - Lith. smùkti, 3rd. sing. pres. smuñka '(ab)-gleiten, -rutschen, langsam sinken, wohin schlüpfen' and smaũkti, 3rd. sing. pres. -kia, past -ke '(Blätter, Beeren u. dgl.) mit streifender Handbewegung abreissen, -rupfen, -zupfen, etc.', with correspondences in Latvian, OIc. smjúga 'sich schmiegen, durch eine enge Öffnung eindringen', OE smügan 'schlüpfen, kriechen', MHG schmiegen: North IE *smeuk-, another variant is Balto-Slav. *meuk- (PSl. *mъknqti), see Trautmann 189 s.v. munko 'entgleite' (Stang 51).

53.) starb 'old', attested in all Slavic languages, e.g. OCS starb, Russ. stáryj, Pol. stary, etc. - Lith. stóras 'dick', OIc. stórr 'gross', OLG stôri 'gross, berühmt', etc. (Stang 55). 
54.) stobor 'column-like pole', attested only in South Slavic and Old Russian (?), e.g. Serb. Church Slav. stoborъ 'Säule', S-C stöbor idem, etc. - Lith. stãbaras 'trockener Baumast, etc.', dial. stẽbaras, Dan. staver 'abgeschnittener, behauener Ast', Norw. dial. stavar 'Baumstumpf', etc. PGermc. *stabura-//stabara- (Stang 54).

55.) stožerz 'stack-pole' and stogz 'stack', attested in most Slavic languages, e.g. ORuss. stožerъ/-arъ 'Schutzpfahl eines Heuschobers', S-C stöžer 'Tennenpfahl', Cz. stožar 'mast', etc. and Church Slav. stogz 'Heuhaufen, Schober', S-C stôg, Pol. stóg, etc. - Lith. stãgaras 'dürrer, verdorrter (Kraut-, Pflanzen)stengel, -strunk; dürrer (Baum)ast', OE staca = NE stake, OHG stecho 'Pfahl, Stecken', OSwed. staki 'Pfahl, Leuchter', etc. and OIc. stakkr 'Heuschober' (of course Eng. stack belongs here, too): Balto-Slav. shows a common suffix *-e/oro- while Germc. has *-elon- (Stang 54).

56.) strěla 'arrow', attested in all Slavic languages, e.g. OCS strěla 'Pfeil, Geschoss', Russ. strelá idem, S-C strijèla 'Pfeil, Blitzstrahl', Pol. strzała 'Pfeil', etc. - Lith. strèlà//strèlẽ 'Pfeil', Latv. strễla 'Geschoss, Pfeil, Streifen, Wasserstrahl', OHG strâla 'Pfeil' (in NHG Strahl is 'ray'), OE strál' 'Pfeil'16 only West Germc. (Stang 55).

57.) *stzlbz (stzlba) 'pole, post', attested in this basic form only in East and South Slavic, e.g. ORuss. stzlbz, Russ. stolb, gen. stolbá 'Säule,

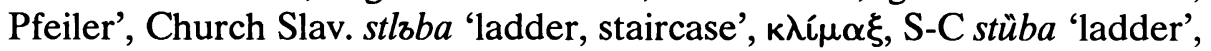
Bulg. stzlb//stlıb 'Pfeiler', etc. - Lith. dial. stuĺbas 'Pfosten, Pfahl ... Säule, Pfeiler', Latv. stulbs 'Pfosten; Schienbein, Wade', OIc. stolpi 'Pfosten, Säule, Pfeiler', MLG stolpe; besides *stzlbz there is a variant *stzlpz in Slavic (Stang 56).

58.) sbrebro 'silver', attested in all Slavic languages, e.g. OCS sbrebro, ORuss. sbrebro, Russ. serebró, S-C srèbro, Pol. srebro, etc. - Lith. sidãbras, with correspondences in Latvian and Prussian (in the latter siraplis, sirablan), Goth. silubr, OHG silabar, OE seolfor, etc.; the word is most probably of non-IE origin, and underwent various assimilations and dissimilations in the above languages (Stang 47).

59.) *ร̌čbrba//*̌̌čbrbz; *skßrbb 'notch'; 'worry' (?), attested in most Slavic languages, e.g. Russ. ščerbá 'Riss, Lücke, Schramme, etc.', Sloven. šćrba 'Scharte', Pol. szczerba 'notch', szczerb m. idem, etc; OCS skrъbb 'Trübsal, Kummer, Sorge', Russ. skorb', S-C skrb idem, but Pol. skarb m. 'treasure', etc.; also in Slavic there is the basic verb for the latter noun: *skъrběti, -bl'Q, -iši 'be sad, afflicted', etymologically 'to be cut, bitten', e.g. OCS skrъběti 'betrübt sein', Russ. skorbét', skorbljú, S-C skŕbiti, etc., which seems to represent an old intrans. stative of a basic trans. active verb attested in Baltic and Germanic (see below!) - Latv. škir̈ba 'Ritze, Spalte', Lith. skurbe 'Gram, sorrow', Lith. skerbti, 3rd. sing. pres. -bia, past 
-bé 'tief einschneiden, etc.', skurbti 'in Elend sein', Latv. skàrbt 'ohnmächtig, beduselt werden', OHG scirbi = NHG Scherbe, scarbon 'in Stücke schneiden, zerschneiden', OE sceorfan 'schneiden, beissen' (Stang 49, see also Trautmann 266, and Vasmer III 650-651).

60.) 'tęgъkz//*tęžbkъ 'heavy', attested in most Slavic languages, e.g. OCS tęžbkz 'schwer, gefährlich' (the older, primary form is still represented by o-tęgъč-iti 'beschweren'), Russ. tjážkij, S-C téžak, Pol. ciężki, etc. - Lith. tingùs 'träge, faul, langsam in der Arbeit', OIc. pungr 'schwer' (Stang 58).

61.) *tysętji//*tysotji 'thousand', attested in most Slavic languages, e.g. OCS tysęštil/tysqušti f., Russ. týsjača, S-C tǐsuća, Pol. tysiquc m., etc. - Lith. túkstantis, Latv. tūkstuõts, Pruss. tūsimtons f. acc. plur. (the closest correspondence of Slavic), Goth. püsundi, OHG thûsund, OE püsend, etc. (Stang 59; for the reconstruction of the primary form, see E. Hamp, Papers from the IX Regional Meeting of the Chicago Linguistic Society, 1973, 172-178).

62.) veblica 'worm', attested only in North Russian: véblica - Lith. vãbalas 'Käfer', Latv. vabale//vabals idem, OHG wibil 'Kornwurm, Käfer', OE wibba 'Rosskäfer' (Stang 60).

63.) višb 'swamp-grass', attested only in ORuss. višb 'Sumpfgras', Sloven. vîs m., f. 'Schilf, Riedgras', OPol. wisz idem - Lith. viksvà 'langes, hartes im Sumpf wachsendes Gras, Riedgras', Pruss. wissene 'Porsch, ledum palustre', OHG wisa = NHG Wiese, OIc. veisa 'Sumpf, Pfütze', etc.; Vasmer I, 325-326 quotes also Norw. dial. vîs(e) 'besom' (metelka, verxuška rastenija) (Stang 63).

64.) *voldQ, *volsti 'rule', attested, often in secondary forms, in most Slavic languages, e.g. OCS vlado,, vlasti // vladějo, -ěti 'herrschen', ORuss. voloděti, S-C vládati, Cz. vladu, vlásti, OPol. włodać, NPol. władać (-łafrom Czech influence), etc. - Lith. velděti, 3rd. sing. pres. vélda//-i 'besitzen, regieren, etc.', valdýti '(be)-herrschen, regieren, lenken', with correspondences in Latvian and Prussian, Goth. waldan 'walten', OIc. valda 'walten, herrschen', OE wealdan = NE wield, etc. (Stang 61-2).

65.) voskz 'wax', attested in all Slavic languages, e.g. OCS voskz, Russ. vosk, gen. vóska, S-C vôsak, Pol. wosk, etc. - Lith. vã̌skas 'Wachs', Latv. vasks//vaska idem, OHG wahs, OIc. vax, OE weax (Stang 61).

66.) *vblgz $(\mathrm{kb})$ 'moist, wet' besides *vblgnoti 'become moist' and *volga 'moisture'; the adjective is attested in most Slavic languages, e.g. Russ. Church Slav. volgzkz 'feucht', Russ. vólgkij, OPol. wilgi, Cz. vlhký, etc.; the verb is found in Pol. wilgnqcé, Cz. vlhnouti, Russ. dial. vólgnút', and Sloven. od-volgnoti (sic!, see Machek 570), the noun in OCS vlaga, Russ. vológa, $\mathrm{S}-\mathrm{C}$ vlâga, Sloven. vlága, Cz. vláha - Lith. vilgyti 'an-, befeuchten, nass machen', vilgti, 3rd. sing. pres. -sta 'feucht, nass werden', with correspon- 
dences in Latvian, among others the adj. vilgans and valgs 'feucht', OHG wëlk 'feucht, welk' (Eng. arch. verb welk 'fade, wither' belongs here too), Stang 63.

67.) "vblná 'wave', attested only in OCS vlına 'Welle, Woge', Russ. volná, Bulg. vəlná, Cz. vlna, OPol. wetna - Lith. vilnis 'Welle, Woge', Latv. vilnis, OHG wëlla = NHG Welle (Germc. $\sim$ Balto-Slav. *uln-; $\quad$ see also the basic verb with the vocalism *ul- in OCS volati (se) trans. 'in Wallung bringen', intrans. 'von den Wellen hin und her geworfen werden' and Goth. wulan 'wallen'), Stang. 63-64.

68.) *zolto 'gold', attested in all Slavic languages, e.g. OCS zlato, Russ. zóloto, Pol. złoto, etc. - Latv. zèlts 'Gold', Lith. žéltas 'golden, blond', Goth. gulp 'Gold', OIc. gull, OHG, OE gold, etc. (a common Germc. Balto-Slav. feature is the same suffix to, i.e. PIE * ${ }^{*}$ 'he/ol-to- and *g'hl-to-), Stang 64.

69.) žaba ("gēbā) 'frog', attested in all Slavic languages, e.g. Russ. žába, S-C žăba, Pol. żaba, etc. - Pruss. gabawo 'Kröte', OSax. quappa 'Quappe' (i.e. 'eel-pout'), MLG quabbe 'feuchte Masse' (for details, see Stang 20-21).

70.) žalb 'grief' and its verbal derivatives žaliti, žalovati; the noun is attested in all Slavic languages, e.g. OCS žalb 'Grabmahl', Church Slav. žalb 'Schmerz, Mitleid', Russ. žal' (in impersonal predicatives) 'it is a pity', etc., S-C žăo used predicatively as in Russ. žal', Pol. żal m., gen. - u 'regret, grievance, etc.', also used predicatively, etc. - Lith. gèlà 'heftiger Schmerz' and the basic verb gélti, 3rd. sing. pres. gẽlia, past gělè 'stechen, wehtun (physisch und psychisch)', with correspondences in Latvian and Prussian, OHG quëllan 'Schmerzen erleiden, sich abmartern', quäla 'Pein', etc.; against Stang's opinion the connection with Slav. želěti 'wish, desire' (cf. OCS) should be rejected (for details, see Stang 21 and Vasmer II, 40).

71.) 'žegzz-ica//-ul'a, etc. 'cuckoo', attested in ORuss. žegzzica, Russ. dial. zegzica, žegozúlja, Cz. žežhule, Pol. gżegżótka - Lith. gegužẽ 'Kuckuck', with correspondences in Latvian and Prussian, OIc. gaukr 'Kuckuck', OHG gouh: Balto-Slav. *geguž-, i.e. PIE *gheghug'-, (reduplicated root), Germc. *gauk- (i.e. PIE *ghoug'-, simple root), Stang 21.

72.) židq, žbdati 'wait', attested in most Slavic languages, e.g. OCS $\check{z} i d q / / \check{z} b d q$, žbdati 'warten, erwarten', Russ. ždu, ždat', OPol. $\dot{z} d a c ́$, etc. Lith. geĩsti, 3rd. sing. pres. geĩdžia, past -dé 'wünschen, begehren, verlangen', Latv. gàidît 'warten, harren, erwarten', Pruss. gēide 'sie warten', OHG, MHG git 'Habgier, Geiz' (Stang 21).

73.) zělz 'vehement', zělo 'very', attested only in OCS zělo 'sehr, gewiss', Church Slav. zělı 'heftig', ORuss. arch. zeló 'very', BRuss. do zela 
idem, Sloven. zelô, OCz. zielo - Lith. gailùs 'beissend, wütend, scharf, etc.' gailas 'heftig', Latv. gails 'wohllüstig; schlank, etc.' - OHG geil 'mutwillig, ausgelassen'; see also Goth. gailjan 'erfreuen' (Stang 21, Vasmer II, 92).

\section{Germc. Slavic}

1.) běditi 'force, compel', attested in most Slavic languages, in West Slavic usually indirectly through the noun běda 'need', e.g. OCS béditi 'zwingen', Russ. bedit' 'Leid antun' but po-bedit' 'besiegen', u-bedit' 'überzeugen', S-C bijèditi 'slander', po-bijèditi 'win', OPol. biedzić się 'wrestle, struggle' (but in toponyms Pobiedziska 'the place of victory'), etc. - Goth. baidjan 'zwingen', OIc. beiða 'um etw. bitten', OHG beitten 'drängen, fördern' (Stang 14-15).

2.) blědz 'pale', attested in all Slavic languages, e.g. OCS blědz, Russ. blédyj, S-C blïjed, Pol. blady, etc. - OE blât 'blass, bleich', etc. (Stang 15).

3.) blbknqti 'fade', attested only in Russ. blëknut' 'bleichen, verschiessen, welken', Ukr. bléknuty and Pol. blaknqć ( $a$ in the root under the influence of blady) - OIc. blígja 'watch intensively', etc. (Čemodanov, l.c. 79).

4.) bolb 'pain', attested in most Slavic languages, e.g. OCS bolb m. (sic!) 'Kranker', Church Slav. bolb f. 'Krankheit', Russ. bol' f. 'Schmerz', but dial. m. 'Kranker', S-C bôl m. 'Schmerz', Pol. ból m. idem, etc. - OHG balo 'Verderben, Übel', OIc. bol, dat. bolvi 'Schaden, Unglück', OE bealu idem (NE bale belongs here), etc. There is also a correspondence between the Slav. verb bolěti, 3rd. sing. pres. boliţ (e.g. OCS) 'krank sein, Schmerz empfinden' and Goth. balwjan 'martern', etc.; the Germc. noun represents PIE *bholu-, the Slav. - PIE *bholi- (Stang 15).

5.) bor ( $u$-stem) 'pine, pinewood', attested in most Slavic languages, e.g. Russ. Church Slav. borz, plur. borove 'Nadelwald, Fichtenwald', Russ. bor 'Fichtenwald, S-C bôr 'Föhre, Kiefer', Pol. bór, loc. w boru 'Wald', etc. - OIc. bqrr, dat. bqrvi 'Baum' (poetic), OE bearu 'Wald', OHG baro 'Hain, Wald'; the Germc. noun represents also a $u$-stem (Stang 15, but see also Martynov's views about the possible borrowing of the Germc. word from Slavic in Chapter VI, in the paragraph on the Slavic-Germanic lexical exchange).

6.) 'borvz 'castrated hog', attested in most Slavic languages, e.g. Russ. bórov 'Borg, verschnittener Eber', S-C brâv 'Schafvieh', dial. 'verschnittenes Schwein', Pol. dial. browek 'gemästeter Eber' - OHG barug, barh 'verschnittenes Schwein', OE bearh, bearg, OIc. borgr: the PSI. form stems from *bhoru-, and the PGermc. from *bhoru-ko- (Stang 15).

6a.) brězgnqti, etc. look under obrězgnoti, etc. 
7.) *buxnoti 'swell', attested in most Slavic languages, e.g. Russ. búxnut' 'anschwellen, schwellen', S-C nà-buhnuti 'anlaufen, anschwellen', Kash. bucha 'Stolz', etc. - MLG bûs 'Aufgeblasenheit, schwellende Fülle', būsen 'schwelgen', Norw. dial. baus 'stolz, ungestüm, hitzig' (Stang 16, see also Berneker 97-98).

8.) bystro 'quick', attested in all Slavic languages, e.g. OCS bystr 'schnell, verschlagen', Russ. býstryj 'schnell, scharfsichtig', S-C bïstar 'klar' (cf. bistrica as a frequent hydronym), Pol. bystry 'reissend, schnell', etc. OIc. bysja 'mit grosser Gewalt ausströmen', Norw. dial. busa 'hervorstürzen': PIE archetype for Slavic *bhüs-ro- (Stang 16, see also Berneker 113).

9.) *bbrdo 'sharp-ended tool for pressing the weft', the meaning 'hill', common in South Slavic, seems to be secondary, attested in all Slavic languages, e.g. Russ. bërdo 'weaver's reed', S-C brdo, Pol. bardo, etc. PGermc. *burpa-//*burda- as proven by NHG Borte 'ham', Eng. board, etc.: PIE *bher- 'sharp' (Trubačev 1966: 130-131).

10.) *cup $(r) z / / *^{*}$ cubs 'tuft', the former attested only in East Slavic and Serbo-Croatian, e.g. Russ. dial. čup, čupr 'Schopf', S-C čüpa idem (referring to hair) - OIc. skúfr 'Quaste, Bündel', skauf 'Quaste', OHG scoub 'Garbe, Strohbund', OE scéaf idem, etc. (Stang 17, see also Vasmer IV, 384).

11.) daviti 'strangle', attested in all Slavic languages, e.g. OCS daviti 'würgen, erwürgen', Russ. davit' 'drücken, pressen, würgen', S-C dáviti 'würgen', Pol. dial. dawić, Standard Pol. dławić idem, etc. - Goth. af-dauips 'geplagt, gehetzt' from *af-dojan (PGermc. *-dōwjana) the causative to PGermc. *daujana 'sterben': for the latter see OIc. deyja 'sterben', OSax. dojan, and of course NE die, etc. (Stang 18).

12.) drobiti 'crush, crumble', attested in all Slavic languages, e.g. OCS drobiti 'zerreiben, zerbrechen', Russ. drobit' 'zerstückeln', S-C dròbiti idem, Pol. drobić 'klein machen, zerbröckeln, zerstückeln', etc. - Goth. gadraban 'aushauen', OIc. draf 'Abfall, Brocken, Staub' (cf. Russ. drob' 'Bruch, Bruchteil, Schrot'), drafna 'sich (in kleine Teile) auflesen'; but there is also Lith. drebẽnas 'Trümmer' with an $e$-vocalism corresponding to Russ. drebezg 'Scherbe, Trümmer' (Stang 20; see also Berneker 226).

13.) *dъžžb (if from *duzg-ĭo-) 'rain', attested in all Slavic languages, e.g. OCS $d z z \check{z} d b$, Russ. dožd', S-C däžd, Pol. deszcz (phonetic spelling!), etc. - Norw. dusk-regen 'Staubregen', Swed. regn-dusk idem, Norw. dusk 'feiner Regen', dysja 'fein regnen, herabrieseln', etc. (Stang 20).

14.) *ěstěja (*ěstbje, *ěstb) 'orifice in the oven', attested only in Sloven. istéje plur. f. 'orifice in the oven', OCz. niestějě plur. f. 'hearth, door in the oven', NCz. nistěj, ULus. něsć 'hearth, opening in the oven, oven', LLus. jesće, jesćeje idem - PGermc. *essjo, attested by NHG Esse 'furnace in a 
smithy, hearth': in IE terms the PSl. archetype is * $\bar{e} d-t-\bar{e} j \bar{a}$, etc., the PGermc. archetype is *ed-t-ja (this is a new etymology by Trubačev, 1966: 315-320).

15.) glumb 'joke' (?), attested directly or through the intermediary of the verb glumiti in most Slavic languages, e.g. OCS bezъ gluma 'beständig', Russ. glum 'Scherz, Spott', S-C glúmiti se 'scherzen, glúma 'Scherz, Spiel', Pol. dial. ghum 'Misshandlung, Missachtung', etc. - OIc. glaumr 'Lärm, Getöse, Jubel', OE gleam 'Munterkeit, Jubel'; there is also an Ic. verb gleyma 'ausgelassen sein, vergessen' = PSl. glumiti (Stang 22-23).

16.) gneto, gnesti 'press', attested in most Slavic languages, e.g. OCS gneto, gnesti 'drücken, pressen', Russ. gnetú, gnestí idem, S-C gnjètem, gnjèsti 'kneten, drängen, klemmen', Pol. gniotę, gnieść 'drücken, kneten', etc. - OHG knetan 'drücken, kneten', OIc. knoða 'kneten' (of course Eng. knead from OE cnedan belongs here), Stang 23.

17.) gols 'naked', also 'bald', attested in all Slavic languages, e.g. OCS gols 'nackt, bloss', Russ. gólyj, S-C gô, f. góla, etc., Pol. gohy, etc. - OHG kalo 'kahl', OE calu = NE callow; but there is also Latv. gàls 'eisglatt', gàle 'dünne Eisdecke' (Stang 24).

18.) grobъ 'grave', attested in most Slavic languages, an old derivative from the verb grebo, gre(b)ti 'dig' (see above), e.g. OCS grobs 'Grab', Russ. grob, gen. gróba, S-C grôb, gen. gròba, Pol. grób, gen. grobu, etc. Goth. graba (n-stem) 'Graben', OIc. grof 'Höhle, Grab', OHG grab = NHG Grab, OE græf = NE grave. (Berneker 353).

19.) grots 'arrow-, spear-head', attested only in older Russ. grot 'Wurfspiess', Pol. grot idem, and also 'Pfeilspitze', Cz. hrot 'Spitze' MHG grât 'Gräte, scharfe Spitze', NHG Grat, Gräte 'edge, fishbone' (Stang 24, see also Kluge 268).

20.) isto, plur. istesa 'kidney', attested only in OCS isto, plur. istesa 'Niere', Russ. Church Slav. jestesě nom. dual 'Hoden', and Sloven. ob-îst f. 'Niere' - OIc. eista 'Hode' (Stang 25).

21.) kamy, gen. kamene 'stone', attested in all Slavic languages, e.g. OCS kamy, -ene, Russ. kámen', S-C kâmen (but also kâmi), Pol. kamień, etc. - OIc. hamarr 'vorstehender, steiler Felsen rundlicher Form; Hammer', OHG hamar = NHG Hammer, OE hamor = NE hammer, etc. (Stang 25; see also under kentum elements above).

22.) *klenъ 'maple', attested in all Slavic languages, e.g. Russ. klën, gen. klëna 'Ahorn', S-C klèn//kljên//kûn, Pol. klon, etc. - OIc. hlynr 'Ahorn', OE hlyn, NHG dial. lehne, lenne; in Slavic and Germanic the same stem variation *klen- * *lln- is found (Stang 28-29).

23.) *kobbcb 'kind of falcon', attested chiefly in East Slavic, e.g. Russ. kóbec, gen. kóbca 'Bienen-, Wespenfalke', and South Slavic, e.g. S-C kòbac, gen. kòpca 'Sperber', and Pol. kobiec 'Art Falke, Bienenfalke' - 
OHG habuh 'Habicht', OIc. haukr (of course Eng. hawk belongs here), for details see Stang 30. It should be noted that in Polish there are also the forms kobuz and kobz (*kobuzz//*kobbzz) that seem to be more closely related to the Germc. archetype *habuka- (see Berneker 535).

24.) *kogztb 'fang', attested only in East Slavic, e.g. Russ. kógot', gen. kógtja 'Klaue; Fang des Raubvogels; gekrümmte Eisenspitze', and in ULus. kocht 'Dorn, Stachel' - OHG hakô 'Haken', OE haca//hóc = NE hook, etc. (Stang 30).

25.) kozbls 'he-goat', attested in all Slavic languages, e.g. OCS kozblz,

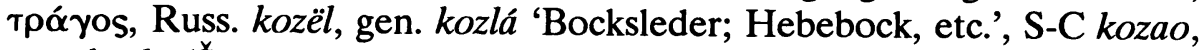
gen. kozla (Štokavian and very rare), kòzlac, gen. kozaòca, etc. 'Arum' (a plant), Pol. koziot, gen. kozła 'Ziegenbock', etc. - Goth. hakuls, OIc. hqkull, OHG hachul 'Mantel' (Čemodanov 1.c. 80, see also Vasmer II 277: what particularly connects Slav. and Germc. words is the -lo- suffix).

26.) kroms 'loom' (?), kromiti 'fence in with boards' (?), attested only in Russ. krómy plur. 'Webstuhl', zakromit' 'mit Brettern umstellen', Ukr. pry-kromýty 'bändigen', Pol. po-s-kromić 'hemmen, bändigen, mässigen' OHG (h)rama 'Rahmen, Gestell', OE hremmian 'einengen, behindern' (here also Goth. hramjan 'kreuzigen' belongs), Stang 31 and Berneker 622).

27.) krogz 'circle', attested in all Slavic languages, e.g. OCS krogz 'Kreis', Russ. krug 'Kreis, Zirkel, runde Scheibe', S-C krûg, Pol. krag, gen. kręgu, etc. - OIc. hringr 'Ring', OE, OHG hring, etc.: Slavic represents the primary $o$-vocalism, Germanic $e$-vocalism (Stang 30-31).

28.) lěsz 'forest, wood', attested in all Slavic languages, e.g. OCS lěsъ 'Wald', Russ. les, gen. lésa 'Wald; Holz als Material', S-C lijes 'Wald, Holz', Pol. las 'Wald', etc. - OE lás, gen. láswe 'Weide' (for details see Stang 32).

29.) lošb 'bad', attested only in South Slavic, e.g. S-C lôš 'unglücklich', Bulg. loš 'schlecht, übel, schlimm, hässlich', etc. and in Russ. dial. lóšij 'schlecht' - Goth. lasiws 'schwach', OE lysu (*lusiwa-) 'schwach, falsch, übel, böse', etc. (disputable according to Stang 34).

30.) luds 'foolish', attested in most Slavic languages, often indirectly through the verb luditi, e.g. Church Slav. ludz 'töricht', Russ. lud 'Narr', S-C lûd 'närrisch, töricht', Pol. tudzić 'täuschen, trügen, etc.', etc. - Goth. liuts 'heuschlerisch', usluton 'irre führen', OE lot 'Betrug', OHG lioz 'lügnerisch', etc. (Stang 34).

31.) lyko 'bast', attested in all Slavic languages, e.g. Russ. lýko 'Linden-, Weidenbast', S-C liko, Pol. tyko, etc. - PGermc. *lauha- (rather *lauho-?): NHG Lohe 'tan'; this is a new etymology rejecting the connection of Slav. lyko with Lith. lùnkas, and relating it to lučb, luna,

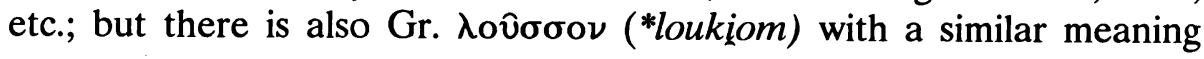


(“belaja čast' drevesiny”), Trubačev 1966: 164-66.

32.) løžq, logati 'lie', attested in all Slavic languages, e.g. OCS lъžq, logati 'lügen', Russ. lgu (old lžu), lgat', S-C läžem, làgati, Pol. tżę, tgać, etc. - Goth. liugan 'lügen', OIc. ljúga, OHG liogan = NHG lügen (Eng. lie, of course, belongs here), etc.; Slavic shows the IE vocalism *lugh-, Germanic *leugh- (Stang 35).

33.) majo, majati 'tire', attested only in Russ. máju, májat' 'ermüden, erschöpfen, plagen' and Bulg. mája 'verzögere, störe' - OHG muoen 'mühen', Goth. af-mauips 'ermüdet', etc. Slavic and Germanic show the stem in -ie, i.e. PIE *moje- (Stang 35).

34.) mèlb 'sandbank', attested only in East Slavic, e.g. Russ. mel', gen. méli 'Sandbank', and West Slavic, e.g. Pol. miel f. - OIc. melr 'Sandbank', Swed. dial. mjäg ('mjalg) 'Sandhügel, hohes Flussufer': between Slavic and Germanic there is only a root-connection (Stang 36).

35.) měniti 'mean', attested in OCS měniti 'meinen, glauben, erwähnen, halten für, gedenken', Ukr. po-minyty 'denken auf, vorhaben', Pol. mienic 'nennen, erwähnen', OCz. mieniti 'meinen', Sloven. męniti 'meinen, glauben, dafürhalten' - OHG meinen 'etwas im Sinne haben...meinen; sprechen, behaupten', OE mǽnan 'verkündigen, klagen' (= NE mean), etc. (Stang 36).

36.) *mędlo > *mędlica 'brake for flax, etc.', attested chiefly in North Slavic, e.g. Russ. (dial.) mjalo, mjalica 'brake' (especially for flax and hemp), Pol. międlica and Mac. melica, etc. - OIc. mondull 'handle of a handmill', MHG mandel 'roll, wad': PGermc. *man-pla-//man-dla(Trubačev, 1966: 69-72).

37.) mogg, *mokti 'can', attested in all Slavic languages, e.g. OCS mogo, mošti, Russ. mogú, moč', S-C mògu, mòci, Pol. moge, móc, etc. Goth. mag 'kann', OHG mag, OE mæz = NE may, OIc. má (infinitive mega); there is a complete formal and semantic agreement between the Slav. and Germc. verbs, whereas the Balt. correspondences differ either formally (e.g. Latv. mêgt 'vermögen, taugen, gewohnt sein') or semantically (e.g. Lith. magêti 'gefallen, angenehm sein, etc.'), Stang 37.

38.) "moktb 'power', attested in all Slavic languages, e.g. OCS moštb 'Macht, Stärke', Russ. moc̀', S-C môć, Pol. moc, etc. - Goth. mahts 'Macht, Kraft', OHG maht, OIc. mátt (of course Eng. might belongs here); Stang 37-38.

39.) molb 'moth', attested in all Slavic languages, e.g. Church Slav. molb f. 'Motte', Russ. mol' f., S-C mòljac ( ${ }^{*}$ mol-j-bcb), Pol. mól, gen. mola, etc. - Goth. malo 'Motte', OIc. molr (Stang 37).

40.) *mblniji 'thunderbolt' (?), 'flash of lightning', attested in South Slavic, e.g. OCS mlınii (i.e. *mlıniji) 'Blitz', S-C múnja, in East Slavic, e.g. Russ. mólnija, and in Polab. måuña - OIc. Mjollnir 'Thors Hammer, 
Blitz', myln 'Feuer' (?): Slavic represents the stem *mln-, Germanic *meln- (Stang 37).

41.) mъnogъ 'numerous', attested in all Slavic languages, e.g. OCS m̋nogъ 'viel', Russ. mnógij, S-C mnògo, Pol. mnogi, etc. - Goth. manags 'mancher, viel', OHG manag, OE manig = NE many (for details see Stang 39, see also North-West IE vocabulary above).

42.) *nakovъ//nakova etc. 'anvil', attested in ULus. nakow, Cz. (Moravian) nákova, LLus. nakowa, S-C nâkovanj m., Sloven. nakovenj (the latter two from *nakov-bn'b); in other Slav. languages, the continuants of PSl. *(na)kovadlo occur, e.g. OCS nakovalo, etc. PGermc. *anahaua-: OE anhēaw, MHG anehou, anhau; see also Lat. incūs, gen. incüdis which may have provided a model for Slav. and Germc. words (Trubačev 1966: 348-349 and 352, 355-356).

43.) *obrězgnoti//*obrbzgnqti, brězgz 'turn sour', 'sour taste', attested in Russ. Church Slav. obrězgnuti//obrbzgnuti 'sauer werden', Russ. dial. obréznut' 'sauer werden von der Milch', Ukr. zbrésknuty idem, Pol. obrzazgnqác/lobrzyzgnqá idem; besides that, Cz. bresk 'herber Geschmack', Pol. brzazg idem - Norw. dial. brisken 'bitter, herb', briskna, bresna 'sauer werden' (Stang 40).

44.) odrb 'wooden platform (serving as a bed, etc.)', attested in most Slavic languages, e.g. OCS odro 'Lager, Bahre' (but odrbcb 'kleines Gestell, Rost'), Russ. odr (dial. odër) = lože, S-C òdar, gen. òdra idem, Cz.

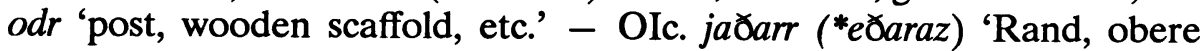
Zaunstange', OE eodor 'Hecke, Zaun'; 'Wohnung, Fürst', OHG etar = NHG dial. Etter 'Zaun, Rand', etc. (Cemodanov, 1.c. 81, see also Pokorny 290 s.v. edh- 'Zaunstecken, Zaun aus Pfählen').

45.) *olbqdb//elbedb ? 'swan', attested in most Slavic languages, the former e.g. in Pol. łabędź, S-C läbud, Sloven. labód, the latter e.g. in Russ. lébed', Sloven. dial. lebę́d, Bulg. lébed, etc. - OHG albiz, elbiz 'Schwan', OIc. álpt (plur. elptr, álptir): the Germc.-Slav. word is derived by means of the suffix - $d$ - from PIE *albho-, see Lat. albus, 'white' (Stang 31).

46.) *olsb 'moose', attested only in North Slavic, e.g. Russ. los', gen. lósja, Pol. toś, etc. - OIc. elgr (plur. -ir) 'Elch', OE eolh, OHG ëlaho, NHG Elch (which has been borrowed by NE as elk!): both the Germc. and Slav. words represent PIE *olki-//*olk'i- (Stang 33-34).

47.) * $q g r ъ / b$ 'pimple, (skin) maggot', attested in most Slavic languages, e.g. Russ. úgor', gen. ugrjá, 'Finne, Mitesser', Bulg. vəgoréc 'Made, Larve', $\mathrm{S}-\mathrm{C}$ ùgrk idem, Pol. wagr 'Finne, Mitesser', etc. - OHG angar 'Kornmade', NHG Engerling 'Maikäferlarve' (Stang 40).

48.) *pasmen-, i.e. *pasme > pasmo 'part of skein of thread', attested in all Slavic languages, e.g. Russ. pásmo, pásmeco, pásmenka, S-C pãsmo, Pol. pasmo, etc. - PGermc. ${ }^{*}$ fapma- : OHG fadum = NHG Faden, OE 
fær $m$ 'the width of one's extended arms' = NE fathom; Pokorny 824 quotes also OIc. fa $\mathrm{rmr}$ 'Umarmung, Klafter, Faden'; the PIE archetype for Slavic is *pot-smen-, for Germanic "pot-mo- (Trubačev 1966: 102-103).

49.) *porms 'ferry boat', attested in most Slavic languages, e.g. Russ. poróm 'Fähre', S-C präm, Pol. prom, etc. - OHG farm 'Nachen, Fähre', OIc. farmr 'Last, Fracht, Bürde'; the basic verb is preserved in Germanic, e.g. Goth. faran 'wandern, ziehen', farjan (= Eng. ferry) 'fahren, schiffen', etc. (Stang 43).

50.) *prędajg, "prędati//prę(d)noti 'spring, attested in East and South Slavic, e.g. OCS vas-pręnǫti 'emporfahren, sich erheben', Russ. prjadát' 'hüpfen, springen' (vos)prjánut' 'aufspringen, sich erheben', S-C prèdati 'sich fürchten', prênuti se 'aus dem Schlaf auffahren', etc. - OIc. spretta 'springen', ME sprenten 'springen' (NE sprint also belongs here), etc. (Stang 43).

51.) progz 'grasshopper', attested only in OCS progz 'Heuschrecke' and Russ. prug idem; for an internal Slav. motivation see S-C prézati se 'vom Schlaf aufspringen' (i.e. "pręzati imperf. to preg(nq)ti, see above) - OHG houuespranca literally 'hey-hopper', MHG spranke, sprinke 'Heuschrecke': the Germc. nouns are obvious old derivatives from Germc. springan = Slav. pręg(nq)ti, etc. (Stang 43).

52.) rebro 'rib', attested in all Slavic languages, e.g. OCS rebro, Russ. rebró, S-C rèbro, Pol. żebro (dissimilated from rzebro), etc. - OHG ribbi, rippi 'Rippe', OE ribb, OIc. rif, etc. (Stang 44).

53.) sędra 'coagulated liquid', attested only in Church Slavic sędra, 'geronnene Flüssigkeit', from which is derived Russ. sjadra, and in S-C sêdra 'Kalksinter', Cz. sádra 'Gips' - OIc. sindr 'Sinter, Schlacke, Abfall von Eisenfunken', OE sinder, OHG sintar (Stang 46).

54.) sbjajo, sojati and 'singti 'shine', attested only in South and East Slavic, e.g. OCS sijajg, sijati 'leuchten, glänzen, strahlen', Church Slav. sinuti, S-C sjä̀ti, Russ. sijat', etc. - Goth. skeinan 'leuchten, scheinen', OE scínan = NE shine, OHG skinan = NHG scheinen, etc., all from PIE *sk'ei- (Stang 47-48).

55.) snops 'sheaf', attested in all Slavic languages, e.g. OCS snops, Russ. snop, gen. snopá, S-C snöp, gen. snòpa, Pol. snop, etc. - OHG snuoba 'Binde', snuobili 'kleine Kette' (Stang 52, see also Pokorny

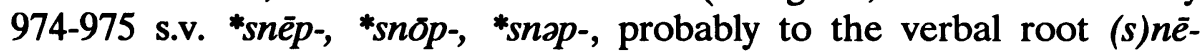
'zusammendrehen').

56.) "solvz 'sallow' (as an adjective), attested only in East Slavic, e.g. Russ. solovój 'gelblichgrau, isabellgelb' (referring to horses), Russ. Church Slav. slavo-ocije = serro-ocije etc. - OHG salo, saloweer 'dunkelfarbig, trübe', OE salu = NE sallow, etc.: Slav. and Germc. show 
the same stem-formation *soluo- (Stang 52).

57.) stado 'stud', attested in most Slavic languages, e.g. OCS stado 'Herde', Russ. stádo, S-C stâdo, Pol. stado, etc. - OIc. stóర 'Stutenherde', OE stód = NE stud, OHG stuot idem, NHG Stute 'mare'; the primary meaning in Slavic seems to have been also 'herd of horses', i.e. 'stud' (Stang 54).

58.) -stegneti 'knot, tie (by stitching)', attested only in Church Slav. ostegnoti 'knüpfen', Russ. zastegnút' 'zuklopfen' and stegát' 'steppen, nähen, peitschen, schlagen', Cz. pristehnouti = Russ. pristegnut' (in other Slavic languages there are only nominal derivatives from this verb) -

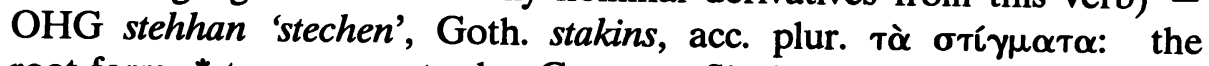
root-form *steg- seems to be Germano-Slavic in contradistinction to *steig- in other IE languages (Stang 55); see also Vasmer III, 751).

59.) stěna '(clay, stone) wall', attested in all Slavic languages, e.g. OCS stěna 'Wand, Mauer', Russ. stená 'Wand', S-C stijèna 'Felswand, Fels, Stein', Pol. ściana 'Wand', etc. - Goth. stains 'Stein', OIc. steinn, OE stān = NE stone, etc. (Stang 55).

60.) stogz 'stack', attested in all Slavic languages, e.g. Church Slav. stogz 'Heuhaufen, Schober', Russ. stog, gen. stóga, S-C stôg, gen. stöga, Pol. stóg, gen. stogu, etc. - OIc. stakkr 'Heuschober' (with correspondences in contemporary Scandinavian languages); Eng. stack is borrowed from Scandinavian; the primary meaning was 'die Stange, um welche der Heustapel konzentriert ist' (Stang 54-55); see stožer above.

61.) *svbrdbla 'drill, borer' (primarily a kind of "piercing weapon" like a dagger, etc.), attested in most Slavic languages, e.g. Church Slav. svrzdblo 'Bohrer', Russ. svérdel//sverló, S-C svŕdao, gen. svŕdla, Pol. świder, gen. świdra (from an expected *świ(e)rdziet, gen. *świ(e)rdta), etc. - OHG swërt = NHG Schwert, OE sweord = NE sword, OIc. sverö: the primary meaning of the Germc. *swer-ða- is 'stechende Waffe' (see Pokorny 1050); in spite of Stang's doubts caused by the semantic difference between Slavic and Germanic, a genetic relationship of these words can be accepted if we admit that a primary 'piercing weapon' (a kind of dagger) became a tool (cf. the etymology and functional change of the Slav. nožb from 'dagger' (weapon) > 'knife' (tool)), Stang 57.

62.) *క̌cir 'clear', attested only in North Slavic, e.g. Russ. ščíryj 'richtig, echt, wahrhaft, aufrichtig, Cz. ciny 'lauter', Pol. szczery 'rein, lauter, aufrichtig' - Goth. skeirs 'klar, deutlich', OIc. skír 'rein, klar'; Eng. sheer belongs here, too (Stang 58).

63.) vabiti 'lure, call', attested in all Slavic languages, e.g. OCS vabiti

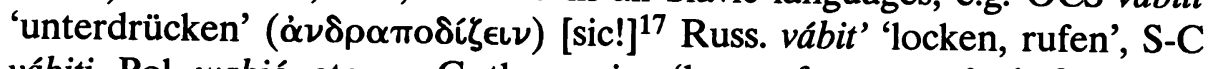
vábiti, Pol. wabić, etc. - Goth. wopjan 'laut rufen, ausrufen', OIc. ōepa 'rufen, schreien', OE wēpan = NE weep, etc. (Stang 60). 
64.) *vektb 'thing', attested only in South and West Slavic, e.g. OCS veštb 'Sache, Ding, Materie, Natur' (Russ. vešč' borrowed from OCS), Cz. věc (sic!), etc. - Goth. waíhts f. 'Ding, Sache', OIc. váttr f. 'Wesen, Wicht, Geschöpf, etc.', OE wiht f. 'Wesen', (NE nought $\leq \mathrm{OE}$ ná-wiht!), etc. (Stang 63; see also E. Hamp: OCS veštb, in G. Cohen, ed. Comments in Etymology, Vol. VIII, 15 (1979), p 2-3).

65.) věxa 'a strawbundle on a pole' (used as a signal), attested in most Slavic languages, e.g. Russ. véxa (not vexá quoted by Stang) 'Ackerpfahl, Strohwischstange, etc.', OCz. viech, Cz. vích 'Strohwisch', věcha 'strawbundle', Pol. wiecha idem; Sloven. véha 'stalk and leaves of cultivated plants' and Russ. véxa seem to indicate a PSl. old acute from a long diphthong: *uōisā - OIc. vísir 'Knospe, Keim, Spitze eines Gewächses', Norw. veis f. ( 'waisō-) 'stalk', dial. víse 'Spitze, Büchsel'; see also Norw. visk = NHG Wisch, etc. (Stang 63 and Vasmer I, 308).

66.) *vórba//*võrbs (?) 'reel, warp' (?), attested only in Russ. voróba 'Zirkelschnur', voróby 'Zwirnmühle, Garnwinde', vórob 'Haspel' - OIc. varp 'Netzwurf; Kette eines Gewebes', Norw. dial. varp 'Kettengarn, Aufzug; Netzwurf', OHG warf = OE wearp = NE warp: the Germc. words are derived from *werpan (Goth. waírpan, NHG werfen, etc.) 'throw' (Stang 64).

67.) vzlati (vъlajo, -eši) 'wave', attested only in OCS vzlati sę (-ajo, -eši) 'von den Wellen hin und her geworfen werden', Church Slav. vzlati 'in Wallung bringen' (from which Russ. Church Slav. vlájat'(sja) 'move, roll' comes) and in Cz. vláti (vlaji, etc.) 'wave, roll' - Goth. wulan 'wallen', etc.: because of an exact formal and semantic correspondence between Slavic and Germanic, the prehistorical dialectal IE relationship seems to be highly plausible (Stang 63-64 under Lith. vilnis 'Welle, Woge', see also Vasmer I, 327 and Pokorny 1142-1143).

The above list, undoubtedly, is not exhaustive. I tried to include in it all the words which in the available literature (first of all in Stang's book) have been treated as representing either certain or highly probable Baltic $\sim$ Slavic Germanic correspondences ("sichere oder wenigstens durchaus wahrscheinliche ... Sonderwörter", Stang 77). In this connection, one should add that according to Stang's statistics, the sum total of the above correspondences amounts to 188 (68 occur in all three language groups, 66 only in Baltic and Germanic, and 54 only in Slavic and Germanic, which gives a number of 122 for words common to Slavic and Germanic). My statistics, as presented in the preceding pages, where 17 words selected from the lists of Čemodanov and Trubačev have been included, show 139 prehistorical Slavic-Germanic correspondences.

But I am inclined to increase this number. As mentioned earlier, there are words in Stang's book which are marked with a crosslet, indicating 
that the correspondence is uncertain. From among such words the following eleven can be considered highly probable:

1.) -glbběti (OCS uglbběti, -bljo, -iši 'stecken bleiben', etc.) OHG klebèn 'kleben an', etc. (Stang 22, with some unsubstantiated semantic doubts).

2.) godz (OCS godz 'Stunde, (passende) Zeit', etc.) Goth. gops, gods (stem goda-) = Eng. good, etc. (Stang 23-24) [correspondences in Baltic]

3.) nozdri (OCS nozdri plur. f. 'Nasenlöcher', etc.) MLG noster = NHG Nüster, etc. [also correspondences in Baltic] (Stang 39).

4.) n'uxati, n'ušiti (Russ. njuxat' 'riechen, schnüffeln, umherspürren', etc., S-C njüšiti idem) Goth. biniuhsjan 'auskundschaften', etc. (Stang 40).

5.) *polzz and its basic verb *pelžo, *pblzati (Russ. póloz 'Schlittenkufe', S-C plâz 'Pflugsohle', Pol. ptoza 'Schlittenkufe', etc. and OCS plěžo, plbzati 'kriechen, schleichen', etc.) OHG fëlga = NHG Felge, etc. (Stang 43 and Vasmer III 314, 309).

6.) *yčati (more basic than rykati quoted by Stang; OCS rykati, -ajo 'brüllen', but Pol. ryczeć, ryczę, -ysz, etc.) OHG ruhen ( $\leq$ *ruhjan), etc. (Stang 46) [also correspondences in Baltic]

7.) snovati, snujo (Russ. snovát', snujú 'hin und her laufen, anzetteln (beim Weben), Aufzug anlegen', etc.) Goth. sniwan 'eilen', but OIc. snúa 'wenden, drehen, winden, flechten', etc. (Stang 51-52).

8.) stols (OCS stols 'Sitz, Schemel, Thron', etc.) Goth. stols 'Stuhl, Thron', etc. (Stang 55) [also correspondences in Baltic]

9.) şlati, šljo, -eši (OCS şlati, słl'Q, -eši 'senden', etc.) Goth. saljan 'darbringen, opfern', but OIc. selja 'überliefern übertragen, verkaufen', etc. (Stang 56).

10.) *svbrběti, 3rd. sing. -iţ (Russ. sverbét' 'jucken', S-C svŕbeti, Pol. świerzbieć, etc.) and an old derivative *svorbs (OCS svrabz 'Krätze', Russ. svórob 'Jucken; dial. 'Krätze', etc.) Goth. af-swairban 'abwischen', OIc. sverfa (svarf, sorfinn) 'feilen', etc. [also correspondences in Baltic] (Stang 57).

11.) vedro (OCS vedro 'schönes Wetter', Russ. vëdro idem, etc.) OHG wetar $=$ NHG Wetter, etc. (Stang 61).

In such a case, the sum total of Slavic-Germanic correspondences with a relatively high degree of probability will rise to 150 , which is quite an impressive number in comparison with, for example, 75 (49) Slavic Indo-Iranian correspondences. (But I must remind the reader of Moszyński's opinion regarding these statistical data).

Such a relatively high number of Slavic-Germanic lexical correspondences is undoubtedly not only conditioned by the simple circumstance that we possess better and richer collections of Germanic words than, for 
instance, those of Iranian, from which to choose respective material, but also by the relatively younger (in prehistorical terms) - i.e. closer to the historical epoch, character of Slavic-Germanic dialectal contacts within late Indo-European. Actually, we should speak of Pre-Slavic Pre-Germanic contacts. These contacts could have still been being maintained about the year 2000 B.C. (?), probably simultaneously with more intimate Balto-Slavic contacts. It is also probable that many of the Slavic-Germanic correspondences which exclude Baltic are due to the so-called "Venetic" (kentum) substratum ${ }^{18}$ absorbed gradually by both, the Proto-Slavs moving from the east and the Teutons (Proto-Germanic tribes) moving south-east from Scandinavia and Jutland, which obviously occurred in a relatively younger epoch. This hypothesis would explain why the Teutons, from the oldest times, have called the Slavs "Veneti" (*Viniða-: Winden, Wenden, etc.). However, there is a more detailed discussion about this ethnicon in the chapter devoted to the primary habitat of the Slavs.

A semantic analysis of the Slavic-Germanic lexical correspondences has been done by Stang in a separate chapter of his book (70-78) and some general conclusions are drawn in the last chapter (79-82). I can only quote these conclusions in extenso (omitting the Baltic-Germanic correspondences):

Hier ist erstens zu bemerken, dass die intimeren Elemente der Sprache, Pronominalstämme und Partikeln ... in unserer Sammlung völlig fehlen, Wenn man die gemeinsamen Nomina und Verba betrachtet, fällt in die Augen, dass Wörter fur religiöse Begriffe und Wörter abstrakten Charakters, die einer höheren Gedankenwelt angehören, fast nicht vorhanden sind. Auch Verwandschaftswörter kommen auf unserer Liste nicht vor. Einige gemeinsame Namen für Körperteile kommen vor, aber nicht sehr viele. Die Wörter, die Pflanzen, Tiere, Boden, Naturerscheinungen bezeichnen, sind in unserer Sammlung verhältnismässig zahlreich, nicht aber besonders charakteristisch. Sie zeugen von alter Nachbarschaft, legen aber von der natürlichen Beschaffenheit oder von der geographischen Lage der alten Wohnplätze kein klares Zeugnis ab. Über spezielle Berührungen auf dem Gebiete der Landwirtschaft geben die balt.-slav.-germ. Sonderwörter wenig Auskunft. Man merkt sich aber das Wort für "Roggen": lit. rugiaĩ, ksl. røžb, ano. rugr. Die Verbreitung des Wortes hängt wohl mit der Verbreitungsgeschichte dieser Getreideart zusammen ... Die Wörter, die soziale Erscheinungen bezeichnen, sind nicht 
zahlreich, dafür aber wichtig: "Dorf” (balt.-germ.), "gewöhnliches Volk", "Arbeitskamerade" - "Gefolge", ursprünglich wohl auch "kollektive Arbeit ausführen", sind bedeutungsvolle soziale Begriffe, die durch gemeinsame balt.-slav.-germ. Wörter ausgedrückt sind. Dazu kommt vielleicht noch das Wort fur "Einernten, strenge Feldarbeit." Verhältnismässig viele Übereinstimmungen finden wir auf dem Gebiete der technischen Kultur. Man findet Bezeichnungen für eine Reihe von Gegenständen aus $\mathrm{Holz}$, seltener aus anderem Material. Es handelt sich oft um primitive Geräte, Stöcke, Stäbe, Stangen, ausgehöhlte Baumstämme usw. ... Die meisten balt.-slav.-germ.- Gemeinwörter technischer Natur sind Bezeichnungen für einfache Geräte und Gegenstände aus Holz.... ... Gleichzeitig mit dem gemeinindoeuropäischen und nordwestlichen technischen Vokabular haben also die drei Sprachgruppen eine Reihe von gemeinsammen Wörtern aus dem Gebiete der primitiven Handwerkskultur, die nicht anderswo zu finden sind. Dies deutet auf eine nahe Verbindung zwischen den Trägern der betreffenden Mundarten im Kleinen, in den einfachen Verhältnissen des täglichen Lebens, was wohl auf geographischer Nähe und aktiver Nachbarschaft beruhen muss. Man kann nach formellen Kriterien nicht feststellen ob diese Wörter älter or jünger sind als diejenigen, die zum "nordwestlichen Vokabular" gehören. Die von uns behandelten Sonderwörter, die einfache Geräte und Werkzeuge bezeichnen, beweisen natürlich keinswegs, dass die Vorläufer der slavischen, baltischen und germanischen Völker zur gegebenen Zeit im Ganzen eine besonders primitive materielle Kultur hatten, geschweige denn eine primitivere Kultur als die übrigen ieur. Stämme. Sie zeigen nur, dass auf diesem speziellen Gebiete, wo es sich um die einfachen Geräte und Gebrauchsgegenstände des täglichen Lebens handelt, eine besonders intime Verbindung zwischen den Vorläufern der baltischen, slavischen und germanischen Völker bestanden hat. ${ }^{*}$ )"

The footnote: "Ungefähr die Hälfte der "technischen" Wörter sind balto-slavo-germanisch. Es verdient vielleich erwähnt zu werden, dass auf diesem Gebiete die speziell balto-germanischen Übereinstimmungen erheblich zahlreicher sind als die slavo-germanischen (ich zähle 10: 3)" 
(Stang 79-81).

The latter statement deserves special attention. It seems to support Trubačev's observation about the orientation of the younger (?) Proto-Slav. technical terminology towards the Italo-Celtic world. It also suggests that the contacts between the Pre-Balts and the Pre-Teutons lasted longer than those between the latter and the Pre-Slavs. I am inclined to connect these phenomena with a hypothetical northern route of migration of the Pre-Teutons from Eastern Europe to Scandinavia (see below).

In connection with the supplementary material of Cemodanov, and particularly that of Trubačev, we should ask the following question: to what extent does this material strengthen or weaken the conclusions reached by Stang? The answer seems to be simple: they strengthen Stang's conclusions. Eleven out of seventeen words are technical terms belonging to weaving ( ${ }^{*} b b r d o,{ }^{*}$ mędlo, *pasmen-, *prędlo), blacksmithing ( ${ }^{*}$ stěja, "nakovz), carpentry (odrъ, *žbrdb) and others (*laty, *lęčb, lyko). Here I would like to again refer the reader to the general conclusions of Trubačev already quoted above in this chapter. Leaving aside the relative chronology of the prehistorical contacts and cultural-terminological exchange between the respective ethno-linguistic groups, which is open to discussion, we must say that the orientation of the PSI. handicraft terminology towards prehistorical Central Europe (Germanic Italic Celtic) underlined by Trubačev, i.e. Slavic Germanic Italic Celtic correspondences in this domain with the exclusion of Baltic, induces us to modify the statement by Stang which was formulated in the footnote quoted within his conclusions. It seems probable that there were two epochs in the prehistorical Slavic-Germanic lexical contacts: an older epoch, when the cultural-lexical exchange was spreading across the whole Germanic Balto-Slavic (i.e. North IE) dialectal zone, and a younger one, when the Teutons on the one hand, and the Proto-Slavs on the other, came into closer cultural-lexical contacts with the early Italic and Celtic tribes dwelling in Central Europe, while the Balts were left aside. Here again, I should underline the possibility of the so-called "Venetic" substratum absorbed by both the Teutons and the Proto-Slavs, and acting as a "propagator" of some of the cultural terms.

The last problem left to our consideration is the problem of the prehistorical Balto-Slavic lexical correspondences, i.e. those words which are common only to Baltic and Slavic. Here we touch upon the hypothesis of the so-called prehistorical Balto-Slavic linguistic unity which, as is known, has been accepted by some scholars and rejected by 
others. I think that the whole discussion is suffering from the lack of clearly defined terms; the very term "unity"19 belongs here. Of course, I cannot enter into a discussion of the prehistorical linguistic contacts between the Proto-Slavs and the Proto-Balts in this paragraph. There is no doubt that they were close and multifarious, and must have lasted longer than the contacts between any of the other dialectal groups of late Indo-European (except those between Iranian and Indian, which practically can be treated as two dialects stemming from the same source: Aryan). The sum of common innovations pertaining to all levels of language: phonemic, morphological, syntactic, and lexical is so impressive that we can even try to reconstruct a kind of Proto-Balto-Slavic as an intermediary dialect between Proto-Indo-European on the one hand, and Proto-Baltic and Proto-Slavic on the other. In this connection, Proto-Slavic (strictly speaking, late Proto-Slavic) can basically be derived, at least as far as the phonemic form is concerned, from Proto-Baltic ${ }^{20}$, which proves the more conservative character of the latter. All these facts are quite well known. Also important is the relative chronology of the common Balto-Slavic innovations. Some of them must have originated in a very remote epoch of the first dialectal differentiation of IE (about the year 3000 B.C.); e.g. the so-called split of the IE syllabic sonorants $*_{r}, *_{l}, *_{m}, *_{n}$ into $*_{i r / u r} *_{i l} / u l$, etc. must have taken place still in the "laryngeal" stage of IE since $R+H+C \geq i R / u R H C$ and then we obtain consistently long diphthongs of the type $i R / \bar{u} R$ after the fall of laryngeals (see p. 47-48). Thus, there is no question that the linguistic ancestors of the Balts and Slavs have experienced a long prehistorical period of close linguistic (which ultimately means ethno-cultural) contacts or relations starting from the PIE epoch, and extending far beyond the final dissolution of the PIE linguistic community. Of course, any precise chronological boundaries are impossible. The fact that, in addition to striking innovations, we also observe deep differences, e.g. in the development of tense systems and some parts of vocabulary, ${ }^{21}$ between Baltic and Slavic seems to indicate that the prehistorical dialectal complex evolving towards a kind of Com. Balto-Slavic ceased to exist at a time (the end of the second millennium B.C.?), and the ancestors of the Balts on the one hand, and those of the Slavs on the other, loosened their earlier contacts and began to develop independently. It is difficult to say what were the external socio-historical circumstances conditioning that separate development. The most probable seem to be demographic shifts connected with prehistorical migrations, which in their turn were caused either by the external pressure of foreign tribes, or by the internal pressure of a growing population unable to subsist in the old regions of a primitive extensive and semi-migratory agriculture. That we should take 
seriously into account such mass population shifts at the level of primitive prehistorical agriculture seems to be proven by deep differences in the basic agricultural terminology between Baltic and Slavic (to which a separate paragraph will be devoted below.)

But let us return to our special subject: the lexical correspondences between Baltic and Slavic. Since 1923, we have been in possession of a useful comparative study of Baltic and Slavic vocabulary, namely $R$. Trautmann's Baltisch-Slavisches Wörterbuch. This dictionary contains more than 1,600 entries. No doubt, the number is impressive. But we must remember that the author has included in his book not only the obvious Balto-Slavic innovations which do not have exact lexical correspondences in other IE languages (e.g. Lith. galvà PSl. "golva 'head', Lith. rankà $\sim$ PSI. rqka 'hand', Lith. rãgas PSl. rog̋ 'horn', Lith. geležìs PSI. želězo 'iron', Lith. liépa PSl. lipa 'linden', etc.), but also many North IE words which were discussed in the preceding paragraph, and many common archaisms which are irrelevant for the problem of the so-called Balto-Slavic linguistic unity. (e.g., see the examples under *aki'eye', Traut. 4, *ausi- 'ear', Traut. 18, *nāsi-, *nasa- 'nose', Traut. 193, etc.) In this connection it should be noticed and stated emphatically that the Balto-Slavic dictionary by Trautmann requires a careful analysis from the standpoint of real Balto-Slavic innovations, either formal (derivational) or semantic. Only after having separated such words, will we be able to estimate their actual number and judge their semantic significance, which will be indispensable for the reconstruction of the ethno-cultural prehistory of the Balts and the Slavs.

As yet only F. Sławski, a well-known Polish etymologist, has attempted an analysis of the substantives contained in Trautmann's dictionary. The results of his work have been published as a short article in Donum Balticum (1970: 501-506). The statistical data from this article are particularly worth mentioning, and are quoted as follows:

Das Wortmaterial Trautmanns umfasst drei klar und proportionell voneinander abgesonderte Hauptgruppen: I. Das indogermanische Erbe, II Die Gruppe von Substantiven, die nur in den slavischen Sprachen oder nur in den Baltischen Sprachen bezeugt sind, III Baltisch-slavische Neuerungen.

I. Das indogermanische Worterbe bildet etwa 265 Substantive (also ungefähr 30\% des Ganzen), davon sind 201 Wörter - Grundwörter, etwa 64 - Derivate.

II. Gruppe von Substantiven, die nur in den slavischen oder nur in den baltischen Sprachen bezeugt sind, is durch 
die 334 Schlagwörter (ungefähr 37,5\%) vertreten, davon sind 214 Grundwörter und 120 Derivate enthalten. Die Mehrheit bilden die nur baltischen Substantive: 181 (davon 111 Grundwörter, 70 Derivate).

III. 289 Substantive bilden baltisch-slavische Neuerungen $(32,5 \%)$, davon 195 Grundwörter und 94 Derivate. (Sławski, 1970: 502)

Der überwiegende Teil des untersuchten Wortmaterials geht selbstverständlich auf die erebten Wurzeln zurück, die auf dem Grund des Baltisch-Slavischen oder durch spezielle Suffixe, oder aber auch durch andere morphologische Mittel (der spezifische Ablaut, Reduplikation), zuletzt durch spezielle semantische Verānderungen modifiziert wurden... (1.c. 505).

Sławski quotes all the Balto-Slavic lexical innovations and classifies them semantically. It is striking that the largest group (124 words) refers to nature (flora, fauna, landscape, weather, etc.). Words which the author classifies as referring to social life represent only a very small number (27). We can quote all of them (in the reconstructed form used by Trautmann): 1. mēira- 'Friede', 2. šlounā- 'Ruf, Ruhm', 3. ueinā'Ursache, Schuld', 4. uada-: uadā- 'Führer, Führung', 5. drauga'Gefährte', 6. unarga- 'Feind', 7. šventika- 'der Heilige', 8. dausīa -, duasiā 'Atem, Seele' (why is this included in the social vocabulary?), 9. aldijia'Kahn, Schiff' (why is this included in the social vocabulary?), 10. maina-: mainā- 'Tausch', 11. brunj̄ās 'Brünne', 12. barni- 'Zank, Streit', 13. gintla-: gindla- 'Waffe, 14. lanka- 'Bogen', 15. kalkala- 'Schelle', 16. daudā'Pfeife', 17. gerba- 'Stück, Los', 18. uainika- 'Kranz', 19. daliā- 'Teil'; kinship terms: 20. bābā- 'altes Weib', 21. bräli- nickname for brāter, 22. maldenüka- 'Kind', 23. seserēna- : sesrēna- 'Schwestersohn', 24. strūiu'Alter', 25. šeimā- : šaimiāa-, šaimiìa- 'Familie', 26. uaika- 'Knabe, Knecht', 27. žênta- : žênti- 'Schwiegersohn'.

However, we must add some critical remarks to Sławski's analysis. First of all, he does not separate the so-called North European dialectal elements, and therefore he includes in the Balto-Slavic innovations substantives such as aldiija -, drauga- which have etymological correspondences only in Germanic, and which represent, according to Stang, an older dialectal IE layer in Balto-Slavic. He also unnecessarily includes in his list an obvious Germc. loanword: *brunjās (see Trautmann 38). This approach is justified by Sławski's method: he compares and analyzes separate, individual words, and not word-families. There is also no historical analysis of the relative age of the Balto-Slavic innovations; 
some of them are undoubtedly quite recent formations (copied in Lithuanian from Slavic, e.g. šventika-: Lith. šventíkas 'Geistlicher' OCS svętbcb, etc. 'Heiliger'). Of course, such recent "innovations" are irrelevant for the whole problem of Balto-Slavic prehistorical "unity". But it should be emphasized that Sławski's attempt has provided us with a useful basis for further study of Balto-Slavic relationships in vocabulary.

Within Balto-Slavic lexical innovations, we should look first of all for those which pertain to the primary agricultural, technical (handicraft), religious-magical, social, and legal terminologies, since these are the most important aspects of ethnic life in which the relative unity of an ethnos should be reflected. Needless to say, Balto-Slavic awaits a systematic, comparative study from this standpoint. We already know today that the two linguistic groups show deep differences in several of these fields. It is commonly known, for instance, that the basic religious terminology, first of all the terms for 'god' and 'demon', have developed differently in Baltic and Slavic. The former linguistic group basically preserves the primary PIE words (Lith. diẽvas 'God': vélnias 'demon, devil') ${ }^{22}$, the latter introduces characteristic formal and semantic changes (bogz 'God': divъ 'demon') common to Slavic and Iranian (see above). This fact alone would suffice to cast doubt on any closer socio-cultural ties between the prehistorical Balts and Slavs; as is well known, a common religious cult and ritual is a very important and essential feature of primary ethnic unity, whether it is a tribe or a tribal federation, etc. But there are also significant differences in agricultural and handicraft terminology. The latter phenomenon has been emphasized by Trubačev in connection with his research (see the statement quoted above). As far as agricultural terminology is concerned, we will now analyze some words in order to illustrate the fact that in this important, virtually basic field of a primitive economy, the number of common Balto-Slavic innovations is insignificant. In this connection, a hypothesis of an early dissolution of the so-called Balto-Slavic linguistic unity can be ventured.

Assuming that the prehistorical peoples of the parkland (and forest) areas of Eastern Europe subsisted mainly by agriculture, we can hypothesize that the agricultural terminology in the languages of their descendants represents a very archaic layer reaching back into deep antiquity. In view of this hypothesis, the etymology of the basic agricultural terms in Slavic and Baltic (mainly Lithuanian) acquires a special significance. In the etymological analysis of such terms, the following three questions must be answered: to what extent do the terms under investigation represent common IE archaisms (i.e., words inherited by Balto-Slavic from an earlier IE period and commonly preserved), to what extent can they be proven as being common Balto-Slavic 
innovations (i.e., formed in the prehistorical period of close ethno-linguistic relations between the ancestors of the Balts and the Slavs), and ultimately, to what extent can they be treated as separate, independent innovations in Baltic and in Slavic. There is no need to repeat that the central problem in this context - and a decisive one for the relative chronology of the so-called Balto-Slavic unity - is the fact of common Balto-Slavic innovations.

Following is the list of basic agricultural terms whose lexical counterparts in Baltic and Slavic have been investigated in the present paragraph: 1. 'to plow', 2. 'to sow', 3. 'to reap', 4. 'to thresh', 5. 'to grind', 6. 'cultivated/arable field', 7. 'furrow', 8. 'garden bed', 9. 'seed' (of grain), 10. 'bean' (faba), 11. 'pea', 12. 'millet', 13. 'barley', 14. 'wheat', 15. 'oats', 16. 'rye', 17. 'grain' (cereals), 18. 'plow', 19. 'plowshare', 20. 'hoe', 21. 'sickle', 22. 'flail', 23. 'handmill'.

For the sake of conciseness, the examples will be quoted only from Lithuanian and Old Church Slavic in the case that the respective words can be treated as Com. Baltic and Com. Slavic; in the case that they cannot be thus treated, examples from other Baltic and Slavic languages will be used. The IE correspondences and reconstructed forms are quoted in more difficult instances in order to substantiate the etymology of the respective words.

1.) Lith. ariù, árti OCS orjg, orati; a common archaism (Traut. 13).

2.) Lith. sěju, sěti OCS sějo, sě(ja)ti; a common archaism (Traut. 253).

3.) Lith. pjáuju, pjáuti : OCS ž๖njo, žęti; Lithuanian continues PIE *pēuijo, see Lat. paviō, -ïre 'schlagen, stampfen', etc. (Buck 507, Pok. 827), Slavic represents PIE *guhen(a)- (i.e. *ghen(H)-) 'schlagen' (Pok. 491-492) specialized in the agricultural meaning, whereas Baltic has preserved this verb in an older nonagricultural function, namely Lith. ginù, ginti 'wehren' (Traut. 85).

4.) Lith. kuliù, kùlti : OCS mlašto, mlatiti (i.e. *moltjo, *moltiti) and Church Slav. vrbxo, vrěšti (i.e. *vbrxo, *verxti); the Lith. verb is a cognate with Slav. koljq, *kolti (OCS klati), and the Slav. verbs do not have etymological correspondences in Baltic, although Latv. vârsms 'Haufen Getreide' contains the root *uers- = PSl. *verx-; as far as Latv. màltît 'shake slightly' is concerned, it seems to be a Slav. loanword. It is worth emphasizing that *uers- represents an old IE agricultural term (see Hitt. uarši ia - 'grind grain' and Lat. verro 'sweep (grain after threshing?)'; Vasm. I, 302, 255, Pok. 1169.

5.) Lith. malù, málti OCS meljo, mlèti (i.e. *melti); a common archaism (Traut. 168).

6.) Lith. dirvá : OCS n'iva; the Lith. word is most probably a derivative 
of derù//diriù, diřti//dìrti '(zer)reissen, prügeln, schinden' (see Fraen. I, 97), thus its primary meaning would be 'clearing' (Russ. derevnja, i.e. *dbrvbnja, with the so-called secondary polnoglasie 'village' may be an old borrowing from Baltic, see Vasm. I, 501); Com. Slav. *njiva, without correspondences in Baltic, has, however, a "match" in Gr. velós f. ("neiuo-) 'Feld, Flur' (the latter meaning from the primary 'Niederung', see Buck 490, Pok. 313, Moszyński, 1957: 74).

7.) Lith. vagà (in Szyrwid's dictionary translated by Pol. 'brózda') : OCS brazda (i.e. *borzda); the Lith. word indirectly represents an IE archaism, namely a derivative of the root *uegu $h$ - (see OPers. $\bar{d} d$-avajam 'ich stach aus') from which the name of 'plowshare' in the IE languages of Europe stems (see Fraen. II, 1179 and Pok. 1179-1180, where an excellent equation between OPruss. wagnis 'Pflugmesser' and Gr. (Hesychius) óфvís is also quoted); PSl. *borzda seems to be an innovation with etymological links to Gr. * $\phi \alpha ́ \alpha \omega$ 'spalte, zerstückele', $\phi \alpha \rho o ́ \omega$ 'pflüge', фó́pos n. 'Pflug, Pflügen', which ultimately comes back to PIE *bher- 3 'mit einem scharfen Werkzeug bearbeiten, ritzen, schneiden...' (Pok. 133-135); this root is, of course, continued by PSl. borjo sę, *borti se (OCS brati se) 'to fight (with weapons)'. It is interesting, however, that *borzda has old correspondences in Baltic: Lith. biržis f. 'Ackerfurche', Latv. birze 'Saatfurche', which are derivatives of the Balt. verb *be/irž-ti (Latv. ber̂zt 'reiben, scheuern') representing PIE *bher- 3 with the extension $-g$ ' $(h)$, i.e. Balt. $\check{z}$ : thus the PSI. *borzda could be interpreted as a derivative with the vocalism $o$ and the suffix - $d h \bar{a}$ from that extended root, and the extension itself would be a Balto-Slav. innovation.

8.) Lith. lýsé (only in Lith. and OPruss.) OCS lěxa; a common archaism (Traut. 163).

9.) Lith. sěkla (a new derivative of sěti), sěmens//sermenys m. plur. 'Saat' (the old term) OCS sěmę; the two latter words represent a common archaism (Traut. 253-254). In this connection, it is worth mentioning that the PIE agricultural term * $g^{\prime}$ 'Hno- 'seed of grain' in Lithuanian (žirnis) and Latvian (zirnis) has acquired the secondary specialized meaning 'pea' (Traut. 372, Pok. 391).

10.) Lith. pupà (but OPruss. babo identical with Slav. bobı!): PSl. *bobs (Pol. bób, etc.); the Lith. word is a derivative of the verb *paup-ti, Latv. paupt 'swell' (see Pok. 848), the Slav. word, however, is an old element of the so-called North-Western IE lexicon discussed above (see Lat. faba, etc., Pok. 106).

11.) Lith. žirnis m. : PSl. *gorxъ (Pol. groch, Russ. goróx, S-C grāh, etc.); the Lith. word represents a semantic specialization of PIE *g'rHno- (see above), the Slav. word, however, has etymological connections not with Lith. gařšas 'ein Kraut', garšvà//gáršva 'Saukraut, Giersch', as it is generally 
accepted, but because of semantics, with Gr. Kéyxpos 'Hirse, Korn' (dissimilated from *gher-ghro-) and with Lat. furfur (i.e. *for-for-) 'der Balg, die Hülse des Getreides und der Hülsenfrüchte'; it may represent a vrddhi derivative of the verbal root *gher-s-: OI gharsati 'reibt' (notice that a pea is husked by rubbing it between two palms); Traut. 79, Pok. 439 s.v. gher- 2. and Vasm. I, 444.

12.) Lith. sóra : PSl. proso (in this form found in all Slavic languages) and *brrb 'Panicum miliaceum' (e.g. Pol. ber, gen. bru, Ukr. bor, gen. bru, $\mathrm{S}-\mathrm{C}$ bâr, etc.); the Lith. word is most probably an old derivative of séti 'sow' (see Schrader I, 504) [The similarity of Lith. sóra to Mordv. súro, sură is accidental; see A. Joki, 1973: 60.] The Slav. words in their turn

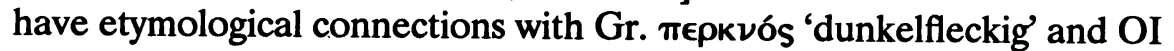
prśni- 'gefleckt, bunt' (Vasm. III, 378-379 and Pok. 820 s.v. perk'-, prek'- 2.) on the one hand, and with the verbal root *bher-3 mentioned under *borzda (see Bern. 110) on the other. In connection with the latter, *bzr could be interpreted as a PIE adjective in $-u$ with zero-vocalism (bhr-u-) secondarily substantivized. We have semantic parallels of such a development in the case of *gorxz from *ghers- and *pbšeno from *pbxati (see below).

13.) Lith. miẽžai m. plur. (Balt. *maižza-; Latv. màize 'bread', in Fraenkel's dictionary without an etymology (sic!), also belongs here) : PSl. *jęčımy, e.g. Russ. Church Slav. jačımy, Pol. jęczmień, S-C jêčmen, etc.; the Balt. word corresponds, in my opinion, to PSl. *mězga, i.e. PIE "moig'h-skā (see Bern. II, 54-55 and Vasm. II, 593), a derivative of the verbal root *meig'h- 'wet, moisten': thus the primary meaning of Balt. *maižla - would be 'a pulp of moistened barley' (cf. Eng. mash which etymologically also belongs here, see Pok. 713), then 'barley', similarly as in Slavic *pbšeno *pbšenica 'grain ground with a pestle' > 'wheat'; in this connection, Trubačev's identification (Ėtimologija 1965: 12) of the Balt. word with Iran. maiz- 'to sow' is questionable, particularly since the Iran. word itself requires an etymological explanation. The Slav. name of barley, represents, in my opinion, an archaic derivative, a primary nomen agentis, *nk-men-, of the PIE root reconstructed by Pokorny (1.c. 45), as *ank-, *ang- (i.e. ' $H_{2} e n k / g-$ ?) 'biegen'; so the primary meaning of the word would be 'sprout', which finds support in the derivatives of this root in other languages, e.g. OI a pkurá- m. 'junger Spross, Schössling', originally 'Keimspitze, gebogener Keim', Norw. dial. ange (*ankón-) 'Keim, Zacke', etc. (see Pok. 45-46).

14 a.) Lith. kviečiaĩ m. plur., b.) Žem. pūraĩ m. plur. 'Winterweizen' PSl. "pyrı and "pyro (e.g. Russ. Church Slav. pyro, S-C pirr, etc., but Pol. perz, Cz. pýr and Russ. pyréj with a changed meaning 'Triticum repens', which is a result of abandoning the cultivation of this cereal and of its 
secondarily growing wild, see Moszyński, Kultura ludowa Stowian I, 232); the first Lith. word is most probably a North Germc. loanword (Goth. hvaiteis, OIc. hveiti, etc., Fraen. I, 326), the second represents (together with the Slavic word) a common archaism (Traut. 232 and Pok. 850 s.v. *pū-ro- 'Korn-/frucht/). Slav. "pb̌̌enica, as, for example, in OCS, must be a late and characteristic innovation; it is a transparent derivative of *pb̌eno, past pass. part. of "pbxati 'stamp'; but it is interesting that *pušeno (e.g. Pol. pszono, Russ. pšenó, etc.) in most Slavic languages has the meaning 'cracked millet, millet groats', which would indicate that millet was primarily the most popular cereal of the Slavs (for etymological parallels of Slav. * ${ }^{*}$ ऍ̌-en-o, see Vasm. III, 417).

15.) Lith. ãvižos f. plur. PSl. ovbsъ (e.g. ORuss. ovbsz, Pol. owies, etc.); a common archaism (Traut. 21).

16.) Lith. rugiaĩ m. plur. PSl. rъž̌ (e.g. ORuss. røžb f., OPol. reż, gen. $r \dot{z} y$, etc.); a common North IE dialectism with correspondences in Germanic, e.g. OIc. rugr (an $i$-stem), OE ryze, etc.; perhaps Thrac. $\beta \rho i ́ \zeta \alpha$ (*urughīā) 'Emmerhorn, Roggen' belongs here, too (Traut. 246 and Pok. 1183).

17 a.) Lith. grúdai m. plur., b.) javaĩ m. plur. : PSl. žito (e.g. OCS žito, S-C žîto, etc.; in Pol. and Russ. with a secondary meaning 'Secale cereale'); the first Lith. word is a transparent derivative of grústi, grúdžiu//grúdu 'stamp' and has correspondences in Germanic, e.g. OIc. grautr 'Brei, Grütze', OE grūt = NE groats, OHG gruzzi = NHG Grütze; Baltic and Germanic show here a common semantic development, whereas Slavic seems to have preserved the primary meaning of IE *ghroudo/ā-, i.e. PSl. gruda, 'Klumpen', etc. (Traut. 99, Fraen. I, 173, Vasm. I, 463); the second Lith. word is an IE archaism with correspondences in Greek: $\zeta \epsilon(\iota)$ á 'Spelt', even in Aryan: OI yáva- m. 'Getreide, Gerste, Hirse', Av. yava- m. 'Getreide', and with some traces in East Slavic, e.g. ORuss. ovinz 'Getreidedarre, Riege', etc. (Fraen. I, 192, Vasm. III, 113, Pok. 512). The Slav. name of grain is, of course, an obvious innovation based on the verb ziti 'live'; parallels of this type of semantic derivation can be found in many languages, e.g. OPruss. geits 'bread' (acc. geitin,geitan), which, if it is not a borrowing from Slavic, may represent a common innovation (see Traut. 82 s.v. geeita-), Lat. victus 'food' (from vivo,, -ere), which in Arum. yíptu has already the meaning 'grain', etc. (Traut. 82 and Vasm. II, 57).

18.) Lith. árklas 'primitive wooden plough' PSl. *ordlo (e.g. OCS ralo, Pol. radło, etc.); a common archaism (Traut. 13).

19.) Lith. lẽmežis//lãmežis m. 'hölzernes Pfluggestell an dem die Pflugschar angebracht wird' (undoubtedly a secondary meaning), but Latv. lemesis 'Pflugschar' (the primary meaning) PSl. lemešs (e.g. 
Church Slav. lemešb, Pol. lemiesz, etc., but Bulg. leméž!); this word may be a common Balto-Slav. innovation, although there are some difficulties in the reconstruction of a common archetype (*lemesia-?); at any rate, in Slavic it has a transparent etymology: a stem in -es extended secondarily by -ijo derived from the verb *lem-ti (see Lith. lémti, lemiù 'fügen, bestimmen, bescheiden' and S-C iterat. lijèmati, i.e. *lěmati, 'schlagen'; in addition to this in Slavic, there is only the old iterat. lomiti 'brechen'). The hesitation of the form in Baltic and the secondary meaning of the word in Lithuanian suggest rather that it is a borrowing from Slavic (Bern. I, 700, Fraen. I, 354, Vasm. II, 480, and Pok. 674).

20.) Lith. kaplȳs//kãplis m., kaplẽ f. : PSl. motyka (e.g. OCS motyka, Pol. motyka, etc.); the Lith. word is an obvious derivative of kapóti 'hacken, spalten, hauen' (= Slav. kopati) [cf. Pol. kopaczka 'hoe'.] But the Slav. word, mistakenly interpreted as a borrowing from Vulg. Lat. mattiuca 'club', refers to one of the most archaic agricultural tools, deeply rooted in the traditions of Slavic folklore (see E. Gasparini, 1973: 37-43) and therefore it cannot be a borrowing from Vulgar Latin. Moreover, the borrowing from Vulg. Latin is phonologically impossible as one should expect PSl. *motjika from mattiuca, i.e. OCS *moštika, Pol. ${ }^{*}$ mocyka, Russ. *mocika, etc.: motyka is rather an archaic IE agricultural term (extended in Slavic by the suffix -yka) with correspondences in Latin,

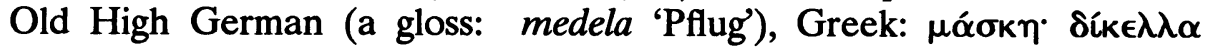
(Hesychius), and in Old Indian: matyá- n. 'Egge' or 'Kolben', mati-krta'geeggt' or 'gewaltzt' (Vasm. II, 665 and Pok. 700).

21.) OLith. piúklas (contemporary meaning 'saw'), NLith. piáutuvas, but Latv. sirpis (a Slav. loanword?) and izkapts, an obvious derivative of iz-kapât 'hew, cut out' (= Lith. -kapoti, Slav. -kopati) : PSl. sbrpz (e.g. ORuss. sbrpz, Pol. sierp, etc.); the Lith. words (and OPruss. piuclan) are transparent derivatives of the verb piáuti 'mow' (see above), but the Slav. word seems to be an IE agricultural archaism with correspondences, e.g. in Gr. ״̈ $\rho \pi \eta$ 'Sichel' and Lat. sarpio//sarpo,, -ere 'beschneiteln, abschneiteln', etc. (Buck 508, Traut. 260, Vasm. III, 609-610 and Pok. 911-912, who even reconstructs PIE *serp- 'Sichel, krummer Haken').

22.) Lith. sprãgilas, kùltuvas, Latv. sprigalis, spriguols : PSl. cěpz (e.g. Pol. cep, Russ. cep, S-C cijep, etc.); the Balt. words, according to Fraenkel (II, 877), are derivatives of the verb represented by Lith. sprageti '...platzen, bersten, knallen, knarren', and the Lith. kùltuvas - a derivative of külti 'thresh' (see above); for the PSI. céps one should reconstruct *(s)koipo- and compare it with Gr. okoinos 'die Grundbalken, auf denen die Ziegel ruhen', also 'Töpferscheibe', $\sigma \kappa i$ ' $\pi \omega \nu$ 'Stab', Lat. scipio idem, etc., which indicates the primary meaning 'split branch, stick' (Bern. 125, Vasm. IV, 299 and Pok. 922). 
23.) Lith. gìrnos f. plur. PSl. *žbrny, gen. -ъve (e.g. OCS žrъny, -ъve f. and žrınovъ m., OPol. żarnow, Russ. žërnov, etc.); a common archaism (Traut. 89, see also Palomé, 1972: 53).

Let us now recapitulate the results of this etymological survey of basic agricultural terms in Baltic and Slavic. Among the 23 notions discussed above, 9 are expressed by common archaisms: these are the activities 'plow', 'sow', 'grind', 'the “objects" 'garden bed', 'seed', 'wheat', 'oats', 'plow', 'handmill'; 13 notions are expressed by unrelated words from among which the majority represents independent formal or semantic neologisms separate in each linguistic group (Lith. kviečiai, a Germc. loanword, also belongs here). Only 2 notions 'rye' (Secale cereale) and 'plowshare' are expressed by common neologisms. But the former (*rugia-//*rugi-) has an exact correspondence in Germanic and belongs to the North IE lexical innovations, the latter (*lemesia-) may be a Slav. loanword in Baltic. Thus no certain Balto-Slav. neologism is left among the basic agricultural terms.

I think that this situation is symptomatic. It seems to prove that the prehistorical ethno-linguistic contacts between the Balts and the Slavs, or the so-called Balto-Slav. "communicative unity" (Verkehrsgemeinschaft) ceased to exist in the very remote past, at the stage of very primitive agriculture, which explains why $40 \%$ of common Balto-Slav. agricultural terms are IE archaisms preserved in these two linguistic groups.

That the ethno-linguistic split between the Balts and the Slavs took place at that primitive stage of culture is, among others, proven also by the characteristic semantic change which affected the PIE term *'r'Hno'seed (of grain)' in East Baltic, namely: Balt. *žirna- means in Lithuanian and Latvian 'pea' (Pisum sativum and others). This change acquires its significance in connection with the prehistorical fact that the pea belongs to the oldest cultivated cereals in Eurasia at the stage of the so-called "hoeing agriculture." This semantic specialization in East Baltic seems to indicate that at the time when it took place, the pea was the most common cereal (grain), grain par excellence, at least among the ancestors of the Eastern Balts. It is also probable that the preservation of the primary general meaning of PIE *'r'Hno- in Old Prussian (syrne f. 'Korn') was due to the Slav. (Polish?) influence.

Obviously, I do not intend, nor do I feel sufficiently prepared, to analyze the whole traditional vocabulary of the Balt. and Slav. languages in a similar way. But even a superficial glance at some "semantic fields" suffices to convince one that the Baltic, and particularly the Lithuanian vocabulary is in general more archaic, or rather, more conservative than the Slavic vocabulary. Many good examples are provided by the pastoral terminology, which in Baltic has preserved a very archaic character. For 


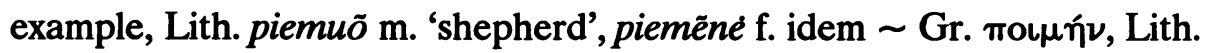
pienas, Latv. piẽns 'milk' OI páyas n. '(Lebens)saft, Wasser, Milch', Av. payah n. 'Milch', paèman- n. 'Muttermilch', etc., Lith. pýti (pyjù//pyniù) 'become "lactiferous" (referring to cows)', etc. OI pyáyate, páyate 'strotzt, schwillt' (Fraen. I, 585 and Pok. 839 s.v. $p \delta(i)-$ 'Vieh weiden, hüten', and 793-794 s.v. pei(a)- 'fett sein, strotzen'). Slavic shows traces of the latter root in OCS pitěti 'nähren, ernähren' and pišta 'Speize, Nahrung, Üppigkeit', both from PIE *pitu- 'Trank, Speise'. In connection with these archaisms of the pastoral terminology in Baltic, we should also mention the preservation of the PIE name for horse, *ek'uo-, in this linguistic group: OLith. ašvà, ešva 'mare'. As is well known, in Slavic even the vestiges of that name have not been preserved. Here we should also recall the results of the semantic analysis of the innovative Balto-Slav. substantives performed by Sławski (see above). Namely: among 289 common innovations, only 27 terms belong to vocabulary that can be defined as "social". It is a strikingly small number. Therefore, if the so-called "Balto-Slav. communicative unity" existed, then this event must have taken place at a relatively low level of culture, i.e. without a higher tribal organization, common war expeditions, common religious beliefs and rituals, etc. Such a stage fits into the picture of the culture which is usually reconstructed for the PIE epoch around the year 3,000 B.C.

In view of the above facts, a statement by J. Rozwadowski, formulated in 1912 in the essay mentioned earlier, deserves to be quoted:

Thus the following pattern of the development of Balto-Slav. linguistic relations can be assumed with a high degree of probability:

1.) The period of primary community (prawspólność) lasting probably into the third millenium B.C.;

2.) The period of a split and separate linguistic development, somewhere in the second and first millennia B.C.; of course, it is impossible to delineate more precisely its chronological limits - that period could have begun a little earlier or later, it could have lasted a little longer or shorter time;

3.) The period of new contacts and neighborhood, which started more or less about the time of the birth of Christ, and has lasted until today. (Rozwadowski, l.c. 24)

After the split between the Pre-Balts and the Pre-Slavs, their linguistic ancestors began to live separate ethno-linguistic lives, and an independent development of the two linguistic groups began; the Balts, 
already dialectally differentiated into the western (Old Prussian) and eastern (Lithuanian and Latvian) branches - preserving the more archaic character of their language(s) on the one hand, and the Slavs, i.e. Proto-Slavs, moving quite rapidly in the direction of the characteristic changes which ultimately produced the linguistic stage reconstructed as the so-called Common Slavic, i.e. late Proto-Slavic. Needless to say, this reconstruction is substantially facilitated by Old Church Slavonic, which represents a stage in the second half of the ninth century A.D., and is quite close to late Proto-Slavic, in spite of some dialectal South Slavic, and particularly Macedo-Bulgarian, features.

It is difficult to determine when the characteristic Proto-Slavic linguistic development began. Such a development must have been a result of the loosening - and ultimately breaking - of closer ethnic (i.e. social and cultural) contacts between the linguistic ancestors of the Slavs and those of the Balts. According to J. Rozwadowski, this happened sometime between the third and second millenia B.C. But the comparative historical grammar of Slavic languages studied against IE background seems to indicate that Proto-Slavic preserved quite an archaic or conservative character until the birth of Christ. In its essential phonemic features, it was not different from, at least, East Baltic: e.g. the preservation of the basic quadrangular vowel system

$\begin{array}{ll}\check{l} & \check{u} \\ \check{\rightleftarrows}(\stackrel{\check{e}}{)} & \check{J}(\check{a})\end{array}$

and also of the diphthongs, and the velars were still unchanged before front vowels and probably before [j], etc.

But this archaic phonemic system could already have been accompanied by quite an innovative morphological system and by many lexical changes stemming from different geographical and cultural conditions, and from ethno-linguistic contacts with other IE groups (Iranian, "Venetic", etc.). So we can imagine a gradual development of a characteristic Proto-Slavic (PSl.) lexicon starting somewhere already in the second millennium B.C. In this way we reach the subject of PSI. lexical innovations.

As we have seen, Trubačev discovered some very interesting old lexical ties between Slavic and West IE languages (Germanic, Italic, and Celtic) in the technical terminology, which do not encompass Baltic. This fact seems to indicate a different "geographical orientation" (i.e. different areal ties) of Slavic in comparison to Baltic. Undoubtedly, at about the same (prehistorical) time Slavic started to develop its own, characteristic 
words using the preexisting (i.e. inherited) material (i.e. roots and derivational suffixes). Of course, at the present stage of our comparative-historical knowledge of Slavic vocabulary, it is impossible to give even a sketchy list of PSl. words that could be considered prehistorical Slavic innovations with respect to other IE languages. For we do not as yet possess a complete reconstructed PSl. dictionary. Three such dictionaries are, however, in preparation: in Cracow, edited by $\mathrm{F}$. Sławski; in Moscow, edited by O. N. Trubačev; and in Brno (Bern), edited by $\zeta$. Ondruš. The first two have published already initial fascicules or volumes (see the bibliography), and can be used as a source. But we possess many etymological dictionaries of individual Slavic languages from among which that of Russian, by Vasmer, and that of Polish, by Sławski, are particularly valuable because of the rich comparative IE material. Of course, there are also well known general Slavic etymological dictionaries by Miklosich and Berneker (only until morz) which provide the basic ground for any comparative-historical study of the Slavic lexicon. This situation enables us to separate some PSI. lexical innovations.

A general evaluation of Proto-Slavic vocabulary from the standpoint of IE, as is well known, was given by A. Meillet in the last chapter of his book Le slave commun 492-517, second edition, in a new printing in 1965. Some of the author's remarks concerning the preservation or the treatment of Common IE lexical elements are very instructive, although Meillet seems to imagine the Common IE vocabulary and its cultural system of reference stemming far too much from a model of the ancient IE civilizations of India and Greece (see, for example, his statement " $L e$ vocabulaire slave indique la conservation d'une vie patriarchale sans prestige, et sans trace ancienne d'une organisation sociale plus large que l'agglomération familiale... Ainsi le slave garde beaucoup du vocabulaire indo-européen, amputé de quelques-uns des termes les plus caractéristiques de la civilisation aristocratique indo-européenne. Mais il présente les mots indo-européens qu'il conserve sous des formes en grande partie remaniées." 1.c. 497).

But Meillet also admits a separate prehistorical period in the development of Proto-Slavic vocabulary and culture: "Ce qui marque le mieux l'existence d'un certain vocabulaire de civilisation créé en slave même, c'est le fait qu'on trouve à l'époque historique des composés ou des dérivés d'allure entièrement slave, mais qui ne sont plus analysables ou dont la formation n'explique plus le sens: ainsi člověkъ 'homme', nevěsta 'jeune mariée', otrokb 'enfant, esclave', srzdobolja 'parent',...(1.c. 500).

Lexical examples like those above quoted by Meillet can be multiplied. Their etymology, for example, that of člověks (*čelověkz//*čblověkz) and 
that of srodobolja ( ${ }^{*}$ sbrdobolja) can shed some light on some interesting aspects of PSI. culture. There is no place to undertake such a task. I will mention only that the obscure term ${ }^{*}$ sbrdobolja, or rather perhaps *srbdobolja, attested only in OCS and ORuss. seems to have nothing in common with *sbrdbce 'heart' and bolěti 'suffer' (this would be a typical "folk etymology"), but if dissimilated from a primary *srbdo-borja could be connected with an archaic IE term *k'red- 'trust' (OI śrad-, Lat. cred- in crēé from cred-dō, etc.) and interpreted as 'trust-bearer', i.e. as the IE archetype *k'red-bhor-ia, etc. ${ }^{23}$

To be sure, we can quote a long list of typical PSl. lexical innovations without any special investigation. For instance, some of these words are discussed in a paragraph of Vstup do porivnjal'no-istoryčnoho vyvčennja slov'jans'kyx mov (ed. O. S. Mel'nyčuk, Kiev, 1966: 526-530).

What follows is an illustrative list of the most common examples quoted in OCS form if attested, otherwise in the reconstructed PSl. form. Since the etymology of the following words can be easily checked in any Slavic etymological dictionary, I will restrict explanatory remarks to only a few cases.

\section{A. Social terms (besides those quoted by Meillet)}

1.) brakz (*borkz or perhaps *bbrakz) 'wedding' (primarily limited to OCS and its underlying dialect, see Trubačev, 1959: 147).

2.) čeljadb 'domestic servants, including one's own children'.

3.) kara, attested in Serb. Church Slav., etc. 'punishment' (derived from koriti 'scold, denounce').

4.) kažo, kazati 'show, tell, etc.' (the primary meaning is 'pronounce in public, announce'?).

5.) koriti 'scold' (a more general meaning in Proto-Slavic seems to have been 'humiliate'), hence kara 'punishment', see Vasm. II, 320-321).

6.) plemę 'generation, tribe' (probably a secondary transformation through the "folk etymology" of PIE *pleHdh-men- whose first component would correspond to Gr. $\pi \lambda \eta \theta \hat{u}$ s, $\pi \lambda \hat{\eta} \theta$ os n., Lat. plēbs).

7.) pols 'half, side, region; sex' (the primary meaning seems to have been 'moiety', i.e., that of a tribe or a tribal settlement, which accounts for the basic meaning 'community' of this stem in West Slavic, e.g. Polish społek, społeczny, społeczeństwo, etc.

8.) *potbběga, attested in OCS potbpěga, podbběga, etc. 'divorced wife', i.e. 'a wife sent back to her family' (undoubtedly a compound of *potb = Lat. potis, etc. 'lord, husband' and běga from běgg, *běgti 'run away').

9.) rods 'kind, origin, birth' (the most general meaning in Slavic languages 'kin', replacing PIE *g'enos). 
10.) sębrъ, attested in ORuss., modern Russ. sjabër, gen. sjabrá, etc. OSerb. sebrb, etc.; the basic meaning seems to be 'neighbor, member of the same community', as, for example, in ORuss., see Vasm. III, 824.

11.) sodz 'judgment, court', and its derivatives:

12.) soditi 'to judge'

13.) sqdiji (sqdija) 'judge'

14.) šurb (Church Slav.), šurinz (ORuss.), etc. 'wife's brother'; PSI. *šurbjb (for the etymology, see Trubačev, 1959: 138-139, but in my opinion this is probably a regular satem-word whose root is identical with that of the kentum-forms kury, gen. kurzve and *pras-kurz//*pras-čur, i.e. the PIE archetype would be *'éuriio-, etc.; for details, see page 100 of this chapter).

15.) svoboda//(sloboda), the latter, e.g. in Serbo-Croat., ORuss., and Slovak, 'freedom'; in this connection, it should be mentioned that the ethnicon Slověne from an older *Sloběne//*Svoběne, see Ptolemy's

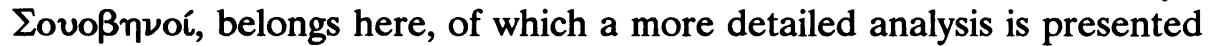
in Chapter Five of this book.

16.) svobodb indecl. adj. 'free' (probably transformed from *svo-potb, see Av. $x^{\mathrm{v} a e \bar{p}}$ atay- 'er selber, selbst', Bartholomae 1860-1861, under the influence of svoboda: so in Slavic we would have another vestige of PIE *poti-, besides gospodb and *potbběga, again a Slav. Iran. correspondence.

17.) tbstb 'wife's father'.

18.) tbšta ("tb̌ča) 'wife's mother'.

19.) velbmoža 'prince, ruler' (a compound of vel-bjb 'great, big' and mogQ 'can').

20.) velbjb 'great, big' (probably connected with velěti 'order, command').

21.) vladyka ("voldyka) 'ruler, commander'.

22.) vojevoda 'military leader' (cf. OHG herizogo, NHG Herzog, Gr.

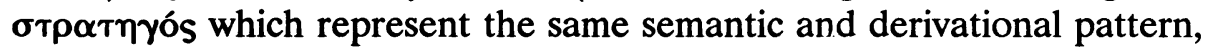
but not necessarily the model for the Slavic word).

23.) vojinb (vojb) 'warrior'.

24.) vojina, attested in Russ. Church Slav., etc. 'war'.

25.) vojwska 'army' (the last three words derived from the IE verb *ueio, see Lith. vejù, výti 'chase, etc.', represented by OCS po-vi-nq-ti 'subjugate').

26.) vznukz, attested in ORuss., etc. 'grandson' (a PSl. derivative of IE *an(ou)- 'old man, ancestor, old woman', etc., see Lat. anus, gen. anūs 'old woman'; for comparative IE material, see Pok. 36-37).

27.) zakonz 'law' (of course, this means 'customary law', an old derivative of $z a-c ̌ b n Q,-\check{c} e ̨ t i$ 'begin', so etymologically, this is 'principle', i.e. 
'principium, what is at the beginning (of social order)', etc.).

28.) žbrbcb 'priest' (a PSl. derivative of žbrq, *žbrti 'sacrifice, a characteristic Slav.-Iran. correspondence in religious terminology).

B. Names of some animals

29.) bykz, attested in Russ. Church Slav. and all Slavic languages, 'bull' (for a recent etymological attempt, see Gribble: Linguistics 113 (1973), p. 53-61).

30.) kobyla 'mare' (probably ko-byla, with prefixal ko-, treated in my etymology of komonb, see below).

31.) komonb, attested in ORuss., Ukr., and Czech, 'battle horse' (see my recent etymological attempt, according to which komonb stems from PIE *k'omo- 'hornless', see Pok. 556, thus another kentum element in Slavic). ${ }^{24}$

32.) kon'b 'horse' (derived from the latter, i.e. *komnio-).

33.) kura, attested in most Slavic languages, e.g., Russ. kúra, S-C küra, Cz. koura, etc. 'hen'.

34.) kurb 'rooster'.

35.) lisz//(lisica) 'fox'.

36.) medvědb, attested in Church Slav. and all Slavic languages, 'bear' (a classical example of a PSI. euphemism: *medhu-édis, replacing a primary IE word prohibited by hunters' taboo).

37.) $p b 56$ 'dog'.

38.) vols 'ox'.

39.) zajęcb (early PSl. *zj̄inkos), attested in Church Slav. and in all Slavic languages, 'hare'.

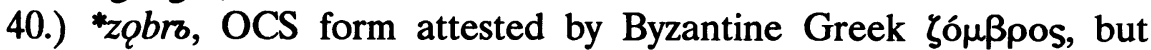
historically known only in North Slav., e.g., Russ. zubr, OPol. zqbr, contemporary Pol. żubr (but in toponyms of the Zębrzyce, etc. type a regular continuation of the original nasal vowel), 'Polish bison'.

C. Words referring to some elements of landscape, both natural and cultural, and to nature in general.

41.) cěsta, unknown in North Slav., except for Czech, 'road'.

42.) *dorga, attested in most Slavic languages, e.g. Russ. doróga, Pol. droga, Cz. dráha, etc. 'road'; the primary meaning '(small) valley', preserved in Serbo-Croat. and Sloven. (see Bern. 212).

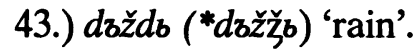

44.) mosts 'bridge'.

45.) oblakb (*ob-volkz) 'cloud'.

46.) ostrovb 'island' (undoubtedly on a river, because of the clear 
etymological meaning 'circum-fluence', etc.).

47.) pol'e (i.e. *polje) 'plain, field'.

48.) rěka 'river, stream'.

49.) tọca, in OCS 'torrential rain, blizzard', but in Russ. 'cloud, storm, rain' and in Pol. 'rainbow', etc.; thus the primary meaning was probably 'storm cloud' (see Vasm. IV, 129).

50.) zarja//zorja 'light (in the sky), aurora' (but cf. Lith. žarà idem).

51.) *žerdló, e.g. Church Slav. žrělo 'spring, source', Russ. žereló 'opening, outlet, etc.', Ukr. (d)žereló 'spring, Pol. źródło idem, etc.

The above group of PSl. lexical innovations can be treated as a sample of PSl. "lexical creativity", i.e. the lexical creativity of the Proto-Slavs stimulated by the specific conditions of their prehistorical environment. For there is no doubt that changing conditions of life, both in the sense of the natural environment and the socio-cultural one, present the speakers of any language with new semantic-lexical demands which must be met. The whole problem boils down to the necessity of expressing new ideas that are indispensable for social communication under the new conditions. There exist several ways of satisfying this necessity or rather this need. First of all, the old inherited words can be semantically adjusted to the new conditions, i.e. they may change their meanings: this seems to be a very economical way of maintaining the flexibility of a lexicon. But the condition that enables such a semantic readjustment of an old word to a new communicative requirement is the disappearance of the old idea (whose carrier the given word has been). This is, however, not a very frequent case because the old ideas, reflecting old conditions, experiences, beliefs, etc. never disappear suddenly and completely. They live in the cultural tradition of every ethno-linguistic group. This preservation and transmission of old conditions, experiences, beliefs, etc., i.e. old ideas, is especially characteristic of the preliterate societies whose whole spiritual culture is continued by oral tradition. Moreover, we know that such societies change very slowly and only rarely are faced with sudden socio-cultural upheavals requiring deep semantic readjustments of their traditional vocabularies. So it seems that this path in the development of vocabulary does not play a significant role in prehistory, although it would be very interesting and rewarding to show such semantic changes in the inherited IE vocabulary of Proto-Slavic. They would prove, for instance, which socio-cultural changes took place in the life of the Proto-Slavs after they had begun their separate ethnic development, etc. For example, the fact that PIE *poter 'father' (as chieftan of an extended patriarchal family) disappeared in Slavic and has been replaced by a derivative of PIE *atta 'daddy' (PSl. *otbcb) ${ }^{25}$, an 
obvious nursery word, seems to suggest that the authority and formality of the primary patriarchal system must have been somehow weakened among the Proto-Slavs. This suggestion agrees well with recent arguments of E. Gasparini, who attempts to prove some matriarchal features in the primary Slavic culture.

The second way of adjusting the vocabulary of a language to the new requirements of changing life is simply derivation of new words, which, of course, uses inherited lexical morphemes, combining them into new words according to existing derivational (or word-formational) patterns. This way seems to play the principal role in the prehistorical development of slowly changing and relatively isolated languages or ethno-linguistic groups. If a language under investigation belongs, as Proto-Slavic does, to a well-known and extensively studied linguistic family whose protolanguage is reconstructed - then we have a chance to separate such new words (lexical innovations with respect to the reconstructed common stock of the protolanguage), and in this way we also obtain the possibility of reconstructing the corresponding changes in the life conditions (both natural and cultural) under which such lexical innovations originated. The list of PSI. words quoted above in most cases seems to belong to this category.

The third way for a language to make lexical adjustments to the requirements of changing life is simply to borrow from foreign languages. Lexical borrowing from foreign languages usually presupposes direct contact between the speakers of the respective languages. These may be contacts "en masse" between whole ethnic groups, or only between some individuals belonging to the two groups. In the first instance, the phenomenon of bilingualism may develop, i.e. a sufficiently spread knowledge and usage of the two languages by the ethnically heterogeneous population in areas of close territorial and social contacts (e.g. ethno-linguistically mixed settlements or settlements of two separate ethno-linguistic groups, but located so close together that social contacts are everyday occurences, etc.). In the second case, bilingualism, if it occurs, has an individual character and seems to be insignificant for socio-linguistic processes. Whether a lexical borrowing spreads under conditions of bilingualism or not, is relevant for the semantics of the borrowing (see the important insights and contributions of Martynov in this respect in his book on the Slavic-Germanic lexical contacts, which are discussed in the appropriate chapter of this book). Bilingualism also produces so-called calques linguistiques (loan-translations). A separate chapter of this book is devoted to obvious foreign borrowings in the PSI. vocabulary, and is entitled "The Slavs and Neighboring Peoples". As the title itself indicates, the analysis of loanwords is the main source of our 
knowledge of the type of prehistorical relations between the Slavs and other peoples of that part of Europe where the Slavs lived and spread out.

However, in the present chapter we have been interested in and concerned with the different dialectal IE strata in the PSI. vocabulary. Having completed our analysis, we should attempt to translate the spatial relations represented by different layers of dialectal IE words in Proto-Slavic into corresponding chronological relations. In this way we may obtain some insight into the relative chronology of the gradual crystallization of the Proto-Slavs within the IE peoples of prehistorical Europe, their changing geographical location, and their prehistorical culture.

Let us recapitulate briefly the general results of the preceding paragraphs in terms of a probable chronological sequence of successive dialectal IE layers in the PSI. vocabulary:

1. Satem.

2. Kentum.

a) older, including Baltic.

b) younger, excluding Baltic.

3. Eastern, i.e. Balto-Slavic Aryan correspondences.

a) older, including Baltic

b) younger, excluding Baltic

c) the youngest, containing Slavic Iranian correspondences only.

4. North-West Indo-European, i.e. Balto-Slavic Germanic Italic $\sim$ Celtic correspondences.

a) older, including Baltic

b) younger, excluding Baltic

c) the youngest, containing special Slavic Italic correspondences.

5. North Indo-European, i.e. Balto-Slavic Germanic correspondences.

a) older, including Baltic

b) younger, excluding Baltic

6. Balto-Slavic

7. Proto-Slavic (innovations).

Some of the above layers seem to overlap, at least partly; e.g. satem and eastern, younger kentum and NW Indo-European. Other layers are difficult to chronologize (of course, in relative terms), e.g. younger kentum, to some extent younger eastern, and particularly the youngest eastern, younger NW Indo-European, and particularly the youngest NW 
Indo-European (i.e. special Slavic Italic correspondences), also younger $N$ Indo-European (i.e. special Slavic $\sim$ Germanic correspondences).

Nevertheless, the diagram on page 173 can be proposed.

Some explanations to the diagram:

1.) The lexical layers representing various dialectal zones within Proto-Indo-European are ordered in a hypothetical chronological sequence: the oldest are at the bottom, the youngest at the top.

2.) The absolute dates on the left have only a very general orientation value: they have been suggested by prehistory and history. It is important to emphasize that they denote terminus ad quem a given layer developed, but they do not reveal anything about the beginning of that layer. For instance, there is no doubt that the Balto-Slavic lexical innovations started much earlier than the year 1000 B.C., some of them before 2000 B.C.

3.) The depth of individual layers reflects the number of words belonging to it. Only in the case of Balto-Slavic, the depth has been reduced at least three times for technical reasons. The indented lines indicate that the number of words has not been established. It should also be added that the depth of the Balto-Slavic layer is tentative: I counted substantives and multiplied them by 2 , assuming that all the remaining parts of speech make up the other half.

When we take a look at the diagram of dialectal IE layers in the PSl. vocabulary, one thing appears quite clearly: the older layers are thinner than the younger ones, and the former represent similar depths. But the Balto-Slavic Germanic layer (both parts) already has a total of 150 words, i.e. roughly twice as many as the previous layers. And Balto-Slavic has at least 600 words. These statistical differences between the older and the younger strata of the PSI. lexicon undoubtedly reflect their chronological depth, that is, the great antiquity of such layers as kentum, eastern and NW Indo-European, although, as we have seen, not all elements of the same stratum have to come from the same remote period. We should also remember that the very concept of older and younger lexical layers is purely relative: it concerns not so much the terminus $a$ quo but rather the terminus ad quem, in other words, the so-called younger layers represent those dialectal contacts which lasted longer, reaching the relatively "younger" times. This is obvious in the case of Balto-Slav. 
A Diagram of the Lexical Stratification of Proto-Slavic

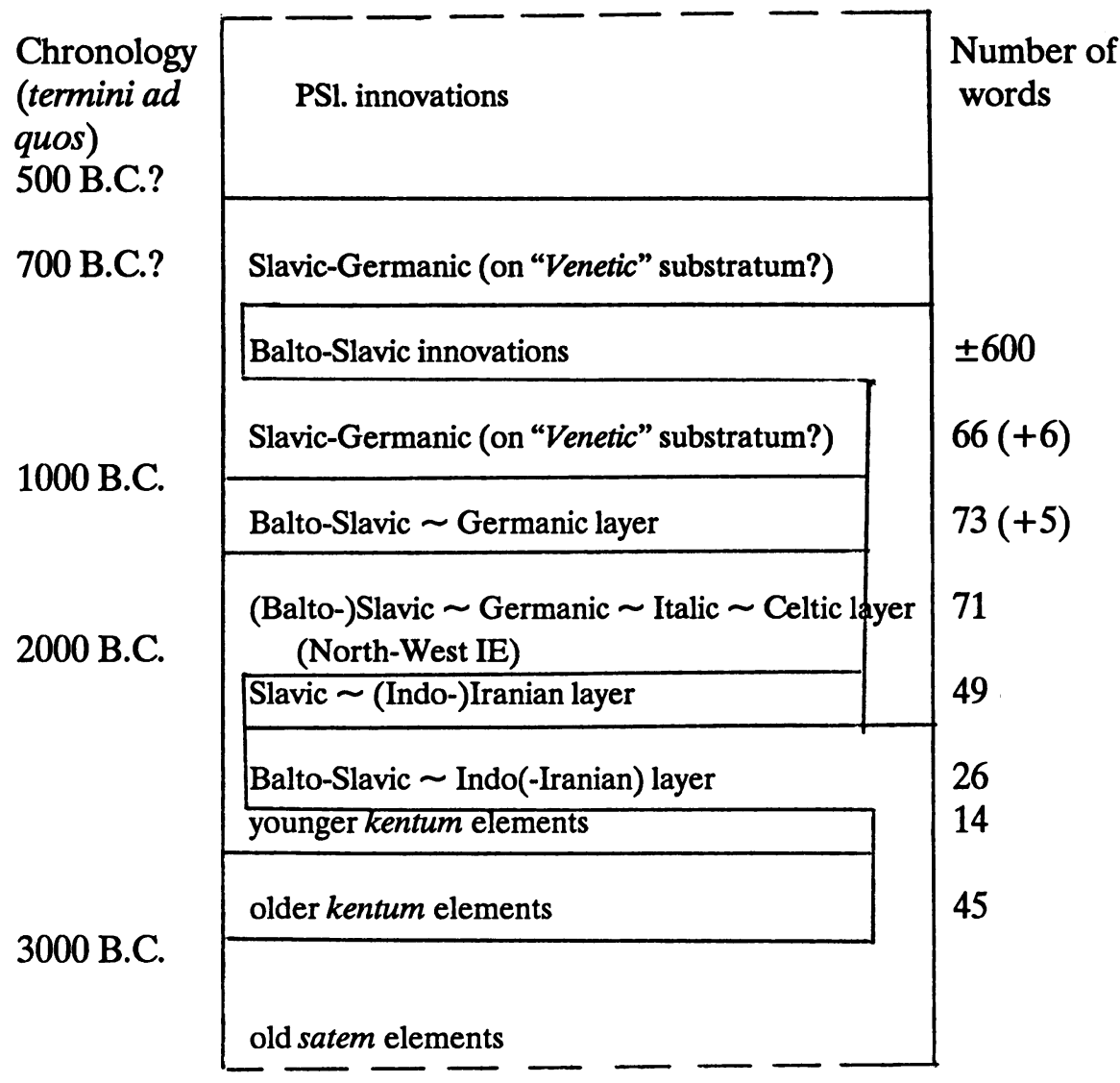

For a linguist concerned with ethnic prehistory, however, a semantic analysis of the successive strata of PSl. vocabulary is of decisive importance. In this respect what have been our conclusions? Among the old kentum words, there are nine terms connected with cattle-breeding, six terms connected with wooden architecture, three names of tools, seven terms referring to social life, that is, twenty-five words referring to culture rather than nature. Among the Slavic (Indo-)Iranian words, eleven terms refer to religion and magic, nine terms - to morality, law, and social functions, and ten terms - to health, parts of the body, and organic functions: thus, we have thirty words connected with some very important aspects of life. Here we should especially underline the twenty terms belonging to the religious and social sphere of life. Among the NW Indo-European words we have some old agricultural terms (11), very few social terms (5), no religious terms (sic!), and a lot of technical terms. This latter fact is very significant. Among the $\mathrm{N}$ Indo-European words 
there is a general lack of religious terms, very few social terms (drugz, l'udbje, *voldq); the overwhelming majority are technical terms referring to simple objects and tools made of wood.

A similar semantic analysis of Balto-Slavic words would require a separate chapter. For example, I attempted to show that in the basic agricultural terminology there are very few common Balto-Slav. innovations (actually only one: *lemesia-). According to Sławski, among the 289 innovative Balto-Slav. substantives 124 terms refer to nature (flora, fauna, lanscape, weather, etc.), only 28 terms refer to social or rather socio-cultural life (including weapons and musical instruments); from among which at least four should be eliminated as irrelevant or actually belonging to the North Indo-European lexical stratum - thus we have at most 24 socio-cultural terms out of 289 substantives! To be sure, there are among them some important concepts: 'enemy', 'peace', 'fame', 'deal', 'family', 'nephew', 'son-in-law', etc.

It is striking that in the two first (oldest) layers (kentum and Slavic (Indo-)Iranian) the number of social terms (here also including religious, etc. terms) is relatively the highest $(44: 7,75: 20)$, while in the later layers the number of such terms is insignificant $(76: 5,150: 3,289: 24)$. In these later layers from among the words referring to culture, the technical terms seem to be the most numerous (e.g. among Balto-Slav. innovations 81 terms according to Sławski refer to "human work").

This semantic distribution of words belonging to the five old layers of Proto-Slavic vocabulary is significant. It seems to indicate that the basic social institutions and corresponding ideology were formed in a very remote epoch when the ancestors of the Slavs still remained within the dialectal configuration of late Indo-European. On the other hand, everything points toward close ethno-cultural ties with the Aryan and especially the Iranian group of IE dialects. Of course, we should not imagine those different dialectal ties reflected in Proto-Slavic vocabulary as a simple chronological sequence starting with the satem-kentum exchange and ending with the Balto-Slav. Verkehrsgemeinschaft. The actual sequence of ethnic contacts and demographic shifts, which ultimately underlie any ethnic contacts, was undoubtedly more complicated. Can we reconstruct that sequence and its chronology? I think that some lines of the prehistorical development in question still remain sharp.

First of all, among the kentum words we were able to distinguish older and younger elements, which seems to suggest that the linguistic ancestors of the Slavs twice entered into closer contact with some kentum dialects (or tribes). The first time this probably happened was still in the late PIE epoch (about 3000 B.C.) within the PIE dialectal zone - in 
which they lived close to the kentum : satem isogloss. The period of that contact could have lasted rather long in connection with a gradual movement of the Pre-Slavs and Pre-Balts in a western direction, which must have brought them to the territories previously occupied by the kentum dialects. From that period stem the kentum elements which are common to Slavic and Baltic, e.g., (in Balto-Slav. terms) *kāruāa-, *kerdā-, *garda-, etc. The second close contact with the kentum dialects took place relatively late; it seems to have involved only the Proto-Slavs, already a separate ethnic entity, and some kentum people hypothetically called Veneti somewhere in the Vistula basin, and was connected with an obvious westward movement of the Proto-Slavs. The Proto-Slavs were being pressed in this direction by the Iranian nomads (the Scythians) of the Pontic steppes (about 700 B.C.). The hypothetical Veneti people were at least partly absorbed by the Proto-Slavs: hence a new stratum of kenutm elements in Proto-Slavic that has correspondences in NW Indo-European dialects, e.g., kotiti (se), kotora, golobb, etc.

The prehistory of Slavic-(Indo-)Iranian ties should also be divided into two epochs: older and younger. In the older epoch which can still be located within the IE dialectal period ( \pm before 3000 B.C.), the linguistic ancestors of the Balts and the Slavs must have had direct territorial contact with the ancestors of the Aryans so that common terms could spread in both groups, i.e., in the pre-Balto-Slavic dialects and in the pre-Aryan dialects, then the pre-Balts moved away (in a northwesterly direction towards the Upper Dniepr basin), while the pre-Slavs seem to have remained for some time at least in territorial contact with the Northern (Iranian) branch of the (pre-)Aryans: hence appeared the old Slavic-Iranian word correspondences. But in connection with a general migratory movement of the (pre-)Aryans in a southeasterly direction to Iran and India, these pre-Slavic (pre-)Aryan (especially pre-Slavic (pre-)Iranian) contacts were broken. This took place somewhere before the year 2000 B.C., since around that year the Proto-Indoaryans arrived in Northern Iran (see M. M. Winn, The Journal of Indo-European Studies, Vol. 2.2, 1974: $133 \mathrm{ff}$.). But after some 1300 years the back wave of Iranian nomads, who adapted horses for riding and developed a high level of horsemanship, appeared in the Pontic steppes (reaching as far north as the Upper Don and Upper Sejm basins!). Thus the second, younger, but more prolonged period ( \pm until the arrival of the Goths in the third century A.D.) of close ethno-cultural and linguistic exchange between the Proto-Slavs and the Northern Iranians began. From that period a characteristic set of Slavic-Iranian correspondences in religious terminology (bogz : divz = ba ya- : daevva-, etc.) has emerged. ${ }^{26}$ Of course, it is impossible to separate the older layer of Slavic-Iranian correspon- 
dences (from the epoch before 2000 B.C.) and the younger one (from the epoch 700 B.C. - 300 A.D.). But we must be aware of that. In the older layer we are dealing rather with late IE dialectal correspondences, in the younger one - with a kind of semantic readjustment of inherited IE words by the Proto-Slavs to their etymological correspondences in Iranian on the basis of close ethno-cultural ties (a kind of tribal federation - if not Iranian domination, see Herodotus's description of the northern neighbors of the Scythians, the Nevpoí and the Bovôvol).

The problem of the so-called North-West IE layer in Proto-Slavic, which, as we have seen, comprises chiefly old European agricultural and technical terms, is very interesting. First of all, we should remember that the technical terms (Trubacev's handicraft terminology) do not have any correspondences in Baltic, which clearly indicates that in this respect Proto-Slavic participated in the so-called Central European cultural zone (Italo-Celtic, Germanic, Slavic). How can we explain this phenomenon? I think that we are again dealing here with two epochs of dialectal contacts: an older one from which chiefly stems agricultural terminology (these terms usually have correspondences in Baltic), and a younger epoch, from which the handicraft terminology comes. The former epoch belongs to the dialectal IE period (still probably before 3000 B.C.), the latter represents the period of a later linguistic and cultural exchange between the Proto-Slavs, who were at least geoghraphically separated from the Balts, and the Central European tribes - Italic, Celtic, "Venetic", and ultimately, Germanic. This period of exchange could have begun around 2000 B.C., and become particularly intensive during the second, and especially the first millennium B.C., when the Proto-Slavs were moving westward and ousting or absorbing the "Veneti".

Here I would like to repeat the hypothesis already expressed in the course of my earlier analysis - that some characteristic correspondences in the technical terminology between Slavic and Germanic may be due to the fact that both the Proto-Slavs and the Proto-Teutons seem to have absorbed the hypothetical kentum tribe of "Veneti", who in the second millennium B.C. separated the two IE groups from each other. Of course, it would be tempting to connect the "Veneti" with the so-called Lusatian culture (1300-600 B.C.). In any case, the lexical correspondences between Slavic, Italic, Celtic, and Germanic should be treated as an example of a common cultural terminology spreading across dialectal or linguistic boundaries in connection with the development of a cultural zone of intensive economic exchange (primitive metalurgy, barter trade, etc.). Baltic, which at that time was already located north of Prypeć, and in the Upper Dniepr basin, did not participate in this hypothetical cultural zone, but Slavic (whose core at that time probably was located in 
Volynia and in the adjacent regions) had close ties with the Central European cultural zone, which included contemporary Poland, Bohemia, and southern Germany. It is striking that the north-eastern boundary of this hypothetical cultural zone seems to overlap with the so-called rubiez etnograficzna in Polish territory (see J. Czekanowski, 1957: 385-391, especially the map on page 386). By this term is understood a bundle of lines marking the range of different objects from the historical and prehistorical folk culture - for example, the southwestern range of the so-called duha and socha, etc., the eastern boundary of the so-called Lusatian culture in the first millennium B.C., and the northern boundary of the so-called Thracian culture in the same millennium, etc. This rubiez parallels, roughly speaking, the axis formed by the Prypeć and the lower Bug rivers, usually running south and southwest of these rivers. In this way most of ethnographic Poland and the western Ukraine (exactly speaking, the greater part of Volynia, the whole of Rus Czerwona (Red Ruthenia) and Podolia are separated from the historical territory of the Grand Duchy of Lithuania, which comprises ethnographic Lithuania and Byelorussia. It has been noted that the ethnographic-prehistorical boundary under discussion overlaps with an old botanical boundary in this part of the European continent, namely between the north-eastern zone of evergreen (coniferous) woods and the southern and western zones of parkland. This coincidence between old botanical and cultural boundaries on the one hand, and old lexical isoglosses within prehistorical IE dialects on the other, is worth emphasizing. It seems to prove that ethno-cultural and linguistic contacts have followed the same geographical pattern ultimately conditioned by the natural landscape.

Let us pass on to the North European stratum (Germanic-Baltic-Slavic). We can, and should admit that at least some of the lexical correspondences in question originated in the epoch of IE dialects around 3000 B.C. This supposition seems to be supported by other old linguistic features connecting the North IE dialects, in both phonemic and morphological developments (see above). For example, the numeral '1000' ('tūsk'mntia -) belongs here. But the dialectal ties, i.e., the close territorial neighborhood among the corresponding IE tribes (Pre-Teutonic, Pre-Baltic, and Pre-Slavic), which made the spread of lexical innovations possible, was undoubtedly prolonged into the next (III) millennium B.C., probably until around 2000 B.C. At this time, the ancestors of the later Teutons moved westward, ultimately reaching southern Scandinavia and Jutland.

But there are also special Germanic Slavic lexical correspondences without parallels in Baltic. They must be treated as probably younger. Technical terms are especially characteristic among them. My contention 
is that they appeared in the two linguistic groups as the result of a common West IE substratum ("Venetic"?), absorbed gradually by both the early Teutons (or Pre-Teutons) and the early Proto-Slavs (or Pre-Slavs) sometime in the first half of the first millennium B.C.

As we have seen, the problem of the so-called Balto-Slavic linguistic unity, etc., or rather, as Bernštein proposed, Verkehrsgemeinschaft still remains one of the most controversial problems of comparative IE linguistics. However, the numerous lexical correspondences between Baltic and Slavic, coming from a prehistorical epoch, are an undeniable fact, and foremost among them are an impressive number of common lexical innovations. This phenomenon, together with many specific Balto-Slavic innovations in the phonemic and morphological development of these languages, must be accounted for in historical terms. I think that the concept of Verkehrsgemeinschaft is very productive in this respect. If we agree that two adjacent tribes sharing a long common border, and speaking very similar dialects had an exchange of goods and services, then we must accept a kind of common vocabulary enabling them to communicate. Such a common vocabulary referring to things and activities involved in exchange could be a result of the expansion - by imitation - of the lexical innovations formed in either of the respective dialects. For example, the Balto-Slavic word *rankā- 'hand' (Lith. rankà $\sim$ OCS rqka, etc.) has a transparent etymology in Baltic, because in Lith. the basic verb renkù, rinkaũ, riñkti 'gather' is still preserved, while in Slavic it remains unmotivated. So we could hypothesize that it represents a lexical innovation which originated in Proto-Baltic and then spread to Proto-Slavic at the time of the Balto-Slavic Verkehrsgemeinschaft. Note that 'hand' plays a very important role in the primitive social (especially legal) symbolism. In this respect, it would be quite interesting and rewarding to check which of the common Balto-Slavic innovations still have an etymological motivation ${ }^{27}$ in only one of the branches or languages in question.

But the question that is central to the whole problem of Balto-Slavic ethno-linguistic relations in prehistorical times is the chronology of these relations. I have quoted above the views of J. Rozwadowski about a prolonged prehistorical period of ethno-linguistic separation between the Balts and the Slavs which accounts for deep differences in the vocabularies of the respective languages. I propose the following chronology regarding this: the linguistic ancestors of the Balts and the Slavs formed a close dialectal group within late IE before 3000 B.C. This group had as immediate neighbors the ancestors of the Teutons somewhere in the west or north-west, and the ancestors of the Aryans somewhere in the east or south-east. Such a configuration of the 
respective late $\mathrm{IE}$ dialects probably lasted until the first half of the third millennium B.C. But during the second half of that millennium, decisive population shifts (migrations) seem to have taken place: the pre-Teutons moved westward, the pre-Aryans south-eastward, leaving the ancestors of the Balts and the Slavs as an isolated group which now entered a period of common Balto-Slavic innovational development known as the Proto-Balto-Slavic period. ${ }^{28}$ How long it lasted, we do not know. But in order to create such an impressive number of common Balto-Slavic innovations, it had to have lasted for a relatively long time, probably deep into the second millennium B.C. or even longer. In any case, in the first half of the next millennium, when the Proto-Slavs entered into closer ethno-linguistic relations with the Iranian Scythians (about 700 B.C.), the ties with the Proto-Balts were already severed. Thus typical Slavic-Iranian lexical correspondences and obvious Iranian loanwords in Slavic do not find counterparts in Baltic. In any case, when the eastern Slavs had begun moving northward into the Upper Dniepr basin after the middle of the first millennium A.D., and similarly, when the western Slavic tribes had settled (much earlier) in the Lower Vistula regions they encountered the Balts as a completely separate, different group of tribes with whom a Verkehrsgemeinschaft was no longer possible. A period of at least 1500 years of separate cultural and linguistic development without any significant cultural exchange between these two dialects (primarily so closely related) was sufficient to transform them into separate languages. Of course, in order to account for that dissolution of the Balto-Slavic Verkehrsgemeinschaft, we must take into consideration the primary geographical location of the respective peoples and their subsequent shifts. This problem will be discussed in the next and last paragraph of this chapter, which is entitled: The hypothetical geographic distribution of IE dialects in the fourth through the third millennium B.C. and its successive changes.

In order to facilitate the presentation of the problem it will be useful to apply a technical device. If we accept the East Ukrainian and South Russian steppes with adjacent park-land and forest belts reaching northward as far as the Upper Dniepr and Upper Oka, and with enclaves extending southward towards the Kuban and Terek rivers, and eastward beyond the Volga - as the prehistorical habitat of the Indo-Europeans in the fourth millennium B.C. (see J. Mallory 1973), then we shall have a concrete geographical basis onto which we can project a diagram of the prehistorical IE dialects proposed by J. Kuryłowicz (1956: 166-171)). As a result, we shall obtain a schematic map (Chart 4, p. 186) on which a line separating the steppe zone from the forest zone should be added. This map, if read and interpreted carefully, tells us all the relevant things 
about the prehistorical movements of the separate IE peoples, and in this respect, about the gradual formation of the Slavs, i.e., their ethnogenesis.

First of all, the North IE dialectal group encompassing the ancestors of the later Proto-Teutons, Proto-Balts, and Proto-Slavs ${ }^{29}$ could occupy only the northern part of the above demarcated IE habitat, i.e., the forest and park-land areas extending east of the Upper Dniepr, south of the Upper Oka, across the Upper Don towards the lower Volga, but not reaching it. On the basis of the later expansion and historical distribution of Germanic, Baltic, and Slavic on the one hand, and on the basis of old linguistic ties between these three branches of IE on the other hand, we can assume that the distribution of the respective IE tribes and dialects (i.e. Pre-Germanic, Pre-Baltic, and Pre-Slavic) in the fourth millennium B.C. within the northern area of the primary IE habitat was as follows: the ancestors of the Teutons dwelt in the north-west of that area between the Upper Dniepr and the Upper Oka, the ancestors of the Balts occupied a more eastern or south-eastern position towards the Upper Don basin, the ancestors of the Slavs dwelt in the south-east of the area in direct contact with the Pre-Aryans who were concentrated along the Lower Volga (notice the old Iranian name of this river: 'P $\hat{\alpha}$, see Rozwadowski 1948: 256). The southern group of IE dialects occupied, of course, the steppe regions of what is known as the historical Ukraine. Such a location for the early IE dialects and respective tribes in the fourth millennium B.C. accounts (in a simple way) for the directions of their later expansion (marked on the map with arrows).

Now, if we look carefully at the map, we see that the Pre-Teutons had only one route westward: the northern, along the Niemen and Dvina Rivers towards the Baltic Sea. Obviously, this is the same route which was taken later on by the Proto-Balts, and in historical times by the Eastern Slavs (the Byelorussians). But an important question arises: how did the Pre-Teutons reach Jutland and Southern Scandinavia, where they were ultimately transformed linguistically into Proto-Germanic people? There are two possible routes: one along the southern coast of the Baltic Sea (roughly speaking, this is the way of the later Prussians), another across the Gulf of Riga and the northern Baltic Sea, which are, of course, frozen in winter. Probably both routes were used. That northern route of the Pre-Teutons moving westward is the only logical consequence of the geographical location of the North IE dialectal group within the IE habitat in the fourth millennium B.C. ${ }^{30}$

The southern route to the west was taken by the ancestors of the Celtic and Italic tribes together with some smaller groups like those of the Proto-Illyrians and "Veneti". The two routes were separated from each other by the Prypeć marshes. Of course, there was still a south-western 
route to the Balkans: this was taken by the ancestors of the Greeks, Armenians and Thracians. All these migrations to the west, i.e., to Central and South-Eastern Europe probably took place between 3000 and 2000 B.C. And it is striking that the above geographical pattern of the prehistorical IE migrations overlaps in its essential features with the late prehistorical and early historical migrations of the Slavs, if we agree that the oldest habitat of the Slavs (Proto-Slavs) was in the Middle Dniepr basin (roughly speaking, where the Pre-Italo-Celtic group is located on our map). So, the Western Proto-Slavs moved westward, north of the Carpathians into the Vistula and Upper Odra basins, from where they later turned southward to Moravia and Bohemia; the ancestors of the Southern Slavs took probably a route across the Central Carpathians to Northern Pannonia, and from there by two different ways: a western one, between the Danube and the Alps, and an eastern one, across Transylvania, they invaded the Balkans. It is possible that the route between the Eastern Carpathians and the Black Sea was also used by some tribes belonging to the eastern branch of the Southern Slavs (i.e., by the ancestors of the Macedonians and Bulgarians).

But let us return to the prehistory of the North IE dialectal group. After the emigration of the Pre-Teutons towards the Baltic Sea, etc., and that of the Pre-Aryans towards Iran (across Turkestan and the Caucasus?), which ultimately happened around 2000 B.C., the ancestors of the Balts and the Slavs who remained in their primary habitat isolated from the rest of the IE peoples, since the ancestors of the Italics, Celts, Greeks, etc. also left the territories of the present-day Ukraine, entered the period of a separate linguistic development, known as the "Balto-Slavic epoch" (2500 - 1000/700 B.C.?), which was a simple result of their having stayed in the old habitat. It does not mean, however, that the Pre-Baltic and Pre-Slavic populations were remaining motionless in the once occupied territories. It was simply impossible economically in connection with a primitive extensive agriculture which exhausted the soil and periodically required new arable land. Thus we should also assume some movements and geographical shifts of the Pre-Balts and Pre-Slavs, which probably started before 2000 B.C., mainly as gradual shifts of a primitive agricultural population. After the emigration of the Pre-Teutons, the Pre-Balts took over the territories vacated by the former, and oriented their expansion towards the Upper Oka and Upper Dniepr basins, and then towards the Niemen and Dvina rivers.

In this connection, it is worth mentioning that the hydronym Oka seems to indicate a kentum origin (i.e., Pre-Teutonic). Namely, if we agree with M. Vasmer (III: 127), who derives it from IE *ak'uz 'water' (see Lat. aqua, Goth. ahva, etc., and the hydronyms Osva, $A$ šva $a^{31}$ on the 
Byelorussian and Lithuanian territories) - then Slav. Okà instead of ${ }^{*} O k v a ̀$, which would be a regular borrowing from a kentum *akūa, could only be interpreted as a hypercorrect form of some kentum people of the region (the remnants of the Pre-Teutons?) trying to speak a kind of satem Balto-Slavic.

While the ancestors of the Balts were gradually occupying the Upper Oka and the Upper Dniepr basins, their primary south-eastern neighbors, the ancestors of the Slavs, were also moving gradually westward along the line separating the northern forest zone from the southern steppe zone, i.e., they were taking advantage of the so-called park-lands, which were most favorable for a primitive agriculture. This natural botanical line, which in the region which interests us here, has a distinct south-western direction, inevitably led them towards the Middle Dniepr basin south of Kiev and across the Dniepr towards what is known as historical Volynia and Podolia. In this way they ultimately occupied the regions inhabited earlier by the Pre-Italo-Celtic group. This probably happened during the second millennium B.C. All this time the ancestors of the Slavs were in the Verkehrsgemeinschaft with their northern neighbors, the ancestors of the Balts. Thus, for that period (2500-1500 B.C. at least) we can use with full justification the term "Balto-Slavic epoch", and for the dialects of the respective tribes the term "Proto-Balto-Slavic group." The ultimate break between the Proto-Baltic and Proto-Slavic halves of the ProtoBalto-Slavic Verkehrsgemeinschaft could take place only when the center of the Proto-Slavic tribal community had been established west of the Middle Dniepr in Volynia ${ }^{32}$ : this seems to have happened not earlier than around 1000 B.C. In this final separation between the Proto-Balts and the Proto-Slavs, the Prypeć marshes must have played a significant role. To be sure, during all these migrations and population shifts, whose causes might be both internal (natural population increase and subsequent demographic pressure) and/or external (the invasion of pastoral nomadic tribes), there was never complete desertion of a region by its earlier inhabitants - some groups usually remained on the spot. Consequently, the newcomers encountered the old inhabitants, who were gradually absorbed. Such a situation accounts for a linguistic interference between the dialects of the newcomers (superstratum) and those of the old inhabitants (substratum). In the case of cultural differences between the two groups of population, the interference of vocabulary may be especially significant.

As can clearly be deduced from our map, the Pre-Slavs in their movement westward settled the territories previously inhabited by the Pre-Italo-Celtic group of the IE kentum tribes. Here they undoubtedly met some remnants of that population. This hypothetical situation can 
account for many kentum elements in Slavic, and perhaps also for some old lexical ties between Slavic and Italo-Celtic. In this connection, we should emphasize the fact that the territories west of the Dniepr subsequently occupied by the Pre-Slavs belong to the zone of the so-called Tripolye culture, the oldest agricultural society in this part of Europe (already by the fourth millennium B.C.). Originally this culture, so far as we can judge, was not Indo-European in the ethno-linguistic sense, but undoubtedly it underwent a linguistic indoeuropeanization (3000-2000 B.C.?) in connection with the general westward movement of the primitive Indo-European tribes (Pre-Italo-Celtic and Pre-Greek). The Pre-Slavs who during the second millennium B.C. took over the northern part of the indoeuropeanized Tripolye region could become to some extent the successors of the old agricultural traditions rooted in this region because some groups of the primary Tripolye population survived biologically, changing only their language (for the anthropological background of these processes, see W. Kóčka. 1958: 89-94). It seems highly probable that the absorption of the remnants of the indoeuropeanized Tripolye population by the Pre-Slavs and their geographical separation from the Pre-Balts, after a long period of a common development of these two groups, finally created the conditions under which the Pre-Slavic part of the Balto-Slavic Verkehrsgemeinschaft was transformed into the linguistically and ethnically separate Proto-Slavs. In this connection, we should also emphasize a parallel fact concerning the Balts and their language: namely the generally accepted more archaic (conservative) character of the original Baltic culture (e.g., the role of the horse!) and of the Baltic languages, much closer to what we reconstruct as Proto-Indo-European than Slavic (compare, for example, Lithuanian and Old Church Slavic) - is probably due to the relative lack of any significant impact of a culturally superior ethnic substratum upon the Pre-Balts. They simply seem to have spread and settled in forest areas practically uninhabited or only sparsely inhabited by primitive Finnic hunters and fishermen.

Thus we can accept that about 1000 B.C., a separate Proto-Slavic ethnos with a language at least lexically different from Baltic, began to exist.

Let us now turn our attention to the contacts of the Pre-Slavs with the Aryan East. Undoubtedly, the oldest contacts reach as far back as the fourth and third millennia B.C., when the Pre-Slavs occupied the south-easternmost position within the North IE dialectal complex. A great number of words (40\%) common to Slavic and Aryan, which come from that time, also occur in Baltic. But, as we have seen above, there is a whole set of words characteristic of Slavic and Iranian, especially in 
religious and moral terminology (e.g. the pair bogz : divz), which must have come from a later period, most probably from the first part of the first millennium B.C. At that time the "back wave" of Iranian nomads, the Scythians, appeared on the Pontic steppes and came into contact with the sedentary Proto-Slavic population (Nevpoi $={ }^{*} N e r v i$ 'people' and

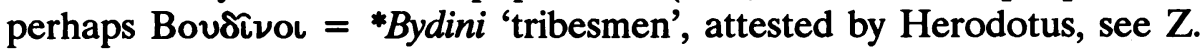
Gołąb, 1974). This contact lasted until the arrival of the Goths in the Ukraine (+/- 300 A.D.) and left distinct traces in the culture and vocabulary of the Proto-Slavs. Of course, in the present chapter we are interested in such lexical elements which cannot be interpreted as direct material borrowings from Iranian, as, for instance, words with an initial $x$ instead of PIE *s-: xotěti, xromz, xvala, *xvorz, *xyrz, etc. (see Z. Gołąb, 1973) - we are interested in those words which the Proto-Slavs, together with the Iranians, inherited from Proto-Indo-European, but to which a characteristic new meaning borrowed or copied from Iranian was assigned ("semantic borrowing"), as in the pair bogz : divz quoted above.

Special attention should also be paid to the contacts of the Pre-Slavs with the Italo-Celtic West and the Germanic North, which are represented by two linguistic strata: the so-called northwestern and northern. The oldest Slavic words showing correspondences in Italo-Celtic and Germanic undoubtedly come from the period of Proto-Indo-European community when the ancestors of the Slavs and the Balts were in direct contact with the kentum dialects owing to their location along the kentum - satem isogloss (the fourth and third millennia B.C.). Later on the number of such words increased (especially those which are common to Slavic and Italo-Celtic in technical terminology, according to Trubačev) first of all as a result of occupying by the Pre-Slavs in the second millennium B.C. the indoeuropeanized areas of the Tripolye culture (the west-bank Ukraine) previously inhabited by the ancestors of the Italics and Celts. And here we must underline another important phenomenon: the technical terminology - that of pottery, weaving, blacksmithing, e.g., ${ }^{*} g$ rms $\sim$ fornus and their derivatives, stativa $\sim$ stativa, kladivo $\sim$ gladius - seems to indicate the existence of a prehistorical Central European zone of intensive cultural-linguistic contacts and exchange which encompassed Proto-Italic, Proto-Germanic, and Proto-Slavic dialects with the exclusion, however, of Proto-Baltic. Such a zone is postulated by Trubačev. At a later stage it overlapped with the so-called "Lusatian culture" (1300-600 B.C.). We have noticed in this respect a characteristic fact: the eastern border of that zone, demarcated on the basis of lexical elements (with the exclusion of Baltic!) overlaps with the so-called "ethnographic frontier" (rubiez etnograficzna) on the Polish territory, established by K. Moszyński. 
In the formation and continuation of the Central European cultural zone in question, an important role should probably be assigned to the hypothetical "Veneti", a kentum people who before their final ousting, or rather absorption by the Proto-Slavs some time in the second half of the first millennium B.C., dwelt on the territory of contemporary Poland. The north-western part of these "Veneti" could also have been absorbed by the Teutons, which accounts, perhaps, not only for the transfer by the latter of this ethnicon to the Slavs (see Tacitus's Venedi, Ptolemy's

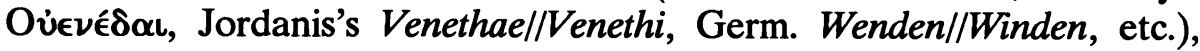
but also for a number of common kentum and other words occurring in Slavic, Germanic, and Italo-Celtic, or in Slavic and Germanic only.

So combining the stratification of Proto-Slavic vocabulary from the standpoint of PIE dialectology with the geography of hypothetical Indo-European migrations, we have obtained a synthetic picture which sketches the prehistory of the formation of the Slavic ethnos within the family of Indo-European peoples. 


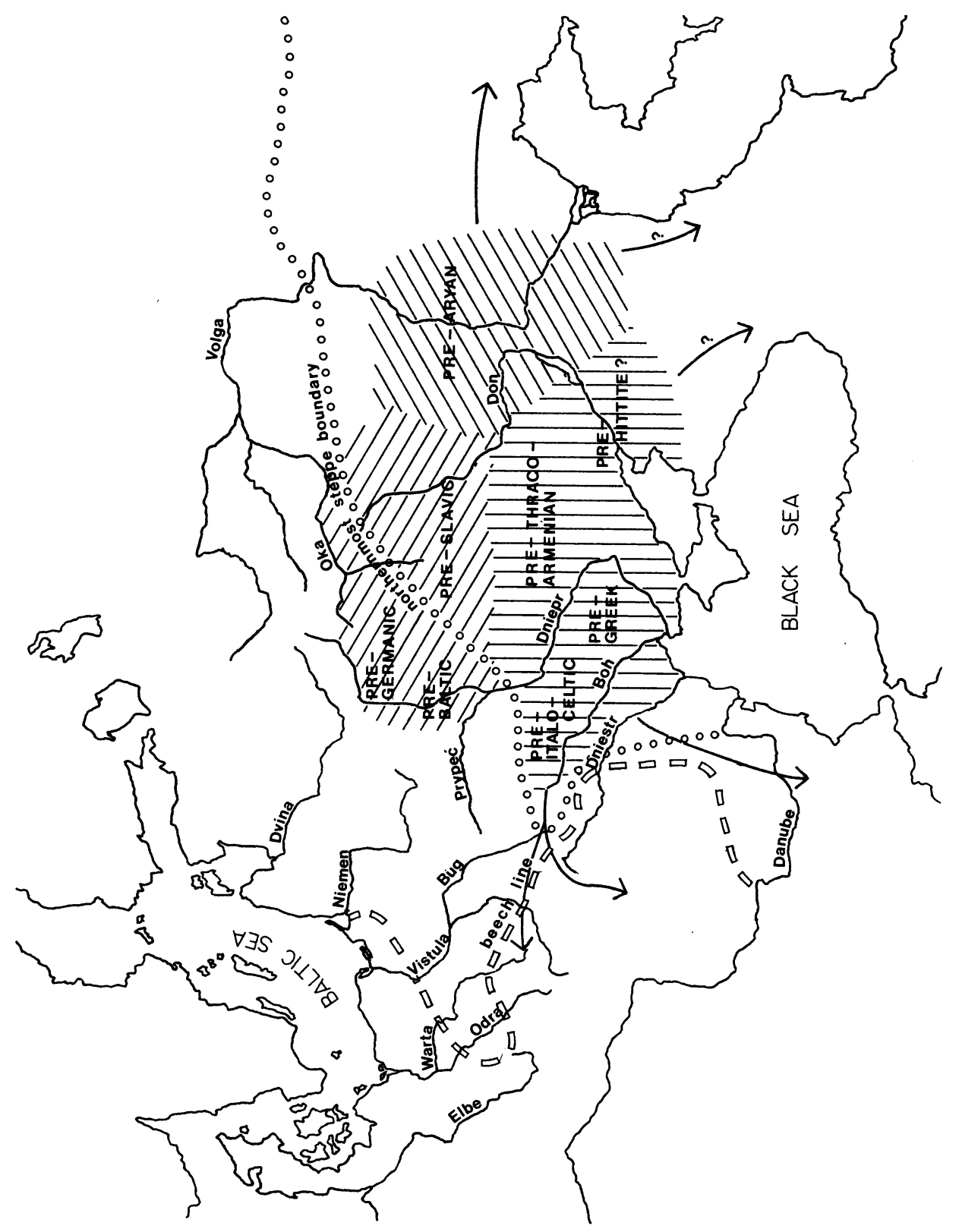




\section{Chapter IV}

\section{The Problem of the Primary Habitat of the Indo-Europeans}

First we should formulate precisely what should be understood by the term "primary habitat" (Urheimat, praojczyzna, prarodina) of the Indo-Europeans. There are two elements involved here: 1.) a determinate geographical region, and 2.) a determinate ethnos, i.e., a group of people speaking a prehistorical language which we presuppose and reconstruct as a common source of all historically attested IE languages, the so-called Proto-Indo-European. Regardless of all the objections and doubts with respect to the very concept of an Ursprache, it nevertheless remains the only realistic hypothesis which makes historical and cognitive sense out of the comparative studies on genetic relations between languages. And since no language exists in a social vacuum, i.e., every language is an instrument of communication within a social group - natural (Gemeinschaft), e.g. a tribe, or artificial (Gesellschaft), e.g. the international association of esperantists - the acceptance of a protolanguage (Ursprache, prajezzyk, prajazyk) entails the acceptance of a prototribe, protoethnos (Urvolk, pralud, pranarod). But again any ethnos lives in a more or less limited territory, here including vast areas of nomadic peoples.

So the problem of reconstruction of the primary habitat of a protoethnos is not deprived of an historical, cognitive sense. An excellent parallel can be provided by a retrospective history of the Romance languages, which cover an impressive area today: South-Western Europe, a part of South-Eastern Europe, and two-thirds of America. Of course, we know that the expansion of Spanish and Portuguese in the New World is a relatively recent phenomenon (since the end of the fifteenth century), but the expansion of Latin in Mediterranean Europe and ancient Gaul, triggered by the expansion of the Roman empire, is at least sixteen centuries older, and can be traced only owing to the preservation of written historical sources which have witnessed the political career of the city of Rome. Ultimately as the protolanguage from 
which all Romance languages have developed, i.e., the common source of their lexical substance, we reach Latin, the language of Rome and of its immediate vicinity, Latium. The protoethnos which used this language (Latin) as its native means of communication was a tribe of primary Romans (Latini) before the political expansion of the city of Rome to other regions of ancient Italy. Thus, the size of the protoethnos and its protocountry is, in this particular, but very instructive case, surprisingly small in comparison not only with the impressive present-day area of Romance languages, but also in comparison with the area where Vulgar Latin was spoken in the late imperial epoch (e.g., Italia, Hispania, Gallia, Illyria, Moesia, even Africa). Notice that Vulgar Latin was not only a kind of koine, but also a native language for large groups of population descended either from Roman colonists or from the local tribes which had abandoned their primarily different languages and had accepted Latin as the means of communication within their communities.

I repeat: the history of Latin and the Romance languages is very instructive, and, in spite of different specific political and cultural conditions, under which these languages and respective peoples have developed, it can be treated as an example enabling us to understand mutatis mutandis the possibilities of the prehistorical development of Indo-European languages, starting with the hypothetical ProtoIndo-European language.

In connection with the analogy of Latin sketched above, we can distinguish between the oldest retrievable habitat of the Indo-Europeans, a region where Proto-Indo-European was spoken as a still relatively uniform language by a relatively homogeneous tribe or tribal federation of the Proto-Indo-Europeans - and their younger prehistorical habitat resulting from their expansion, i.e., a region where Proto-Indo-European was spoken as an already dialectally differentiated language by different tribes, either direct descendants of the earlier Proto-Indo-Europeans, or the descendants of other, originally non-IE tribes, which had undergone linguistic indoeuropeanization (whatever the social mechanism of this process may have been). For we must remember that the expansion of an ethnos rarely takes place in a demographic vacuum. Usually it is connected with conquest, especially when the expansion is rapid; a slow expansion may simply be the result of infiltration. We should also take into account the possibility of an expansion based on the tribal federations of linguistically different groups in which the language of the leading tribe gradually and peacefully takes over: here the cultural superiority (at least in some domains) of the leading tribe may be decisive (see, for instance, the so-called royal Scythians mentioned by Herodotus). Thus, whatever the social mechanism of the oldest, prehistorical 
expansion of the Proto-Indo-Europeans and their language, we should distinguish at least two stages (or two epochs) in the development of the Proto-Indo-European habitat. The oldest is early PIE, which by definition must have been rather restricted, and the younger one is later PIE, which, being the result of expansion, must have been relatively extended.

Having clarified these basic concepts, let us attack the problem itself. Here the reader should be reminded that the author of the present book uses exclusively linguistic evidence for the solution of the problem of the primary habitat of the Proto-Indo-Europeans. This approach may not bring very precise answers (in the geographical sense), but it has the advantage of homogeneity, i.e., answering the question of the primary habitat of an ethno-linguistic group with ethno-linguistic arguments. Any archeological and anthropological (in the sense of physical anthropology) arguments here must have only an auxiliary character, and for the time being we are not interested in them.

First of all, we can use the lexical evidence to simply answer the following question: what kind of landscape can be reconstructed on the basis of Common Indo-European vocabulary (by CIE vocabulary we understand here words which are present - or have been preserved in the main branches of IE, i.e., in Indo-Iranian (Aryan) and in European, and which in their derivational structure show an archaic character). In the same way we can proceed to climate, flora, and fauna. At the end we should ask about natural (primitive) economy as it can be reconstructed from similar lexical evidence. Let us answer these questions one by one.

\section{Landscape}

More than forty years ago, W. Brandenstein (see bibliography) made a successful attempt at a reconstruction of the landscape of the oldest PIE habitat on the basis of respective vocabulary. Here I shall quote his conclusions and illustrate them with some examples:

Wenn wir den indogermanischen Wortschatz auf die erdkundlichen Sinnbezirke hin durchmustern, so finden wir mehrere umfangreiche Bedeutungsfelder. Eines davon weist auf eine erhebungsreiche und felsdurchsetzte Gegend hin. Die Wörter dieses Bedeutungsfeldes gehören so gut wie ausschliesslich der frühidg. Zeit an; in dieser Zeit waren also die Idg. gezwungen, sich eine solche "Terminologie" zu schaffen, d.h. der Zwang, solche Realitäten zu unterscheiden, führte notwendigerweise dazu, den begrifflichen und natürlich auch sprachlichen Apparat dafür auszubilden. Ein zweites frühidg. Bedeutungsfeld beschäftigt sich mit der Steppe und 
ihren Eigenheiten. Es handelt sich somit beim frühidg. Raum um eine gebirgige felsdurchsetzte Steppe. Diesen Bestimmungen widerspricht auf das stärkste ein anderes reich entwickeltes Bedeutungsfeld, das auf eine sumpfige Gegend hinweist. Doch löst sich dieser Widerspruch sofort auf, wenn wir bemerken, dass dieses Bedeutungsfeld im frühidg. Wortschatz so gut wie keine Wurzeln hat, hingegen zur Gänze erst in spätidg. Zeit geschaffen wurde, weil eben die Notwendigketi hiefür erst durch die Eigenart des spätidg. Raumes herbeigeführt wurde. (1.c. 31)

This fundamental discovery by W. Brandenstein is the basis of his hypothesis about die erste indogermanische Wanderung which separated the ancestors of the European branch of the Indo-Europeans from the Asiatic, i.e., Aryan branch: the European branch moved from the primary stony and mountainous steppe to a relatively marshy area. How this should be interpreted in terms of Euro-Asian geography seems to be quite simple (see below).

Let us quote some old terms ${ }^{1}$ referring to mountains, hills, rocks, stones, etc., with special emphasis on Slavic correspondences (if any):

1.) eros n. 'etwas das hervorsteht, Erhebung, anhöhe': Gr. ǒpos n. 'Berg', in other IE languages there are only indirect traces, e.g., OI rsșáadj. 'hoch' (Brand. 32, Walde I, 137, Pokorny 328);

2.) *uersmñ 'Anhöhe': OI várșman- n. 'Anhöhe, Hügel, Oberstes, Spitze', Gr. 'є́p $\mu \alpha$ n. 'Klippe, Sandbank, Hügel'; B-S shows the formation *ursu-, i.e., Lith. viršùs 'das Obere, höchste Spitze', OCS vraxъ (loc. vrbxu!) 'Oberstes, Gipfel', which was primarily an adjective, etc. (Brand. 32, Walde I, 267, Pokorny 1151-1152);

3.) *kaiur-t, *kaiun-t (gen. *kịunés?) n. 'Grube, Kluft': OI kēvata- m.

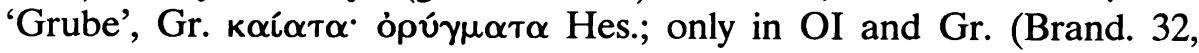
Walde I, 327, Pokorny 521);

4.) *kakud- 'gewölbter Gipfel': OI kakúd- 'Kuppe, Gipfel', Lat. cacūmen 'Spitze, Gipfel' (analogically to acümen), Germ. *hagu- probably in OFries. heila 'Kopf' from *hagila- $\leq$ *hagula-; this noun is quoted under the root 2. keu-, keuz- as a reduplicated formation *ka-kud- (see Pokorny 588); Balto-Slavic seems to continue other derivatives of this root of the type *kouko-, *koukā-, etc., i.e., with a guttural extension: Lith. kaũkas 'Beule, Eitergeschwür', kaukarà 'Hügel', Russ. kúča 'Haufen' (known also in Czech and Polish, see Berneker 637) and Carpathian oronym Kyčera, Kičera (Pol. Kiczora) undoubtedly from *kūkera similar to Lith. kaukarà (Brand. 32, Walde I 371, Pokorny 588-589);

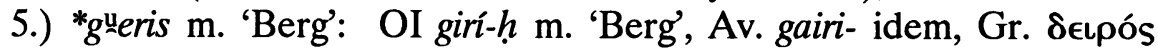

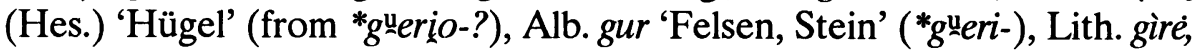


girià 'Wald' (see the same semantic change in SSlav. gora!), OCS gora 'Berg'; no correspondences in Italo-Celtic or Germanic (Brand. 32,

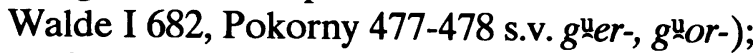

6.) *bhrstis f. 'Gipfel, Zacken': OI bhrsțíh f. 'Zacke, Spitze, Kante, Ecke' = Germ. *bursti- in OIc. burst f. 'Borste, Dachfirst', etc; Slav. *bъrstịo- $\geq$ *bъrščb in Russ. boršč 'Bärenklau' (Heracleum Sphondylium), Pol. barszcz, etc. (see Berneker 109) with a secondary meaning; Lat. fastigium (*bharsti-) 'Spitze, Gipfel, Abdachung' belongs here, too (Brand. 32, Walde II 131, Pokorny 109);

7.) *bherg'h m. (sic!) 'steilabfallender Berg' (Pokorny reconstructs *bherg'hos): Av. baraz 'hoch'; 'Höhe, Berg, Arm. berj 'Höhe', Cymr. (Welsh) bera 'Haufe', etc., Germ. *berga- in OIc. bjarg and berg, OHG, OSax. berg 'Berg', OE beorg 'Höhe, Grabhügel', etc.; here also Goth. baurgs f. 'Stadt, Turm', OHG burg, etc. 'Burg' = Av. baraz-, i.e., IE *bhrg'h- whose primary meaning in Germanic was 'befestigte Höhe als Fluchtburg; Slav. *bergz in OCS brěgz 'Ufer, Abhang, S-C brïjeg 'Hügel, Ufer', Russ. béreg idem, Pol. brzeg 'Ufer' (in dialects 'Abhang'), etc.; the Slav. word represents the kentum treatment of ${ }^{*} g$ ' $h$; there are no correspondences in Lith. (Brand. 32, Walde II 172, Pokorny 140-141);

8.) *āk's, gen. *ak'nés n. 'scharfkantiger edler Stein, der für Werkzeuge geeignet ist' (Pokorny 19-21 reconstructs *ak'en-, *ak'er-, *ok'erand the heteroclitic paradigm *ak'-r-, *ak'-n-es): OI aśáni-h 'Pfeilspitze,

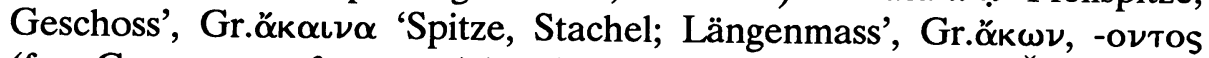
(for Gr. -ovos after participles) 'Wurfspiess', etc., Lith. Žem. ašnis 'Schneide, aufkeimende Saat'; OI áśri-h̆ 'Ecke, Kante, Schneide', Gr.

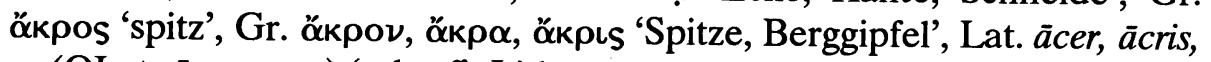
-e (OLat. ācra, -um) 'scharf', Lith. ašrùs, aštrùs (OLith. aštras), OCS ostrı idem (see also Russ. (dial.?) osn 'sting; blade' (Vasmer III, 162) and OCS osla 'Wetzstein', known in most Slavic languages) (Brand. 32, Walde I 28, 30, Pokorny 19-21 s.v. $a k$ ', ok'- 'scharf, spitz, kantig' and 'Stein');

9.) *ak'mōn ${ }^{2}$ m. '(gewölbter) Felsblock': OI aśman- n. 'Stein, Himmel' (als Steingewölbe), Av. asman- m. 'Stein, Himmel', Gr. ö́ $\mu \omega \nu$ 'Amboss',

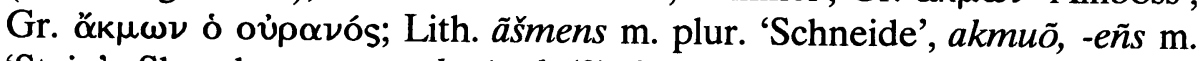
'Stein'; Slav. has a metathesized (?) kentum form kamy, gen. kamene, 'Stein', similarly Germ.: ONorse hamarr 'Stein, Klippe, Hammer', OHG hamar 'Hammer', etc. (Brand. 32, Walde I 29, Pokorny 19, Gołąb 1972);

10.) *ondr, gen. ñdnés n. 'Stein, Fels': only in OI ádri- 'Stein, bes. zum Somaschlagen gebrauchter'; 'Fels, Berg; MIr. ond, onn, gen. uinde (stem *ondes-) n. 'Stein, Fels' (Brand. 32, Walde I 181, Pokorny 778);

11.) *karkaros (reduplicated) 'steinhart': OI karkara- 'rauh, hart' =

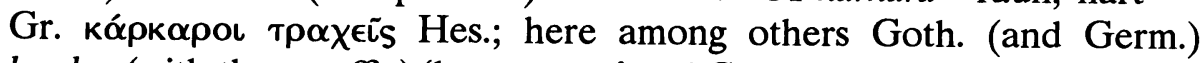

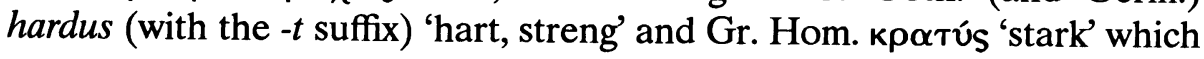




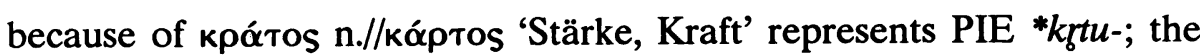
latter is continued by Slav. *čbrstvz, e.g. RussCS. črbstvz 'solidus, fest', Russ. čërstvyj, Pol. czerstwy, etc., instead of *čbrtvz undoubtedly influenced by adjectives like čęstz, čistz, prostz, etc. (Brand. 32, Walde I 354, Pokorny 531-532, Berneker 171);

12.) *karnos m. 'Stein': a reconstruction based only upon OIr., Cymr., Bret. carn 'Steinhügel, Steingrab', and Av. ča $\theta$ ru-kar(a)nam 'Ohrgehänge mit Schmucksteinen' (Brand. 32, Walde I 354 f., 31, Pokorny 531-532, see above);

13.) *k'orkā 'grobes Geröll': OI śarkarā 'Gries, Kies, Geröll,

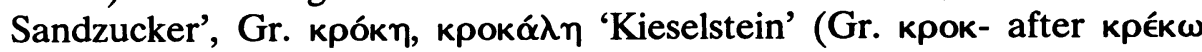
'schlage'); no correspondences in other languages (Brand. 32, Walde I 463, Pokorny 615);

14.) *k'orkelä 'feines Geröll, Gries' (see above);

15.) *pelos n. (Pokorny 807 reconstructs *peli-s-, *pel-s-) 'Fels': OI

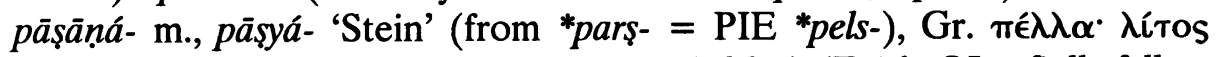
Hes. ( $\left.{ }^{*} \pi \hat{\lambda} \lambda \sigma \alpha\right)$, OHG felis m., felisa f. ( ${ }^{*}$ felis-) 'Fels', OIc. fjall, fell n. ('pelso-) idem (Brand. 32, Walde II 66, Pokorny 807);

16.) *läur, gen. l(a)unés n. (Pokorny reconstructs *lēu-: lau-) '(plattiger?) Stein': Hom. $\lambda \tilde{\alpha} \alpha \varsigma$, gen. $\lambda \tilde{\alpha}$ os 'Stein' ("Ausgleichung von

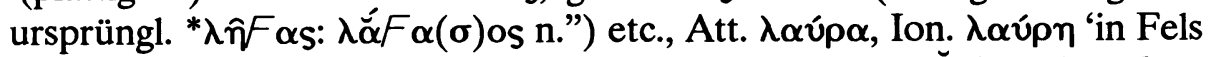
gehauener Weg, etc.: the latter based upon the stem * $\lambda \check{\bar{\alpha}} F \alpha \rho$; Alb. lerë, - $a$ 'Gestein, Felssturz' ( $\left.{ }^{*} l_{a ̆ u} e^{r a \bar{a}}\right)$; correspondences also in Celtic; the Iranian toponym Luri-stan belongs here, too; (Brand. 32, Walde II 405, Pokorny 683);

17.) stei- 'spitzig wie ein kleiner Stein' (Pokorny reconstructs (s)tei-

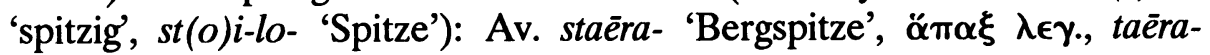
'Bergspitze, Gipfel', Lat. stilus 'Spitziger Pfahl, Stiel, Stengel'; only in these languages (Brand. 33, Walde II 612, Pokorny 1015).

The above survey, in which only the correspondences from the main IE languages and Slavic have been quoted, helps us to understand Brandenstein's contention. It is important that from among the seventeen words posited for PIE by Brandenstein, eight (respectively nine) - +/- 50\% - are preserved in Slavic ( ${ }^{*} v b r x z, k u c ̌ a,{ }^{*}$ Kyčera, gora, *bъrščb, bergz, ostrz//*osnz, kamy, *čbrstvz); only one of them, *bъrščb, represents a significant semantic change, the remaining continue, basically, the primary meaning. This evidence cannot be neglected; it seems to prove that the ancestors of the Slavs did not lose the lexical tradition stemming from the earliest PIE epoch, which in its turn suggests that the ancestors of the Slavs must have stayed for a relatively long time near the oldest habitat of the Indo-Europeans. Of course, the Slavic 
correspondences quoted above show morphological transformations, according to innovative and productive tendencies characteristic of Slavic, e.g., the heteroclitic stems, so characteristic of the oldest lexical layer of IE, have been completely removed from Slavic, although such vestiges as ostro *osnz should be underlined.

\section{Climate}

Here the situation is quite obvious: the terms referring to 'winter', 'snow', 'spring', 'summer', etc., are Common IE and represent very archaic types of word-formation. They indicate that the climate of the oldest habitat of the Indo-Europeans was moderate and continental. In this connection, it is worthwhile quoting again some data from Brandenstein's book. (The forms are "modernized" after Pokorny!) But before that, let us repeat his conclusions:

Im Raum der Frühidg. herrschte Steppenklima, d.h. ein kontinentales Klima. Die Sommer waren heiss mit ewig blauem Himmel und trocken, die Winter kalt und Schneereich, von Stürmen begleitet. Dies weist wiederum auf die Steppe hin. Dabei ist zu beachten, dass die vier Jahreszeiten deutlich voneinander verschieden waren und auch unterschieden wurden. Wir dürfen daher den frühidg. Raum nicht allzuweit nach dem Süden verlegen, sondern nur in die "subarktische" Steppe! Dafür spricht auch die Tatsache, dass im Tagesverlauf die Übergänge zwischen hell und dunkel deutlich ausgeprägt waren, was bekanntlich in südlichen Gegenden nicht der Fall ist. (Brand. 44)

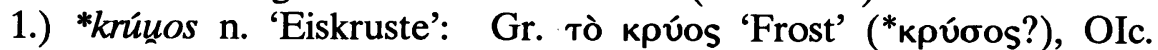
hriōsa, hraus 'schaudern', OHG (h)roso, (h)rosa 'Eis, Kruste', OE hrūse 'Erde, Grund', Latv. kruvesis, kruesis 'gefrorener Kot', Lith. at-krũsti, pret. -krūsaũ 'wiederaufleben, von Erfrorenem'; and without the extension -sprobably Norw. dial. ryggja 'schaudern'; I would also include here Slav. *kra, as a singular back-formation from an expected *kry, which was interpreted as plur., e.g., Russ. (old) kra//ikra, 'Eisscholle', Pol. kra, idem., Cz. kra 'Klumpen', etc. (see Berneker 424 s.v. ikra 3), in spite of a quite widespread hypothesis connecting this kra (allegedly jbkra) with *jbkra 'Rogen'; 'Wade' (see recently Vasmer II 126); the semantic connection between the underlying *kreu(a)- : *krü- 'dickes, stockendes Blut' and its derivative *kreus-, *krus- (for Slavic *krū-!) 'Eis' is given by Walde (I 479) and Pokorny (621) through the intermediary of 'Kruste' "usprüngl. von Eis oder Wundschorf” (Brand. 44, Walde I 479, Pokorny 621-622);

2.) *g'heimn n. 'Wintersturm ("etwas, das treibt und Geschosse schleudert”): OI héman loc. 'im Winter', Gr. $\chi \in \hat{\imath} \mu \alpha$ n. 'Winter, 


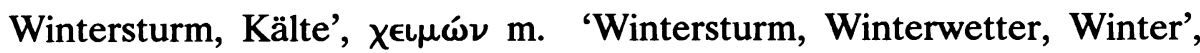
Alb. Geg. dimën m., Tosk. dimër(ë) 'Winter' (old acc. *g'hei-men-m-), B-S *žeimā- (from *žeimnā) in Lith. žiemà, OCS zima, etc. 'Winter', Hitt. gimmanza 'Winter' = OI hemantá-h m. 'Winter' (Brand. 44, Walde I 546, Pokorny 425);

3.) *g'h(i)īom, gen. g'himós 'Instrument des winterlichen Treibens, d.i. Schneefall': Av. zyä f. 'Winter' (acc. zyqum, gen. zimō), Arm. jiun 'Schnee'

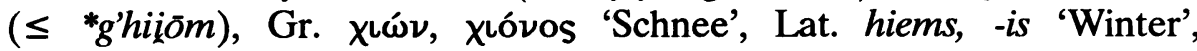
correspondences also in Celtic, e.g., OCymr. gaem, etc., and Germanic, e.g., OIc. gōi f., gāe f., gōi-mānaðr 'der Monat von Mitte Februar bis Mitte März', etc. (gō- $\leq$ *gio-); Brand. 44, Walde I 547, Pokorny 425-426;

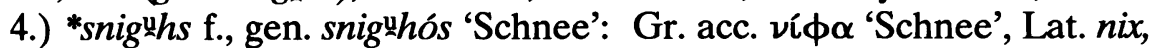
nivis idem, Ir. snige n. 'Tropfen, Fliessen', Cymr. nyf 'Schnee'; besides that the PIE archetype *snoiguhos is also continued in: OI snēha- 'Schnee', (reconstructed on the basis of Prakrit sineha-) Goth. snaiws, OE snāw, etc., Lith. sniẽgas, OCS sněgz, etc., everywhere 'Schnee' (Brand. 44, Walde II 695, Pokorny 974);

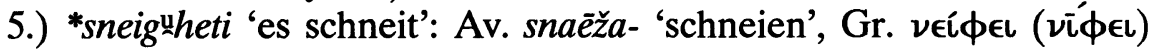
'es schneit', Lat. nīvit idem, and the nasal present ninguit, Ir. snigid 'es tropft, regnet', etc., OHG, OE sniwwan 'schneien', etc., Lith. sniẽga, sniñga ${ }^{3}$ 'es schneit', infinitive snigti; Slav. *sněžitz (e.g., S-C snijēž $\imath$ ) 'es schneit' is a secondary denominative from sněgz (Brand. 44, Walde II 695, Pokorny 974);

6.) *tāieti (or *tāiti) 'taut, schmilzt': Osset. thayun 'tauen, schmelzen' = OCS tajetz 'schmilzt', Arm. t'anam 'benetze' (aor. t'açi); 'werde feucht' (aor. $\left.t^{\prime} a c ̧ a y\right)$; in other languages with different extensions, e.g., Lat. $t a \bar{b} b \bar{o}$,

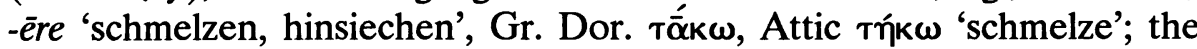
Germanic verbs are derived from the base in $-u$, i.e., *tāu-: *təu-: *tŭ-, e.g., OIc. peya, OHG douwen, deuwen 'tauen, $\mathrm{zu}$ schmelzen anfangen, zergehn', OE dawian ('pawōn) = NE thaw 'tauen', etc. (Brand. 45, Walde I 701, Pokorny 1053-1054);

7.) *uesg n., gen. usnés 'Frühling': OI vasan-tá- m. 'Frühling' (like heman-tá- 'Winter', see above!), Av. varyi loc. 'im Frühling', Gr. ě $\alpha \rho$,

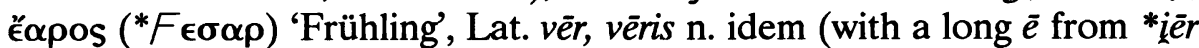
'Jahr'), OIc. vār, Sw. vår, Dan. poet. vaar idem (with a long $\bar{e}$ as in Latin), OIr. errach (from *ferrach $\leq$ *uesr-äko) 'Frühling', etc., Lith. vãsara, vasarà 'Sommer' (!), OCS vesna, 'Frühling', etc.; ultimately derived from the verbal root *aues- 'leuchten', e.g., OI uccháti, Av. usaiti (*us-sk'éti), Lith. aũsta 'es tagt' (Brand. 45, Walde I 311, 26, Pokorny 1174, 86-87);

8.) *sem-, gen. $s_{e} m o ́ s$, with the $\bar{a}$-extension $s_{e} m \bar{a}-$, and also an $r$-stem: ${ }^{*} s_{e} m_{e} r$ - (according to Pokorny 905) 'Sommer': OI sámā f. 'Halbjahr, Jahreszeit, Jahr' (= Arm. am), Av. ham- 'Sommer', OIr. sam- (*semo-) 
and samrad ( ${ }^{*} s_{e}$ mo-rōto-), etc. 'Sommer", OHG sumar, OE sumor m., OIc. sumor n. 'Sommer'; no correspondences in Greek and Balto-Slavic; the noun shows obvious traces of heteroclisis $r / n$, see, e.g., Gall. samonios 'Sommermonat' (Brand. 45, Walde II 492, Pokorny 905);

9.) esen-: *osen- (with traces of heteroclisis -n/r-, see Pokorny 343) 'Erntezeit, Sommer': Gr. Hom. ò $\omega \omega \rho \alpha$ 'Sommersende, Erntezeit' from

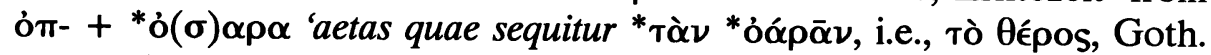
asans f. 'Ernte, Sommer', etc., OPruss. assanis 'Herbst', ChSl. jesenb, Russ. ósenb, etc. idem (Brand. 45, Walde I 161, Pokorny 343); Brandenstein tries to reconstruct an early PIE heteroclitic stem esemr, gen. *smnés 'Sommer' > late IE 'Erntezeit' whose morphological structure would be parallel to that of $\dot{\alpha} \kappa \mu \dot{\omega} \nu \sim$ Hammer (see l.c.).

As we see from the above examples, the names of the three seasons 'winter', 'spring', and 'summer' (the latter split secondarily into 'summer' and 'autumn') can be established as early PIE (all heteroclitic stems!). Slavic has preserved all of them (zima, vesna, (j)esenb) with the shift of the primary esen- 'harvest time, summer' to 'autumn' caused by the neologism lěto 'summer', which according to my opinion meant primarily 'gain from land, crops' > 'harvest, harvest time', and then 'summer'; for this new etymology, see Pokorny's material under 2. lē(i)- 'gewähren,

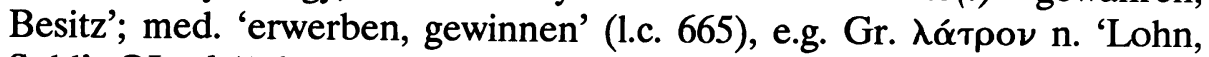
Sold', OIc. lōð f., n. (*lō(i)tā/o-?) 'Ertrag des Bodens', OCS lětb, instr. lětbjo as a predicative with jestı 'licet', Lith. lieta 'Sache, Angelegenheit' borrowed from Latv. lieta 'Sache, Zubehör' and with another suffix, Lith. láima 'Glück'; of course, Slav. lěto (see Russ. léto, S-C ljềto) $\leq$ lōito 'gain, profit'. In this connection, it should be mentioned that the semantic change 'harvest' > 'summer' is quite well-known, see, e.g., ChSl. žętva (etymologically 'harvest') rendering both Greek $\theta$ épos 'summer' and

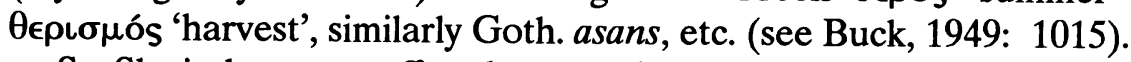

So Slavic has not suffered any radical change in this microsystem of primary IE seasonal terms, which would indicate the absence of any significant changes in the climatic conditions under which the primary Indo-Europeans and the primary Slavs were living. In contradistinction to this situation, Germanic has abandoned the old IE term denoting 'winter' (= 'snowy winter') and replaced it by a neologism wintrus (e.g. Goth.), etc. which probably means etymologically 'wet season' (see Buck, 1949: 1014). Such changes as this one in Germanic seem to prove climatic changes, i.e., indirectly, great prehistorical migrations of a given ethno-linguistic group from one climatic zone to another.

\section{Flora}

It is characteristic (according to Brandenstein, l.c. 63) that PIE did not 
possess any special term denoting a dense primeval forest ("dichter Urwald"); what can be reconstructed for the oldest retrievable stage of IE languages (including the Aryan and the "European" branch) are rather the words referring simply to 'a wood' ("Wald, Gehölz, Baumgruppe") as a group of trees. There are only two PIE words which can be quoted in this connection:

1.) *uenom 'Wald, Gehölz': OI vána- n. 'Wald', Goth. winja f. 'Weide, Futter' (a jā-derivative), OHG winne, OIc. vin f. 'Weideplatz', etc.; in Slavic, the adverbs OCS vonz, Russ. von, OPol. wen, etc. 'outside' (referring to direction) and OCS vъně, Russ. vne, Cz. vně, etc. 'outside' (referring to location) - belong here: the first represents the old accus. *unóm, the second the old locative *unói (see OI váne 'in the wood'); Brand. 63, Walde I 259, Pokorny 1147, Vasmer I 328, 348.

The semantic change that we observe in Germanic would prove the primary meaning of the word as simply 'thin wood, a group of trees': “es handelt sich bei diesem Wort um einen sehr schütteren Wald oder um eine Bauminsel, da das Wort im Germ. zur Bezeichnung der Weide verwendet wurde und bekanntlich der schüttere Wald beim Kleinvieh sehr beliebt ist."

2.) *drumos 'Gehölz, Baumgruppe': OI drumá- m. 'Baum', Gr. Hom.

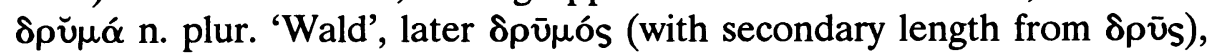
OE trum adj. 'fest, kräftig, gesund' (*drumós), Slav. *drımъ in Russ. drom 'thicket, uprooted trees' (not "Urwald" as Pokorny quotes!), Bulg. drímka 'bush', Sloven. drmášča (from *drımı/*drıma contaminated by *čęšča, see Russ. čašča 'thicket'?); Brand. 63, Walde I 804, Pokorny 214-216, Vasmer I 541;

Even in later PIE (after the separation between the Aryan and the "European" branches), the increase in words referring to the concept 'wood' as a collection of trees is insignificant. This would mean that 'forest' did not play any important role in the primary natural environment of the Indo-Europeans.

According to Brandenstein, the following tree-names can be established for early PIE - here the material can be quoted chiefly after P. Friedrich, who devoted a separate book (1970) to the problem of PIE tree-names:

1.) *ueitos m. and *ueitis f. 'biegsames Wassergewächs', probably 'Weide'; OI vetasá- n. (Pokorny 1122 also quotes veta- m.) 'willow, rod, switch', Av. vaẽtay- 'willow, switch', Gr. oíoos (from Foîtuos?) 'a kind of willow', Fĩ $\mathbf{x} \alpha$ 'willow, a shield woven of willow shoots', Lat. vītis 'grape, tendril, shoot, willow', Ir. fēith 'fiber, cord' ("veiti-), OIc. vípir or vīdir 'willow', OE wīðig 'withy, willow', OHG wīda = NHG Weide; probably Arm. gi with the secondary meaning 'juniper' also belongs here; Lith. vytis 
'willow, switch', žil-vitis 'willow', Slav. *vitb in OCS vitb 'res torta in modum funis', Russ. vit' idem, Pol. wic f. 'long switch, tendril, especially of willow', OPol. wici plur. 'a bundle of willow switches used as the sign of levy in mass', etc. (Brand. 65, Walde I 224, Pokorny 1122, Friedrich 55-56, Vasmer I 322). The etymology of *ueitos, *ueitis, etc. is obvious: it has been derived from the verbal root *uei(a)- 'drehen, biegen' (Pokorny 1120) whose meaning well reflects both the characteristic features of the tree and its practical use.

2.) *deru n. (Pokorny also has *dŏru-) 'Holz, hergerichteter Baumstamm, Nutzholz (?)'; the semantic development to 'oak' is according to Pokorny secondary, and intermediated by the meaning 'useful wood': OI dâru-, gen. droh n. 'Holz' (according to Pokorny, but Friedrich 'species of pine, block, piece of wood'), Av. dāuru'Baumstamm, Holzstück, Waffe aus Holz, etwa Keule', Hitt. taru 'Baum,

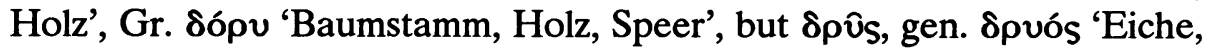
Baum', probably Lat. larix 'Lärchenbaum' from an IE Alpine dialect $\left({ }^{*} d_{e}\right.$ rik-s?) with the Sabine substitution of $l$ - for $d$ - as in levvir from *däiuer-, lingua//dingua and lacrima//dacruma; Middle Welsh (Cymr.) derwen 'Eiche', etc.; with the underlying stem *dreu- in Germanic: Goth. triu n. 'Holz, Baum', OIc. trē, OEng. trēow = tree, etc., Alb. dru f. 'Holz, Baum, Stange', but the old es-stem, drush-k 'Eiche'; B-S *derua- 'Baum': OCS drěvo, Russ. dérevo, Pol. drzewo, etc. Lith. collect. dervà f. 'Kienspan; Pech, Teer, harziges Holz', etc.; the zero-vocalism stem *druunderlines PSl. *drova: OCS drzva, Russ. drová, Pol. drwa, etc. 'Holz'; the very alternation (apophony) ${ }^{*}$ deru-//*doru-, *dreu-//*drou//*dru- and numerous derivatives of this stem prove its antiquity; for details of semantic development, see Friedrich 140, etc. (Brand. 65, Walde I 804, Pokorny 214-217, Friedrich 140, etc.).

If the meaning of *deru-, etc. was really 'useful wood' (like that of Slav. *drova) then it is possible to etymologize this PIE noun as derived from the verbal root *der-, "heavy basis" *dera-, *dré- 'schinden, die Haut abziehen, abspalten, spalten' (see Pokorny 206) well attested in most IE

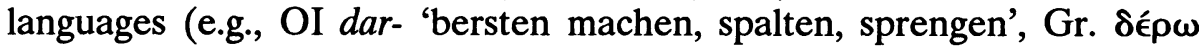
'häute ab, schinde', Goth. ga-tairan 'zerreissen, zerstören', OCS derq, dbrati 'reissen, schinden', etc.); the derivational pattern would be the same as that of *pék'u-, gen. *pek'ués 'das Geschorene, Wolltier, Schaf'

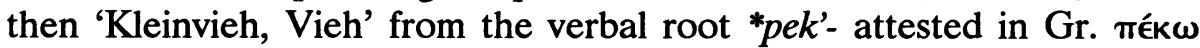
'kämme, schere', Lith. pešù, pèšti 'rupfen, an den Haaren zausen' (see Pokorny 797).

3.) *dhanu- 'elastisches Nutzholz, Bogenholz'; because of this meaning, Brandenstein suggests larch - attested only in OI dhánvan- $\mathrm{n}$., dhánu- m., dhánuş- n. 'Bogen', dhanvana- m. 'ein bestimmter 
Fruchtbaum' and in OHG tanna 'Tanne, Eiche' (*danwō); Brand. 65, Walde I 825, Pokorny 234; Friedrich does not mention it.

4.) *perk ${ }^{\mathrm{u}} \mathrm{s}^{4}$ (Pokorny 822 reconstructs ${ }^{*}$ perk $\left.{ }^{\mathrm{u}} u s\right)$ 'Eiche’: OI parkati'heiliger Feigenbaum', Mind (a New Indian dialect) pargāi 'Steineiche', Lat. quercus f. 'Eiche', Celt. Hercynia silva 'das deutsche Mittelgebirge' (from *Perkuniā, older *Perk ㄴuniā), Goth. faírguni n. 'Gebirge', etc. (this is interpreted as borrowed from Celt. 'Perkuniā), OHG fereheih 'Speiseeiche', OIc. fjorr 'Baum, Mann', OE furh, OIc. fura f. 'Föhre', OHG forha 'Kiefer' (the latter three come from the zero-vocalic *prku-). OLith. Perkúnas 'Donnergott' = OIc. Fjorgjynn idem (whose tree was the oak), NLith. perkúnas 'Donner', Slav. (ORuss.) Perunz 'Donnergott', perunz (e.g., in Russ. and Pol.) 'Donnerkeil, Blitz' (the Slavic forms were undoubtedly transformed by folk etymology or taboo, adjusting the primary *perkynъ to peruns from perq, pbrati 'to strike'); Friedrich still quotes Alb. Perëndija, perëndi 'God' and Hitt. perunaš 'cliff' (for the similar semantic development of this IE word, see Celt. Hercynia, Goth. faírguni, etc. quoted above); Brand. 65, Walde II 47, Pokorny 822-823, Friedrich 133, etc., the latter with very interesting mythological connections; see also Vasmer III 246-247;

5.) *pitu-deru 'Saftbaum, Harzbaum', i.e., 'Kiefer' as the tree richest in resin, hence only in individual languages the abbreviated form *pitús 'Fichte' originated, etc.: OI pïtu-dāru 'eine Fichtenart', actually 'Harzbaum' (Pokorny thus, but Friedrich 'a kind of pine, or fir, or resinous tree') and an abbreviated form pit 'Fichte' in Pamir dialects, Gr. mívs 'Fichte', i.e. 'spruce' but also 'pine' (see Friedrich), Lat. pinus, -ūs ( $\leq$ *pit-s-nus) 'Fichte, Föhre, Kiefer', Alb. pishë ( $\leq$ *pit-s- $i \bar{a})$ 'Fichte, Kienfackel' (Brand. 65, Walde II 74, Pokorny 794, Friedrich 34, etc.). Pokorny derives *pltu- from the verbal root *pei(a)-, *pt- 'fett sein, strotzen' and interprets the primary meaning of this noun as 'Trunk, Speise' (see, e.g., OI pitú- m. 'Saft, Trunk, Nahrung, Speise', Lat. pituïta 'reiche Feuchtigkeit, Schnupfen', etc.), then 'Harz' from which *pitu-deru-, etc. as a 'resinous (coniferous) tree'. This etymology could be supported by a semantically parallel etymology of Slav. *smerk-//*smbrk(see ORuss. smerč 'spruce, larch', Vasm. III 686) if the latter stems from *smbrkati 'blow one's running nose' (see Vasm. III 691): thus *smerk-//*smbrk- 'a tree with "snots", "icicles" of resin'.

6.) *bh $e^{r a g ' o ́ s ~ ' B i r k e ': ~ O I ~ b h u ̈ r j a ́-~ m . ~ ' e i n e ~ A r t ~ B i r k e ', ~ O s s e t . ~ b a ̈ r z ~}$ 'Birke', Lat. farnus (*fár[a]g-s-no-s, primarily an adjective) 'Esche', fräxinus (*bh rag'-s-enós) idem, OHG birihha (*bherag'-iā), OE beorc, birce, OIc. bjork (*bherag'ā) 'Birke', Lith. béržas m., Slav. *bérza in Russ. berëza, Pol. brzoza, Cz. bríza, S-C brèza, etc. idem (Brand. 65, Walde II 170, Pokorny 139, Friedrich 26 , etc.) The tree has undoubtedly been 
called this for its shining white color (i.e., the color of its bark) since the etymology of its name is obvious: it is derived from the verbal root *bherag'-, *bhrēg'- 'glänzen' attested, for example, in OI bhrājate 'glänzt, strahlt', B-S *brēšk- ('bhrēg'-sk-) in Lith. brěkšta, brěško, brěkšti 'dämmern' (referring to the dawn), Slav. *brěskъ 'Morgendämmerung', in Pol. brzask, Cz. bresk, Sloven. brệsk, etc. (for details, see Friedrich 1.c. and especially his remarks about birch as "a female virgin symbol for many Indo-Europeans for over five thousand years" (1.c. 27)).

Since we are dealing here with the problem of the oldest linguistically retrievable habitat of the Indo-Europeans, we can neglect the names of other trees which appear only in the European branch of IE, i.e., after the splitting off of the Aryan branch. What was the geographical range of the above species ('ueitos 'willow', *perk ${ }_{\llcorner}^{\mathrm{u} o s}$ 'oak', *pitu- 'pine' or 'spruce', *bh $h^{r a g ' o s}$ 'birch') at the time for which we still can accept the existence of a PIE linguistic community, i.e., in the fourth millennium B.C.? According to a presentation of the problem by P. Friedrich, who has used the results of recent paleobotanical research (see his bibliography), the situation was as follows:

For central and eastern Europe during the Atlantic the four main considerations are as follows. First, the natural boundary between the forest and the /forest-/ steppe of the Russian plain was established during the mid-Holocene, probably the early Atlantic. Second, the southern line of this forest-steppe extended about two hundred miles north of the Causasus, merging with the northern forest line somewhere just east of the Volga; presumably a narrow deciduous belt continued eastward to the central Asiatic uplands. Third, the north German plain /and also much of what today is Poland/ was significantly warmer than today, and the entire east European area enjoyed a moister and essentially temperate climate. Fourth, the arboreal attributes of the great river systems of "southern Russia" are important for this paper and have been vividly summarized by Nejshtadt /1957, p.221/: scattered but often large forests and groves of pines and hardwoods /oak, linden, willow, hornbeam, maple, beech, alder, hazel/ were found along the southern Bug and the Dnieper, and similar mixtures grew along the Don and Volga all the way to the Sea of Azov and the Caspian Sea. In sum, from the foothills and steppe north of the western side of the Caspian westward through what is now the Ukraine and northwestward into the north German plain there ran a fairly continuous and fairly homogeneous ecological zone - by 
and large one of temperate climate, open plains, and mixed hardwood forests. I assume that it was precisely in this east European area during the Atlantic period that speakers of Proto-Indo-European were distributed in a block of dialects about three hundred miles wide and five hundred or more miles long: the area may have been only a third as large, but in any case probably included the central and eastern Ukraine. Subsequently, during the last of the late Atlantic and the first part of the Subboreal, the speakers of at least three dialects /Celtic, Italic, and Germanic/ entered, crossed, or occupied central Germany and adjacent areas to the west, south and north.

/P.Friedrich, 1970: 15-16/

It is important that Friedrich's results do not contradict the conclusions drawn from the analysis of the oldest PIE tree-names by Brandenstein, who says:

Wir finden im frühidg. Wortschatz ein biegsames Wassergewächs /d.i. eine Weidenart/, ein elastisches Nutzholz /Lärche/, die Eiche, einen Harzbaum /Kiefer, den wohl harzreichsten/ und die Birke. Wenn wir diesen Baumbestand mustern, so fällt uns vor allem auf, dass spezifisch europäische Bäume wie Buche, Esche, Eibe, Ulme, Haselnuss und Ahorn fehlen. Hingegen finden wir gerade jene Bäume, die den Rand der Steppe bilden, insbesondere aber solche, die in den Bauminseln der Steppe anzutreffen sind, wie etwa die Birke. Diese ist aus pflanzengeographischen Gründen besonders wichtig, da sie unter den frühidg. Bäumen am weitesten nach dem Süden geht. Da sie aber den 50 . Breitegrad nicht überschreitet, weist sie die Frühidg. abermals in die nördliche Kirgisensteppe. Von besonderer Bedeutung ist die Eiche/Stieleiche/, da sie zwar noch im Ural, aber nur bis zum 57. Langengrad, in den Waldinseln der Steppe nur noch zwischen Samara und Orenburg vorkommt. Selbst wenn wir annehmen, dass dieser Teil der Steppe erst im Laufe einer Westwanderung und im jüngsten Abschnitt der frühidg. Zeit erreicht wurde - worauf hinzuweisen scheint, dass die Eichel noch nicht bekannt war - , verbietet die Eiche doch auf jeden Fall den frühidg. Raum allzuweit im Osten /etwa ausserhalb der bergigen Steppe/ anzusetzen. Anderseits verbietet das Fehlen der Fichte /Pinus silvestris/, mehr als höchstens einen Breitegrad über die Linie Orenburg-Samara hinauszugehen. Für die 
Festlegung der Westgrenze ist es von Bedeutung, dass die Linde fehlt, die in der südrussischen Steppe bis zur unteren Wolga vorkommt.

Bei allen pflanzengeographischen Ansätzen ist noch zu beachten, dass sie auf Grund der heutigen Verhältnisse erfolgten; vor 5000 bis 6000 Jahren sind die Grenzen unbedingt etwas weiter nach dem Osten hin gelegen gewesen, da damals die Austrocknung noch nicht so weit vorgeschritten war. Beträchtliche Verschiebungen ergeben sich dadurch jedoch nicht /sicher nicht mehr als um etwa 100 bis $200 \mathrm{~km} / . .$.

Wesentlich mehr Baumnamen zeigt die spätidg. Zeit. Es tauchen mehrere Weidengattungen auf, was auf sumpfiges Gelände hinweist, Die Linde weist auf das Land westlich von der Wolga, Esche und Spitzahorn westlich vom Ural, die Haselnuss westlich von der südrussischen Steppe, die Buche westlich von der Linie Königsberg-Karpathenostrand /die Buchengrenze lag vor 5000 Jahren natürlich etwas weiter östlich; etwa Riga-Kijew-Karpathenostrand/. Die Fichte hat ihre Südostgrenze in einer Linie ungefähr von Moskau bis zum Karpathenostrand was den spätidg. Raum im Südosten noch etwas stärker einengt.

/W. Brandenstein, 1936: 64-65/

The only difference between the two authors is that Friedrich concentrates more on the habitat of the European branch of IE, somehow neglecting the hypothesis of "die erste indogermanische Wanderung." Since this hypothesis plays a central role in the whole reasoning of Brandenstein, and stems from linguistic evidence exclusively, we should add here other relevant arguments on its behalf. These arguments concern the prehistory of IE agricultural terminology.

It has been mentioned that typical agricultural terms such as, e.g., 'to plow', 'to sow', 'to grind', 'seed', 'plow', 'quern', 'arable field', and 'furrow' are restricted to the European branch of IE, i.e., they do not have any etymological correspondences in the Aryan branch ("Asiatic") or, if they have correspondences in Aryan, these show a more primitive (older) general, not specialized agricultural meaning. To this category of words we can also add the name of the pig as a typical animal and the oldest domestic animal of primitive farmers.

Let us take a brief look at the words in question:

1.) *ar(a)- 'pflügen', e.g. Gr. ’’óó 'pflüge, ackere', Lat. arō, -āre idem, etc. (attested only in the European branch, including here Armenian and Tokharian (!); cf. Pokorny 62 and the chapter about the stratification of 
PSl. vocabulary above).

2.) *sē(i): *sai: *sí-, etc. 'ein Wurfgeschoss entsenden, werfen' and 'säen' (according to Brand. 27 and Pokorny 889), e.g.: with the first meaning OI sāyaka- m., n. 'Wurfgeschoss, Pfeil', etc. sênā 'Wurfgeschoss, Wurfspiess; Schlachtreihe, Heer', etc., with the second meaning Lat. serō

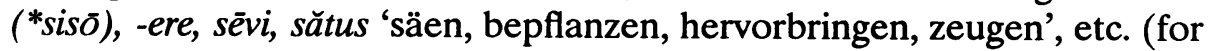
more comparative material see information above in the chapter on the stratification of PSI. vocabulary). The semantic development of this verbal root towards a technical agricultural term is characteristic of the European branch of IE, and can represent a classical example of what Brandenstein formulates in a separate chapter of his book as "Die Bedeutungsgeschichte als wichtiges chronologisches Mittel der kulturgeschichtlichen Auswertung". In this connection it is worth quoting his remarks on the semantic evolution of the verbal root in question:

Wiederum ist die Richtung der Bedeutungsentwicklung eindeutig: man kann wohl das Auswerfen des Samens mit dem Entsenden von Geschossen vergleichen: das Umgekehrte ist nicht möglich, dass mann nämlich zur Bezeichnung des Wurfgeschosses eine Ableitung des Verbums "säen" benützt. Wenn daher das Altindische diesen Verbalstamm lediglich 5 in der Bedeutung "werfen" aufweist, während die anderen idg. Sprachen einheitlich und ausschliesslich die Bedeutung "säen" haben, so hat eben das Ai. den sonst allgemeinen Wandel zu "säen" nicht mehr mitgemacht! Abermals zeigt sich das Indoiranische als die Sprache, die sich zuerst abgetrennt hat, während die Einheit der übrigen Sprachen die Entwicklung dieses Wortes weiter führte und obendrein die alte Bedeutung vollständig verlor!

3.) *mel(a)-: *mlë- 'schlaff, weich machen' and 'mahlen' (according to Brand. 27; Pokorny 716: "zermalmen, schlagen, mahlen, speziell Korn"), e.g.: OI mrnnáti 'zermalmt, mahlt', mürnáa 'verwelkt, schlaff' and 'zermalmt', Gr. $\mu u ́ \lambda \lambda \omega$ 'mahle, zerreibe, zermalme', Lat. molō, -ere 'mahlen', etc. (for more comparative material see information above in the chapter on stratification, etc.). Again - according to Brandenstein, 1.c. - OI shows the older, unspecialized meaning 'schlaff, weich machen', whereas the European branch indicates the semantic change towards specialized agricultural meaning 'mahlen', which would prove that the split of Aryan took place before the semantic specialization of the verb in question.

4a.) *sēmen- 'Same', e.g., Lat. sēmen, OHG sāmo, OCS sěmę, etc. (cf. Pokorny 889 and see also above in the chapter on stratification, etc.); it is a clear derivative from *sé(i)-, etc., unknown in Aryan. 
4b.) 'g' '̆nom 'Reibefrucht, Korn' (this meaning is reconstructed by Pokorny 390-391), but it is actually attested in the specialized agricultural meaning 'Korn', i.e., corn of grain in the "European" languages only: Lat. gränum, OIr. grān, Goth. kaúrn, etc., Lith. žirnis 'Erbse' (!), Slav. *zbrno in OCS zrono, Russ. zernó, Pol. ziarno, etc.; its correspondence in OI, the participle jürná-, jīrná-, means simply 'gebrechlich, abgelebt, abgenutzt, etc.' and again represents an older, "pre-agricultural" PIE meaning of the

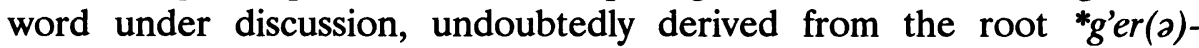
'morsch, reif werden, altern', e.g., OI jüryati, jïryati 'wird gebrechlich, morsch, altert', Gr. $\gamma \in \hat{\rho} \rho \omega \nu$ ( $\gamma \in \rho \circ \nu \tau-)$, 'Greis' (old part. praes.), Slav. zbrěti 'reifen', etc.

5.) *aratrom 'Pflug' (of course, a primitive one, i.e., 'colter') a typical agricultural term of the European branch, derived from the root *ar(a)-

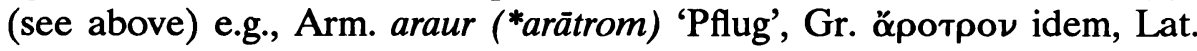
arātrum (with $\bar{a}$ from aräre) idem, etc. (for more comparative material see information above in the chapter on stratification, etc.).

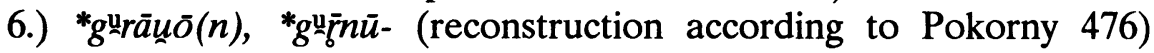
'Mühle' (actually 'a primitive handmill, quern'), but an older meaning 'a heavy stone', preserved as in the above cases in OI where grâvan- $\mathrm{m}$. 'Stein zum Somapressen' (for examples see above in the chapter on stratification, etc.). The noun is derived from the root or adjectival stem

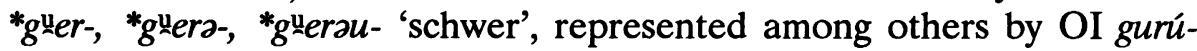
'schwer, wichtig, ehrwürdig', Gr. ßapús 'schwer', Lat. gravis 'schwer, gewichtig, etc. Brandenstein asigns a special significance to the semantic development of this word in the two branches of IE, summarizing his analysis in the following words: "im Altindischen hat das Wort lediglich die ursprüngliche Bedeutung: Stein zum (Soma-)pressen! Das Altindische is demnach bei diesem Stand der Entwicklung aus der indogermanischen Sprachgemeinschaft ausgeschieden. Die nächste Stufe der Entwicklung zeigt das Armenische, wo unser Wort die Bedeutung "Mühlstein" hat. In allen underen id. Sprachen, also den sogenannten "europäischen" Sprachen hat das Wort neben der Bedeutung "Mühlstein" überall auch die Bedeutung "Mühle" (Brand. 27).

7.) *ag'ros, the meanings of this word according to Brandenstein are 'freie Flur, Gefilde', but also 'Acker', e.g., OI ájra- m. 'Fläche, Flur, Gefilde (ohne Beziehung auf Ackerbau), Gr. ’’ $\gamma \rho$ ós 'Feld, Land (im Gegensatz zur Stadt)', Goth. akrs etc. (in all Germanic languages, e.g., NHG Acker, Eng. acre, etc.) 'Acker', Arm. art idem (-t- unexplained!): the semantic development from 'Ort, wo das Vieh hinausgetrieben wird, Weide' to 'Feld, Acker' is obvious; it is supported on the one hand by the older non-agricultural meaning of this IE word in OI and by the Gr. adjective ö $\gamma \rho$ os 'im Freien wachsed, wild', and on the other hand by its 
transparent etymology as a derivative from *ag'ō 'treiben', e.g., OI ájati 'treibt', Gr. ó $\gamma \omega \omega$ 'führe', Lat. ago 'treibe, führe', OIc. aka 'fahren', etc.; parallels of similar derivation can be found in NHG treiben $>$ Trift, Pol. wygonić 'drive out (cattle)' > wygon 'village pasture', etc. (Brand. 28, Walde II 37, Pokorny 4, 6). Here again Aryan has preserved the older, non-agricultural but pastoral meaning of the term! The semantic development from 'open space, where cattle are driven to graze, pasture' to 'arable, cultivated field' is also supported by the historical evolution of human economy.

8.) *perk'om (Pokorny reconstructs *prk'ā) 'Kluft, Riss in der Erde' and 'Ackerfurche', e.g., OI párśāna- m. 'Kluft, Abgrund, Einsenkung', this "preagricultural" meaning is also preserved in Lith. pra-peřšis 'Blänke in Eis', pra-par̃̌sas 'Graben', but in other IE ("European" branch) languages, this word already shows a specialized agricultural meaning: e.g., Lat. porca 'Furche im Acker', porculētum 'Ackerbeet', OHG furuh, OE furh $\mathrm{f}$. 'Furche' ('prk'-), etc., Norw. fere m. ('perk'-) 'Ackerbeet' (Brand. 28, Walde II 46, Pokorny 821).

In connection with the above agricultural terms, which either do not exist in Aryan or represent there an older "preagricultural" meaning, it is worthwhile to mention also PIE *pork'os 'pig', 'Hausschwein' as opposed to *sü-s, gen. *suu-ós 'swine, Wildschwein' (cf. Brand. 77): the former word is attested in Lat. porcus, MIr. orc 'Ferkel, junges Tier', OE fearh m., n., OHG far(a)h n., Lith. pařšas 'männliches verschnittenes Schwein', Slav. 'porsę, e.g., OCS prasę, Russ. porosënok, Pol. prosię, etc. 'Ferkel', i.e., in most "European" languages, but among the Aryan languages only in the westernmost, in Sakian pāsa (*parsa) and Kurd. purs. This distribution is characteristic: it seems to indicate that *pork'os, as a special term denoting the young of domesticated swine, originated in the "European" branch of IE after the separation of the main bulk of Aryan dialects. As is well-known, nomadic shepherds do not keep pigs. That *pork'os is a relatively young word proves its transparent etymology as a derivative from *perk'- 'aufreissen, aufwühlen, aufkratzen', thus 'Wühler', "rooter" (cf. Pokorny 821).

\section{Fauna}

We should make a distinction between the names of wild and those of domesticated animals. The latter are more instructive, since they indicate the type of economy of the Proto-Indo-Europeans, which in its turn can have direct connections with archeological evidence. Besides this, we can also try to establish some relations between the PIE domesticated animals and the probable centers of their domestication suggested by zoology.

Among the wild animals, for example, the following were known in the 
PIE epoch:

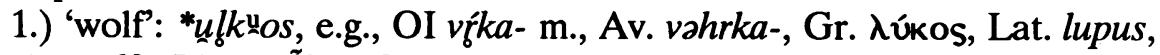
Goth. wulfs, Lith. villkas, Slav. *vblkz, in OCS vlbkb, Pol. wilk, Russ. volk, etc.; - $p$ - in Lat. and Germanic can be connected rather with the following word, *ulpēil-, etc. (cf. Pokorny 1178);

2.) 'fox': *ulpē/i-, *lupē/i-, e.g., Av. urupi- m. 'Hund' (*lupi-), raopi'Fuchs, Schakal', OI lopāśa- m. 'Schakal, Fuchs', Arm. aluēs 'Fuchs', Gr. $\dot{\alpha} \lambda \omega \tilde{\pi} \epsilon \xi$ f. idem, Lat. volpēs idem, Lith. lãpé (*ulopē), etc.; according to Pokorny "es handelt sich zweifellos um verschiedene tabuistische Umbildungen" (Pokorny 1179);

3.) 'lynx': *lu(n)k's, e.g., Gr. $\lambda u ́ \gamma \xi, \lambda$ vүкós, OHG luhs, OE lox, Lith. lúšis, Slav. rysb with $r$ - instead of $l$-, probably influenced by an unattested Iranian *rus-, cf. OI ruśant- 'licht, hell, weiss': it seems quite probable that 'lynx' was denoted by IE *leuk-//*leuk'- 'leuchten, licht' because of his bright, "grauweiss" fur (cf. Pokorny 690);

4.) 'bear', besides that of wolf, one of the best attested IE manes of a wild, predatory animal: ${ }^{*} k^{\prime}$ pos (or ${ }^{*} r k^{\prime}$ sos $/{ }^{*} r k k^{\prime} t o s ?$ ), e.g., OI $\lceil k s a-$ m., Osset. ars, Gr. öрктоs, MIr. art, Lat. ursus, Hitt. probably hartagga- the name of a predatory animal; in Germanic and Balto-Slavic replaced by new euphemistic names because of taboo, e.g., Slav. medvědb from *medhu-édis 'honey eater'; PIE *rk'pos itself seems to have an etymology related to destroying (beehives), cf. OI rákşas- 'Zerstörung', Av. raš'beschädigen', Gr. é $\rho$ é $\chi \theta \omega$ 'zerre und beutle hin und her', which presupposes ${ }^{*} r e k$ 'ph- (sic!, as in Pokorny 864): hence ${ }^{*} r k$ 'pos, etc. 'Schädiger' (Pokorny 875).

It is striking that a PIE name for fish cannot be reconstructed. This fact parallels the lack of PIE name for sea.

Among the domesticated animals cattle, sheep, goat and horse were known and kept in the PIE epoch. The names of these animals are PIE and continued in the main IE languages of the two branches, i.e., Aryan and "European."

1.) ' $g$ uัous 'cattle', i.e., 'cow' and 'ox', differentiated only by gender-pronouns, cf. Gr. ஸ் ßô̂s : ò ßoûs, etc.: OI gáuh m.f. 'Rind', gen. góh, Av. gāuš idem, Arm. kov 'Kuh', Gr. Att. ßoûs m. f. 'Rind, Kuh', Dor. $\beta \hat{\omega}$ s; OI acc. gām and Dor. acc. $\beta \hat{\omega} \nu$ indicate a very old irregular paradigm with the diphthong *ou in N-A; Lat. bōs, bovis m.f. 'Rind' (Osk.-Umbr. loanword instead of Lat. *vōs), OIr. bó f. 'Kuh', etc., OHG chuo, $\mathrm{OE}$ cú, etc. 'Kuh', Latv. gùovs idem, in Slavic only the derivative (collective) *govędo 'Rind', e.g., in S-C gòvedo, Russ. govjádo, Cz. hovado; Toch. A ko 'Kuh', B kau 'Kuh' (Brand. 72, Walde I 696, Pokorny 482, Vasmer I 425);

2.) *tauros 'bull', i.e., 'uncastrated bull, used for breeding': Gr. 


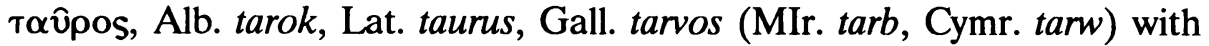
metathesis under the influence of Kelt. carvos 'Hirsch', OIc. pjorr, etc., transformed under the influence of stjorr (IE *steuro-), B-S *taura-, e.g., Lith. taũras, OCS turb, etc. 'Auerochs' (the older meaning?); in OI only the adj. túmra- 'strotzend' as an epithet of 'bull' is found: the name seems to be derived from IE *tēu-, *tau-, *teuə-, *tŭ- 'schwellen' (cf. Pokorny 1080); as far as Slavic is concerned, in my opinion the variant *türo- may have survived in the second component of *pas-tyr'b 'shepherd' (Brand. 72, Walde I 711, Pokorny 1083);

3.) *pek'us according to Brandenstein 'Schafherde' and from this *pek'eti 'rupft die Wolle aus' (sic!, but Pokorny accepts just the opposite direction of derivation, Pokorny 797): OI páśu-, paśú- n., gen. paśvá- $h$, also paśú-m. 'Vieh', Av. pasu- m. idem (usually 'Kleinvieh', i.e., sheep), Lat. pecu, -ūs n. 'Vieh' besides pecus, -oris n., Goth. faihu 'Besitz, Vermögen', but OIc. fé, OE feoh, OHG fihu 'Vieh'; Lith. pekus, OPruss. pecku (with kentum $k$ !) 'Vieh' (no traces in Slavic!); Gr. Tékos n. 'Fliess, Wolle' represents PIE *pek'os-, etc. (Brand. 73, Walde I 16, Pokorny 797);

4.) *moisós 'Widder; Fellschlauch': OI mēșá- m. 'Widder', mēşi'Schaffell', Av. maēša- 'Widder, Schaf', OIc. meiss n. 'Korb', OHG meis(s)a 'Gepäck', OCS měxъ 'Schlauch' (in all Slavic languages, e.g., Russ. mex, Pol. miech, etc.), Lith. máišas, màiše 'Heunetz' and similar things, Latv. máiss, máikss 'Sack', etc. (Brand. 73, Walde II 303, Pokorny 747);

5.) *u $e^{r e \bar{n}}$ according to Brandenstein 'Wollschaf' primarily as opposed to *ouis 'gezähmtes Wildschaf': OI urä (the stem uran-), urana- $\mathrm{m}$. 'Lamm, Widder', Arm. garn, gen. garin 'Lamm', Gr. Hom. $(F) \alpha \rho \eta$ ' $\nu$ gen.

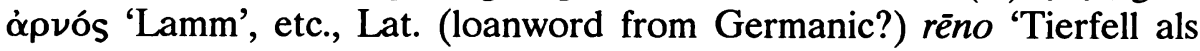
Kleidung, Pelz' ( *urēnōn-) (Brand. 73, Walde I 269, Pokorny 1170);

6.) *óuis according to Brandenstein '(gezähmtes Wild-)Schaf', suggested among others by his etymology of the word from the verbal root eu-7 'sich gewöhnen', so *ouis 'das Gezähmte': OI ávi- m., f. 'Schaf', aviká 'weibliches Schaf' (= Slav. ovbca), Gr. óís, oîs 'Schaf', Lat. ovis idem, OIr. öi idem, etc., OIc. ǣr, OE èowu, èowe = NE ewe, OHG ouwi, ou 'Schaf' (from Proto-Germ. *awi, gen. *awjōz), Lith. avis, OCS ovbca, etc. (Brand, 74, Walde I 167, Pokorny 784);

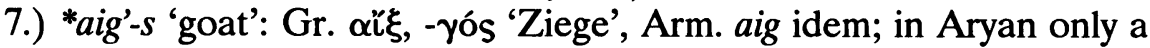
derivative: Av. izaēna- 'aus Leder', i.e., 'aus Ziegenleder' like Gr. oǔ $\gamma \in \iota$ (*(a)ig'eio-); according to Brandenstein a prehistorical loanword from a non-IE language of the Carpathian or Balkan region, according to Pokorny rather an "orientalischer Kulturwort" (Brand. 75, Walde I 8, Pokorny 13); 
8.) *气ӑg'os according to Brandenstein 'Ziege', according to Pokorny 'Ziegenbock, Ziege': OI ajá- 'Ziegenbock' : ajá 'Ziege', MPers. azak 'Ziege', NPers. azg idem, Alb. dhi (from *adhi, i.e., IE *ag'i-) idem, Lith. ožỹs ('äg'ios) 'Ziegenbock' : ožkà 'Ziege'; Slavic has only a derivative *azbno 'Haut, Leder', actually 'goatskin', in Church Slav. (j)azno, ORuss. jazbno corresponding to OI ajína- n. 'Fell', Lith. ožinis 'zum Ziegenbock gehörig', etc.; whether Slav. koza belongs here as representing *k-oza (with a "prothetic" $k$ of pronominal origin: ${ }^{*} k{ }^{\mathrm{u} O} \mathrm{O}$ ?) is disputable. O.N. Trubačev (1960: 87-88) argues quite convincingly for the Altaic origin of

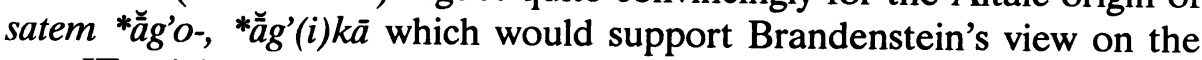
non-IE origin of this name, although the source of the borrowing would be different (Brand. 75, Walde I 38, Pokorny 6-7, Trubačev, 1960: 87-88).

9.) *bhüg'os 'buck': Av. büza- m. 'Ziegenbock', Arm. buz 'Lamm', MIr. bocc, etc. 'Bock', NIr. boc, etc. idem; Germanic forms representing *bukka-, e.g., OIc. bukkr, bokkr, OE bucca, OHG boc, etc., are considered Celtic loanwords; according to Brandenstein, the name of 'bock' has been influenced by the verb *bheug- 'fliehen' (Brand. 75, Walde II 189, Pokorny 174);

10.) *kapros 'buck', according to Brandenstein 'Ziegenbock': OI

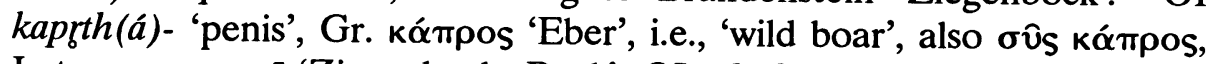
Lat. caper, capri 'Ziegenbock, Bock', OIc. hafr 'Ziegenbock', OE hæfer idem, etc. Proto-Celtic *gabros 'Bock' in OIr. gabor, Cymr. gafr, etc. with g- from *ghaido-, e.g., Lat. haedus, Goth. gaits, etc., another West IE name of "he goat"; because of OI and Gr. meanings, Pokorny reconstructs 'mänliches Tier' as the basic meaning of *kapros (Brand. 75, Walde I 347, Pokorny 529);

11.) ek'uos 'horse': OI áśva-, Av. aspa-, Gr. ï $\pi \mathrm{os}^{8} \mathrm{~m}$. and f. originally without spiritus asper: "A $\mathrm{A} \lambda_{\mathrm{k}-\iota \pi \pi \mathrm{os}}$, Lat. equus, OIr. ech, Gaulish epo- in Eporēdia, Epona 'muliōnum dea', etc., OE eoh m., OIc. iōr, Goth. aíhva-tundi 'Dornstrauch', literally "Rosszahn", Toch. A yuk, B yakwe 'Pferd' with prothetic $y$-; feminine in -ā: OI áśvā, Av. aspā-, Lat. equa, OLith. ašvà, ešvà 'Stute'; no traces in Slavic; Brandenstein's etymology deriving this noun from the onomatopeic root $e k$ 'a- 'neigh' and treating it as an adjective with the suffix - $u$ - is not very convincing; in any case, the morphological shape of ek'uos is not so archaic as that of ${ }^{*} g^{\mathrm{u}} \overline{o u s}$ or ${ }^{*}{ }^{*} e^{\prime} u(s)$ and in this connection, we can consider it a younger acquisition of the PIE vocabulary (Brand. 77, Walde I 113, Pokorny 301).

In connection with the names of domesticated animals (cattle, sheep, horse) it should be emphasized that they cannot be considered in isolation from other names semantically related to them, like 'to milk', 'milk', 'cheese', 'wool', 'wagon', 'wheel', etc., because only in this framework are we able to reconstruct and understand the relative significance of the 
individual species in the material and spiritual culture of the Proto-Indo-Europeans. Much has been written about the role of the horse in the life of the ancient IE peoples and that of the Proto-Indo-Europeans. A synthetic picture of the Proto-Indo-Europeans as "ein Volk von ausgesprochenen Viehzüchtern... Viehzüchtern grossen Stils, für die Rind und Schaf der wichtigste Besitz und Reichtum waren" has been recently presented by $H$. Krahe (1970: 63), of course, on the basis of lexical evidence. The same author (1.c. 63-64) underlines the role of the horse as a sacrificial animal ultimately connected with some religious-mythological beliefs and symbols, e.g., the brotherly pair of stars represented as horses: OI Aśvínau (dual) $\sim$ Gr. $\Delta$ เóokoupo also called $\Lambda \epsilon \cup \kappa о \pi \omega \dot{\lambda} \omega$ (dual) 'white colts' OE Hengist and Horsa (?) - all of which probably referred to the 'morning/evening star' (cf. also O. Schrader, 1901:672-673). It seems, however, unfounded (unjustified) to consider the horse as "in erster Linie" an animal for riding as H. Krahe does. The lack of PIE names for saddle and bridle (in contradistinction, e.g., to those of yoke and wagon/wheel) argues against this hypothesis. The PIE horse was first of all an animal bred for meat, then it was used as a draft animal (for war-wagons, chariots). The development of a riding horse (with saddle, stirrup, etc.) appears later, especially among the northern Iranians (in this connection, cf. again O. Schrader, 1901: under Pferd). In any case, the significance of the horse in the life of the ancient IE tribal aristocracy is reflected in an old type of compound personal name containing as one of its components PIE ek'uo-; these names are attested in Aryan, Greek, Celtic, and Germanic, e.g.: OI Aśva-pati- 'Lord of horses', Brhhad-aśva- '(Owner) of tall horses', Av. Aurvat-aspa'(Owner) of swift horses', Med. Aspa-čanā- 'Horse-lover', Gr.

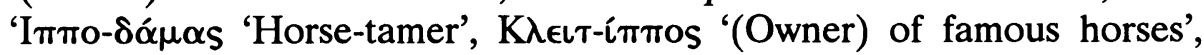

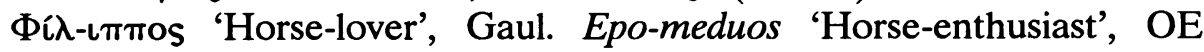
Eo-mær 'Famous because of horses', etc. (cf. T. Milewski, 1969:59, H. Krahe, 1970:64). It should be noted that the above names show and continue the PIE structural pattern but not necessarily the PIE "substance." Therefore, it is questionable whether such names really prove the importance of the horse in the life of the PIE tribal aristocracy. The fact, for example, that there are no traces of such names in Lithuanian, which otherwise has preserved a vestige of the PIE ek'uo- in the noun ešvà/ašvà 'mare' and which, as is well-known, is very conservative in its anthroponymy (cf. T. Milewski) - would speak against that importance. I think that the "career" of the horse, first as a draft animal, and then as a mounted animal used for military purposes, is post-PIE. It is especially characteristic of the Aryans, the Greeks, and the Celts. In this connection, the results of F. Hančar's book (1955:542-544) 
seem to be crucial $^{9}$. We can also repeat here the observations by $\mathrm{T}$. Milewski (1969:148-150) which seem to be instructive in this respect:

The analysis of Greek anthroponymy of the Mycenaean epoch (1450-1200 B.C.) and its comparison with Homeric and classical anthroponymy (600 - 100 B.C.) will enable us to discover many interesting facts pertaining to the history of Hellenic culture... Here we will limit ourselves to one detail only, namely to the comparison of the role of the names of the horse, ox, and goat in the anthroponymy of the last millennium B.C., and in the anthroponymy of the Mycenaean epoch. In the collection... of names of the last millennium... by F. Bechtel and A. Fick: Die griechischen Personennamen (2nd. ed. 1894) we meet the word immos 'horse' in about 230

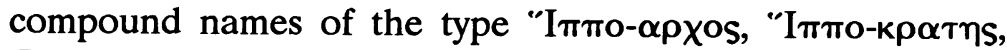

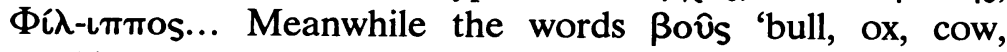
ox-skin shield' occur only in the 19 compound names of the last millennium, and 13 from among them are the names of mythical heroes, e.g., Bouלvirns... or the names in the

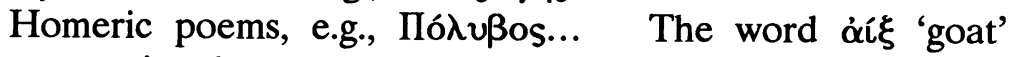
occurs in the names of the last millennium, namely...

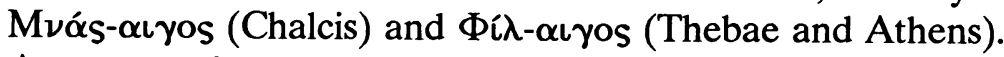
As we see, the names containing the word 'horse' were very popular in the classical epoch; on the other hand, the words denoting ox and goat did not play almost any role in the anthroponymy. Completely different were the relations in the anthroponymy of the Mycenaean epoch. In the monuments of this epoch, the stem aigi- derived from ó $\mathfrak{\alpha}_{\xi}$ 'goat' is found most frequently in the function of the first component: Aigi-pōs (ai-ki-po) '(Having) goat's legs', Aigi-wastos (ai-ki-wa-to) 'Living with goats', Aigi-noos (ai-gi-no-o) '(Having) a goat's mind...' The word guou-, an older form of the classical ßov̂s, occurs in a name from the end of the fifteenth century B.C.: Guow-akseus (go-wa$k e-s e-u$ ) 'Bull-leader'... . But among all the Mycenaean monuments, there is no one sure example of a compound name containing the name of the horse. This deep difference in the selection of words used in anthroponymy is undoubtedly a reflection of differences in the cultures of the two milieus, also since the art of the Minoan-Mycenaean epoch very often represents goats and oxen in contradistinction to horses, which only in the last millennium became a frequent subject in visual arts. Landau supposes 
that numerous Mycenaean names containing the word "goat" originated in connection with a fertility cult... It is highly probable that in the Mycenaean epoch, in the fifteenth through the thirteenth centuries, horses played an insignificant role in the life of the Achaian tribes, which were dominating at that time, but the breeding of cattle and goats had a great economic significance for them; the breeding of goats had probably a religious function as well. On the other hands, in Homeric times (ninth and eighth centuries), and in the classical epoch, the horse was the most prized (valuable) domestic animal, first of all for his role in the war, and especially in sport. The development of hippic sports, unknown to the Pre-Hellenic population, and introduced by the Indo-European newcomers, overshadowed old domestic animals, such as goats and cattle. Hellas of the Mycenaean epoch, as far as domestic animals are concerned, was closer to Pre-Indo-European Greece than to the later Homeric and classical epoch.

Thus, everything seems to indicate that we should not exaggerate the role of the horse in the real PIE times, i.e., at the latest before 2500 B.C., although the animal was known and probably domesticated.

All the above lexical arguments concerning landscape, climate, flora and fauna (wild and domesticated) common to the two branches of IE, i.e., Aryan and "European", seem to support the idea of Brandenstein that the oldest really PIE habitat must have been located in the sub-Uralian (Kirghiz) steppes, more precisely, in their north-western part, thus beyond the Volga River. But let that author speak for himself:

Ergebnisse und Ausblick

Wenn man den idg. Wortschatz historisch auswerten will, ist es nötig, die Tatsachen, die sich aus der Analyse des Wortschatzes ergeben, in ein chronologisches Verhältnis zueinander $\mathrm{zu}$ bringen. Wie ich gezeigt habe, sind wir imstande, eine Chronologie aufzustellen. Es ergibt sich dabei, dass sich eine ganze Sprachgruppe, nämlich das Indoiranische, früher entwickelte als irgend eine andere Sprache, und weiters, was viel wichtiger ist, dass diese Teilung der Idg. vor einer "Zeitenwende" geschah, vor einem kulturellen Umbruch. Mit Hilfe dieser chronologischen Schichtung lassen sich die aus der Sprache gewonnenen Tatsachen (die, nebeneinander gestellt, unvereinbar sind) sinnvoll hintereinander ordnen. Bisher hat man vielfach aus 
den widerspruchsvollen Daten die genehmen ausgewählt, unter "Abstraktion" der anderen, so dass sowohl die Nordthese als auch die Ostthese gewisse Umstände für sich buchen konnten; jetzt aber vermag die chronologische Ordnung aus den gegensätzlichen Tatsachen, - gegensätzlich nur innerhalb der verkehrten Auffassung, sie seien gleichzeitig - einen sinnvollen historischen Verlauf zu erschliessen. Es liegt somit kein Kompromiss vor (den ich unter allen Umständen ablehnen würde); dieses Resultat ergibt sich bei unbefangener Betrachtung der Tatsachen von selbst (und auch den Autor überraschend); es erklärt aber auch nunmehr sehr leicht, warum es überhaupt zu den beiden feindlichen Thesen kam.

Der frühidg. Raum war eine gebirgige und "subarktische" Steppe mit allen ihren Eigenheiten. Dazu gehört vor allem ein kontinentales Klima, weshalb auch der Name für "Meer" fehlt. Von dem Steppengürtel, der von Südrussland bis zu den zentralasiatischen Hochgebirgen reicht, kommt nur die nordwestliche Kirgisensteppe in Betracht: die Beschreibung des frühidg. Raumes, die ich auf Grund des Wortschatzes geben konnte, deckt sich vollständig mit den Reiseschilderungen, die uns ganz unbefangene Reiseschriftsteller von diesen Steppen bringen, stimmt aber nicht zu den Beschreibungen anderer Steppen.

Weil die Frage der idg. Urheimat vielfach gefühlsmässig belastet ist, möchte ich betonen, dass ich noch vor wenigen Jahren Anhänger der Nordthese war. Weiters möchte ich hervorheben, dass ich die Landesbeschreibung, die ich vom frühidg. Raum geben konnte, erst nachträglich mit den Reisebeschreibungen der frühidg. Steppen konfrontierte, so dass ich also von diesen Autoren in keiner Weise beeinflusst war.

An welcher Stelle immer ich ein für die frühidg. Zeit spezifisches Bedeutungsfeld heraushob, es ergab sich immer wieder dasselbe Resultat. Die Wörter für Steigen, Gehen und Laufen sind frühidg. und weisen auf die gebirgige Steppe him usw. usw. Ganz besonders schöne Bestätigungen ergab die Untersuchung der Flora und Fauna. Wir fanden im frühidg. Wortschatz nur solche Tiere und Pflanzen vor, die wir in der Steppe erwarten. Hingegen fehlen alle typisch europäischen Tiere und Pflanzen. Einige Beispiele gaben uns die Handhabe, den weiteren Osten auszuschliessen (was 
nichts über eine protindogermanische (sic!) Zeit besagen kann). Die Domestikationsherde der frühidg. Haustiere liegen in allernächster Nähe des frühidg. Raumes, sozusagen ringsherum; einige davon sind vielleicht mit ihm sogar identisch.

Ganz anders sieht der spätidg. Raum aus. Es handelt sich dabei um ein sumpf- un wasserreiches Gebiet, das ausserdem gegenüber dem frühidg. Raum eine bemerkenswerte Vermehrung der Niederschläge zeigt. Demgemäss sieht auch die Tier- und Pflanzenwelt aus. Es lassen sich nunmehr typisch europäische Arten nachweisen, darunter besonders solche, die wasserliebend sind. Einige Beispiele gestatten eine weitere Einengung in den Raum des heutigen Ostpolens, und zwar ungefähr vom Karpathenvorland bis zur Ostsee. Die Rokitnosümpfe wirkten wie ein Keil, auch in wortgeographischer Hinsicht. Daher wurde das Meer nur einem Teil der Spätidg. bekannt. Weiter nach dem Westen oder Süden zu gehen, verbietet das Fehlen der Tanne. Das in spätidg. Zeit dazukommende Haustier ist das Schwein, dessen Domestikationszentrum im Hinterland der Ostsee liegt, eine neuerliche Bestätigung meiner Ansätze!

Aus alledem müssen wir den Schluss ziehen, das die Idg. aus irgendeinem uns noch unbekanntem Grund ihre Weideplätze in der nordwestlichen Kirgisensteppe verliessen und gegen das heutige Polen zogen, während eine Rest zurückblieb, der erst später gegen Westen wanderte, aber nach dem Süden (über den Kaukasus) abbogt. Dieser Rest entwickelte sich nach der Trennung zum Volk der Indoiranier, deren Weg durch die Untersuchungen Kretschmers bestimmt wurde: Siedlungen an der Wolga und im Kaukasus sind gesichert (WZKM33, 1 ff. und KZ55, 75 ff.)

Recently (1970), H. Krahe, also starting from the lexical evidence, reached similar results, namely:

Alle diese Dinge: die Grossviehzucht, der Besitz des gezähmten Pferdes, die Grossfamilie, die Vehrehrung eines höchsten Himmelsgottes - muss man zusammen sehen. Sie schliessen sich zusammen zu einem einheitlichen Kulturbild, und das Wortmaterial, welches zur Gewinnung dieses Bildes geführt hat, erstreckt sich in gleichmässiger Verbreitung über alle idg. Sprachen, d.h. es ist gemeinindogermanisch und mit einer an Sicherheit grenzenden Wahrscheinlichkeit daher auch der idg. Grundsprache zuzuschreiben... 
Um damit unsere Proben für die "linguistisch-kulturhistorische Methode", soweit sie den Lebensraum der frühesten Indogermanen betreffen, abzuschliessen, wird man - wenn auch mit allem Vorbehalt - sagen dürfen, dass mehr Indizien für eine östliche (asiatische) Herkunft der Indogermannen sprechen als für eine Lokalisierung der sog. Urheimat in Europa, etwa im Ostsee-Gebiet oder ähnlich.

(H. Krahe, 1.c. 66)

Against the background of the above conclusions based exclusively on linguistic (lexical) evidence, the western location of the primary habitat of the Proto-Indo-Europeans somewhere in central or northern Germany and the adjacent regions of Poland ( $P$. Thieme believes that it is the region between the lower Vistula and the lower Weser) seems to be unfounded. To be sure, the adherents of that "western" hypothesis also use linguistic arguments, namely the names of the beech-tree, salmon, and the bee. So let us take a look at these words from the standpoint of their arguing power for the western PIE "Urheimat."

The IE name of the beech-tree, *bhägós or *bhāg'ós f. ${ }^{10}$ (the reconstruction of the palatal $g$ ' is substantiated by PSl. *bazz, cf. LLus. baz 'Sambucus nigra' (i.e., 'lilac'), Ukr. baznyk 'Sambucus ebula', etc., see Trubačev, ESSJa I, 172, and details in the next chapter, although Pokorny 1078 accepts the velar $g$ ) is attested in the following languages: with the meaning 'beech' in Lat. fägus f., Gaul. bägos in the toponyms Bāgācon, Bägono-, OHG buohha = NHG Buche ("bokōn-, cf. silva Bäcenis = Harz in Caesar's Commentarii..), OIc. bōk f., OE bōc, bēce (*bōkjōn-), but Goth. bōka f. 'Buchstabe', OIc. bōk, OE $b \bar{c} c$, OHG buoh f., n. 'Buch';

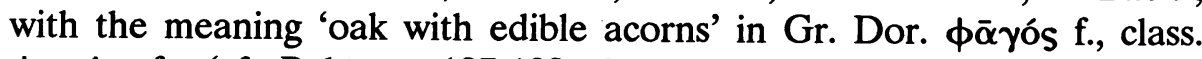
$\phi \eta \gamma \dot{\omega}$ f f., (cf. Pokorny 107-108; for details, see P. Friedrich, 1970: 106-115). We excluded from the above correspondences Slav. *buzz, *bzzъ 'lilac', since their primary shape *bh(a) ug'o- (?) is too remote from *bhāg'o-.

Whether IE *bhägós, restricted to the western and southern IE languages, actually denoted Fagus silvatica and/or Fagus orientalis (the latter known in the Caucasus), is not sure: if we reject the comparison with Slav. *bazz, then perhaps the primary meaning would be 'tree with edible nuts', which would explain the Greek meaning, and make possible the etymology deriving *bhägós from the PIE verbal root *bhag- 'zuteilen'

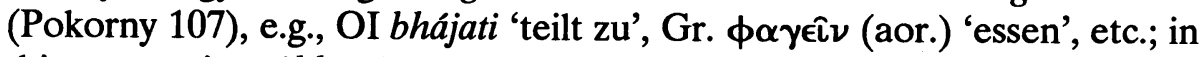
this connection, *bhāgós could be a vrddhi adjective from *bhagos '(food) allotment', etc. In any case, the tree name *bhägós is not common PIE and even if it actually referred to the 'beech tree', it must have originated in the west, where this tree grows (now it does not extend eastward of the 
Königsberg (Kalingrad)-Odessa line, and is unknown even in the central Vistula basin). P. Friedrich summarizes his analysis of the "beech problem" in the following way:

Taken all together, the botany of the common beech and of the eastern beech assures us that many early IE tribes, especially those adjacent to the southern Bug (= Boh), the Carpathians, and the Causasus, essentially must have been familiar with the genus - indeed, for some of them it may have been a conspicuous and highly valued tree. Its westward migration and climax during the Subboreal roughly coincides with the westward movement of the Italic and Germanic speakers - precisely the two dialects which preserved both the presumed original denotation and the phonologically regular form. On the other hand, the millennial scarcity or absence of beeches from the east Baltic area neatly correlates with the absence of a reflex of *bhäg'os in the Baltic languages. Such inferences and hypotheses strike me as a valid use of the "beech line."

(P. Friedrich, l.c., 112-115)

The PIE (?) name for salmon, *lak'so-, is attested in the following languages: OHG lahs, OE leax, OIc. lax m., OPrus. lasasso f., Lith. lãšis m. (gen. lãšio), lašisà f., Latv. lasis m., Slav. lososb in Russ. losos', Pol. tosoś, etc., Osset. læsæg 'Forellenart' (!), Toch. B laks 'Fisch' (!); Thieme (1953) adds here OI lakşá- '100,000' allegedly from 'spawn, roe' and läkşa 'rotes Baumlach', i.e., originally 'lachsartig, rot', a vrddhi adjective from *lak'so-; Pokorny (653) connects *lak'so- with the root *lak'- 'sprenkeln, tupfen', attested in Lith. lašěti 'tröpfen', etc., hence *lak'so- 'gesprenkelt'.

First of all, it is not certain whether the word actually denoted salmon (Salmo salar) or any similar type of fish (note the Osset. meaning 'Forellenart', i.e., a kind of trout, and Toch. 'fish' in general); secondly, the fact that Salmo salar lives only in the rivers emptying into the Baltic and North Sea loses its arguing power in the face of Osset. læsæg, which lives in the rivers flowing from the Caucasus to the Caspian Sea. Here it should be emphasized that salmon also lives in the Arctic Ocean and is known in the rivers of Western Siberia belonging to the $O b$ basin: Irtyš, Tobol, and the rivers originating in the Southern Urals (cf. M. Rudnicki, Biuletyn Pol. Tow. Językoznawcz. XV (1956), 134-5) ${ }^{11}$ Thus, the whole salmon argument as allegedly proving the western habitat of the Proto-Indo-Europeans becomes completely invalid. In any case, *lak'soin the meaning 'salmon' is only NW Indo-European: Germanic, Baltic, Slavic, which analogically to *bhägós 'beech', in this meaning also 
restricted only to Italic, Celtic, and Germanic, cannot be used as an argument in the discussion about the primary habitat of all the Indo-Europeans, i.e., real Proto-Indo-Europeans before the separation between the Aryan and the "European" branch (Pokorny 653, Thieme, 1953, Krahe, 1970:58-59).

The IE name for bee, *bhei- with $n$-, $k$-, $t$ - extensions (cf. Pokorny 116 ), or *bhiā f., posited by Brandenstein (62) as the oldest form, is also attested in NW Indo-European: OIc. by-fluga, Alem. bì, OHG bini n., bīa f. $\left({ }^{*} b i-\bar{o} n-\right)=\mathrm{OE}$ béo $=\mathrm{NE}$ bee, NHG Biene etc.; Slav. bъčela, bъčela (in OCS) could belong here if from *bhikelā (cf. Vasmer III, 416), Cymr. bydaf 'Bienestock', OPrus. bitte, Lith. bité, Latv. bite; OIr. bech(*bekos) differs in the vowel; Vasmer 1.c. also includes here Lat. fücus, $-\bar{\imath}$ (allegedly from *bhoikos) 'Brutbiene, Drohne', which, however, is interpreted by Pokorny (163) as *bhouk $k_{\circ}^{\mathrm{u}}$ 'summendes Insekt' and as corresponding to OE béaw m. 'Bremse', LG bau idem.

Since the bee (of course, primarily the wild honey-bee) is unknown in the Kirghiz Steppes, i.e., in the south of the Urals, and in West Siberia ${ }^{12}$, it is obvious that its IE name is restricted again to NW Indo-European (Celtic, Germanic, Baltic, Slavic): we face here the same situation as in the case of the beech and the salmon, namely a dialectal IE term which originated relatively late in the "European" branch of IE, not even spreading to the whole European area. There are, however, some puzzling aspects to the problem. For instance, the name for honey: mead, *médhu n., is really PIE, known in both Aryan and the "European"

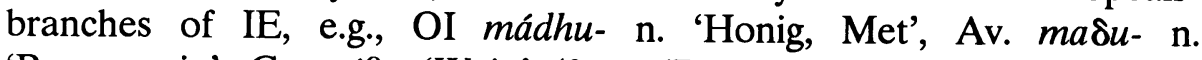
'Beerenwein', Gr. $\mu$ é $\theta v$ 'Wein' (from 'Rauschtrank'), OIc. mjodr, OE meodo, OHG metu 'Met', Lith. medùs m. 'Honig', Slav. medz (in OCS, etc.) idem (Pokorny 707). How did it happen that there is no PIE name for bee, but there is such a name for honey and mead? I think that a convincing explanation of this alleged discrepancy has been suggested by Gauthiot, who, in discussing the striking correspondence between Ugro-Finnic *mete- and PIE *medhu-, proposed a prehistorical direction of borrowing from Ugro-Finnic to PIE; I would support this hypothesis with reference to a possible primitive barter trade between the prehistorical UF forest people and the PIE cattle breeders (maybe already including some primitive farmers?), the former (Ugro-Finns) exchanging wild honey for cheese (and grain) of the latter (cf. A.J. Joki, 1970:283-284, 367).

As the reader has already noted, the present book approaches the problems of ethnogeny from a purely linguistic standpoint, i.e., all of the conclusions concerning the original habitat of a linguistic group are primarily based on linguistic, mainly lexical evidence. This method has 
been consistently applied to the problem of the PIE "Urheimat." As yet, we have used lexical evidence. But this evidence provided by a careful analysis of historical-comparative data and their reference to respective denotata is not sufficient, although it is of basic importance. In order to delineate a possible region in which the primary IE languages could originate (may have originated), we should also take into consideration the etymology and geographical distribution of the oldest, most persistent toponyms in these parts of Europe and Asia in which the IE languages appeared at the dawn of history. As is well-known, such toponyms are represented by hydronyms and oronyms (the names of mountains) since rivers and mountains are the most stable elements of the natural landscape. So we can ask the following question: what conclusions about the oldest IE territories (not necessarily the primary habitat of the Proto-Indo-Europeans) are suggested by the hydronyms (and eventually oronyms) of central and eastern Europe and of the adjacent region of NW Asia (since in this direction the lexical evidence points out quite clearly)? Because there are no high mountains in that area, except for the Carpathians, we will concentrate our attention on hydronyms.

The European hydronymy has been quite well investigated. Here we will present only the most general results which are relevant for our study. First of all, it should be emphasized that the European hydronyms between the Rhine River and the Volga River, with the exclusion of the NE part of this continental bulk, are of IE origin: what I mean here is not their recent origin, which is explicable in terms of the historical or present-day IE languages of the regions in question (e.g., Germanic, Slavic, Baltic, etc.), but their primary origin, i.e., their ultimate root and derivative affix pedigree. In this connection, we should analyze and quote not the contemporary hydronyms of the area mentioned above, but their oldest forms attested in early historical sources. The more reason that in some instances there have been radical changes in the hydronymy of this area, replacing ancient names with new ones as a result of ethnic shifts.

The main credit for the investigation of European hydronyms in recent times goes to Hans Krahe, a German Indo-Europeanist, who ventured the hypothesis about the so-called "alteuropäische Hydronymie" as the reflection of "Alteuropäisch", allegedly an intermediary dialectal stage between PIE and Italic, Celtic, Germanic, Illyrian, and Baltic (cf. H. Krahe, 1964:32-33). The area of that "old-European" hydronymy reaches on the one hand from Scandinavia to "Lower" Italy (i.e., the southern half of Italy), on the other from Western Europe, including the British Isles, to the Baltic region (precisely "baltische Ostseeländer"). Among the three South European peninsulas, Italy partakes in this hydronymy 
most intensively, the Balkans very weakly (almost exclusively in their northern part). The regions north of the Alps represent the oldest linguistically retrievable stratum, whereas in southern France and in the Mediterranean area, the "old-European" hydronymy was secondarily introduced and covered older, non-IE strata there. Let us illustrate this hydronymy with some examples:

1.) *Olä: e.g., Ala a river in Norway and in Latvia, Ola a river in Byelorussia (a tributary of the Berezina in the Bobrujsk county), Ala a stream and a town "an der Etsch" (in Germany?), etc.; the IE root is *el-//*ol- 'flow', cf. Lith. aléti 'von Wasser überschwemmt werden' (Krahe, 1964:35, also W.P. Schmid, 1966:3-4);

2.) *Salā: e.g., Saale (older Sala) several rivers in Germany, e.g., a left tributary of the Elbe ( $Ł a b a)$ river, Szala (read Sala) a river and town at

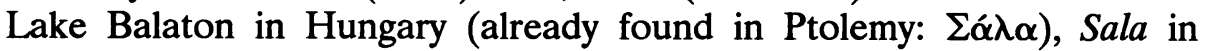
Norway and Lithuania; here we should also add Sota, ${ }^{13}$ a right tributary of the Upper Vistula in Poland, etc.; the IE root is *sal-, in Lat. salum 'offene See, Flusströmung', OPrus. salus 'Regenbach', etc. (Krahe, 1.c. 49, Schmid, 1.c. 4).

3.) *Uorā: e.g., Vara (still in 1354, today Wohra), a right tributary of the Ohm ( $\leq$ Amana) in Germany; Varus (today Var) in Caesar, a tributary of the Mediterranean Sea at Nizza, Varia from which Varie//Veyre a left tributary of the Allier (Puy-de-Dôme) and a right tributary of the Var (Basses-Alpes); identical with the latter is the Vãre in Lithuania at Tauragẽ; all these hydronyms came from IE *uer-//*uor-//*ur'Wasser, Regen, Fluss', attested, e.g., in OI vār, vári 'Wasser', Toch. A wär, B war idem, etc. (Krahe, 1.c. 39, Schmid 1.c. 4).

The above three "old-European" hydronyms can be supported by additional examples from the book by V.N. Toporov and O.N. Trubačev (1962), where we find in the Upper Dniepr Basin: Sol'//Solja (all together three rivers, 1.c. 209) and Varja, Vora (two rivers in the Desna Basin, l.c. 178, 181). The etymological references should also be corrected according to Pokorny: *el-//*ol- not 'fliessen, strömen' but rather 'modrig sein, faulen' (?), 1.c. 305 and *sălo- 'wogend' (1.c. 879-880).

Krahe's disciple, W.P. Schmid, has more precisely delineated the eastern boundaries of the so-called "old-European" hydronymy. Namely, owing to the names which were collected and convincingly etymologized by Toporov and Trubačev in their well-known book on hydronyms of the Upper Dniepr Basin (1962) ${ }^{14}$, which proves the primary Baltic character of that region (for more on this subject, see below), W. P. Schmid establishes the Orel-Kursk-Kiev line (and then, roughly speaking, the Prypeć river) ${ }^{15}$ as the eastern or south-eastern boundary of the "old-European" hydronymy. What is significant in this connection is the 
participation of the whole Baltic zone in this hydronymy, whereas the primary Slavic region (according to Schmid), located south of the Prypeć, does not participate, except in some rare cases, such as the hydronyms derived from PIE *ner-//*nor- 'eindringen, untertauchen' (cf. Lith. neriù, nérti; OCS -nbrq, -nrěti, etc.; Pokorny 766): Nora left tributary of the Zver' in the Dniestr Basin in Galicia, Norec right tributary of the Polkva in Wolynia, Neretva a tributary of the Bug in Wolynia, etc. (cf. W. P. Schmid, 1966:12). So the "old-European" hydronymy seems to be concentrated north of the Alps between the Rhine in the west and the Don in the east, including the Upper Dniepr Basin in its eastern zone, but excluding the Middle and Lower Basins of this river. The fact that the oldest retrievable Slavic habitat (see the following chapter) does not belong to that "old-European" hydronymic zone should be especially underlined here. It will be relevant in our further considerations concerning the ethnogenesis of the Slavs.

But the main problem in connection with the so-called "oldEuropean" hydronymy is the question whether it actually proves the existence of an intermediary linguistic (prehistorical-dialectal) stage between PIE and the historically known groups of IE languages from the region defined above, i.e., whether the so-called "old-European" nomenclature for an earlier stage of Celtic, Italic, Illyrian, Germanic, and Balto-Slavic can be accepted. Krahe tried to prove that there are some phonemic and morphological features which characterize the "old-European" hydronymy (cf. Krahe, 1963: 294-303). Among them a very archaic set of derivational suffixes -r//-n//-nt, e.g., Isna // Eisra // Aisontios, Albana // Albara // Albanta, Varana // Vararos // Varantia, etc. (1.c. chart 1), is especially characteristic showing obvious traces of the PIE vocalic apophony (cf. the first set above). The replacement of the primary $\check{o}$ by $\check{a}$ is also very characteristic of the "old-European" hydronyms, although there are cases of the preservation of the ${ }^{*} o:{ }^{*} a$ opposition (of course, if we subscribe to the traditional view that PIE had a three-vowel system: ${ }^{*} e:{ }^{*} a:{ }^{*} o$, which, as we know, is disputable, see Kuryłowicz's presentation of the primary IE dialectal division in Chapter 2).

Now, the problem is whether the phonemic, and particularly the morphological features specified by Krahe as characterizing the "old-European" hydronyms, are sufficient ground for the separation of "old-European" as a special, archaic IE dialect existing somehow in the first part of the second millennium B.C., before the crystallization of Italic, Celtic, Germanic, Illyrian (?), Baltic, and Slavic in central and eastern Europe. To be exact, I will report here Krahe's respective statements: 
Gerade in dieser Situation aber liegt, wie ich meine, einer der wertvollsten Beiträge, welche die Erkenntnis des Alteuropäischen für die Beurteilung des Indogermanen-Problems beisteuern kann: in der Verschiedenheit zwischen den Verhältnissen im Bereich des Alteuropäischen und denen in anderen gleichzeitigen Teilen der Indogermania. Ich habe kürzlich daran erinnert, dass heute drei grosse idg. Sprachgruppen in Schriftquellen schon aus der Mitte des 2. Jahrtausends bekannt sind, welche damals bereits in voller Ausprägung alle wesentlichen Züge ihrer Individualität tragen, die Züge nämlich (nicht zuletzt auch solche des Lautstandes und des Formenbaues), welche diese Sprachen - unverwechselbar und scharf gegen die Schwestersprachen abgegrenzt - zu dem gemacht haben, was sie sind: zum Hethitischen, Indischen und Griechischen, - um dieselbe Zeit also, in welcher, wie wir ausführten, im Raum des Alteuropäischen noch alle Grenzen fliessend sind und von streng umrissenen sprachlichen Individualitäten noch nicht die Rede sein kann.

Dieser Befund zeigt aber einwandfrei, dass die Auflösung der idg. Grundsprache und die Ausgliederung der späteren Einzelsprachen nicht gleichzeitig und auf einmal, und wohl auch nicht in dem gleichen geographischen Raum stattgefunden hat. Denn wir haben ja ein zeitliches Nebeneinander von mehreren bereits voll aus- und durchgebildeten Sprachindividuen einerseits, und anderseits in Gestalt des "Alt-europäischen" einen - wenn sicherlich auch in Entwicklung begriffenen - Komplex von noch unfertigen, sozusagen noch nicht ausgetragenen Sprachen. Damit ist u.a. die Stammbaumtheorie, wenn es noch nötig war, endgültig widerlegt (denn beispielsweise gehört ja zum Alteuropäischen auch wenigstens eine Satemsprache: das Baltische). Aber auch die Schwächen der Wellentheorie werden sichtbar: "allmähliche Übergänge" zwischen den genannten drei "fertigen" Sprachen (Altind., Griech., Hethit.) sind um die Zeit, in welcher wir sie bereits in Texten vorliegend haben, nicht mehr möglich, während beim Alteuropäischen sozusagen noch alles in solchen allmählichen Übergängen besteht, die Wellentheorie also höchstens partiell anwendbar ist.

(Krahe, 1970: 78-79) 
So, the so-called "old-European" level represents a historical stage in the development of that part of IE which remained probably closer to the primary habitat of the Indo-Europeans, after the split of Aryan, Hittite and Greek, and which later spread into central and western Europe. The structure of the "old-European" hydronyms indicates that "old-European" had very conservative characteristics: it simply represents a well-preserved Common IE (or PIE) stage and no common innovations characteristic of that period of IE can be found (they should be recognizable in Italic, Celtic, Germanic, "Illyrian", and Balto-Slavic). And in this connection, W.P. Schmid's criticism with respect to a dialectal concept of "old-European" (as a prehistorical IE dialect group from which the above-mentioned languages developed) - is correct (cf. Schmid, 1968: 243-258). After having analyzed the respective morphological features and lexical components of the "old-European" hydronymy, Schmid states the following:

Das Gesamtbild, das sich aus dem negativen und positiven Argumenten ergibt, lässt sich nun etwa wie folgt skizzieren: Von den Sprechern einer relativ einheitlichen indogermanischen Gemeinsprache wurden die Gewässer in Europa genauere Grenzen müssen noch bestimmt werden - mit appelativischen Bezeichnungen versehen. Dann zogen die späteren Indo-Iranier, Hethiter und Griechen ab und kamen in Gebiete, wo die Gewässer schon von der einheimischen Bevölkerung bennant waren, wo also zu einer neuerlichen Namengebung nur noch begrenzt Anlass gegeben war. Die in Europa verbliebenen Sprachen und Sprachengruppen machten inzwischen unabhängig voneinander grammatische und lexikalische Veränderungen durch, die zugleich die alten Gewässerbezeichnungen zu Namen erstarren lassen mussten. Neue Namen wurden mit alten Bildungsmitteln geschaffen. Die Flexionweise wurde den jeweils lebendigen Sprachsystemen angepasst. Volksetymologische Umdeutungen gab es wie eh und je. Es gibt also eine auch in sich noch historisch gegliederte alteuropäische Hydronymie indogermanischer Provenienz, und diese aufgedeckt zu haben, ist das bleibende Verdienst Hans Krahes, - eine alteuropäische Gemeinsprache, die jünger ist als das Indogermanische, gibt es dagegen nicht.

(Wolfgang P. Schmid, 258)

I subscribe to the linguistic interpretation of the so-called "oldEuropean" layer by Schmid as simply PIE, but I do not see any 
compelling reasons for his prehistorical-ethnic conclusions, according to which the ancestors of the Aryans, Hittites, and Greeks split off from the rest of the primary Indo-Europeans after the appearance of the so-called "old-European" hydronymy. It is perfectly imaginable, and indeed very probable, that the northwestern part of PIE, which for a longer time ${ }^{16}$ remained closer to the primary IE habitat and only later spread westward, also had preserved the archaic linguistic stage for a longer period which is reflected in the hydronymy. In this sense I would basically agree with Krahe.

Let us now quote and analyze etymologically the names of the main rivers in Central and Eastern Europe between the Rhine and the Volga (including these two hydronyms).

1.) Rhine: Lat. Rhēnus, Gr. 'P̂ิvos (both reflecting the Celtic form), OHG Rin; the IE form *Reinos 'Fluss, Strom'; an identical hydronym known in Italy: Rhènus, attested by Pliny, today Reno near Bologna: in France: Reins (in 879 attested as Rénus) and in the form Rin quite frequent in Switzerland. Comparative IE material: MIr. rian 'Meer' (*rei-no-) from PIE *rei-//*roi- (according to Krahe l.c. 96) or rather ${ }^{*}$ reia-//*ri- 'fliessen' (cf. Pokorny 330, and for Slavic Vasmer III, 484 s.v. rínut') from which are derived, among others, Lat. rivus, OE rīð 'Strom, Bach' and Slav. rěka ('roi-kā) 'Fluss'; it is interesting that a formation almost exactly corresponding to *Reino- exists in OI rẹnú- m. 'Staub' and ORuss. rěnı 'Sandbank', which however is interpreted differently by Vasmer (III, 470).

2.) Weser, a typical "old-European" hydronym: Visara // Visera // Visura (Visurgis), etc. in ancient Latin sources; this hydronym is also known in France: Visera (IX-X c.), today Vézère (two rivers) and as Visera, today Vesdre//Weser, in Belgium; it is derived from the PIE *ueis- // *uis'fliessen, zerfliessen', cf., e.g., OI véşati 'zerfliesst', etc. (more about this verbal root under Vistula, Wista; cf. Krahe, 1.c. 50-51).

3.) Elbe (Pol. Łaba), in ancient Latin sources Albis, a typical "old-European" hydronym; besides NHG Elbe, there is a dial. form Albe (sic!, cf. Lehr-Spławiński, 1946: 59). The ancient Albis, acc. -im, "Aגßıs, gen. "Aגßıs, a clear $i$-stem, is innovative (typical "old-European" formations with this root are: Alba, Albana, Albantia); it is based on the Germanic (Gothic) *Albi, gen. *Albjós (an old -i//-jā -stem!), which underlies the primary Slav. ${ }^{*}$ Albje ${ }^{17}$ i.e., *jlbiææ) attested by Cz. Lábe, ULus. Łobjo, Polab. Låbi. The "old-European" hydronyms derived from the base *albh- are very numerous (cf. Krahe 1.c. 52-53) and the root *albh- is well attested in IE languages with the basic meaning 'white', e.g.,

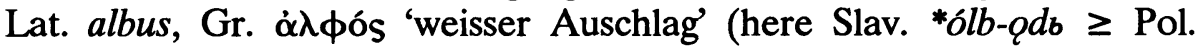
tabędź, S-C läbud, etc. 'swan' belongs); it even provided the noun 'river' in 
Germanic languages: OIc. elfr (Swed., Norw. elv) and MLG elve 'Flussbett' (undoubtedly through the intermediary 'white (water'), etc.).

4.) Oder (Pol. Odra). This hydronym is very disputable. Krahe (1.c. 41) considers it "old-European" and connects it with the hydronyms Adra (788 in pago Adra-gaoe) preserved in the contemporary Atter-see and Atter-gau in Upper Austria, Adrana (Tacitus, Annales) $=$ Adrina (800) $\geq$ Eder, a tributary of the Fulda, etc.; here also belongs the ancient city of Adria in northeastern Italy, from which the name of the Adriatic Sea stems, etc. (cf. Lehr-Spławiński, 1946: 68, who considers Odra "Venetic", i.e., "old-European" in Krahe's terms). But, as has been shown by M. Rudnicki (1969: 99-107), neither Krahe nor Lehr-Spławiński (and others) satisfactorily analyzed the entire available philological material concerning the oldest forms of the Slavic Odra: and these forms are relevant for the etymological interpretation of our hydronym. They are as follow: Odera ("orientem versus flumen Odera"), 947 A.D., Adora (967-968, Widukind), Oddora (Adam of Bremen XI c.), etc. Thus we can establish the variants Odera//Odora//*Odbra representing the well-known Slavic apophony of IE origin, e.g., sz-berq//sz-borb//sb-bbrati, etc., or with the root probably identical with that of our hydronym, Pol. za-dziora (*za-der-a)//Za-dor-a//za-dr-a (*za-dbr-a), etc. (cf. Rudnicki l.c. 105). It is important to note that hydronyms of the type Odra occur elsewhere on Slavic territory, e.g., Odra or Odrov a right tributary of the Upper Dniepr, Odra a tributary of the Snov' near Cernihov, Odra or Odrava, a river between Bohemia and Bavaria, etc. (Rudnicki, 1.c. 100). The Odra in the Upper Dniepr Basin is explained by Toporov and Trubačev (1962: 199, $175)$ as "perhaps" of Baltic origin and connected with the hydronyms Drut', Druec, Dr'jut' in the same region and with Latv. Druve (a river), Old Pruss. Drawe (a hydronym), Latv. drava 'wild bee's nest' (sic!, really 'a hole poked in a tree stem'). It is strange that the two well-known authors do not mention the other Odra near Cernihov and do not make any reference to the big western Odra in Poland. In any case, the above facts do not allow us to accept without doubts Krahe's explanation of the Odra as "old-European" (he reconstructs here the archetype *Adara (sic!)) and ultimately derives it from PIE *adu-//*adro- 'Wasserlauf': Av. $a \delta u$ - 'Bach, Kanal', OPers. adu- 'Wasserkanal' (Krahe, 1.c. 41). Unfortunately, Krahe does not explain the morphological relationship between *adu-//*adroand ${ }^{*}$ Adara (rather ${ }^{*}$ Adarā $)$ postulated by him. There are too many uncertainties in this whole reasoning and the very IE pedigree of the underlying *adu-, etc., attested only in Aryan, is questionable. In view of all this, I subscribe rather to Rudnicki's etymology, which considers our hydronym as basically Slavic: $O-d b r-a$ (note the older variants $O$-der- $a$ // $O$-dor- $a$ ) and derives it from the PIE *dher-18 'springen, bespringen' 
(Pokorny 256) $l$ *der- 'schinden, die Haut abziehen, abspalten' (Pokorny 206); the latter root is well represented in Slavic vocabulary, e.g., dero, dereši, dbrati in OCS, etc. For the meaning of the Slavic hydronyms of the type *Odbra cf. Pol. cicha woda brzegi rwie 'a quiet water (= river) erodes the banks' where rwie can be replaced by drze ('dbretz). Thus, *O-dor-a from *Ob-dbr-a could simply mean 'the eroding (water)', etc.

We have dwelt on the etymology of Odra trying to show a high degree of probability for its Slavic origin, because at least the upper basin of this river (Silesia) should be considered as one of the earliest territories occupied by the prehistorical Slavs moving gradually westward (see the next chapter of this book).

Among the remaining big Central and East European rivers, only the Dvina (emptying into the Gulf of Riga) and the Volga under its oldest name, *Rōua $\bar{a}$, (Ptolemy's 'P $\hat{\alpha}$, see below) seem to have a general IE character, i.e., they cannot be assigned to any particular IE linguistic group. The other river-names: Vistula (Pol. Wista), Niemen (Lith. Nemunas), Dniestr (ORuss. Dzněstrъ), Dniepr (ORuss. Dzněprъ), Don and Danube (Lat. Danuvius//Danubius, Germ. Donau, Slav. Dunajb//Dunavb), already show a more determinate ethnolinguistic character: Slavic, Baltic, Iranian, and even Celtic (Danuvius, etc.). The etymologies of Wista, Dzněstro, Dzněpro, and Don will be discussed later in the chapter specifically devoted to the oldest prehistorical habitat of the Slavs, since they are very important in this connection. Also, I will only mention the Lithuanian etymology of Nẽmunas ( > Slav. Nemъnъ, Pol. Niemen, gen. Niemna, etc.) and the Celtic etymology of Danuvius (the oldest Latin form). The interested reader should check the pertinent explanations and literature in Vasmer's etymological dictionary (III, 61, s.v. Néman) and in Moszyński (1957: 310-311); as far as the etymology of Dānuvius, etc. is concerned, the best presentation can be found in Lehr-Spławiński (1946: 74, in connection with the Slav. dunajb which primarily does not have anything to do with the Celtic *Dānovios). In this connection, it should be noted that Krahe, whose publications and views I have been quoting in this paragraph, very often neglected the hydronymic materials and analyses presented by Polish scholars (e.g., by J. Rozwadowski and T. Lehr-Spławiński). A result of this omission is sometimes detrimental to :he scholarly value of his conclusions. More about this matter will be liscussed in connection with the etymology of Wista.

So I will pass on to a brief presentation of the general IE character of he hydronyms Dvina and *Rōu $\bar{a}(=$ 'P $\hat{\alpha})$, the ancient name of the Volga. The general IE character of these hydronyms has been convincingly roved by Rozwadowski (1948: $72-78$ and 256-258). I will simply ummarize his views: 
First we must establish the primary form of Dviná (Russ.), which underlies the Scandinavian, Finnic, and German forms (OIc. Dýna, Duna, etc., Livian Vēna, Estonian Väina (-jõgi), Germ. Duna, Dune (older), Düna, Düne (contemporary, etc.). Such a form can only be older Slav. ${ }^{*}$ Dovina, which represents PIE ${ }^{*} D h(u)$ ueina. The latter is derived from the verbal root *dheu-, defined by Pokorny (259) as 'laufen, rinnen', and illustrated among others by OI dhávate 'rennt, rinnt', dhávati idem, Gr. $\theta \epsilon ́ \omega, \theta \epsilon i \omega$ 'laufen' (from older $\theta \hat{\epsilon} F \omega$, etc.), OIc. dggg ( ${ }^{*}$ dawwö), OE déaw, OHG tou (*dawwa-) 'Tau' (NE dew). Pokorny (l.c.) also quotes some old

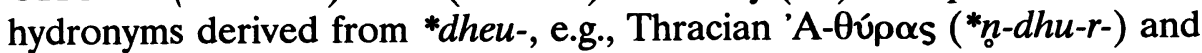
the so-called (in his terminology) "Venetic-Illyrian" type Dur(i)a in Hungary, Alsace, Switzerland, etc. Here also belongs Slav. Dunajb//Dunavs, representing an old common name with the meaning 'big water' (cf. Lehr-Spławiński, 1946: 74). Of course, *Dzvina $\leq$ ${ }^{*} D h(u)$ ueina is derived from the extended form of the root *dhuei-, which in terms of early IE morphology is well substantiated. We should also remember that the name of the Dvina emptying into the Gulf of Riga, the so-called Western Dvina, was transferred to another big river emptying into the White Sea, the so-called Northern Dvina; moreover, there are several other hydronyms of this type, i.e., either Dvina/o or its derivatives in the Niemen and Dniepr basins, e.g., Dvina a right tributary of the Titiva in the Desna Basin (cf. Toporov-Trubačev, 1962: 183 under Baltic hydronyms, sic!).

The other general IE hydronym is *Roūa, referring to the Volga River. It has been reconstructed by J. Rozwadowski on the basis of Gr. P $\hat{\alpha}$ (in Ptolemy, II c. A.D.) and Mordvinian (E) Rav, Ravo 'der Fluss Volga', also 'Meer, grosses Wasser, die Flussüberschwemmung in Frühjahr', Mordvinian (M) rava 'Fluss' (the meanings quoted above are given by A. Joki, 1973: 307). Of course, the Mord. form would be based upon an Iranian ${ }^{*} R \bar{a} v \check{a}$ - (fem. or masc.) with the preservation of the intervocalic $-v$-, whereas the Gr. form 'P $\hat{\alpha}$ would represent the same underlying Iranian (Sarmatian) *R $\bar{a} v \bar{a}$ - with the fall of the intervocalic $-v$ - and the contraction of $a a$ into $\hat{\alpha}$, a regular change in Greek. The reconstructed PIE *Rōū has obvious correspondences in other hydronyms on the Balto-Slavic territory and in IE vocabulary, namely: Slav. Rava, e.g., Rava a right tributary of the Rova (sic!) a right tributary of the Berezina in Byelorussia, considered Baltic by Toporov-Trubačev (1.c. 205); Rawa, a village on the Minina River, a tributary of the Wieprz in Poland: the Minina River forms a large pond (lake) at this village; Lith. Rovejja, a derivative from Rova, in the upper Aa Basin. It should be noted that the hydronym Rawa also occurs in central and western Poland, e.g., in the Czarna Przemsza Basin, Oświęcim county, which precludes its Baltic 
character (for details see Rozwadowski, 1.c. 256-258). The hydronym ${ }^{*} R \bar{o} u \bar{a}$ represents an IE common name *rōūa well attested by Lith. rova 'Rückstand von Überschwemmung', Latv. rāva 'stehendes faules eisenhaltiges Wasser,... Pfütze, Morast', Germanic *rōwō 'quiet, rest', e.g., OIc. ró, OE rów, OHG ruowa = NHG Ruhe, and Gr. '́ $\rho \omega \eta$ 'a retreat from, a rest from', etc. - all of them derived from the PIE root era-, ré'ruhen' (cf. Pokorny 338 where the PIE nouns *rē-uñ, *rō-ūa are also reconstructed). It is obvious that a noun meaning 'quiet; quiet water' is best qualified for the name of a big, but very quiet river; in this connection, it is worth noting that the Volga has an extremely small down-grade: $229.5 \mathrm{~m}$. for 3,689 km. (emphasized by Rozwadowski). In view of all of the above facts, I prefer the etymology proposed by Rozwadowski than that by A. Joki (l.c.), who explains the Mordv. Rav(o) as borrowed from an Iran. *(h)ravă-, i.e., PIE *srouo/ā- 'das Fliessen' (cf. Pokorny 1003).

As we see, the European hydronyms from Rhine to Volga ('P $\hat{\alpha} \leq$ $\left.{ }^{*} R \bar{o} u \bar{a}\right)$ in many cases show a general IE character only without any specific ethno-linguistic features which would enable us to assign them to individual (historical) IE languages or groups of such languages. It should also be emphasized that many of them, the so-called "old-Europeans" stratum according to Krahe's terminology, exhibit very archaic features. So everything seems to indicate that the zone between the Volga and the Rhine, with the exclusion of most of the Mediterranean region, and of Scandinavia, i.e., roughly speaking, the bulk of the East and Central European continent, has been from a remote prehistorical time an area of the expansion of the IE linguistic family. Now, the question arises whether the hydronymic material itself can indicate the primary direction of that expansion. I think that it can. The evidence for the primary direction of the prehistorical expansion of Indo-European is provided by the stratification of the IE hydronyms in different parts of Europe. In order to draw the correct conclusions from this stratification, we should check the density of the hydronymic strata in different parts of Europe, namely: on the one hand in the East, on the ther in the West. Thus, we will see a quite transparent pattern: in the East (historically, on the Balto-Slavic territory), especially in the Dniepr Basin, we can establish the following hydronymic strata: "old-European" or general Indo-European, Baltic, Slavic, Indo-Iranian, thus we have four iuccessive layers of hydronyms, e.g., Ola (from Lith. Ala) in Byelorussia see above), or Rawa (just discussed), Nẽmunas (see above), Wisła, Jъněstr̋, Dzněpr and Don (see the following chapter); in the West, e.g., n France and West Germany, we can establish only two layers: 'old-European" or general Indo-European and Celtic, e.g., Vara and its 
correspondences (see above) or ${ }^{*}$ Reinos $=$ Rhine (see above) and already in Central Europe - Danuvius, etc. (see above). It seems quite obvious that proceeding from Western Europe (France) eastward we gradually enter territories with a denser "sediment" of IE hydronyms which can be analyzed into four (sometimes even five) different linguistic strata. So, in France and West Germany (the Rhine Basin) we have virtually two strata: "old-European" or general Indo-European and Celtic, in East Germany we already have three strata: besides the two former, there is a Germanic stratum (of course, I am speaking here about those strata which seem to reflect a prehistorical ethno-linguistic expansion and colonization; historically attested movements of population and their impact on hydronymy do not interest us here, for example, the Slavic colonization of the regions between the Odra and the Łaba in the early medieval epoch, etc.). On the Slavic territory, especially in the Dniepr Basin, we find the thickest "sediment" of IE hydronyms: four or even five different strata as was mentioned above (the five hydronymic strata can be established in the West Ukrainian part of the Dniepr Basin (cf. Trubačev, 1968), namely: "old-European" or general Indo-European, Baltic, "Illyrian" or Thracian, Slavic, Iranian. Such a stratification of IE hydronyms can be interpreted only as evidence for gradual migrations of different IE ethno-linguistic groups from the east westward, starting with an early prehistorical movement of undifferentiated IE tribes which have left traces in the form of "old-European" or general Indo-European hydronyms, later covered by subsequent waves of already dialectally differentiated IE peoples who have each left their hydronymic layer in the regions under discussion.

The conclusions drawn from the etymological analysis of the hydronyms between the Rhine River in the West and the Volga (P⿳亠丷⿵冂) River in the East, which undoubtedly point towards the south-eastern borderlands of the European continental bulk as the center from which radiated the prehistorical IE migrations (i.e., "Urheimat") - can additionally be corroborated by other linguistic data, namely: by the vestiges of ancient linguistic contacts between IE and Finno-Ugric (or, in a broader sense, Uralic) languages. As is well-known, this linguistic family, which in historical times has occupied the northeastern outskirts of the European mainland, roughly speaking, from the eastern coast of the Baltic Sea to the Ural Mountains, with relatively late inroads of Eas 1 Slavic (Russian), is one of the two non-IE language groups which have survived the expansion of Indo-European (the other being Basque, which is found at the opposite end of Europe). It is striking that the number 0 either old common elements (which could suggest a very remott prehistorical kinship between Indo-European and Uralic) or olc 
borrowings from PIE and ancient IE dialects in Uralic or Finno-Ugric is so impressive that the only plausible interpretation of this fact would be the hypothesis of a long prehistorical period of neighborhood between these two linguistic families, a neighborhood which necessarily existed and developed in eastern Europe to the south of regions primarily inhabited by the ancestors of the Uralic peoples. Since most Uralists agree that the primary habitat of the Uralians was located between the Middle Volga and the Ural Mountains (with its center in the Kama Basin) ${ }^{19}$, the only logical conclusion is that the Indo-Europeans, or at least their eastern branch, during the times of close Uralic-Indo-European contacts dwelt south of the region indicated above, i.e., somewhere in the lower Volga and the Ural River Basins.

The literature concerning the prehistorical contacts and exchange between Uralic and Indo-European is very copious. The facts presented and discussed in the following paragraphs are taken out of a recent thorough review of the whole problem, namely from the book Uralier und Indogermanen. Die älteren Berührungen zwischen den uralischen und indogermanischen Sprachen by Aulis J. Joki, Helsinki 1973 (henceforth referred to as Joki). The most valuable part of the book is the etymological dictionary of IE elements in Uralic which contains 222 entries (!). Having analyzed this dictionary from the standpoint of the oldest IE elements in Uralic, i.e., leaving aside obvious Aryan or Iranian and younger Baltic or Slavic loanwords, I was able to come up with the following results:

A. There are twenty-seven words in Uralic or Finno-Ugric which with different degrees of probability can be classified as common IE-Uralic (or IE Finno-Ugric) lexical elements, proving a kind of remote prehistorical kinship between the two linguistic families. These are the following words (quoted in a reconstructed Proto-Uralic or Proto-Finno-Ugric form and illustrated, if possible, with Finnish examples):

1. FU (Ural.?) *aja-, e.g., Fi. aja- 'treiben, jagen; fahren, lenken, kutschieren' IE *ag'- 'treiben, schwingen, in Bewegung setzen, führen', e.g., OI ájati 'treibt', Lat. agō, agere, Gr. ö $\gamma \omega$, etc. (Joki, 248) ${ }^{20}$.

2. Ural. *aśe-, e.g., Fi. ase-, asu- 'stellen, setzen, legen', asu- 'sich aufhalten, wohnen, sein, sich befinden' $\sim$ IE *es- 'sein' and *ёs- (only

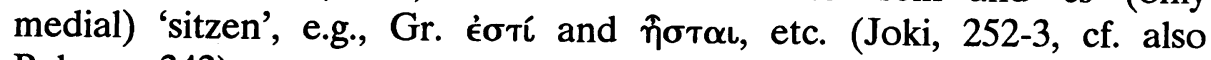
Pokorny 342).

3. FU *jo-, e.g., Fi. pron. stem jo- in joka 'wer, welcher (relative); jeder' IE *io- (relative), e.g., OI yah m. yā f., yat n. 'wer, welcher', Gr.

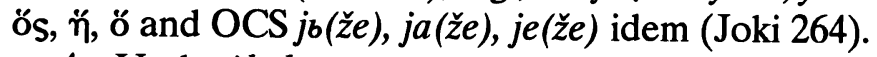

4. Ural. *käle-w3, e.g., Fi. käly 'Schwägerin, Frau des Bruders, Schwester des Mannes (der Frau)' $\sim$ IE ${ }^{*} g_{(e)}^{\prime} l \overline{l o u}$ - (cf. Pokorny 367-8) 
'Schwester des Gatten', e.g., Lat. glos, Gr. yód $\lambda \omega s$, Church Slav. zъlъva, PSl. *zъly, -ъve, etc. (Joki, 267-268).

5. Ural. *ke-, *ki-, e.g., Fi. ken $(\leq * k e-n)$ 'wer' $\sim$ IE *ku ${ }^{\mathrm{u} i-}$ 'wer', e.g., Lat. quis, Gr. Tís, etc. (Joki, 268).

6. Ural. *ku-, e.g., Fi. pron. stem kuka 'wer', ku-ssa (inessive) 'wo', etc. $\sim$ IE interrogative ${ }^{*} k^{\mathrm{u}} u$ - (adverbial) and ${ }^{*} k^{\mathrm{u}} o$ - whose correspondences have merged in most Ural. languages, e.g., Lat. $n \bar{e}$-cubi (from which secondarily $u b i$ ' where'), quo-d, OI kü, 'wo', ká-h 'wer', OCS kz-de 'wo', $k z-t o$, gen. ko-go 'wer', etc. (Joki 273-4). Of course, the two Uralic pronominal stems *ke-, *ki- and *ku ko- exactly correspond to the IE variants ${ }^{*} k^{\mathrm{u} i} i-\sim{ }^{*} k^{\mathrm{u}} \mathrm{o}-\sim{ }^{*} k^{\mathrm{u}} u$ - or rather ${ }^{*} k i-\sim{ }^{*} k o-\sim{ }^{*} k u-$.

7. Ural. *kur3-, e.g., Fi. kuras 'Messer' IE *(s)keru-, *(s)kreu- (cf. Pokorny 947), e.g., Lith. kirvis 'Axt', Russ. červb 'Sichel', Goth. hairus 'Schwert'; also possibly a borrowing from IE: the Uralic vocalism $u$ would indicate an early Balto-Slav. ur from ${ }^{*}$, something like *kurV- $(?, \mathrm{ZG})$; Joki, 275-6.

8. Ural. *lapa, e.g., Fi. lapa 'Bug, Schulterblatt, Schaufelblatt, Ruderblatt, Ruderschaufel' IE *lēp-, *lōp-, lap- 'flach sein; Hand, Fussfläche, Schulterblatt, Schaufel, Ruderblatt', *lōpā 'Hand, Pfote' (cf. Pokorny 679), e.g., Lith. lópa 'Pfote', Slav. (Russ. and Pol.) lápa idem, lopáta 'Schaufel', etc. The correspondences are restricted to Irish, Germanic, and Balto-Slavic, therefore it may be rather a common NIE Uralic element (ZG), Joki, 277.

9. FU *luke-, e.g., Fi. lukea 'zählen, rechnen; lesen; sagen; lernen, studieren' IE *leg'- *log'- e.g., Lat. legō, legere 'zusammenlesen, auflesen; wählen; lesen', Gr. $\lambda \epsilon ́ \gamma \omega$ 'auflesen, sammeln, zahlen', etc. disputable (Joki, 278-9): the Uralic vocalism *luke- could indicate the IE iterative *log'eie- as a possible source (ZG).

10. Ural. *mõl3, e.g., Lap. moallo 'crumb, little bit, piece, morsel', also known in SamJur. IE *mel-, actually *(s)mel(a)- according to Pokorny 716 - 'zermalmen, schlagen, mahlen, speziell Korn'; Joki rejects this comparison because of the limitation of this root to Lap. and Sam. (Joki, 285).

11. Ural. *mone, e.g., Fi. moni 'mancher', plur. mone-t 'viele' IE *mon(e)gh-, *men(e)gh- 'reichlich, viel' (also *mngh-, cf. Pokorny 730), e.g., Goth. manags, OCS mъnogı and OI maghá- n. 'Gabe, Geschenk' (Joki, 286).

12. Ural. *muśka- or *mośke-, e.g., Est. mõske- 'waschen' IE *mozge-, *mezge-, the root *mezg-, e.g., Lith. mazgóti 'waschen', OI májjati 'sinkt, geht unter, geht zugrunde', Lat. mergo, mergere 'eintauchen, versenken' (Joki, 286-7).

13. Ural. *mur3 or *mor3, e.g., Fi. muru 'Krume, Brocken, Brosame, 
Korn, Bisschen' and Hung. mar 'zerreissen, auffressen, beissen' IE *mor-, actually the root is *mer(a)- 'sterben' which is equivalent to 'aufgerieben werden' (cf. Pokorny 735) and ultimately identical with *mer(a)- 'aufreiben, reiben; packen, rauben' (Pokorny 1.c.), e.g., OI $m r n a \bar{a} t i$ 'raubt', Gr. $\mu \alpha \alpha_{\rho} \nu \alpha \sigma \theta \alpha \iota$ 'einander packen' (Joki 287); the vocalism of the Ural. word would correspond to the IE $o$-vocalism of the primary deverbal nouns of the ${ }^{*}$ moro- type and that of the causative-iterative verbs of the *moreie- type (cf. Slav. morz, moriti).

14. Ural. *müra or *mŏra, e.g., Fi. muurain, muurama (-in, -ma derivational suffixes) 'Rubus chamaemorus, Moltebeere' IE *moro-,

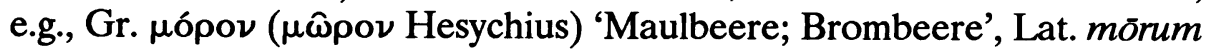
idem, etc. (Joki, 287-288).

15. Ural. *mēke- or *mi ${ }^{*}$ - (?), e.g., Fi. myö-, myy- 'verkaufen' IE *mei(gh)- 'wechseln, tauschen', e.g., OI mināti 'tauscht, wechselt, täuscht', Latv. miju, mit 'tauschen' (here also Slav. minqti, mijati 'pass'), etc. This word undoubtedly belongs to a primary barter-trade terminology (Z.G.), Joki, 288-9.

16. FU (?) *ńiða, e.g., Fi. nitoa 'binden, heften' IE *ned'zusammendrehen, knüpfen' (cf. Pokorny, 758-9), e.g., Lat. nödus 'Knoten', etc. (Joki, 291); the Aryan *nadh-, e.g., OI náhyati 'bindet, knüpft' quoted by Joki, is unknown to Pokorny.

17. Ural. *nim(e), e.g., Fi. nimi (the stem: nime-) 'Name' $\sim$ IE *en(o)mn-, *(o)nomñ-, nömn- (cf. Pokorny, 321), but *nēmn- also possible "Als altes Kulturwort (sic!) noch weiter verbreitet: Jukag. niu, neve, nim, Chukch. nonn. nónnb(y)..." (Joki, 291). Perhaps the Ural. form better corresponds to a Balto-Slav. *inmen represented by the Slav. (j)b́mę (cf. S-C ime, Russ. imja): in such a case it could be a borrowing from early Balto-Slav. (Z.G.) and the oldest IE archetype would be *enHmen-(?).

18. Ural. *panka, e.g., MordE pango 'Pilz, Schwamm; Flechte', MordM panga 'Schwamm, Brätling' IE *(s)pongho- (not listed by Pokorny), e.g.,

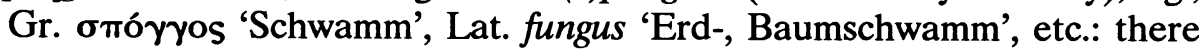
are also possibilities of a borrowing from Aryan (for details, see Joki, 300-301).

19. Ural. *sōne, e.g., Fi. suoni (gen. suone-n) 'Ader, Sehne; Nerv, Muskel(faser); Holzfaser' IE *snē̌u-: *snū- (Pokorny, 977) 'drehen', etc. *snēu-(e)r-, -en- 'Sehne, Band', e.g., OI snāvan- 'Sehne, Nerv, Muskel'; 'Bogensehne', Av. snāvar- 'Sehne, Schnur', Gr. vєûpov 'Sehne, Saite': the Uralic form would better correspond to an early IE form of the root *se/on-u- (Joki, 316).

20. Ural. *tă , e.g., Fi. taa 'dieser, jener' (arch. and dial.), tai 'dieser' IE *tă- (sic!), the fem. stem, e.g., Gr. Dor. acc. sing. тó $\nu$, Lat. is-tam, Slav. 
nom. sing. ta, etc. (Joki, 322).

21. Ural. *teke-, e.g., Fi. teke- (1. sing. pres. teen $\leq *^{*}$ teye-n) 'tun, machen' $\sim$ IE *dhe- (actually older *dheH-), Pokorny, 235-7, 'setzen, stellen, legen' or *dha-k-, for which cf. Lat. faciō, etc. (Joki, 327-8).

22. Ural. *tō-, e.g., Fi. tuo 'jener, der' IE *tō-, the masc.-neut. stem, e.g., Gr. acc. sing. masc. тó $\nu$, neut. тó, Lat. is-tum, is-tud, Slav. to, etc.; cf. *t

23. Ural. *toke-, e.g., Fi. tuo-da 'holen, bringen, führen, mitnehmen', cf. also LapS duoka- 'vorkaufen' IE *do- : *da : *do-u- : *do-u- (cf. Pokorny, 223) 'geben'; actually the oldest IE form of the root is ${ }^{*} \mathrm{deH}_{3}$ (Joki reconstructs ${ }^{*} d o \gamma^{\mathrm{w}}$-, sic!), e.g., Gr. $\delta i \delta \omega \mu$, Lith. dúoti, etc. (Joki, 231).

24. FU *oksa or *oska, e.g., MordE uks(o) 'Ulme, Ulmus campestris' IE *oskā, e.g., Gr. ỏ łú 'Buche', OHG asc, ONorw. askr 'Esche', etc. (Joki, 333).

25. Ural. *vete, e.g., Fi. vesi (the stem vete-) 'Wasser' IE *ued-ör,

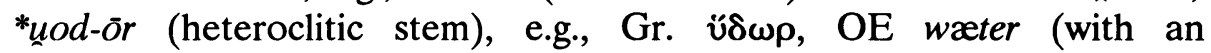
$o$-vocalism) but Hitt. gen. ue-te-na-ás and Phryg. $\beta \in \delta v$ (with an $e$-vocalism), cf. Pokorny 78-80 (Joki, 344).

26. FU *vetä-, e.g., Fi. vetä- (1. sing. pres. vedä-n) 'ziehen', in Mord. also 'führen, leiten, bringen' IE *uedh- (before nasals), *ued- (Pokorny, 1115) 'führen, heimführen, heiraten', e.g., Av. vad- 'führen, zu Ehe führen', Lith. vedù, vèsti 'leiten, führen, heiraten', OCS vedo, vesti idem (Joki, 344-5).

27. FU *vike or *weye-, *wiye-, e.g., Fi. vie- 'bringen, führen, leiten, befördern, transportieren', in Zyr. also 'zur Frau nehmen' IE *ueg'h(Pokorny, 1118) 'bewegen, ziehen, fahren', e.g., Lat. vehō, vehere 'ziehen, tragen, schaffen, fahren', Lith. vežù, vèžti 'fahren', OCS vezo, vesti idem, etc. (Joki, 345).

Of course, the above examples do not exhaust all possible common "Indo-Uralic" (i.e., Indo-European Uralic) elements in Uralic: further research may add some interesting supplements. In this connection, it is worth mentioning that the hypothesis about laryngeals in Uralic, recently quite convincingly ventured by a Polish linguist, Jerzy Bańczerowski, (Lingua Posnaniensis 1971, 81-96) seems to be especially promising. Let us quote some plausible examples from his article:

A.1. Ural. yeHe-, e.g., Fi. jä̈̈ 'bleiben', but in other Uralic languages, e.g., Hung. jöv- 'kommen' IE yeH-, e.g., Slav. ja-ti, etc. (Bań. 84).

2. Ural. peHe-, e.g., Fi. pii 'Zinke; Feuerstein' IE (s)p(H)ei-, e.g., OI

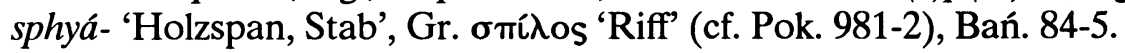

3. Ural. seHe-, e.g., Fi. syö- 'essen, fressen', etc. IE seH-, e.g., Lith. sotùs 'satt', Lat. satis, Goth. gasōtjan 'sättigen' (Bań. 85). 
4. Ural. seHe-, seH-ye?, sHe-?, e.g., Fi. syy 'Faser, Fiber', suone- ( $\leq$ *soHe-ne-) 'Sehne, Ader', etc. IE seHi-, sHei-, syeH-, e.g., OI syáti 'bindet', Lith. siêti 'binden', OCS sětb 'Netz', Balto-Slav. sīūiōo = OCS šijo 'nähen', OI sivyati 'näht', syūtá- 'genäht' (cf. Pok. 891-2 and 915-6), Bań. 86; but cf. also under Ural. *sōne treated above.

5. Ural. teHe-, e.g., Fi. työ 'Arbeit, Tat, Werk', teke- 'tun, machen' IE dheH-, etc. (Bań. 86) cf. also under Ural. *teke- above.

6. Ural. toHe-, e.g., Fi. tuo- 'bringen' IE $d e H^{\mathrm{w}}$ - (i.e., *dō- 'geben'), Bań. 86; cf. also under Ural. *tóke- above.

B. The second group, consisting of sixteen words, represents the oldest layer of IE loanwords in Uralic borrowed either from Proto-Indo-European or from early (prehistorical) IE dialects. The only sure criterion in this respect is the phonemic form which can be posited as the source of a given loanword. In this connection, I should take exception with the author (A. Joki) who very often uses the term "Vorarisch" (Pre-Aryan) in order to indicate that a given borrowing took place before the crystallization of Aryan; but linguistically it means that the word was taken from as yet undifferentiated Proto-Indo-European. What follows is the list of all such words qualified by A. Joki as "Pre-Aryan" (or "early Aryan") plus those which he clearly defines as PIE.

1. FU *ertä, e.g., Norwegian Lapp æŕte 'Seite, Rand' $\leq$ PIE *erdho-, cf. OI árdha- 'Teil, Seite, Hälfe', etc. (cf. Pokorny, 333: *er-dh-), Joki, 255.

2. Perm *gert, e.g., Votyak gurt 'Wohnplatz, Dorf', etc. $\leq$ PIE ${ }^{*}$ 'herdho- ${ }^{21}$, not as Joki suggests from Proto-Iran. or Aryan *gerda (sic!) since the merger of $e \nmid o) a \geq a$ is characteristic just of Aryan; for the meaning of the word, cf. among others PSl. *gords (*ghordho- from kentum) 'fortified settlement, fort' (Joki, 263).

3. FU *jüvä ( $\leq$ *jeva), e.g., Fi. jyvä 'Korn, Getreide, Same', etc. $\leq$ PIE *ieuo-, cf. OI yáva- m. 'Getreide, Korn, Feldfrucht', Lith. jãvas

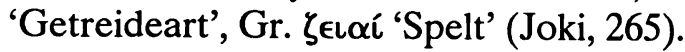

4. FU *kota-, e.g., Fi. kota 'kegelförmige Wohnung, Hütte, Zelt; Kochhütte; Gebärmutter', etc.; also here belongs Hung. ház 'Haus, Zimmer, Stube' $\leq$ PIE *kotä-(?), because of the vocalism, not from Aryan as Joki suggests (cf. Pokorny 586 *kě̈t-//*kot- 'Wohnraum', originally 'Erdloch als Wohngrube', e.g., Slav. (OCS) kotbcb 'cella, Nest', Av. kata- m. 'Kammer, Vorratskammer, Keller', etc.), Joki, 272-3.

5. FU *mete, e.g., Fi. mesi (the stem mete-) 'süsser aromatischer Saft in Blumen, Honig; Met', etc. $\leq$ PIE *médhu-, cf. p. 215 of this chapter; but there is also a possibility of a reverse direction of borrowing (Joki, 283-5); of course, Baltic-Finnish, e.g., Fi. metu, is of Balto-Slav. origin.

6. FU(?) *onke, e.g., Fi. onki 'Angel, Angelhaken; Angelrute', etc. $\leq$ 


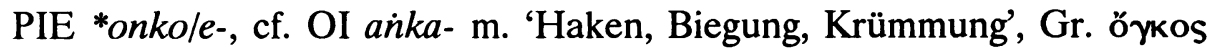
'Widerhaken', Lat. uncus 'gekrümmt, Haken', etc.; here should be quoted also Slav. (Church Slav.) qkotb f. 'Haken', an obvious derivative from an adj. * ${ }^{*} k 3$ (Pokorny 45-6), Joki, 295-6.

7. FU *ora, e.g., Fi. ora 'Dorn, Stachel; Ahle, Pfrieme', etc. $\leq \mathrm{IE}{ }^{*} \bar{o} r \bar{a}$, cf. OI árā 'Ahle', OHG àla idem, etc.; Pokorny (310) reconstructs PIE *ēla (supported by Germanic), thus the FU form must come from "Pre-Aryan" (Joki's "Urarisch", 296).

8. FU *orpa (s) *orva(s), e.g., Fi. orpo 'Waise; verwaist', etc. $\leq$ PIE *orbho(s), not, as Joki says, from Aryan; cf. OI arbha- 'klein, schwach; Kind', Arm. orb, -oy 'Waise', Gr. ò $\phi \alpha \nu$ ós 'verwaist', Lat. orbus 'einer Sache beraubt, verwaist', etc.; here also belongs Slav. ${ }^{*}$ orbs $=$ OCS $r a b s$ 'Sklave, Diener', etc. (Pokorny, 781-2). There is a rich family of FU derivatives of this basic *orpa which denote different relatives. It is interesting that the Slav. *orbs 'Sklave, Diener' seems to be also an old borrowing from an IE dialect since the meaning 'Waise' is rendered in Slavic by the root sir-, e.g., sirota, etc. (Joki, 297-8).

9. FU *onća, e.g., Fi. osa 'Teil, Anteil, Glück', etc. $\leq$ IE satem not Aryan, *onśo- (PIE *onk'o-) 'Anteil', cf. OI amśa- 'Anteil', Av. quō (qusa-) 'Partei', Gr. óyкos 'Tracht, Last', etc. (Pokorny, 316), Joki, 298.

10. FU *vos(a)-, e.g., Fi. osta- 'kaufen' ( $v$-preserved in Votyak: vuz 'Ware, Handel', Zyryan: vuz 'Steuer, Abgabe', etc.) $\leq$ PIE *uos- (from a basic *ues-, reconstructed by Pokorny, 1173, with the meaning 'kaufen, verkaufen'), e.g., Hitt. unaš-, uašiiła- 'kaufen, erwerben' and PIE *ues-no'Kaufpreis' with the hesitation of $e \sim o$ vocalism in individual languages, e.g., Gr. $\hat{\omega} \nu o s$ 'Kaufpreis' Lat. vēnus (only in acc. vēnum, dat. vēno) 'Verkauf', etc.; probably Slav. věno 'Mitgift', also 'bride-price' (e.g., in ORuss.) belongs here (Joki, 298-9).

11. FU *pata-, e.g., Fi. pata 'Topf, Kochtopf; Tontopf' (known in most FU languages) $\leq$ PIE or rather North IE ?, cf. Lith. púodas 'Topf', OIc. fat 'Gefäss'; Joki, 301, reconstructs IE *pěd - // *pŏd- 'fassen, Gefäss'; cf. also Pokorny 790.

12. FU *porśas//*porćas, e.g., Fi. porsas 'Ferkel' (known in most FU languages) $\leq$ a satem *porśos, cf. Lith. par̃̌as idem, Sak. pā'sa 'Schwein' ( ${ }^{*}$ parsa-), Kurd. purs, idem, etc. (Joki, 303).

13. FU *reśmä, e.g., LapN. ræš'me, LapI. reešmi 'Obersimm aus Wurzelfasern an einem Netz, dünne Schnur aus Wurzelfasern ( $\geq$ Fi. dial. räsmä idem), etc. $\leq$ a satem *reśm-, cf. OI raśmí- m. 'Schnur, Strick; Seil, Zügel, Peitsche, Strahl', raśmán- 'Zügel', etc.; no correspondences besides Aryan. But Slav. *remy, remenb (cf. Russ. remén', gen. remnjá, OCS remenb, etc.) 'thong, strap' could be compared here as a primary kentum form with the simplification of $-\mathrm{km}->-m^{-}$('rek'-men-); in this 
connection, cf. 'rek'-//*reg'- 'binden' reconstructed by Pokorny 863, with examples from OI and Germanic (Joki, 308).

14. Fi-Perm. *sal3, e.g., Fi. suola 'Salz', etc. $\leq$ Balto-Slav. sali-?, Joki posits a "frühtocharisch" *sale (Toch. A sāle!); Joki 316.

15. Ural. (?) *vaske//*vaśke, e.g., Fi. vaski (stem vaske-) 'Kupfer, Bronze' (known in most FU languages; Hung. vas 'Eisen' belongs here) $\leq$ PIE ?, cf. Toch. A wäs 'Gold', B yasa (y- $\leq *^{*}$-) idem, Arm. oski idem; probably connected with Lat. aurum, Sabin. ausom 'Gold', Lith. áuksas idem, etc. (primarily 'rötlich'): IE *ăus-, *ues- according to Pokorny 86-7. "Die in grösseren Teilen des idg. Gebietes vorkommenden Metallbezeichnungen sind als Wanderwörter gekennzeichnet durch lautliche Abweichungen, die es nicht gestatten, sie auf einheitliche Grundformen zurückzuführen" (Scherer, Kratylos I, 12-13), Joki, 339-40.

16. Fi.-Lap. *vermen, e.g., Fi. vermen 'Oberhaut, Epidermis', etc. $\leq$ PIE (because of the preservation of the primary front vocalism!) *uermen-, cf. OI várman- n. 'Panzer, Schutzwehr', etc., Av. vār pman- n. 'Brustwehr' (Iran. var- 'bedecken' = OI vrnóti 'verhüllt, bedeckt, umschliesst'; for the spread of this root and its derivatives in IE, cf. Pokorny 1160-62), Joki 343.

C. In this last group I quote several IE loanwords in FU which can be interpreted with a high degree of probability as borrowed from Baltic. The following examples show this:

1. Mord.-Cher.-Vot. k'äräs, etc. 'Honigscheibe' $\leq$ Balt. *kär(i)as not an "altiranisch" unattested *käras, as Joki suggests; cf. Latv. plur. káres

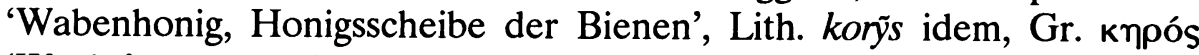
'Wachs', кnpíov 'Wabe(nhonig)', from which Lat. cēra 'Wachs'; cf. Pokorny 532 *kär- 'Wachs' (Joki, 268).

2. Ural. *kur3-, e.g., Fi. kuras 'Messer' $\leq$ Balt. archetype *kuru-?, cf. Lith. kirvis 'Axt' whose ultimate source is PIE *(s)keru-, *(s)kreu-, an extension of the root *(s)ker(a)- 'schneiden' (Pokorny 938, 947): cf. Goth. hairus 'Schwert', Hitt. -kuruzzi- 'Schneidewerkzeug'; according to Joki "uraltes Wanderwort" with correspondences in Altaic, etc., but the Ural. form *kur3- rather indicates a borrowing from a Balt. *kuruV- $\leq$ PIE *kru $V$ - with a regular treatment of ${ }_{r}$ as $u r$ after velars (Joki, 275-6); see also above, page 228 .

3. Fi. ola 'Flint, Feuerstein' (known in Baltic Finnish) $\leq$ Balt. *ōlä, cf. Lith. uolà 'Fels; Kalkstein; Wetstein', Latv. uõla 'kleiner runder Stein; Kiesel, Fels; Ei': probably one of the oldest borrowings from Balt. because of ${ }^{*} \bar{o}-\geq o$-; also Mord. al 'Ei' may come from Balt. (Joki 294).

4. FU *tala-s, e.g., Fi. talas, tala 'Winddach, Schuppen, Scheune, Hütte... ; Gestell, Gerüst; Treppe, Stange oder Gerüst, worauf etwas getrocknet wird' $\leq$ Balt. *tala-, cf. Lith. pã-talas 'Bett;, OPrus. talus 
'Fussboden', or $\leq$ Aryan *tala-, cf. OI tala- n. 'Fläche, Ebene, Handfläche, Sohle' (these meanings quoted by Pokorny, 1061, but Joki adds 'flaches Dach'); this is ultimately PIE *tel(a)-, *telu- 'flach, flacher

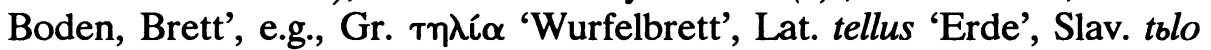
'Boden'; because of the meaning the borrowing from Balt. is more probable (Joki, 324-5).

5. Proto-Fi. *tine $\leq$ *teine?, e.g., Fi. tiine (rare), tihne 'trächtig' (known in Baltic Finnish) $\leq$ Balt. *deinīa-?, cf. Lith. dienì, Žem. dienià 'trächtig' = OI dhéna- f. 'weilbliches Tier, Weibchen, Milchkuh', etc.; it is ultimately PIE *dheinā- 'trächtig' from the root *dhē(i)- 'saugen, säugen' (cf. Pokorny, 241); Hung. tehen, tejen (*tein3) 'Kuh' belongs here as a direct borrowing from Aryan (Joki, 329).

6. Western FU, e.g., Fi. tuhat (stem tuhante-) 'Tausend' $\leq$ Balt. *tūšamtī̄a-?, cf. Lith. túkstantis $\mathrm{m}$. and OPrus. tūsimtons acc. plur., a regular reconstructed Balt.-Slav. form is *tüšimtiāa- (Traut. 332), but the Slav. (OCS) variant tysǫsti indicates the archetype *tūšumtị̄a- or *tūšamtị̄a-; it is characteristic that in Eastern FU the same numeral was borrowed from Aryan: e.g., Vot. surs, etc. $\leq$ *sarsa *sasra and this from Proto-Aryan *(sa)-źhasra- : OI sahásram, Av. hazaram, etc. $\leq \mathrm{PIE}$ *g'heslo- (Joki, 319).

7. Fi.-Mord.-Cher., e.g., Fi. udar (gen. sing. utare-n) 'Euter' $\leq$ Balt. *üde/ar-, cf. Lith. üdruó-ju, -ti 'eutern, trächtig sein', üdrotas 'schwanger', pa-üdré 'Unterleib; Netz (beim Schwein) or $\leq$ Aryan üdhar-, cf. OI udhar-, 'Euter, Busen'; it is ultimately the PIE heteroclitic stem *üdher/n-,

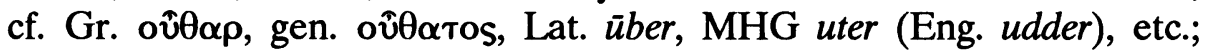
because of the geography of this loanword, the borrowing from Baltic seems to be more plausible (Joki, 332-3).

8. Baltic. Fi., e.g., Fi. varsa 'Fohlen, Füllen', but an older form vires, värõs, värâs, v́eras, etc. ( ${ }^{*}$ veres-//väres-) also occurs in Mord. $\leq$ Balt. verş̧a $a$ (Trautmann, 353), cf. Lith. veřšis 'Ochse, Kalb', Latv. vèrsis 'Ochse' or $\leq$ Aryan, cf. OI v̛́şa- 'Stier', vrsșán- 'Mann, männliches Tier', Av. varšni'Widder, Schafbock'; it is ultimately PIE *ursen- 'semen emittens' (Pokorny, 81); the Mord. forms would rather indicate a Baltic source (Joki, 337).

As we see, there are at least fifty old lexical elements in Joki's list which can be classified as either common Uralic-Indoeuropean (twenty-seven items) ${ }^{22}$ or early (prehistorical) borrowings from PIE, especially its eastern satem dialects (twenty-four items) 22 . Among the latter the words (eight items) suggesting a prehistorical Baltic source seem to be especially significant since they indicate that the prehistorical contact between the "Uralians" or Finno-Ugrians and the Indo-Europeans took place along quite an extended line south and 
southwest of the primary habitat of those peoples, which means from the Southern Ural westward across the "big bend" of the Volga River towards the Oka Basin. Most of this line, as far west as the big northern turn of the Oka River, roughly corresponds to the geographical boundary separating the northern forest zone from the southern steppe zone. We have already called the reader's attention to this geographical fact in the previous chapter, when discussing the prehistorical migration route of the "Pre-Slavs" at the time of their gradual separation from the "Pre-Balts." Here I would like to underline only the significance of this geographical fact which somehow seems to have escaped the attention of many scholars interested in the origins of the IE peoples and languages.

When we switch to the western periphery of the European continent and to the only non-IE ethno-linguistic group which has survived there from prehistorical times, namely the Basques, the situation will look quite different than in the case of the Finno-Ugrians: there are no prehistorical IE loanwords in Basque; the oldest IE elements in the vocabulary of this language have a clear-cut Celtic character and cannot come from a period before +/- 500 B.C., the time when the first Celtic tribes invaded the northern half of the Iberian Peninsula (cf. Löpelmann, M., 1968, $\mathrm{XI}) .{ }^{23}$ I think that this linguistic argument, when combined with the hydronymic one discussed on pages $225-26$, is a decisive linguistic proof that the primary habitat of the Indo-Europeans cannot be looked for in Central Europe: everything points towards the east, towards the parklands and the steppes of, at least, the Ukraine and Southern Russia.

In this general prehistorical-geographic framework we should treat the problem of the origins of the Slavs. 


\section{Chapter V}

\section{The Primary Habitat of the Slavs The Testimony of Hydronomy, Dendronymy, and Ethnonymy}

This chapter is a continuation and elaboration of the historical-geographical perspectives sketched on the basis of IE dialectology, particularly IE dialectal lexicology, in Chapter III. These perspectives show quite clearly the primary region and then the subsequent route of migration taken by the linguistic ancestors of the Proto-Slavs within the late IE linguistic zone in Eastern Europe. Of course, at that time (3000-1000 B.C.) we cannot speak about the Proto-Slavs (Prastowianie, Praslavjane, etc.), but only about those IE tribes and their dialects from which the prehistorical Proto-Slavs and early historical Slavs ultimately crystallized in the first millennium B.C. To denote those remote prehistorical ancestors of the Slavs I have been using the term "Pre-Slavs". For we must remember that any ethnos is a product of a long historical development involving some preceding stages at which its identity was not yet formed. So, to speak of the "Slavs" about the year 2000 B.C. would be the same kind of mistake or historical nonsense as to speak of the "Poles" or "Russians" around the birth of Christ. In Chapter II I have suggested that the Pre-Slavs split from the "Pre-Balts" and began to develop socially, culturally, and $a$ fortiori linguistically as an ethnic entity, i.e., as Proto-Slavs, no earlier than about 1000 B.C. At that time they seem to have been concentrated mainly around present-day Kiev and in Volynia (Pol. Wołyn m., ORuss. Volynb // Velynb f., etc.), a primarily parkland region located between the middle Dniepr in the east and the Bug river in the west, and separated by the Prypeć (Pol. Polesie) marshes from the Baltic zone in the north. The southern boundary of this region is formed by the natural edge, rim of the Podolia (Pol. Podole) plateau. This location of the early prehistorical Slavs, as an already separate, crystallized ethno-linguistic entity, has been obtained as the simple result of projecting the diagram of Late IE dialects on the map of Eastern Europe and tracing the natural routes of migration westward. As 
we have seen, the decisive factor in the gradual movement of the Pre-Slavs westward (or rather in a southwesterly direction) was the axis representing the natural boundary between the northern zone of predominantly coniferous forests and the southern zone of steppes, the belt of the so-called parklands, which is the most favorable landscape for primitive agriculture. This axis running southwest from the big bend of the Volga River crosses the Dniepr at Kiev and then extends straight west through northern Volynia. It had to bring any primitive agricultural peoples migrating along it to the Kievan region, i.e., today's central Ukraine, and to Volynia. Of course my hypothesis, based primarily upon linguistic and geographical evidence, does not preclude the possibility of some early prehistorical Slavs dwelling east of the middle Dniepr; they would simply represent the remnants of those tribes which had remained along the route of migration closer to its point of departure (the upper Don basin?). So we have serious arguments in favor of the Kiev district and Volynia as the center where the early Proto-Slavs crystallized. ${ }^{1}$

Now our next task is to find additional, more detailed linguistic arguments to support the above hypothesis.

First, I would like to discuss the etymology of the toponym *Volyn' $i$ // Volynb f., since in its primary meaning the very concept of the original domain of the Slavs seems to be expressed.

The philological evidence, namely ORuss. Velýnb (f.) in the Laurentian Codex of the Old Russian Chronicle (under 1018 A.D.), Volynb in the Radziwill Codex of the same Chronicle, and the Czech toponym Volyně in southern Bohemia, settled primarily by the tribe Dudlebi (ORuss. Dulěbi $\leq{ }^{*}$ Dudlěbi), who had come there from Volynia in the sixth century (cf. H. Łowmiański, 1963: 28) - indicate clearly the PSlav. form *Ve/olyn'i. Whether the name of the West Pomoranian island (at the mouth of the Odra River), known in German as Wollin and repolonized after 1945 as Wolin (m.) belongs here is uncertain. Vasmer (I: 347) connects all these toponyms. What should be underlined, however, is the fact that the ORuss. toponym Velynb // Volynb refers to a citadel (gorodz, gradz) located at the confluence of the Huczwa River with the Bug, that is, on the westernmost boundary of the province known historically as Volynia. According to the Polish historian H. Kowmiański (loc. cit.), the mention of this citadel under the year 1018 and its older Czech correspondence proves the "much older existence of the Volynia province (ziemia wotynska). Because the migration of the Dudlěbi took place in the sixth century A.D. in connection with the Avar invasion, this toponym certainly was already in use at the time of the great migration of the Slavs, and we are entitled to suppose that the genesis of this toponym goes back to even older times, perhaps to the very beginnings of the Slavs in the Dniepr and 
Vistula basins" (p. 28). In view of the above, the question arises, whether the name of the castle (capital?) has been derived from the name of the region or vice versa? This question cannot be answered easily. Historically, the extension of castle-city names to the surrounding regions seems to have been quite common. Consider, for example, the case of the Polish Mazowsze or the Russian Moskva. But we cannot be completely sure whether the toponym ${ }^{*} V e / o l y n ' i$ referred primarily only to a castle; it is highly probable that it denoted the whole region controlled by the ruler of the gorodz ${ }^{*}$ Volyn'i. This interpretation seems to be corroborated by the etymology of this toponym. Vasmer (loc. cit.) does not solve the etymology of Velynb // Volynb, quoting only previous unconvincing attempts. The root vocalism $-e$ - is decisive in this case. It allows us to start from the verbal root vel-, attested in the Slav. verb veléti 'order, command' (from IE *uel- 'want', cf. Lat. velle, OSax. williu 'I will', etc.) and its derivatives, e.g., velbjb, velikz 'great' (primarily 'powerful'). Thus *vel-yn'i could be interpreted as an abstract noun derived either from the adjective of the type velbjb (with its primary meaning 'powerful') or from the verb veléti. In both cases the meaning of the derivative would be 'power' (in the sense of Lat. dominium and then 'the region remaining under (somebody's) power' (i.e., Eng. dominion), from which ultimately the general meaning 'country, fatherland' could have developed. A convincing parallel to such a semantic development can be found in the Slav. *volstb 'power' (from the verb *voldo, *volsti 'rule', cf. OCS vlastb, vlado, vlasti), which in ORuss. volostb means 'region, territory, administrative district, power', in OPol. włośc 'latifundium', in Czech vlast 'fatherland', etc. Incidentally speaking, the verb *voldo, etc., which as we have seen represents an element of North IE vocabulary (cf. Goth. waldan!), seems to be an extension of the verbal root *uel- by the dental determinant $-d h$-. So we can assume that the reconstructed PSlav. *velyn' $i$ and *volstb were synonyms, which would account for the analogical spread of the vocalism - $O$ - instead of the primary - $e$ - in the former noun according to the latter ( ${ }^{*}$ velyn' $i / / *^{*}$ volstb $>*^{*}$ volyn'i).

The derivation of abstract nouns with the suffix -yn'i from underlying adjectives or verbs is well attested in OCS. We have, for example, deadjectivals: blagz 'gut, gnädig' > blagyn'i 'Güte', grbdb 'übermütig, hoffärtig, etc.' > grzdyn' i 'Übermut, Hoffart, Stolz', pravz 'richtig, recht' > pravyn'i 'Richtigkeit, Gerechtigkeit', svętı 'heilig' > svętyn'i 'Heiligkeit, Heiligtum', etc.; and at least semantically deverbal examples: logъčiti (itself from the adjective logzkz) 'erleichtern' > logyn'i 'Erleichterung', prostiti '(ent)lassen, verzeihen, erlösen, erlauben' (itself from the adjective prostz 'einfaltig, einfach, frei, aufgerichtet') > prostyn'i 'Vergebung'. Additional comparative material can be found in F. Sławski's 
introduction to Słownik prasłowiański (1975, v. 1, pp. 139-40).

The above etymology of the toponym Velynb // Volynb $(\leq *$ Velolyn'i) indicates that the region in question must have been inhabited by the Slavs from time immemorial, because only under such circumstances could it be called their "dominion", their "country" par excellence. ${ }^{2}$

But more convincing than the etymology of isolated toponyms is the etymology of whole complexes of hydronyms belonging to a region. ${ }^{3}$ So we now pass to an etymological analysis of the main hydronyms in the middle Dniepr basin.

Undoubtedly, the first question is whether the hydronym Dzněpr (this is the original ORuss. form) can be explained in terms of Slavic lexical material, i.e., whether it has a convincing Slavic etymology. But before answering this question, we should check other names of this river used by the Eastern Slavs, since the philological and folkloric evidence indicates that Dzněpr is not the only, and probably not even the oldest Slavic name for this big river.

J. Rozwadowski (1948: 251), discussing the etymology of Dunajb, reminded us that this hydronym is also partly used for the Dniepr River, and expressed the supposition that the noun dunajb, commonly used in Slavic oral poetry with the meaning 'big river', might refer primarily to the Dniepr River. To be more exact, the hydronym Dunáj is used for the Dniepr by the Byelorussians (White Ruthenians) in the Mohilev region (with reference to the upper stretch of the river). K. Moszyński (1957: 150-51) emphasizes this point and supplements it with facts from Ukrainian folk songs collected in the Cernyhiv region (thus south of Mohilev!), according to which the Dniepr is called by the hypocoristic forms Dunáječko, tychyj Dunájeńko. There is also interesting historical evidence provided by the ORuss. chronicles that seems to corroborate the use of the hydronym Dunájb with reference to the Dniepr (for details see K. Moszyński, loc. cit., 151). These and some other facts, e.g., a possible personification of the Dniepr River in the heroic character Dunaj Ivanovič of ORuss. byliny, etc. (cf. Moszyński, loc. cit.), make it almost certain that the primary Proto-Slavic name for the Dniepr was *Dunájb. This hypothesis is the main hydronymic argument in Moszyński's theory that the primary habitat of the Slavs was located in the central Dniepr basin. So there seems to be little doubt that the Proto-Slavs primarily called the Dniepr by the name *Dunájb, now preserved only in Byelorussian and Ukrainian folklore. And this name is not isolated in the Slavic hydronymy north of the Black Sea and the Carpathians, i.e., in the regions where the primary habitat of the Slavs should be located. Since the problem is central to our linguistic discussion about the location of that habitat, let us quote all the pertinent 
hydronymic material.

The Dniepr basin:

1.) Dunaec: right tributary of Polnaja, left tributary of Sejm, variant Dunaj.

2.) Dunaec: right tributary of Èsman', right tributary of Kleven', right tributary of Sejm.

3.) Dunaec: a tributary of Zalazna, right tributary of M. Vopec, right tributary of Dniepr, variant Bužek.

4.) Dunavec: a tributary of Kalinovka, right tributary of Sudost', right tributary of Desna.

5.) Dunajka: right tributary of Greza, left tributary of Drut', right tributary of Dniepr.

6.) Dunajčik: left tributary of Vorsklica, right tributary of Vorskla, left tributary of Dniepr.

The above hydronyms are quoted after V.N. Toporov and O.N. Trubačev (1962: 224). They can be supplemented by two rivers mentioned by Moszyński (loc. cit., 153):

7.) Dunajczyk in the Vorskla basin (undoubtedly identical with that under 6).

8.) Suchy Dunajec near Kaniów (Ukr. Kaniv).

The Vistula basin:

1.) Dunaj: right tributary of Wistoka.

2.) Dunaj: left tributary of Vistula between Jeziorna and Czerwonka (attested only in historical sources; it no longer exists).

3.) Dunaj: right tributary of Przewodówka, right tributary of Narew (attested only in historical sources).

4.) Dunaj: right tributary of Bzura (variant of Lidzianka // Ludzianka).

5.) Dunaj: a lake in the basin of the lower (?) San.

6.) Dunajec: right tributary of the upper Vistula (divided in its upper course into Biały and Czarny Dunajec, in the thirteenth century Dunawiec!).

7.) Biata Dunajcowa // Dunajecka: right tributary of Dunajec, variant Biała.

8.) Dunajek: German Donaicken, a lake connected with the lake Świętajno (Germ. Schwentainer See) in East Prussia, variant Kietki // Chetskie Jezioro (Germ. Kechler // Chechler See).

9.) Stare Dunajczysko: right tributary of Dunajec.

The above hydronyms are quoted after Hydronimia Wishy, 1965: v. 1. They can be supplemented with some names in the Vistula and Warta (i.e., Odra!) basins mentioned by T. Lehr-Spławiński (1946: 73-74):

10.) Dunaj: a stream in Ludzisko, Strzelno county. 
11.) Dunaj: a branch of the Warta River in Sulęcin.

12.) Dunaj: a stream in Starężyn.

13.) Dunaj: a pond in Kwilcz (all the above in Wielkopolska, i.e., western Poland).

14.) Dunajki: a swamp between Wierzchucino and Swinarzewo in Pomorania.

15.) Dunajka: a small tributary of the Hroza ${ }^{4}$ near Bychów (Ukr. Bychiv?).

It is readily evident that all the above hydronyms containing the stem Dunaj- are widely spread in the East and West Slavic territory, i.e., in the Dniepr, Vistula, and Warta basins. In view of the fact that the noun dunaj is also known in the oral poetry of all the Slavs as a name for any big river - and in Polish and Ukrainian dialects it simply denotes any larger natural reservoir of water - we can assume the existence of PSI. *dunajb as one of the appellatives used by the Slavs in their hydronymy. The etymology of this noun in Slavic and Indo-European terms does not present any difficulties. It has been convincingly interpreted by $\mathrm{T}$. Lehr-Spławiński (loc. cit., 75) as continuing the IE archetype *dhou-nā

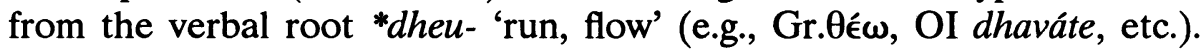
This archetype is perhaps represented by the hydronyms Dunia (in Silesia) and Duńka (twice) in the Dniepr basin (*dhou-nịa, etc.). In any event, derivatives in - ajb // -avb from stems in - $a$ seem to be quite frequent in Slavic, e.g., Pol. noga > nogaj, ręka > rękaw (the latter is Com. Slav.), etc. (Lehr-Spławiński, loc. cit.). For a detailed discussion and argumentation in favor of the Slavic origin of the hydronym Dunajb see also K. Moszyński, Kultura ludowa Stowian, II 2, pp. 852-853, and recently J. Udolph, 1979, pp. 359-367.

Against the background of the above linguistic facts it seems obvious that the Celtic (or rather Latinized Celtic) Dānuvius 'Danube', borrowed by the Teutons in the form *Dōnawjo- (Goth. *Dōnawi), was transmitted later by them to the Slavs. The latter could adapt it phonetically only as *Dunovb. However, since they were quite familiar with their own hydronym Dunajb // *Dunavs, they simply substituted the latter for the former: hence the South Slavic Dunav, North Slavic Dunaj 'Danube'.

All these problems have been exhaustively discussed and explained by Lehr-Spławiński in his book O pochodzeniu i praojczyźnie Słowian (1946: 74-75, 187-88), and more recently by J. Udolph in Studien zu slawischen Gewässernamen und Gewässerbezeichnungen (1979: 359-67). Therefore it is rather puzzling that V.N. Toporov and O.N. Trubačev in their book about the hydronyms of the upper Dniepr basin (1962: 224) derive the Slavic hydronyms based upon the stem Dunaj- // Dunav- from Latino-Celtic Danuvius through the intermediary of Goth. *Donawi. 
Historically this interpretation cannot be defended. It is an example of an etymology which neglects the concrete spatio-temporal conditions under which names can spread in a linguistic milieu.

Now let us turn to the discussion of the hydronym Dzněprz, which, in view of what has been said above, is chronologically younger and has replaced the older, original Slavic Dunajb as the name of that big East European river so intimately connected with the origins of the Slavs. The older (prehistorical) form of Dzněpr from a purely Slavic standpoint can represent either ${ }^{*}$ Dunǣprùs or ${ }^{*}$ Dunoiprùs (note the end-stress in the oblique cases!), where the ending -us is analogical as in all primary Slavic $o$-stems (e.g., *gordus instead of *gordos, according to *sünus, etc.): so the primary early PSl. form of this hydronym might be *Dunǣpros // *Dunsipros. Of course, for the time being we need not decide whether this name is original Slavic or not in terms of the regular PSI. continuation of inherited PIE words and morphemes. We simply state its primary PSl. form, which probably existed until the period of the monophthongization of the PSl. diphthongs, i.e., at least until approximately 400 A.D. This chronology of PSl. forms is relevant in any discussion of prehistorical loanwords in Slavic and the treatment of and substitution for foreign phonemes in these loanwords. To condense the discussion of Dzněprr (which should be treated parallelly with Doněstrı, as we will see), I basically subscribe to the almost universally accepted view that this hydronym is of Iranian origin (Scythian, or rather Sarmatian) and represents a compound which in Iranian terms was something like *Dānu-apara- 'river-back', i.e., 'back river, more remote river' (as opposed to *Dzněstrı S Iran. *Dānu-nazdya- 'river-closer', i.e., 'closer river'; for details and bibliography see Vasmer I: 518). Since the above etymology is only an attractive hypothesis and treats the two hydronyms as coined by the Balkan-Scythians dwelling on the lower Danube no earlier than around the third century B.C. (see Kretschmer, Glotta 24: 11, etc.), we are entitled to raise some chronological-philological questions. First, what were the oldest attested forms of these hydronyms? Second, can the Slavic forms be directly derived from those oldest attested forms? Third, if not, then what intermediary should be accepted in order to account for the Slavic forms?

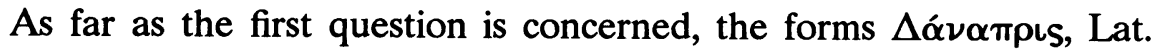
Danapris // Danaper (the latter in Jordanis, sixth cent. A.D.) appear only from the fourth cent. A.D. on. Before that time the Dniepr River was

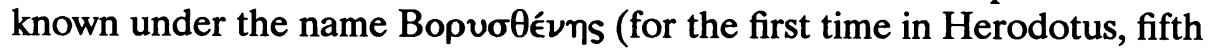
cent. B.C.), most probably also of Iranian origin. So the hydronym in question seems to be of relatively late origin. Similarly, the older name of the Dniestr River - Túpas, Lat. Tyras, after the fourth century A.D. was 


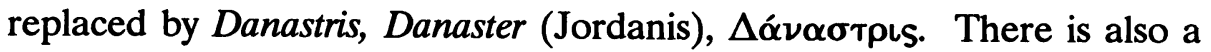
form Danastius (Ammianus Marcelinus, fifth cent. A.D.), which is important for the reconstruction of the alleged Iranian archetype *Dānu-nazdya- (see Vasmer, loc. cit., and Rozwadowski, 1948: 243-45).

With regard to the second question, it is obvious that the attested forms Danapris, Danastris (the stems Danapr-, Danastr-) cannot be the direct sources of the corresponding Slavic forms. We would then expect something like *Danoprb, *Danostrb if we maintain the accent marked in the Greek forms, or *Donaprb, ${ }^{*}$ Donastrb if we maintain the Latin accent,

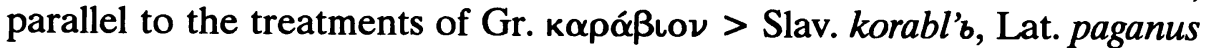
$>$ Slav. poganz, etc.

Therefore there is no doubt that these hydronyms were not borrowed by the Slavs from the same source as the above Greek and Latin forms. We must accept an intermediary. The phonetic treatment of the Iranian archetypes *Dānu-apara-, *Dānu-nazdya- (the latter is rather controversial!) reflected in Slavic Dъněprъ, Dъněstrı points towards an Ossetic intermediary. The Ossetians in the northern Caucasus are linguistically the descendants of the late Sarmatian tribe of the Alanians who played a significant role in the Hunnic invasion of Europe in the fifth cent. $\mathrm{AD}$., and who originally roamed the steppe region between the lower Dniepr and the Caucasus.

In Ossetic the primary Iranian $a$ and $\bar{a}+n \geq o+n$ (this $o$ is narrow!), e.g., dänu- 'river' $\geq$ don (which occurs also as the hydronym Don), and the primary Iran. $a \geq æ$ (very open!). Therefore the Iran. archetypes *Dānu-apara-, *Dānu-nazdya- (?) would sound in early Ossetic as *Don(u)-æpæræ-, *Don(u)-næzdyæ-. According to Rozwadowski (following Miller), these changes took place in Ossetic during the fifth to seventh centuries A.D., i.e., relatively late (see Rozwadowski, 1948: 245). Now the problem is whether the Slavs at that time could have replaced the Ossetic /o/ with their / $/$ and the Ossetic /æ/ with their /ě/, or in more precise terms, with an earlier stage of their $\mid \check{z} /$ and $\mid \check{e} /$, i.e., with $|\breve{u}|$ or $|\breve{y}|$ and /æ̋/. The period of the above changes in Ossetic approximately overlaps with the period of deep changes in the PSI. vocalic system (the monophthongization of diphthongs and its consequences) which brought about the following system, the so-called Middle Proto-Slavic vowel sysem:

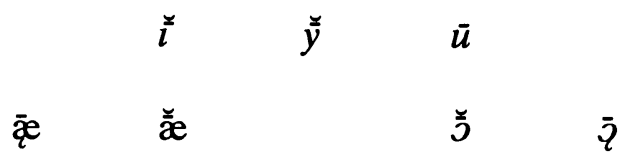


Within the framework of this system the Ossetic narrow /o/ could be replaced only by $|\breve{y}|$, i.e., later $|z|$, hence $\operatorname{Don}(u)-\geq D z n-$, but it is incomprehensible how Ossetic /æ/ could be replaced by Slavic /ā/ (long!), later /ě/. To eliminate this difficulty I propose a somewhat different etymology of the second components of these Iranian archetypes. Namely, for Dzněpr I suggest the Iran. form *Dān(u)-aip(i)ra- 'river upper', i.e., 'upper river', where *aipira- is an adjective formed with the suffix -ra (IE -ro) from the "preposition" (actually a primary adverb) aipi (PIE epi), whose meaning in OIranian is 'über-hin, bei' (with acc.), 'bei' (with loc.) (Bartholomae, 82-83), but primarily it meant 'on, over' (?), cf. Alb. épërë (PIE epi-ro-) 'oben befindlich' (see Pokorny, 323-24). Thus *Dānu-aipira- may have been used by the Pontic Iranians - in opposition

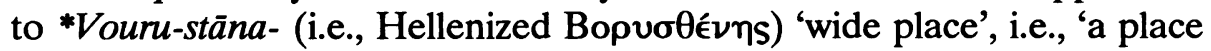
where the river extends widely', the lowest segment of the Dniepr - as a name for the middle segment of the Dniepr, from the standpoint of the Pontic nomads "the upper river".

For D̋něstrı I suggest an Iranian form *Dan(u)-aēšra- 'river-swift', i.e., 'swift river', where *aěšra- is an adjective formed with the suffix -ra (IE -ro) from the verbal root aěš- (PIE eis-) 'sich in eilige Bewegung setzen' (see Bartholomae, 31, and Pokorny, 299). It is worth mentioning that this verbal root occurs quite frequently in IE hydronyms, e.g., Lith. Eisra, Bruss. Istra, Gr. "Iotpos (the primary name of the lower Danube), etc. (Pokorny, ibid., 300). Of course, the Slavs replaced -aēsra- with their *-oistro-, since the primary IE $s$ - $r$ regularly developed an epenthetic $-t$ - in Slavic, and the sequence $s-r$ (or $s-r$, as was undoubtedly the primary Iranian sequence) had to be realized as $s-t-r$.

All the above facts and hypotheses support the view that the hydronyms Dzněpr and Dzněstrı are of Iranian (Sarmatian-Alanian) origin and were borrowed by the Proto-Slavs relatively late, between the fifth and seventh centuries A.D. Before that time the Slavs called the Dzněpr by its primary and original name Dunajb. We can even hypothesize that the primary hydronym was preserved to denote the northern segment of this river, i.e., north of Kiev, whereas the southern segment flowing across the steppes acquired the Iranian name Dzněpr because it was there that the Slavs got acquainted with that hydronym from their Sarmatian-Alanian neighbors. In this connection I think that the hypothesis ventured by Trubačev (Nazvanija rek pravoberežnoj Ukrainy, 1968: 217-18), according to which Dzněpr and Dzněstrъ come from Iranian-Dacian hybrids ${ }^{*} \operatorname{Da} n(u)$-ipr(o)- and ${ }^{*} \operatorname{Da} n(u)$-istr(o)through a Dacian intermediary to account for $a+n \geq u+n$ and $i \geq e a$ (as in Rumanian!) is unnecessary. In this hypothesis the second

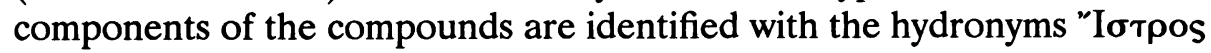


(lower Danube, see above) and Ibr // *Ipr (for the latter see Solon-iper in the right bank Ukraine), known from the Dniepr basin. Of course, there is no need to elaborate on the corresponding historical (or ethno-historical) facts pertaining to the lower Dniepr and adjacent regions known from ancient sources (starting with Herodotus in the fifth cent. B.C. and ending with Jordanis in the sixth cent. A.D.), which provide us with ample information about the Scythians, Sarmatians, Alanians, and other Iranian tribes of that zone, and their contacts with the Slavs. Those facts constitute a solid background for all linguistic hypotheses concerning possible Iranian influences in Slavic, in this case - the Iranian influences in the hydronymy of the Dniepr basin.

Further questions connected with hydronymy are whether the middle Dniepr hydronyms are mostly Slavic in comparison with those of other parts of that basin, whether they have correspondences in other parts of the North Slavic territory (i.e., in the Vistula basin), and whether on a purely linguistic (hydronymic) basis we can draw a conclusion about the direction in which the etymologically identical hydronyms spread in the respective regions (i.e., from the Dniepr basin-westward to the Vistula basin, or vice versa). These questions have attracted and absorbed the attention and energy of many outstanding Slavic and non-Slavic linguists, among whom we can mention at least such names as Jan Rozwadowski, Max Vasmer, Tadeusz Lehr-Spławiński, Kazimierz Moszyński, V.N. Toporov, and O.N. Trubačev. Because of the impressive material collected, analyzed, and explained (of course, often only hypothetically) by these authors, we are today able to attempt a synthesis from which can be drawn conclusions relating to the problem of the primary habitat of the Slavs. In the following paragraphs I shall try to present the results of the studies of the above scholars concisely and to formulate pertinent conclusions. I shall limit myself to the most important facts and hypotheses, referring the interested reader to the appropriate literature.

With respect to the first question, it should be emphasized at the very beginning that thanks to the exhaustive studies of V.N. Toporov and O.N. Trubačev there is nowadays little doubt that the hydronymy of the Upper Dniepr basin has a distinctly Baltic character. Simple statistics illustrate this fact. Among the 1569 hydronyms of the region, 800 are of Baltic origin (a little more than 50\%); the rest stem from Slavic, Iranian, and Finnic sources (see Toporov and Trubačev, 1962: 236 and indexes). The heaviest concentration of Baltic hydronyms occurs in the Berezina basin (west of the Upper Dniepr), then in the Sož' basin. It is also worth mentioning that the axis of the Prypeć River does not represent a sharp boundary between the Baltic (north of this river) and the Slavic (south of the river) hydronyms. In a characteristic way some hydronyms of Baltic 
origin appear south of the Prypeć (Russ. Pripjat'), concentrated along the rivers Ubort', Slavečna, and Ǔ, i.e., in the eastern part of Polesie (Russ. Poles'e), but in the western part of this region along the rivers Styr', Horyn', and Sluc' they do not occur (except for a few cases, see map 3, loc. cit.). This last fact deserves more attention. It seems to support my hypothesis about the route of migration of the Pre-Slavs from the east across the Middle Dniepr (somewhere near present-day Kiev) towards Volynia. If we look carefully at the hydrographic net south of Prypeć and west of Kiev, we readily notice that the rivers of the eastern corner of Polesie had to be left aside by the waves of population migrating westward along the forest-steppe boundary, but the same population reached in a natural way the Upper Sož', Horyn', and Styr' and then proceeded downstream along these rivers. As we know, Volynb // Velynb $\left({ }^{*}\right.$ Velyn $\left.i\right)$ is located in the southern half of the basins of these rivers.

Also important is the question of the southernmost reach of Baltic hydronyms in the Dniepr basin, since it indicates the oldest borderlands between the Balts and the Slavs. Map 2 (loc. cit.) is very instructive; the Baltic hydronyms reach from the north along the Dniepr and Desna rivers to the very vicinity of Kiev, e.g., Mordosy, a right tributary of Desna (cf. Lith. Mardosai, the name of a village). All the above facs undoubtedly indicate that the Upper Dniepr basin did not belong to the primary habitat of the Slavs. This region was ethnically Baltic until a relatively recent Slavic colonization, which started no earlier than the middle of the first millennium A.D. and was completed only at the beginning of the second millennium (in the twelfth cent. there are still Baltic Goljadb, Lith. *Galindai, near Možajsk, west of Moscow). So the Upper Dniepr basin was colonized not by the Proto-Slavs, but by the Eastern Slavs. In this connection a whole paragraph from the book by Toporov and Trubačev is worth quoting:

In particular the hydronymic data undoubtedly corroborate the supposition that the spread of the Eastern Slavs to the north moved first of all along the rivers of the Dniepr basin whose names show older Slavic features than the names of the rivers of the Don basin. To some extent the direction of the Slavic colonization of the Upper Dniepr basin can be determined by the areas of some old hydronymic suffixes.... The northerly and northeasterly direction of the migration of the Slavs into the Upper Dniepr basin is proven by the repetition of the hydronyms of Slavic origin on the one hand in the "right bank" Ukraine: in the Middle Dniestr basin and the adjacent Upper Bug basin, and in the Styr', Horyn', and Sluč' basins, and also in the Middle Dniepr basin; 
on the other hand in the basins of the Desna, Sož', and Iput' (and to a lesser degree in the Sejm basin). The data of the Slavic hydronymy on our territory entitle us to say that the Eastern Slavs moved to the north and northeast along the Dniepr itself and along the Sož' and Desna rivers.... Analysis of the Slavic hydronyms north of the Pripjat' (Prypeć) River as far as the Upper Neman (Niemen) region makes almost certain the idea that the Eastern Slavs who occupied this territory had come here from the east, from the left bank of the Dniepr River and only later, already under the eyes of history, did they begin to spread to the north, ousting or assimilating an older population." (loc. cit. 243-44)

Because of the availability of the book and the large number of hydronyms in question, I will limit myself to illustrating the most typical Baltic hydronyms in the Upper Dniepr basin with only a few examples.

These are first of all hydronyms with the Baltic suffixes -sa, -asa, -esa, -osa, -usa (other Baltic hydronyms have been Slavicized not only phonemically, but also morphologically, i.e., they acquired Slavic suffixes), e.g., Vodsa, Lučesa, Volčesa // Volčasa, Ovčesa, Očesa // Očasa, Ores(s)a // Orossa, Vodosa // Vedosa // Vadosa, Nerusa, etc. Some of them have exact correspondences in Lith. and Latv. hydronyms, e.g., Lith. Laukesa, Latv. Laucese, Lith. Vilkesa, Lith. (Žemajtian) Vedosa, etc. (loc. cit., 155). The last example is especially important, as it contains not only the suffix characteristic of Baltic hydronyms, but also the root nar- // ner-, which is very common in hydronyms in all Baltic lands (IE *ner- 'immerse', cf. Lith. nérti 'untertauchen', OCS vz-, iz-nrěti, etc.).

Now we can move on to a linguistic analysis of the Middle Dniepr hydronyms, concentrating on the right (western) tributaries of this river. Here again a recent exhaustive study has been written by O.N. Trubačev (1968). We will use his results and supplement them, if necessary, with other works (chiefly those by Rozwadowski, Lehr-Spławiński, Moszyński).

Trubačev's book includes the hydronyms of the "right bank Ukraine" in a broader sense, i.e., including the southern tributaries of the Prypeć River, all the tributaries of the Dniestr River (with its Moldavian part), and the rivers of the Boh (i.e., the so-called "Southern Bug") basin. Furthermore, all the left (eastern) bank tributaries of the Middle and Lower Dniepr are also incorporated into his linguistic analysis. The results of this study are very important (see the last chapter of the book, pp. 269-89). They allow us to reconstruct the ethnic history of that region during at least the last two thousand years. The most striking phenomenon is a strong concentration of very archaic Slavic hydronyms south of the Prypeć, especially in the Sluč' and Uš basins on the one hand, 
and then in the Upper Dniestr region on the other hand; the third area where they occur densely is the Middle Dniepr axis (for details see the map on p. 271, loc. cit.). Thus the zone between the rivers Prypec in the north, Dniepr in the east, and the Upper Dniestr in the west seems to represent the core of the archaic Slavic hydronymy. These are the historical regions of western Kijowszczyzna, Volynia, and Western Podolia. Another important discovery of Trubačev's is a group of hydronyms which have obvious correspondences in South Slavic hydronymy. These are: Sopot, Zver' (Zvir), Dolboka, Stubla, and Osoj, three of which are connected with the Dniestr. Here we should observe that the hydronym Zvir represents an original Ukrainian development of PSl. *jbzvorz (SSlav. izvor) 'source'. The above facts, plus some others (see below), seem to represent the old geographical separation of the ancestors of the Southern Slavs from the prehistorical eastern branch of the Slavs (the concentration in the Upper Dniestr region?).

Since one of our main problems is the Slavs' relationship with and eventual separation from the Balts, we should pay careful attention to the remnants or isolated examples of Baltic hydronyms south of the Prypeć. Already in the book discussed above (Toporov and Trubačev, 1962) the authors called attention to the Baltic hydronyms that occur along the Ubort', Slavečna, and Uš Rivers in the eastern part of the southern Prypeć basin. Now this southern reach of Baltic hydronyms should be supplemented with some hydronyms concentrated in the Sluč' basin (see map 16, p. 285, loc. cit.). These facts cannot be neglected: they indicate that in spite of the concentration of the main bulk of the Proto-Balts in the Upper Dniepr basin (especially north of the Prypeć) and that of the Proto-Slavs in the Middle Dniepr basin (especially south of the Prypeć), the contacts between the two ethno-linguistic groups never ceased completely. Such a supposition sheds light on the problem of the ways in which some common Balto-Slavic lexical innovations spread in these languages.

What follows is a list of the relevant Slavic and Baltic hydronyms in the area under consideration.

Baltic hydronyms south of the Prypeć (Trubačev, 1968, map 16, p. 285). (Eastward)

1. Kudrjanka

2. Peresuta

3. Vilija

4. Vilija

5. Cvil'ka

6. Šrišovka on Sluč

7. Cerem 
PRIMARY HABITAT OF SLAVS

8. Ceremskij

9. Smolka

10. Cmolka

11. Smolka

on Sluč

12. Neresna // Neresnja

13. Verpa

14. Norin

15. Vovčasova

16. Vovčasok

17. Veresna

18. Saremskij

19. Žoloska

20. Baly

21. Vilija

22. Šandra (south of Kiev!)

Archaic Slavic hydronyms in the Middle Dniepr basin (including the southern tributaries of the Prypeć and the Dniestr basin) (Trubačev, 1968, map 11, p. 271)

1. Žerev (a)

2. Suvil

3. Irpen'

4. Certoroj

5. Kobrin(a)

6. Zeremjanka

7. Čamišel

8. Subol'

9. Tupča

10. Trubež + Trubež (far east!)

11. Koveržin

12. Supoj

13. Subolica

14. Kovraj (3x)

15. Obytočka

16. Motyr'

17. Osoj

far east

18. Katuržika

19. Kovžiga // -ža

20. Golt(v)a

B. Southern Prypeć (Eastward).

1. Svorotovka

2. Styr' 


\section{Stubla}

4. Stubel'

5. Gdansk (sic! Upper Horyn')

6. L'va

7. Tustal'

8. Rubča

9. Koxvyl'nja

10. Zeremel'ka

11. Libožada

12. Radorobel'

13. Glumča

14. Devisjabra

15. Rodča

16. Bezud

17. Čertorija

18. Ljubožiža

19. Zerimyšel'

20. Žerev (cf. Žereva on Dniepr)

C. Upper Dniestr (Eastward).

1. Močas

2. Zabolja

3. Stebnik

4. Litmiž

5. Sopot

6. Zver' (Zvir) (2x)

7. Guretvina

8. Vibče

9. Stebnik $(2 \mathrm{x})$

10. Kolomejka

11. Dolboka (far south!)

In the above considerations we have omitted the Iranian hydronyms established for the region by Trubačev (see map 13, p. 277 of his book). They contribute no new information to the subject. As they are concentrated east of the Middle and Lower Dniepr, they simply corroborate other sources in suggesting that the Iranian tribes of the Scythians, Sarmatians, and Alanians maintained contacts with the Proto-Slavs along the eastern boundary of the Proto-Slavic habitat, mainly steppes. But we cannot neglect other facts discovered and emphasized by Trubačev. He demonstrated some interesting non-Slavic hydronyms in the right-bank Ukraine which have correspondences with either West Balkan (Illyrian) or East Balkan (Daco-Thracian) hydronymy (see maps 16 and 17 , pp. 278, 283, loc. cit.). ${ }^{4}$ It is striking that the former 
hydronyms are concentrated in the Upper Dniestr basin, whereas the latter ones show no special geographical concentration; they seem to represent isolated remnants of an earlier prehistorical ethno-linguistic stratum, ousted or absorbed by the Proto-Slavs. The concentration of Illyrian hydronyms in the Upper Dniestr basin overlaps with the concentration of a group of archaic Slavic hydronyms in this region (see above), among which there are some with obvious South Slavic correspondences. All these facts suggest that the ancestors of the Southern Slavs began to crystallize in that region and then moved gradually southward through the central Carpathians to the Danube basin, following in this way the route taken much earlier by the ancestors of the Illyrians (at least by some of them).

Of course, not all of Trubačev's etymologies are equally convincing. As an example of a highly uncertain and controversial etymology we can take his interpretation of the oronym Beskid // Bieszczad (in the Carpathians) $\leq{ }^{*}$ Beskydz // Beščadı (*Beskēd-) (loc. cit., 281). According to Trubačev it is a relic of the Illyrian toponymy in the Carpathian region, connected with other Illyrian elements concentrated, as we have seen above, in the hydronymy of the Upper Dniestr basin. For a discussion of the problem, see the excursus about Beskid // Bieszczad in the next chapter. But most of this experienced and knowledgeable scholar's etymologies are undoubtedly correct, and his general conclusions can be relied upon. ${ }^{5}$

Now we can go on to the second question formulated on page 245, whether the Middle Dniepr hydronyms have correspondences in the Vistula (and possibly Odra) basins.

Already before $1935 \mathrm{~J}$. Rozwadowski, analyzing the hydronym Wista (*Vistla), stated clearly: "It cannot be an accident that in the Upper Vorskla and Sejm (Sem') basins the names Wistok, Dunajec, Sanok, Sanica, and Bużok reoccur several times exactly as on the old Polish territory; and in the Upper Dniepr and Desna basins, and in northern Polesie we have again Wisła, Wistówka, Dunajec and Dunaj, Bużek, and Sana" (1948: 296), and "This spread of our hydronym [i.e., Visla and its derivatives $-Z G$ ] is very characteristic, especially if we take into account that on the Polish territory it is still found as a common name (appellativum); then, that as far as we know, on the South Slavic and in general Balkan territory, and also among the Balts, it does not occur, and finally that in the Vorsklica basin, in the same region where Wistok occurs, the names Sanok... and Dunajczik... also occur. Because not far away, in the basin of the Sejm (Sem') river, the name Dunajec is still found twice, and within the Polesie "nest" (in its southern half) Sanica and Bużok are found, then in the upper Dniepr basin Dunajec, Bużek, and Sana are 
found..., then it looks as though in these regions, between Charków [Ukr. Charkiv - ZG] and Kursk, and further north along the upper Desna and the Upper Dniepr there once dwelt those Slavs who later on moved both to Poland and towards northern Polesie and further west towards East Prussia, bringing with them the above hydronyms. For the opposite direction for the transfer of these hydronyms does not seem probable" (loc. cit., 290) ${ }^{6}$.

Once we introduce certain corrections based upon Toporov's and Trubačev's work, according to which migration along the western route (across northern Polesie towards East Prussia) cannot be accepted as an early event, the rest of the above statement by Rozwadowski is convincing. Everything seems to indicate that the transfer of the above hydronyms of the Upper and Middle Dniepr basin took place in a westerly direction, i.e., from the Dniepr basin to the Vistula basin. In this way we have also answered the third question formulated on page 245 .

The last big problem in the North Slavic hydronymy which should be discussed here is the etymology of the name of the Vistula river. This hydronym has been the subject of etymological analysis by many linguists, and various hypotheses have been proposed. Among them Rozwadowski's (loc. cit., 264-76 and 282-92) still seems the most convincing. Therefore I shall present it with some additional remarks.

First of all we should establish the oldest philologically attested forms of this hydronym: Vistula (Mela, about 44 A.D.), Vistula, Visculus, Visula, Vistla (?) (Pliny, 23/4-79 A.D.), Oủıoтoú $\alpha$ (s) (Ptolemy, 100-178 A.D.), and Vistula, Viscla, Vistla (Jordanis, about the middle of the sixth century). Those forms, when compared with the Slavic Visla (Pol. Wista), allow us to reconstruct the earlier PSl. form *Vistla $\left(\leq{ }^{*}\right.$ Uis-tlā or ${ }^{*}$ Ueis-tla $)$. The insertion of $u$ between $t-l$ in the most common Latin and Greek forms is a regular Latin device to break up the consonant cluster, which is unusual in that language. Similarly, the forms with $-k l$ - instead of the original $-t l$ - represent the Baltic (Old Prussian) dissimilation of the cluster $-t l-\geq-k l-$, which is characteristic of Baltic historical phonology. Here it is worth mentioning that the Germanic form of the hydronym, e.g., Germ. Weichsel ( $\leq$ *Wihsala), has been explained by its Old Prussian correspondence, with the metathesis $s k \geq k s$. Probably Pliny already used this form under the influence of Germanic or Baltic informants who were in touch with Roman merchants traveling for amber to the mouth of this river (note that the ancient amber trade route ran from the northern Adriatic coast through the Eastern Alps to the Moravian Gate, then along the Upper Odra river (Silesia), to presentday Wielkopolska and Kujawy, and then along the Lower Vistula to its estuary). So there is no question that we should start from the PSl. form *Vistla. Now, before 
attempting its etymology within the Slavic morphological material, let us take a look at the spread of this hydronym in the Slavic (i.e., North Slavic) territory.

In discussing the connections between the Dniepr and the Vistula basin hydronyms, we have already mentioned the fact that *Vistla, i.e., historical Visla, and its derivatives occur in both basins. The interested reader can check the list of those names in the articles by Rozwadowski whose basic content is summarized here, and in the two books by Toporov and Trubačev discussed above. Here I would like to call the reader's attention to derivatives with the prefix s8- 'with,' formed from the base *vis(t)la-, e.g.: Świslina is a right tributary of the Kamienna, a left tributary of the Middle Vistula, which, as Rozwadowski emphasizes, originates from the confluence of several streams (loc. cit., 267); Świstocz is a right tributary of the Berezyna, a right tributary of the Upper Dniepr, and it is characteristic that the Swistocz empties into the Berezyna River at a town called Świstocz, located on a kind of peninsula formed by the confluence of the two rivers (loc. cit., 267); and another Swistocz is a left tributary of the Niemen in the Grodno district. All the above derivatives

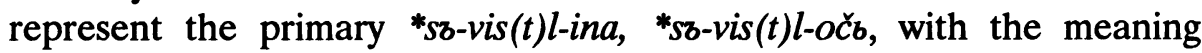
'confluence'. As Rozwadowski correctly assumes for the latter name, "It is a frequent name (confluentes, numerous Santoki, Sutoki, etc. [i.e., PSl. *sq-tokb 'con-fluence - ZG]), which the river takes from the name of an earlier settlement. The words wisła, wistok must have been used in their respective regions as appellativa of running waters when those hydronyms were formed" (loc. cit.). However, the Slavic etymology of Świstocz (i.e., Russ. Svisloč') is uncertain. As Toporov and Trubačev have suggested (1962: 207), it may instead be a Baltic hydronym, for in the first place it is surrounded by other Baltic hydronyms, and secondly it seems to contain the Baltic word akis 'source', which is quite common in Baltic hydronyms, cf. Nar-oč', In-oč'; cf. also Lith. Švieslaukis (Brückner, AfslPh XVIII: 314, 1891). Nevertheless, the interpretation of Świślina as *sz-vis(t)l-ina 'confluence' is certain.

Since the etymology of Vis(t)la bears on the problem of the chronology of the prehistorical Slavic immigration into the basin of this river, it will be instructive to quote all the hydronyms on the Polish territory that contain this stem.

The list of hydronyms with the stem *vis(t)la/o- on the Polish territory:

1. Wista, the main Polish river.

2. Wisetka (Biała and Czarna, whose confluence gives rise to the Wista).

3. Wisetka, a lake on the right bank of the Vistula between Nida and Breń in southern Poland (Długosz in the fifteenth cent.: 
Wistka).

4. Wistok, a left tributary of the San, a right tributary of the Vistula in southern Poland (also a small river, a tributary of the Jabłonka, a left tributary of the San).

5. Wistoka, a right tributary of the Vistula in southern Poland.

6. Wistoczek // Wistoczka, a left tributary of the Wistok.

7. Wistoczysko occurs many times as the name of an older riverbed of the Wistok.

8. Wiślanka // Wiślanówka, a right tributary of the Przedpolna, a right tributary of the Zglowiqczka, a left tributary of the Lower Vistula.

9. Wiślina a right tributary of the Vistula between the Dunajec and Nida in southern Poland.

10. Wiślina // Wiślinka (?), a tributary of the Lower Vistula between the Mottawa and the mouth of Vistula at the Baltic Sea.

11. Wiślina, a pond on the right bank of the Vistula between the Nida and Bren in southern Poland.

12. Wiślica, an old name (before 1800) of the presentday Wyżica // Wyźnica, etc., a right tributary of the Vistula between the Sanna and Kamienna in central Poland.

13. Wiślisko, a left tributary of the Vistula between the Skawinka and Wilga in southern Poland.

14. Wiślisko, a right tributary of the Vistula between the Raba and Uszwica in southern Poland.

15. Wiślisko, occurs many times as the name of an older riverbed of the Vistula in southern Poland.

The above list can be supplemented with several toponyms (the names of settlements): Wiślica, an old town on the Nida River in Małopolska (southern Poland) and a village in Cieszyn Silesia; note that there are also some toponyms containing the same stem on the Ukrainian territory: Wysła (Pol. Uwisła), a village on the Tajna River, a tributary of the Zbrucz in Husiatyn county; and Wysta (Rum. Vâsla), a valley-like field crossed by a stream in the village Mahala in Bukowina (for the latter, see Lehr-Spławiński, 1946: $72-73$ and Rozwadowski, loc. cit., 290).

The above list of hydronyms, based upon the recent work Hydronimia Wishy (1965), contains historically heterogeneous material. Besides undoubtedly old names which are not directly connected with the name of the big Polish river, such as Wistok, Wisłoka (and the toponym Wiślica), we also have here younger names directly derived from the name of the Vistula River or from Wistok(a), such as Wistka (diminutive), Wiślisko (augmentative-pejorative), Wistoczek // Wistoczka (diminutive), Wistoczys$k o$ (augmentative-pejorative), which were formed in a close physical 
connection with the rivers Wisła, Wistok, and Wistoka. In any case, the number of hydronyms derived from th base *Vis(t)la/o- is not small. If we add to this the similar number of identical hydronyms from the Dniepr basin $^{7}$ (for which see J. Rozwadowski, loc. cit.; Lehr-Spławiński, loc. cit.; and Toporov and Trubačev, loc. cit., 180), then we can conclude that this stem must have been used by the prehistorical Slavs as quite a popular appellativum in hydronymy (or toponymy in general), analogically to *dunajb, discussed in connection with the hydronym Dzněpro. A well-known basic rule for the etymology of proper names is to look for their sources in the vocabulary of the language to which they belong. So the question arises, whether there is in Slavic any trace of a common noun of the *visla // *vislo type. Indeed there is; these posited common nouns are used at least in Polish dialects: in southern Poland (Pińczów, Podhale) wista 'flood waters, big water, big river'; in Pomorania (Kluki, a Slovincian dialect) vjislo 'stream' (see Rozwadowski, loc. cit., 289, and Lehr-Spławiński, loc. cit., 73). Since proper names are usually derived from common nouns (the reverse process is exceptional) it should be assumed that the above Pol. dialectal words do not stem from the hydronym Wista, but rather that this hydronym was derived from a PSl. common noun *vis(t)la, which has survived in the Polish dialects (possibly secondarily supported by the hydronym?). In view of the above, the problem of the etymology of the hydronym $V i s(t) l a$ is reduced to the etymology of the common nouns *vis(t)la, *vis(t)lo.

Among many etymologies proposed for the hydronym Vis(t)la and its direct cognates, and of course its hypothetical source, the reconstructed PSI. nouns *vis(t)la, *vis(t)lo, the etymology by Rozwadowski (loc. cit., 267, 271-73, 291) is undoubtedly the most convincing. According to him we are dealing here with the early PSI. or IE archetype *ueis-tlā (or in the case of the neuter noun, *ueis-tlo), derived with the suffix -tlä, -tlo (the former can simply represent the primary plural of the latter!) from the IE verbal root *ueis-, which according to Rozwadowski (loc. cit., 291) denotes "'various kinds of fluids' and 'flowing [in general - ZG]' and which is quite widespread in the IE languages, but in common nouns occurs only as a relic. It is, however, copiously represented by hydronyms in the territories occupied in historical times by the Celts, Teutons, Balts, and Slavs, especially in Central and Eastern Europe. In particular, the root ueis- denotes a fluid that spreads and produces - due to mud and the putrifaction of plants in it - a characteristic odor. It also denotes water plants: cf. Sanskr. vésati 'spill, flow spreadingly', vișa- n. 'poison; fluid', visra- 'stale, musty (about smell)', etc.; Gr. iós (*uīsos) 'fluid (organic), poison; stagnant smell and taste (of swamps, sea)'...; OIc. veisa 'mud (in water)', etc." (Rozwadowski loc. cit., 291; more comparative 
material also on pp. 271-72). In Slavic, besides the aforementioned *vis(t)la, *vis(t)lo represented by the Pol. dialectal words, we also have Pol. wisz $\mathrm{m}$. 'tall sharp grass growing densely on waters and swamps' and Russ. víša, dial. viš' f. 'floating aquatic plants, river verdure, foam, plant, river fungus; Spongia fluviatilis'. The derivational structure of *vis(t)la, *vis(t)lo is obvious. If we agree that the neuter form is basic and the feminine secondary (the lexicalized plural of *vis $(t) l o$ ), then we can interpret it as a quite common type of deverbal noun with the inherited IE suffix -tlo-, whose variant - slo $^{8}$ is represented by such Com. Slav. derivatives as maslo (*maz-slo) 'butter' (etymologically 'greasy smear'), veslo ("vez-slo) 'oar' (etymologically 'that which helps to "ride", i.e., to sail a boat'), etc. These derivatives usually have the meaning of nomina instrumenti, but there are some old nouns with the meaning of nomina actionis ( > nomina acti), e.g., čislo 'number' (etymologically 'counting') from čbto, čisti 'count' (see F. Sławski, 1974: 103-104). Of course, in view of the above the noun *vis(t)lo must be a PIE formation inherited by Slavic, since the variant -tlo of the suffix proved not to be productive in Slavic (in contradistinction to Germanic, see Specht, 1947). The meaning of this noun can be reconstructed as 'flood waters', Pol. 'rozlewisko'. Therefore it is understandable that it or, in the case of the hydronym $V i s(t) l a$, its plural qualified for the nomenclature of widely spreading, swampy or lowland rivers and lakes. Note that the hydronyms of the Visla type on the East Slavic territory are concentrated in the notoriously swampy region of Polesie. As far as the Polish Wista is concerned, we should also recall that most of its course represents a typical lowland, slowly flowing, and widely spread river, notorious for its floods and forming many lateral channels i.e., a kind of back-waters.

After all that has been said above we can now include in the family of $V i s(t) l a$ the hydronyms of the *Vixla type (from an earlier *uis-lā with the passage of $s \geq x$ according to Pedersen's law): Wychotka, a right tributary of the Ipuć (Russ. Iput'), a left tributary of the Sož' in the northwestern part of the Cernigov district (Ukr. Cernyhiv); Wichotka, a large lake through which the above river flows; Wychla, a village in Radomyśl county (the Kiev district); see Rozwadowski, loc, cit., 270. These hydronyms and toponyms written in a Polonized form represent through Ukr. Vychlja, Vycholka primary Slavic ${ }^{*} V i \chi l(j) a,{ }^{*} V i x l z k a$, which in view of the PSl. variation between the suffixes - slo/a $\sim-l o / a$ (see Sławski, loc. cit.) can be derived from a PSI. common noun of the type $*_{v i x} l o, *_{v i x} l a=*_{v i s}(t) l o$, *vis(t)la. In this regard it is worth mentioning that among the forms of the hydronym Vis(t)la attested by the ancient authors we also find Visula (!) in Pliny (first cent. A.D.) and Ammianus Marcelinus (fourth cent. A.D.); see Rozwadowski, loc. cit., 265. Against the background of all the 
facts presented and discussed above, it is rather surprising that Toporov and Trubačev write: "Visla, a right tributary of the Vyslica, a right tributary of the Bobrik, a left tributary of the Pripjat'. Much has been written about the etymology of this name in connection with Pol. Wista (among recent works see Rudnicki, Onomastica 5: 43-ff., 1957). The possibility of a Baltic origin, cf. OPruss. Wizla, Wixla $\leq{ }^{*} V i k s l a ̄ a{ }^{*} V \bar{s}-k l a \bar{a}$, from Balt. *viss-/*veis-, is not excluded" (Toporov and Trubačev, loc. cit., 180). Vixolka (Russ. form) is not mentioned in the book.

We have devoted so much space to the problem of the etymology of the hydronym Vis(t)la and its Slavic cognates because it is the central linguistic argument in the whole discussion about the presence of the Slavs in the Vistula basin in ancient times. The reasoning is simple: if the hydronym Vis(t)la is Slavic (as we hope to have proved), and if it has obvious historical connections with identical or cognate hydronyms in the Dniepr basin, then the fact that it was known in the West (to the Roman writers, etc.) at the beginning of the Christian era proves that the Slavs must have been well established in the Vistula basin at that time. Hence, their arrival in the region should be shifted to a much earlier epoch (perhaps several centuries before the birth of Christ?). So the basin of the Vistula River, at least its southern (Małopolska) and central (Mazowsze) parts, seems to be an integral part of an extended Proto-Slavic habitat in the last centuries B.C. The question is whether other hydronyms on the territory of presentday Poland (including as it does the whole basin of the Vistula and most of the Odra basin) can also be qualified as originally Slavic. In this respect the book by Lehr-Spławiński (1946) can render valuable services.

The second big river in Poland, a right tributary of the Odra, is the Warta, which was attested in the tenth cent. A.D. by Thietmar as Wurta. This hydronym, representing PSl. *Vbrta (cf. one of the Warta's tributaries in Wielkopolska - Wiercica $\leq{ }^{*} V_{b}$ rtica, a diminutive of $\left.{ }^{*} V_{b} t a\right)$, is obviously Slavic: the alternation Warta // Wiercica (cf. also the town Zawiercie $\leq{ }^{*} Z a$-vbrt-bje and the village Powiercie $\leq{ }^{*}$ Po-vbrt-bje in the Upper Warta basin) - with the characteristic Polish treatment of the PSl. $\mathrm{CbrC}$ cluster - proves that the hydronyms are prehistorical. They are derived from the verb *vbrtěti (sę) (cf. OCS vrbtěti sę, Pol. wiercić (się), etc.) 'turn' (IE *uert-, Lat. vertō, etc.) and are semantically self-explanatory (see Lehr-Spławiński, loc. cit. 73, and cf. also Pol. dial. wart-ki 'swift'). Hydronyms from the same root (IE *uert-) are known on the Baltic and East Slavic territory: cf. OPruss. Wirthen, Wirtil; Žemajtian (dial. Lith.) Virtupis (i.e., Virt-upis); Russ. Vertejka, a right tributary of the El'nja(?), a right tributary of the Iput', a left tributary of the Sož' (probably from Balt. *Virtēja // *Vertēja; possible also is a Slavic origin); 
Vertec (a), a left tributary of the Borana, a left tribuatary of the Dniepr; Verčanka, a left tributary of the Dniepr (Toporov and Trubačev, loc. cit., 179-80); all of them in the Upper Dniepr basin. Coming back to Poland we can further cite: Wartopnik (before 1800), a left tributary of the Liwiec, a left tributary of the Bug ( ${ }^{*} V$ brt-op-bn-ikz), cf. Bulg. vrotop, Sloven. vrtèp 'water-whirl'; and Wiercioch ( ${ }^{*} V$ brt-exz), a lake in the Drwęca basin (northern Poland), and Wiercioch (German Wierczach See), a lake in the Omulew (a right tributary of the Narew) basin (northern Poland). It is disputable whether the hydronym Wierna Rzeka, a left tributary of the Nida in central Poland belongs here (if simplified from Wier(t)na, i.e., *Vbrt-bn-a). So, again Warta (*Vbrta) and its derivatives and cognates seem to represent quite old Slavic hydronyms in Poland. Another big river in western Poland (in its lower part the boundary between Poland and Germany) is the Odra (Germ. Oder). Its possible Slavic etymology has been discussed in the chapter about the primary habitat of the Indo-Europeans.

The last hydronym of a big river north of the Carpathians that is worth etymological analysis in connection with the posited prehistorical movement of the Slavs from the Middle Dniepr basin westward is the Bug (Russ. Zapadnyj Bug in opposition to Južnyj Bug, the latter called Bogz in Old Russian, which is continued by Ukr. Boh). It is the main right tributary of the Vistula, and from the beginning of recorded history it has formed the ethnic boudary between the Western and Eastern Slavs, i.e., the Poles and the Ukrainians. It originates from the confluence of the Bużek Opacki and Bużek Kruhowski (see Rozwadowski, loc. cit., 241). There is also the Bużek Oleski, a right tributary of the Upper Bug (see Hydronimia Wishy, p. 146). Besides this large Bug there is another, little Bug (so called before 1800), today Ruziec // Różec // Ruzica, a left tributary of the Drwęca in northern Poland (Hydronimia Wisty, p. 239). Two lakes called Stary Bug in the Middle Bug basin can also be mentioned here. The hydronyms derived from Bug, namely Buznia, the western half of the lake Świtaź; Bużysko, a lake emptying into the Wlodawka, a left tributary of the Bug; and Buzysko, two lakes on the left bank of the Bug between the Ptonka and the Brok - all located in the Bug basin - seem to be connected not only onomasiologically, but also physically with the Bug River, the right tributary of the Vistula.

On the East Slavic territory we have: Bužek // Bužok (also called Dunaec!), a stream, tributary of the Vopec, east of Smolensk; Bužok, a stream in the Lower Sejm basin north of Putyvl', and Bužok, a stream in the Upper Ubort' basin north of Zvjahel (Polesie); Buha ( $\leq{ }^{*}$ Buga), a tributary of the Unava, a right tributary of the Irpen', a right tributary of the Middle Dniepr (south of the Prypeć). We can also quote obvious 
derivates of Bug-: Bużanka, a right tributary of the Tykicz Gnity in Zwinogród county in the Ukraine (there is also a village Bużanka nearby); and Bużowa, a river in Kiev county in the Ukraine (the latter names are quoted in Polonized forms after Rozwadowski and Lehr-Spławiński); here also belongs Buża, a lake west of Lake Drywiaty in northeastern Lithuania (see Rozwadowski, loc. cit., 242, and Lehr-Spławiński, loc. cit., 64). Among the toponyms derived from Bug- we should mention first of all the adjectival archetype ${ }^{*} B u z ̌ b s k ъ / o: B u s k(o)$, a town in Stopnica county in central Poland, a well-known resort that is attested as early as the 12th century; and Busk (ORuss. Bužbskz), a town on the right bank of the Upper Bug, already attested in the 9th century, and at one time an important fortress. Perhaps we can also include here Buszcz (1450-1520), a settlement in Krajna (northern Poland), if it is derived from *Bužbsk + $j(e)$ according to Lehr-Spławiński (loc. cit., 64). Other derivatives (like Bużyska, Bużyn, Bużany, for which see the quoted works) can be omitted from our analysis as obvious.

The above hydronyms, concentrated in the Bug basin (the old borderland between the Poles and the Eastern Slavs) and in the Middle Dniepr basin, along with their old derivatives seem to indicate that ane time the appellativa of the type *bugz, *buga were used by the Proto-Slavs in forming their hydronymy, analogically to *duna, dunajb and *vis(t)la, *vis(t)lo. As usual, we should look for traces of these appellativa in the vocabularies of living (or historical) Slavic languages. And here too we find them. First of all we have Russ. dial. búga 'low banks of a river, overgrown with osier-beds, black poplar groves, and bushes to cover the area of the floodlands', which Vasmer (I: 227) compares with Latv. bauga 1. 'a marshy place by a river; a steep road', 2. 'poor soil'; then there is Pol. dial. bugaj 'bushes or woods in a river valley or on a steep river bank', which is frequent in toponymy. The IE cognates of these Slavic and Latvian words indicate clearly that we are dealing here with derivatives of the IE verbal root *bheug- (in Germanic also the variant *bheugh-) 'bend', cf.: OI bhujáti 'bends, moves away', bhōgá- 'turn, bend, ring'; the Germanic verb *beugan, baug, bugans 'bend', Goth. biugan, etc., Germ. biegen, etc.; in Greek and Latin with a special meaning 'run away', Gr.

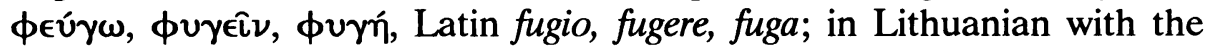
meaning 'get afraid' búgti, búgstu and buginti 'frighten', baugùs 'terrifying', etc. For this latter special semantic development compare the Slavic parallel represented by the development of the verb lękq, *lękti (OCS lęko, lęšti) 'bend' > Pol. lękać się 'be afraid', etc.

So for *bugz (PIE *bhougos) we can reconstruct the meaning 'bend' (or, if *bhougós as in OI bhögá-, then 'bending' nomen agentis); here Russ. búga (and the Ukr. hydronym Buha) may represent an old vrddhi 
adjective derived from that deverbal noun: *bhóugo- $>$ bhōugá-, which in Slavic has to produce regularly the old acute accent *búga, i.e., the immobile stress on the root in Russian (búga). The structural meaning of such a vrddhi adjective would be 'pertaining to a (river) bend', which perfectly accounts for the real meaning of búga in Russian. Pol. bugaj would be a derivative of *búga like dunajb from *duna, etc. (see above). In view of these facts and derivational patterns, I see no need to treat the hydronym Bug (Bugz $\leq{ }^{*}$ Bhougos) as a Balto-Slavic element as Lehr-Spławiński does (citing hydronyms like OPruss. Bougen (1371); Bawgin (1355), a lake, in the 20th cent. Bawien-See; Baugen (1353); Bougen (1399), a forest close to the settlement Bogen in Heilsberg county in East Prussia; and the lake Buza in Lithuania which has been mentioned above in connection with East Slavic hydronyms derived from Bug-), the more so in that Trautmann does not have any Balto-Slavic archaism or innovation of the *bauga- type in his Balto-Slavic dictionary. The fact that Lithuanian has preserved the basic verb (IE *bheug- 'bend') - with deeply changed meaning - whereas Slavic has not proves nothing, since such a situation is very common in the case of common IE elements in these two languages; very often Slavic preserves only derivatives while Lithuanian preserves both derivatives and basic verbs. The topographical details referring to the Bug River seem to corroborate the above etymology (proposed in the most general terms by Rozwadowski before 1938, loc. cit., 241-43). Namely, "the valley of the Bug in its upper part is in general marshy; past Kamionka Strumitowa it is divided into many scores of branches that form numerous islands and swamps. Similarly at the town Sokal, where the riverbed is deep, but the current is still slow; in the hilly region of Wotyn the current becomes swift, but also here the banks are often marshy and low, the current is often bending" (Rozwadowski, loc, cit., 241). As far as the Polish town Busk $\left({ }^{*} B u \check{z}\right.$-bskz/o) is concerned, we should note that there is no hydronym containing Bug- in its vicinity, but the town is located on several hills above a valley and its name undoubtedly has been derived from *bugz in the more general meaning 'curve' (in this case referring to the surface of the land); Rozwadowski, loc. cit., 43.

The above etymology of the hydronym Bugz, starting from Rozwadowski's basic convincing suggestion, has attempted to prove against the background of Slavic lexical material and old derivational devices that this hydronym should be considered Slavic. In this way we have reached the conclusion that the names of the biggest rivers on the Polish territory: Wista, Warta (perhaps Odra if from *O-dbr-a?), and Bug are of Slavic origin and have obvious correspondences in the Dniepr basin. Since the westward migration of the early Proto-Slavs (in the first 
millennium B.C.) is almost certain in view of the spread of IE languages in ancient Europe, the etymological connections between the hydronymy of the Vistula basin and that of the Dniepr basin (especially its more central part) can be interpreted to be the result of the transfer of the Dniepr hydronyms or old appellativa used there to the Vistula basin. So we have an additional argument for the prehistorical westward movement of the Slavs.

Our survey of the main hydronyms in the Middle Dniepr and Vistula-Odra basins would not be complete without mentioning a recent work by Jürgen Udolph: Studien zu slavischen Gewässernamen und Gewässerbezeichnungen. Ein Beitrag zur Frage nach der Urheimat der Slaven (Heidelberg, 1979). This impressive study (640 pages, 119 maps) is the most important contribution to the field of Slavic hydronymy published since the works of Toporov and Trubačev quoted so extensively in this chapter. Its basic approach consists in tracing the use of Slavic "Wasserwörter", i.e., common nouns referring to streams, rivers, ponds, lakes, swamps, etc., in the derivation of hydronyms. The whole historical territory occupied by the Slavs in Europe is taken into consideration, moving from the east to the west: the Don, Upper Volga, Dniepr, Dniestr, Vistula, Odra, and Elbe basins in the north, and the South Slavic territories. A critical review of some etymologies would require a separate essay. What is relevant for the subject of this chapter, however, are Udolph's conclusions about the location of the "Urheimat" of the Slavs. Let us quote the pertinent formulation:

"Als Hauptgründe, die Urheimat der Slaven an den Nordhang der Karpaten - etwa zwischen Zakopane im Westen und der Bukowina im Osten - anzusetzen, können die folgenden Überlegungen und Argumente gelten" (loc. cit., 619).

And then follow the arguments, which I summarize:

1.) This is the region in which we observe the above-average concentration of hydronyms based upon appellativa (common names) occurring in all three branches of the Slavic languages (East, West, and South Slavic). See map 40, p. 322.

2.) One of the most important arguments for the North-Carpathian "Urheimat" of the Slavs is the occurrence there of hydronyms derived from appellativa attested only in South Slavic. Recent research has proven that the alleged "Yugoslavisms" in the Carpatho-Ukrainian dialects are archaisms preserved from the Proto-Slavic period.

3.) Another important argument is provided by the preservation of old apophonic (vowel gradation) variants *bron- // *bryn-, *gneie- // *gnai-, *gręz- // *grqz-, *kron- // *kryn-, *ezer- // *ezor- in the region (see p. 620, loc. cit.). 
A more precise delineation of the Slavic "Urheimat" is given in the following words: "ursprüngliches Kerngebiet der slavischen Siedlung war mit großer Wahrscheinlichkeit der Nordhang der Karpaten, Namenhäufungen sind vor allem an den Punkten zu beobachten, wo Gewässer aus den Karpaten austreten, besonders auffällig im San-Gebiet und bei den Zuflüssen des Dnestr aus südlicher Richtung.... Die Namenhäufungen erlauben es dennoch im gewissen $\mathrm{Maße}$, die ursprüngliche Ausdehnung der urslavischen Siedlungen zu bestimmen: das slavische Kerngebiet umfaßt im west-östlicher Richtung etwa 300 $\mathrm{Km}$., in nord-südlicher - bedingt durch die geologisch schwankende Struktur des Karpatenvorlands - einen Streifen von etwa 50 bis zu 150 $\mathrm{Km}$. Schon früh wurden jedoch auch die Karpaten selbst, die Südhänge (vor allem der Karpato-Ukraine) und die nördliche Mittelslovakei von Slaven besiedelt, so daß eine Trennung in ursprüngliche und spätere Siedlungsräume nicht in jedem Fall mit letzter Sicherheit getroffen werden kann" (loc. cit., 620, 623, and the map on p. 622).

The above location of the core of the primary habitat of the Slavs is determined chronologically as valid for the time around the birth of Christ. So much for J. Udolph on the basis of the linguistic analysis of respective hydronyms. These results are a logical conclusion of the geographical distribution of his material and in this respect we cannot have any basic objections. But anybody with some knowledge of the history of the colonization of the Carpathian regions is simply surprised by Udolph's conclusion: the concentration of the whole Proto-Slavic ethnos at the foothills of the Northern Carpathians around the birth of Christ seems to be demographically impossible.

We know that the Carpathians were colonized relatively late, except for some wide and easily accessible valleys. For example, in the thirteenth century the city of Myślenice, $30 \mathrm{~km}$. south of Cracow, was practically the last settlement in the region (the village Stróża, $5 \mathrm{~km}$. south of Myślenice, as its name indicates, was already a frontier post). We must also remember that the sub-Carpathian regions were well forested and their soil is rather poor, so they could not attract early settlers. If anything, they were rather refuge areas, which is quite typical of mountain and sub-mountain regions. And I think that from quite early prehistorical times the Carpathians and their foothills played just that role: they attracted and concentrated various Proto-Slavic tribes which at times of demographic upheaval (raids, e.g., those of the Scythians, and big migrations, such as those of the Goths) tried to withdraw to these relatively less accessible peripheries of the Proto-Slavic habitat. This fact explains the concentration in the sub-Carpathian region of the hydronyms derived from PSl appellativa as defined above. Then the very 
fact of the geographical concentration of such hydronyms in the Carpathian zone, in comparison, for instance, with the Middle Dniepr zone, which is clearly emphasized by Udolph, seems to stem from an obvious circumstance, namely that in the mountains and at their foothills the net of streams and rivers is usually much more dense than on wide open plains. A look at the maps of the Upper Dniestr basin on the one hand, and of the Middle Dniepr basin south of Kiev on the other hand is quite instructive in this respect.

Another explanation of the concentration of the Slavic hydronyms in the sub-Carpathian zone, as opposed to non-Slavic elements in this region, is also connected with the relatively late colonization of the mountains. On the more open, accessible territories north of the Carpathians the expanding Proto-Slavic population encountered rivers, particularly big rivers, already named by the previous Indo-European waves of migrations, whose remnants were eventually absorbed by the arriving Slavs. In the sub-Carpathian regions (at the foothills and in the mountain valleys), rather skirted by the earlier migrations, this seems to have been relatively rare.

In discussing the hydronyms of the Upper Dniepr basin above, we have established the old Baltic character for the main bulk of them. Consequently, their slavicization and a younger Slavic layer of hydronyms in that region are evidence for the relatively late colonization of the Upper Dniepr basin by the Slavs. Thus, we have two basic strata of hydronyms in that region: an older Baltic layer, and a younger Slavic layer (other marginal influences, e.g., Iranian and Finnic, are irrelevant here). Similarly in the basin of the Middle Dniepr, especially west of the river we have established three old strata relevant for the subject of the primary habitat of the Slavs: a disputable relic stratum of hydronyms with Balkan (Illyrian and Daco-Thracian) connection, a marginal Baltic stratum, and the main Slavic stratum; the latter is here older than in the Upper Dniepr basin. Now the question is whether in the Vistula (and Odra) basins an older non-Slavic stratum (or strata) of hydronyms can also be established, and what conclusions can be drawn from it. In the book by Lehr-Spławiński, which is basic for this problem, the author distinguished among non-Slavic hydronyms first of all a copious layer of what he calls Venetic ${ }^{9}$ hydronyms on this territory, which show West and South IE connections. Below I quote the whole list of these hydronyms:

1.) Odra and its derivatives: see above in the chapter about the primary habitat of the Indo-Europeans (p. 222-23).

2.) Drawa: Germ. Drage, a right tributary of the Noteć, a right tributary of the Odra.

a.) Drawiec: a settlement in Lower Silesia. 
Wilno county.

b.) Drawce (plur.): three settlements, two in Slovakia, one in

c.) Drawsko: a lake from which the Drawa flows.

d.) Drawe: (1303 A.D.)

e.) Drowinen: (1258 A.D.)

f.) Drowsken: (1353 A.D.) // Drawsken: (1466 A.D.).

(The last three are toponyms referring to East Prussia in historical sources.)

All the above hydronyms and toponyms represent the family of *Drava and can be subsumed under the entry Drawa: so we have Odra and Drawa.

3.) Drwęca: *Drovotja, a right tributary of the Lower Vistula and a right tributary of the Pasarga in East Prussia, cf. Druentia, a left tributary of the Lower Rhine, today French Durance.

4.) Drama: a tributary of the Kłodnica, a right tributary of the Odra in Upper Silesia. It has many derivatives: Dramino, a village in Płońsk county; Draminek, a village in Sierpc county; Dramsko (1510 A.D., today Drawsko), a village in Wielen county; all are in northern Poland.

5.) Radęca: a right tributary of the Orla, a right tributary of the Odra in Poznañ "wojwodship".

6.) Mroga: *Morga, a right tributary of the Bzura, a left tributary of the Middle Vistula, and its tributary and derivative Mrożyca. Other derivatives, physically independent of the Mroga River, are the toponyms Mrozisko, in the village of Skotniki in Turka county (east of the Upper San River); and Pomrożyce, a village in Olkusz county. Cognates of Morga are known in the Dniepr basin, e.g., Moroža, a left tributary of the Oressa, a right tributary of the Ptiča, a left tributary of the Prypeć; and Morogi, a lake in Borisovo county (see Toporov and Trubačev, loc. cit., 196). There are also correspondences in Baltic.

7.) Sawa: a right tributary of the Wistok, a left tributary of the San. There are three geographically separate derivatives of this hydronym: Sawka, a stream in Wieliczka county with the village Sawa; a stream in Limanowa county (both in southern Poland); and Sawki, a settlement in Radzyn county (central Poland). There are also correspondences in the East Slavic territory: Sava, a left tributary of the Plisa, a left tributary of the Bobr, a left tributary of the Berezina (Toporov and Trubačev, loc. cit., 206). Lehr-Spławiński (loc. cit., 70) quotes in addition Sava and the town Sěvsk in the Orel district, beyond the Dniepr basin. There are also Baltic correspondences here, as well.

8.) Noteć: OPol. Notesz, 1234 A.D., dial. Noć, Germ. Netze, all from *Notbšb; a right tributary of the Warta, the historical boundary between Wielkopolska and Pomorze. Etymologically identical is Nieca, the OPol. 
name of the lower Noteć and dial. name of the Middle Łobżonka in Gniezno county (cf. loc. cit. p. 182-83).

9.) Ina: a right tributary of the Lower Odra in Pomorania (1233 A.D.), with its tributary Ina Mała and a lake Insko (1248 A.D.), Germ. Enziger See. It has a correspondence in Ina, a left tributary of the Prypeć, also called Ipa (Toporov and Trubačev, loc. cit., 189, have only the latter!).

10.) Srem: (*Sermb), a town in Wielkopolska on the Warta River.

11.) Eupia: a right tributary of the Bzura, a left tributary of the Vistula (near Skierniewice). It has numerous derivatives: Łupica, a historical hydronym (1310 A.D.) denoting a river on the boundary between Silesia and Wielkopolska; Łupka, a left tributary of the Osława, a right tributary of the Upper San; Łupięża (Germ. Lupenze), a right tributary of the Odra near Sulechów; Łupawa (Germ. Lupow), a tributary of the Baltic Sea in Pomorania (flows from Lake Łupawsko); and Luppenow (repolonized Łupniów?), a village NE of Stupsk in Pomorania. It has a correspondence in Łupa // Łupia (according to Lehr-Spławiński, loc. cit., 71), a left tributary of the Irpen, a right tributary of the Middle Dniepr (Lupa, according to Trubačev, 1968: 256), and in $\operatorname{Lup}(p) a$, a right tributary of the Mereja, a left tributary of the Upper Dniepr (see Toporov and Trubačev, 1962: 194). There are also Baltic correspondences.

12.) Opawa: a left tributary of the Upper Odra with a town Opawa (hence the name of the region Ślqsk Opawski) and its tributary Opawica.

13.) San: a big right tributary of the Vistula in southern Poland with the old town of Sanok located on its left bank. It has derivatives in other regions of Poland: Sanica, a right tributary of the Schodnia, a right tributary of the Czarna, a left tributary of the Vistula in Stopnica county (southern Poland); Sanna, a right tributary of the Vistula near Zawichost (southern Poland); and Sona (the Ablaut ${ }^{*_{o}}:{ }^{*_{\bar{o}}} \geq$ Slavic $o: a$ ), a left tributary of the $W k r a$, a right tributary of the Lower Vistula with two settlements, Sońsk and Zasonia. It has many correspondences, mostly in the Upper Dniepr basin (see the list in Lehr-Spławiński, loc. cit., 71-72). Here I do not understand the remark by Toporov and Trubačev (loc. cit., 206): "Sana, a left tributary of the Bobr, a left tributary of the Berezina.

Obscure. In any case one should not confuse it with numerous names of this type quoted by Rozwadowski (Studia nad nazwami wód stowiańskich, 89-ff.). Perhaps a more probable connection is with the name San, a right tributary of the Venta [a Lith. hydronym - ZG]." Trubačev seems to connect with the Polish San and its derivatives only the Sanok in the Vorskla basin, about which he states: "Brought from the west (cf. Pol. San // Sian, a tributary of the Vistula), a hydronym of pre-Slavic (Illyrian?) origin" (Trubačev, 1968: 
262). ${ }^{10}$

Lehr-Spławiński's concept of "Venetic" hydronyms seems to overlap with that of "Old European" hydronyms, as established by H. Krahe (with some modifications by W.P. Schmid; see the chapter about the primary habitat of the Indo-Europeans). It is striking in this regard that many of the above quoted "Venetic" hydronyms not only have correspondences on the Celtic and Illyrian territories, but also in the Baltic area. These are the hydronyms for which we have emphasized correspondences in the Dniepr, mostly the Upper Dniepr basin). This distribution overlaps with the typical distribution of the Old European hydronyms. So we could consider the above hydronyms as reflecting an older ethno-linguistic stratum, found and absorbed by the early Proto-Slavs coming from across the Bug River into the Vistula and Odra basins.

Special attention has also been given to the above problem by $\mathrm{T}$. Milewski in an article in Slavia Antiqua (XI, 1964). He quotes the following hydronyms on the territory of contemporary Poland which are suspected of Venetic or Illyrian origin: 1.) Oúl $\alpha \delta$ oús, the name of the Lower Odra, according to Ptolemy (2nd cent. A.D.), segmented by him into Vi-adu-a-s; 2.) Śrem; 3.) Raba, a right tributary of the Upper Vistula; 4.) Sawa; 5.) Drawa; 6.) Drama; 7.) Drwęca; 8.) Opawa; 9.) Noteć; 10.) Nieca; 11.) Wierzyca, medieval Verissa, a left tributary of the Lower Vistula. As we see, Lehr-Spławiński has treated most of them as Venetic. There are, however, three hydronyms added: Viaduas, Raba, Wierzyca, and six deleted: Odra, Radęca, Mroga (*Morga), Ina, Łupia, San. Most of Milewski's etymologies agree with those proposed by Lehr-Spławiński, except the etymology of Śrem ( ${ }^{*}$ Serms $)$, which according to Lehr-Spławiński represents PIE *k'er-, cf. Lith. širmas, šarmà 'hoar-frost', OIc. hjarn 'frozen snow', etc.; but according to Milewski rather PIE *ser-, cf. OI. sárma- 'flowing down', etc. (for details see Milewski, loc. cit., 60). The three new hydronyms added to the list by Milewski are etymologized as follows: Viaduas is derived from *Vi-adu-a- (cf. the Venetic Aduas in Pliny, contemporary Italian $A d d a$, a left tributary of the $P o$ ), with the prefix vi-, corresponding to the OI vi-, 'asunder', and the root $a d u$-, corresponding to the Av. $a \delta u$ - 'river-current, stream'; Raba, corresponding to the Illyrian $A r a b \bar{o}$, contemporary Raba, Raab in western Hungary, is interpreted as *arā- // ara- + bho- 'field' (see Milewski, loc. cit., 61); Wierzyca (*Verissa) contains the PIE *uěr- 'water, wet, etc.', attested among other examples by OI vārī 'water', and also represented in the Celtic languages. The Venetic hydronym Varanus and the toponym Verona also contain it. The suffix -issa has a parallel in the Venetic hydronym Nat-issa (for the latter, see the etymology of Notec, Lehr-Spławiński, loc. cit., 70). 
Milewski tries to map the above names and to establish the respective zones of their concentration on Polish territory. He obtains two zones (see his map between pages 80 and 81): the northern zone comprises Pomorania, Northern Wielkopolska and the western part of East Prussia (approximately the region between the Lower Vistula and the Lower Odra), where he locates hydronyms that have correspondences in Venetic; and the southern zone along the Sudeten and the Carpathians (i.e., Silesia and Southern Matopolska), where he locates hydronyms that have correspondences in Illyrian. Of course, this is a tentative geography. In any case a characteristic feature of this geographical distribution is that central Poland, extending from the Bug River in the east to the Middle Odra in the west, is free of Venetic or Illyrian traces in its hydronymy. I think that this remarkable phenomenon can be explained by the following hypothesis.

Early prehistorical Slavic migration (or expansion) westward moved on along a determinate geographical route which - continuing the old habits from the Dniepr basin - ran across the parklands covering the central territories, while the northern (sub-Baltic) and southern (sub-Carpathian) territories, covered more with virgin forests, were left aside and became for some time the refuge area of an older non-Slavic population (Venetic and Illyrian).

I should add that this interpretation is fundamentally different from Milewski's. He thinks that the Venetic names in northern Poland are the result of an invasion of a Venetic tribe, which came from the west somewhere about the second century B.C. I do no think that we have to resort to unverifiable hypotheses about Venetic or other migrations, or invasions, from the west. The general prehistorical spread of the Indo-Europeans from the east westward, and in this framework also the later westward movement of the Proto-Slavs, can account satisfactorily for an older hydronymic Venetic and Illyrian substratum in the Vistula and Odra basins.

In view of this older IE hydronymic stratum (in the Vistula and Odra basins), which because of its correspondences on the historical Venetic (northeastern Italy) and Illyrian (western Balkans) territories has been conventionally called Venetic and Illyrian, the tempting hypothesis can be ventured that it was this substratum which provided Slavic (i.e., Proto-Slavic) with most of the kentum lexical elements discussed above. ${ }^{11}$ Both historical Venetic and Illyrian belonged to the kentum branch of the prehistorical IE dialects. Whether we are dealing here with a homogeneous prehistorical ethno-linguistic group from which Venetic and Illyrian later developed, we cannot decide; and any attempt at answering this question must remain in the realm of pure speculation. 
To be sure, some scholars (e.g., H. Krahe, Lehr-Spławiński, T. Milewski, K. Moszyńki, etc.) accept the existence of a hypothetical people, the Veneti, dwelling between the Proto-Slavs and the Teutons (Proto-Germanic people) somewhere in presentday western Poland in the first millenium B.C. Those hypothetical Veneti were later ousted or absorbed by the Proto-Slavs (or according to Lehr-Spławiński, their mixture with the Pre-Slavs at the time of the Lusatian culture produced a new ethno-linguistic entity known as the Proto-Slavs). The very ethnicon Veneti // Venedi, used by the ancient authors for the Slavs, would be, according to the above authors, indirect linguistic evidence of the prehistorical existence of such a kentum people, intermediaries between the Proto-Slavs and the Teutons. Since most of those Veneti were absorbed by the Proto-Slavs, who took over their territories, it is understandable that the Teutons transferred this ethnicon to the Slavs; the old name remained unchanged in spite of the change of its ethnic content. Such cases are known in history; cf., e.g., the transfer of the ethnicon Prussians, primarily denoting a Baltic tribe, to the Germans who took over the original Baltic-Prussian territory, having annihilated or absorbed its primary inhabitants.

This hypothesis about the primary non-Slavic Veneti is better supported by the hydronyms discussed above and by the kentum and other West IE elements in Proto-Slavic (analyzed in the chapter about the stratification of the Com. Slavic lexicon), than by the origin and etymology of the ethnicon Veneti itself. Therefore, the identification of that ethnicon with the hypothetic kentum people ${ }^{12}$ who preceded the Slavs in the Vistula and Odra basins is purely arbitrary. In order to substantiate this point I shall briefly discuss the etymology of Veneti.

The idea that the ethnicon Veneti (for details see below) refers to the descendants-remnants of the same prehistorical IE ethnos, wherever it occurs, i.e., on Celtic, Italic, Illyrian, Slavic territories, and even in Asia Minor: Paphlagonia, was first expressed at the end of the nineteenth century by Gustav Kossina, a well-known German archeologist who tried to find ethno-linguistic correlates for the kinds of prehistorical material cultures that he reconstructed on the basis of excavations. In this particular case, the culture whose ethno-linguistic background the hypothetical Veneti supposedly represented was the so-called Lusatian culture (1300-600 B.C.). This idea, being only a weak hypothesis, then became quite popular among linguists, who modified it in different ways. Hans Krahe especially seems to adhere tenaciously to it (for details, see M. Rudnicki, Prasłowiańszczyzna-Lechia-Polska, I, 1959, pp. 99-103). The idea itself, i.e., that the ethnicon Veneti is a remnant of one prehistorical ethnos, which spread from a primary more compact region (center) to 
different countries, has a high degree of probability (compare the similar spread of the ethnicon Sloverne and its derivatives in early historical times). But besides this ethnicon and possible hydronyms (or other toponyms) co-occurring with it on some territories, we should have more linguistic evidence to support such a hypothesis, for example, some characteristic old words appearing in the languages of those IE peoples who have been influenced by the alleged Veneti (probably acting as a substratum, etc.). In this connection we could only quote some characteristic technical terms common to Italic, Celtic, Slavic, and Germanic, discussed in chapter III of this book.

As yet, apart from the hydronyms discussed above and the ethnicon $V e n e t i$ itself, nothing indicates that there really was a prehistorical ethnos Veneti somewhere in Central Europe, whose remnants were ultimately absorbed by the Slavs and to some extent also by the Teutons.

But let us move on to the etymology of the ethnicon Veneti. Since I have devoted to this problem an exhaustive article in The Journal of Indo-European Studies (v. 3(4), 1975), in the following paragraphs I will repeat only the most relevant points (with some additions). First, where and in what form does this ethnicon appear within the IE linguistic territory? Briefly, the list of places and names is as follows:

1.) Paphlagonia (the northwest corner of Asia Minor): 'Eveтoí (Homer, Iliad).

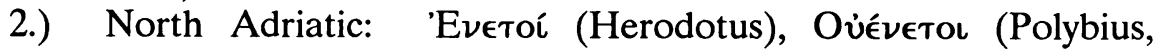
203(?)-120 B.C.).

3.) Dardania (Central Balkans): 'Evetoí (Appianus, 2nd cent. A.D.).

4.) Gaul (contemporary Bretagne): Veneti // Venelli (Caesar).

5.) Latium (central Italy): Venetulani (derived from a place-name *Venetulum, itself stemming from Veneti), mentioned by Plinius.

From among the above tribes the Balkan 'Evєтoi were undoubtedly Illyrian, the Gaulish Veneti - Celtic, the Adriatic Oúéveto /Veneti Venetic sensu stricto (i.e., an Italic tribe in linguistic terms). The ethnic membership of others is uncertain, especially that of the Asian 'Evetoí.

Now, as far as the Veneti of the Slavic-Germanic borderlands are concerned, we have the following names and locations:

1.) Venedi // Venedae: in Latin sources: Plinius, Tacitus. ${ }^{13}$

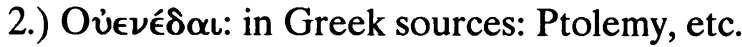

3.) Venethi // Venethae: in Jordanis, 6th cent. A.D.; he can be considered a Latin-Germanic source.

The location of those Veneti // Venedi of the Slavic-Germanic borderlands is constantly associated with the Vistula River, e.g., Ptolemy (Geogr. III, 5, 7): "Sarmatia is inhabited by very large peoples: by the

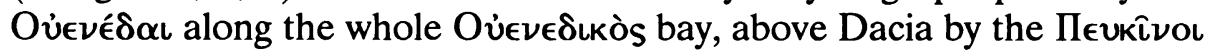




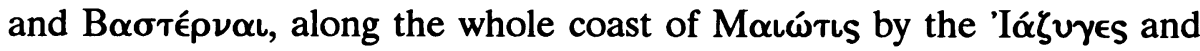

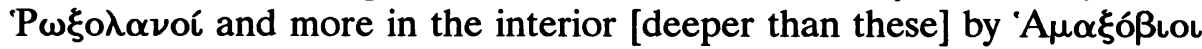

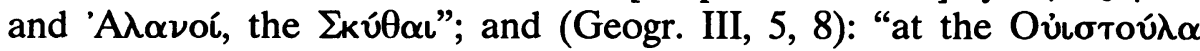

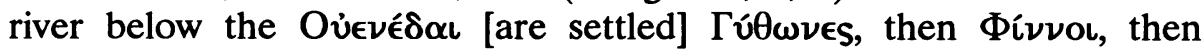

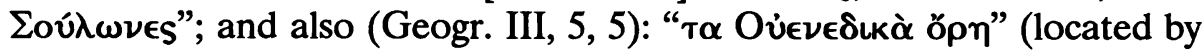

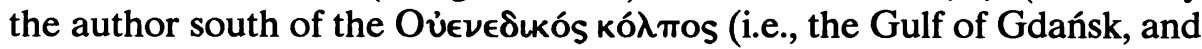
most probably referring to the Carpathians, although Łowmiański I, 172, criticizes the latter view). Compare also Jordanis (Get. V, 34, 35): "Within them [i.e., the rivers Tisia, Danubius, and Flutausis] is Dacia like a crown surrounded by the steep Alps; and near their left ridge, which inclines towards the north, and beginning at the source of the Vistula ${ }^{14}$ dwells the populous race of the Veneti, occupying a great expanse of land. Though their names are now dispersed amid various clans and places, yet they are chiefly called Sclaveni and Antes" (quoted after 1. Niederle, Slov Star. I, 1, 187-88; II, 2, 292; for a detailed analysis and interpretation of the sources, see L. Niederle ibidem and Lehr-Spławiński, 1946, 15-17).

Thus there seems to be no doubt that the prehistorical Veneti // Venedi of the Slavic-Germanic borderlands, so expressively identified by Jordanis (the middle of the 6th. century A.D.) with the Slavs, occupied the Vistula basin between the Carpathians and the southern coast of the Baltic Sea. Of course, this is the most general, extensive location. It is striking, however, that Ptolemy, who died about 178 A.D. and had used earlier sources, attached the term "Venetic" to the southern coast of the Baltic Sea (undoubtedly the Gulf of Gdańsk and its vicinity), and also to the Carpathian mountains (the latter is questionable; see above). This would indicate that the Veneti were firmly rooted in the region.

The problem is, however, whether those Veneti // Venedi of the fourth-sixth centuries A.D., identified by Jordanis with the Slavs, were ethnically (i.e., linguistically) Slavs (= Proto-Slavs) in the first century A.D., since ethnica, as we have seen, can be transferred from one tribe to another by foreigners. Linguistically, there are two ways to prove a possible Slavic character of the ancient Veneti // Venedi in the Vistula basin around the birth of Christ: first, the Slavic character of the old hydronyms in the region, and second, the Slavic etymology of the ethnicon Veneti itself. With regard to the first point I refer the reader to the linguistic analysis of the hydronym Vis(t)la presented above, and with regard to the second point I will present the results of my article about the etnicon Veneti.

According to a basic rule of the etymology of proper names, we should try to explain the ethnicon in question within Slavic lexical material and morphological (derivational) patterns. The form from which we should start is undoubtedly the one with the suffixal voiceless $-t-$ Veneti; the 
variant Venedi represents a Germanic form *Weneð- // *Winið- with the Germanic Lautverschiebung $t \geq \theta$ and the voicing of the intervocalic spirant $\boldsymbol{\theta}$ according to Verner's law. It is worth noting that the forms Venethi // Venethae (with th) used by Jordanis reflect a Germanic variant of our ethnicon with the Lautverschiebung, but without the action of Verner's law, which would suggest a hesitation in the primary stress: ${ }^{*}$ Uenet- $\hat{V} \sim{ }^{*}$ Uenét-V, etc.; the former resulting in Germ. ${ }^{*}$ Winið- $V$, and the latter in *Winé $\theta-V$. Derivationally, the form Veneti seems to have an exact parallel in another Slavic ethnicon, Veleti (= L'utici, a notorious belligerent Polabian tribe in Brandenburg), mentioned already by

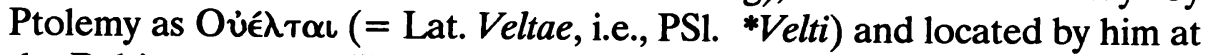
the Baltic coast east (!) of the Veneti. Since we have Russ. dial. velet, Ukr. vétet(eń), ORuss. volot 'giant', which allow the reconstruction of *vel(e)tz, the ethnicon Veleti can be explained simply as a derivative with the suffix -(e)t-from the PSl. root vel-, which occurs, e.g., in OCS veléti 'command', velbjb/-ijb, velikz 'great' (primarily 'powerful').

Against this background Veneti could be interpreted as an identical derivative from the verbal root *ven- (PIE *uen $\mathrm{H}$-, see below) preserved in the PSl comparative *vętjb(jb) 'greater' (cf. OCS vęštijb) - the oblique case stem *vętjbš- - which in its turn is based upon an old deverbal adjective *vętz, i.e., in PIE terms *uénH-to- or rather *uñH-tó-. The PIE verbal root *uen $(H)$ - 'streben', whence 'wünschen, lieben, befriedigt sein' on the one hand, and 'erarbeiten, Mühe haben', "perfective" 'erreichen, gewinnen, siegen' on the other (according to Pokorny, 1146), is well attested in the two IE branches that were the Slavs' neighbors in prehistorical times: Aryan and Germanic. For example, Avestan: 1.) van-: 'superare': a.) intransitive 'die Oberhand haben, überwiegen'; b.) transitive 'überwinden, besiegen', also absolute without a direct object 'den Sieg davontragen, siegreich sein' (Bartholomae, 1350-52). 2.) van-: 'gewinnen, an sich reissen' (Bartholomae, ibid.). 3.) van-: a.) 'wünschen'; b.) 'lieben' (not used in the present!) All of these occur with numerous nominal derivatives. Goth. winnan 'leiden'; OIc. vinna 'arbeiten, ausrichten, überwinden'; OSax. winnan 'streiten, kämpfen'. Of course, Eng. win and Germ. gewinnen belong here. The basic meaning 'wünschen, lieben, befriedigt sein' is also attested in Germanic: OIc. una ("wunèn) 'zufrieden sein', etc. (for details see the aforementioned article).

In view of these facts, I reconstruct PSl. *veneti (or *venete) // *ęti as two variants of the same noun, meaning 'winner, conqueror; a member of the warrior class', and used primarily as a social term. Derivationally, the above nouns represent a nomen agentis with the suffix -et- (primary consonantal stem!), i.e., *uen(H)-et- in PIE terms, and a substantivized 
deverbal adjective, i.e., *unH-tó- in PIE terms. They seem to be very old formations, since the PIE suffix -et- is not productive in Slavic (it was quite productive in Greek with the long vocalism: - $\eta \tau-$, e.g., ké $\lambda \eta S,-\eta \tau o S$ from ké $\lambda \lambda \omega$ 'drive', etc.; see P. Chantraine, 1933) and the continuation of *unH-tó- carries on, as expected, the old acute in Slavic (cf. the accent of $\mathrm{S}-\mathrm{C}$ vêći and of the ORuss. ethnicon Vjátiči). The latter ethnicon is relevant in the whole discussion about the Slavic etymology of Veneti. It seems to be a morphological transformation of a primary *vęti through the addition of the patronymic suffix *-itji (Russ. -iči), quite common in ORuss. ethnica (e.g., Radimiči, Kriviči, Dregoviči). Even so, the well-known legend according to which the Vjatiči stem from an ancestor-tribal leader Vjat(z)ko does not need to reflect a historical fact: it could have simply been invented in order to explain the patronymic form of the ethnicon.

Summarizing the above discussion, we can state that the PSI. *veneti ("venete ?) // *vęti was a social term with a good IE pedigree used by the Proto-Slavs moving westward as a denotation of their leading (ruling) warrior-class (Tacitus, Germania 46, 2: "Venethi... nam quidquid inter Peucinos Fennosque silvarum ac montium erigitur latrociniis pererrant."). Then their neighbors, especially the Teutons, transferred it to the whole ethnos extending in this way a primary social term to an ethnicon, a phenomenon that is quite frequent in intertribal and international relations (cf. the recent Nazis, Soviets, etc., as names denoting Germans, Russians, etc.). It is probable that the Slavic term Veneti (rather *Venéte, a primary consonantal stem) was confused with the Italo-Celtic Veneti $\left({ }^{*}\right.$ Uenetói $),{ }^{15}$ known to the Teutons from their earlier contacts with that branch of the Indo-Europeans. This confusion produced in Germanic the hesitation between the two forms PGerm. ${ }^{*}$ Wine $\theta \bar{o} z$ and PGerm. ${ }^{*}$ Winiðōz (the former represented by German Winden/Wenden, the latter

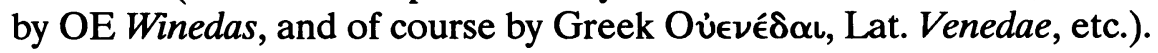

Thus there is no need to see in the ethnicon Veneti as applied to the Slavs any trace of a prehistorical IE kentum people, closely related to the Italo-Celtic or Illyrian group and only later absorbed or ousted by the Proto-Slavs. This, of course, does not discredit the whole hypothesis about a kentum substratum in Proto-Slavic: sufficient evidence for it is provided, as we have seen, by the so-called Venetic and Illyrian (to some extent also Old European ?) hydronyms in the Vistula basin, and by numerous kentum and western lexical elements in Slavic, from which the latter are absent in Baltic in most cases. Compare the results of Trubačev's and Martynov's works discussed in chapter III.

Now we are justified in raising the question, when did the Proto-Slavs appear or settle in the Vistula basin? In the preceding sections I have 
emphasized that the undoubtedly Slavic hydronym *Vistla (= Lat. Vistula, etc.) had been known in Latin and Greek sources since the beginning of the first century A.D. (attested for the first time in Agrippa, 12 B.C.?). Similarly the ethnonym Veneti, etc., which as we have seen may be of Slavic origin, was applied to the population of the Vistula basin at the same time. But the most convincing arguments concerning the western frontier of the Proto-Slavs and the chronology of their movement westward are provided by botanical terms, namely by the names of trees. The reasoning is simple. If the names of the trees with a clearly western range, i.e., in our case restricted to the Vistula basin and unknown to the east, represent a regular Slavic continuation of corresponding PIE archetypes, then the conclusion must be drawn that the Slavs have dwelt in the area from time immemorial, or rather from the epoch of the oldest IE movement westward. But if the names of these trees are not originally Slavic and represent obvious borrowings from west IE dialects or languages, then the conclusion will be that the Slavs (= Proto-Slavs) came to the Vistula basin relatively late (of course, still in prehistorical times). So let us check the names and etymology of typical western trees on the Slavic territory.

The significance of tree-names for the demarcation of the primary habitat of the Slavs was first formulated and elaborated by the Polish botanist Józef Rostafiński in $O$ pierwotnych siedzibach $i$ gospodarstwie Stowian $w$ przedhistorycznych czasach (Cracow, 1908). It is worthwhile to quote his summarizing statement from that essay: "The Balts know neither beech, larch, nor fir; they also do not know the yew, for they transfer its name to the Alder buckthorn. The Slavs transfer the PIE name of the yew to the willow (wierzba iwa); they do not know the larch, fir, and beech either. So the analysis of tree-names points to the central belt of Russia as the cradle of the Balto-Slavic family" (loc. cit., 10). About fifty years later K. Moszyński, in the book I have already quoted many times, devoted the largest chapter to this question (Chapter IV, pp. 23-66: Słowiańskie nazwy drzew a zasigg języka prasłowiańskiego na przetomie starej $i$ nowej ery), which is the best presentation of the whole problem to date. The conclusion of this author is as follows: "Summarizing all the facts, for the fifteen trees growing from the Odra basin to beyond the Dniepr, the Slavs have either names that they coined themselves or archaic names that have old cognates in other IE languages; for the seven western and southern trees, however, they use names of obvious foreign origin (*buks 'beech', *(j)avor 'Acer pseudoplatanus', *modroderv- 'larch', *tiss 'yew', *čerša 'cherry-tree') or of probable foreign origin ( were at least transferred from another tree that grows not only in the 
west, but also in the east $\left(^{*}(j) e d l-\right)$. There is only one conclusion that emerges from this; no other is possible if we wish to remain within the boundaries dictated by critical sense, undisturbed by extrascientific motives. This only conclusion is: the range of Proto-Slavic was located beyond the range of the western trees: beech, fir, one kind of maple, larch, yew, and sorb-tree (and also the cherry-tree, which is less important)" (loc. cit., 59). As we see, Moszynski's view is clear. What remains to be discussed is the foreign origin of the above tree-names.

At their head stands the name of the beech-tree, whose PIE form was *bhäg'ó-s (see Chapter IV, pp. 213-14). The reconstruction of the palatal $g$ ' is assured by the Slavic correspondence *bazz, reconstructed by Trubačev (ÉSSJa I: 172) on the basis of LLus. baz 'Sambucus nigra (lilac)', Russ. dial. bas = buzina and Ukr. dial. baznýk = siren' or 'Sambucus ebulus', etc. Of course, what strikes one about the Slavic correspondence is the shift of the primary meaning 'Fagus silvatica or orientalis (?)' > 'Sambucus nigra, etc.'. This seems to suggest that the Proto-Slavs had inherited the PIE name of the beech-tree, but because they dwelt, and really crystallized as a separate ethnos in beechless regions, they transferred the old name of the beech $\left({ }^{*} b a z b\right)$ to another species that resembled the beech-tree in some features (the color of the bark and the shape of the leaves ?). A similar transfer of an old PIE name can be observed in the case of the yew (for which see below). The above interpretation of the semantic change of the PIE name of the beech in Slavic is corroborated by paleobotanical data relating to the prehistorical flora of Central and Eastern Europe. Namely, between 5500-3000 B.C. (the epoch of the PIE linguistic community!) during the so-called Atlantic period, with a relatively warm and maritime climate, the vegetation consisted of mixed oak, elm, linden, and fir, with oak predominant at the end of the period. Between 3000-800 B.C. during the Subboreal period, with a more continental and drier climate, the vegetation consisted of beech, which dominated (with hornbeam), spruce, and mixed oak (see a chart in P. Friedrich, 1970: 23). To this presentation, however, we must add a fact emphasized by Friedrich: "In the Ukraine the cold of the Subboreal was less distinctive than its aridity. The beech was considerably reduced [my italics - ZG]. But this same beech (Fagus silvatica) became frequent or dominant in many western regions, extending from England to the middle European and north Mediterranean highlands. This was during precisely the millennia of the early and middle Subboreal, when the early Indo-Europeans were migrating westward and southward. Much of the Caucasus continued to be covered by climax forests of beech" (loc. cit., 22). As is well-known, the present range of the beech in Central-Eastern Europe does not extend to the east of a line which 
connects Kaliningrad (i.e., Königsberg) in East Prussia with Odessa at the Black Sea. But a more exact description would exclude from this range the very center of the Vistula and Warta basins, i.e., the Polish Mazowsze and Wielkopolska - in other words, the lowlands of central Poland (see the map on page 306 from K. Moszyński's book).

In view of the above facts, the semantic shift of *bhāg'ós (Slav. bazz), 'Fagus silvatica' > 'Sambucus nigra, etc.', is easily understandable and requires no speculation about complicated prehistorical migrations of the Proto-Slavs in two different directions successively. It is also understandable why the Slavs, having arrived and settled in the more central European regions (roughly the territory of contemporary Poland), where they found quite frequent beech-trees (especially in the sub-Carpathian and sub-Baltic regions), borrowed the name of this tree from the neighboring population, which was well acquainted with it, namely from the Teutons (the Goths?).

As we saw in Chapter IV (p. 213), the PGerm. name of the beech was ${ }^{*} b \bar{k} k \bar{o}(n)$, as reflected by Goth. böka ( $n$-stem!), which, incidentally, is attested with the secondary meaning 'letter', OHG buohha = NHG Buche, etc. Its regular treatment in Slavic was buky (bukzv-), since the Germanic long closed $o$ was identified in word-middle position with an intermediary PSI. ${ }^{*} \bar{Q}$ coming from the diphthong * $u$, i.e., with Late PSI. and historical $u$ (cf. the correspondence between Germc. *ploga- and Slav. plugz etc.). The earlier morphological form buky (or its secondary transformations based upon the stem of the oblique cases bukbv-, e.g., bukzvb, buk(ъ)va, etc.) has been preserved in OCS buky, -zve 'letter' $(\gamma \rho \alpha ́ \alpha \mu \alpha)$, Russ. bukva 'idem' (probably borrowed from OCS, but there is also Polab. plur. bükvoi 'books'), etc., and, which is relevant in this case, in S-C bükva (old bükav) 'beech, Fagus silvatica', Sloven. búkev, gen. -kve, bûkva idem, OCz. bukva 'beech-tree and its fruit' (sic!), ULus. (old) bukow (?) 'beech' (in other Slavic languages forms of the type buk(z)va, bukъvb denote beech-nuts, e.g., Pol. bukiew, gen. -kwi, etc.; for details see Trubačev, ÉSSJa III: 91-92). The more common historical Slavic form of the name of the beech is bukb, which should be interpreted as a secondary morphological adjustment of buky f. to the masculine gender common to the Slavic names of similar trees, e.g., dobs 'oak'. The semantic split of the name of the beech into primary 'beech-tree, Fagus silvatica' and secondary 'beech tablet for writing' > 'book, letter(s)' with concomittant morphological changes is already a Proto-Germanic phenomenon (cf. Eng. beech $\leq{ }^{*} b o \overline{k j o} n$ - and book $\leq{ }^{*} b \bar{o} k a-?$ ), and it is also reflected in Slavic (OCS and Polab.!). But the meaning 'beech' is older and common in Slavic; it is characteristic that most Slavic languages attach it to a "remodeled" form bukz, whereas the continuation of the 
primary Germanic form ( 'beech nuts' in most Slavic languages (except for S-C, Sloven., Old Czech (?), and ULus.).

So there is no question that buky and bukz in their two meanings represent an obvious prehistorical Germanic borrowing in Slavic. The problem which is important in our discussion boils down to the chronology of this borrowing, because if we are able to establish it, we can determine approximately at what time the Proto-Slavs became familiar with the tree, which, as we have seen, must have taken place somewhere in the Upper Dniestr and Upper Vistula basins and in Pomorania. The phonemic change of the PIE (kentum) *bhägo- into PGerm. *bok-on- contains two processes: the Lautverschiebung ${ }^{*} b h \geq b$ and ${ }^{*} g \geq k$, and the narrowing and labialization ${ }^{*} \bar{a} \geq \bar{q}$. The chronology of these changes is quite well known: the former was completed by the year 300 B.C., and the latter must have been much later, as Caesar in his Commentarii still writes Silva Bäcenis (= Harz), the second component of which undoubtedly reflects an early PGerm. *Bäken- (cf. NHG Buchen-). In view of these facts, the Slavic borrowing of the Germanic *bōko cannot have taken place in the first century B.C., but only much later. What is decisive is the replacement of the Germanic $\phi$ by Slavic $u$, which in original Slavic words inherited from PIE continues *ou ${ }^{*}$ *au (through an early PSl. $s u$, then ${ }^{*} \sigma$ in connection with the monophthongization of diphthongs in Proto-Slavic). So everything indicates that the treatment of Germanic $\bar{Q}$ as Slavic $u$ is closely related to the period of the monophthongization of diphthongs in Late Proto-Slavic, which most Slavists (Shevelov, Stieber, etc.) date between 400 and 600 A.D. For example, all Gothic loanwords containing diphthongs underwent the monophthongization in Slavic: kausjan, *kaupjan $\geq$ kusiti, kupiti, etc. But closer Gothic-Slavic contacts started, as we know from history (e.g., Jordanis), at the end of the second century A.D., i.e., when the Goths, having moved from the lower Vistula basin southeast to the Ukraine, settled there (in coastal regions) and ruled until the invasion of the Huns.

Of course, these are only very general chronological indications. Before that time (the third century A.D.) the Proto-Slavs had some contacts with other East Germanic tribes as well (first of all with the Burgundians and Vandals) who a little earlier, already in the first century B.C. swarmed from Scandinavia along the Danish islands to the Lower Odra basin (Western Pomorania) and further south (Silesia). But if the Germanic name of the beech $\left({ }^{*} b \bar{o} k \bar{o}\right)$ had been borrowed at that earlier time (pre-Gothic), i.e., between the first and third centuries A.D., then we would rather expect in Slavic the form *byky (bykzv-), etc., since before the monophthongization of diphthongs the Early Proto-Slavic 


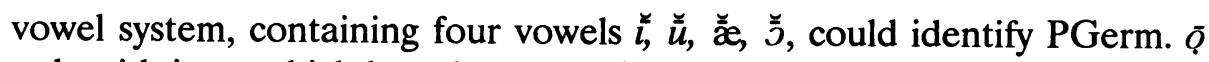
only with its $\bar{u}$, which later became $y$ (e.g., PGerm. ${ }^{*}$ mota $\geq$ Slav. myto). ${ }^{16}$ So linguistic considerations point to a rather late borrowing of buky, most probably from an earlier Gothic (or Gepidic ?, see below) *bōkō. I mentioned here "Gepidic", i.e., the dialect of the Gepids, a tribe closely related to the Goths, which having crossed the territories between the Baltic Sea and the Carpathians (by what route?) settled in the third century A.D. in presentday Transylvania (ancient northern Dacia). They are first mentioned in Roman sources in 269 A.D.; at the end of the third century a new group arrived in Dacia from the Vistula region. The most probable route to Transylvania was through the central Carpathian passes, which means that we may accept that the tribe stayed transiently in the Upper Dniestr basin. ${ }^{17}$

In view of the above I am inclined to derive Slavic buky ( > bukz) from Gepidic somewhere in the sub-Carpathian regions, rather than from Gothic sensu stricto, although the first contacts between the Proto-Slavs (Veneti, etc.) and the East Germanic tribes (including the Goths) took place about the birth of Christ somewhere in the sub-Baltic regions where, as we have seen, the beech-tree is quite frequent.

Another tree name of obviously foreign, also Germanic origin is the Proto-Slavic (j)avor ( $j$ - is a later prothesis), which in most Slavic languages means 'Acer pseudoplatanus', e.g., OCS avor // javor 'platanus', S-C jävor 'Acer platanoides', Pol. jawor // jawór idem, Russ. jávor 'white maple', 'Platanus orientalis', etc. The source of this borrowing is most probably OHG ähorn = NHG Ahorn (as far as the form is concerned there are dialectal German variants without $-\boldsymbol{n}$; for details see Trubačev, ĖSSJa I: 96-97, and Moszyński, loc. cit., 37-40). General opinion is that the borrowing is relatively young (sixth-seventh century A.D.); Trubačev, ibid., and Moszyński, ibid. This would be understandable in view of the geographical distribution of Acer pseudoplatanus, which for the most part closely follows that of Fagus silvatica, i.e., beech (see the map on p. 306). Here again the region where the Slavs got acquainted with the tree and subsequently borrowed its name from those people who had long been familiar with it is the wide sub-Carpathian (and sub-Sudeten) belt, extending east as far as the Upper Bug and the Upper Boh (= Južnyj Bug) basins. This eastern extension of (j)avors makes possible the borrowing of the tree name from Gothic (?), specifically West Gothic (Gepidic?), not necessarily from Old High German, although the linguistic details are not clear.

The third Germanic loanword among tree-names is *modroderv-, reconstructed on the basis of Pol. dial. modrodrzew, Standard Pol. modrzew, gen. -drzewia (with haplology!), Cz. modř́n, Pol. modrzeń (from 
which the Ukr. modrén) 'larch, Larix sp.'. It is characteristic that in accordance with the geographical distribution of this residual species (see the map on p. 306) its name is restricted to only Polish, Czech, and Ukrainian (in the latter borrowed from Polish). According to Moszyński (loc. cit., 41-45) we are dealing here with a calque linguistique (loan translation) of a Germanic compound *madra-triu (Gothic archetype) whose meaning was 'red tree or wood'18 which reflects the characteristic red color of the inner layer of larch-bark. The Slavs translated the second component of the name; the first they preserved, since they borrowed the Germanic adjective madra- 'red' separately as Slav. modro (the meaning of this adjective, attested only in West and South Slavic, is 'dark blue', which implies an old semantic change 'red' > 'purple' $>$ 'dark blue').

The fourth western tree (see the map) which bears a non-Slavic borrowed name is the yew - tiš (S-C accent tïs!) 'Taxus baccata'. Its range does not even extend to the east of the Vistula River. Indo-European has two names for this tree: *eiuo- (attested in eight IE languages but with widely divergent meanings) and *tVk'so- (attested in Latin, Greek, Iranian (?); see P. Friedrich, 1970, 121-29). It is characteristic that as a result of making bows out of yew-wood, both PIE names for this tree secondarily mean 'bow' in several languages, e.g., ONorse $y r$ and OIr. ibhar (in both meanings), MPers. taxš ( $\leq *^{*} \operatorname{taxša-)}$ 'bow' (genetic identity with Lat. taxus is questionable), Homeric Gr.

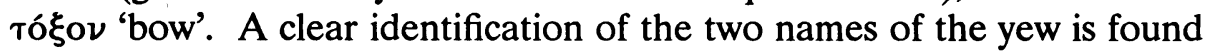
in a Latin text: "taxus arbor quam vulgus ivum vocat" (Friedrich, loc. cit., 125, after A. Meillet). The Proto-Slavs primarily used the inherited IE name of the yew - *eiua a, in Slavic iva (S-C accent iva, Russ. iva, etc.), but later, living in yewless regions, transferred it to the willow (possibly in connection with the common feature of elasticity of the wood?). The acquaintance of the early Proto-Slavs with the name *eiu $\bar{a}-\geq i v a$ 'Taxus baccata' could have been conditioned by the barter trade of yew-wood used for bows, rather than by their familiarity with the tree itself in their primary habitat. It is worth emphasizing that the yew is known in the Northern Caucasus (see Friedrich, loc. cit., 123). In any case, having moved westward and entered regions where the yew grows (west of the Vistula River and in the west and central sub-Carpathian zone) they became familiar with the tree itself and borrowed its name from some Northwest Indo-European dialects. This is of course only a hypothesis, based on K. Moszyński's etymology of Lat. taxus. According to this etymology (Moszyński, loc. cit., 46-50) it represents IE *tog-so- with the root *teg- 'to cover', secondarily in adjectival derivatives like PGermc. ${ }^{*}$ Oeku- = Eng. thick, NHG dick, etc.; PCelt. ${ }^{*}$ tigu- ${ }^{19}=$ OIr. tiug 'covered 
$>$ thick', etc. Note that the yew, whose branches form a very characteristic thicket, has been called simply "the thick" (this from K. Moszyński, who does not explain all the phonemic details). Of course, the Latin form with the root vocalism $a$ cannot be original: it must have been borrowed from a North IE dialect (Illyrian?) in which there was no distinction between the vocalism $o$ and $a$ (one back low vowel $\rho$ as in Early Proto-Slavic). The regular Slavic continuation of the PIE archetype *togso- (or with the front root vocalism *tegso-) would be *toxz or *texz (since there is no reason to reconstruct a palatal $g$ ' for this root, which in the cluster $g$ '-s would give $s$ !), but we have PSI. *tisz. This form indicates: first, that it was borrowed from a foreign IE dialect after Pedersen's law $(s \geq x$ after $i, u, r, k$ ) ceased to operate in Slavic and the cluster $k s$ (from $g$-s) was simplified into $s$; and second, that the front vocalism $i$, i.e., earlier Proto-Slavic ${ }^{*} \bar{i}$, must have come from an IE dialect where ${ }^{*} \bar{e} \geq \bar{i}$ (as, e.g., in Celtic, cf. Lat. $r e \bar{x}=$ Celt. $r \bar{x}$ ).

So for Proto-Slavic tisъ we can posit a foreign *tikso- (etymologically

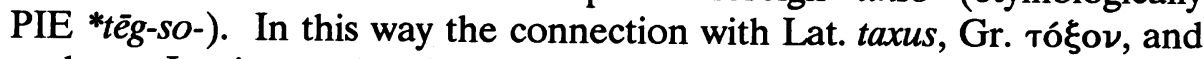
perhaps Iranian taxša- is preserved, and the long vocalism of the hypothetical *tēkso- probably represents a vrddhi formation (a primary denominal adjective with the lengthening of the initial (root) vocalism of the base). We do not even have to assume a hypothetical dialectal IE *tiksso- from PIE *tēg-so-; a foreign long closed $e^{-20}$ was regularly replaced by Proto-Slavic $i$ in connection with the monophthongization of the primary diphthongs in Slavic according to the process: $e i$ (or rather $æ i) \geq$ ${ }^{*} \bar{e} \geq \bar{i}$, parallel to ${ }^{*} o u$ (or rather $\partial u$ ) $\geq \bar{Q} \geq \bar{u}$. This would indicate that the borrowing of *tēkso- (tệkso-) took place in Proto-Slavic at the time of the monophthongization of diphthongs (starting about 400 A.D.?), i.e., relatively late; in other words, roughly at the same time as the borrowing of the Germanic *bóko ( $\geq b u k y$, etc.). But this word must have been borrowed from another West IE dialect (and specifically from a North-West IE dialect, because of the Latin vocalism $a$ in taxus, borrowed most probably from the Alpine region). This might be Illyrian, a kentum North-West IE dialect, which in prehistoric times undoubtedly reached to the north Carpathian regions (see the hydronyms!). Furthermore, the word *tékso-, which if compared with *tokso- (reconstructed on the basis

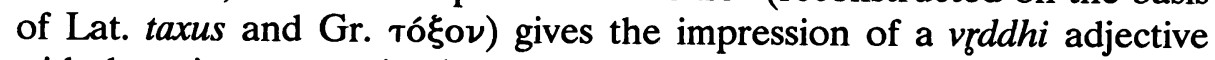
with the primary meaning 'pertaining to the yew', could have been used in barter trade to denote yew twigs that the Proto-Slavs bought from their western and southwestern (Venetic, Illyrian?) neighbors. Even as late as the sixeenth century there was extensive yew trade between the Alpine and Carpathian countries and the Netherlands and England, through Gdańsk-Danzig, i.e., through Poland (see Moszyński, loc. cit., 50). 
The two remaining names of trees with a clear western range are *čeřa // *čeršbn'a 'cherry tree (wild?), Prunus avium' and *berka // *berkъ // *berkyn'i 'sorb-tree, Sorbus torminalis'. Both of them are of foreign origin: the former was borrowed from VLat. ceresia, either directly or through the intermediary of OBavar. *chersia, chersse (Vasmer, IV, 343); and the latter is probably of Germanic origin (according to Moszyński, loc. cit., 53-56), namely from *berko-, *berkünja- 'birch', where the semantic shift 'birch' > 'Sorbus torminalis' is justified by the similarity of the bark of these two trees (for details, see Moszyński, loc. cit.). Illustrative material: Serb. Church Slavonic črěšnja, Bulg. čereša, Mac. creša, Cz. třešně, Pol. trześnia, Russ. čeréšnja, etc.; Sloven. bréka, Russ. berëka, etc.; S-C brêk, Sloven. brêk, Cz. břek 'Pirus torminalis' // dial. brakak 'Sorbus torminalis', LLus. brok, Pol. brzęk (with secondary nasalization); the forms continuing *berkyn' $i$ are attested only in South Slavic and Czecho-Slovak, e.g., S-C brèkinja, Bulg. brékina, brekínja 'Pirus torminalis,' Sloven. brekinja 'Sorbus aria', Cz. brekyně 'a fruit of Pirus torminalis', Slovak brekyña, etc. (for details about the names of the latter tree see also Trubačev, 1974, ÉSSJa, I, 194-195). For a foreign (Germanic) origin of the Slavic name *berka, *berkyn'i, apart from formal reasons (that is, if we accept Moszyński's hypothesis), the very restricted western distribution of the tree seems decisive. On the map from Moszyński's book, it does not cross east of the Lower Vistula and the Upper Warta, and concentrates in the sub-Carpathian regions, including Podolia (northeast of the eastern Carpathians).

The above facts, which consist of a combination of linguistic data (foreign origin of six tree-names) and of the distinct western range of the corresponding trees, bear significantly on the whole problem of the primary habitat of the Slavs. They do not allow us to locate it in the Vistula and Odra basins, as has been attempted by Lehr-Spławiński (and the followers of the so-called "western hypothesis" about the primary habitat of the Slavs). However, before I present a synthetic map showing the primary habitat of the Slavs and their prehistorical migrations, I will first analyze the oldest historical data about the Slavs, first of all about the ethnica which refer to them and their geographical location.

As we know, the first ancient author who gave a reliable description of the lands north of the Black Sea (Scythia and its adjacent regions) was Herodotus, a Greek from Halicarnassus (ca. 480 - ca. 425 B.C.). In his nine-volume History he presented the events of the Persian wars against a broad background of Greek and Near Eastern conditions at that time. In Volume IV the campaign of the Persian king Darius I against the Pontic Scythians in the year 514 B.C. is narrated. On this occasion the author gives quite a detailed geographic and ethnographic description of Scythia 
and of the adjacent regions. Among the tribes dwelling north of Scythia proper and allied with the Scythians there are two which could belong to the Proto-Slavs with a great degree of probability: Nevpoi and Bovঠivou.

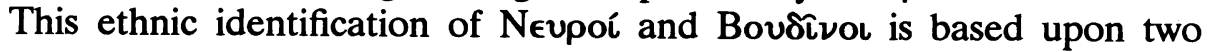
arguments: their geographical location (against the background of the later early historical expansion of the Slavs), and the etymology of the ethnica themselves. But let us first quote the pertinent loci in Herodotus' book:

"Above the trading-port of the Borysthenites, which is situated in the very center of the whole seacoast of Scythia, the first people who inhabit the land are the Callippidae, a Graeco-Scythic race. Next to them, as you go inland, dwell the people called the Alazonians. These two nations in other respects resemble the Scythians in their usages, but sow and eat corn, also onions, garlic, lentils, and millet. Beyond the Alazonians reside Scythians, cultivators who grow corn, not for their own use, but for sale. Still higher up are the Neuri. Northwards of the Neuri the continent, as far as it is known to us, is uninhabited. These are the nations along the course of the river Hypanis, west of the Borysthenes."

(Herodotus, Persian Wars, Book IV, 17)

"When one crosses the Tanais, one is no longer in Scythia; the first region on crossing is that of Sauromatae, who, beginning at the upper end of Lake Maeotis, stretch northward a distance of fifteen days' journey, inhabiting a country which is entirely bare of trees, whether wild or cultivated. Above them, possessing the second region dwell the Budini, whose territory is thickly wooded with trees of every kind."

(Herodotus, ibid., 21)

“... As for the inland boundaries of Scythia, if we start from the Ister, we find it enclosed by the following tribes, first the Agathyrsi, next the Neuri, then the Man-eaters, and last of all, the Blackcloaks."

(Herodotus, ibid., 100)

"The Neurian customs are like the Scythian. One generation before the attack of Darius they were driven from their land by a huge multitude of serpents which invaded them. Of these some were produced in their own country, while others, and those by far the greater number, came in from the deserts on the north. Suffering grievously beneath this scourge, they quitte their homes, and took refuge with 
the Budini..."

(Herodotus, ibid., 105)

"The Budini are a large and powerful nation. They have all deep blue eyes, and bright red hair. There is a city in their territory, called Gelonus, which is surrounded with a lofty wall, four miles each way, built entirely of wood. All the houses in the place and all the temples are of the same material. Here are temples built in honour of the Grecian gods, and adorned after the Greek fashion with images, altars, and shrines, all in wood. There is even a festival, held every third year, in honour of Dionysus, at which the natives fall into a Bacchic fury. For the fact is that the Geloni were anciently Greeks, who, being driven out of the trading-ports along the coast, fled to the Budini and took up their abode with them. They still speak a language half Greek, half Scythian."

(Herodotus, ibid., 108)

"The Budini, however, do not speak the same language as the Geloni, nor is their mode of life the same. They are the aboriginal people of the country, and are nomads; unlike any of the neighbouring races, they eat lice. [Photius defines the same word as fir-cone. - ZG] The Geloni, on the contrary, are tillers of the soil, eat bread, have gardens, and both in shape and complexion are quite different from the Budini..."

(Herodotus, ibid., 109)

"As long as the march of the Persian army lay through the countries of the Scythians and Sauromatae, there was nothing which they could damage, the land being waste and barren; but on entering the territories of the Budini, they came upon the wooden fortress above mentioned, which was deserted by its inhabitants and left quite empty of everything. This place they burnt to the ground; and having so done, again pressed forward on the track of retreating Scythians, till, having passed through the entire country of the Budini, they reached the desert, which has no inhabitants, and extends a distance of seven days' journey above the Budinian territory. Beyond this desert dwell the Thyssagetae, out of whose land four great streams flow. These rivers all traverse the country of the Maeotians, and fall into Lake Maeotis. Their names are the Lycus, the Oarus, the Tanais, and the Syrgis." 
Herodotus is cited according to the English translation by $\mathrm{G}$. Rawlinson, New York, Random House, 1942).

Many scholars have devoted effort and ingenuity to interpreting Herodotus' work, especially as far as the geographical location of these two tribes is concerned. After seventy-five years of discussion and contributions, I think that the presentation by L. Niederle is still the best, i.e., on the one hand faithful to Herodotus' text, yet on the other realistic in terms of geography and our historical knowledge of the ethnographic situation of the region in later times. Of course, Niederle's map (see Slovanské starožitnosti, 2nd ed., 1925. I, 2, 272-73) requires some slight corrections, particularly with regard to the far northwestern reach of the Nevpoí, which is not justified by Herodotus' text, but rather is suggested by a false etymology of the ethnicon (see below). Also, the location of the Bousivou seems to be pushed too far towards the middle Dniepr, which led the author to a hypothesis that the intriguing wooden city in the country of the Bousivou - Гє $\lambda \omega \nu$ ós - could be identified with the site of early historical Kiev. I include on page 307 a corrected version of Niederle's map. But on the other hand the interpretations (e.g., those by Moszyński, 1957, 100-102, and H. Łowmiański, 1963, I, 119-122) which shift the Bouøivo far to the east between the Upper Don and the Middle Volga neglect Herodotus' own text, which states clearly that

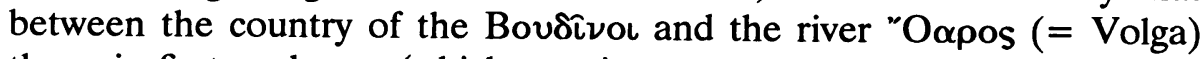
there is first a desert (which requires a seven days march), then the

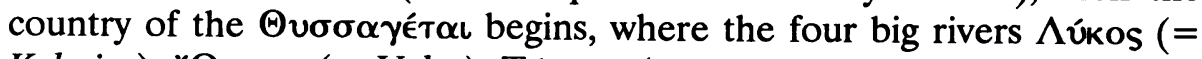

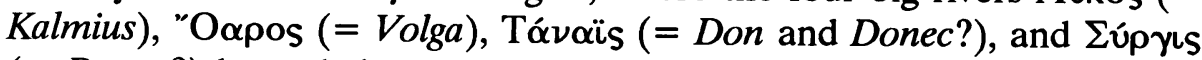
(= Donec?) have their sources. So the habitat of the Bousivou did not

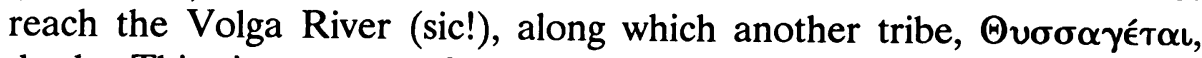

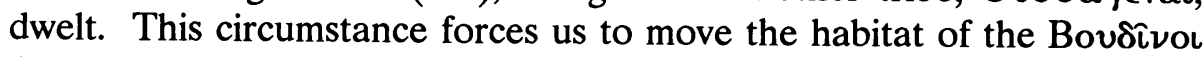
(probably quite a large area, as the tribe is presented as nomadic hunters living in the forest) farther to west with the center probably between the Upper Don and the Upper Donec, and because on this northern latitude there is no other tribe between the Nevpoi, dwelling west of the Middle Dniepr, and the Bousivo in Herodotus' description, we can imagine that the hunting ranges of the latter might extend as far west as the Lower Desna (along the Sejm River?); all the more so in that according to a strange tradition transmitted by Herodotus the Neupoi (or rather some part of them) about the middle of the sixth century B.C. left their country and moved to the area of the Bousivou, with whom or among whom they settled. ${ }^{21}$

All these facts based upon the testimony of Herodotus would suggest that the Neupoi and Bousivou were the northernmost non-Scythian tribes known to the Pontic Greeks in the first part of the fifth century 
B.C. as immediate neighbors of the Iranian Scythians and Sarmatians, and especially closely related to each other (witness the peaceful settlement of the Neupoi among the Bousivoo). In view of this, I cannot agree with Moszyński and Łowmiański, who are inclined to treat the Bousivou as a Volga Finnic tribe. They give rather the impression of the easternmost part of the Proto-Slavs. This hypothesis is supported by two arguments: the Slavic origin of some hydronyms on the left bank of the Middle Dniepr (in the Sejm basin), ${ }^{22}$ and the etymology of the ethnicon

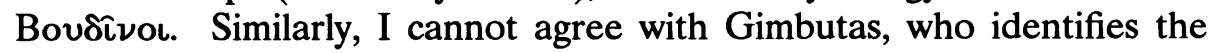
Nevpoi with the prehistorical Eastern Balts (see M. Gimbutas, 1971, 42, and also earlier in her book The Balts, 1963, 97-102). This identification does not have support either in Herodotus' text - according to which the Nevpoi are located in the Upper Boh basin (i.e., historical Volynia and, undoubtedly, its adjacent regions, most probably extending east to the Middle Dniepr and west to the Upper Dniestr) - or in the hydronymy of the right bank Ukraine which, as we have seen, shows only insignificant Baltic elements, whereas Slavic names (among them some very archaic ones) prevail there. Furthermore, the very ethnicon Nevpoí, as we shall soon see, has quite a convincing Slavic etymology.

Now I will turn to the etymology of these two ethnica, Neupoi and

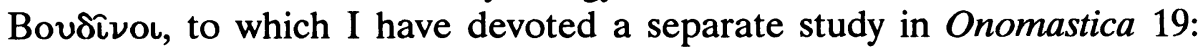
1974. For a detailed linguistic analysis of the problem, see that article. Here I will only present a summary of my etymological considerations and emphasize the most significant points.

First, we must establish the correct phonemic form of the ethnica as they sounded at the time of Herodotus (approx. the middle of the fifth century B.C.). All scholars who have had occasion to discuss the etymology of Neupoi have taken for granted the form attested by Herodotus, although in later documents, e.g., in Ammianus Marcellinus (fourth century A.D.) we find the form Nervi(i), which may reflect another tradition (possibly transmitted by the Dacians?). In any case there is no compelling reason to consider the form /Neur-oi/ - the phonemicization of the Greek spelling - as the primary one. But this was precisely the practice of all etymologists (except for Moszyński, who reconstructs *Sneuroi, from the verbal root *sneu- cf. Slavic snovq, snuti, etc. 'bind'; see Moszyński, 1957, 98-99), and it led them simply to a Wurzeletymologie, identifying the alleged root of Neur-oi with the Slavic verbal root nur- $\left({ }^{*}\right.$ nour-). This root occurs in the verb *nuriti, e.g., OCS iznuriti 'rauben, erbeuten', a secondary meaning that stems from the primary 'emerge, make emerge', Russ. (po)núrit', (po)núrju 'lower', Pol. (za)nurzyć 'immerse', etc. (see Vasmer, III: 90), and in the hydronyms of the *Nurb, *Nurbcb type, which seem to be concentrated in the Bug basin, 
e.g., Pol. Nur // Nurzec, Ukr. Nureć 'a right tributary of the Lower Bug', etc. (for details, see Lehr-Spławiński, loc. cit., 13). This last fact forced L. Niederle to extend the territory of the Nevpoi from the Upper Boh basin northwest to the Lower Bug basin (crossing the latter river; see the map in Starožitnosti..., I, 2, 272). Of course, the northwest extension of the Neupoi was suggested by the etymology, which interpreted this ethnicon as derived from hydronyms containing the root nur-. It is strange that the linguists maintained this etymology even though apart from the root connection it is deprived of any morphological justification: ethnica derived from hydronyms, as, e.g., ORuss. Bužane from Bug, Poločane from Polota, Pol. Wislanie from Wista, etc., must show a derivational suffix (in these cases -ěn/-jan), etc. Thus the etymology of Nevpoi as a dehydronymic ethnicon from Nurs, etc., should be rejected. It is also improbable in the light of the historical tradition and ethnographic information recorded by Herodotus, who clearly states that about the middle of the sixth century B.C. the Nevpoi migrated from their (old?) country to the territory of the Bousinou (which can be interpreted in two different ways), and that they have Scythian customs, probably a nomadic way of life. They are presented as a mobile (migratory) tribe, and such people cannot take their names from toponyms: detoponymic ethnica seem to characterize sedentary, agricultural peoples whose social life is based upon territorial ties.

Therefore I venture another etymology of Nevpoi which, as we will see, fits better into the general framework of linguistic and sociological facts. As I said above, we must start from a correctly established or rather reconstructed phonemic form of the ethnicon, which in my opinion is *Neru-oi. In connection with regular changes in their phonemic system,

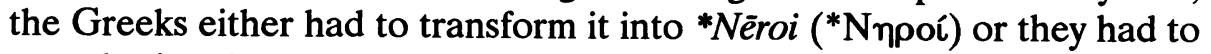
metathesize the cluster -ru-in order to preserve it - hence the attested Neur-oi (Nevp-oí). So I start from the reconstructed primary form ${ }^{*} N e r u o i,{ }^{23}$ which opens up very interesting and convincing etymological possibilities. Namely, it can be interpreted as derived from the PIE noun *néru- // nóru- 'vital force, etc.', itself representing an $u$-extension of *ner(according to Pokorny, 765) 1.'(magische) Lebenskraft', 2. 'Mann'; in the second meaning it is continued, for example, by Greek $\dot{\alpha} \nu \eta \hat{\rho}$ ( $\dot{\alpha}-$ is secondary!), OI nár- (nom. nā, etc.), Alb. njer, etc.; Lith. nóras 'will', norěti 'want' also belong here (for more details, see my article quoted above). The relationship between *Neruo- (the underlying stem of our ethnicon) and the posited néru- would be the same as that between Slav. *dervo 'tree' and PIE *déru-; it also should be mentioned that traces of the posited variant *nóru- can be found only in PSl. *norvz (e.g., OCS nravz 'Sitte', Russ. nórov idem, etc.), whose primary meaning seems to have 
been 'inborn strength, stubbornness', etc. (cf. the Russ. denominal verb norovit' 'to strive stubbornly'). In view of the above facts we can interpret ${ }^{*}$ Neruoi ( $\geq$ Late PSl. ${ }^{*}$ Nervi) as a substantivized adjective derived from an extended stem *neru- with the meaning 'strong (i.e., mature) male person, man', ultimately the same as the radical nouns $\dot{\alpha} \nu \eta \dot{\rho}$, nar-, njer quoted above.

Now, as far as the semantics of this etymology is concerned, it seems to be quite trivial: comparative anthropology provides us with numerous examples of ethnica which mean simply 'tribesmen, clansmen' or 'people', e.g., Ala-manni, Bantu, Hopi, Na-Dene, etc. (see E. Benveniste, 1969, I, 371). In my opinion they belong to the oldest endogenous stratum of ethnica in most languages. So we could consider *Neruoi (Late PSl. *Nervi) to be the oldest attested endogenous Slavic ethnicon used by a large Proto-Slavic tribe concentrated in the sixth-fifth centuries B.C. along the northwestern frontier of Scythia, which corresponds roughly to the historical East Slavic province of Volynia. I emphasize a large Proto-Slavic tribe because we have at least one more tribe in Herodotus' description of Scythia which for geographic and linguistic reasons can

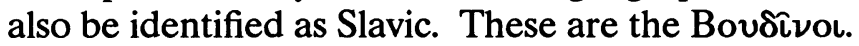

Here again we should start from the correctly reconstructed phonemic form of the ethnicon. The Greek Bousivvo of the fifth century B.C., i.e., phonemically $\mid B \bar{d}$ dinoi/ can reflect a foreign word, in this case the hypothetical Early Proto-Slavic *Büdin-(oi) (-oi is the Greek desinence of the nom. plur. masc.), which in Late Proto-Slavic and in early historical Slavic would sound like *Bydini. As we see, the reconstruction Budini, commonly accepted by linguists and historians (see recently Stownik starożytności stowiańskich, 1961, I, 188), which suggests a connection with the Slavic verbal root bud- (e.g., in buditi 'wake up' trans., and in many anthroponyms of the type Budimirb, Budislavz, Budivojb), is not phonemically justified if we remember that Proto-Slavic should be conceived of dynamically as a prehistorical epoch in the development of Slavic, during which several stages can be distinguished. Among these stages at least Early Proto-Slavic, before the monophthongization of diphthongs, and Late Proto-Slavic, after the monophthongization, are clearly separated from each other. There is no question that the epoch of Herodotus corresponds to the Early Proto-Slavic stage, when the primary $|\bar{u}|$, later $|y|$, was opposed to the primary $\mid o u /$ (rather $\mid o u$ ), later $\mid u /$; thus

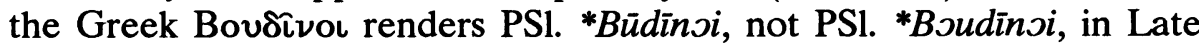
PSl. terms, *Bydini, not ${ }^{*} B u d i n i{ }^{24}$ This simple phonemic interpretation of the Greek graphic form Bousîno has somehow escaped the attention of linguists who even recently have regarded Proto-Slavic as a chronologically uniform entity. 
It is understandable that the reconstructed form *Bydini (in a conventional Late Proto-Slavic phonemicization) opens completely different etymological horizons than does ${ }^{*} B u d i n i .^{25}$ In order to condense my presentation (the details of which the interested reader can check in my article quoted above), I will give only the conclusions. I interpret the basic Slavic stem *Bydin-, upon which the Greek plural is formed, as a singulative with the suffix -in-from a collective noun of the *bydb/da/do type (for this type of derivation cf. ORuss. Rusb $>$ Rusinz, Litъva > Litъvinъ, OCS ljudъ // ljudıje > ljudinъ, čeljadı > čeljadinъ, etc.). Now, can we reconstruct a PSI. noun *budb/da/do as a collective with the suffixes $-d b,-d a,-d o$ ? Slavic material suggests such a possibility, e.g., čę-ti 'conceive' > čę-db 'children > people' (or čędo 'child' > čędb); svobo-da ( ${ }^{*} s v o b z$ 'clansman, free person'); sta-ti > sta-do 'herd of horses', etc. So *bydb, etc., if derived from byti (and this is the only etymological possibility in Slavic) would mean 'a collective of grown (human) beings > clan, tribe', etc., since byti (PIE *bheuH-// *bhuH-) has the basic meaning 'grow' (i.e., dynamic existence). For this derivation of the name of a human tribal collective from the verb meaning 'grow' we find several obvious parallels in the IE languages, e.g., Greek $\phi \bar{u} \lambda \eta$ 'tribe', from $\phi v$ u $\mu \alpha$ 'grow, spring up' (here even the root is etymologically the same as in the posited PSl. *bydb); Slavic ljudz 'people' from *leudho (cf. Goth. liudan 'grow'); Slavic narods 'people, nation' from na-roditi 'give birth', which etymologically represents PIE *uerdh- // uredh- (cf. OI várdhate) 'grow', etc. So nothing seems to prohibit our etymology: *by-ti 'grow' > *by-db ( // byda // bydo) 'growth' > 'tribe' > *byd-ins 'tribesman', and the latter is transformed into a proper name ${ }^{*}$ Bydins as a result of the popular self-identification of the tribesmen in the presence of foreigners. ${ }^{26}$ It should be added that the reconstructed Early PSI. *Büdin- could also be Baltic, because only in Lithuanian is there a noun büdas (= PSl. *bydo) derived from büti (= PSl. byti), meaning 'Art und Weise, Gewohnheit, Charakter' (see Fraenkel, I, 68), which can easily be derived from a primary meaning 'nature'. But the derivation of

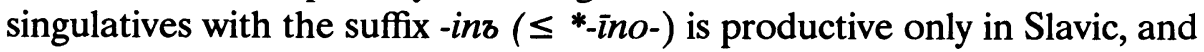
this plus the geographical location of Herodotus' Bovoivor indicate rather that the tribe was ethnically Slavic. ${ }^{27}$

The third probably Proto-Slavic ethnicon recorded in the ancient Roman and Greek sources is Veneti, which we have already discussed. Now we should check the precise geographical location of those people, who, as we have seen, can be identified with the early Proto-Slavs as a whole (I remind the reader of the identification of the Veneti with the Slavs made expressively by Jordanis in the sixth century A.D.). The first ancient author to mention the Veneti (in the germanized form Vened-i/ae) 
was Pliny (the Elder), a Roman naturalist and geographer who died in 79 A.D. In his Historia naturalis, probably based upon earlier information from Agrippa and Mela that dated from the years around the birth of Christ (12 B.C.-5 A.D.), the following ethnographic situation in the Lower Vistula basin is presented (specifically between the Lower Odra and the Lower Vistula; see a recent convincing interpretation by $\mathrm{H}$. Łowmiański, I, 152-160, especially the map on p. 153).

After describing the coast of southern Scandinavia and of Jutland, with their adjacent islands and Germanic inhabitants, moving gradually eastward (following popular ancient maritime itineraries, the so-called $\pi \epsilon \rho i \pi \lambda o \iota)$ Pliny states: "And Aeningia ${ }^{28}$ [= Pomorania (?) - ZG] is allegedly not smaller. Some people report that it is inhabited as far as the Vistula River by the Sarmatian ${ }^{29}$ Venedi, Sciri, Hirri" (Pliny, IV, 96). As we see, the Veneti, with the qualification "Sarmatian" (Latin Sarmatae Venedi is quite a frequent double ethnicon in the ancient authors), dwelt west of the Lower Vistula before the Germanic Sciri and unidentified Hirri, which means that viewed from the west (from the Lower Odra region), they must have occupied Pomorania. The Sciri were probably the last remnant of the people who migrated to the Pontic region (Olbia) in the third century B.C. At the beginning of the first century A.D. they still dwelt at the mouth of the Vistula, the notorious first step of most prehistorical migrations from Scandinavia to the Black Sea coast (but cf. Czarnecki's hypothesis about the Goths discussed in Chapter VI).

The next ancient author who not only mentions the Slavic Veneti but also gives a brief ethnographic description of them is Tacitus (ca. 55-ca. 120 A.D.). In his famous work De origine et situ Germanorum (popularly called Germania), published in 98 A.D., speaking about the eastern borderlands of Germania, which in his opinion extended as far as the Vistula River, he clearly states: "Here ends Svebia. I am not sure whether the tribes of Peucini, Veneti, and Fenni should be assigned to the Teutons or to the Sarmatians.... The Veneti have accepted many of their [the Sarmatians'] customs: for whatever woods and mountains there are between the Peucini and Fenni, they roam them in their plundering raids. But they belong rather to the Teutons because they build permanent houses, bear shields, and like fast marching, all of which is different with the Sarmatians, who live on wagons and horses" (Tacitus, Germ., 46, quoted after Niederle I, 1, 187).

From this quotation we can locate the Slavic Veneti east of the Vistula River between the Germanic Peucini (= Bastarnae), who dwelt somewhere along the eastern Carpathians as far as the Lower Danube, and the Fenni (= Finnic tribes), who undoubtedly dwelt in the East Baltic and Upper Volga region. Of course, the easternmost range of the Slavic 
Veneti is not specified; nor is there any mention of their northern neighbors, the Balts, who separated them from the Finns, because Tacitus did not have sufficient information about these questions. Furthermore, the radical statement that Svebia (= eastern Germania) ends on the Vistula River is a generalization based upon information provided by Teutonic informants from the so-called "amber trail" who, impressed by the recent expansion of the east Germanic tribes between the Odra and the Vistula rivers, neglected the fact that the basic mass of the Slavic Veneti had remained in the big bend of the Vistula, i.e., in the territory of presentday central Poland. Some earlier sources seem to prove explicitly that this was the case. Pomponius Mela, a Roman geographer, wrote De chorographia about 44 A.D., which, although mediocre in its informative content, nevertheless gives us for the first time concrete data about the Baltic Sea (based upon information provided by a Roman maritime expedition of 5 A.D.). In this work the Vistula River is explicitly treated as the boundary between Sarmatia and Asia (sic!), and there is no mention of the Germanic tribes of the left, western bank of this river. As we know, at this time Sarmatae and Sarmatia were popular Roman terms that denoted not only the Iranian Sarmatians per se, e.g., those on the Lower Danube, but all the Central and East European non-Germanic tribes who dwelt east of the Teutons: "Sarmatia extends to the interior, being there wider than at the sea and separated from what follows by the Vistula River, and there it extends back as far as the Hister [Danube] River" (Mela III, 33, quoted after H. Łowmiański, I, 142).

In this brief description of European Sarmatia, which in the context of other sources should be identified with the country of the Slavic Veneti, there is a characteristic piece of information - that this country is wider in its interior, i.e., south and east, than at the Baltic coast. This information corresponds to the real geographical situation of the Venetic habitat, which hardly included any regions east of the Lower Vistula (i.e., East Prussia), inhabited by the Baltic tribes at that time. Pliny also locates the Veneti on the left, western bank of the Vistula. But by the time of Tacitus several East Germanic tribes, expanding to the southeast from Jutland and southern Scandinavia, who were undoubtedly attracted by the economic advantages of the old amber-trade route, had managed to settle along this route, between the Sudeten and the Moravian Gate on the one hand, and the estuary of the Vistula on the other. These were: Harii, Helveconae, Manimi, Helisii, Naharvali in order from north to south (all of them forming the federation (?) of Lugii, probably originally a powerful Celtic tribe; see Lowmiański I, 226-36); then "behind the Lugii the Gotones reign.... further up at the Ocean [= the Baltic Sea] the Rugii and Lemovii” (Tacitus, 43, after Łowmiański I, 221). 
If we project this list of the Germanic tribes on the map of present-day Poland we obtain the following picture (see map on page 308).

The main bulk of the Slavic Veneti was obviously concentrated in the Central Vistula basin and east of it, in the Central Dniepr basin (cf. in the above quotation from Tacitus, that the Veneti roam as robbers between the Peucini in the south and the Fenni in the north).

Among the Germanic tribes on the amber-trade route there is an ethnicon which seems to be connected etymologically with a historical Polish toponym: Helisii, which probably corresponds to the toponym K $\alpha \lambda \iota \sigma i \alpha$ on Ptolemy's map, which in its turn is represented by Pol. Kalisz (*Kalǐ̌b), an old city on the Prosna River, a left tributary of the Warta River in western Poland. Lehr-Spławiński ( $O$ pochodzeniu $i$ praojczyźnie...., 142-43) considers this toponym to be originally Slavic (from the nominal root kal- 'mud' + the suffix -ǐš, the latter allegedly popular in place-names, e.g., Brodzisz, Stępisz, Miękisz, etc.). But if we accept that the Germanic ethnicon Helisii reflects a germanized (with Lautverschiebung) form of an earlier non-Germanic (Celtic?) ethnicon ( ${ }^{*}$ Kĕ/ŏlis- ?), then the Polish toponym Kalisz could be a possessive adjective derived from that earlier non-Slavic ethnicon, according to the pattern: *Kölīs- + jo- $\geq$ Kališs (cf. the possessive toponyms derived from ethnica with the same suffix like Niemcy > Niemcza, a town in Silesia; Siling- $i>$ Ślęża, a river in Silesia, about which see below, etc.). We should remember that Kalisz was an important settlement on the amber-trade route, and during the domination of the Celtic Lugii north of the Sudeten some Celtic groups (garrisons ?) may have controlled such places. ${ }^{30}$ But cf. a better interpretation on page 302 .

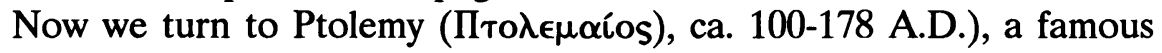
Greek geographer of Alexandria whose encyclopedic work An Outline of

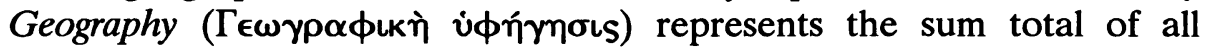
ancient scholarship in that field. It is important to note that Ptolemy did not collect new information himself by travelling to some countries as, for example, Herodotus did, but rather he gathered and summarized written sources, first of all the work of Marinos of Tyros (first half of the 2nd cent. A.D.). The most valuable feature of his Geography is that he locates precisely - according to the knowledge of the time - all places in terms of longitude and latitude. What interests us in Ptolemy's work is his description of European Sarmatia, i.e., the whole eastern part of the Euopean continent between the Vistula and the Don (Tanais) rivers, and the corresponding map. He places significantly more ethnica in this region than earlier authors. But their location requires careful analysis, and the fact that the author, who used various sources, very often repeats the same ethnicon twice in its variants complicates the task of 
interpretation. ${ }^{31}$ In the following paragraph I will base my discussion on a recent excellent historical-geographical analysis of Ptolemy's description by H. Łowmiański (loc. cit., I, 166-80).

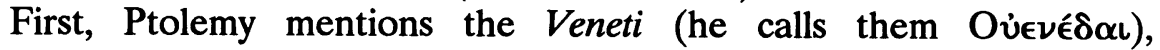
classifying them as one of the "huge" peoples dwelling in European Sarmatia: "Huge peoples inhabit Sarmatia: the Venedae along the whole Venedian Bay, above Dacia the Peucini and Basternae, along the whole coast of Maeotis [ = the Sea of Azov] the Iazyges and Roxolani, and in the midst of them the Hamaxobii and the Alani Scythae" (Geogr. III, 5, 7, quoted after L. Niederle, Slov. starožit., I, 1, 187). All the above peoples are also marked with large letters on the corresponding map (see Niederle's reproduction, loc. cit., I, 2, 276-77). There is, however, an inconsistency between Ptolemy's statement that the Veneti are "é $\theta \nu$ os

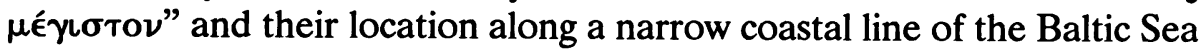
east of the Vistula (sic!), above the Gythones ( $\Gamma \dot{v} \theta \omega \nu \in \mathrm{S}=$ Goths), the Galindae $(\Gamma \alpha \lambda i \nu \delta \alpha \iota=$ Prussian Galindai, cf. medieval Galindia), and the

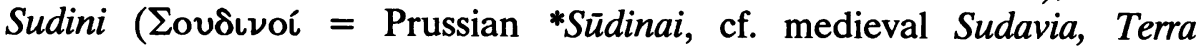
Sudorum). This inconsistency could stem from an old tradition about a large tribe of Veneti in the Vistula basin (cf. Tacitus), or from some maritime itineraria interested only in information concerning the coastal regions. Then the shift of the Veneti to the east of the Lower Vistula may reflect some demographic shifts caused by the Gothic invasion, or rather a geographic mistake by Ptolemy, who mistook the Baltic coastal line for the Vistula River. In any event, we cannot overlook this strange contradiction in Ptolemy's work.

But the Slavs also appear under another name in Ptolemy, this time under their own (endogenous) name, which represents the oldest attested form underlying the well known historical form (OCS) Sloverne, Hellenized into $\Sigma \theta \lambda \alpha \beta \eta \nu o$ or Latinized into Sclaveni. Actually, in the Geographia we find two quite different graphic variants of this ethnicon in two different spots. First, in the list of the nomadic Scythian tribes between the Volga ('P $\hat{\alpha}$ ) and the Ural mountains ("I $\mu \alpha o \nu$ öpos)

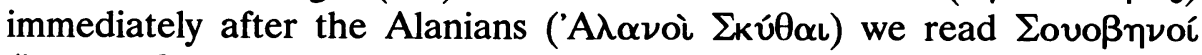
(i.e., Suobenoi) (Geographia, VI, 14, 9); and second, in the list of the sedentary tribes between the Baltic Sea and the Black Sea we read $\Sigma \tau \alpha v \alpha \nu o$ i.e., Stauanoi or Latinized Stavani) located in the following

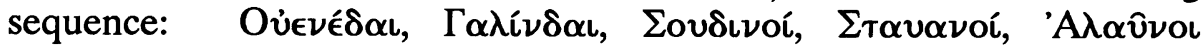
(Geographia, III, 5, 21). In spite of the fact that these two ethnica are located quite remote from each other there seems to be little doubt that they refer to the same Slavic ethnos. We can also admit that Ptolemy made a mistake, citing the same ethnicon in its two variants in different places in his book. But I think that in this case no such correction is 
necessary. We can easily imagine that some East Proto-Slavic tribes, or one particular tribe, in a close alliance with the nomadic and belligerent Alanians or under their hegemony accepted their life-style and got involved in their migrations (in this case east of the Volga River). Such facts are known from history and ethnology and should not surprise us. As a parallel, we might recall the participation of the Old Russian contingents in the Tartar war-raids. So we can accept the possibility of a Proto-Slavic tribe's having ventured far eastward beyond the Volga River and having left their original ethnic name, recorded by the Pontic Greeks

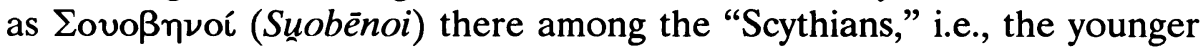
wave of the Iranians known in history as Sarmatians. As far as the location of $\Sigma \tau \alpha v \alpha \nu o$ is concerned, it seems to fit very well the location of the early historical Eastern Slavs, the Antes (fourth-sixth centuries A.D.) of Jordanis, about whom see below. This identification simply stems from the fact that the $\Sigma \tau \alpha v \alpha \nu$ o i are mentioned after the undoubtedly Baltic

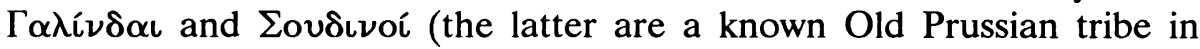
East Prussia), and from the hydronymic evidence, which indicates the old Baltic character of the regions north of the Prypec River. The above circumstance and the clear statement by Ptolemy that the $\Sigma \tau \alpha v \alpha \nu$ oi extend " $\mu \epsilon \operatorname{\chi x} \rho \iota \omega \nu$ 'A $\lambda \alpha v \nu \hat{\omega} \nu$ " 'up to the Alanians', whom we know to have been concentrated on the steppes of Azov, allow us to accept the Middle Dniepr basin as the habitat of the $\Sigma \tau \alpha v \alpha \nu o$. It is worth emphasizing that we are again speaking of roughly the same area where we have located Herodotus' Nevpoí $\left(={ }^{*} N e r v i\right)$ and at least a part of his

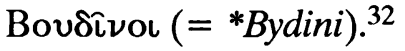

Now the question arises whether we can connect the above Greek forms, which undoubtedly refer to the Slavs, and explain them as reflecting two PSl. variants of the ethnicon known historically as Sloverne. P.J. Šafařı has already proposed this connection, interpreting $\Sigma \tau \alpha u \alpha \nu o$ í as corrupted from ${ }^{*} \Sigma \tau \lambda \alpha v \alpha \nu$ oi (or ${ }^{*} \Sigma \theta \lambda \alpha v \alpha \nu o$ ), which shows the regular Greek insertion of $\tau$ or later $\theta$ in the Slavic initial cluster $s l$-: thus $\Sigma \tau(\lambda) \alpha v \alpha \nu$ oi would reflect PSl. Slověne. This interpretation is convincing and cannot be objected to from a purely linguistic standpoint, especially now that we are aware that the primary PSI. phonemic system without the distinctions $o: a$ and $e: \check{e}$ compels us to reconstruct the prehistorical *Sloūenæ for the historical Slověne. In this form the back low / / was perceived by the Greeks as $\alpha$, and similarly the front low /æ/ also as $\alpha$, since the Greek language did not have corresponding vowels. Note the later regular rendering of the Slavic Slověne by Greek $\Sigma \theta \lambda \alpha \beta \eta \nu o i$, where

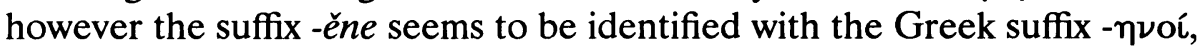
known in detoponymic ethnica such as Пep $\gamma \alpha \mu \eta \nu o$, etc.

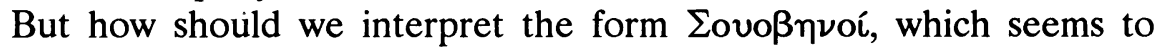


reflect PSI. *Svoběne (or early PSI. *Susbǣnæ)? In my opinion this form, which is attested outside of the compact area of the prehistorical Slavs as the name of a Slavic tribe surrounded by the Iranians, has preserved its primary, etymologically quite transparent character, which frequently occurs on the ethnic peripheries, and should be taken into serious consideration in any attempt to etymologize the historical ethnicon

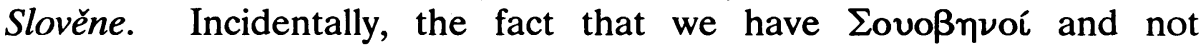
* ov $\alpha \beta \alpha \nu o$, which would better render early PSl. *Susbǣnæ, can be explained first through the labialized articulation of the vowel $/ \mathrm{J} /$ conditioned by the preceding $/ u /$, and then through the substitution of the

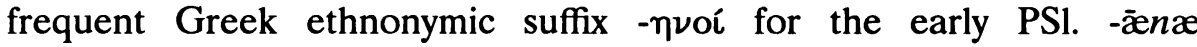
(historical -ěne).

Now we can attempt to etymologize the ethnicon *Svoběne and explain its secondary, historical form *Slověne. I propose to derive it from the early PSl. adjective $s \mathrm{obz}^{33}$. This adjective underlies PSI. svobodà (and dissimilated slobodà) 'freedom' and OCS svobbstvo 'persona.' Compare Russ. svobóda 'freedom', but slobodá 'free settlement', i.e., 'a settlement of free peasants'; OCS svoboda 'freedom'; S-C slobòda idem, Pol. swoboda idem, etc. It is worth noticing that a variant with the vocalism $e$ is also attested, e.g., OPol. świeboda and dial. śleboda, which indicates that the underlying adjective can be reconstructed in two forms: *svebs // *svobs.

The question is what the meaning of this adjective was. The only hint we have in Slavic is the meaning of svob-bstvo 'persona', i.e., 'oneself'. So we can hypothesize that *svobs // svebs meant 'one's own'. This meaning seems to be supported by the IE etymology of the adjective; it is usually interpreted as IE *sue/o-bho- 'von eigener Art' (e.g., Pokorny, 883), and illustrated with the following IE lexical facts: the Germanic ethnicon Suēbi (a Latinized form), OHG Swābā (PGermc. *suéta-, plur. *suétōzz, or *swǣbjōz according to Prokosch; see Trubačev, 1959, 170), OI sabhă f. 'Versammlung, Gemeindehaus', Goth. sibja,, OGH sipp(e)a 'Sippe, Gesamtheit der eigenen Leute' (from PGermc. *sebjō). The last two formations presuppose IE *sebho- (see Pokorny, loc. cit., where a set of ethnica derived from the extended *se/obho-, e.g. Semnones $\leq$ PGermc. ${ }^{*}$ Sebnan-, Sabini, Sabelli, etc., are quoted). Against this background PGermc. *suêta- $=$ Schwabe represents a vrddhi formation derived from a nominalized (collective ?) PIE *suebhä- (cf. PGermc. sebjö) and meaning, according to Pokorny, 'frei, zum eigenen Volke gehörig'.

But the problem is what the primary meaning of the PIE adjective

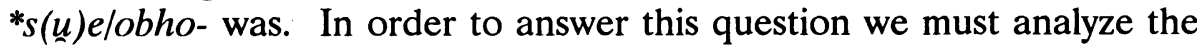
derivation of $*_{s}(u)$ e/obho- within the primary IE system of lexical morphemes. It is clear that the adjective is derived from the adverbial 
particle *se (secondarily *sue because of the influence of reflexive pronominal forms of the $*_{s}(e)$ ue type, themselves based upon $*_{s e}$; see Pokorny, 882; Mezger, 1948; Benveniste, 1969, I, 329, and 1954, 36-37), whose meaning was 'abseits, getrennt, für sich', preserved for example in the Latin prefix se- in se-ducere, se-parare, etc., and indirectly in OCS svěn'e 'besides'.

So *s(u)e-bho- would denote a person (or thing) 'apart, separate'. However, under the concrete social conditions of the primitive tribal life of the Indo-Europeans the adverbial meaning of $*_{s}(\underline{u}) e$, posited above, referred to the apartness, separateness of an exogamic moiety. Traces of this social meaning of $*_{s}(\underline{u}) e$ are preserved in the PIE *suek'rū-, *suek'uro-, and *s(u)esor-. According to Benveniste (loc. cit., 330-31): "Ces dénominations relieraient ceux qui les portent à l'autre 'moitié' exogamique; de fait la 'soeur' y partient en puissance, et la 'belle-mère' en realité." In connection with this etymology of $*_{s}(\underline{u}) e b h o-$ its primary form would contain the vocalism $e$ (thus $*_{s}(\underline{u}) e b h o$ - without vowel gradation!), and the forms with the vocalism $o$ should be interpreted as analogical, influenced by the reflexive-possessive pronoun $*_{\text {suo- }}$ (cf. OI svá- 'suus' Gr. Fós, ös, Lat. suos, suus, Slav. svojb, etc.). If the above semantic interpretation of PIE *s(u)ebho- is correct, then we should change the formulation by Pokorny, who defines the word as 'von eigener Art' into something like 'von anderer Hälfte', i.e., 'a person who is an actual or potential spouse or affine of a given ego'. Of course, collective

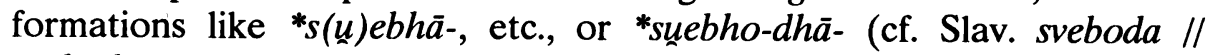
svoboda, etc.) would simply mean 'all the members of an exogamic moiety' > 'actual or potential affines'.

In view of these semantic reconstructions based upon the derivational analysis of the PIE $*_{s}(\underline{u})$ ebho-, the continuation of the latter in various IE ethnica (including here *Svoběne) seems to be self-explanatory: they simply denote groups of affines, like other old IE ethnica that denoted

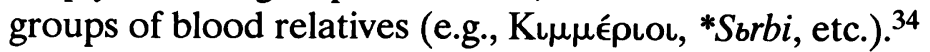

The reconstructed PSl. adjective $*_{s v e b z} / /$ svobs, which seems to continue a very important element of PIE social terminology, provided in Proto-Slavic several derivatives, as we have seen, among them a noun *svoběnz (with the suffix -ěn-) preserved in the ethnicon *Svoběne. The primary function of the suffix -ěn-consists in the derivation of nouns from nouns or adjectives, not in the exclusive derivation of names of inhabitants from the names of their habitat, as, e.g., OCS Kritěne from Kritz, ORuss. Poljane from polje, etc. (this last point has been unnecessarily and mistakenly generalized by most etymologists who have tried to explain the ethnicon Sloverne; see Vasmer, III, 664-66). For that primary function of the suffix -ěn- in Slavic compare OCS mladz 'young' 
$>$ mlad-ěn-bcb 'boy, child', OCS prbvъ 'first' > prbv-ěn-bcb 'first-born', OCS sestra 'sister' > sestr-ěn-ica idem (but Pol. siostrzenica 'sister's daughter' and OPol. siestrzan 'sister's son').

So nothing prohibits us from accepting the PSI. noun *svoběnz as an extension of *svobs (IE *suobho-). This common noun, which primarily denotes an affine, and in the plural (*Svoberne) the whole group of affines, the community of affines (and in the case of ethnica, the plural seems to be more frequently used) - became in the course of time the most common PSI. endogenous name which was used as a term of self-identification for PSl. tribes with respect to foreigners. This is obvious because the basic social ties in a primary small tribe are consanguinity and affinity, the latter forming broader entities than the former.

The only problem which remains and requires explanation is the formal change of the reconstructed primary *Svoberne to the secondary, historically attested Slověne. In order to account for this change, we should accept two processes. First, the form *Svoběne was dissimilated $(v-b \geq l-b)$ into *Sloberne (perhaps already on the level of the underlying adjective $*_{\text {svobz }}>*_{\text {slobs }}$ ?). This took place only in some dialects; others preserved the old undissimilated form with $s v-$. But the result was the variation *Svoběne $\sim$ *Sloběne in Proto-Slavic. Second, the dissimilated form *Sloběne, which ceased to be motivated as a result of the disappearance of the basic adjective *svobs // (slobs?), underwent an association with the words slovo 'word' and sloviti 'speak' (the latter attested in Serb. Church Slavic), a typical instance of folk etymology. This association was undoubtedly facilitated by the fact that foreigners, unable to speak Slavic, were simply called Nermbci 'the mute' (the term was restricted historically to the Teutons and Germans). So the folk etymology, through the association (adideation) of the unmotivated *Sloberne to slovo, sloviti, entailed the substitution of $v$ for the primary $b$. Hence the form Sloverne somehow shows a "restored" motivation, i.e., "those who slovętz 'speak (our tongue)"”.

It is important to emphasize that the process of folk etymology described above must have taken place quite early in Proto-Slavic, since Ptolemy already records $\Sigma \tau \alpha v \alpha \nu o i$ (i.e., $\left.{ }^{*} \Sigma \theta \lambda \alpha v \alpha \nu o i\right)$, which, as we have argued, reflects the original Slavic Slověne (at that time - 2nd cent. A.D. - *Sloūenæ). ${ }^{35}$

After Ptolemy only two other ancient sources give us geographical information about the primary Slavs: these are the Tabula Peutingeriana ${ }^{36}$ (2nd-4th cent. A.D.) and De origine actibusque Getarum ("The history of the Goths") by Jordanis (6th cent. A.D.). The first work is a map in the form of a papyrus roll, which presents the "world's" countries from west 
to east in a panoramic, artificially extended strip. In its European section only the provinces of the Roman Empire are drawn, but on the upper margin below the line of the Northern Ocean there is a list of peoples dwelling beyond the boundaries of the Empire. Among them, north of Dacia (north of present-day Transylvania) are located the Venadi Sarmatae, and to the west of them the Lupiones (undoubtedly = Lugiones) Sarmatae; the apposition Sarmatae here underlines the non-Germanic character of the tribes. There is no doubt that Venadi = Venedi $=$ Veneti, and all refer to the primary Slavs. The Slavic character of the Lugiones Sarmatae can only be inferred from the whole geographical and philological context. The location of these tribes is obvious: they dwelt north of the Carpathians on the territory of present-day southern Poland (see a detailed analysis of the problem by $\mathrm{H}$. Łowmiański, loc. cit., I, 180-81). It is interesting that the ethnicon Venedi is repeated on the Tabula Peutingeriana once more beyond the Danube, mear its delta. Was this the first trace of the early historical expansion of the Slavs towards the Lower Danube, which, as we will see, was a fait accompli in the sixth century A.D.? In any case, the evidence of the Tabula Peutingeriana is important, because the list of tribes on the upper margin was probably written in the third century A.D.

The second of these works, and the last ancient source in this context which already reflects the early historical expansion of the Slavs across the Carpathians to the Danube and beyond, and at the same time explicitly identifies the ethnicon Veneti with Sclaveni (= Sloverne) - is the well-known history of the Goths written about the middle of the sixth century A.D. by Jordanis, a late Roman historian (probably of Gothic origin). Jordanis condensed a larger work written in the first half of the sixth century by Cassiodorus, a learned Roman, the chancellor of the Gothic King Theodoric. The work is largely based on Gothic oral tradition and relates the history of that East Germanic tribe from their arrival at the estuary of the Vistula to the great migration of peoples. Thus the relations between the Goths and the Slavs, whose territory the former had crossed and partly controlled, are also depicted in the work. Since the location of the southern branch of the Slavs (Sclaveni in Jordanis' specification) along the Lower Danube and the extension of the eastern branch (Antes for Jordanis) towards the Lower Dniestr and the Pontic coast represent already historical facts, I will limit myself to quoting those passages from Jordanis which contain the most significant information about the early historical distribution of the Slavs and where the ethnica Veneti and Sclaveni are explicitly identified. Describing Scythia, i.e., the eastern half of Europe (outside Germania and the Roman Empire), in which he includes Dacia, Jordanis states: (for the 
beginning of the statement, cf. p. 270) ..."The Sclaveni dwell from the city of Novietunum and the lake called Mursianus to the Danaster and in the north as far as the Viscla; they have marshes and forests for cities. The Antes, however, who are the bravest of them, extend from the Danaster, where the Pontic Sea makes a curve, as far as the Danaper; and these rivers are within the distance of many stations [i.e., daily marches] from each others" (Getica, V, 30, quoted after Niederle II, 2, 291-2).

Now we have reached a point where we can summarize (or rather synthesize) the results of hydronymic (and toponymic), dendronymic, ethnonymic, and historical-geographical research presented in this chapter. Since the problem boils down to the demarcation of the geographical boundaries within which the prehistorical Slavs, i.e., the Proto-Slavs as a still uniform ethno-linguistic entity, could be located the methological device that suggests itself is cartographic: we should simply mark on the map of Central and Eastern Europe (present-day Poland and the Soviet Union) lines representing the ranges of Slavic hydronyms, trees with original Slavic names, and Slavic ethnica (the latter according to the ancient authors). Where these ranges overlap, i.e., where we observe a thick bundle of lines, the boundary seems to be sharp and well-established; where they do not overlap, i.e., where the lines are relatively independent and not parallel, the boundary seems to be vague, not fixed, which could be interpreted as evidence of relatively recent Slavic expansion. In order to give such a synthetic map historical depth, we should also mark on it lines representing the range of Baltic and "Venetic" "Illyrian" (Old European ?) hydronyms, which, as we have seen, are intimately connected with Slavic hydronymy as a substratum on its periphery. Because the proposed map speaks for itself, I will simply present it on page 309 with only a few comments.

When we take a look at the map we can clearly see the area in which the Proto-Slavs should be located at the time between their crystallization and their great expansion south beyond the Carpathian and west beyond the Odra and Elbe ( $K a b a)$ rivers (5th-6th centuries A.D.). This area is a wide belt of parklands extending from the Upper Don basin to the Central Odra basin. This extension of $1600-1700 \mathrm{~km}$. in a straight line was undoubtedly the result of gradual prehistorical migration and expansion from east to west in accordance with the general direction of the spread of most prehistorical IE peoples in Europe. Its easternmost starting point, the Upper Don basin, was reconstructed by projecting the Late Proto-IE dialectal diagram on the map of the hypothetical primary East European habitat of the Proto-Indo-Europeans. But as we have seen, it is also supported by the most probable location of Herodotus' Bouóivo (= PSI. *Bydini), whom we can consider a PSl. tribe. The fact 
that about 700 years later Ptolemy mentions most probably the Slavic

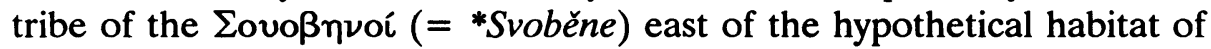

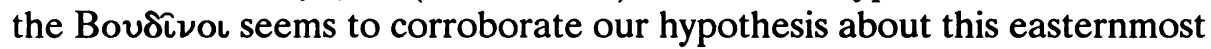
corner of the primary PSl. abode. Ptolemy's *Svoběne 'affines, clansmen' may have been an isolated PSl. tribe which allied with the Iranian Alanians, became pastoral and nomadic, and migrated beyond the Volga (if we can trust their location by Ptolemy, who is not very reliable in this respect). Under those circumstances the term *Svoberne with its primary meaning would meet a tribe's self-identification needs in a foreign milieu. ${ }^{37}$ The only weak point in this hypothesis about the inclusion of the Upper Don basin into the PSl. habitat is the hydronymy of this region. To my knowledge, there are no etymological studies as yet of the river names in the Upper Don basin. What I can quote in this connection does not, however, exclude the possibility of a prehistorical Slavic presence there. The names of the tributaries of the Upper Don are as follows:

1. Krasivaja Méča, a right tributary, $260 \mathrm{~km}$. long.

2. Bystraja Sosna, a right tributary, $302 \mathrm{~km}$. long.

3. Voronež, a left tributary, $368 \mathrm{~km}$. long.

4. Tixaja Sosna, a right tributary, $151 \mathrm{~km}$. long.

5. Osered (Osered' on the map in the Atlas SSSR), a left tributary, 103 $\mathrm{km}$. long.

6. Bitjug, a left tributary, $379 \mathrm{~km}$. long.

7. Cernaja Kalitva, a right tributary, $156 \mathrm{~km}$. long.

8. Xopër, a left tributary, $1008 \mathrm{~km}$. long.

9. Medvedica, a left tributary, $745 \mathrm{~km}$. long.

10. Ilovlja, a left tributary, $364 \mathrm{~km}$. long.

See Samoxin, A.F. Reka Don i eё pritoki, Rostov-na-Donu, 1958, pp. 64-67.

Of the above hydronyms, which by no means exhaust all the hydronymic material of the Upper Don basin, most have an obvious Slavic etymology:

Sosna: cf. Russ. sosna 'pine tree', a North Slavic word.

Voronež: cf. Russ. vorona 'crow', a Com. Slavic word (incidentally, in the same region there is a river called simply Vorona, a right tributary of the Xoperr).

Osered': cf. Russ. sered', seredina 'middle' and other derivatives from the same root, PSl. *serd- - the primary meaning of this hydronym would be 'the middle river' (?).

Kalitva: cf. Russ. kalit' 'temper' (primarily about heating iron and then submerging it in water), which according to Vasmer (II, 168-69) may be related to kal 'dirt, mud', or if transformed from Kalita (there is just such a hydronym in the Upper Dniepr basin), then directly from kal: 'the 
muddy river'.

Medvedica: cf. Russ. medvedica 'she-bear', a Com. Slavic word.

Ilovlja: cf. Russ. il 'loam', ilováj 'a small, low marshy place near a river' (a Com. Slavic word, primarily and $u$-stem, hence *ilov-ja $\geq$ Ilovlja 'the loamy river', but the formation cannot be very old because it shows as the basis the adjective *ilovz, not the primary stem *eilou-, which if extended by the suffix -ja would have resulted in the form *Iluja, etc.).

Bitjug: the only undoubtedly non-Slavic hydronym in the list; it is of Turkish origin: cf. Turkish bitük 'tall, robust' (Vasmer, I: 169).

The two others, Méča and Xopër, require more etymological analysis.

Méča: it seems to be Slavic: ${ }^{*} m b \check{c}-a$ can be derived from the verbal root $m b k$ - // mik-, attested in mečtá 'dream' (ORuss. mbčbta 'day-dreams', OCS mbčbtъ 'apparition', etc.) and in Lusatian mikać // mikaś 'blink, twinkle, sparkle', which presupposes PSl. *moknoti, mikati and is related to Lat. micō, -äre with a similar meaning (cf. Vasmer, II: 614). The only problem is that we must admit here an exceptional or rare vocalization of the weak jer in the first open syllable, which happens in Slavic languages under stress (see Shevelov, 1965: 448-52). So Méča (if from *mbča, i.e., ${ }^{*} m b k$-ja) would mean 'the flashing, glimmering river'.

Xopër: raises the suspicion that it is of foreign origin just because of its initial $x$-. To be sure, Vasmer $(I V, 261)$ tries to derive it from the verb xopit' 'grab, snatch', which is Com. Slav. and perhaps native, but semantically the connection is not clear, and besides that this would be a typical Wurzeletymologie. Therefore I prefer to derive this hydronym from an early Iranian *kšapra- 'dark', which would regularly result in PSI. *xopro and then in historical Russ. Xopër, genitive Xoprá. We have support for the reconstructed early Iranian form in Avestan words for 'night': xšap- f., xšapan- f., n., xšapar- n., xšapā- f., from among which $x$ šapar- (IE * $k$ usep-e/or-) could be the basis for the adjective *xšaprá(Bartholomae, 548-49); for comparative material in other IE languages, e.g., OI kșap, ks.apá 'night', see Pokorny (649, s.v. $k$ usep- (?) "Worte für Dunkel"). So the semantics of the Iranian Xopër 'dark' would be the same as that of the Slavic Vorona, one of its tributaries.

The occurrence of an Iranian hydronym in the Upper Don basin is nothing astonishing: this region, as the Iranian etymology of the Don indicates itself, has from time immemorial been an area of close ethnolinguistic contacts between the prehistorical Slavs and the Iranian tribes of the Scythians, Sarmatians, etc. Toporov and Trubačev have tried to prove that these contacts extended even farther to the west, citing as evidence the concentration of alleged Iranian hydronyms in the Sejm basin (a left tributary of the Desna), see map 2 in Toporov and Trubačev (1962). 
All the above facts, i.e., the probable "slavicness" of the Bovoivou (=

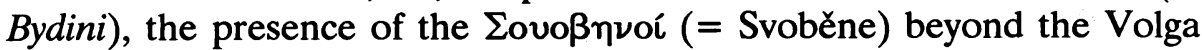
close to the Alanians, and the Slavic character of most of the bigger tributaries of the Upper Don - together with the location of the Pre-Slavs (3000-2000 B.C.) in just that part of the primary habitat of the Indo-Europeans - seem to support the idea that the Upper Don basin belonged to the oldest habitat of the Slavs, although it was always on the periphery and was culturally assimilated (in the sense of the stabilization of the population, etc.) only in historical times. Note that Herodotus'

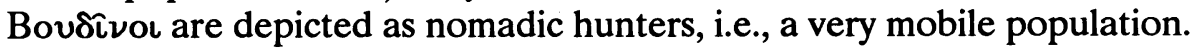

Undoubtedly the center of the primary habitat of the Slavs was the basin of the Middle Dniepr. This view is supported by the predominantly Slavic etymology of hydronyms in that region, and by the fact that the ethnicon Sloverne (in the form of Ptolemy's $\Sigma \tau \alpha u \alpha \nu o$ ) was located there. The archaic character of the Slavic hydronyms in eastern Volynia (the right bank Ukraine) plus the location of Herodotus' Nevpoi ( ${ }^{*}$ Nervi $)$ in roughly the same region seem to indicate that the right bank Ukraine (between the Middle Dniepr and the Bug River) was the center of the oldest habitat of the Slavs (6th century B.C. to 1st century A.D.), which can be further supported by the primary meaning of the toponym Volynb // Velynb ('Volelyn'i) 'country par excellence', i.e., 'fatherland'. From this center the Proto-Slavs expanded westward as early as the second half of the first millennium B.C., because the eastern and especially southeastern regions (beyond the Dniepr) were occupied by the nomadic Iranians, who interfered with agricultural colonization (the plow was necessary for tilling heavy black soil). The Tartars' similar role in the same region between the thirteenth and sixteenth centuries A.D. can be mentioned as a historical parallel. So, the main thrust of the prehistorical Slavic expansion seems to have been west across the Bug River into the Vistula basin. Here I would like to emphasize the following points: many Slavic hydronyms in the Vistula basin have been transferred there from the Dniepr basin (Visla, etc., Bugz, Dunajb, etc.); and the dendric boundaries of typical western trees with etymologically non-Slavic names, which on our map are represented by the eastern boundary of the beech tree, indicate clearly that the Central Vistula basin, with the inclusion of the Central Warta basin (which already belongs to the Odra system), must have been a relatively old zone of prehistorical Slavic colonization, which at the beginning avoided sub-Carpathian forested areas (rich in beech woods) and sub-Baltic areas (also with beech trees). But the natural waterways of the Bug and the Vistula had to bring the Proto-Slavic tribes to the Baltic coast at the mouth of the Vistula quite early, because the ethnicon Veneti, which in that region is most probably of Slavic origin, is 
well established there as early as the first century A.D. (recall, i.a.,

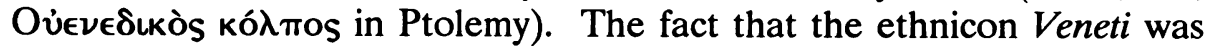
repeatedly mentioned in connection with the Vistula River, from its mouth (Pliny, Ptolemy) to its source (Jordanis), with emphasis on the multitude of that ethnos (Ptolemy, Jordanis), seems to indicate that the Veneti were the western Proto-Slavs who already occupied the Vistula basin and the eastern part of the Odra basin (the Warta River, whose etymology is Slavic) before the birth of Christ. Here the reader should recall Ptolemy's K $\alpha \lambda \iota \sigma i \alpha$, which undoubtedly stems from Latin sources (the amber trail itineraries); it probably represents a corrupted (by Marinos ?) transcription of Latin Caliscia, which in its turn renders PSI. Kališča (from kals 'mud, dirt') neuter plural 'marshes' (note that the primary town was surrounded by marshes). ${ }^{38}$ So the old stronghold on the amber trail seems to have an obvious Slavic name.

The wide expansion of the Veneti (i.e., western Proto-Slavs) around the birth of Christ must have been facilitated by external (demographic) and some internal (social) conditions. The former were simply created by the sparse population of the regions in question (the remnants of the Illyrians ?), the latter probably by the development of a class of warriors who led the raids. This last point seems to be corroborated by the very etymology of the ethnicon Veneti which, as I have tried to prove, meant 'victors', and primarily referred only to the class of warriors, and by Tacitus' clear statement that the Veneti live by robbery (latrocinia).

The span of time during which the Proto-Slavs colonized the regions extending from the Upper Don basin (?) to the Vistula and Warta basins encompasses more than a thousand years (from Herodotus' description of the ethnic situation of Eastern Europe about 500 B.C. to Jordanis' description of the ethnic situation of Eastern and Central Europe around 550 A.D.). During that time the Proto-Slavs, who crystallized as a separate ethnos, i.e., became culturally and linguistically distinct from the Balts, in the Middle Dniepr basin, particularly in Volynia and western Kijowszczyzna (cf. the location of the Neupoi $={ }^{*}$ Nervi of Herodotus and the Antes of Jordanis) before the middle of the first millennium B.C. were constantly moving westward. As we have seen, in the first centuries A.D. they were well established between the Carpathians and the Baltic Sea, i.e., on the territory of present-day Poland. We should remember that this was before the great migration of peoples, which was ushered in at the end of the fourth century A.D. by the Huns.

It should, however, be noted that we cannot precisely demarcate the western boundaries of that late Proto-Slavic habitat; e.g., the regions of Western Pomorania and Lower Silesia seem to be zones of close Slavic-Germanic contacts, of mixed colonization. The fact that even 
before the great migration of peoples the most important Germanic tribes in the Odra basin, the Burgundians and the Vandals, left that region, after which the Slavic population instantly reemerged, suggests that the following interpretation is most plausible: the Teutons seem to have dwelt among the basic Slavic population as transient warrior groups, most probably in some strongholds (compare the present-day Israeli settlements on the west bank of the Jordan River). Once they had abandoned them (perhaps under the pressure of the local Slavic population), the Slavic masses, no longer inhibited, moved further west and occupied the whole basin of the Odra River and poured into the Łaba basin (6th-7th cents. A.D.). These early historical times do not belong to the subject of this book. Even so, I would like to emphasize here the origins of the toponym Silesia, i.e., Slavic *Sblęžbsko (cf. Pol. Ślqsk, OPol. Ślqsko). This adjectival derivative is based upon the hydronym *Sblęža, Pol. Ślęża and the oronym *Sblęža // Sblęžb, Pol. Ślęża (góra), etc.

The case of the hydronym and oronym Ślęża and its derivatives Ślqsk(o), Ślężanie is not only very important, but also very revealing of a certain nationalistic bias which, unfortunately, has not been rare in European onomastics. The founder of Slavic antiquities, P. Safarik, accepted the hypothesis proposed by I. Imsieg in 1830 of an etymological connection between these names and the Germanic ethnicon $\Sigma$ i $\lambda i \gamma \gamma \alpha \iota$ (Ptolemy), Silingi (Hypatius, 5th cent. A.D.). This view has been maintained by the majority of leading scholars (among others L. Niederle, F. Miklosich, A. Brückner, J. Rozwadowski; see S. Rospond, Słownik starożytności stowiańskich, 1975, V, pp. 566-67). Historical evidence about the Vandalian Silingi (Germanic Silingozz) and linguistic (phonemic and derivational) analysis of these Slavic names strongly supported the hypothesis.

As to the location of this tribe, the Silingi dwelt first in present-day Upper Lusatia (the Upper Spree basin) and then, after the Markomannian Wars, they moved to Lower Silesia (3rd cent. A.D.). It is probable that their remnants still remained in Silesia in the fifth cent. A.D. and were subsequently absorbed by the Slavs (see H. Lowmiański, Stownik starożytności stowiańskich, 1975, V, pp. 180-81). This historical background is sufficient for an unbiased linguist, who sees the not only regular but even quite banal treatment of Germanic lexical material in the Slavic development *Silingaz (sing.) > ${ }^{*}$ Sblęzb (cf. Germanic *kuningaz $\geq k \preccurlyeq n e ̨ \zeta b$, etc.), then in the derivation of a possssive adjective $*_{s b l e ̨ z b}>*_{s b l e ̨ z ̌ b} / a / e$ (cf. kßnę̧b $\geq k \preccurlyeq n e ̨ z ̌ b / a / e$, etc.). Now, it would be quite understandable that the Slavs, who surrounded the Silingian enclave, called the river and the mountain located in the center of that enclave the 
'Silingian river' and 'Silingian mountain', in Proto-Slavic *Sblęža (rěka) ${ }^{39}$, *Sblęža (gora) or ${ }^{*}$ Sblęžb $\left.{ }^{*} v b r x z\right) .{ }^{39}$ Compare the similar old possessive toponym Niemcza (*Němbča) 'German (settlement)' also located in Silesia, just south of Mount Ślęża Sobótka. It is revealing to note that the same oronym has also been attested in Lower Lusatia: Zlensegor (1225), Slensegor (1227), i.e., *Sblęža Gora, Pol. Ślęża Góra (cf. Rospond, loc. cit.), which would prove the older location of the Silingi. This convincing etymology, which cannot be attacked either on linguistic or historical grounds, has been strongly opposed by M. Rudnicki and S. Rospond on rather weak grounds. Since the Rudnicki-Rospond hypothesis shows some serious linguistic gaps, I will devote some remarks to a critique of it.

The whole idea of these authors (see M. Rudnicki, Slavia Occidentalis 8: 534-36, 1929, and 12: 398-402, 1933, and S. Rospond, Stownik starożytności słowiańskich V, 1975, p. 564 s.v. Ślęża and pp. 566-67 s.v. Ślęzanie) is connected with the hypothesis of the historian W. Semkowicz, who in his article Historyczno-geograficzne podstawy Ślqska (the first chapter of the book Historia Ślqska, ed. St. Kutrzeba, PAU, Cracow, 1933) proposed a Slavic (Polish) etymology for these toponyms. Namely, he attempted to show that Ślęża, Ślęz can be derived from the root *slęgcontained in Pol. dial. (Wielkopolska and Małopolska) ślęgnqć 'soak, get wet', ślęganina 'rainy season, humidity', ślagwa // ślqkwa 'humid, foggy air; foul weather; sleet', prześlagły 'soaked through' (W. Semkowicz, loc. cit., 12). The derivatives *slęg-jb/ja, i.e., Ślęż, Ślęża, referring to the mountain and the river respectively, would simply mean 'foggy and humid mountain', and 'river flowing across swampy ground', which actually has justification in the climate and physiography of the region. Here I would like to note that Semkowicz's reasoning is theoretically correct at first glance; even his reconstruction of the primary form of the toponyms with $-\check{z}$ - from $-g j$ - is better than Rospond's speculation about the forms *ślędza $\geq$ ślęza, etc., allegedly from *slęga in connection with the third palatalization of velars in Proto-Slavic. But if we scrutinize the dialectal Polish forms in the context of comparative Slavic material, then the "nativist" etymology loses its ground: the comparative Slavic material, supported by IE correspondences, shows that the primary form of the root, the alleged *slęg- (Pol. dial. ślęg-, etc.) was slęk-, i.e., with a final voiceless $k$ (cf. Russ. sljákot' f., dial. sljáča 'rare mud from rain and snow', S-C slëka 'tide'; here also belong the regular Polish forms with $k$ : ślqknqć 'get wet', ślqkwa 'wet weather', Vasmer III: 682). The primary form *slękhas good support from comparative IE material: e.g., Lith. sliñkti, slenkù 'schleichen (von der Schlange)', Latv. slikt 'sich senken, im Wasser untergehen', etc.: only in Germanic is there an IE variant in -g: e.g., OE 
slincan 'kriechen', etc. (for details see Pokorny, 961, s.v. slenk-, sleng'winden, drehen; sich schlingen, kriechen'). Of course, the semantic development 'creep' > 'get wet', etc., is complicated, but if we realize that as an intermediary state we could have 'to flow slowly' or something similar, the change becomes possible. In any case the dialectal Polish forms with $-\mathrm{g}$ - seem to be secondary, later: they probably represent an expressive voicing of primary voiceless consonants, which takes place in certain words, e.g., wielki > wielgi, glista > glizda, etc. So, the toponyms Ślęża, Ślęz (or rather Ślqż in modernized Polish form) cannot be derived from *Slęg-ja, *Slęg-jb, since the Proto-Slavic form of the root (i.e., dial. Pol. slęg-nq-ć, etc.) was *slęk-. The old derivatives in -ja, -jb of this root would sound like *Slęča, *Slęčb - which, of course, do not exist. In view of all these facts, we must return to the old etymology of Ślęża, etc., which presupposes *Sblęža, etc., a possessive derivative from the ethnicon *Sblęzi, which was borrowed from the Germanic *Silingōz (Ptolemy's $\Sigma$ ¿ iry $\alpha$, Hypatius' Silingi). I will end my critique here, although it could be expanded, especially to take in some obvious mistakes in $M$. Rudnicki's linguistic reasoning (for example, his statement that "obce *Siling- z sufiksem -akz dałoby słow. *Sblęg-akz...", which is wrong because it does not take into consideration the third palatalization of velars: from *Siling-akz we would regularly obtain Sblezzakz). Such details would not add anything substantial to the discussion. It seemed necessary to me to raise the subject because it shows how careful we must be in etymological analysis and that attempts to prove the native etymology of a toponym at any price may divert us from linguistically and historically well-justified explanations to vague speculations.

The territories located north of the Carpathians became in the fifth-sixth century A.D. the basis from which the great southward movement of the Slavs started, i.e., to Moravia and Bohemia, and to Pannonia and Dacia (Transylvania). Although these problems do not belong to the scope of my work, I shall remind the reader of some linguistic facts which seem to indicate the main route of migration of the Southern Slavs. Trubačev has shown that in the Upper Dniestr basin there is a characteristic concentration of two layers of hydronyms: those with possible West Balkan connections (Illyrian ?) and those with South Slavic connections. On the opposite side of the Carpathians (in the Upper Tisa basin) we again have a characteristic South Slavic hydronym Topla, i.e., 'warm' (river), etc.). Such facts suggest that the main route taken by the ancestors of the Southern Slavs in their migration south towards the Danube was the ancient trail through the central Carpathian passes, and the region where a kind of Proto-South Slavic linguistic community developed (before its split into the western, Sloveno-Croato-Serbian, and 
the eastern, Macedo-Bulgarian, branches) was northeastern Pannonia, i.e., later sub-Carpathian Ruthenia. From that transitional stage the Southern Slavs later moved to the Danube River along two separate routes, one more western, another more eastern (through Transylvania). ${ }^{40}$ 


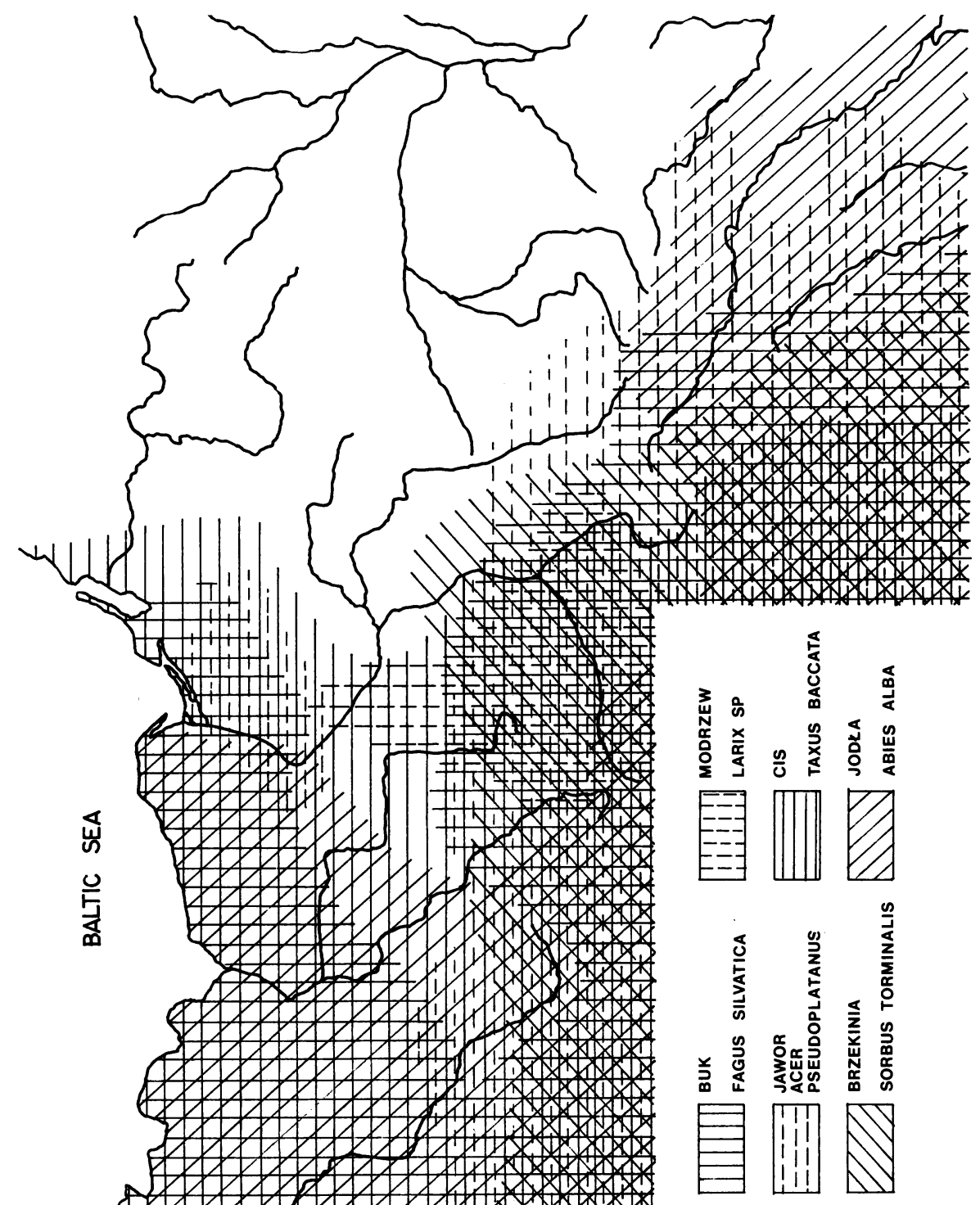


Chapter 5, Map 2

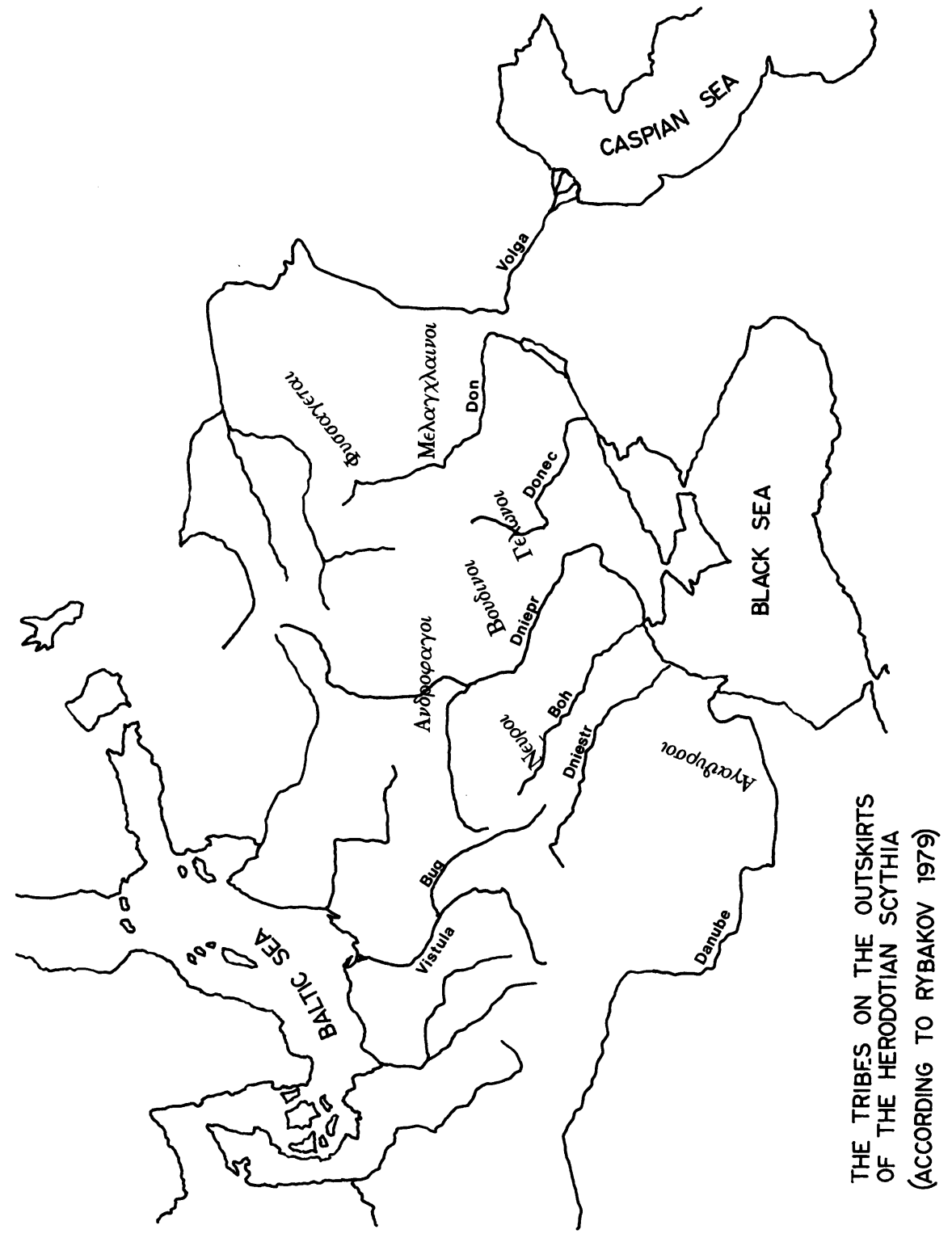




\section{Chapter 5, Map 3}

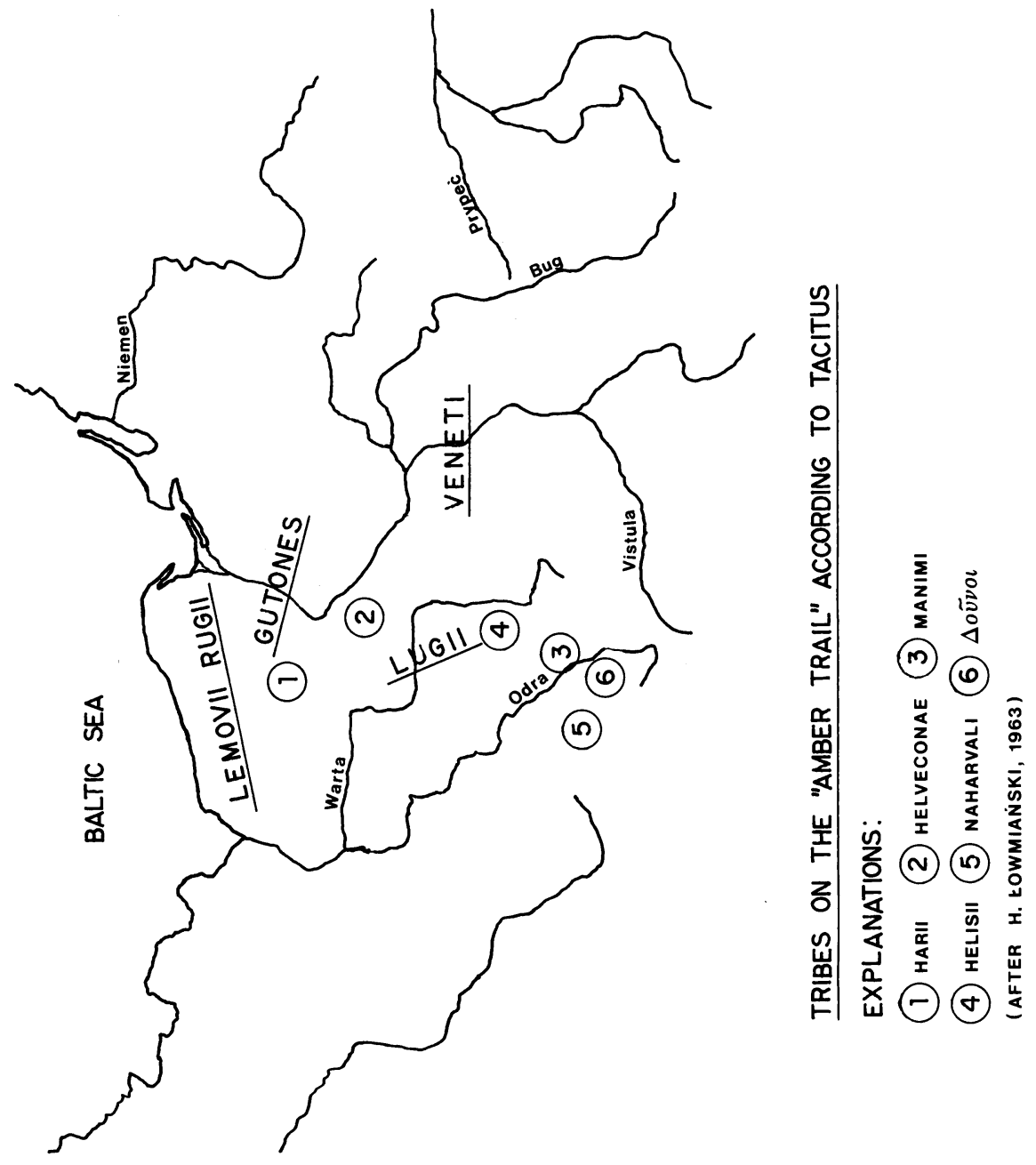


Chapter 5, Map 4

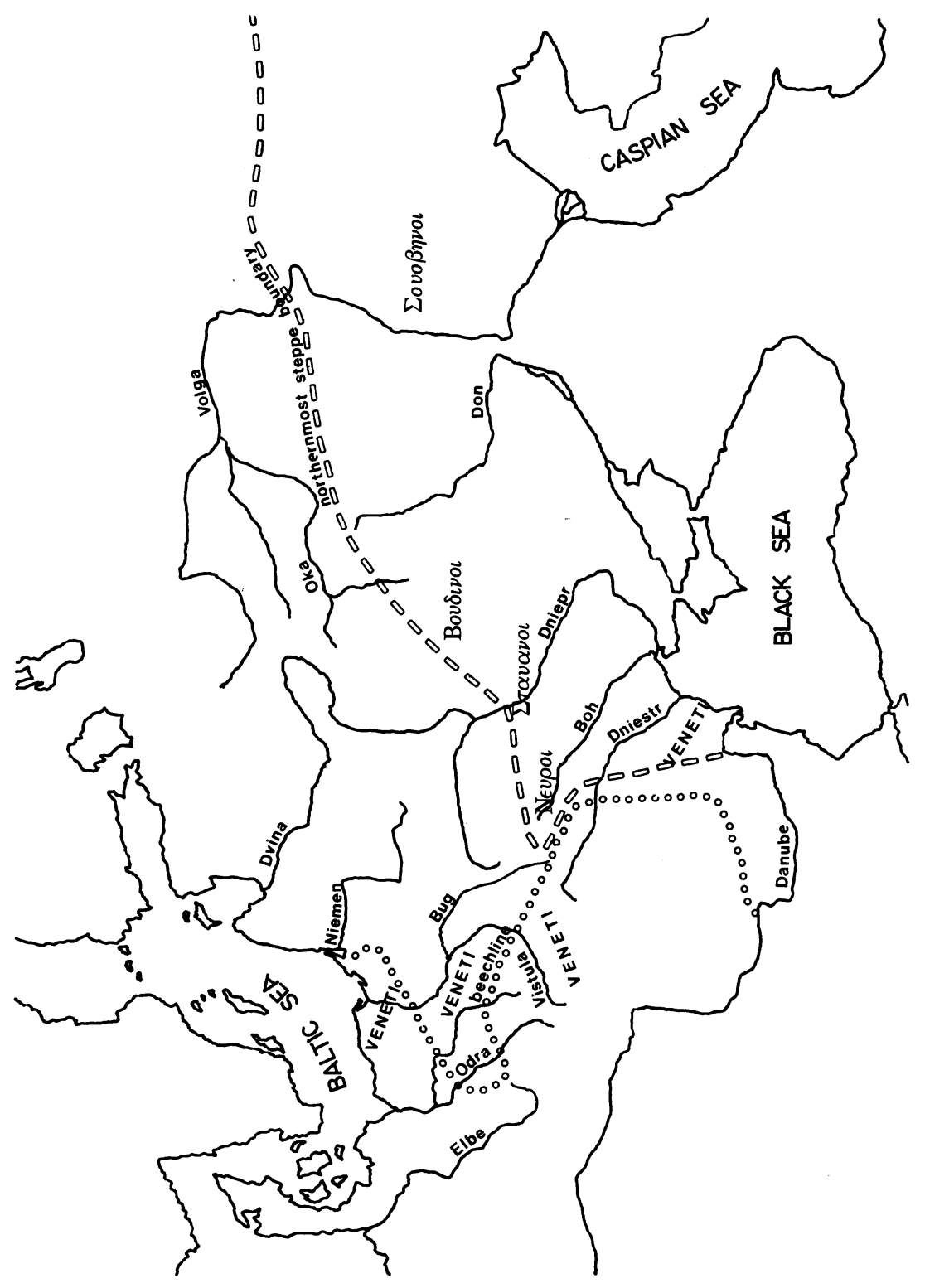




\section{Chapter VI}

\section{The Slavs and the Neighboring Peoples (the Problem of Foreign Loanwords in Proto-Slavic)}

We have established that before the year 500 A.D. the main bulk of the Proto-Slavs occupied an extended territory from the Middle Dniepr basin in the east to the Odra basin in the west, reaching the Baltic coast only between the Vistula and Odra rivers, but not reaching the Pontic coast. They were separated from the rest of the Baltic coast by the Balts (the Old Prussians, Lithuanians, and Latvians, or rather the ancestors of these historical tribes), who at that time inhabited the whole region of Northeastern Europe, extending from the Upper Oka basin across the Upper Dniepr basin toward the Baltic Sea. The Proto-Slavs were separated from the Black Sea coast first by the Iranian peoples (the Scythians and Sarmatians), then by the Goths and the Huns. The rest of the southern boundary of that late Proto-Slavic habitat was formed by the Carpathians and also partly by the Sudeten. The boundaries in the east and in the west were open and rather indeterminate. In the Odra basin we should accept a neighborhood of the Slavic and Germanic populations before the great migration of the (Germanic) peoples. In the east (the Upper Don region?) the Iranian pastoral tribes seem to have been the most stable and constantly pressing ethnic neighbor. Only after the Hunnic invasion were they gradually replaced by Turkic tribes (the Avars, the Khazars, etc.).

Of course, this general geographic and ethnographic picture was not a static one. We must remember that when speaking about the extended Proto-Slavic habitat we have in mind a dynamic process of gradual land occupation which lasted at least one thousand years (if we agree that the primary core of the Proto-Slavic habitat, the country of Herodotus' Nevpoi [= Nervi], was located between the Middle Dniepr and the Bug rivers [Volynia and the western part of the Kievan region]; including the trans-Dniepran region here is rather disputable). A characteristic feature of the late Proto-Slavic habitat is its longitudinal, relatively narrow 
east-west extension (note that the regions north of Kiev, the Prypeć, and the Lower Bug [the Narew basin] did not belong to that habitat). That the prarodina or praojczyzna of the Slavs has such a shape seems to be well justified by the natural floral zones in that part of Europe: the parklands, i.e., the mixed woods with large meadows, corresponded to the late Proto-Slavic habitat, whereas the dense zone of mainly coniferous woods extended to the north and northeast of it (cf. here the justification of the so-called rubież etnograficzna in Poland, mentioned in Chapter V). There is no doubt that for primitive agriculture using the soxà and *órdlo (two kinds of primitive wooden plows) the parklands were more favorable than either the dense coniferous woods or the open steppes with their heavy black soil, which required an improved plow with a metal shoe, the plugz. ${ }^{1}$ So the Proto-Slavs, as an essentially agricultural population, expanded mainly to the west along the natural belt of parklands.

Now, against this general geographical background we can raise the question: with which of their old neighbors did the Proto-Slavs have contacts that left perceptible traces in their vocabulary, i.e., loanwords? Here at the very beginning of our discussion we must exclude the contacts between the Slavs and the Balts, not because they did not occur in the period under consideration (although after the ultimate crystallization of the two ethno-linguistic groups and the concentration of their main bulks south and north of the Prypeć River respectively those contacts were considerably weakened), but because the phonemic and grammatical similarity of the two proto-languages brought about a system of substitution which makes it impossible to distinguish phonemically the old common innovations from old loanwords either from Slavic to Baltic or from Baltic to Slavic today. The only possible criterion in this situation would be the etymological isolation of a word in one of the languages, i.e., if a word is isolated in Baltic but "surrounded" by cognates in Slavic, then it could be a loanword from Slavic; and if the opposite is true, then it could be a loanword from Baltic to Slavic. Therefore we must leave the whole problem unresolved.

\section{Part I. Prehistorical Slavic-Iranian Contacts.}

Much more promising is the investigation of the Iranian loanwords in Proto-Slavic. Many scholars (Meillet for one) have doubted the existence of such elements in the Slavic vocabulary. But it should be emphasized that the close geographical proximity of the Slavs and the Iranians, i.e., the Scythians and Sarmatians (including their late representatives, the Alanians), lasted at least a thousand years (from about 700 B.C. until 
about 300 A.D., when the Goths established themselves as a powerful ethnic and political factor on the Pontic steppes, reducing the role of the Alanians). This is longer than the Slavic-Tartar relations in the Ukraine and Russia lasted after the Mongol conquest in the thirteenth century. Nevertheless, from that shorter period we have an impressive amount of Tartar loanwords in East Slavic (and through Ukrainian in Polish). It would be inconceivable that the much longer period of Slavic-Iranian contacts left no distinguishable traces in the Slavic vocabulary. After all, the type of the social and cultural relations between the two ethnic groups in the prehistorical epoch was undoubtedly similar to that in the historical epoch: one was a sedentary agricultural population, and the other was a nomadic pastoral population (we are speaking here about the cores of the respective peoples, not about their peripheries). In this situation there are many things (cultural goods) suitable for exchange, i.e., conditions exist which favor lexical borrowings, not to mention the notorious military-organizational superiority of pastoral nomads, who very often force sedentary tribes into federation under their hegemony.

So there seems to be little doubt that the conditions of Slavic-Iranian relations favored cultural and linguistic exchange. But there is one point which complicates the investigation. As we saw in the chapter about the stratification of the Proto-Slavic vocabulary in terms of IE dialectology, among the words which represent striking formal and semantic correspondences between Slavic and Iranian there are some that undoubtedly belong to an old dialectal IE stratum common to these two languages (in many cases also including Baltic and Old Indian). Besides these words, however, there are some that seem to represent later semantic borrowings from Iranian, i.e., words which had been inherited by Slavic from IE but whose meanings were then adjusted to the meanings of their etymological correspondences in Iranian. For example, this is the case with such religious terms as ${ }^{*} b o g z$ : divo (which match the Avestan pair baya- 'God' : daēva- 'demon' semantically), *bolgz and its derivatives *bolgati, *bolžiti, svętz, and perhaps some others. It is practically impossible to draw a precise distinction between the old common terms, inherited from the Proto-Indo-European period when the Pre-Slavs and the Pre-Aryans (or their Pre-Iranian part) shared common IE dialectal features and the later semantic borrowings from the period of close ethnic contacts between the Proto-Slavs and the Pontic Iranians. Therefore, in order to show real Proto-Slavic borrowings from Iranian, i.e., loanwords, we should concentrate on those examples which, first, show characteristic Iranian phonemic features; second, have characteristic Iranian derivational morphemes; and third, are etymologically isolated in Slavic, whereas in Iranian they show obvious 
derivational connections with other words of that language (or rather language group).

My opinion, which I expressed and substantiated in a paper at the VII International Congress of Slavists in Warsaw, 1973 (see American Contributions to that Congress) is that among the Proto-Slavic words with an initial $x$ - the overwhelming majority are foreign loanwords from two sources: Iranian (older) and Germanic (younger). As we know, word-initial Slavic $x$ - in inherited IE words can come from the primary

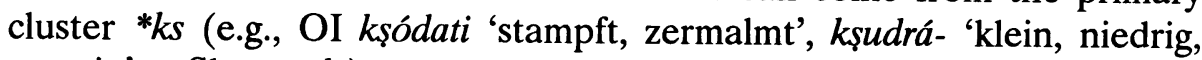
gemein' Slav. xudz), or exceptionally, under some sandhi rules, from an initial *s- in verbs preceded by the primary "loose" prefixes ending in $-r$, $-u,(-k),-i$ (cf. the only certain example xoditi from *sodeitei). But the number of IE roots beginning with $* k s$-, $* k$ 's- is very small (Pokorny has only seven such roots, or eight if we include the variant of the numeral 'six' - *ks(ü)ek's; cf. Avesta xšvaš, Slav. šestb, i.e., *ksek's-ti-). So most Proto-Slavic words with the initial $x$ - should be interpreted as borrowings from those ancient IE languages with which the Proto-Slavs had contacts in the past, and, of course, whose phonemic systems contained phonemes of the $/ x /$ and/or $/ h /$ type, developed in those languages regularly from IE sources. It is Iranian and Germanic that satisfy this condition.

In Iranian any primary, i.e., IE $/ s /$ passes into $/ h /$ (voiceless glottal) in all environments except for in the clusters $s p$, $s t, s k(s c ̌), s n$, and $p s$, e.g., OI sádas- Avesta hadiš- 'residence', etc.; similarly older Indo-Iranian *kh (from IE ${ }^{*} k H$ - !) passed into $/ x /$ (voiceless velar), e.g., OI kháraAvesta xara- 'donkey', etc. The Proto-Slavs imitated these two types of Iranian $h$ with their $x$, as in historical times the Poles and the Southern Slavs do for foreign $/ x /$ and $/ h /$.

Now after these introductory remarks let us quote the list of sure Iranian loanwords containing an initial $x$-.

1. xájati, xájo, xáješi 'take care of, curare', etc.; the primary meaning is undoubtedly 'hold, keep, tenere. This verb is directly or indirectly attested in all Slavic languages, e.g., S-C häjati, häjem (Rječnik, III, 548-51) 'curare', with examples starting from the 15th cent.; ORuss. oxajati se 'move away, restrain oneself' (Sreznevskij, II, 837); in south and west Russian dialects xájat' 'sorgen, sich um jemand kümmern', etc. But in most Slavic languages the negative archetype *nexati, *nexajo is used, based undoubtedly upon the particle *nexajb, itself a petrified form of the imperative sing. ' *nexaji 'leave', hence *nexati 'leave'; cf., e.g., Pol. niechaj, niech, a particle of the 3rd person imperative, niechać, etc. As I have shown in the article quoted above the source of this verb is an early Iranian *kşa $\bar{a}(y)$-, later Avestan and Old Persian $x \bar{s} \bar{a}(y)$ - (cf. Bartholomae, 551), e.g., Av. xšayati ( $\leq{ }^{*} k s$ saéeti) 'hat Macht, Gewalt, herrscht, verfügt 
vorüber, besitzt' (IE * $k s \bar{e}(i)$ - 'erwerben, Verfügung and Gewalt worüber bekommen'; Pokorny, 626, s.v. *kpe (i)-, *kpə(i)-). The regular Slavic development of the root would be *ksē(i)- $\geq x \bar{e}(i)-\geq \check{s} a(j)$ - and indeed we find o-šajati (sę), -šajo (sę), -šaješi (sę), 'removere' (non-reflexive), 'abstinere' (reflexive) in Miklosich's Lexicon (549), which corresponds exactly to the older S-C (15th-18th cents.) ohajati, ohajam 'neglect, leave' and oxajati sę 'mittere' (sic !), rather 'abstinere', quoted by Miklosich from Misc.-Serb. and Mon.-Serb. The variant with $x$ - can only be explained as an early Iranian loanword. This example does not represent the Slavic rendering of an Iranian $x$ - or $h$-, but nevertheless, because of its initial $x$-, which can be accounted for only through an early Iranian $* k s \bar{a}-$, I have included it in the list of Iranian borrowings with $x$-.

2.) xòxa 'coquette', only in Ukrainian. Its verbal derivative xoxati, -ajo, -aješi, however, with the general meaning 'carry on a love affair' is attested in OCzech, OPol., and it can be retrieved for Russian from such dialectal forms as xáxal' 'Betrüger, Gauner, Beck,' etc., xáxal'nica 'Geliebte, Liebchen' (Vasmer, Germ. ed. III, 233), undoubtedly from *xoxal', etc., under the influence of xáxat' 'laugh'. The source of xòxa is probably Iranian *haxā- 'female companion, hetaera', cf. Avestan and OPersian haxā // haxa m. 'Freund' (Reichelt, 193); the stem haxay- 'Freund, Genosse' (Bartholomae, 1744) = OI sákhā 'Gefährte, Genosse, Freund'.

3.) *xolstz 'caelebs, bachelor, young unmarried man', adj., attested only in Church Slavonic and East Slavic: xlastz, Russ. xolostój. It has no etymological connection with *xolstiti (OCS xlastiti, Russ. xolostit') 'castrate' (Benneker, 394) and probably represents an Iranian haršta-perf. pass. participle 'released' from the verb haraz- 'entlassen, entsenden, ausschicken' (Bartholomae, 1792-1793; Reichelt, 509). The presence of $-l$ instead of the expected $-r$ - could be explained as due to the influence of *xolks (e.g., ORuss. xólok 'ledig, unverehelicht'), a Germanic loanword (Kiparsky, 277). The semantic passage 'released' > 'adolescent', etc., has been conditioned by the old custom of releasing growing boys from their mother's protection and initiating them into the community of mature men.

4.) xotěti, *xotjo, *xotješi, 3rd. plur. xotętz 'want, velle', etc. From among several etymologies of this verb two, by Vaillant (1966: 404) and by Meillet (Mémoires de la Société linguistique de Paris, VIII, 315) deserve attention. In my aforementioned article (Gołąb, 1973) I have criticized and refuted the former (which started from *svotěti as a basic intransitive to svatiti 'appropriate' > 'catch', etc.), and I have developed the latter (which proposed an etymological connection between Slav. xotěti, Lith. sintěti 'think', and Lat. sentire), trying to explain xotěti, instead of the expected *sętěti (preserved in OCS sęštb 'klug'), through an Iranian 
intermediary. Namely PIE *sent- // *snt- 'eine Richtung nehmen, gehen' and in the psychological sense 'empfinden, wahrnehmen' (Pokorny, 908), which underlies the above verbs, gives Iranian hant- // hat-. Such a verb is actually attested in Avesta: hant- 'gelangen, gelangen lassen' with the present tense hantya- or hatya- (Reichelt, 114-16). The latter was borrowed by the Proto-Slavs as *xotje-, etc., probably at the time when an original Slavic *sętěti still had the meaning 'aim mentally at a goal, intend', i.e., when it was closer to the meaning of Iranian hant-. The above etymology also accounts for the root variant with the nasal vowel - $Q$ - in an old nominal derivative of xotěti - *xqtı (cf. Cz. chut' 'appetite', Pol. chęć 'want, wish, desire').

5.) xovati, xovajq, xovaješi 'preserve, guard, protect', only in North Slavic. The conjugation type is that of an old denominal verb dělo > dělajo, dělati, etc. The older meanings of this verb suggest more specialized semantics, e.g., in Old Polish and Old Czech 'bring up (children), rear, breed (animals)', which makes such derivatives of xovati as Pol. dial. chowaniec 'adopted child', Ukr. xovanec' idem, Cz. chuva 'nurse', etc., understandable. I derive this verb from the Iranian hava'one's own' ( $\leq$ PIE *souo-), i.e., PSl. *xovo- 'one's own' > xovati 'to make one's own, to treat like one's own' > 'bring up, adopt' with respect to children, 'rear, breed' with respect to animals, and 'preserve, hide', and even 'bury' with respect to inanimate objects.

6.) xromb 'lame', attested in all Slavic languages along with its old verbal counterpart ${ }^{*} x r z(m) n q t i$, reflected in OCS oxrom $q$, 3rd plur. asigmatic aorist, and in Cz. ochrnouti 'get lame'. Since it has almost an exact correspondence only in OI srämá- 'lame', the most probable origin is a borrowing from an unattested Iranian *hrama-, and the verb with its reduced vocalism would prove the antiquity of the borrowing (see Vasmer, IV, 277-78).

7.) xvalà 'glory' in all Slavic languages. It is virtually a synonym of sláva 'fame, glory', although there are some differences in usage; e.g., xvalà may mean 'thanks' (see Sadnik and Aitzetmüller). It is characteristic that the stem $x v a l$ - in Slavic anthroponymy is combined chiefly with the noun bogz (a semantic borrowing from Iranian), and the name Bogo/u-xvals has an exact correspondence only in Persian-Median Baga-farna(*Baga-xvarna-), (Trubačev, 1967: 29 and Milewski, 1957: 50). In view of these facts I consider xvalà a loanword from Iranian, specifically from Alanian *xvālà, which in its turn renders Com. Iranian *xväryā-, a cognate of Av. x'aronah-, OPers. farnah- n. 'Ruhm, Ruhmesglanz, Glanz, Herrlichkeit, Hoheit, Majestät', explained by Bartholomae (loc. cit., 1872) as "eine Art Glorienschein, der insbesondere die Könige aus den angestammten Herrscherhäusern umgab... und ihnen übernatürliche 
Machtfülle verlieh". The Old Persian form is also continued by Ossetic farn 'paix, bonheur, richesse' (Benveniste, 1959: 127). For OI and IE correspondences see Gołąb: 1973.

8.) xvátiti // xýtiti (cf. S-C hvätiti // hïtiti) 'catch', attested in all Slavic languages. The meaning 'catch' is the most frequent, but not the only one: an older meaning 'throw' of the variant xytiti is attested in Serbo-Croatian, Slovenian, and Lower Lusatian. On the basis of semantics (see Gołąb, 1973) the primary meaning of the verb can be reconstructed as 'to make a sweep with the arm (in order to catch or to throw something)', which brings us to the next verb.

9.) xvě(ja)ti, xvějo, xvěješi (sę) 'sway', attested in most Slavic languages, e.g., Russ. Church Slav. xvějati sja, Russ. xvéjat'sja, xvéjus', OCz. chvieti = $\mathrm{MCz}$ chvěti (sic!), Pol. chwiać się, chwieję się, etc. The verb continues PIE *süe (i)- (Pokorny, 1041) through an Iranian *xvāy-, which is actually reflected in Sogdian $\gamma w^{\prime} y(=x w \bar{a} y-)$ 'frapper, briser', in Yagnobi -xăy and Ossetic xwayin 'frapper' (Gauthiot, 1914-23: 150). The Slavic verbs under 8 can be interpreted as denominal derivatives from something like xvāta$/ /{ }^{*} x \bar{u} t a-$ and would have a striking correspondence in Ossetic xväcun // xäcin 'to embrace' $\leq$ *xvati- according to Miller (1962: 50, 53); for IE cognates, cf. among others OE swadian = NE swathe, see Gołąb, 1973: 147).

10.) xvojà // xvojb (the latter only in Russian) 'branch of coniferous tree' and their collective derivative xvojina are known in all the principal Slavic languages. I reject any etymological connection with Lith. skujà 'Tannennadel und -zapfel' and Latv. plur. skujas 'Tannenreisig' for phonemic reasons and derive this noun from $x v e \check{(j a}(j i$, itself borrowed from Iranian (for details see Gołąb, 1973: 147).

11.) xvostz 'bunch, tuft, brush', then also 'tail', attested in all Slavic languages // xvastz, directly attested only in Polish 'weed' and Ukrainian 'bent', but indirectly by the derived verb *xvastati (sę) (e.g., Russ. $x v a ́ s t a t$ 'sja, etc.) 'brag' in all the principal languages. I consider these two nouns old derivatives from the IE root *sue $(i)$ - i.e., *sueH-i-, which underlies $x v \check{e}(j a) t i$, with the suffix -stu- : *sü-stu- $\geq x v o s t z$ and *sueH-stu$\geq x v a s t z$ with the initial $x$ - and vocalism due to the Iranian intermediary. The only evidence of the existence of such nouns in Iranian is the Ossetic xos // xwasæ 'hay' (Abaev, 1958: 415), probably a backformation from the expected *xwastæ misinterpreted as a plural. For details see Gołąb, 1973:148-50.

12.) *xvorna, its primary meaning 'food' preserved in South Slavic (e.g., S-C hrána, etc.) and West Slavic (e.g., Polab. chórna 'food', Kashub. charna 'fodder', etc.). This meaning is unknown in East Slavic, where for example Russ. xoróna means 'protection' (Dal', IV, 1222); the latter is conditioned by the influence of a secondary meaning of the verb *xvorniti 
'feed' > 'protect, preserve, etc.', attested in most Slavic languages (e.g., already in OCS xraniti 'hüten, bewachen, bewahren'). The noun has been borrowed from Iran. xvarzna- (so in Avesta) 'food, drink', which is continued by Ossetic xwar 'grain, barley' (see Trubačev, 1965: 36).

13.) *xvorb // xyrz: the first variant with the basic meaning 'ill, sick' is known only in North Slavic, e.g., Russ. xvóryj, OCz. chvorý, Pol. chory, etc.; the second variant is also attested in the South, e.g., Russ. dial. xiryj = xvoryj, xilyj, Pol. dial. chyrać 'be sickly', chyra 'illness, pest', chyrek 'sickling', OCz. (rare) chyravý 'sickly' // churavý (sic !), Serbian Church Slavic xyra // xira 'weakness, sickness', pro-xyrělъ 'vilis', S-C (Čak.) za-hirët, $z a$-hîrim 'waste away', Sloven. hírati, hiréti idem. I have quoted the verbs too because they seem to provide the basis for the variant xyro if we accept as Proto-Slavic *xyrěti, or rather *xъrěti, -jo, -iši // xyrati, -ajo, -aješi (Sławski, I, 63). In any case the first variant, *xvorz, has an exact correspondence in Av. $x^{\mathrm{v}}$ ara- m. 'wound', and Ossetic æfxæryn 'offend, punish' may represent a trace of a corresponding Iranian verb (Vasmer, IV, 231-32). The IE source is *suer- 'schneiden, stechen, schwären, eitern' (Pokorny, 1050), attested inter alia by OHG sweran (a strong verb, $\mathrm{V}$ class) 'schmerzen, schwären, schwellen'. The initial $x$ - in Slavic can best be explained through a borrowing from Iranian.

14.) $x z m e l ' b$ is known in all Slavic languages in connection with the ancient practice of beer brewing, cf. e.g. ORuss. xъmelb (Pov. vrem. let., 985 A.D.), S-C hmëlj, gen. hmèlja, etc. 'hops'. Among many etymological attempts (see Vasmer, III, 249-50), the hypothesis that it is a loanword from Iranian is the most convincing (K. Moszyński, 1957: 217-24): Av. haōma = OI sōma- 'eine für heil- und zauberkräftig geltende Pflanze sowie das aus ihr gewonnene Getränk' (Bartholomae, 1732-34). K. Moszyński connects it with Av. hav- 'auspressen', whose present, among others, shows a reduced vocalism hun(av)-, perf. pass. participle huta-; cf. OI sunóti, sutá-, etc. (Bartholomae, 1781). The IE root is *seu(a)-, sū(i.e., *seuH-, *suH-) 'Saft, Feuchtes; Saft ausdrücken', etc. (Pokorny, 912). The Slavic form presupposes end-stress ('xъmel'b, *xzmel'à) and could be an extension of an Iranian form with a reduced vocalism: *huma-. About PSl. -el'b in denominatives see Sławski, 1974, I 108, e.g., *kzrpa 'patch, patch of leather' > *kzrpel'b 'a primitive shoe', etc.

15.) *xzrtz 'greyhound', known in all Slavic languages, e.g., Russ. xort = borzaja, Pol. chart, S-C hrt, etc. Moszyński's hypothesis (1957: 136) that it comes from *szrtz 'fast' (PIE *ser- 'strömen, sich rasch und heftig bewegen', e.g., OI sárati 'fliesst, eilt, jagt wornach, verfolgt', etc.; Pokorny, 909) through sandhi, i.e., after $i, u, r, k$, is not necessary if we accept the possibility that the word is of Iranian origin: PIE *sr-tó- (a verbal adjective) $>$ *hrta-, etc. 
Here I would like to remind the reader about a set of characteristic words of Iranian origin: *korgujb, rarogz, rysb, sapogz and a group of words with the suffix -ogz, starting with the theonym Svarogz (Moszyński, loc. cit., 129-37). These words seem to be related to hunting, horseback-riding, feasting, and war, which are all typical activities of an aristocratic warrior class.

16.) *xýnqti 'bend', attested only in Polish and North Russian, but its obvious derivatives $x y l b$ adj. 'geneigt, gebeugt, etc.' and $x y l i t i$ (from $x y l z$ ) are known in all the principal Slavic languages. Compare Russ. dial. xínut'sja = naklonit'sja (Vasmer, IV, 238), Russ. xilyj // xilój 'weak, sickly' (primarily 'bent'), xilit' 'bend' (ibid., 236); Pol. chynać 'neigen' (cf. the examples in Brückner, 1927: 188, however, with an incorrect etymological explanation !), chyły, pochyły 'schief, abschüssig, etc.', chylić = chynqć (for other Slavic languages see Berneker, 413 s.v. chylb, chyl'o, chyliti). Besides the derivative $x y l s>x y l i t i$, we can also establish the parallel $x y n z$ $>$ xyniti, e.g., OSerb. hina 'Betrug' from which híniti 'betrügen, heucheln', Sloven. hiniti idem, but Russ. dial. xínit' 'tadeln, schelten' (Berneker, ibid.). In the latter cases the semantic development from 'to bend' $>$ 'to scold' or 'to cheat' seems to be quite obvious. In any case, in all the above words we are dealing with derivatives of the basic xynqti, which itself, because of its initial $x$-, seems to be an Iranian loanword, namely from Iran. (Av.) hav- 'antreiben, in Bewegung setzen' (Bartholomae, 1782). The present tense of the Av. verb is huna- and $x^{\mathrm{v}} a n u-$, the latter representing the IE *-neu // -nu present, which is also indirectly continued by the Slavic -nqti verbs. The perf. pass. participle is hüta-, which clearly indicates a primary IE *seuH-; this would account for the Slavic $y$ $\left({ }^{*} x y n q t i\right)$, not $z\left({ }^{*} x z n q t i\right)$. The meaning of the IE root is reconstructed by Pokorny (914, s.v., seu- : su-; seuə- : sū- ${ }^{3}$ ) as 'biegen, drehen, antreiben'. Of course, we could also accept the generalization of the sandhi forms with $x$ - after the "loose" preverbs in $-i,-u,-r$, e.g., *per-synqti $\geq$ *per-xynqti, etc., but this seems less probable in view of the preservation of the original $s$ - in most verbs with such preverbs.

17.) xúla 'blasphemy', attested in ORuss., Ukr., Bulg., S-C, and indirectly in OCz. chúlost; and xuliti 'blaspheme', attested in the above East and South Slavic languages, and undoubtedly with the primary meaning in Czech chouliti 'neigen, bücken, kauern', Slovak chúlit' sa 'sich ducken, sich bücken', Sloven. húliti 'biegen, neigen', and S-C hüliti se 'contrahendo inclino me vel incurvo'. The above semantic difference may be due to the special development of xula and xuliti in OCS and its subsequent influence on the other languages. In any case, Berneker's etymology connecting the above words with the verb xynqti, etc. (Berneker, 406) seems to be the only plausible one (as opposed to 
Machek, 1938-39: 213-14). The Serbo-Croatian and Czecho-Slovak evidence (S-C hüla, hüliti, $\mathrm{OCz}$. chúlost, $\mathrm{MCz}$ chouliti, Slovak chúlit' sa) support the reconstruction *xúla, *xúliti with the old acute on the first syllable, i.e., with the primary long diphthong *xoula (or rather * $x \overline{\bar{\nu}} u l \overline{\bar{y}}$, from an early Iranian *hauz- ?). In any case, the noun *xúla would be a derivative with the suffix -la (cf. mbg-la, tes-la, etc.) from the verbal root discussed under number 16 in its full vocalism: *seuH- $\geq$ early Iran. *hauว-, etc.; or, perhaps, the whole word was borrowed very early from Iranian, in which case we could speculate about an Iran. *hau(a)-ryā (for this suffix cf. Lith. siaüras $\leq$ *seu-ro- 'schmall, eng', quoted under *seu(a)by Pokorny). Ultimately we could even establish an antonym opposition *xvalà : *xúla (i.e., Iran. *xväryá : *hau(a)ryā, of course, with the Alanian $l$ $\leq r y$ ). That the laryngeals can be traced back in prehistorical Slavic borrowings from the adjacent IE dialects is proven by Proto-Slav. (or rather Balto-Slav.) *kórva ( $\left.{ }^{*} k \bar{a} r u \bar{a}\right)$ from a kentum *korHūā, etc. The verb *xúliti seems to be a regular derivative from *xúla. The semantic connections between *xy-nq-ti and *xú-l-i-ti are obvious if we start from the basic meaning of the verb 'to bend'.

I have devoted more space to the above word because it seems to belong to the religious vocabulary so characteristic of the prehistorical Slavic borrowings from Iranian (or prehistorical Slavic-Iranian lexical correspondences). Perhaps we could even treat the pair xvalà : xúla as a dualistic religious opposition parallel to that of bogz: divz (xvalà is due to bogz, xúla to divъ ?).

18.) rysb 'lynx', known in most Slavic languages, e.g., Russ. rys', gen. rýsi; S-C rǐs, gen. rǔsa; Pol. ryś, gen. rysia, etc. Here we find another phonemic feature characteristic of Iranian against a comparative-historical IE background, the regular replacement of primary IE $l$ by $r$. In view of the obvious correspondences in other IE languages with the initial $l$ - (Lith.

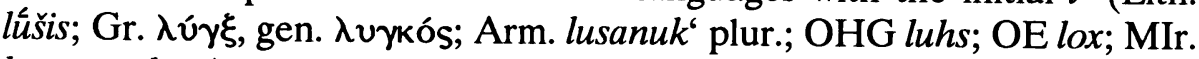
lug, gen. $\log a$ ), the best interpretation of the Slavic $r$ - is that which assigns it to Iranian influence, although for the time being no corresponding word has been attested in Iranian (Vasmer, III, 530-31; Pokorny, 690, s.v. leuk'-; and especially Moszyński, 1957:132).

19.) čara 'furrow', attested only in West Slavic: Cz. čára 'Linie' (from which čárati and čáriti 'Linien ziehen'), ULus. čara 'Furche; Strich, Linie; Durchhau, Wildbahn im Walde', LLus. cera 'Furche' (Berneker 136). This is another word whose rotacism (i.e., $* l \geq r$ ) seems to prove its Iranian origin. This hypothesis is based upon the correspondence between the above Slav. word and the following Iran. examples: Av. čaraiti 'versatur, obliegt einer Tätigkeit', čarāna- 'Feld', and with a primary $o$-vocalism käraya- (iterative) 'einfurchen, (Furchenstriche, 
-streifen) ziehen' (but with a primary $e$-vocalism in Sarikolī, a Pamir dialect, čaram 'bebaue das Feld'). There is also OI cárati // cálati 'bewegt sich, wandert, weidet, treibt' and čāra- m. 'Gang'. All the above Aryan words represent PIE ${ }^{*} k$ u $e l(a)$ - (or ${ }^{*} k e l(H)$ - in our reconstruction) 'drehen, sich drehen, sich herumbewegen' (Pokorny 639). It is interesting that the agricultural meaning has also been assigned to this verbal root in Latin colō 'bebaue, bewohne'. The restriction of čara $\left({ }^{*} k \bar{e} r \bar{a}\right)$ to West Slavic harmonizes with a group of other Iranian loanwords limited to this branch of Slavic, as established by Trubačev (Arntz 37, Zaliznjak 34, Bartholomae 450).

The group of Iranian loanwords characterized by special Iranian derivational suffixes is controversial. K. Moszyński in his 1957 book (129-ff.) ventures the hypothesis that among the words with the suffixes -ogo-, -ago- (allegedly from Middle Iranian -ăga- $\leq *_{-}$ăka-) we have Iranian loanwords at least in some cases from which these suffixes were abstracted and then used in Slavic derivation. Here belong as Iranian loanwords:

20.) sapogz (e.g., Russ. sopóg, sopogá) 'top boot', known in Russian

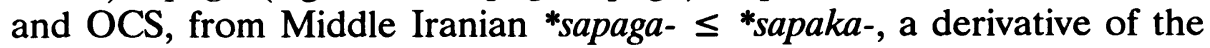
Iranian name for 'hoof' - *sapha-, cf. Av. safa- (for a convincing explanation see Trubačev, Ėtimologija 1965:40). The Slavic $a$ in the first syllable would rather indicate a variant with a long $\bar{a}$ in Iranian (?), attested otherwise by Germanic, e.g., OE hōf, OIc. höfr, OHG huof (Pokorny, 530).

21.) črbtogz 'Schlaf-, Brautgemach, Kammer', attested in OCS, whence it was borrowed by Russ. (čertóg), Ukr. (čertóh), and OSerb. (črtog, črtag). It is usually interpreted as Pers. čârtāk 'balcony' which reached Slavic through Turkic Bulgarian; a younger form would be Russ. čerdák, South Slavic čardak (Vasmer, IV, 348). But if we accept Moszyński's suggestion that ${ }^{*} \check{c}$ brtogz may be connected with Ossetic kart 'court, courtyard', then we could posit an Iranian *kartaka- // *cartaka- $\geq$ Middle Iranian -aga-, etc., and attempt to derive the Slavic word from the second Iranian variant. However, the whole argument is highly hypothetical. So we are left with only one sure Iranian loanword among the words in -ogz (if we neglect the theonym Svar-ogz, whose etymology is rather obscure; about the latter see p. 328-31). Other Slavic words in -ogz, e.g., batogz 'whip', ostrogz 'palisade post', pirogz 'cake, wedding cake', etc., have clear Slavic etymologies, not only with respect to their basic stems (batz, ostro, pirb), but also with respect to the suffix itself, which is original Slavic (see Sławski, 1974, I, 67).

Now we should move on to such words which are explained as Iranian loanwords in Proto-Slavic because of their etymological isolation in 
Slavic, whereas they are well motivated within Iranian (or Indo-Iranian). These are very often separate items which do not form any definite semantic groups. But at the very beginning of the list I would like to discuss an example which ever since Meillet has been considered by most Slavists as a loanword from Iranian, the noun topor 'hatchet' (cf., e.g., Russ. topór, gen. toporá; Bulg. topór; Pol. topór, etc.; Vasmer, IV, 79-80). In spite of its obvious motivation in Slavic (tepg, te $(p) t i$ 'beat' $>$ top-orb like *stebljo, stebati ' *stab ?', 'beat, whip' > stob-or 'post, column' - cf. Lith. stem̃bti 'Stengel ansetzen', stãbaras 'trockener Ast' - and perhaps like Lith. gaujù 'heule' > Slavic gov-orı 'speech') and the complete lack of such motivation in Iranian, or generally in Aryan (the verbal root tep'beat' is Balto-Slavic !) it has nevertheless been treated as one of the most certain Iranianisms in Proto-Slavic, allegedly borrowed from OIran. *tapara-, which is continued by Middle Pers. tabrak, New Pers. teber, Beluchi tapar, etc. (for details see Vasmer, loc. cit.; for a convincing criticism of the Iranian origin of topors see M. Rudnicki, Slavia Occidentalis, 1960, XX(1): 85-88; for the formations with the Slavic -orb see Vondrák, 1924, I, 561, and Sławski, 1976, II, 24-25). In view of all the above facts I subscribe to the hypothesis adumbrated by M. Rudnicki that Iran. *tapara- is in fact a loanword from Slavic borrowed at the time of Scytho-Sarmatian and Slavic contacts in the Ukraine. This hypothesis seems to be well justified: the hatchet is a typical weapon of pedestrian peasants, as opposed to the saber and lance, the weapons of horsemen. Here I should mention a younger Iran. loanword in Slavic, through a Turkic intermediary: kor(ъ)dъ/a, e.g., Russ. kórda, Pol. kord, S-C kôrda, etc. 'short (curved) sword' (Vasmer, II, 324).

The problem of Iranian loanwords in Proto-Slavic (i.e., in prehistorical Slavic, even in dialects !) has been the subject of discussion by many scholars. Among relatively recent treatments that by O.N. Trubačev (Iz slavjano-iranskix leksičeskix otnošenij) seems to be the most convincing. So I shall simply quote a list of words which in Trubačev's and my opinion represent loanwords from Iranian:

22.) kotz $\rightarrow$ kotbcb, with the basic meaning 'shed or pen for small domestic animals' from which all other meanings can be derived, but in Church Slavic (12th cent.) kotbcb 'cella'; attested in most Slavic languages, e.g., Russ. kotéc, usually in the plural kotcý 'weir for fishing', S-C kôt, gen. köta // kòtac, gen. kòca 'small shed for lambs, kids; coop', Cz. kot, kotec 'cottage, cabin', etc. This seems to be a migratory culture word whose source is Iran. kata-, cf. Av. kata- m. 'Kammer, Vorratskammer, Keller', probably related to the OI adjective catant- 'sich versteckend'. In spite of Bartholomae's objection it should first of all be compared with the Av. verb kan- 'graben', perf. pass. participle kanta-; perhaps kata- represents 
*knto- and its primary meaning would be 'dugout' (?); see Vasmer, II, 351-52.

23.) gunja, the primary meaning seems to be 'fur coat'. The word is attested in most Slav. languages, e.g., Russ. gúnja 'alter abgetragener Anzug; alter Halbpelz', Ukr. húnja 'grober Tuchrock', Pol. gunia “grobe wollene Decke; Kotz; Mantel aus grobwollenem Zeug', Bulg. gúnja 'Mantel von Ziegenhaar', S-C gûnj, gen. gúnja (sic!) 'Art Oberkleid', etc. It is most probably an old borrowing from Iran. *gauna-, cf. Av. gaōna- n. 'Haar'. Because there are variant forms with a hard $n$, e.g., Bulg. gúna 'Pelz' and Russ. gúna = gúnja, the forms in -ja can be a Slav. derivative of the type koža from koza (see Berneker, 363; Vasmer, I, 475; and Moszyński, Język Polski, 1956, XXXVI:198-200).

24.) *gzpanz 'lord', only West Slavic, e.g., OCz. hpán, Pol. pan, etc. from Iran. 'gu-pāna- // *gau-pāna- 'cattle guard', cf. e.g. Afghan yōba 'cowboy' and compounds of the type *šsu-pāna- 'shepherd' in Iran. languages, e.g., Afghan špa, špūn, NPers. šubān, etc. (Trubačev, loc. cit., 73-75). The semantic shift from 'shepherd' (probably 'main, chief shepherd') to 'master, lord' seems to be quite obvious under the conditions of social dominance of shepherds-warriors over farmers-tillers. The word has nothing to do with županı 'governor of a province', which seems to be derived from župa 'region' (Vasmer, II, 65-66). But there is also a high probability that both *gъpanı and županı are native Slavic derivatives of *gzpa and župa 'dugout'.

25.) *ob-ačiti $\rightarrow$ bačiti 'watch, guard', only Polish obaczyć, baczyć from Iran. *abi-āx̌̌aya-, e.g., Av. aiwyāxšaya- 'watch, guard', etc. (Trubačev, loc. cit., 44-47). According to Trubačev it is not a direct lexical borrowing, but rather a kind of calque linguistique from a genetically related language which operates with corresponding morphemes.

26.) 'patriti 'look', only West Slavic (Pol., Cz., Slovak, traces in Croatian), e.g., Pol. patrzyć, from Iran. *pätray-, cf. Av. infin. pä日räi 'zu hüten, schützen, schirmen' (Trubačev, loc. cit., 45-46, 50-51, and Bartholomae, 888). We are dealing here with an old denominal verb from the noun *pātra- 'Schutz, Schirm', e.g., Av. adj. pä日ra-vant- 'Schutz-, Schirm gewährend' (Bartholomae, ibid.).

27.) *šatriti 'watch' $\rightarrow$ 'guard'; West Slavic (Pol. and Cz., and Slovak from Cz.) with traces in Slovenian and Croatian, e.g., OPol. szatrzyć się 'watch out', dial. szatrzyć 'know, understand', Cz. šetriti 'guard, save, preserve', etc. - from Iran. *xšatraya-, a denominal verb based upon Iran. x̌̌atra-, cf. Av. xša $\theta r a-$ 'imperium, regnum, Herrschaft, Reich' (Bartholomae, 542, etc.). The semantic development in Slavic can be understood if we start from šatriti as 'dominer du regard' $\rightarrow$ 'watch in a special (commanding, etc.) way’ (Trubačev, loc. cit., 51-55). The form of 
the verb with $a$ instead of the expected $e,,^{3}$ should be explained as analogical to patriti.

Among the above Proto-Slavic words of Iranian origin a special group is formed by those which are restricted to West Slavic, particularly to Polish and Czech. These are the following: *gzpanı (?), *ob-ačiti (?), *patriti, *šatriti. The credit for having called attention to such prehistorical Iranian loanwords in West Slavic belongs to Trubačev. In his essay quoted above he has more such examples, but I have selected and listed only those with the most convincing Iranian etymology. I have also omitted words which according to the author represent old parallelisms or correspondences in both linguistic groups, such as *pitvati 'cut,' *trøvati 'last,' tušiti 'hope.' These words are discussed in Chapter III (The Stratification of the Proto-Slavic Vocabulary).

But before drawing any more general conclusions from the Iranian loanwords in Slavic, I would like to mention two more probable, although controversial Iranian borrowings in West Slavic, to which Trubačev devotes several pages of very interesting and stimulating remarks. I mean here the pair *rarogz and *počbvara. The former is attested in Pol. raróg 'a kind of falcon (Russ. saryc); monster,' Cz. raroh 'the most predatory kind of falcon,' Slovak rároh = Russ. krečet (Ukr. rárih is borrowed from Polish). The latter is attested only in Pol. poczwara 'monster, evil spirit, nightmare' and has a parallel in Lithuanian áitvaras 'nightmare, flying ghost, dragon', which is also suspected of Iranian origin. Trubačev sees the source of the two above West Slavic words in the Iranian mythological pair *(pati-)vāra- 'flying dragon, evil ghost' : *vāragna(God) dragon-killer' (for details see Trubačev, loc. cit., 64-71). Of course, the corresponding terms in Slavic, particularly rarogz, changed their meaning considerably, but indirectly they can still be connected with their Iranian mythological model (e.g., in Czech the derivatives of raroh - rarach, rarášek mean 'evil ghost, devil,' 'ghost provoking wind and flying in its whirl,' etc.). It should be emphasized that the belief in a winged dragon and in the victorious struggle with him by mythological heroes (e.g., Pol. Krak) seems to be a vestige of Iranian influence among the Slavs (K. Moszyński, 1967, II, 1, 578-80). However, there are some linguistic difficulties (phonemic and morphological) which do not allow us to accept Trubačev's (and as far as *rarogz is concerned, Machek's) hypothesis about the Iranian origin of these two words. Nevertheless, the hypothesis remains very attractive, and it is well situated in the whole context of linguistic-cultural contacts between the Proto-Slavs and the Iranians.

In the above discussion of the Iranian loanwords in Slavic I have omitted proper names, because their etymology usually entails more 
difficulties and uncertainties than that of common nouns. There is, however, an ethnicon that for serious phonemic and morphological reasons seems to be of Iranian origin: the ethnicon ${ }^{*} X$ rrvate/i, i.e., S-C Hrváti, Hrvate in older sources (nom. plur.), Hrvâtâ (gen. plur.), and Hrvatin (nom. sing. in older sources).

Since the Iranian etymology of this ethnonym is only a hypothesis, on equal footing with other hypotheses about its Slavic and Germanic origin, I feel obliged to devote a separate excursus to this problem.

\section{Excursus 1: The Puzzle of the Ethnicon Hrváti}

1.) First, we should reconstruct the primary, i.e., PSl. form of the ethnicon. On the basis of the following facts:

a.) S-C Hrivāt, gen. Hrváta, plur. Hrváti (old Hrvate);

b.) ORuss. Xorvate, Xrovate, Xrvate, Xrbvate;

c.) OCz. (from OPol.) Charvaty (as a toponym);

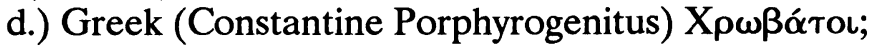

e.) Latin Chrouati (10th-11th cent.), also Chruvati vicus (in Thietmar referring to a Lusatian territory, known now as Klein-Corbetha) from North West Slavic *Xrovat- $\leq$ PSl. *Xorvat- (?);

f.) Greek toponyms: X $\alpha \rho \beta \alpha$ tı and so forth (in Vasmer's Slaven in Griechenland, where $\alpha \rho$ seems to stand for an unmetathesized Slav. tart, cf. Г $\alpha \rho \delta$ ík for *gardbkb, etc.);

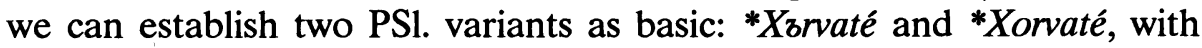
the primary consonantal-stem plural in a stressed $-\dot{e}$.

In all early medieval sources various forms of this ethnicon refer first

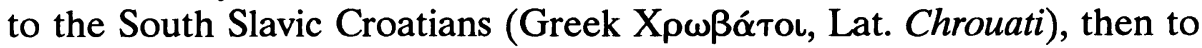
the sub-Carpathian Croats in the Upper Dniestr basin (an East Slavic tribe in the Povest' vremennyx let: Xorvate, etc.) or to the Croats in the Polish-Bohemian borderland in the region of the Sudeten (OCz. Charvaty, etc.), and once to a tribe on the Upper Sorbian territory (Thietmar's Chruvati). These facts, supported by a clear statement in Porphyrogenitus, seem to indicate that the South Slavic Croatians represent the main branch of a prehistorical Proto-Slavic tribe whose primary habitat, before their migration to the Balkans, was located north of the western Carpathians.

2.) For any linguist acquainted with comparative historical Slavic grammar the very form of the ethnicon ${ }^{*} X z r v a t e ́$ provokes the suspicion that it is of non-Slavic origin. First, the original Slavic character of the initial $x$ - would be justified only in the case of PIE *ks-, which is quite a rare case. Second, the derivational form with a consonant-stem suffix is also rather exceptional in the Slavic material (among Slavic ethnica I 
would quote here as possible parallels *Venete/i and Veleti). Therefore it is no wonder that most Slavists have proposed a non-Slavic etymology for *X̋rvaté.

3.) Here I will briefly discuss the existing etymologies, reject them, and propose a new one which seems to meet the requirements of exact historical-comparative methods.

a.) Iranian etymology, recently supported by Trubačev (Ètimologija 1965:32).

Variant i) Sarmatian personal name Xopó $\alpha$ Oos, Xopova $\theta$ os (in Tanais), 2 nd-3rd cent. A.D., i.e., *HurvaAa'bonus amicus' - but then we should expect ${ }^{*} X$ ¿rvot- or rather a patronymic form ${ }^{*} X z r v o t-i t j i$, i.e., S-C ${ }^{*} X r v o t i c i$.

Variant ii) Av. haurvatāt- // haurvāt-, i.e., *harvatāt- // *harvät- 'totality,' etc. (from *harva- = Lat. salvus) - but then the only form in Slavic would be *Xorvat-, although semantically there are interesting parallels in Germ. Allemannen and, with a reversed semantic order, in Oscan touto 'civitas,' Umbrian tota 'civitas' as opposed to Lat. totus, $-a,-u m$.

b.) Germanic etymology, based upon a phrase Hárvaða or Hærvapa fjöll, i.e., 'Berge der Chorvaten' (according to R. Heinzel's interpretation), in the Old Scandinavian Hervararsaga, a passage referring to the Carpathians, with which the primary Croats, *Xırvaté, were closely connected, as we have mentioned. But what is the Germanic source of Harvaða // Hærvapa, i.e. PSl. *Xorvaté, cannot be established: its interpretation as a Germanized

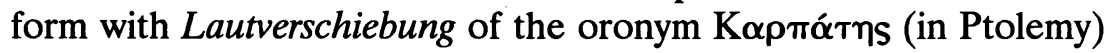
is semantically inexplicable and highly improbable in view of the bookish and learned character of this oronym, which is unknown in the native linguistic tradition of the Slavs dwelling in the Carpathian region.

c.) The third traditional etymology proposes a Slavic origin of the ethnicon. According to this hypothesis ${ }^{*}$ Xrrvaté // ${ }^{*}$ Xorvaté is related to Lith. šarvúotas 'armored' ('geharnischt'), which in its turn comes from šárvas 'armor' ('Harnisch, Panzer, Rüstung'); so *Xırvaté would mean 'the armored.' But there are serious formal objections to this etymology. First, Lith. šárvas does not continue any $* k s$ - which would result in Slavic $x$-, but rather represents primary IE *k'orHuos, a substantivized adjective from the IE stem * $k$ 'erH-u- 'horn,' and it has obvious correspondences in IE languages, for which see below (cf. here also Gr. kópvs n. 'helmet'; Fraenkel, 965, and Pokorny, 574). In this connection the primary 
meaning of Lith. šárvas would be 'horn-armor,' a type of armor well-known to the ancient East European peoples. An exact Slavic correspondence representing the regular satam treatment of ' $k$ 'should be *sorvz, then *Sorvaté, etc. Second, the Lith. adjectives in -uotas have exact correspondences in Slavic denominal adjectives in -atz (with the old acute), e.g., *bordatz, Russ. borodátyj, etc. In addition, the primary word-final stress and the consonant-stem declension of the ethnicon ${ }^{*}$ Xorvaté // ${ }^{*}$ Xrvvaté does not permit us to equate it with Lith. šarvúotas. Thus the correspondence Lith. šarvúotas PSl. *Xorvaté, etc., is illusory and should be rejected.

4.) Now, after this criticism of existing etymologies I shall propose a new one which seems to be better substantiated both formally and semantically.

My contention is that PSl. *Xørvat- // *Xorvat- (a consonantal stem!) was derived from a common noun *xzrvs // *xorvz 'armor' (primarily 'horn-armor'), which should be treated as a prehistorical loanword from Germc. *hurwa- // *harwa-, the latter representing the PIE adj. *k'rHuo-

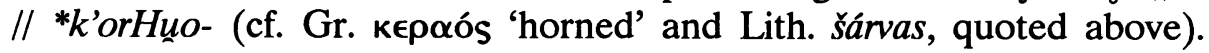
The fact that the historical Germc. languages have not preserved the hypothetical *hurwa- // *harwa- may be merely an accident of history. We know of such cases in the history of languages. For example, there are some Slavic loanwords in Rumanian that have no correspondences in historical Slavic languages (e.g., zăpádă f. 'snow,' from Slav. *zapada, etc.). Of course, other derivatives of the root ${ }^{*} k$ 'erH- are known in Germanic, first of all the noun *hurna = horn. The PIE adjective ${ }^{*} k^{\prime}$ erHuo- (full vocalism) // ${ }^{*} k^{\prime} r H u o-$ (zero vocalism) is well attested in many IE languages; as is well-known, Balto-Slav. *kärua $\bar{a}-$ 'cow' with an exceptional kentum treatment of ${ }^{*} k$ '- belongs here too (see Pokorny, 576).

Some interesting traces of the borrowed PSl. *xzrvz can be found in West Slavic, specifically in Polish. The most important is OPol. (1494 in the Poznan city-book) charwat 'miles in servitio civitatis,' which seems to represent an adjective with the suffix -atz from the hypothetical *xzrvz, but is not the exact counterpart of the ethnicon because from a primary stem in $-t$ we would rather expect *charwać, cf. paznokieć, tokieć, dziesięć. Another one is Slovak (with the Polish treatment of *tzrt) charvat' sa // charvit' sa 'defend oneself,' charva // charvanie 'defense.' There are also two Kashubian words: charwatynia 'abandoned cottage,' primarily 'sentry shelter' (?), also a place name, and charwańc ("xzrvanbcb) 'sheaf of grain full of weeds,' probably a derivative from *charwać 'protect' and primarily meaning 'a sheaf used to cover the top of a shock.'

All these lexical facts seem to indicate the existence in the Northwest 
PSI. dialects of the noun *xzrvz 'armor' and its derivatives *xъrvati se // *xzrviti se 'get armored' $\rightarrow$ 'defend oneself.' In this connection we should also mention some toponyms in Poland that seem to continue the ethnicon ${ }^{*} X$ rrvat- in its third variant ${ }^{*} X r b v a t-$ (e.g., OPol. Chrwaty, etc.), which is well substantiated by the phenomena of the historical phonetics of Germanic. Other toponyms continuing the most frequent variant ${ }^{*} X$ rrvat - are known in Northern Bohemia and Northern Moravia. All of them, incidentally, represent the Polish treatment of the primary *tzrt as tart: Charváty.

The geographical distribution of these linguistic facts would clearly point towards the primary location of the prehistorical Croats ( $\left.{ }^{*} X ъ r v a t e ́\right)$ north of the Carpathians on the historical South Polish territory (Małopolska) and towards a subsequent emigration of their main bulk south through the Moravian Gate. We can even hypothesize that the borrowing of the Germc. *hurwa- 'horn-armor' took place somewhere in the sub-Carpathian region, and that its source was the PGermc. dialect of the Bastarnians, who dwelt along the eastern Carpathians in the first to third centuries A.D.

What still remains to be explained is the derivational type of the ethnicon ${ }^{*} X$ rrvat-e, etc., i.e., its consonant-stem suffix -at-. The consonantal stems with the PIE suffix -et- (admitting the vowel gradation -ёt- // -ŏt-) are rare in Slavic: the only sure example is pečatb $\mathrm{m}$., gen. pečate 'seal.' Among the Slavic ethnica we can quote *Venete/i and Veleti, both derived from verbal roots *uen $(H)$ - 'desire; win' and *uel- (Slav. velěti) 'command.' But comparative IE evidence indicates that there were also denominal derivatives with this suffix (-et-: Lat. equus $\rightarrow$ eques (gen. equitis) 'horseman, horse-soldier' (*equet-s), pes (ped-) $\rightarrow$ pedes (gen. peditis) 'pedestrian, foot-soldier' (*pedet-s), miles (gen. militis) with no

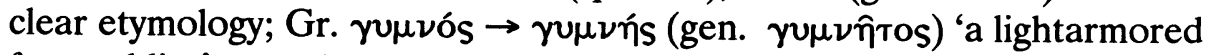
foot soldier' can also be quoted here. So the derivation of ${ }^{*} X z r v a t-/ /$ ${ }^{*} X o r v a t$ - from *xъrvъ // *xorvъ with the PIE suffix -ōt- (PSl. -at-) seems to have sufficient substantiation. Of course, it must have been an old and not very productive process.

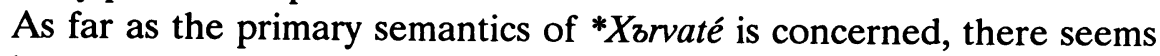
to be no doubt that it originally meant 'warriors clad with horn-armor' and may not have been a name used by a certain tribe for self-identification, but rather a description applied by the neighbors of a tribe whose characteristic feature was the use of horn-armor. It is also possible that ${ }^{*} X z r v a t-$, etc., also denoted a warrior-class as opposed to plain folk, the latter participating in war without armor. These suppositions would explain why just on the territory where we should locate the prehistorical *Xırvaté // ${ }^{*}$ Xorvaté, i.e., in Southern Poland, 
there are no traces whatsoever of the ethnicon in the local early medieval chronicles and other sources. In any case, a primary descriptive and exogenous (i.e., used by the neighbors) name of the tribe known later in history as $C(h)$ rovati, X $\rho \omega \beta \alpha$ tou, Hrváti, in the course of time became an ethnicon, adopted ultimately by this tribe itself, which is expressed clearly in the official title of the first Croatian ruler: Trpimirus dux Chroatorum (852 A.D.).

Another PSI. proper name, in this case a theonym, which many scholars have considered an Iranian borrowing, is Svarogz and its patronymic derivative *Svarožit'b (cf. ORuss. Svarógz, defined by Ivanov-Toporov, 1965:28, as the father of Dažbbogz - Svarožičb, and the great-grandfather of the Old Russians). He is intimately connected with fire, and therefore in the translations he is identified with the Greek Hephaistos and Helios; his attribute is the ram. This theonym is also attested among the Western Slavs, specifically among the Polabians: Zvarisici = Svarožic "deus Sclavorum in Rethra" according to Thietmar, and defined by Ivanov-Toporov (1965:44, under Svarožič-Radgost) as the main deity of the Ratarians (*Ratar'e 'warriors'), the leading tribe in the Lutician federation. He is a god of war (like most Polabian deities!), and his attributes are the horse, battle insignia, weaponry, horns, and the boar. Other traces of Svarogz in West Slavic and South Slavic (?) toponymy can be neglected; for details see Vasmer, III, 569-70.

There is no doubt that, besides Perunz, Svarogz represents the second certain Proto-Slavic deity. Therefore its possible Iranian etymology acquires special significance. Before I attempt a criticism of the most widely accepted Iranian etymology of Svarogz and propose another explanation, which also operates with a basic Iranian element but of different origin, I will quote the opinion of K. Moszyński, who in the book (1957:87-88) which I have quoted many times already, when discussing Slavic-Iranian lexical correspondences, once again clearly stated his conviction about the Iranian origin of Svarogz:

"There is one more connection joining the religious-ritual vocabulary (sensu largo) of the Aryans and the Slavs. In this case, however, we are already dealing with a clear borrowing by the Slavs from the Aryans. I mean here the only theonym (except for the name of Perunz) which can with great probability be considered Proto-Slavic, namely *Svarogz. If one trusts the Hypatian chronicle completely, then one can assume that the Slavs (at least the Northern Slavs) worshipped under the name of Svarogz a fire deity or a solar deity, who in the course of time embodied in himself both the 
deified great "celestial fire" (i.e., the sun) and the usual terrestrial fire. The word *Svarogz was formed by means of the suffix -ogo-, which as we will soon see is of foreign, Scythian origin. But the root svar-also has correspondences in Aryan: Sogdian $\operatorname{spar}^{\circ} \boldsymbol{\gamma}$ - 'shine, gleam,' Av. hvars 'sun, light, sky,' OI súvar, svár idem, Svarita. As the etymology of these Aryan words indicates, the phoneme $r$ continues here the IE $l$, which is regularly preserved by the Slavs in their original words; hence the correct conclusion is that the name *Svarogo is rather of Iranian, specifically Scythian origin. The root vocalism of the word, which is not what we would expect in comparison with the Iranian loanword toporb, can easily be explained, for example, by the influence of the words *svariti (se), *svarz, *svara, which is very common among the Slavs (especially in the area of beliefs; I myself recorded from a Polesie fisherman on Lake Kniaź: 'Boh svàrycsa,' pronounced about thunder; similarly the Polish peasants used to say: 'Bóg sie swarzy'). The cause of the difference may be the different time of the two borrowings (*topor earlier, *Svarogz later), etc."

Moszyński's etymology confuses two different Aryan words, representing two different IE roots: on the one hand Aryan svar- (in Iranian regularly hvar- in connection with $s \geq h$ ), which continues IE *suel- 'schwellen, brennen,' e.g., OI svárati 'leuchtet, scheint,' svargá- m. 'Himmel,' this root undoubtedly being related to the IE name of the sun *säuel- (see Pokorny, 1045, 881) - and on the other hand Aryan *(s)p(h)arig- (?), represented by OI sphúrjati 'bricht hervor, kommt zum Vorschein,' parāgas 'Blütenstaub,' Av. sparaga- 'Sproß' ("von den Widerhaken unterhalb der Pfeilspitze"), frasparaya- 'Schößling, Zweig,' and by Sogdian 'spry-, reconstructed by Gauthiot as ${ }^{\circ} s p a r^{0} \boldsymbol{\gamma}$ - 'briller, fleurir, jaillir, ${ }^{4}$ (all of which continue IE ${ }^{*}(s) p(h)$ ereg-, ${ }^{*}(s) p(h)$ erag'streuen, sprengen, spritzen' (see Pokorny, 996-97).

It is obvious that Moszyński's identification of OI svar- (svargá- 'sky'), Av. hvara 'sun,' etc., with the Sogdian ${ }^{\circ}$ spár ${ }^{\circ} \gamma$ - 'bloom' (sic!), then 'shine' is wrong: he simply did not check all the relevant data in the Sogdian grammar by Gauthiot and Benveniste. From a primary IE *su-we must regularly have $h v$ - in Iranian ( $x v$ - in Sogdian). So there is insufficient ground to derive PSl. Svarogz from Iranian. If we accept a hypothetical Aryan *svar-aka- 'sunny, shining' (?), i.e., Iranian *hvaraka- or Middle Iranian *hvaraga-, then we would expect PSl. *xvorog-, but the form we actually have, Svarogz, cannot be in any way connected with that posited 
Iranian model. The whole Iranian etymology of this theonym is void of any linguistic (historical-comparative) background and should be rejected. However, the old Slavic etymology deriving Svarogi from svars (e.g., OCS svarb 'fight'), whose basic meaning in most Slavic languages seems to be 'quarrel,' which is supported by the IE etymology of the word (Vasmer, III, 569), does not satisfy us either from the semantic standpoint: Svarogz is not a war-god. ${ }^{5}$ So the idea that the name suggests a relation with quarrel, fight seems to be unjustified. Therefore I propose another etymology, which can be briefly presented as follows.

I would derive this theonym by means of the Slavic suffix -ogo (for the Slavic character of this suffix see F. Sławski, Słownik prasłowiański, I, 67) from the Iranian *svära- 'strong, powerful' $\rightarrow$ 'hero, lord.' The Iranian word is posited on the basis of copious IE material: OI sávira- (instead of *śavira-) 'stark, mächtig,' śüra- 'kräftig,' usually 'Held,' śvātrá- 'gedeihlich, kräftig'; Av. sŭra- 'stark, gewaltig' (according to Bartholomae, about men and gods and with the genitive 'gebietend, Herr'); the Aryan root variant

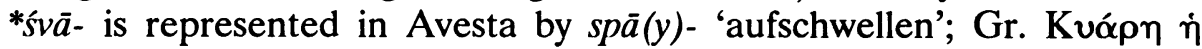
A $\theta \eta \nu \bar{\alpha}$, Hesychius (the primary meaning 'die Starke'; an apophonic

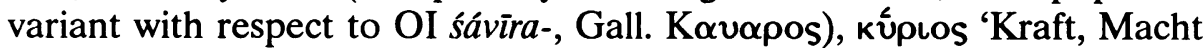
habend, herrschend, maßgebend; Herr'; the root-variant * $k$ 'una- (like OI śvä-trá-) is attested in the Dorian aorist $\pi \hat{\alpha} \sigma \alpha \sigma \sigma \theta \alpha$ 'Verfügung, Gewalt über etwas bekommen'; Gaulish anthroponyms Kavopos Cavarillus (from *covaro- = OI śavira-), Welsh cawr (*cawar), Corn, caur 'Riese,' Middle Ir. nom. plur. cōraid 'Helden'; and finally Lith. (with the IE suffixes -no-, -neu-, šaũnas, šaunùs 'derb, tüchtig.'

All the above facts are quoted by Pokorny (592-93, s.v. k'eu-, k'euz- : $k^{\prime} \bar{u}$-, $k^{\prime} u \bar{a}-$ 'schwellen, Schwellung, Wölbung...'), where the PIE adjective ${ }^{*} k$ 'oua-ro-s : *k'ü-ro-s 'geschwollen, stark, Held' is also reconstructed. The IE variant * $k^{\prime} u \bar{a}$-ro-s (i.e., ${ }^{*} k^{\prime} u e H_{2}$-ro-) of the adjective is highly probable: cf. OI śvā-trá- and Gr. Kuóp $\eta\left({ }^{*} k\right.$ 'uz-rā- ?). So the Iranian form *svära- (later *spāra-) 'strong, powerful, hero, lord' which we posit as the source of Slav. Svarogz was possible. In this case we would have a perfect PSl. substitution of *svaro- for Iran. *svarra-, and then the extension of the adjective *svar 'strong, powerful' by the nominal suffix $-o g z \rightarrow$ Svarogz 'hero, lord.' Calling a god by a name meaning primarily 'powerful; hero, lord' seems to be quite a banal phenomenon. It may also reflect not the proper name, but a general honorific address-form, perhaps conditioned by religious taboo. In any event, it would be instructive to mention that in Macedonian God is regularly called not Bog but Gospod ( $\leq$ OCS gospodb 'lord,' usually referring to God). The use of Engl. Lord is, of course, similar.

I prefer to derive PSl. svar- (in Svar-ogz) from Iranian because the 
verbal root *k'eu(a)-, etc., with its meaning 'be strong,' is represented in Slavic only by the adjective svętz 'strong, powerful' (so, e.g., in the names *Svętopłlkz, *Svętovitz, *Svętoslavz, etc.), then 'holy,'6 which itself is an old dialectal IE element common to (Balto-) Slavic and Aryan, whereas in Aryan the root is well represented and productive.

In all the essays on the prehistorical relations (contacts) between Proto-Slavic and the North Iranian languages (Scytho-Sarmatian) so far published the point of view represented by their authors has always been one-sided: only possible Slavic borrowings from Iranian have been considered, i.e., the Proto-Slavs have been treated exclusively as the receivers in what was undoubtedly a regular reciprocal relationship. After all, the cultural levels of the Proto-Slavs and the Pontic Iranians were not so radically different as to justify only one-way influence and borrowing, from the Scythians and Sarmatians to the Slavs, but not vice versa. Such a situation occurs rarely, for example when a primitive tribe comes in contact with modern industrial civilization.

So we are fully justified in asking whether there are any traces of prehistorical contacts with the Slavs in those contemporary Iranian languages which directly or indirectly continue the Scytho-Sarmatian group. As is well known, Ossetic, spoken in the central part of the northern Caucasus, represents the only remnant of Alanian, a late Sarmatian dialect. Thus, etymological analysis of the Ossetic vocabulary may be revealing in this respect. To some extent the Iranian languages and dialects located far to the east, Afghan (Pushtu) and the Pamirian group, which are considered descendants of the prehistorical Sakyan, the easternmost branch of primary Scythian, can also be taken into account. For it is possible that some western (i.e., Slavic) elements borrowed, for example, by the Pontic Scythians, spread in prehistorical times far to the east across the Eurasian steppes. Similar far-reaching migration of terms is frequently observed in the cultures and languages of large nomadic-pastoral groups. Of course, the question formulated above could only be answered by an expert in historical Iranian and comparative Indo-European linguistics. Fortunately, in recent times one outstanding Soviet Iranist of Ossetic origin, V. J. Abaev, has devoted to these problems a very revealing book: Skifo-evropejskie izoglossy Na styke vostoka i zapada (Moscow, 1965). As the title of the book indicates, the author is interested in the prehistorical isoglosses connecting Scythian (i.e., the old North Iranian branch of languages, including Scythian, Sarmatian, Alanian, and probably also primary Sakian) and the IE languages of Europe. The author tries to show - and I think he succeeds - that Scythian had many old common isoglosses with Balto-Slavic, Germanic, and Italo-Celtic not shared by other Iranian 
languages. These isoglosses, belonging mainly, though not exclusively, to the lexicon, seem to prove that the Scythian branch of the Iranian languages was autochthonous in Eastern Europe, i.e., it did not represent the "back wave" of the Iranian peoples. I would like to quote a paragraph from Abaev's book, the conclusion of the chapter "North Iranian tribes - the original inhabitants of Eastern Europe" (121-24):

"And just the opposite, everything falls into place once we admit that the Iranian element was present in southern Russia at least from the beginning of the second millennium B.C. Then the process that brought about the formation of Scythian-European isoglosses can be sketched in the following way. After the Iranian ethno-linguistic community in Southeastern Europe dissolved, one part of the tribes which had formed it moved south and east, to Media, Parthia, Persia, and Central Asia. Another part, the ancestors of the future Scythian tribes, remained in Europe and in the course of many centuries developed in contact with the peoples of the Central and Eastern Europe area, including the future Italics and Tokharians. It was in this period that the identity of Scythian within the Iranian language group was determined and numerous Scythian-European isoglosses originated."

For our purposes the analysis of old Slavic-Scythian lexical isoglosses established by Abaev acquires special significance. According to him, "The special Scythian-Slavic isoglosses far exceed in number and weight the special ties of Scythian with any other European language or language group" (loc. cit., 135). Of course, Abaev speaks about isoglosses in most cases without deciding whether a given word, common for example to Scythian and Slavic, ultimately represents an element borrowed in prehistorical times from Slavic into Scythian, or simply continues a dialectal IE element of the contact area. To be sure, in most cases such a decision is even impossible. But I have scrutinized the list of those special Slavic-Scythian lexical isoglosses and I have been able to discover some which can be treated instead as prehistorical borrowings from Slavic into Scythian (i.e., modern Ossetic).

Above I have mentioned that Iranian *tapara- 'hatchet' should be considered a prehistorical Slavic loanword in Iranian, not vice versa (Slavic topors from tepq, te(p)ti has an obvious derivational motivation within Slavic), so we can expect that there will be more such old Slavic loanwords in Scythian and its descendants, first of all in Ossetic. This expectation seems to be fulfilled in the following examples, taken from 
the list of Slavic-Scythian isoglosses established by Abaev:

1) Oss. cæd(æ) (“čata) 'a pair of oxen' PSl. četa, e.g., Russ. dial. četa bykov, Church Slav. četa фó $\lambda \alpha \gamma \xi$, etc. (Abaev, 23).

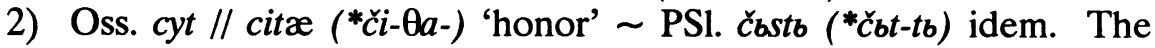
underlying verbal root ${ }^{*} k e i t-$ and its derivative in -ti-, e.g., Av. čisti'Denken, Einsicht,' OI citti- idem, are known in Aryan, but the Oss. word seems to have been affected semantically by Slavic čbstb (see Abaev, 31).

3) Oss. fæxt // fæstæ 'stamping trough,' from PSl. *pěstz, cf. Russ. pest 'pestle,' Pol. piasta 'hub, nave,' and Lith. piestà, piestas 'stamping trough.' Abaev accepts here a borrowing from Slavic (loc. cit., 23).

4) Oss. qælæs // ğælæs 'throat; voice' from PSl. *golsъ (?); Abaev (loc. cit., 19) suggests a borrowing from Church Slavic glass (sic!) which makes no sense. Because of the polnoglasie perhaps it is instead from early East Slavic *golasz.

5) Afgh. rumba 'swelling' PSl. gqba, e.g., OCS gqba 'sponge,' Russ. gubá, Ukr. gúba 'touchwood,' etc. Abaev (loc. cit., 13) quotes only Lith. gum̃bas 'Auswuchs,' but Slavic seems to be geographically closer and ultimately identical semantically: gqba 'any organic excrescence.'

6) Oss. xsyrf // æxsirf (xsirf $\leq$ *sirp-) 'sickel,' undoubtedly borrowed from PSl. *sbrpz (cf. Russ. serp, etc.), although Abaev simply treats it as a Scytho-Balto-Slavic isogloss (loc. cit.). However, the treatment of ${ }^{*} r$ as ir (br) is a characteristic Balto-Slavic innovation (IE *sypo- B-S *sirpa-), and furthermore, the term itself seems to be primarily unknon in Baltic (it is attested only in Latvian, where it may be a Slavic loanword); see in this connection my remarks about Baltic and Slavic agricultural terminology in Chapter III. Ultimately the very fact of the preservation of the IE $s$ proves that the word cannot be an old IE dialectal element of the area continued in Ossetic.

7) Oss. xumætæg, xumætægi 'simple; ordinary, insignificant' (about persons) PSl. kъmetb, e.g., ORuss. kzmetb 'warrior, hero,' Ukr. kmit' 'free, prosperous peasant,' etc. This example is highly controversial because Slav. kъmetb seems to be a late borrowing from Vulgar Latin comite 'companion' (Vasmer, II, 261), and in all Slavic languages it primarily denoted a dignified, not ordinary person (Abaev, 21).

8) Oss. kajyn 'touch' PSl. kosnqti, kasati idem, e.g., Russ. kósnut'sja, kasát'sja; Lith. kasýti, kàsti 'scratch' is etymologically identical (IE *kes-), but semantically remote (Abaev, 15).

9) Oss. $k$ ' yllaw // k'ullaw 'hernia, rupture' PSI. kyla, e.g., Church Slavic and Russ. kyla idem., Lith. kúla 'excrescence.' OHG hōla, OIc. haull 'hernia, rupture' show a different vocalism (Abaev, 19).

10) Oss. lænk // læncæ ('lanka- // *lankja-) 'gully, valley' PSl. *loka, e.g., Russ. luká 'meadow in a river-bend,' Pol. łqka 'meadow,' etc.; and 
Lith. lankà 'Flußwiese; Tal', Tokh. lenke 'small valley.' There are no Aryan correspondences (Abaev, 17). Since the noun has obvious derivational motivation in Slavic, namely: lęko, ${ }^{*} l e ̨ k t i{ }^{7}$ 'to bend' $\rightarrow{ }^{*} l q k a$, *loks 'bend,' etc., and in Baltic as well (see Trautmann, 159-60), it is rather a borrowing from $\mathrm{PSl}$.

11) Oss. mæcyn 'wallow' (in a fluid), e.g., in the curse Dæ tuǵy fæmæcaj! 'May you wallow in your own blood!' PSl. močiti, e.g., Russ. mocit' 'wet,' etc. If it is restricted to cursing, then it may be a borrowing (Abaev, 16).

12) Oss. büræ-mæz 'miraculous glue,' precisely 'yellow ointment,' where the second component equals PSl. mazb (from the verb mazati 'smear'), e.g., Russ. maz', Pol. maź, etc. There are no Aryan correspondences. In my opinion it is a borrowing from PSl. (Abaev, 18).

13) Oss. mit // met 'snow' Slav. nouns derived from the verb meto, mesti 'sweep,' e.g., Russ. dial. za-met' 'blizzard,' Pol. za-mieć idem, Rum. (from Slavic) omete 'snow,' etc. It is a possible loanword (Abaev, 31).

14) Afgh. mēšta 'dwelling place' PSl. město, e.g., OCS město 'Ort, Platz, Stelle,' Russ. mésto idem, etc. Because of Av. maēOana- 'dwelling place' (IE *meit-) and the Balto-Slavic archetype *maista- from the same verbal root (Trautmann, 185, s.v. mintō- 'wohne'). I consider Afgh. mēšta an old Slavic loanword in the Scythian group (Abaev, 13).

15) Sakian pā'sa ("parsa-) 'pig' Balto-Slav. *parša-; cf. Lith. pařšas, PSI. *porsę, e.g., S-C prâse, Pol. prosię, Russ. porosënok idem, etc. The word may represent an old borrowing from Balto-Slavic or early Proto-Slavic (!) parallel to the borrowing of the same noun by the Finnic languages (e.g., Finnish porsas, etc.). As is well-known, the pig is a typical animal of sedentary farmers unknown to the pastoral nomads (Abaev, 12).

16) Afgh. pünda (*pāntā-) 'heel' PSl. pęta, e.g., OCS pęta, Russ. pjatá, S-C péta idem. Lith. péntis is formally more remote because of its $i$-stem. Perhaps, like mēšta, this is also an old borrowing from early Proto-Slavid (through Sakian), although there is a difference in the quantity of the root vowel (Abaev, 13).

17) Oss. stæn (regularly from *scæn-) 'he-dog,' used only in the expression stænmæ cæwyn, literally 'go to a he-dog,' referring to a bitch in heat PSl. *ščen- (*sken-), attested in Russ. ščenók, plur. ščenjáta; ORuss. ščenja, gen. -jate, ščenbcb; Church Slav. štenę, gen. -ęte; Pol. szczenię, gen. -ęcia; S-C štène, gen. -eta, plur. štênci, etc., everywhere with the meaning 'puppy, young dog,' undoubtedly conditioned by the deminutive character of the suffixes $-e ̨ t$ - and $-b c-$. The Oss. word has correspondences in Pamirian dialects: e.g., skan, skanok 'puppy, young dog,' which undoubtedly represents an earlier stage of PSl. ščen-, i.e., 
*sken-. The word may be an old borrowing from early PSI. if we accept its derivation within Balto-Slavic from the verbal root *sken-, cf. Latv. skanêt 'sound,' Pol. szczękać (*sken-k-) 'jangle, rattle' (Vasmer, IV, 502; Abaev, 14 and 21-22).

18) Oss. tajyn 'melt' PSl. tajati idem, e.g., OCS tajati (tajo, -eši), Russ. tájat', etc. There is an exact correspondence, i.e., a stem in $-j-$, only in Slavic (Abaev, 15).

19) Oss. (Dig.) tærfæ 'valley' PSl. *torpъ ?, e.g., Church Slav. trapъ 'fovea, pitfall.' The Slavic word is thus semantically quite different, and besides that the noun is restricted to South Slavic (Skok, III, 491). There is also Lith. tárpas 'Zwischenraum, Lücke, Kluft,' and Tokh. tarp 'swamp, pond' (Abaev, 17).

20) Oss. (Dig.) tillæg 'crop, harvest' (about grain) from PSl. tblo 'soil,' e.g., OCS tblo 'Boden,' etc. Abaev (loc. cit., 24) quotes only Germanic correspondences, e.g., Eng. till ( $\leq$ tilljan), but he does not realize that the Germanic verb is based upon a Proto-Slavic loanword in Germanic: PSI. tblo $\geq$ Germc. *tila, from which the denominal verb *til-jan $\geq$ tilljan, etc., was derived (see Part II of this chapter on Slavic loanwords in Germanic). PSl. tblo represents a regular treatment of IE *telo- with the $\emptyset$-vocalism of the root, i.e., *tlo-, cf. Lat. tellūs, -üris f. 'earth' (Pokorny, 1061). The form of the root in Ossetic indicates a borrowing from Proto-Slavic, which in the case of such a basic agricultural term would not be surprising.

21) Oss. ulæn 'wool' (*ulnæ) from PSl. *vblna or early East Slavic *vъlna, e.g., OCS vlına, S-C vüna, Pol. wetna, etc. idem; Av. varami- 'wool' is formally far remote. It is rather surprising that the name of such an important product of the pastoral economy was borrowed from Slavic, but the borrowing may have been conditioned by barter trade (Abaev, 22).

22) Oss. wældæf 'air,' a compound of wæl 'top' (Russ. verx) and tæf 'spirit' (Russ. dux), an exact calque linguistique of PSl. (?) vzzduxz, e.g., OCS vzzduxz 'Luft, Hauch,' Russ. vozdux, etc. (Abaev, 31).

23) Oss. wīs // wes 'twig' ( *vaiša-) PSl. *věxa, e.g., Russ. véxa, Ukr. vixá, Pol. wiecha, etc. The basic meaning in Slavic seems to be 'stick with a straw bundle atop.' There are also some Germanic correspondences not mentioned by Abaev, e.g., Norw. veis f. (*vaisō-) 'Stengel.' Since in other Iranian languages the parallel derivatives from the same verbal root *uei- 'wind' show the suffix -ti-, this word may be an old borrowing from Slavic, before the early PSl. passage of *uoisā $\geq *^{*} u o i x \bar{a}$ (Abaev, 20-21).

24) Afgh. wraža ('bruša-) 'flea' Balto-Slavic *blusã-, i.e., PSl. *blaxa, e.g., Russ. bloxá, etc. This corresondence has already been quoted by Zaliznjak, who has Afgh. wraža (sic!); see Chapter III (Abaev, 13). 
25) Afgh. zanai (regularly from *zrna-ka-) 'grain' (Russ. zernó) PSl. *zbrno, e.g., OCS zrbno, etc.; Lith. žirnis 'pea' (sic!). An old Scythian-European semantic correspondence, but perhaps ultimately influenced by early Proto-Slavic (Abaev, 13).

26) Oss. zivææ ('zaivaka-) 'lazy, idler' from PSl. zěvati 'yawn' with the Iran. suffix -aka-. The verb is well attested in Slavic, e.g., Russ. zevát', Pol. ziewać, etc., but unknown in Iranian (Abaev, 20).

I have supplemented the above list of Slavic-Scythian lexical isoglosses (according to Abaev) with some additional facts and remarks, which help us to distinguish among these isoglosses words representing probable Proto-Slavic loanwords in Scythian (i.e., historically mainly in Ossetic). As such I consider the following:

1) Oss. cæd(æ) from PSl. četa;

2) Oss. fæstæ from PSl. *pěsţ // *pěsta;

3) Oss. ğælæs from PSl. *golsъ // *golasъ (?);

4) Oss. xsyrf from PSI. *sbrpz;

5) Oss. lænk from PSl. *loka;

6) Oss. mæcyn from PSl. močiti;

7) Oss. -mæz from PSl. mazb;

8) Oss. met from PSl. *-metb;

9) Afgh. mēšta from PSl. město;

10) Sak. pā'sa ( ${ }^{\text {parsa-) }}$ from early PSl. *porsz;

11) Oss. stæn and Pamir. (Vakh.) skan from early PSl. *skenz // *ščenz;

12) Oss. tillæg from PSl. tblo;

13) Oss. ulæn (*ulnæ) from PSI. *vblna // *vъlna;

14) Oss. wes from early PSl. *uois̄̄, later věxa;

15) Afgh. zanai ("zznaka-), semantically influenced by PSl. *zbrno (?);

16) Oss. zivææg from PSl.zěvati.

As we see, there are sixteen words which with different degrees of probability can be considered as old borrowings from Proto-Slavic into Scythian. Among them the agricultural terms (or terms connected directly and indirectly with agriculture) are the most characteristic: cæd(æ), fæstæ, xsyrf, pā'sa, tillæg, zanai. Of course, not all of these borrowings stem from the same epoch. Those which are attested in Afghan and Pamirian dialects, as probably inherited from Sakian, must be the oldest, i.e., they took place before the middle of the first millennium B.C. (Abaev, 12-13). But the Slavic loanwords in Ossetic also represent a varied chronology, e.g., wes from early PSl. *uoisj must be much older than ulæn from East Slavic *vblna, etc. So the very fact of the chronological differences between individual loanwords seems to support the idea of a long period of close ethno-linguistic contacts between the prehistorical Slavic and Scytho-Sarmatian tribes. That period 
undoubtedly started much earlier than the 8th century B.C., the traditional date of the alleged Scythian invasion of the Pontic region. Abaev argues convincingly against this traditional view and accepts the autochthony of the Scythians in Eastern Europe. If we agree with him, then the contacts between the linguistically separate Proto-Slavs and Iranian Scythians (already crystallized as separate ethno-linguistic entities) must have started at least about 1000 B.C. So the whole period of the prehistorical ethno-linguistic contacts and exchange between the Slavs and the Scytho-Sarmatian tribes lasted 1500 years (until the 6th century A.D. ?). It would be incomprehensible if the linguistic traces of such a long period of contact were insignificant on both sides. The lexical facts I have presented and discussed here seem to corroborate the hypothesis that this contact was really fertile (productive) in linguistic-cultural exchange. Here I would like to mention, with some additions, Abaev's remarks (142-43) headed "From whom did the Scythians learn agriculture." The Scythians unquestionably learned agriculture from the natives of Europe. As Abaev states, in Ossetic there is only one agricultural term, jæw 'millet,' which was inherited from Common Iranian and Aryan. Other agricultural terms have many old and obvious correspondences in the European languages. Abaev quotes the following: xsyrf 'sickle,' with correspondence in Slavic; fsir 'ear of grain,' with correspondence in Germanic; fsonz 'yoke,' with correspondences in Baltic, Germanic, and probably in Latin; stivz 'a plug connecting a yoke with its shaft,' with correspondence in Germanic; fæxt // fæstæ 'mortar,' with correspondences in Slavic and Baltic; tillæg 'harvest, crop,' with correspondence in Germanic (this statement, as I have shown, is wrong; tillæg is a borrowing from PSl. tblo). Among these six agricultural terms three are of Slavic origin. We should also add here $c æ d(æ)$ from PSl. četa. Thus, the Proto-Slavs seem to have been the people from whom the nomadic Scythian shepherds learned agriculture.

\section{Part II. Prehistorical Slavic-Germanic Contacts}

Passing from the eastern neighbors of the Proto-Slavs, the Iranian tribes of the Pontic region, who have left quite considerable traces in the Common Slavic vocabulary, to their western neighbors, the Germanic tribes of Central Europe, whose influence upon the Slavic vocabulary seems to be even more significant, we should first answer some preliminary questions. These questions can be formulated as follows:

1) When did the territorial and social contact between the prehistorical Slavs and Teutons start? We mean here the contact between already clearly crystallized ethno-linguistic entities, i.e., 
Proto-Slavic and Proto-Germanic, not between late PIE tribes and their dialects, i.e., Pre-Slavic and Pre-Germanic.

2) If that contact started relatively late, then what peoples and languages preceded the Teutons as the western neighbors of the Slavs?

3) Which Teutonic tribes appeared in the immediate vicinity of or simply within the Slavic territory and in what temporal (chronological) sequence and geographic distribution? In other words, what was the chronology and geography of the prehistorical and early historical Germanic migrations in Central and Eastern Europe?

Only after answering the above questions will we be able to understand the historical and socio-cultural background against which a linguistic exchange took place between the Teutons and the Slavs.

In order to answer the first question we must critically digest all the available information about the ethnography of Central Europe obtained from the ancient written sources. Not being a historian myself, I will simply summarize a relatively recent presentation of the problem by $\mathrm{H}$. Łowmiański (loc. cit., I, 184-273), whose book can be treated as an up-to-date supplement to the classical work by Niederle. ${ }^{8}$

The geographical horizons of the ancient Greeks and Romans were primarily rather limited, and the interests of these peoples were oriented towards or concentrated on the Mediterranean and, in the case of the Greeks, also on the Pontic coast. Later on, when early imperial Rome had reached the line of the Rhine and Danube, these interests did not transcend the borderline zones of the "barbaric" world. The only exception seems to be the amber trade route leading from Aquilea in northeastern Italy across the eastern Alps to the Central Danube, then across Moravia or Bohemia to Silesia (the Upper Odra basin), and from there across contemporary western Poland (the Warta River) to the Lower Vistula and the Baltic coast. So it is understandable that information about the ethnographic situation in the "barbaric" lands north of the Danube River and beyond the Carpathians, i.e., in the regions which must have been the contact zone between the prehistorical Slavs and Teutons, appears relatively late and is quite vague. Only important demographic movements, tribal migrations and wars, which caused some repercussions at the Roman "limes" usually came to the attention of the Roman authorities and found some reflection in the written sources.

However, the first mention of the appearance of Germanic tribes in the vicinity of the Proto-Slavic territory comes from the last decades of the third century B.C. This is the inscription from the Greek colony

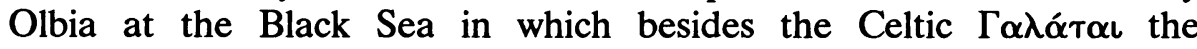
undoubtedly Germanic $\Sigma$ kípol are named as one of the two barbarian 
tribes menacing the city. It is worth underlining that the Germanic Skirians appeared in an alliance with the Celtic Galatians. This fact helps to understand the history of the Bastarnians, another early Germanic tribe that appeared in the same region, i.e., the Lower Danube area. The

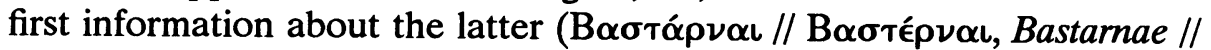
Basternae, later, e.g., in Tacitus, called Peucini) comes from 239-229 B.C., when they pressed against the northern boundary of the Macedonian state along the Lower Danube (somewhere in present-day Banat and Wallachia?). In the next century they were involved in the Balkan wars of the Macedonian kingdom, supporting the Macedonian kings even against Rome. At that time the ancient writers considered them a Celtic tribe on the basis of their language, which was allegedly similar to that of the undoubtedly Celtic Scordisci, who occupied the hydrographic "node" of the Danube and Sava with a stronghold in Singidunum (=Belgrade). Later information about the Bastarnians (1st cent. A.D.) already treats them as a Germanic tribe, for example Pliny and Tacitus, cf. from the latter: "The Peucinians, whom some call Bastarnians, are like the Teutons by language, cult, settlements, and houses." Of course, from the Lower Danube, i.e., the Pontic area, the Bastarnians seem to have expanded northward along the eastern Carpathians, ${ }^{9}$ where we find them in the first century A.D. All these historical data allow us to assume two things: that the tribe was of mixed Celto-Germanic origin, and that its primary route of migration from Northern Europe (Scandinavia) ran along the Odra River (?) to the Moravian Gate and then along the Danube River towards the Black Sea. This is the view of H. Kowmiański, whose concise formulation deserves quotation.

"In the period of the Celtic expansion they [Germanic tribes from Northern Europe - ZG] mixed with the Celts and produced a bilingual entity, since they spoke a language similar to that of the Scordiscians, but they had not forgotten Germanic; besides that they were absorbing recent "pure" Germanic newcomers like the Scirians ... The weakening of the Celtic element in the (Lower) Danube area and the influx of the new Germanic forces resulted in the removal of the Celtic 'varnish' from the Bastarnians in the first century A.D., so that they passed for a Germanic tribe. The name of this tribe, which etymologically denotes the crossbreeds, of course, Germanic-Celtic, not Germanic-Sarmatian crossbreeds, fits into this conception of the genesis of the Bastarnians. It is not impossible that the name of the Bastarnians originated in opposition to the ethnicon Scirians 
(PGermc. *Skīrōz), i.e., "pure Teutons"10 (H. Łowmiański, loc. cit., 206-7).

I have devoted more time to the problem of the Bastarnians because in all works about Slavic antiquities they are considered the earliest Germanic tribe with whom the prehistorical Slavs came into contact. And the route by which they allegedly reached the Pontic coast is also presented as crossing the Proto-Slavic territory north of the Carpathians. The analysis and presentation of the problem by $\mathrm{H}$. Lowmiański seems not to leave any doubts about the Danubian route of the Bastarnians' migration and their close relations (bilingualism !) with the Celts. So their first contacts with the Proto-Slavs could not have taken place north of the Carpathians anytime before the third century B.C.; they probably started much later (the 1st cent. B.C.?) at the foothills of the eastern Carpathians (called Alpes Bastarnicae in the Tabula Peutingeriana !), somewhere in the Upper Dniestr basin. Here we are entitled to ask about possible vestiges of the Bastarnians (their language) in the toponymy of the respective region. Of course, as usual, the hydronymy may give us some clues. And indeed we have the first indication in the hydronym Agalingus (Tabula Peutingeriana VIII, 4, 3rd cent. A.D.), which undoubtedly refers to the upper part of the Dniestr and has quite an obvious Germanic etymology: it is a formation with the well-known Germanic suffix -inga- from the adjective aglus (Goth.) 'burdensome, onerous' (see Lehr-Spławiński, 1946:81; Trubačev's objection, 1968:188, is not convincing). But we should check whether there are any traces of Germanic hydronyms in this region (the Upper Dniestr basin) taken over and preserved by the Slavs in historical times. For many years (see, e.g., Lehr-Spławiński, loc. cit., 80-81, and quite recently Trubačev, 1968, map 17) a group of hydronyms in the Upper San and Dniestr basins have been really considered as Germanic. These are the following: Dyrbok, Żołobok, Mołoda, Stynaw(k)a, Piskawa (in Polish spelling according to a recent article by J. Rygier in Rocznik Slawistyczny, XXXI (1):13-25, 1970). However, a critical linguistic analysis using new historical evidence by $\mathrm{J}$. Rygier has convincingly proven that there are insufficient grounds to treat the above hydronyms as Germanic; on the contrary, all of them have more or less transparent Slavic etymologies. For example, the interpretation of the first two as compounds allegedly containing - $b o k(\mathbf{b})$ from PGermc. *-bak(a), cf. Germ. Bach 'stream, creek,' is based upon an incorrect morphological segmentation: they seem simply to be PSl. ${ }^{*} D$ brb-zkz, *Želb-zkz in the regular Ukrainian form (for the derivational basis cf. Ukr. derba, Pol. dzierzba 'turf, sod,' and Ukr. žolob, Pol. żłób 'trough'). Of course, these considerations do not preclude the possibility 
of Germanic hydronyms in that part of the old Slavic habitat. For example, there are three hydronyms between the Lower Prypec and the Middle Dniestr: Velibok (a southern tributary of the Lower Prypeć), Tyryxva (in the Upper Boh = Southern Bug basin), and Morachwa // Murachwa // Murafa (a northern tributary of the Middle Dniestr) that seem to be really of Germanic (Gothic ?) origin; they might mark a route of the historical migration of the Western Goths (Visigothi). All of them contain in their second components the Germanic words -bak(a) and -ahwa (Goth.) 'river.'

But the most probable vestige of the Bastarnians in the sub-Carpathian regions is the oronym Bieszczady // Beskidy (Pol.). Since the etymology of this name is by no means transparent and has provoked several more or less acceptable hypotheses, I will devote a special excursus to this problem.

Excursus 2: Bieszczady // Beskidy, a Vestige of the Germanic Bastarnians in the Toponymy of the Carpathians?

First I should remind the reader that the eastern Carpathians, extending from the source of the San river eastward, are called Alpes Bastarnicae on the Tabula Peutingeriana (2nd-4th cent. A.D.?), undoubtedly in connection with a longer sojourn of the Germanic Bastarnians in this region. Today the oronym Bieszczady refers to the relatively inaccessible and well-forested mountain range between the Ostawa River, a western tributary of the Upper San, and the Swicza River, a southern tributary of the Upper Dniestr, whereas the oronym Beskidy (Zachodnie and Wschodnie) refers to the outer, i.e., northern ranges of the western Carpathians (including here the Bieszczady). This is the official topographic use of these names established finally in the second half of the nineteenth century by the geographers and cartographers. An older folk tradition in this respect is rather shaky; e.g., Beskid // Bieskid and its derivatives occur quite frequently in the Carpathians as names of separate individual mountains (see Słownik Geograficzny Królestwa Polskiego, V, 1880, p. 157). It is worth emphasizing that the Stownik Geograficzny mentions that the name b(i)eskid is still used by the peasants in Małopolska and Silesia as a common name referring to separate mountains. This view is supported by B. Linde in his big dictionary reflecting Polish usage from the sixteenth to the beginning of the nineteenth century: "the Carpathian highlanders call a forest on the mountain beskid, bieszczad" (B. Linde, 1854, I, 75). The use of the corresponding or related words in Ukrainian, namely béskyd // bésked // bésket 1. 'rock, mountain,' 2. 'cliff, precipice,' and beskýduvaty 'to graze 
cattle in the mountains,' is also attested (see K. Moszyński 1968: II, 2, 884; Ukrajinśko-rossijśkyj slovnyk, Kiev, 1965; and J. B. Rudnyćkyj, 1963, 2, 116-17).

So besides proper names (oronyms) we have in Polish and Ukrainian common nouns which seem to continue two Com. Slav. forms *beščadz and *beskydz with the basic meaning 'mountain'; the meaning 'forest on a mountain' attested for Polish dialects in the nineteenth century is secondary, conditioned by the local landscape in which the lower slopes of the mountains have been deforested for quite a long time.

The question which arises now is whether in historical-comparative terms a regular phonemic relationship (correspondence) between the form Bieszczad (*beščadz) and the form Beskid (*beskydz) can be established. I think that such a relationship can actually be established, and the following etymological analysis provides the substantiation of this hypothesis.

Among the attempts at an etymology of these oronyms (see F. Kopečný, 1954:158-73) ${ }^{11}$ only two deserve serious consideration: the Germanic and the Illyrian. The Germanic etymology of Bieszczad // Beskid was proposed by J. Rozwadowski (1914:162, etc.). He derives the variant *beščadz from Germc. *biskaid-, which is represented by MLG beschet (beskēt) 'Trennung' and by Scandinavian bésked, borrowed from Low German; the variant *beskydz is derived from another Germc. Ablaut-form, *biskid. The difference in the Slavic treatment of the consonant cluster $-s k$ - before $a i\left(=\operatorname{Slav} . \check{e}_{2}\right)$ and $\bar{i}$ allegedly reflects the relative chronology of two stages of borrowing, namely: 1) *biskaid- $\geq$

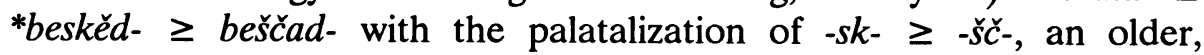
prehistorical stage; 2) *biskid- $\geq$ beskyd- without the palatalization of -sk-, a younger, early historical stage.

Regardless of the very hypothetical and difficult to prove two periods of Slavic-Germanic contacts in the Carpathian region (the second, younger period, according to J. Rozwadowski, somewhere between the 5th and 7th centuries A.D.) - the whole argument about two successive borrowings from Germanic is unnecessary, since the phonetic laws of the historical-comparative grammar of the Slavic languages allow us quite easily to start from only one prehistorical Germc. form. Namely, it is sufficient to start from *biskaida-, or rather from *biskaida- since the primary nominal compounds have a long vocalism in the prefix (cf. Germ. Bei-trag, Bei-spiel, etc., with an original $* b i-$, in contradistinction to be-tragen and other verbs with be-from an original *bi-). This productive compound Germc. noun with a transparent etymology, stemming from a Com. Germc. verb *skaidan (Goth. skaidan, OE scēadan, OHG sceidan, etc. 'divide') was borrowed by the Slavs somewhere in the sub-Carpathian 
region about the birth of Christ in the form *bŭskoidos // *büskoidus. After the monophthongization of diphthongs in Proto-Slavic this form resulted in 'bŭskédu with the second jat' $\left(\check{e}_{2}\right)$. The latter in its turn had to palatalize the preceding sk according to the well-known rules of the second palatalization of velars in Proto-Slavic. And it is here that the whole problem begins.

The second palatalization of the consonant clusters $s k, z g$ in Slavic shows a dialectal differentiation: West Slavic (e.g., Polish and Czech) palatalizes $s k, z g+\check{e}_{2} i_{2}$ (i.e., from an earlier diphthong * $j i$ ) into $\check{s} \check{c}$, $\check{z} \breve{\text {, }}$, which in Czech were later dissimilated into št', žd', e.g., OPol. $w$ Polszcze, Cz. čeští nom. plur. animate of český 'Czech,' etc.; but in the East and South Slavic languages the second palatalization of these consonant clusters gives the same results as the palatalization of the single consonants $k, g$, thus $s k, z g \geq s c, z z$, later quite frequently dissimilated into $s t, z d$, e.g., OCS vojbscě // vojbstě Dat.-Loc. sing. of vojbska 'army,' etc. A special case in this respect is represented by the Polesie-Kiev dialects of Old East Slavic. According to Shevelov's explanation (1965:297-99) in the forms vz knjaženii pinbskě, Smolinbskě (Loc.), vъ rusbskěi storoně velicěi, po dzskě, etc., sequences skě (phonetically [sk'e] should be interpreted as continuing an earlier st'ě from a dissimilated scě. Whether the process $s c \geq s t^{\prime} \geq s k^{\prime}$ was more widespread in the Proto-Ukrainian dialect of Kievan Rus' we do not know. In any case, some words with $s k$ $+\check{e}$ instead of $s c / / s t+\check{e}$ are attested in the Carpathian region; e.g., Shevelov himself quotes skiryty (from *skoir-, cf. Pol. szczerzyć, S-C ceriti, etc.) These prehistorical dialectal processes allow us to explain the variant bieszczad as the West Slavic treatment, i.e., in this case Polish, of the early Proto-Slav. *beskoidus, later *beskězds, etc., whereas the variant beskid would be an old dialectal Ukrainian treatment of the same Proto-Slavic word. Of course, in view of the preceding it is unnecessary to postulate a Proto-Slavic variant *beskydz, as proposed by $\mathrm{J}$. Rozwadowski and accepted by most etymologists. In this connection the contemporary Ukrainian forms with $y$ after $k$ (beskyd) should be interpreted as secondary, conditioned by folk etymology, which associated beskid with the nouns in -kyd derived from the verb kydati (Pol. kidać) 'throw,' obviously from its various prefixed forms, as, e.g., perekydaty $\rightarrow$ perekyd, etc. An older Ukrainian spelling, e.g., beskidy in the 17 th cent. (Rudnyćkyj, loc. cit.), may reflect the primary form of this noun.

There remains, however, still one detail for clarification: the treatment of the Germc. prefix $b \breve{t}$ - in Slavic. Regularly we should expect ${ }^{*} b b$ - or *bi-, depending on the Germc. source. The replacement of this Germc. prefix by be-in Slavic could be explained as an example of the 
preservation and vocalizaon of a weak $b$ in the word-initial syllable for the sake of avoiding an unusual consonant cluster ( ${ }^{*} b b 5 \check{c} c-\geq{ }^{*} b 5 \check{c} c-\geq{ }^{*} p \check{c} \check{c}-$ ?) if we start from Germc. $b i$-; or if we start from Germc. $b \bar{i}$ - it could be reinterpreted and identified with the original Slavic prefix be(z), cf., e.g., besěda from *bez-sěda, etc. The Ukrainian forms of the type bésked, etc., with $e$ after $k$, are also secondary and represent the merger of the phonemes $/ i /$ and $/ e /$ in unstressed syllables.

Now, if we accept the view that the variant beskid is Ukrainian, then the spread of this word and of the corresponding oronym in the western Carpathians (i.e., the Polish Carpathians) should be historically related to the so-called "Walachian" colonization in this region. This colonization, which started at the end of the fourteenth century and reached its peak in the fifteenth century, moved gradually from the east to the west, bringing with it the Ruthenian (Ukrainian) ethnic element into the western Carpathians. Among others such oronyms as Kiczora, Magura, Grun (the last two of Rumanian origin) owe their spread to that "Walachian" migratory wave. Most probably the name Dziat (Ukr. Dit) should also be included here since it is popular on the Rumanian territory (in the form Deal, and as a common noun with the meaning 'hill'). In Rumanian it is an obvious borrowing from Bulg. djal (*dělz) 'part, division,' dialectal 'watershed, ridge.' In connection with the semantic development of Slavic dělı from 'division, watershed' through 'ridge (as boundary)' to 'mountain ridge, mountain' we obtain an excellent parallel to the postulated development of the Germc. *büskaida- from 'Trennung' to 'Bergrücken, Berg.'

The etymology of Bieszczad // Beskid presented above is actually the only one that satisfies the requirements of lingustics and represents a high degree of historical plausibility. Since, however, such an experienced etymologist as O. N. Trubačev returned recently (1968:281) to an Illyrian etymology of this oronym, I consider it proper to take a position in this matter. Trubačev derives Bieskidy // Bieszczady (the forms used by him) from Illyr. *biz-kit- // *biz-kēt-, which in its turn would come from *büz-, Proto-IE *bhüg'- 'beech' + *kit- 'forest,' and for justification he quotes the allegedly Illyr. Kétıov ópos (explained as 'Wiener Wald'?) in Ptolemy and Citius mons in Epirus. So the name is in his opinion a vestige of the Illyrians, who most probably dwelt to the north of the central Carpathians before the prehistorical expansion of the Slavs to the west. The above view can be supported by some hydronyms in the Upper Dniestr basin, which show alleged etymological ties with the historical Illyrian territory in the western Balkans. But the whole linguistic part of this etymology is highly hypothetical: e.g., the very reconstruction of PIE *bhüg'- 'beech'

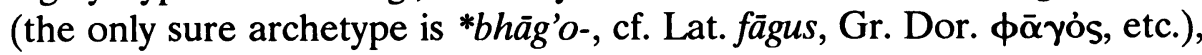


and then the treatment of $s k+i / \bar{e}$ in Slavic, which has not been explained at all, etc. In view of this, the Germc. etymology proposed by $\mathrm{J}$. Rozwadowski, with my interpretation of the double treatment of $s k+\check{e}_{2}$ in Slavic, seems to have much more explanatory power. Furthermore, it is well-rooted in historically verifiable circumstances, namely in the sojourn of the Germc. Bastarnians north of this part of the Carpathians, where the oronym is attested and fixed in the historical epoch.

In concluding this excursus, I would also like to call the reader's attention to the historical-geographical role of the central-eastern Carpathians, including just Bieszczady, with their two passes, Łupków and Użok, and with the low and easy ridges of the Dukla Pass region. From time immemorial it has been that part of the Carpathians through which ethnic and demographic waves flowed chiefly from the north to the south, to the Danube basin. It is highly probable that at least a part of the Bastarnians reached the northern foothills of the Carpathians through this section of the mountains, withdrawing northward from the Danube basin. Later the Goths, retreating from the Ukraine (pushed by the Huns) to the west, also used the central Carpathian passes in their migration to Pannonia. This would be an additional fact in favor of the Germc. etymology of Bieszczady // Beskidy presented above.

The only puzzling thing in all this complex of facts and hypotheses is the lack of other obviously Germanic names in the sub-Carpathian region discussed above, at least at the present stage of our knowledge. My personal suspicion is that the hydronym Strwiqz (Pol.), a tributary of the Upper Dniestr, comes from Germanic: *strü-inga- $\geq$ PSl. *strıvęg- with a change in gender and consequently in the declension type, i.e., ultimately *strıvęžb fem. Besides that, it is highly probable that the PSl. noun *xъrvъ $/ /$ *xorvs 'horn-armor,' which ultimately underlies the ethnicon ${ }^{*} X \mathrm{x} /$ orvate discussed in Excursus 1, and most probably was borrowed from Germanic in the sub-Carpathian region, can also be connected with the Bastarnians.

The Bastarnians were the first Germanic tribe with which the prehistorical Slavs came in contact. Just how intensive and broad that contact was and how long it lasted (until the absorption of that tribe by the pressing and surrounding Slavic masses in the first centuries of the Christian era ?) we are unable to say. It seems, however, that this first Germanic-Slavic contact was limited to the sub-Carpathian zone and to some Proto-Slavic tribes dwelling in this zone. Later contacts between the Teutons and the Slavs were undoubtedly more intensive, lasted longer, and involved or affected a larger number of Slavic tribes, e.g., contacts with the Goths affected practically all the prehistorical Slavic tribes. Those later contacts started in the western part of the 
Proto-Slavic habitat, or rather in its western borderlands. The historical information concerning the presence or the migrations of the Germanic tribes in west Proto-Slavic regions does not go back beyond the birth of Christ. The first source which clearly states the neighborhood of the Slavic and Teutonic tribes between the lower Odra and Vistula rivers is Pliny's Historia naturalis, where we find Sarmatian Venedi and Germanic Sciri and Hirri as a group of tribes in what is now western Pomorania (see the quotation on p. 288).

The next two sources, the most important in this respect, are Tacitus and Ptolemy, whose information dates to the first and partially to the second century A.D. In order not to repeat what has already been discussed many times by historians I will simply quote pertinent and synthetic statements from $\mathrm{H}$. Kowmiański, whose detailed and subtle analysis of the original sources and their previous interpretations represents the most up-to-date and realistic picture of the ethnographic situation in the Odra basin in the first and second centuries A.D.

On the basis of Tacitus' Germania, supplemented by Ptolemy's data, Łowmiański presents the map reproduced on p. 308. As we see, the East Germanic tribes which expanded southward from southern Scandinavia and Jutland occupied the amber-trade route (szlak bursztynowy), extending from the Sudeten northeast along the Warta River to the mouth of the Vistula. The Germanic tribes which dwelt on this route were (from the south): $\Delta$ ov̂vo, Naharvali, Manimi, Helisii, Helveconae, Harii, and Gutones (= Goths); Lemovii and Rugii are located in present-day western Pomorania beyond the amber route. It is important that these tribes included only those who formed a kind of federation controlling the amber-route. As Kowmiański (loc. cit., 234-35) suggests, this federation was founded primarily by the Celtic Lugiones // Lugii, whose name continued to be used for their Germanic allies and followers. But in this connection other Germanic tribes which did not enter the Lugian federation, first of all the Vandals and Burgundians known well to Pliny, were not mentioned by Tacitus. And they seem to have been those Germanic peoples with whom the prehistorical Slavs entered into very close relations before the great migration of the Goths.

Ptolemy, whose knowledge of the ethnographic situation in the Odra and Vistula basins was rather vague and confused, especially with respect to the geographic location of the various tribes in the region, puts the

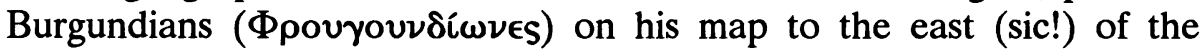
Vistula River (see the map on p. 376 of Niederle, I, 1). But in another

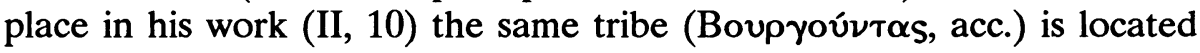
west of the Vistula River in the vicinity of the Silingians (dwelling in Silesia). Other sources support the view that the Burgundians really 
dwelt somewhere in present-day northern Wielkopolska, between the Warta and Noteć rivers (see Łowmiański, loc. cit. 240, and Słownik starożytności stowiańskich I, 204-5).

Another important East Germanic tribe which reached the western borderlands of the late Proto-Slavic habitat was the Vandals. Pliny knows them under the name Vandilii, which he uses as a general term to denote all the Germanic tribes that penetrated the Venetic territories, i.e., the westernmost parts of the late Proto-Slavic habitat. Probably in the first century B.C. they already dwelt in Silesia (specifically in the central part of this province). There were two Vandalian tribes: the Hasdingians, who left Silesia after the year 167 A.D., and the Silingians, who took their place. Neither the Burgundians nor the Vandals stayed very long in the western borderlands of the Proto-Slavic habitat. The former moved gradually westward during the third century A.D.: in 278 the Roman emperor Probus already fought with them in Raetia (along the Upper Rhine ?). The latter, at least their greater part, joined the Hasdingians (who from the end of the second century A.D. had settled in Pannonia) in their notorious raid westward about 400 A.D. But some remnants of the Silingians undoubtedly remained in central Silesia, and their name has been indirectly preserved in the Slavic name of that province, Ślqsk(o) (Pol.) from PSI. *Sblęžbsko (see the last section of Chapter V). ${ }^{12}$

Now, after this condensed presentation of the history of the East Germanic tribes in the Odra basin, the following question arises: what was the character of the Germanic migrations and subsequent settlements in the western borderlands of the Proto-Slavic habitat, and how numerous were those tribes? The whole period of their sojourn on the Slavic territory lasted about 500 years (if we start with the first century B.C.), and during that period we must assume a kind of social, cultural, and linguistic exchange between the Teutons and the Slavs. Of course, the intensity of this exchange varied in different regions and times. For example, the Burgundians left the Slavic territory as early as the third century A.D., and a part of the Vandals (the Hasdingians) left even earlier. Everything indicates that the most prolonged and intensive exchange took place in Silesia, i.e., in the Upper Odra basin. And it is not coincidental that it was there that we find some toponymic vestiges of the early historical Teutonic tribes.

The Germanic tribes, or rather groups of Germanic population, which gradually expanded from Scandinavia and Jutland to the mouth of the Odra and then upstream towards the Sudeten and Moravian Gate, were at first bands of warriors (hansa) who tried to establish some strongholds among the local Slavic sedentary and agricultural population in order to 
control it politically and exploit it economically. The amber-trade route was undoubtedly the main attraction because it opened up the opportunity to monopolize commerce with the Roman merchants. The first groups of warriors were subsequently followed by whole clans (piuda), including women and children, who settled around previously established strongholds and trading posts.

So the Germanic groups seem to have been concentrated only in certain regions around certain points. Of course, they exerted some political and economic control over the surrounding Slavic population, imposing upon it some tributes and services (in this connection cf. such PSl. loanwords from Germanic as myto (?), *želdo, and xlěbz, discussed below). Under these conditions a kind of ethnic and linguistic symbiosis developed between the two strata of population which consequently had to result in reciprocal lexical borrowings. This reciprocity of linguistic exchange between the prehistorical Slavs and Teutons will be presented later along with the relevant lexical material.

To be sure, the above picture of the prehistorical social relations between the Slavs and the Teutons has been reconstructed almost exclusively on the basis of historical and linguistic data, but to a great extent it can be supported by the analogy we draw from the history of the Scandinavian Varangians (ORuss. Varjazi) in early Kievan Rus', and from similar phenomena in other epochs and regions, e.g., the Zanzibar Arabs' expansion in East Central Africa. That the Germanic stratum in the western borderlands of the Proto-Slavic habitat was thin and dispersed seems to be corroborated by the following historical facts.

First, the Lugian federation of the Germanic tribes, which according to Tacitus controlled the amber route in the first century A.D., was dissolved in the next century (see Łowmiański, loc. cit., 242-44), undoubtedly in connection with a mass movement of the Vandalian Hasdings southward through the Moravian Gate to Pannonia (the Tisa basin) and the recapture of political control in the Upper Odra basin by the local Slavic (Venetic) element. This hypothesis would explain why in later Roman sources, after the second century A.D., we do not find the names of Germanic tribes located by Tacitus along the amber-trade route.

Second, the very fact that the Burgundians and the Vandals left the Odra basin before the great migration of peoples was ushered in at the end of the fourth century A.D. by the Huns and their pressure on the Goths seems to prove that the local Slavic population, the demographic stratum which was basic and more numerous, organized a resistance action or an uprising that forced the upper, thin layer of the Germanic invaders to withdraw from the country and to look for other regions, in this case closer to the rich and attractive Danubian provinces of the 
Roman Empire. Simply, the need to oppose the political control and the economic exploitation by the Germanic invaders forced the local Slavs to improve their political and military organization, which ultimately enabled them to push the troublesome newcomers out of their country. The fact that the PSl. term kznęzb 'prince' was borrowed from Germanic has deeper historical significance.

Here, against my basic principle of not using archeological evidence in the reconstruction of the prehistory of the Slavs, I nevertheless feel compelled to quote some recently published relevant data concerning the level of material culture in the region, since they simply seem to confirm the correctness of the above conclusions drawn from historical and linguistic sources. I mean here the book by M. Ju. Brajčevśkyj, Bilja džerel slov'janśkoji deržavnosti, Kiev, 1964, especially the maps on p. 314 and 318, which show the distribution of the remnants of the so-called Cernjaxiv (Russ. Cernjaxov) culture, which spread in the first half of the first millennium A.D. in the parkland zone of East-Central Europe. It is striking that the greatest concentration of these finds in the western half of the whole Proto-Slavic zone is in the Upper Odra basin (in central Silesia). This fact proves that the level of economic and social organization and concomitant demographic density were higher there than in other regions of the western half of the Proto-Slavic habitat, in other words, the conditions for successful elimination of foreign rule were better there than in underdeveloped regions.

Now we move on to the problem of the Goths, the most important East Germanic tribe, which in its migrations not only crossed the whole Proto-Slavic territory, but also seems to have remained in closer relations with various Proto-Slavic tribes for about 500 years. So the reconstruction of the Gothic migrations in Central and Eastern Europe is indispensable for understanding the ethno-linguistic relations between this notorious Germanic tribe and the prehistorical Slavs.

In spite of several ancient historical sources which mention the Goths and the famous work by Jordanis, himself a Latinized Goth, written in 551 A.D., we really do not know exactly the route of their migration from Scandinavia to the Lower Vistula basin, and later from there to the Black Sea coast. A critical but positive analysis of Jordanis' book by J. Lowmiański (loc. cit., 256-73) reconstructs the following picture:

After arriving from Scandinavia about 5 A.D., the Goths (Goth. Gutthiuda, i.e., 'the people of the Goths, Gotenvolk,' but in the classical

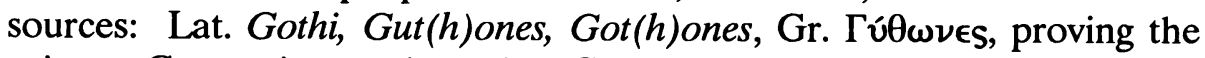
primary Germanic stem in $-n$, i.e., Goth. Guta sing., Gutans plur.), settled in the Lower Vistula region for probably 150-180 years. Then they moved towards the Black Sea. Jordanis, repeating a Gothic tradition 
probably preserved by oral epic poetry, presents the migration as one great move under the king Filimer, but it is more probable that they migrated in several stages over a longer time, since the first sure information about the Goths on the Black Sea comes from the year 238 A.D., when they raided the Lower Danube region (Moesia Inferior) in alliance with the Carpians (a Dacian tribe). By the year 251 A.D. they had already become a dangerous force, and in 257 they conquered and occupied Dacia. So they reached the Black Sea coast (between the Danube and the Dniestr?) sometime around 230 A.D. If we agree that their migration from the Lower Vistula region to the Black Sea started at the end of the second century A.D., then it lasted about thirty years, during which time the basic mass of the Gothic population moved from what is now northern Poland (eastern Pomorania) to what is now the Ukraine and Moldavia.

But some details in Jordanis' description of the migration are quite interesting and undoubtedly refer to historical facts. Namely, he mentions large marshes on the way (most probably the Prypeć marshes), then an open (steppe) country (Oium in the original, which etymologically corresponds to Germ. Aue 'fertile plain, meadow [watered by a brook]'), then a big river (most probably the Dniepr) and again

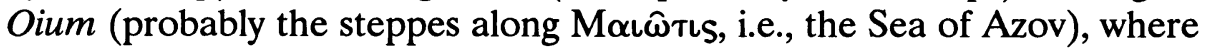
the eastern part of the Goths ultimately settled after a victorious battle with the Sarmatian Spali. These topographical details preserved in Jordanis' work, when combined with other historical sources and the geography of the region, allow us to establish the following route of the migration: upstream along the Vistula River to the estuary of the Bug, then upstream along the Bug River to its middle section, from where an easy portage leads eastward to the Prypeć River, then downstream along the Prypeć towards the Dniepr, but probably without reaching it, which means that the Goths abandoned the Prypeć somewhere in its lower part and moved south towards the Dniestr across Volynia. This hypothetical route suggested by Łowmiański seems to be supported by some hydronymic facts he did not know. In this connection I remind the reader of the three Germanic hydronyms between the Prypeć and the middle Dniestr: Veli-bok (a Slavic-Germanic hybrid), Tyryxva, and Morachwa, already mentioned in this chapter. I think that they may represent the vestiges of the migration route along which the Goths could later maintain their contacts with the Baltic coast for some time, probably also keeping some strongholds there. So Łowmiański seems to be right when he states: "If we accept this route [as presented above - ZG], the crossing of the Dniepr River must have taken place in the steppe regions (Oium), i.e., at the lower course of this river; thus the way of the Goths 
ran not through Kiev and then along the left bank of the Dniepr, as some scholars think, but rather along the Dniestr, which then became the boundary between the Visigoths and Ostrogoths. In this way Jordanis' narration, based upon folk songs, reflects the geographical elements of the migration much more precisely than its chronology" (loc. cit., 262).

In historical presentations of the migration of the Goths to date, most scholars have accepted the hypothesis about their direct arrival from southern Scandinavia across the Baltic Sea to the estuary of the Vistula River. This hypothesis was entertained in spite of the ancient sources (Strabo, Pliny, Tacitus, Ptolemy), none of which locates the Goths directly at the Baltic coast. In this respect Ptolemy is very clear: on his

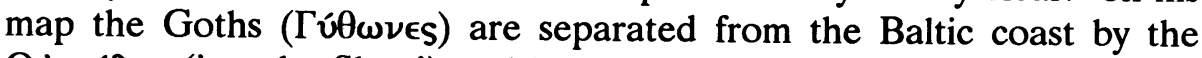

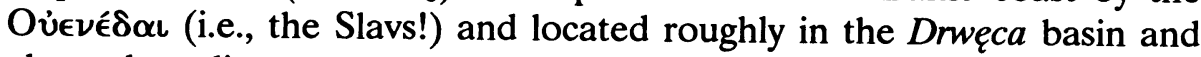
along the adjacent course of the Vistula River, which means basically south of eastern Pomorania (see the map on page 132 in J. Czarnecki, The Goths in Ancient Poland [1975]). This location would be inexplicable if we accepted the above hypothesis: the control of the Gulf of Danzig (Gdańsk), called the "Venedian Gulf" by Ptolemy, seems to be essential for any conquerors-settlers who come to this region from over the sea (note the location of the Swedish garrisons in coastal regions during the Polish-Swedish wars of the seventeenth century). This traditional view about a maritime expedition by the prehistorical Goths from Scandinavia across the open sea to eastern Pomorania has been challenged by J. Czarnecki. Since this book represents a very important contribution to the ancient history of Central Europe, compelling us to revise familiar views in many respects, I will give a condensed summary of its most relevant and convincing results.

The strongest argument against the migration route directly across the open sea is provided by archeological evidence which, as J. Czarnecki convincingly shows, proves that the Scandinavian watercraft of that time (1st cent. B.C.) was technologically too primitive to allow sailing on the open sea; the boats could be used only for trips along coastal lines. Consequently the only possible route of the prehistorical Gothic migration (rather migrations - there was a gradual movement in several stages over a protracted period of time, again conditioned by relatively small vessels) was from Scandinavia along the south-western coastal lines of the Baltic Sea to the estuary of the Odra River and upstream into the interior. This route to the Odra estuary and then upstream, conditioned by the relatively primitive watercraft of the primary Goths, is additionally corroborated by historical evidence obtained from a careful and unbiased analysis of all the classical authors who mentioned the Goths in describing the ethnography and geography of Central Europe. This 
evidence allow J. Czarnecki to locate two consecutive habitats of the Goths in Central Europe (after their arrival from Scandinavia): the primary one (from the middle of the first century B.C. to the end of the first century A.D.) occupied mainly the region located in the Central Odra basin (roughly the Ziemia Lubuska in the historical geography of Poland), a territory between western Pomorania and Silesia; and the secondary habitat, a result of the first continental migration of the Goths eastward (along the Notec River?), occupied the region located in the Drwęca basin and along the adjacent course of the Vistula (roughly the Ziemia Chetmińska and Kujawy in the historical geography of Poland); this secondary habitat of the Goths is quite corectly located by Ptolemy. As we see, according to this presentation the Goths never dwelt at the Baltic coast around the estuary of the Vistula, which seems to be perfectly confirmed by the geographical references in all classical authors (Strabo, Pliny, Tacitus, Ptolemy).

Here some corrections concerning the location of earlier East Germanic tribes on the prehistorical Slavic territory should also be made. The most important of them was, as we know, the Burgundians; Czarnecki's interpretation of the classical sources induces us to locate them first north of the Goths, somewhere between the Odra and present-day Berlin, and then south of the Goths between the Vistula and Warta (this latter location is given by Ptolemy). Whatever our objections are with respect to a detailed location of these two tribes and their possible routes of continental migrations within the western part of the prehistorical Slavic territory, one thing seems to be unquestionable: Czarnecki proves that the Goths reached the Slavic territory not via the Baltic Sea to the Vistula estuary, from the north, but via the Danish islands to the Odra estuary and then from the middle Odra basin eastward, i.e., ultimately from the west. Consequently their first contacts with the Slavs took place in the middle Odra basin (Ziemia Lubuska), then in the north-central part of contemporary Poland (Ziemia Chetminska and Kujawy). Between these two regions extends what is historically northern Wielopolska; this must have been the territory crossed by the first continental movement of the Goths. Thus we obtain the following set of provinces in which the first contacts between the Goths and the prehistorical Slavs (their western branch, the Veneti) took place: Ziemia Lubuska, northern Wielkopolska, Kujawy, Ziemia Chetmińska.

As is well-known, the Goths did not take root in these regions. In Ziemia Chetminska and Kujawy they probably dwelt only until the end of the second century A.D., until their great (second) continental migration southeast to the Black Sea. But this does not preclude the possibility that 
some Gothic strongholds guarding the trade routes and transportation lines between the Black Sea and the Baltic Sea remained in their possession for a long time. For example, it is highly probable that they ultimately established a stronghold (haven and trading post?) east of the Vistula estuary: the city of Elbing (Germ.), Elbiag (Kash.), Elblag (Standard Pol.) would indicate this. The name of the city is obviously Germanic. Primarily it denoted the outlet of lake Druzno (Germ. Draussensee, Truso // Drusa, etc., of medieval sources), then the city (Rozwadowski, Studia ... 174, 303). About this possibility of prolonged contacts between the main bulk of the Goths at the Black Sea and their remnants in northern Poland see the very interesting remarks by J. Czekanowski in Stownik starożytności stowiańskich II (1964) under Goci, where some convinding facts of physical anthropology are quoted as evidence.

Now, are there any toponymic, especially hydronymic vestiges of the posited sojourn of the Goths in the Drwęca basin and adjacent regions? The only sure, linguistically unquestionable name which can be derived from Germanic in this area is the hydronym Skrwa (old Strkwa), a right tributary of the Vistula between the Drwęca and the Bug (note the location on the hypothetical trail of the Gothic migration to the Black Sea!). This hydronym represents PSl. *stroky, which in its turn can easily be derived from Germanic *struko 'stream' (the latter corresonds almost exactly to the PSI. noun struga, known in Polish and East Slavic, and also attested in OCS struga $=\dot{\rho} \in \hat{v} \mu \alpha$, the main difference being $g \sim k$ caused by the PGermc. consonant shift; for details see Lehr-Spławiński, 1946:80).

Other toponyms and hydronyms that have been quoted in this connection have turned out to be either Slavic or at least highly doubtful from the standpoint of their alleged Germanic etymology. First the Polish name of the city Grudziqdz (Germ. Graudenz), allegedly stemming from the Gothic ethnicon Greutungi (a Latinized form), turned out to be a secondary form based upon OPol. Grudzieniec // Grudzieńc, derived from gruda 'clod of earth; frozen mud' (cf. Pol. grudzień 'December' and other toponyms from the same noun). This etymology of Grudziadz was already proposed by J. Perwolf in 1883 and was substantiated in 1934 by V. Kiparsky (see p. 39, footnote 2, and p. 166 in his work about Germanic loanwords in Slavic). Another allegedly Germanic name is represented by the hydronyms Pettew (Pol.), Pottwa (Ukr.), a left tributary of the Upper Bug, on which the city of Lwów is located; Petta (OPol. Pettew // Pottew), a right tributary of the Narew on which the city of Puttusk (OPol. Pottowsk) is located; and Pottwa, a right tributary of the Horyn in Volynia (other alleged variants of this hydronym, such as Polota, a right tributary 
of Dvina in Byelorussia, can be omitted). All these hydronyms represent PSl. *pzlty ("pzltzv-!) and have been connected with Germanic *fuldo (cf. Fulda in Germany!). Thus, for example, Lehr-Spławiński (loc. cit., 80) followed Rozwadowski in accepting this etymology. But a recent critical analysis of this etymology by J. Rygier in Rocznik Slawistyczny XXXI, 1, $15-19,1970$, has shown that there is a possible Balto-Slavic etymology of this hydronym (cf. Lith. pilti among others 'in Strömen fliessen, herunterrinnen,' Latv. pilt 'tropfeln,' Lith. piltùvas // piltuvas 'Trichter, Schöpfeimer, Giesskanne,' Latv. piltuve, piltava 'Trichter, etc., from IE *pela- 'fill'), which compells us to reject the Germanic origin of ${ }^{*} P z l t y .{ }^{13}$ Thus we are left with only one certain toponymic (hydronymic) trace of the Goths in present-day Poland: the river name Skrwa (OPol. Strkwa).

Once the Goths reached the Black Sea coast in the first half of the third century A.D., they established political rule there and formed a kind of state organization in the next century which some historians call the "Gothic empire" (e.g., F. Dvornik, 1956:24-25), undoubtedly an exaggerated term. The apogee of this state took place between 350-370 A.D. under King Ermanarich, who from his base on the Sea of Azov (Maeotis) coast (?) was able to control his northern neighbors, the Slavic Antes (the ancestors of the historical Eastern Slavs), a part of the Sloverne (Sclaveni), at that time the ancestors of the historical Southern Slavs, and according to Jordanis he forced even the Veneti (the ancestors of the historical Western Slavs) to acknowledge his hegemony. This undoubtedly involves an attempt by the Goths to secure their communication routes with the Baltic coast through contemporary northern Poland, i.e., the Lower Vistula region. That was the maximum geographical spread of the so-called Ostrogothic state, which was eventually shattered by the Huns.

Geographically, the center of this state was undoubtedly the southern Ukraine, specifically the steppe regions north of the Crimea and the Sea of Azov. From here the Gothic influences, cultural and linguistic, spread north and northwest to the neighboring dominated Slavic tribes and further to other Slavic and Baltic tribes which remained free of direct Gothic hegemony. What interests us here is the later contacts between the Goths and the Slavs. According to Jordanis, after the defeat of Ermanarich by the Huns and his death in the battle, the Gothic hegemony over the Slavic tribes disintegrated, the Antes under their king Boz rose against the Goths, and in spite of a temporary defeat they seem to have regained their independence. The Ostrogoths themselves decided to leave the Ukraine in order to avoid the hard rule of the new hegemon, the Huns. We do not know exactly whether they tried to retreat northwest towards the Baltic coast or simply towards the 
Carpathians; in any case, they tried to force their way through the territory of the Antes, avoiding any closer contacts with the Huns, who apparently had taken control of the steppe route extending from the Black Sea coast along the Danube into Pannonia. But ultimately the Ostrogoths crossed the eastern Carpathians (somewhere in the Upper Dniestr basin) and settled temporarily in Pannonia, where they again met the Huns and were forced into alliance in the fifth century. Meanwhile, the Visigoths, after the first onslought of the Huns, emptied Dacia and entered Moesia, which launched the fateful migration of peoples. The fact that the Ostrogoths did not withdraw north towards the Baltic Sea, from where they had come to the Ukraine some 150 years earlier, but rather crossed the eastern Carpathians, turning again southward to Pannonia, seems to prove that they met resistance from the Slavic (Antian) population, which at that time was already sufficiently organized in the military respect and able to check the back wave of the invaders. We must take into account all these circumstances, for they help us to reconstruct the general historical-geographical framework within which the ethno-linguistic contacts between the Goths and the Slavs developed.

The forced emigration of the Goths from the Ukraine and Dacia did not, however, break the contacts between them and the Slavs. At that time, in the fifth century A.D., the ancestors of the historical Southern

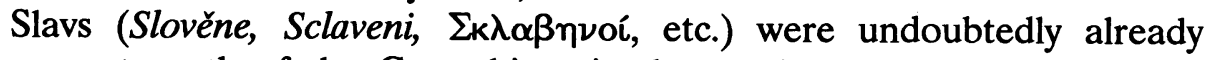
present south of the Carpathians in the northern part of the Danube basin (present-day sub-Carpathian Ruthenia) and in northern Dacia. This means that the contact between the Sloverne and the Ostrogoths continued during the fifth century A.D. and even extended to the middle of the next century, if we include here the Gepids, a tribe closely related to the Goths that controlled Pannonia after the fall of Attila the Hun until 567 A.D., when they were ultimately driven out by new nomadic invaders from Asia, the Avars.

The Slavic-Gothic (+Gepidic) contacts in Pannonia during the fifth and sixth centuries seem to be responsible for the so-called Balkan-Gothic loanwords in Slavic (see p. 377-79). ${ }^{14}$

Against the background of the historical facts presented above we can attempt a synthetic presentation of the linguistic exchange between the prehistorical and early historical Slavs and the Teutons (Germanic peoples). I emphasize here the term exchange, i.e., the idea of reciprocity of lexical borrowing, since it is a priori improbable that such a prolonged period of close Slavic-Germanic contacts left loanwords only in Slavic, leaving the other side, Germanic, untouched by any Slavic influences. It is also improbable for obvious cultural reasons: the cultural levels of the respective peoples or tribes before their encounter with the classical 
Graeco-Roman (Mediterranean) culture were roughly the same, which seems to have been conditioned both by their geographical location in the northern, central, and eastern parts of Europe and by their common IE heritage. But in spite of this quite obvious circumstance, most scholars who have investigated the problem of Slavic-Germanic relations as reflected in the respective vocabularies for more than a hundred years (since J. Safařik's Slovanské starožitnosti, 1837), have concentrated their attention on the Germanic loanwords in Slavic, leaving the impression that the flow of linguistic influence was one-way from Germanic to Slavic. A serious break with this tradition of treating the Germanic loanwords in Slavic, the best expositions of which are by A. Stender-Petersen (1927) and V. Kiparsky (1934), came with V. V. Martynov (1963). Since Martynov has proposed and convincingly demonstrated new points in the whole problem, I will use his data and suggestions extensively, though critically.

As the very title of Martynov's book (Slavjano-germanskoe leksičeskoe vzaimodejstvie drevnejšej pory, 'Slavic-Germanic lexical interaction of the oldest period') indicates, the author clearly stresses the reciprocity of the lexical exchange between the two linguistic groups, limiting his analysis of the pertinent material to an older period on the Germanic side, i.e., to Proto-Germanic (roughly before 100 A.D., i.e., before the Gothic period). Not only does Martynov stress the reciprocity of the borrowings (the relative chronology of the Germanic loanwords in Slavic has been discussed and applied by other scholars, most convincingly by J. Kuryłowicz, 1951; 1958:245-35); but he also introduces the very important distinction between proniknovenie and zaimstvovanie, i.e., 'penetration' and 'borrowing.' Both represent the process of borrowing in general terms and its results, known traditionally as loanwords, but the socio- or ethno-linguistic conditions, the mechanism of the process itself and the semantic aspects of the borrowing are in both cases quite different. Penetration requires bilingualism and close territorial contact between the two ethno-linguistic groups involved (e.g., in a borderline zone, etc.); borrowing does not require such conditions - it may take place as a result of trade and import, conducted by only a few individuals of a foreign ethno-linguistic group. In the case of penetration, a word usually encounters a synonym in the borrowing language with which it necessarily collides, entailing a subsequent semantic differentiation within the lexical pair. The result of this differentiation, which may be limited to the emotional value of the words, is very often indicative of the character of the social and cultural relations between the two ethno-linguistic groups. No such concomitant process and semantic change accompany a simple borrowing; here a foreign word enters the given language along with a 
corresponding new object or idea, introducing into its vocabulary a new formal and semantic entity. The above distinction proposed by $\mathrm{V}$. V. Martynov is of great significance for the reconstruction of the cultural exchange between the Teutons and the Slavs in the prehistorical epoch. Another methodological improvement consistently applied by Martynov in the discussion of the lexical exchange between Germanic and Slavic is the gradation or quantification of the probability (plausibility) of each individual Germanic loanword in Slavic and vice versa. The author distinguished three degrees of probability: minimal, when a word can be proven to be native (inherited from an earlier period) in the giving language, whereas this cannot be proven for the receiving language; maximal, when not only the phonetic evidence suggests the native character of a word in the giving language, but it can also be shown to represent an innovation characteristic of the giving language on the basis of its whole derivational structure; and there is a medium degree of probability, when the minimal degree exists, and there are additionally some extralinguistic or indirect reasons arguing for the direction of borrowing.

Now, after these introductory remarks and explanations we shall review the words which can be considered Germanic loanwords in Slavic (i.e., Proto-Slavic) with a greater or lesser degree of probability, representing either cases of penetration or borrowing sensu stricto. Besides this basic division I will also attempt to qualify them in terms of their relative chronolgy, distinguishing older loanwords from younger ones. The criterion for this distinction, as mentioned above, was proposed by J. Kuryłowicz on the basis of the Slavic treatment of the Germanic accent:

"Les substantifs slaves empruntés au germanique reflètent deux périodes différentes de l'accentuation slave:

1) L'accent germanique était immobile et fixé sur la syllable initiale du mot. Le slave de l'époque antérieur à l'affaiblissement des yers n'a pu conserver cette barytonèse constante du thème quen lui conférant l'intonation rude. Les thèmes à tranche radicale intonable reçoivent par conséquent l'intonation rude. P. ex.:

R. bljúdo, plur. bljúda 'mets,' S-C bljüda < *biud-

R. buk, - $a$, -i, -ov 'hêtre,' S-C bük < *bōk-

R. chleb, - $a,-y$, -ov 'pain,' S-C hljëb < *hlaib-

R. lichva 'usure,' S-C lihva < *lihw-

R. luk, -a, -i, -ov 'oignon,' S-C lük < *lauk-

R. stúpa 'pilon,' S-C stüpa < *stamp- 
R. šelóm 'heaume,' S-C šljềm < *helm-

R. volóch 'Roumain,' S-C vläh < *walh-

L'immobilité des thèmes à tranche brève ne peut être effectuée que par l'imposition de l'oxytonèse puisqu'il n'y avait pas, en slave, de barytons immobiles à vocalisme bref. On a par conséquent:

R. kotël, kotlá 'chaudron,' S-C kòtao, kòtla < *katil-

R. osël, oslá 'âne,' S-C òsao, òsla < *asil-

R. pop, -á 'prêtre,' S-C pôp, pòpa < *pap-

R. post, -á 'jeûne,' S-C pôst, pòsta (à côté de pôst) < *fast-

R. skot, -á 'betail,' S-C sköt, skòta < *skatt-

R. kot, -á 'chat' < *katt-

R. mečb, meča 'glaive, épée,' slovène mèč, méča

2) Les substantifs germaniques à vocalisme long empruntés après l'affaiblissement des yers et après la constitution de l'intonation néorude, sont devenus oxytons en slave parce qu'entretemps, à cause de l'abrègement des longues rudes, les barytons immobiles à vocalisme long ont disparu de la lange. On trouve ainsi:

R. korólb, koroljá 'roi,' S-C krâlj, králja < *karl-

S-C lijek, lijèka 'médecine' < *lēk-

S-C lûg, lúga 'cendre' < *laug-

R. pilá, acc. -ú 'scie,' S-C pila < *fil-

S-C skût, skúta 'ourlet, repli' < *skaut-

R. trubá, acc. -ú 'cheminée,' S-C trúba < *trumb-

R. vinó 'vin,' S-C víno < *win-

La couche d'emprunts la plus récente semble constituée par les thèmes accentués sur une voyelle radicale brève, $\mathrm{p}$. ex. R. pétlja 'maille etc.', S-C peètlja < *fetil-; R. smókva 'figue,' S-C smökva < *smakk-; R. subbóta, S-C súbota 'samedi' < *sambat-. Ces emprunts ont été traités comme les formes slaves à accentuation néorude (accentuation de la more prédésinentielle)."

(L'accentuation des langues indo-européennes, 1958:234-35)

Kuryłowicz's ingenious hypothesis was verified and corroborated by V. Kiparsky (1958), who introduced some corrections and additions provided by historical Russian material. He also attempted an absolute chronology of the Germanic loanwords in Slavic. It looks as follows: 
1) Germanic loanwords that belong to Kuryłowicz's category $1 \mathrm{~A}$ (e.g., tynz: Russ. fixed stress, S-C tîn, etc.) and 1B (e.g., popz: Russ. end-stress, S-C pôp, pòpa, etc.) come from the period extending from the oldest Germanic-Slavic contacts to about 700 A.D. (sic!), i.e., to the time of the penetration of the oldest Christian concepts from OHG into Slavic before the Moravian mission.

2) Germanic loanwords belonging to Kuryłowicz's category 2 (e.g., *korl'b: Russ. koról', koroljá, S-C krâlj, králja, etc.) come from the 8th-9th centuries.

The third group of Germanic loanwords, coming from a later period, is irrelevant for us.

In Kiparsky's absolute chronology the first period seems to be too extended and the second period too contracted. For example, it does not make a clear distinction between the Gothic and Old High German loanwords, suggesting that the first Christian terms penetrated Slavic from Old High German, although there are serious grounds to believe that the first Christian terms were borrowed by the Slavs from the Goths (somewhere in Dacia?) quite early, i.e., probably in the fifth century A.D. ${ }^{15}$ This is the view of A. Stender-Petersen, among others, who in his review of Kiparsky's book (1936:251) speaks about a "got.-arianische Mission": here we could include the terms *cbrky, krbstz, sotona. So it is highly probable that the linguistically established first period of Germanic borrowings in Slavic did not extend past the year 600 A.D. and represented mainly Gothic elements (with some pre-Gothic words borrowed from Eastern Proto-Germanic). The second period started with the year 600 A.D. and represented either Old High German or the so-called Balkan-Gothic elements (the latter were questioned by Stender-Petersen).

But such a broad chronology provided by purely linguistic criteria (i.e., accentual features) is not satisfactory from the historical standpoint. A historian would like to know whether it is possible to chronologize the loanwords of that first long period, which encompasses seven centuries (!). There is no question that not only Slavic (i.e., Proto-Slavic) but also Germanic, and especially Gothic, experienced important phonemic changes during that period and the regularities of phonemic substitution characteristic of Germanic-Slavic lexical exchange were different in different segments of the time of the contact. In this connection I shall quote one example. As we know, primary (early) Proto-Slavic contained the diphthong $/ o u /$ (from PIE ou $l a u$ ), e.g., * Juxs $\geq$ uxo (cf. Lat. auris, Lith. ausis, etc.). A similar diphthong existed in Gothic, e.g., Goth. kausjan 'try.' It is obvious that at that time the Slavs substituted their own /ou/ for the Goth. /au/ in borrowed words; hence Goth. kausjan was first 
borrowed as *kousæitæi, and then after the monophthongization of diphthongs in Slavic (which took place between 400-600 A.D.) it became kusiti, known in Old Church Slavonic and all historical Slavic languages. But the Germanic close $/ \bar{o} /$ was also rendered in the same way in Slavic, e.g., Slav. bukz 'beech,' buky 'letter' from Germanic *bōka-, *bōkōn- (cf. OSax. $b \bar{o} k$, Goth. $b \bar{o} k a$, etc.). Now this identification of the two Germanic phonemes in Slavic seems to prove two different periods of borrowing: an older period when Proto-Slavic still possessed the diphthong $/ \mathrm{ou} /$ and regularly substituted it for the Germanic /au/, and a later one when Proto-Slavic began to monophthongize its diphthongs and already transformed $/ \partial u /$ into a close $/ \bar{o} /$, which only later became $/ u /$. During that later period Germanic $|\bar{o}|$ was identified with that intermediary Proto-Slavic close $/ \bar{\delta} /$. Therefore Germc. *bōka- through PSl. *bōku ultimately became bukz. Here the question arises, how did the Slavs render the Germc. $|\bar{o}|$ in the older period (before the monophthongization of diphthongs)? This question can only be answered on the basis of the comparison of the respective Proto-Slavic and Proto-Germanic vowel systems in that early epoch.

Everything seems to indicate that since Proto-Slavic had at that time the quadrangle system of the type

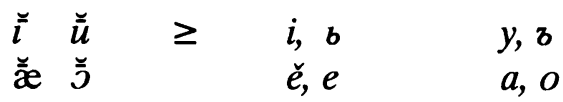

the Proto-Slavs had to substitute their own $/ \bar{u} /$ for the Germc. close $/ \bar{o} /$ (as phonetically the nearest sound). So, for example, Stender-Petersen regarded Slav. myto 'toll' as borrowed from PGermc. *mōta-, which, however, must be rejected for accentual reasons: myto shows final stress in older Russian, corresponding to S-C mito, mita, etc., which proves that the borrowing falls into Kuryłowicz's second period. Ultimately it is from OHG müta (see Kiparsky, 1958:22). To be sure, there are no examples of Early Germanic loanwords in Slavic with the substitution of the historical Slav. $/ y /$ for PGermc. $/ \bar{\delta} /$, but the hypothesis of such a treatment is well justified linguistically and should be taken into consideration in the study of Early Germanic loanwords in Slavic. Perhaps sytz and sytiti belong here, if they were borrowed from Goth. sōpa- 'Sättigung' and ga-sōpjan 'sättigen' (see Pokorny, 876).

It is characteristic that J. Kuryłowicz in his condensed presentation of the Germanic loanwords in Slavic (actually the title of the article is "Germanic-Slavic linguistic relations," 1964:99-100) gave a more detailed chronology of these loanwords in Slavic, without however quoting the linguistic (?) criteria upon which his chronology is based. Undoubtedly, 
the starting point was accentology, as previously proposed, but supplemented by additional information. In any case, he distinguished the following periods of borrowing or chronological layers of Germanic loanwords in Proto-Slavic:

I. Borrowings from Eastern Proto-Germanic taken before the 2nd cent. A.D.

II. Borrowings from Gothic taken between the 2nd and 4th centuries A.D.

III. Borrowings from Balkan-Gothic taken in the 5th and 6th centuries A.D.

Of course, there are loanwords whose chronological classification is controversial because of the lack of sufficient linguistic criteria. But the above chronology, which I will follow in the list of Germanic loanwords below, has greater value for a historian than the purely linguistic and rather too general chronology proposed by V. Kiparsky. In the list of Germanic loanwords which constitutes the main part of this chapter, not only original Germanic words borrowed by the Slavs are quoted, but also Greek and Latin words transmitted by the Teutons to the Slavs, as for

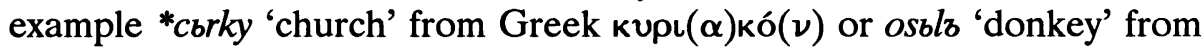
Lat. asellus, etc.

So we are able to determine not only the Germanic origin of a word using phonetic and derivational criteria, but also its relative chronology using chiefly accentual criteria. The two main periods of borrowing (or in Martynov's terms, penetration and borrowing) are undoubtedly connected with two main periods of prehistorical Slavic-Germanic contacts: an older period which involved the Proto-Slavs (or rather their western tribes, the Veneti) and the Proto-Teutons (specifically, their eastern tribes, including the Burgundians, the Vandals, and the early Goths), and a later period which involved the Proto-Slavs (in this case the Antes and Sclaveni = Slověne ) and the later Goths. By "early Goths" we should understand those Gothic clans and tribes which settled and dwelt in the northwestern part of the Slavic territory in the Lower Vistula basin before their migration to the Pontic region (approximately until the second half of the second century A.D.), and by "later Goths" we should understand the Gothic clans and tribes which moved to the Pontic region, having crossed the whole prehistorical Slavic territory and formed a kind of Gothic state (East-Gothic or Ostrogothic) in the southern part of the present-day Ukraine. It should also be mentioned that these later Goths, pushed by the Huns, crossed the eastern Carpathians and dwelt for a time in Pannonia (5th cent. A.D.), where they still remained in contact with the Slavs. To the later Goths we can join their close relatives, the Gepids, who stayed in Pannonia until the arrival of the Avars in the 
second half of the 6th century A.D. So the contacts between the eastern Proto-Germanic tribes, the early Goths, the late Goths, and the Gepids on the one hand and the Proto-Slavs on the other lasted for at least seven centuries (1st cent. B.C.-6th cent. A.D.).

Such a long period of contacts had to leave significant traces in the Proto-Slavic vocabulary and undoubtedly also in the vocabulary of the respective Germanic dialects, although we do not have any direct sources representing these dialects (except for the West Gothic translation of the Gospel by Ulfilas-Wulfila from the 4th century A.D.). Indirectly, however, we will be able to trace some prehistorical Slavic loanwords in Germanic. Therefore our list of Germanic loanwords in Slavic will be followed by a list of Slavic loanwords in Germanic, the latter based chiefly upon the inspiring book by V. V. Martynov mentioned above.

\section{A List of Germanic Loanwords in Proto-Slavic}

A) First period: borrowings from Eastern Proto-Germanic and Early Gothic, before the 2nd century A.D. (Kuryłowicz's layer I).

1) duma 'thought, word, council' (Martynov, 82, etc.), illustrated by ORuss. dúma 'Rat; Gedanke, Absicht,' Russ. dúma 'Gedanke; Sorge; Rat (als Versammlung),' Bulg. dúma 'Wort; Gespräch; Gedanke,' but Pol. duma 'Nachdenken, Erwägen, Nachsinnen; Einbildung, Dünkel, Meinung' (all these meanings in OPol.); 'Eigendünkel, Hochmut' (this meaning only in Modern Polish), etc. The word is usually considered a borrowing from PGermc. *domaz or Goth. döms; however there are some semantic and morphological difficulties. First, the Germc. meaning can be subsumed under 'judgment, sentence,' e.g., Goth. doms 'Urteil, Erkenntnis,' OE dom among other 'Rat; Hof, Versammlung' and ONorse dómr also 'Gerichtsversammlung.' This is substantiated by the etymology of the word - an obvious derivative from the IE verbal root *dheH- 'put' (cf. OE infin. don, OHG tuon = NEng. do, NHG tun, etc.) with the suffix -mo- (*dhoH-mo-), as evidenced by such corresondences as OI dhäman(*dheH-men-) n. 'Satzung, Gesetz, Wohnstätte, etc.' (Martynov, loc. cit., 83, and Pokorny, 238). From this basic Germc. meaning it would be difficult to derive for example Pol. meaning 'pride.' Then the change of gender from masculine in Germanic to feminine in Slavic with the concomitant declension shift (not the expected *dums, as, e.g., bukb from Germc. *boka-, but duma) is also difficult to explain. The absolute synonym of the Germc. *dōma- would be in Proto-Slavic the native noun sodz, which is perfectly preserved in all Slavic languages without any semantic shift. This fact would argue against the penetration of Germc. dōma- 'judment' into Slavic. On the other hand duma enters a synonym 
correlation with myslb 'thought,' ousting even the latter and its verbal derivatives from East Slavic dialects (cf. Russ. dúmat', replacing mysliti, etc.). All these facts undermine the hypothesis about the Germc. origin of duma in Slavic, and consequently the old etymology proposed by some scholars, among others Stender-Petersen, who derived duma from IE *dhouH-mā- (cf. OI dhūma-, Lat. fümus, Lith. plur. dúmai, Slav. dyms 'Rauch,' but Gr. $\theta \bar{u} \mu$ ós 'Seele, Leben; Wille, Verlangen, Trieb, Begierde, Lust; Gemüt, Gesinnung, Denkweise'), seems to be more convincing. This etymology, starting from the verbal root *dheuH- with the general meaning 'blow' (cf. Slav. *dujg, *duti, in Russ. dúju, dut', *dyjo, *dyti, in Sloven. dijem, díti and OCS dune, dunoti, etc.; Pokorny, 261-63), makes it possible to interpret duma (i.e., pre-Slavic *dhouH-mā-) as a vrddhi adjective derived from the IE noun *dhuH-mó-, the semantic relation being *dhuH-mó- m. 'blow, "the blow of life," etc.' (cf. Lat. spiritus, animus) $\rightarrow{ }^{*}$ dhouH $-m \vec{a}$ f. (primarily an adjective) 'pertaining to the blow, to the blow of life,' etc., i.e., 'any expression of the human spirit,' and thus 'thought, "higher" thought about oneself' $\rightarrow$ 'conceit, pride,' etc. The feminine gender of duma can be accounted for by such pairs as duxz duša, -myslъ (e.g., sz-myslz, etc.) myslb (cf. also Latin animus anima and Gr. $\theta \bar{u} \mu o ́ s ~ \sim \epsilon \dot{v} \theta \bar{u} \mu i \alpha$, etc.). So because of the semantic and morphological difficulties the Germc. origin of the Slav. duma is highly controversial, and the Slav. etymology (against an IE background), which has already been proposed by some scholars but is elaborated above for the first time, seems to be preferable. Martynov is right in qualifying duma as representing the lowest degree of probability among the alleged Germc. loanwords in Slavic (for more details see Kiparsky, loc. cit., 171-72; and Martynov, loc. cit., 82-84). ${ }^{16}$

2) glazъ primarily 'shining pebble,' attested only in North Slavic: ${ }^{17}$ ORuss. glazky stekljanyi 'Glaskügelchen,' Russ. glaz 'Auge' (undoubtedly a secondary metaphoric and euphemistic use), Pol. głaz 'Kieselstein; Probierstein; Felsenstück,' OCz. hlazec 'roteris' (a stone). The word is most probably borrowed from prehistorical NGermc. *gläza- 'Berstein' (cf. OE glær 'Berstein, Harz,' MLG glär 'das aus den Bäumen tröpfelnde Harz,' and an earlier PGermc. form *glèsa-, attested by Tacitus: "Aestii...soli omnium sucinum, quod ipsi glesum vocant...legunt"); for details and discussion see Kiparsky (1934:172-74 and 1958:23) and Martynov (loc. cit., 63-65). There are some hesitations in accepting glazb as an early Germc. loanword because it has mobile stress in Russian, but the geography of the word seems to indicate its connection with the ancient amber-trade, whose centers were at the southern Baltic coast.

3) gonbsti, gonbzq // goneznoti, goneznq 'be healed, be liberated,' attested in Russ. Church Slav. gonbsti, gonbzu 'liberari,' OCS goneznqti, 
gonezng 'servari, liberari,' and indirectly in the Cz. toponym Honezovici; the verb is borrowed from Early Gothic ganisan = NHG genesen 'recover' (intr.) (Kiparsky, 1934:174-76; Kuryłowicz, 1964:99).

4) gonoziti, gonožǫ, a causative of the preceding verb, also attested in OCS. It is borrowed from an Early Goth. *ganazjan (Wulfila's Goth. ganasjan 'retten'); for details see Kiparsky (1934:174-76).

5) $x$ lěvъ, primary meaning 'dugout' (i.e., 'underground dwelling'), then restricted to 'shelter for domestic animals,' attested in most Slavic languages, e.g., OCS xlěvz 'stabulum; aedificium; domus; cella, etc.', Russ. xlev, Pol. chlew, Cz. chlév, S-C hlïev, Bulg. xlev, etc., and everywhere the meaning is 'Viehstall.' The word is most probably borrowed from Eastern PGermc. "hlaiwa- 'Grab,' as attested by Goth. hlaiw 'Grab,' OHG hlēo 'Grabhügel, Grab,' OE hlāw 'Grabhügel, Grabstein,' etc., which has a transparent IE etymology and correspondences, e.g., Lat. clīvus (*kleiuo-) 'Hügel' (see Pokorny, 601). The primary meaning of the Germc. word would be 'a dugout in a slope used as shelter, etc.', then 'grave,' which account for the development of the meaning in Slavic. It should be noted that dugouts in hill-slopes have long been known among the Slavs as shelters for people or animals (see K. Moszyński, Kultura ludowa Stowian, 1967, I, 475-77). Martynov (loc. cit., 88-90) underlines the correlation between the borrowed $x l e ̌ v z$ and the native ${ }^{18}$ kotz, kotbcb (what he calls "synonym microstructure"), in which the latter has been specialized in the meaning 'shelter for small domestic animals like sheep or chickens, etc.'. This fact would prove that $x l e ̌ v z$ is a penetration, not simply a loanword from Germanic. However, the stress of the word (oxytone or mobile) evokes some doubt as to the early character of the borrowing (see Kiparsky, 1934:176-77 and 1958:23).

6) $x y s z / / x y z z$; the general meaning of the Slav. word is 'dwelling, house,' and there is a tendency in the historical Slav. languages to assign to it the connotation of 'a primitive type of building, shelter, etc.'; attested with derivatives in -ina, etc., in most Slavic languages, e.g., OCS хуzъ 'domus,' xyzina 'ке́ $\lambda \lambda \alpha$, ' xyžina 'oikí $\alpha$,' Russ. xĩza 'Hütte,' Pol. old and dialectal chyz // chyż, chyza // chyża 'Haus, Hütte, Erdhütte; Viehstall,' S-C hǐža 'Haus,' Bulg. xíža 'Hütte,' Sloven. hì 'hölzerner kleiner Keller, kleine hölzerne Getreidescheuer,' hiz̃a 'Haus, Zimmer, Wohnstube.' The forms with an underlying $-s$ - are attested in: S-C Church Slav. xisz // xiša, Cz. $\operatorname{chyš}(e)$ f. 'Hütte'; S-C hisa, hiš 'Haus,' Sloven. his = hìz, hĩsa = hiz̃a The two underlying forms were borrowed from the continuations of two PGermc. archetypes: xyzъ from *hüsá- and xysz from *hús-. For the first archetype cf. the adjectives: OIc. hýrr 'mild,' OE hȳre 'freundich, mild' (i.e., 'domesticus'), which are allegedly derived from a PGermc. *hüzjá-; for the second archetype cf. Goth. -hūs and OHG, OSax., OIc., OE hüs 
'Haus.' As Martynov convincingly argues, the Germc. penetrants $x y z$ // xyss clashed in Proto-Slavic with the native synonym doms, which brought about the semantic differentiation of these synonyms; the foreign word acquired the status of a marked term 'cottage, shelter, etc.' (for details see Kiparsky 1934:177-79, and Martynov, loc. cit., 46-47).

7) 'xzlms 'hill,' attested in all Slavic languages, e.g., OCS $x$ lъmъ 'collis,' Russ. xolm, Ukr. xolm 'Hügel,' Pol. toponyms of the Chetm type, OCz. chlm, chlum 'Hügel,' S-C hûm 'collis,' etc. It is an obvious borrowing from PGermc. *hulma-, for which cf. OIc. holmr 'Insel,' OE holm 'Woge; See; Insel,' OSax. holm 'Hügel' (for details see Kiparsky, 1934:179-80, and Martynov, loc. cit., 92-93).

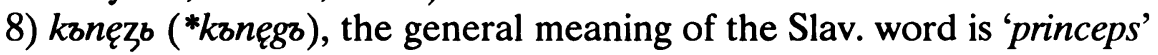
in the sense of 'political ruler, monarch,' rendering the meaning of its Germc. source. It is attested in all Slavic languages, e.g., OCS kъnęzb 'princeps, praefectus,' Russ. knjaz' 'Fürst; Bräutigam (an Hochzeit),' OPol. ksiqdz 'Fürst,' NPol. ksiqdz only 'Priester' (really 'Catholic priest'), Cz. kněz (meanings like in Polish), S-C knêz 'princeps, Fürst,' etc. The source of the word is PGermc. *kuningaz, attested by OSax. kuning, OE cyning, OHG chuning, OIc. konungr. It is unknown in Wulfila's Gothic, where the noun piudans is used in this sense. The word is a loanword, not a penetration, according to Martynov; no synonymous counterpart existed in Proto-Slavic. See Kiparsky, 1934:181-82, and Martynov, loc. cit., 47-48.

9) lukb, the oldest meaning seems to be 'garlic,' then 'onion'; attested in all Slavic languages, e.g., OCS lukz 'Lauch,' Russ. luk 'Lauch, Zwiebel,' OPol. tuk, Cz. luk, S-C lük, etc., in the same meaning. Most scholars assume here a loanword from Germanic, most probably from PGermc. *lauka- (because of the old acute accent in Slavic), for which cf. OIc. laukr, OSax. lök, OHG lauh 'Lauch.' This hypothesis is rather weak, however, since first, the Germc. word does not have an etymology in Germanic, and second, the cultivation of garlic spread in Europe from the east westward. So Martynov seems to be right in trying to explain the word as original Slavic from *louko- 'light, white' (cf. Gr. גєuкós 'white' and the Slav. words with the same root like lučb = světz 'light,' etc.). Therefore PGermc. *lauka- would be a Slav. loanword representing an earlier PSlav. stage with the original diphthong, i.e., *louks-. As far as the old acute of the PSlav. form is concerned, it could be explained in connection with the prehistorical vrddhi formation, namely from the noun *louko- 'light, brightness' $\rightarrow$ *louko-, i.e., PSlav. *lúkz adj. 'light, bright, white,' which then became substantivized to denote a plant whose striking feature is the whiteness of its fruit. In view of all these circumstances lukb should rather be dropped from the list of PGermc. loanwords in Slavic 
(for details see Kiparsky, 1934:249, and especially Martynov, loc. cit., 168-70).

10) *nobozězz 'drill' (?). The word is reconstructed from its alleged continuants in West Slavic and Slovenian, e.g., Pol. dial. niebozas 'Bohrer,' OCz. nebozěz // neboziez, MCz. nebozez // nebozéz, -ziz idem, Sloven. nabộzac // nabộžx 'Naber, Nabinger,' etc., and suggests as its source PGermc. (in any case pre-OHG) *nabagaiza-, attested by OSax. nabugēr, OE nafugār, OHG nabagēr, everywhere 'Bohrer'; for details see Kiparsky, 1934:183-84. It is obvious that this loanword underwent in Slavic various changes due to folk etymology.

11) nuta ("nuto?), the primary meaning of this word in Slavic is 'cattle' ('Rindvieh'), although it underwent secondary changes in some languages; Church Slav. nuta 'bos,' ORuss. nuta 'Hornvieh,' Russ. arch. and dial. núta (fixed stress!) 'lange Reihe' (sic!), Polab. nọto acc. sing. ( $\leq$ "noto with a secondary nasal in the root) 'Herde Vieh,' Sloven. núta 'Rinderherde' attest the word directly. Other Slavic languages show its traces in derivatives (see Kiparsky, 1934:183-84). It is an obvious penetration (according to Martynov, loc. cit., 50-52) from PGermc. ${ }^{*}$ nauta, ${ }^{19}$ represented by OSax. nōt $\mathrm{n}$. 'Rindvieh,' OE néat $\mathrm{n}$. 'Nutzvieh, Tier, Ochs,' OHG nōz n. 'animal, jumentum,' OIc. naut n. 'Rindvieh.' Nuta (*nuto?) clashed in Proto-Slavic with its native Slav. synonym govędo, which entailed various semantic shifts in these two words, nuta either replacing govędo or being pushed by the latter towards a special meaning, such as 'herd,' etc.

12) plugz 'plow,' attested in all Slavic languages, e.g., S-C Church Slav. plugz 'aratrum,' ORuss. plug, Russ. plug (in older Russ. with fixed stress!), Pol. phug, S-C plüg, etc., everywhere with the same meaning 'plow.' It is usually considered a loanword from OHG pfluog- or OLG plog, but the old acute accent would rather indicate a PGermc. *ploga- as its source (for details see Kiparsky, 1934:258-59, 1958:20, and Martynov, loc. cit., 175-78, where a Slav. etymology of this noun is proposed and PGermc. *ploga- is interpreted as a Slav. loanword in Germanic). Since the noun belongs to the field of agricultural terminology so important in the development of human civilization, it is worth discussing the origin of this term.

First of all it should be stated that Germc. *ploga-, the alleged source of PSlav. plugz, has no convincing etymology in that linguistic group, so it is unmotivated from the Germanic standpoint. Besides that, it was primarily restricted to German. In view of this, its foreign origin in Germanic seems to be highly probable. Of course, we cannot discuss the etymology of such a technical term without taking into consideration the realia of primitive or earlier agriculture. According to K. Moszyński 
(Kultura ludowa Stowian, I, 188, §182) the plow is a relatively new acquisition of the Slavic folk culture which came to the Slavs from the south, the region between the Alps and the Pontus, where it was probably invented; but it never eliminated the use and the names of two earlier, more primitive plowing tools, the soxa and *ordlo (OCS ralo, etc.), which have IE correspondences. So it is possible that plugz also stems from that region and represents an IE dialect (Illyrian? Venetic?) of Pannonia belonging to a kentum group of southern type which distinguished the vowels $a: o$. I propose as the original form *plogo-, and using the suggestion of the realia (see the construction of radło ptużne or ptużca in K. Moszyński's Kultura..., I, 181, etc.), namely the fact that the runner of a plow, a construction element unknown to the primitive soxa, is called *polzz in Slavic (Pol. płóz, SSlav. plaz, ESlav. póloz) and represents an obvious old derivative from the verb *pblzq, *pblzeši, *pelsti (cf. OCS plbzati, plěžq, plěžeši, Russ. polztí, polzú, Pol. petzać, petzę, petziesz, etc.) 'creep' - I derive that Illyrian or Venetic *plogo- from the IE biform root *pelg'- // *pleg'-, 20 which according to Pokorny (807 and 850, s.v. pelk'-, polk'- and pelg'-, polg'-) means 'wenden, drehen' (807), 'wenden, biegen' (850) and, we should add, also 'kriechen.' The reconstructed noun *plogo- would be a vrddhi formation from an underlying nomen actionis *plogo- 'creeping,' thus *ploggo- adj. 'pertaining to the action of creeping' $\rightarrow$ 'creeper,' etc.; thus semantically and etymologically we would have identity between the original Slav. ${ }^{*}$ polzs and the posited Illyrian or Venetic *plōgo- (IE *polg'o- *plog'o-!). Incidentally, cf. the similar relationship between PSlav. *görds and *zórds from IE kentum *ghordhoand satom * 'h'hördho-.

Now the problem is whether we need the Germc. intermediary in the borrowing of this Danubian or Pannonian word *plogo- by Slavic. The crucial point is the treatment of $/ \bar{o} /$ : Proto-Germanic in its later period had $\mid \bar{o} /$ (close!), so a Danubian-Illyrian (or Venetic) *plōga- was borrowed after the first consonant shift as PGermc. *plōga-, , whence ultimately NHG Pflug, NE plough, etc. Of course, this PGermc. form would regularly be rendered by the Slavs at the time of the monophthongization of diphthongs (4th-6th centuries A.D.) as *ploggo-, then plugz. But the Germc. intermediary seems unnecessary: we can start from a Pannonian-Venetic *plogo- (see Pellegrini-Prosdocimi, 1967:258), borrowed by the Slavs in Pannonia sometime in the 5th-6th cent. A.D., since even the later Latin $/ \bar{\phi} /$ was replaced by the historical Slav. /u/, e.g., rōsa $\geq$ S-C rusa (Dubrovnik) // ruža, OCS rusalbja, ESlav. rusalıka, etc.

It is worth mentioning here that the variant *pelk'- of the verbal root discussed above has produced some interesting derivatives in Germanic, 
Celtic, and Slavic which seem to be connected with the agricultural terminology, e.g., Germanic *felgan as attested by OHG ungifolgan 'ungewendet,' and the OE preterit fealh, fulgon 'wendete(n),' from which PGermc. *felgō 'Radfelge' was derived, as attested by OHG felga 'Felge, Egge' (!), OE fielg, NE felly idem, etc., and with an Ablaut, the PGermc. *falgo, as attested by OE fealg, NE fallow, Bavar. falg idem, NHG Felge 'gepflügtes Brachland,' etc.; Celtic *polka, as attested by Gall. olca 'Pflugland'; Slavic *polsa, as attested by Russ. polosá, S-C (Čak.) plasà, Pol. ptosa, etc. 'strip of land.' Especially important is the North-West IE

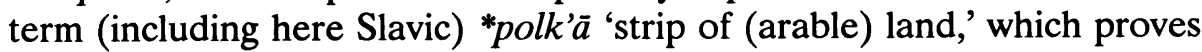
that the verbal root 'pelk'- was used in primitive IE agricultural terminology. Such facts make the above etymology of *plogo- highly plausible (for details see Pokorny, loc. cit., and Kluge, 1960:191). ${ }^{21}$

13) skotz 'cattle.' Its semantic relationship to Slav. govędo is not clear, although we should assume a primary distinction; the word is attested in all Slavic languages, e.g., OCS skotz 'pecus, iumentum,' Russ. skot 'Vieh' (in ORuss. also 'Besitz; Geld, Steuer,' the latter under the influence of ONorse), Pol. skot, S-C sköt, etc. idem. Most scholars derive it from PGermc. *skatta-, attested by Goth. skatts ' $\delta \eta \nu \alpha \dot{\rho} \iota\llcorner\nu, \mu \nu \hat{\alpha}, '$ OHG scaz 'denarius,' OE sceatt 'Schatz, Geld, Besitz, Reichtum; Münze, Denar, etc.,' OIc. skattr 'Steuer,' and only in OFries. skett 'Schatz, Geld' and 'Vieh.' This semantic difference, Germc. 'treasure, money' Slav. 'cattle,' against a comparative background would rather point towards Slavic as the source of the borrowing (cf. lat. pecus 'cattle' $\rightarrow$ pecunia 'money,' etc.), the more so that the word does not have any satisfactory etymology in Germanic. So it is at least questionable that it was borrowed by the Slavs from Germanic (Kiparsky, 1934:186-88). In view of the above Martynov (1963:183-87) has proposed a Slavic etymology of the word and included it in his list of prehistorical Slav. loanwords in Germanic with the medium degree of plausibility. Martynov's etymology (skotz is allegedly related to OCS sъčetati 'verbinden, vereinigen,' etc., and its primary form is *szkotz and the meaning 'increase in breeding' as in $\mathrm{S}-\mathrm{C}$ and Sloven.) is too speculative and does not explain important formal problems, among other things the double consonant in Germanic (skatta-). All difficulties would be removed if we derived PSlav. skots from the primary *skok-to-, a noun based upon the Slav. verb skociti, etc., 'jump' (for the formation cf. pots from *pok-to- 'sweat' *pek-ti 'bake,' mosto from *mot-to- 'bridge' $\sim$ *mesti 'throw,' etc.) ${ }^{22}$ and reconstructed its primary meaning as 'calf, calves (collective), i.e., 'jumping (young animal[s])'; the semantic content is obvious to anybody familiar with the behavior of calves. So the geminate in Germanic could easily be interpreted as reflecting an earlier PSlav. stage *skotto- before the 
ultimate simplification of the consonant clusters ( ${ }^{*}$ skokto- $\geq *^{*}$ skotto- $\geq$ skoto-). In view of the above, skots should rather be removed from the list of Germc. loanwords in Slavic and qualified as a Slav. loanword in Germanic.

The above etymology of skotz as *skok-to- was proposed by M. Rudnicki (Prasłowiańszczyzna-Lechia-Polska, 1961, II, 79). There is, however, another etymology, that by E. Stankiewicz (in $A$ Festschrift in Honor of Boris O. Unbegaun, 1968:219-26), deriving skotz from *skop-to(cf. Slav. skopiti 'castrate'). This latter seems to have better semantic justification against a wide background of cultural and linguistic facts, although formally either one explains satisfactorily the geminate in Germc. skatta-.

14) ${ }^{*}$ šelmъ $\leq$ PGermc. *xelma- 'helmet.' This is an obvious borrowing attested in most Slavic languages, e.g., OCS šlěmı, ORuss. šelomz, šolomz, OPol. szłom, S-C šljëm, etc.; for the Germc. source cf. Goth. hilms and OHG helm, etc.; the early PSlav. form *xelms indicates that we must start from a pre-Gothic source (see Kiparsky, 1934:188-89).

15) tynı $\leq$ PGermc. *tūna- 'fence.' This is also an obvious borrowing attested in most Slav. languages, e.g., OCS tynz 'murus,' Russ. tyn 'Staketen-, Flecht- Pfahlzaun,' Pol. dial. tyn, tynina, tyniec 'Umzäunung aus Kiefern- und Tannenzweigen,' S-C (only in Croatia) tïn 'Scheidewand, paries,' etc. It is also known in toponyms: Pol. Tyniec, Cz. Týn, Týnec; for the Germc. source cf. OIc. tún, OE tūn, OHG zūn, etc. 'Zaun' (in English this nouns shows the same semantic development from 'fence, enclosure' to 'town' as the PSlav. *gordb!); see Kiparsky 1934:189-90.

16) *volx 3 'person of Roman origin'; attested in all Slav. languages as the old name of Romance people in general or of particular Romance people with whom the Slavs were in closer contact, e.g., OCS vlaxz 'vlachus, generatim homo romanae originis,' Russ. volóx 'Walache,' Ukr. volóx 'Rumäne,' Pol. Wtoch 'Italiener,' Cz. Vlach 'Italiener, Wälscher, Wahle,' S-C vläh 'Walache, Andersgläubiger,' Bulg. vlah 'Walache, Rumäne,' etc. The source of this ethnicon is PGermc. *walxa-, as attested by OHG walh 'romanus,' OE wealh 'Fremder, Sklave; Britte, Walliser,' OIc. plur. valir 'Franzosen,' which ultimately reflects the Celtic ethnicon Volcos (Kiparsky, 1934:190).

17) *želdo, *želsti 'repay with money' (?), as opposed to the native platiti 'pay,' then it might be a penetration according to Martynov's approach. The verb is attested only in OCS žlědo, žlěsti // žlado, žlast 'compensare, abzahlen, vergelten' and ORuss. želědu, želěsti // žladu, žlasti // žlěděju, žlěděti 'solvere, Strafe zahlen.' There are also some nominal derivatives from this verb, e.g., OCS žlědbba 'mulcta,' etc. The source of 
this verb is PGermc. *geldan (not Goth. -gildan!), attested by Goth. fra-gildan 'vergelten, erstatten,' OIc. gjalda, OE zieldan, OHG geltan, etc. 'bezahlen, vergelten' (cf. NE yield!).

B) Second period: borrowings from Gothic between the 2nd and 4th centuries A.D. (Kuryłowicz's layer II).

1) bl'udz // bl'udo 'table' $\rightarrow$ 'bowl,' attested in most Slavic languages, e.g., OCS bl'udz // bl'udo 'patina, Schüssel,' Russ. bljúdo 'Schüssel; Gericht; Gang,' OPol. bluda 'Holzschüssel,' S-C bljüda, bljüdo 'patina,' etc. The source of this noun is Goth. biups (stem biuda-) 'Tisch' (for details see Kiparsky, 1934:193-94).

2) cěsar'b 'emperor,' attested in most Slavic languages, e.g., OCS

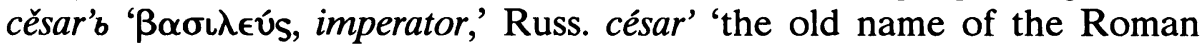
emperor,' Pol. cesarz 'Kaiser,' Cz. císař idem, etc. From this word come the contracted forms cbsar'b, car'b (already in Church Slavic), e.g., Russ. car' 'Zar,' S-C cär 'rex, imperator,' Bulg. car idem, etc. (the contracted form usually refers to orthodox Slavic rulers). The source of this name is Goth. kaisar, which by itself represents a borrowing from Greek к $\alpha \hat{\imath} \sigma \alpha \rho$ ( $\leq$ Lat. Caesar); see Kiparsky, 1934:194-95.

3) gobino 'abundance' (?), attested only in OCS gobino (?, only the Loc. sing. is documented) 'ubertas; copia,' Church Slav. gobina, gobino 'fruges,' and S-C gobino 'Triticum spelta L' (sic!). It is borrowed from Goth. gabei (stem gabein-) f. 'Reichtum' (Kiparsky, 1934:198).

4) gobbzb 'copious,' attested only in some Slav. languages: OCS gobbzb 'reichlich' (deduced from gobbzevati 'reichlich sein,' gobbziti 'fruchtbar sein,' etc.), Church Slav. gobbzz adj. 'fertilis,' gobbzz subst. 'ubertas,' Cz. hobezny' 'reichlich' and in the toponyms Hobza f., Hobzie n. An obvious source of this adjective is Goth. gabigs 'reich' (Kiparsky, 1934:198-99).

5) xlěbъ 'loaf of bread' (?) as opposed to kruxъ 'bread' (then it would be an example of Martynov's penetration; see Martynov, 1963:85-88), attested in all Slavic languages, e.g., OCS xlěbъ 'panis,' Russ. xleb, Pol. chleb, Cz. chléb, S-C hljëb, etc., everywhere with the basic meaning 'bread,' although there where PSlav. kruxz 'bread' has survived the expression *xlěbs kruxa, e.g., Sloven. hleb kruha or S-C hljeb kruha, means 'a loaf of bread,' etc. The source of this noun is Goth. hlaifs (stem hlaiba-) 'Brot,' a Com. Germc. word, cf., e.g., OIc. hleifr, OE hläf, OHG hleib, etc., and the present-day Eng. and NHG expressions loaf of bread, Laib Brot. The primary meaning of the Germc. *hlaiba- was 'in Pfannen gebackenes Brot' as opposed to later *brauda- 'mit Sauerteig hergestelltes, gesäuertes Brot' (see Kluge, 1960:418, 102-03). In view of the latter, we can hypothesize that xlěbs clashed with its synonym kruxъ in 
Proto-Slavic and eventually acquired a secondary meaning 'loaf of bread' (Kiparsky, 1934:199-200).

6) xqdogz 'able, fit,' attested only by OCS xqdožbstvbje 'ars,' Church Slav. xudogz 'peritus; callidus; prudens; aptus,' Russ. xudóga 'Kunst,' Pol. chędogi (old) 'sauber, schön, zierlich, geschmückt'; (new) 'rein, reinlich' (these latter, undoubtedly secondary meanings, are explained quite convincingly by Kiparsky (loc. cit., 201) as a result of "objective treatment": 'tüchtig behandelt' instead of 'tüchtig handelnd'). The source of this adjetive is Germc. *handaga- (not Wulfila's Goth. handugs 'weise' because of the suffix -ug-), which is attested by the OHG variant hantag 'acer, durus, ferox, fortis, etc.'; the primary meaning in Germanic was undoubtedly 'tüchtig, geschickt' (as it is in OIc. and OE). The borrowed $x q d o g z$, representing a penetration, clashed with its synonym xytro in Proto-Slavic, which accounts for either the ouster of the latter from its primary semantic role or the disappearance of $x$ dog 3 in those languages which preserved xytro in its primary meaning (for details see Martynov, 1963:43-45). The chronology of this borrowing cannot be positively established.

7) *xosa; its primary meaning in Proto-Slavic is defined by Kiparsky (loc. cit., 202) as 'auf Raub ausziehende (bewaffnete) Schar.' The word is attested in OBulg. (through Greek sources before 1000 A.D.) as Xovoŕ

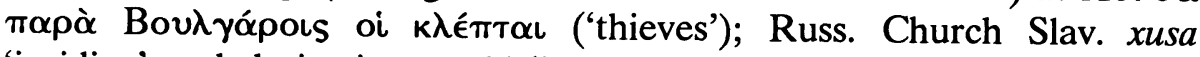
'insidiae' and derivatives xusiti 'latrocinari,' xusovati 'praedam capere'; S-C (14th-16th cent.) husa 'praedatio, incursio, insidiae, manus praedonum'; OPol. chqsa 'Raub,' chqzíba (with the Slavic suffix -bba) 'Raub, Diebstahl.' The source of the noun is Goth. hansa 'Schar, Manipel, Kohorte,' and we have here an obvious example of semantic differentiation and depreciation of the primary Germc. meaning with respect to the original Slav. četa 'detachment (of warriors),' which shows that this is a penetration, not a simple borrowing. See Kiparsky, 1934:201-03, and Martynov, 1963:91-92, who, however, speculates unnecessarily about a possible borrowing from Slavic (sic!) into Germanic.

8) kotbls 'kettle,' an obvious borrowing from Goth. katil( $u$ )s idem, which itself represents in Gothic a Latin loanword (catillus). It is attested in most Slavic languages, e.g., OCS kotblz; Russ. kotël, gen. kotlá; Pol. kociet (old), kociot, gen. kotła, S-C kòtao, gen. kòtla, etc. Everywhere it has the same meaning 'kettle' (see Kiparsky, 1934:203-04).

9) kupiti 'buy,' an obvious borrowing from Goth *kaupjan idem (in Wulfila's Gothic only the form kaupōn occurs, which seems to underlie Slav. kupovati; in any case Germc. kaupjan is well attested by OSax. kōpian, OE céapjan, OHG kouffen, and NHG dial. käufen 'kaufen, 
Handel treiben'). The verb is attested in all Slavic languages, e.g., OCS kupiti 'emere,' Russ. kupit', Pol. kupić, S-C kúpiti, etc.; everywhere it has the same meaning 'buy' (cf. Kiparsky, 1934:204). ${ }^{23}$

10) kusiti 'try, attempt,' an obvious borrowing from Goth. kausjan 'kosten, prüfen.' It is attested in most Slav. languages, usually with prefixes, and in those where $q \geq u$ it merges formally and semantically with *kositi 'bite,' e.g., OCS vz-kusiti 'gustare,' -is-kusiti 'probare,' Russ. from Church Slav. iskusit' 'in Versuchung führen,' Pol. kusić 'kosten, schmecken' (old); 'versuchen' (in the moral sense), S-C küšati 'gustare,' 'experiri; tentare, conari,' etc. (Kiparsky, 1934:204-05).

11) lěkz 'drug, medicine,' primarily 'herb used as medicine,' attested directly or indirectly (through derivatives like lěčiti 'heal,' lěkar'b 'healer,' etc.) in all Slavic languages, e.g., OCS lěčbba 'sanatio, curatio,' Church Slav. lěkъ 'medicina,' Russ. lečit' 'heilen, kurieren,' dial. léko 'Arzenei,' lěká 'Heilung, Kur,' Pol. lek 'Arzenei,' Cz. lék idem, S-C lïjek idem, etc. Most linguists consider it a loanword from Goth. lēk- (sic!, posited as root), which is allegedly supported by the following Germc. material: Goth. lēkeis 'Arzt,' OHG lähhi, OE lǣece idem, etc. But there is no Germc. *lēka- which could be the source of the PSlav. lěkz: so we are left with a highly hypothethical Wurzeletymologie, deriving only the Slav. root lěk- from Germanic. The Germc. lēkeis (*lëkila-) itself does not have a Germc. etymology and its borrowing from Celtic (OIr. liaig 'physician') is uncertain. Also disputable and rather exceptional would be the treatment of the Goth. $\bar{e}$ (which was close) as Slav. $\check{e}$ (which was open). In view of all these objection Martynov's proposal to derive instead Germc. lēkeis from Slavic (cf. Church Slav. 1076 A.D. lěčbcb) seems to put the etymological investigation on the right track (see Martynov, 1963:210-13). According to him, lěkar'b as opposed to *vorčb (OCS vračb) meant 'healer by herbs' as opposed to 'healer by incantation,' but he draws no further conclusions from this hypothetical statement, i.e., from the reconstruction of the meaning 'medicinal herb' for lěkz.

I propose to draw such conclusions and to derive lěk word from PIE *loikó-, nomen agentis from *leik- 'leave' (see Pokorny 669 , s.v. leiku- 'lassen, zurück-, übriglassen' and especially the continuations of the PIE adj. *loik ${ }_{\text {uO-S }}$ 'übrig' in historical IE languages, e.g., Gr.

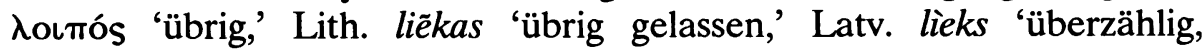
überflüssig, etc.'). The concrete meaning of this noun in opposition to its close cognate otzlěkろ in OCS (= Lith. ât-laikas 'Rest' and OI ati-rēka- m. 'Überbleibsel') would be 'decoction remaining in the vessel from brewing medicinal herbs,' as opposed to 'the solid remainder, dregs.' It is interesting that this etymology, which has been arrived at as a result of Martynov's semantic suggestions and a purely formal analysis of the noun 
lěkъ as a continuation of PIE *loikó-, has strong support in a similar etymology of Lat. līquor, derived from the verb lĭqueó, -ère 'être clair, limpide,' which Ernout and Meillet (1939:555-56) explain as "un verbe d'état appartenant à la racine de linquō...; la racine de linquō qui a eu plusieurs développements de sens divergents, aurait fourni des mots signifiant 'être en état de laisser aller, en état liquide'."

So we seem to have a transparent Slavic etymology of lěkz, representing a quite productive type of old IE deverbal noun in Slavic; the only unusual feature of this noun would be its primary final stress (cf. the neoacute length in $\mathrm{Cz}$. lék and S-C lïjek, Gen. lijèka), which is exceptional in this type in Slavic. But this feature can be explained as a remnant preserved in an isolated, unmotivated noun whose underlying verb *leikō, i.e., PSlav. *likg or *lbkq, etc., disappeared. In any case, late PSlav. lěkz (i.e., *lǣkz) qualifies better as the source of Germc. lék- than vice versa. In view of the above, lěk should be removed from the list of Germc. loanwords in Slavic (for details see Kiparsky, 1934:205-06; Martynov, loc. cit.; and Vasmer, III, 134, s.v. ólek).

12) lixva 'usury' (?), attested in all Slavic languages, e.g., OCS lixva 'usura,' Russ. lúxvá 'Überschuss, -fluss;' unerlaubter Gewinn, Wucher(zins),' Pol. lichwa 'Wucher,' S-C lihva 'Zinsenberechnung.' This noun is usually explained as borrowed from Goth. *leihva (the only attested form in Gothic is the verb leihvan 'leihen, borgen,' which has exact correspondences in other Germanic languages; the noun *leihwō does not exist in Germanic!). In view of these facts serious objections can be raised against this etymology, and a Slavic origin of the noun seems to be more plausible. Namely, lixva could be treated as a derivative with the suffix - va from the adjective lixz 'transcending a measure' and this etymology would account well for the meaning of the noun. Derivationally, nouns in $-v a$ from adjectives are not uncommon in Slavic, cf., e.g., *gol-va 'head' (primarily 'bald pate'), probably derived from gols 'naked,' etc. (cf. Vaillant, IV (1974), 709-11), and Kiparsky's objection $(1934: 207)$ that *leiks-ū $\bar{a}$ should have resulted in *lisva is not justified (cf., e.g., OCS vlaxvz 'magus' vlbsngti 'balbutire'). The only problem is the primary accent, most probably the old acute. So, in view of all the above facts, lixva should be eliminated from the list of certain Germc. loanwords in Slavic, and the relationship between Germc. leihw-an and PSlav. lix-va $\left({ }^{*} l e i k-s-u \bar{a}\right)$ then would only represent a regular phonemic correspondence of roots which in their turn represent the continuation of PIE *leik(u)_ 'leave' in each of the languages (for details and discussion see Kiparsky, 1934:206-07, and Martynov, 1963:93-96).

13) lbstb 'shrewdness' $\rightarrow$ 'trickery, deceit,' attested in all Slav. languages, e.g., OCS lbstb f. 'fraus, dolus,' ORuss. lbstb f. 'Betrug, List; 
Schmeichelei, etc.', Russ. lest' (gen. lésti) 'Schmeichelei, Verfänglichkeit, Verführung,' OPol. leść f. 'Verrat; Heuchelei,' Cz. lest f. 'List,' S-C lâst f. 'Betrug,' etc. It is an obvious borrowing from Goth. lists f. 'List,' which has exact correspondences in other Germc. languages with the meaning 'Klugheit, Kunst, List.' The noun has a transparent etymology in Germanic, where it is derived from the verbal root *leis-, attested in Goth. praeter.-praes. lais 'ich weiß' and in the causative laisjan 'wissen machen,' 'lehren,' etc. It is a penetration in Proto-Slavic which clashed with the original Slav. xytrostb; where the latter was preserved, the meaning of lbstb depreciated from 'shrewdness' to 'trickery, deceit' (Kiparsky, 1934:207-08, and Martynov, 1963:48-50).

14) osblb 'donkey,' attested in most Slavic languages, e.g., OCS osblb; Russ. osël, gen. oslá; Pol. osiot (old osiet), gen. osła; S-C òsao, gen. òsla; etc.; it is usually treated as a loanword from Goth. asilus, which in turn is derived from Lat. asellus, a diminutive of asinus. However, there are serious formal objections against this etymology of Goth. asilus (the simple $l$ instead of the expected geminate!) which suggest just the opposite direction for the loan, namely from Slavic to Germanic. Then Slav. osbls would be an old borrowing from the Iranian East (?) like Lat. asinus (PIE *e/ok'u-ino- related to *ek'úo- 'horse,' cf. Arm. ēš 'donkey') with the Slav. suffix -bl-, known in such nouns as koz-blo 'bock,' or-blb 'eagle,' etc. In view of this, osbls should be removed from the list of sure Germc. loanwords in Slavic (Kiparsky, 1934:208 and Martynov, 1963:98-99).

15) *pblkъ 'collective of warriors' (?), attested in most Slavic languages, e.g., OCS plzkb 'acies; cuneus' (both meanings are clearly military, referring to troops formed in battle array!), ORuss. płlkz, pъlzkz, polkъ 'Heer, Heeresabteilung, Heeresmacht, Schlacht, Heereszug, Lager; Volk; Versammlung,' Russ. polk 'Regiment, Schar, Haufen,' Pol. old petk, new putk 'Regiment,' Cz. pluk 'Haufe; Geschwader,' S-C pûk 'Volk, populus,' etc. In spite of attempts to interpret this noun as a native Slav derivative with the suffix -ko- from the IE verbal root * $p l e H$ - // plH- 'fill' (cf. Martynov, 1963:223-27), the best etymology is still that which derives it from Goth. *fulk(s) (not attested in Wulfila but known under the Latinized form fulcus from the Reichenau glosses). The Goth. form has obvious correspondences in Germanic: OHG folc n., m., OE folc, OIc. fólk '(bewaffnete) Schar,' and it seems to continue a PIE archetype *plH-go-, whose variant *pleH-go- is attested by Alb. plok, plogu 'Haufe' (Pokorny, 799). It is difficult to decide whether *palks represents a regular borrowing or a penetration from Germanic; in any case it must have been borrowed quite early, because it occurs as the second component of the PSlav. personal name *Svętopılkz (cf. OCS Svętoplıkъ, 
Russ. Svjatopolk, Pol. Świętopetk, etc.), whose meaning was undoubtedly '(leader) of a strong troop, etc.' (see Kiparsky, 1934:208-09, and Martynov, loc. cit., where, however, his speculations about a possible penetration of *pslks from Slavic into Germanic are not convincing).

16) stbklo 'glass' (material and vessel), attested in all Slavic languages, e.g., OCS *stbklo, retrieved from stbklbnica 'poculum'; Church Slav. stbklo 'vitrum' and also 'Trinkgefäss'; Russ. stekló 'Glas'; Pol. szkło (OPol. śćkło)

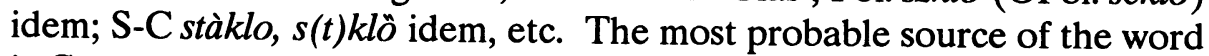
is Goth. stikls m. 'Becher, Kelch,' whose primary meaning as indicated by Germc. correspondences was 'Spitze eines Trinkhornes,' cf. OIc. stikill 'Spitze' (especially 'eines Trinkhornes'), OHG stechal 'calix,' etc. In Slavic the name of the glass vessel became the name of its material, and in this connection the change of grammatical gender occurred from the expected masculine ${ }^{*}$ stbklı $\rightarrow$ neuter $*_{s t b k l o}$ by analogy to želězo, *zolto, *sbrebro, etc. (Kiparsky, 1934:209-11).

17) *t'ud'b ('tjudjb) 'foreign,' attested in all Slavic languages (there is also a dissimilated form, *tud'b), e.g., OCS štuždb, tuždb 'alienus,' ORuss. čužij 'alienus, peregrinus,' Russ. čužój, Pol. cudzy, Cz. cizí, S-C tûd, Bulg. $\check{c} u z ̌ d$ (with $\check{c}$ - by analogy to čudo), etc., everywhere with the same meaning 'foreign.' It is an adjective most probably derived with the suffix -jo-from the noun *t'uda, which in its turn represents a penetration from Goth. piuda 'Volk.' The primary meaning of *t'ud'b would be 'belonging to a Germanic tribe' $\rightarrow$ 'belonging to a foreign tribe' $\rightarrow$ 'foreign' (as opposed to *svoběnı 'Slav'?). Germc. *peudō from PIE *teutá 'populus' is well attested in OHG diota 'Volk,' OE ðéod, OIc. pjód idem, etc. (Pokorny, 1084). That this noun penetrated into Proto-Slavic seems to be proved by Russ. collective čud' 'wilde, meistens finnische, Völkerschaften.' Whether Church Slav. študz, Russ. čud 'giant' belongs here (Kiparsky, 1934:212) is questionable. I would rather derive it with OCS študb f. 'das Gebaren, die Sinnesart' ('behavior') and S-C ćûd, gen. ćûdi 'nature, character' from PIE *tēu-dho- 'strong' (see Pokorny, 1080, s.v. tēu-, tau-, teuə-, etc. 'schwellen,' etc.) and treat it as a native PSlav. word, although there are unsolved problems connected with this etymology (see Kiparsky, 1934:211-13; Martynov, 1963:102-05; and Vasmer, IV, 378-79).

18) *valbods 'camel,' with a secondary velb- (by analogy to velbjb) and -blods (by analogy to bloditi), attested only in OCS (Suprasliensis) and North Slavic (in Slovenian velblód seems to be a Czech loanword), e.g., OCS velbbqdz, velıblodz 'camelus,' ORuss. velbbudz, velbbl(j)udz, Russ. verbljud, Pol. wielbtad, Cz. velbloud, etc. It is a borrowing from Goth. ulbandus 'camel,' which in its turn stems from Gr. é $\lambda \epsilon ́ \phi \alpha \varsigma$, gen.

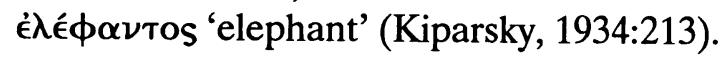


C) Third period: borrowings from "Balkan Gothic" from the 5th and 6th centuries A.D. (Kuryłowicz's layer III).

The term "Balkan Gothic" (Balkangermanisch according to Kiparsky) covers the dialects of all those East Germanic tribes (the Goths, Gepids, etc.) which swarmed into the Danube basin and the adjacent Balkan regions during the great migration of peoples, from where they were ultimately ousted by the Slavs and the Avars. It is obvious that loanwords from Balkan Gothic are virtually restricted to South Slavic and Old Church Slavonic. But since the latter has deeply influenced the East Slavic languages and to some extent also the religious terminology of Czech (and through it, that of Polish), we can find the corresponding words in East and West Slavic.

1) *bordy (gen. -zve) 'hatchet,' attested in OCS brady 'ascia, securis,' Russ. Church Slav. bradzvv idem, S-C brädva idem (in older time as a weapon, now as a tool), Bulg. brádva 'Axt, Beil,' Mac. bradva idem, Sloven. brâdva, brâdlja 'Bartaxt; breite Zimmerhacke.' This is a highly probable loanword from an unattested Goth. *bardo for which there are the following Germc. correspondences: OIc. barda, OHG barta, OSax. barda 'Barte, Beil,' i.e., a typical Germc. battle axe (Kiparsky, 1934:216-17).

2) a) buky (gen. -ъve) 'letter,' attested in OCS plur. bukъvi f. 'тò

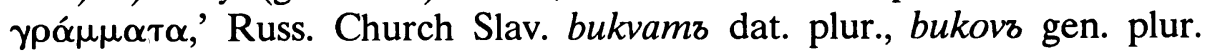
'Buchstabe,' Russ. búkva, Ukr. búkva, S-C bükva, Bulg. búkva, Mac. bukva, Sloven. bûkve plur. 'Buch,' and Polab. bükvói plur. 'Buch'; everywhere it has the meaning 'letter' in the singular, and in the plural essentially 'book.' As we see, the noun is restricted to South Slavic, and through OCS influence it reached also East Slavic; but its occurrence in Polabian is puzzling. The most probable source of Slav. buky 'letter' is Goth. (i.e., Balkan Gothic) bōkōs plur. 'Schrift, Buch, Urkunde,' like (O)CS bukarb 'grammaticus' - Goth. *bōkāreis (Kiparsky, 1934:219). Goth. bōka sing. f. (Germc. ö-stem: *bōkō!) 'letter' represents the Proto-Germanic semantic specialization (metonymy) of the dialectal IE tree-name *bhägo- 'Fagus silvatica' in the sense 'beech-wood plate with written signs, "runes"' (primarily in the plural) $\rightarrow$ 'letters, book' (see Kluge, 1960:106), whereas the old meaning 'beech tree' was carried on by an innovative $n$-stem: Proto-Germc. ${ }^{*} b o ̄ k(j) o ̈ n$-, i.e., NHG Buche, NE beech, etc. In this connection it is worth mentioning that in many languages the word for 'book' is derived from the name of the primary material on which the people used to write, e.g., Lat. liber originally meant 'bast,' which meaning is still attested in classical Latin (Ernout-Meillet, 1939:544). 
2) b) bukz 'beech tree, Fagus silvatica', attested in most Slavic languages (in Bulg. and Mac. we find the fem. - $a$ form: buka), e.g., ORuss. bukz, Russ. buk, Pol. buk, S-C bük (older and dialectal), etc. There is no question that the name of this tree was borrowed by the Slavs from Germanic; the only problem is which Germc. dialect was the source of the borrowing and whether we can posit a Germc. *bōka- m. as the source (Germc. correspondences suggest *bōk(j)ōn-). Since some Slavic languages show the form *buky, -zve, namely Russ. Church Slav. buky, Cz. (15th cent.) bukev, S-C bükva, Sloven. bukva, búkev, everywhere with the meaning 'beech-tree,' and Pol. bukiew, Cz. bukev, bukva, ULus. bukwica, Polab. bükvói plur., Sloven. bukavca, everywhere with the meaning 'beechnut' - it is possible (against Kiparsky, loc. cit., 219) that the latter represent the primary form of the borrowing from Germc. ${ }^{*} b \bar{o} k \bar{o}(n)$ sing. fem., regularly rendered as *buky, etc., whereas the former may represent a Slavic morphological adjustment of that primary form to original Slavic masculine tree names like $d \rho b z$, grabz, klenz, etc. See Chapter V where the names of typical western trees are discussed for the time and place of the borrowing. In any case, *buky, bukz 'beech tree' could not have been borrowed earlier than the first centuries A.D. (for details see Kiparsky, 1934:217-19; Martynov, 1963:60-61; and Trubačev, Etim. slov. slav. jaz., III, 1976:90-91).

3) likz 'round dance (with singing),' attested in OCS likz 'chorus' and its derivative likovati 'saltare, plaudere,' ORuss. likz 'Reigen; Gesang; Würfelspiel,' likovati 'saltare, cantare,' S-C lika 'Freude, Lust' (S-C lik 'chorus' and Bulg. lik idem were undoubtedly borrowed from Church Slavic). The noun is most probably borrowed from Balkan Gothic *liks = Wulfila's Goth. laiks ' $\chi$ opós, Tanz'; a vestige of the latter occurs in Russ. Church Slav. lěkz 'ludi genus, fortasse saltatio' or 'dice rolling' (for details see Kiparsky, 1934:220-21).

4) skuts 'lap, seam, hem,' attested in Church Slav. skutb 'extrema vestis; fringe; garment'; Russ. (from the former) skut 'Saum,' S-C skût 'Saum; rim, hem'; Bulg. and Mac. skut 'Schoss, Saum; Schürze.' The geography of the word supports its derivation from Balkan Goth. skauts 'Schoss, Saum' (for details see Kiparsky, 1934:221-22).

5) *smoky, gen. -ъve 'fig,' attested in OCS smoky 'ficus,' Russ. (from the latter) smókva 'Feige(baum), eingemachte Früchte,' S-C smökva, Mac. smokva, Bulg. smókva, Sloven. smộkav; everywhere 'Feige(baum).' The word is most probably a borrowing from Goth. smakka m. 'Feige,' and the ending $-y$ may be the result of an analogy to $*^{\prime} y k y, *_{m b}$ rky, etc. (names of fruits and vegetables); for details see Kiparsky, 1934:222-23.

6) *usoręzb 'earring,' attested only in Church Slav. (since the 11th century) useręzb, usorezb, etc., 'inauris,' Russ. Church Slav. serjazb and 
Old. Croat. userez idem. The most probable source of this word is Balkan Goth. *ausahriggs = earring (Kiparsky, 1934:223-24).

7) *vinogords 'vineyard,' attested in OCS vinograds 'vitis' and 'vinea,' whence in East Slavic: Russ. vinográd 'Wein, vitis vinifera,' Ukr. vynohrad 'Wein, Weinberg'; Cz. vinohrad 'Weingarten; Setze' (probably from OCS), S-C vinograd 'Weinberg, vinea,' Bulg. (bookish) vinográd idem, Sloven. vinógrad 'Weingarten.' Most probably borrowed from Balkan Gothic weinagards 'Weinberg'; as far as the meaning 'vine' is concerned, it is also attested in Crimean Goth. wingart 'vitis, Weinrebe' (for details see Kiparsky, 1934:224-26).

The Problem of West Germanic Borrowings in Prehistorical Slavic

As mentioned above, in the present chapter I am deliberately limiting my discussion of Slavic-Germanic linguistic contacts to the period before the year 600 A.D. This arbitrary date has been chosen because it represents a point in time after which the previous Proto-Slavic ethno-linguistic community rapidly disintegrated. Actually, if we realize that this is the date around which on the one hand the mass movement of the ancestors of the Southern Slavs across the Danube River took place, and on the other the ancestors of the Lusatians and the Polabians crossed the Laba (Elbe) River, then this purely geographical extension of the Slavs is sufficient to account for the deepening dialectal differentiation of what in earlier centuries had been a relatively uniform Proto-Slavic (Common Slavic) language. However, there are also some direct, purely linguistic facts which prove that the two and a half centuries between the year 600 and the first written Slavic texts (Old Church Slavonic of the second part of the ninth century) were full of profound linguistic changes that ultimately produced the early historical differentiation of the Slavic languages: first of all, the development of the sequences *tort, *tolt, *tert, *telt belongs here. So any Germanic borrowings from that period (600-1000?) directly affected only some Slavic dialects; they eventually spread throughout the Slavic world by penetrating from one Slavic dialect to another, without any general intermediary comparable to that of Old Church Slavonic, which acted as the carrier of Balkan Gothic loanwords.

There is no doubt that after the year 600 the main source of Germanic borrowings in Slavic was Old High German; the Slavic dialects directly affected by this language werre Slovenian, Czech, Lusatian, and Polabian(?), i.e., the dialects of the westernmost Slavic peoples. But because a continuum of Slavic dialects still extended at least through western Pannonia (before the invasion by the Hungarians!), connecting 
the Southern Slavs with the Western Slavs, the spread of OHG borrowings was an easy process, at least in West and South Slavic. Of course, they could also spread to East Slavic either through intertribal contacts or, in some cases, even through Old Church Slavonic.

In accordance with the chronological limits formulated above I am not going to discuss the OHG borrowings in Slavic here. However, some of them became commonly known in the Slavic languages and are important in terms of cultural history, so I feel obliged to discuss them briefly. These are the following nine words:

1) brın'a or rather plur. brın'ę/ě 'coat of mail, chain armor,' attested in OCS bron'ę f. plur. 'thorax, lorica,' ORuss. broně f. plur. 'thorax, paludamentum,' Russ. brónjá, Ukr. brónja 'Brünne, Panzer, Harnisch,' OPol. brnia, OCz. brně f. plur. 'Panzer,' ULus. brónčka 'Panzer,' S-C brinjica 'annulus, fibula, inauris' (clearly secondary meanings of the diminutive in -ica!), Bulg. brónka 'Eisen-, Türring; Masche, i.e., mesh, stitch' (also secondary meanings). For historical-cultural reasons the most probable source of this borrowing is OHG brunja, brunna 'Brünne,' and because OCS, ORuss., and OCz. had plurale tantum, the primary meaning in Slavic was 'iron rings from which armor was made,' which accounts for the secondary meanings of this word in S-C and Bulg. (for details see Kiparsky, 1934:230-31 and Martynov, 1963:58-60, who, however, tries to derive this loanword from Proto-Germanic).

2) *cbr(b)ky, gen. -zve 'church,' attested in all Slavic languages, e.g., OCS crbky, Russ. cérkov', (in ORuss. a form without the palatalization of $k$ is found: acc. sing. krbkъvb, voc. sing. krkvi), OPol. cyrki, NPol. cerkiew (restricted to the meaning 'Orthodox church'), OCz. cierkev, NCz. cirkev, $\mathrm{S}-\mathrm{C}$ crkva, Bulg. cŕrkva, čérkva, etc. The direct source of this borrowing is disputable: for the archetype ${ }^{*} c b r k y$, which seems to underlie the West and East Slavic forms, the most probable source would be OHG (before the second Lautverschiebung) *kirkün (acc. sing., cf. -kirhun, 820 A.D., in place names) 'Kirche,' although some OPol. and OCz. forms of the type cerekw(i)e do not preclude a prehistorical ${ }^{*} c b r b k b v-$; for the archetype ${ }^{*} c b r b k y$, which seems to underlie the Old S-C form crikva, Goth. *kiriko could even be posited (for the whole discussion see Kiparsky, 1934:244-47). Of course, the ultimate source of the word is Gr. Tò

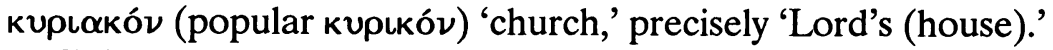

3) krbstz 'cross' (in West Slavic 'baptism'), attested in OCS krbstz 'crux,' ORuss. krbstz, Russ. krest, Ukr. krest, S-C krist, Mac. krst, Bulg. krъst; OPol. krzest, NPol. chrzest 'baptism,' Cz. křest, Slovak krst, ULus. khřest, S-C křst, Sloven. k'st (everywhere with the secondary meaning 'baptism'). The direct source of the borrowing (because of the short root vocalism!) was Goth. Xrüstus [Krǔstus] 'Christ,' or rather OHG (before the second 
Lautverschiebung) Chrŭst, which are both ultimately from Gr. Xpiotós. In Slavic the meaning changed 'Christ' $\rightarrow$ 'cross' (but the primary meaning is still preserved in some instances of Church Slav. krbstz and S-C krist 'Christ'); the Roman Catholic Slavs, those who use križb 'cross,' have changed the meaning of krbstz from 'cross' into 'baptism,' probably under the influence of the verb krbstiti 'to mark with the sign of the cross, baptize, etc.' (for details see Kiparsky, 1934:234-36).

4) *korl'b 'king,' attested in most Slavic languages, e.g., Church Slavic (in younger codices) kral'b 'rex,' Russ. koról', Pol. król, gen. króla, Cz. král, OLus. krol, S-C krâlj, etc., everywhere with the meaning 'king,' but in OCzech also as the proper name Charles (NHG Karl).

The most common etymology derives this nouns from the name of Charles the Great (Karl der Grosse), the first historical Germanic ruler who successfully fought the westernmost Slavs (e.g., the Polabians were subjugated in 789). Linguistically we should start from the OLG form of this name, which preserves the $k$-, Karl, not from the OHG form with a shifted ch-, Charl. Then the borrowed *korl- was morphologically adjusted to Slav. nomina agentis with the stressed suffix $-l^{\prime} b$ (*korl'b), and it underwent the regular phonemic treatment (metathesis, etc.) of the tort group, according to the development of the individual Slavic dialects. The semantic change: 'proper name of a ruler' $\rightarrow$ 'common name of rulers' is not rare (cf. Caesar, ultimately Slav. cěsar'b). But there are some objections to this etymology, recently discussed by Martynov (1963:68-71), who proposes Germc. *karlaz 'old man' (e.g., OIc. karl among others 'man of a noble family,' etc.) as the source of Slav. *korl'b, with the semantic development 'old man' $\rightarrow$ 'head of a patriarchal kin' $\rightarrow$ 'ruler' (cf. similar meanings of Slav. starějbšina, starosta). I can also add another objection, namely, that among the Slav. toponyms in Greece which come from the period of the first Slav. invasion there ( 7 th cent. A.D.), i.e., about a century and a half before Charles the Great, we find

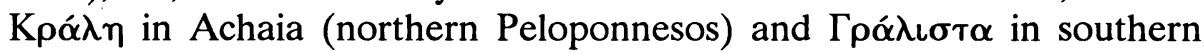
Thessaly. These are undoubtedly SSlav. ${ }^{*}$ Kralji and ${ }^{*}$ Kraljišta, which have correspondences in the S-C toponym Kralje, Sloven. toponym Kralji, and Bulg. toponyms Kralevo, etc. (see Vasmer, Slaven in Griechenland, 1941:135 and 89). How should we explain them? As derived from SSlav. kral'b in its historical meaning 'king' or in an earlier meaning 'starějbšina'? The question remains open. It is possible that in Proto-Slavic there was an earlier Germc. loanword *korl'b 'starějbšina' which was adjusted morphologically to the native Slavic nouns with the suffix $-l$ 'b, and only later when the name of Charles the Great became notorious among the Slavs this noun acquired its historical meaning 'king,' which generally refers to western kings (including here the rulers of the Catholic Slavs); 
for details see Kiparsky, 1934:240-43, and Martynov, loc. cit.)

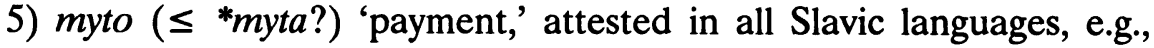
OCS myto 'merces, lucrum,' Russ. (archaic) mýto 'Maut, Zoll,' Pol. myto 'Maut, Zoll; Lohn; Gehalt, Pension,' Cz. mýto 'Maut, Zoll, Lohn, Gabe,' S-C mit, mito 'revenue, tax; bribery,' Sloven. mito 'bribery; Lehenszins, Wucher,' mita (fem!) 'bribery; Zoll,' etc. Because of the $y$ and the primary final stress, corroborated by Serbo-Croatian and older Russian (Kiparsky, 1958:22), the source of this borrowing is not Goth. mōta ${ }^{24}$

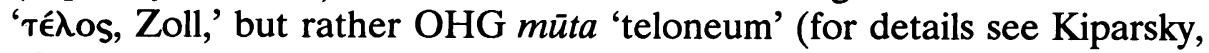
1934:250-51).

6) pěnęzb (dissimilated from *pęnęzb?) 'money,' attested in most Slavic languages, e.g., Church Slav. (since the 11th cent.) pěnęzb, pěnęgъ (sic!) 'coin,' ORuss. pěnjazb 'Geld; (fremde) Münze,' Pol. pieniqdz, Cz. peniz, $\mathrm{S}-\mathrm{C}$ pjênêz, etc., everywhere with the meaning 'money, coin.' The most probable source of this borrowing was OLG penning (from *panningawith the Umlaut $a \rightarrow e$ ), whose form cannot be earlier than the seventh or eighth century (for details see Kiparsky, 1934:256-57).

7) роръ 'priest,' attested in all Slavic languages, e.g., OCS popz, Russ. pop (with final stress in the oblique cases), OPol. pop, NPol. (limited to Orthodox priests), Cz. pop (with the same semantic distinction as in Polish), S-C pôp, etc. The word could be borrowed directly from Gr. $\pi \alpha \pi \hat{\alpha}$, but then we would rather expect *popà, like sotonà from $\Sigma \alpha$ T $\alpha \nu$ òs. Therefore, more probable as a direct source is OHG phaffo = NHG Pfaffe (ultimately of the same Greek origin!), or at the least the form pops which had been borrowed from $\mathrm{OHG}$, ousted an older form *popà, borrowed directly from Greek (for details see Kiparsky, 1934:259-60).

8) postz 'fast,' attested in all Slavic languages, e.g., OCS postz 'ieiunium,' Russ. post (with final stress in the oblique cases), Pol. post, Cz. puist, S-C pôst, pôst, etc., everywhere with the meaning 'fast.' The most probable source of this borrowing is OHG fasto 'fast,' not Goth. fastan 'to fast,' etc., which allegedly was first borrowed as Slav. postiti (se) and then produced a back derivative postъ in Slavic (for details see Kiparsky, 1934:261-62).

9) *vitęzb (dissimilated from *vicęzb or with $t$ substituted for a Germanic palatalized $k$ '?) 'hero; knight,' attested in most Slavic languages, e.g., Church Slavic vitezb, vitjazb 'heros,' Russ. vítjaz' 'Held, Ritter'; Pol. only in derivatives: old wyciężny, wycięski, new zwycięski 'victorious,' zwycięzyć 'win,' etc.; Cz. vitěz 'heros, athleta, agonista; victor,' ULus. wićaz 'Vasall, Lehnmann, Lehnbauer,' S-C vïtez 'Held, heros; Ritter, eques,' etc.

This noun is usually interpreted as coming from Germc. *wikingaz, e.g., 
OIc. vikingr 'Viking,' which etymologically means 'warrior' and is most probably derived from Germc. weihan (i.e., wihan, e.g., in Gothic) 'fight.' The historical meaning 'nordic pirates' is relatively late (after 800 A.D.), e.g., OE wîcing in the expression sâwicingas refers to the Jews crossing the Red Sea, so the historical evidence seems to indicate that the Slavs borrowed the word before the Viking period in its primary meaning 'warrior.' This supposition is also supported by the stress: the old acute on the primary stressed Germanic long root-vowel. The only problem is from which Germanic dialect vitęzb was borrowed. Martynov derives it simply from Proto-Germanic (loc. cit., 105-07). Perhaps it was borrowed from one of the East Germanic dialects (Burgundian, Vandal, etc.) with which the Slavs were in contact in the first centuries A.D. (the word is not attested in Gothic!). In any case, *vitęz seems rather to belong to the first (oldest) layer of Germc. loanwords in Slavic (for details see Kiparsky, 1934:268-69 and Martynov, 1963:105-07, and for the Germanic etymology of the word see Falk \& Torp, 1911:II, 1377).

Conclusions About the Germanic Borrowings in Prehistorical Slavic

The list of Germanic loanwords:

First period (before the 2 nd century A.D.):
1) duma (?)
2) glazb
3) gonbz (nq)ti
4) gonoziti
5) $x l e \check{v}$ ъ
6) $x y s z / / x y z z$
7) *xzlms
8) kъnęzb
9) lukb (?)
10) *nobozězb
11) nuta /penetr./
12) plugs (?)
13) kotz (?)
14) *šelms
15) tynz
16) *volxz
17) *želdo (penetr.)
18) *vitęzb

Second period (2nd-4th centuries A.D.):
1) bl'udo
2) cěsar'b
3) gobino
4) gobbzb
5) xlěbs (penetr.)
6) xqdogz (penetr.)
7) xosa (penetr.)

10) kusiti

11) lěks (?)

12) lixva (?)

13) lbstb (penetr.)

14) osbla (?)

15) *pzlkъ

16) stbklo 

8) kotblb
9) kupiti
17) *t'ud-
18) *valbqds

Third period (5th-6th centuries):
1) *bordy, -ъve
2) buky, -zve (bukъ)
3) liks
4) skuts
5) smoky, -ъve
6) usoręzb
7) *vinogords

Fourth period (after the 6th century):
1) bron'a
2) $c b r(b) k y$, -zve
5) myto
3) krbsto
4) *korl'b
6) pěnęzo
7) pops
8) postz

Now, after analyzing the Germanic loanwords in prehistorical Slavic we can draw some more general conclusions. First, there is a clear difference in the amount of loanwords belonging to the two older periods (the real Proto-Slavic epoch) and those belonging to the two later periods (the time of the dissolution of Proto-Slavic). The loanwords of the two older periods represent an overwhelming majority of all the Germanic loanwords: 18 (or 19, if we include bukz) from Proto-Germanic and Early Gothic +18 from Late Gothic $=36$ (37), whereas only 7 from Balkan Gothic +8 selected from Old High German $=15$; all together there are 51 (or 52) words of Germanic origin. But we should eliminate seven words whose Germanic origin is highly doubtful: in the first period duma, lukz, plugz, skotz; in the second lěkz, lixva, osblz; from among these lukz, skotz, lěkz have convincing Slavic etymologies. So we have only 44 (45) certain Germanic loanwords, which is not an imposing number.

Among these loanwords it would be useful to distinguish cases of penetration (following Martynov), which presupposes a kind of Slavic-Germanic bilingualism (on the western outskirts of the Proto-Slavic territory?), as opposed to regular borrowings, which do not require bilingualism. As certain instances of penetration we can quote: nuta 'cattle,' *želdQ 'pay with money,' xlěbz 'loaf of bread,' xQdogz 'able, fit,' $x$ gsa 'band of robbers,' lbstb 'shrewdness' $\rightarrow$ 'trickery.' It is interesting that they refer to important social and economic phenomena, and in two cases (xosa and lbstb) they illustrate an obvious moral depreciation of the primary Germc. meaning.

The semantics of the above Germc. loanwords is quite broad, 
indicating the multifarious relations between the two ethno-linguistic groups. We not only have names of concrete objects belonging to everyday life, such as glazъ, xlěvъ, xysъ // xyzz, *nobozězb, tynz, bl'udo, xlěbz, kotblz, stbklo, etc., but also very important social terms like kъnęzb, *vitęzb, cěsar'b, xqsa, *pzlkz, *t'ud'b, *korl'b, to which we can include such verbs as *želdo. It should be emphasized that the number of loanwords referring to weapons is rather insignificant: *šelmz, *bordy, and late (OHG) bron'a. The Christian religious terms are omitted here because they are relatively late. What strikes us in the semantics of these loanwords is the lack of any abstract religious terms, in contradistinction to the borrowings from Iranian.

\section{Slavic Loanwords in Germanic}

As I have mentioned above, almost all the works treating Slavic-Germanic lexical exchange in prehistorical times have concentrated on the Germanic loanwords in Slavic, neglecting the opposite direction of possible borrowing, i.e., Slavic loanwords in Germanic. Martynov's book, which I have used in the preceding part of this chapter, is a real turning point: the author devotes equal attention to the Germanic borrowings in Slavic and to the Slavic borrowings in Germanic (actually, more pages are devoted to the latter subject than to the former). Of course, as the title of the book and the introductory note from the author indicate, the lexical material belongs to an older period, i.e., to the prehistorical time between the fifth century B.C. and the second century A.D., to the time of the contacts between the Proto-Slavs and Proto-Teutons as relatively undifferentiated ethno-linguistic wholes. Such an approach has been dictated by Martynov's basic working hypothesis: that the evidence of lexical exchange of the penetration type between prehistorical Slavic and prehistorical Germanic would prove the western hypothesis of the primary habitat of the Slavs in the Odra and Vistula basins, because the early Slavic-Germanic contacts could have taken place only in that region. My opinion is that this evidence, which seems to be quite well substantiated by many lexical facts (for details see below), does not prove the western hypothesis of the primary habitat of the Slavs, but rather shows an early prehistorical extension of that habitat from the Middle Dniepr basin to the Vistula and Odra basins, as I have tried to argue in Chapter V.

Not all of Martynov's examples and arguments are equally convincing; the author himself introduces a gradation of their plausibility. Martynov's chronology is also controversial. In the preceding part of this chapter, in treating Germanic borrowings in Slavic, I consistently used Kuryłowicz's 
and Kiparsky's chronology, based on the criterion of accent. As we have seen, in the first layer of Germanic loanwords in Slavic (pre-Gothic and early Gothic) there are only two sure penetrations: nuta 'cattle' and *želd $Q$ 'pay with money'; we have many more in the second Gothic layer: xlěbs 'loaf of bread,'xqdogz 'able, fit,' xqsa 'band of robbers' lbstb 'shrewdness.' So the argument about penetration, which Martynov emphasizes strongly, should be weakened considerably, at least as far as the Germanic loanwords in Slavic are concerned. I should also add that I have taken a rather conservative approach to the whole problem of Germanic loanwords in Slavic, following in this respect Kiparsky, whose book is a classic example of a careful and well substantiated etymological analysis which will remain a model for any historical lexicologist. Therefore I have not included in the list of Proto-Germanic loanwords in Slavic some disputable and rather unconvincing examples proposed by Martynov (*borvz, dbska, *koldęzb, l'udz, *melko, opica, plъtz, *retęzb, stado, *stopa, *vektb (OCS veštb), among which only stado is qualified as representing the maximum degree of probability). All the above reservations, however, do not undermine the fundamental value of Martynov's book, especially, one would say, its pioneering part devoted to the Slavic loanwords in prehistorical Germanic.

The sum total of the alleged Slavic borrowings in Germanic stemming from the oldest period (before the second century A.D.) reaches 39 in Martynov's book. But we should remember that the author himself qualifies them into three groups depending on the degree of plausibility (as in the case of Germanic borrowings in Slavic). Needless to say, the most convincing is the first group where all the criteria overlap or support each other: phonemic, derivational, and semantic criteria. In this group of maximum plausibility Martynov lists 11 words.

In the following pages of this chapter I will limit myself to a review of these maximally plausible borrowings from Proto-Slavic into Germanic, adding two items not mentioned by Martynov. Of course, not all of the etymologies he proposes can be maintained, so the number of certain Slavic loanwords in prehistorical Germanic will have to be reduced. There is also one additional point in the discussion which should be stressed at the beginning: although Martynov's book is undoubtedly a very important and stimulating achievement of historical Slavic lexicology of the second half of this century with serious implications for the historical lexicology of the Germanic languages, it has somehow remained unnoticed by the Germanists, and consequently I could not find any critical review of Martynov's etymologies from the Germanist's point of view. However, this circumstance does not weaken the merit of those etymologies for which convincing linguistic arguments can be quoted on 
the basis of historical material. Thus I pass to a critical review of the 11 Slavic loanwords in Germanic, as proposed by Martynov.

1) PGermc. *baru- 'forest,' attested in OE bearu 'Wald, Hain,' OIc. borr 'tree,' OHG baro 'Hain, Wald,' para-wāri 'forest guard' $\rightarrow$ '(pagan) priest.' For semantic reasons, because of the development 'coniferous tree, pine' $\rightarrow$ 'pine forest,' well attested in Slavic, the Germc. word was most probably borrowed as a penetration from Slavic borb (old $u$-stem). The latter is attested in the primary meaning 'pine' in South Slavic and in the secondary meaning 'pine forest' $\rightarrow$ 'forest' in North Slavic, .e.g, Russ. Church Slav. borz 'spruce, spruce forest,' Russ. bor 'coniferous forest,' Pol. bór 'forest,' especially 'pine forest,' Cz. bor 'pine forest,' S-C bôr 'pine,' etc. (for details see Martynov, 1963:108-12, and Kiparsky, 1934:61-62). If we neglect the semantic development, then the Germanic and Slavic words could be treated simply as belonging to a characteristic stratum of North Indo-European dialectal elements discussed recently by Ch. Stang (1971:15); see also p. 140 of Chapter III of this book.

2) PGermc. *daila- 'part' ('Teil'), attested in Goth. dails, OHG teil, OE $d \not ̄ e l=$ deal, everywhere 'part, Teil,' OIc. deila 'Zwiespalt.' This is a transparent borrowing (according to Martynov, a penetration) from PSlav. dělı (at its older diphthongal state *doilo-), which represents a derivative with the suffix -lo- (quite productive in Slavic, but not in

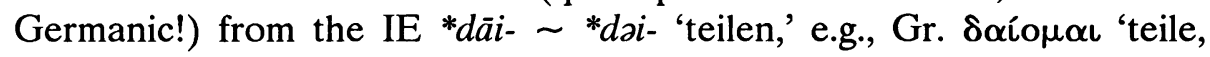
verteile,' OI dáyate 'teilt, nimmt Anteil, etc.' (Pokorny, 175-76). The two arguments, historical-phonetic (the lack of the $* d \geq t$ consonant shift in Germanic, something like *taila-!) and derivational (the productive Slavic -lo- derivative) are decisive for accepting the Slavic etymology of Germc. *daila- (for details see Martynov, 1963:112-16, with an excellent semantic analysis within the framework of his so-called semantic microstructures; Kiparsky, 1934:64-65, with unsubstantiated opposition to the Slavic etymology; and Stang, 1971:17, who treats the Germc., Slav., and Lith. [dailýti 'teilen'] forms simply as North IE dialectal elements).

3) PGermc. *hwata- 'sharp, brave, skilled' (Germ. 'gewandt'), attested by OIc. hvatr 'schnell, mutig, scharf,' OE hvæt 'schnell, mutig,' OSax. hvat idem, OHG (h)waz 'scharf, heftig.' Despite Martynov's very elaborate argumentation, it cannot be derived from Slav. xvatz, e.g., Russ. xvat 'kühner, gewandter, flinker Mensch,' Pol. chwat idem, OCz. chvat 1. 'Eile,' 2. 'Räuber,' etc.: first, regular phonemic equivalence is lacking

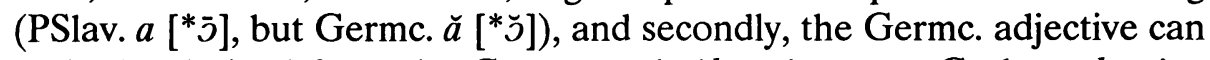
easily be derived from the Germc. verb *hwatjan, e.g., Goth. ga-lwatjan 'antreiben, wetzen, etc.' In view of this Pokorny even reconstructs IE

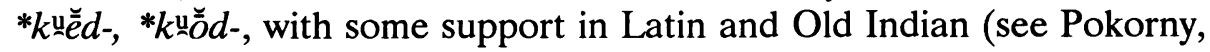
636); for details see Martynov, 1963:116-20, and Kiparsky, 1934:35; for a 
possible Iranian origin of Slav. xvatiti (from which $x v a t z$ was derived) see p. 316.

4) *stubō 'heated room, bathroom,' attested in most Germc. languages, e.g., OHG stuba 'heizbares Gemach, Badezimmer' = NHG Stube, OE stofa 'Badestube' = NE stove, OIc stofa 'Wohnstube,' etc. It cannot be borrowed from Slavic *(j)bstzba, despite Martynov's unconvincing speculations; he proposes the derivation of Slav. (j)bstzba from *(j)bstz + $b a$ 'immobile property, house' (sic!). Both words, Germc. *stubō and Slav. * $(j)$ bstzba, are borrowings from Vulgar Latin *extufa (*estuva?), attested in all Romance languages, e.g., Fr. étuve 'Badestube, Schwitze,' Span. estufa 'stove,' Ital. stufa 'stove; conservatory,' etc. The Romance (VLat.) *extufa // *estuva (?) explains Slav. initial (j)b-; the noun could have been borrowed before 600 A.D. in the Alpine-Pannonian region and then spread north and east (for details see Martynov, 1963:120-26, and Kiparsky, 1934:237-39, where, however, the author maintains the traditional etymology deriving Slav. (j)bstzba directly from OHG stuba; the best treatment of Slav. (j)bstzba is by Sławski, 1956, fasc. 5, 475-76).

5) WGermc. *kurzinō (?) 'fur,' attested in Late OE crus(e)ne, OFries. kersena, OHG chursinna, chursene, kursenna, Latinized cursina, MHG kürsen, everywhere 'Pelzrock' (from this the NHG Kürschner 'furrier'). The most probable source of this WGermc. word is PSlav. *kbrzbno, attested in Serb. Church Slav. krzzno 'vestis pellicea,' ORuss. kъrzno, etc., Russ. kórzno, kórzen' m. 'Mantel,' Cz. krzno 'Pelzkleid,' S-C kìzno 'Pelz, Bettvorhang,' etc. (for details and Slav. etymology see Kiparsky, 1934:97-98; Martynov does not quote this word).

6) PGermc. *malta- 'malt,' attested in OIc. malt, OE mealt, OSax. malt, OHG malz, everywhere with the meaning 'Malz.' This is one of the surest examples of PSlav. loanwords in Proto-Germanic, coming from the PSlav. *molto 'malt,' attested in most Slav. languages, e.g., Ukr. mólot, Pol. młóto, młoto, młota, Cz. mláto, S-C mlâta, etc. The Slav. word has a convincing Slavic etymology indirectly indicated by an ORuss. text: “...kz prazdniku...solodz molotb, pivo varitb," thus *molto is from *mol-to, a derivative of the verb *mel-ti = Russ. molot' 'grind,' etc.; PSlav. *molto together with pivo was also borrowed by Old Prussian as piwa-maltan 'Biermalz' (for details see Martynov, 1963:126-28, and Kiparsky, 1934:46-47).

7) PGermc. *nepiia- 'relative' (by blood), attested in Goth. nipjis 'relative by blood' (Russ. rodič), OIc. niðr idem, 'descendant,' OE nippas plur. 'men.' This is again a very convincing example of an early penetration into Proto-Germanic (before the PGermc. consonant shift, a fact not mentioned by Martynov) of PSlav. netbjb 'nephew.' There are two serious arguments on behalf of this interpretation: first, the 
characteristic Slav. simplification of IE $p t \geq t\left({ }^{*} n e p t-\geq n e t-\right)$, whereas this cluster is preserved in the original Germc. continuation of PIE *nept-, e.g., OE nift, OHG nift 'niece, granddaughter'; and second, the semantic change of Slav. netbjb 'nephew' $\rightarrow$ 'relative' (then 'man,' undoubtedly 'belonging to the same clan,' etc.) in Germanic, conditioned by the clash of this penetration with the original Germc. semantic microstructure, which consisted of *gakunda- 'relative' (by blood): *nefō $(d)$ 'nephew'; the Slav. penetrant simply replaced the unmarked, more general term *gakunda-. Parallels of a similar development of foreign penetrants can be quoted from other languages (e.g., Pol. kuzyn, szwagier, etc.); for details see Martynov, 1963:128-32, where also another etymology of Germc. *nepiia- is convincingly criticized, namely the superficial correspondence between *nepiąa- and OI nitya- 'permanent, one's own ( $\leq$ *'inner').

8) PGermc. *asani- 'harvest,' attested in Goth. asans ( $i$-stem) 'harvest,' OHG aran idem, OIc. qnn (*aznō) 'field works.' This noun is most probably borrowed from PSlav. osenb (variant form (j)esenb) 'autumn,' attested in all Slavic languages, e.g., Russ. ósen', Pol. jesien, S-C jèsen, etc.; everywhere the primary $i$-stem. The argument for the borrowing from Slavic is provided by the etymology of the noun: PSlav. osenb represents PIE *ak'en-i-, a collective in $-i$ from PIE *ak'-en- 'something sharp, pointed,' e.g., OI aśani- 'Pfeilspitze, Geschoß,' and especially used about sharp-ended grass and other plants like Gr. ǒk $\alpha \nu$ os 'Distelart, dorniger Pflanzenkopf,' Lat. agna ( *ak'nā) 'Ähre,' Goth. ahana f. 'Spreu' (and its Germc. correspondences like OHG agana 'Spreu' and NHG Ahne 'Abfall von Flachs und Hanf,' etc.), Lith. ašnis 'Schneide, aufkeimende Saat,' Latv. asns m. 'hervorbrechender Keim.' The primary meaning of the PSlav. word would be 'ears,' then 'the time of (ripe) ears' $\rightarrow$ 'harvest' $\rightarrow$ 'autumn.' In this connection it should be noted that Lat. annus 'year' (but in the rural usage 'harvest') may ultimately stem from *ak'-no-; then it would have a similar etymology. In view of the above facts Germc. asani with a satom $s$ instead of the expected kentum $h$, as in Goth. ahana and its Germc. correspondences, proves that it was borrowed from Slavic. Actually we have here a penetration, since in Proto-Germanic there was an absolute synonym of Slav. osenb, namely *harbista- (OE hærfest 'harvest, autumn,' OHG herbist, NHG Herbst 'autumn,' etc.), with which the Slav. word clashed, causing characteristic semantic shifts (for details see Martynov, 1963:132-36, and for IE comparative material Pokorny, 19-20).

9) PGermc. *sadula- 'saddle,' attested in OHG satul, satal (NHG Sattel), OE sadol (NE saddle), OIc. sqðull, etc. It is commonly assumed that the Germc. word does not directly continue the PIE archetype 
*sed-lo-, etc. (which resulted in PGermc. *setla-: Goth. sitls, OE setl n., OHG sezzal $\mathrm{m}$. 'Sitz, Sessel'), but represents a borrowing from the European East. In view of the native etymology of PSlav. ${ }^{*}$ sedzló ${ }^{25}$ (cf. Russ. sedló, Pol. siodto, S-C sèdlo, etc.) and the native character of the PSlav. horsemanship terminology (cf. K. Moszyński, 1957:233-35), the most probable source of the borrowing is Slavic. In order to account for the phonemic substitution for PSlav. *sedzló we must start from an earlier PSlav. form *sædul', which could have been borrowed first by the Goths as *sadula (with the substitution of $a$ for PSlav. $æ$ since there was no corresponding low front vowel in Gothic) and then spread by them in other Germanic languages during the Great Migration of Peoples (the fifth century A.D.); for details see Martynov, 1963:178-80.

10) WGermc. *skäpa- 'sheep' (as a generic term), attested in OHG scäf (NHG Schaf), OSax. scāp, OE scēap, etc. Its most probable source is PSlav. skopz // *skapz/a 'castrated ram,' an obvious and well motivated deverbal derivative in Slavic from skopiti (already in OCS) 'castrate.' Martynov's difficulty in explaining the relation between Slav. $o$ in skopz and Germc. $\bar{a}$ in skāpa- stems from the fact that he has not taken into consideration Pol.-Cz.-Ukr. škapa 'old (castrated) horse,' an expressive formation with $\breve{k} k$ - from $s k$-. This latter word allows us to posit PSlav. *skāpz, which could be the source of WGermc. *skapa-. Because of the timbre of $a$ in Slavic the borrowing cannot be very old; the passage of an Early PSlav. $\bar{j} \geq \bar{a}$ is a Late PSlav. phenomenon (600-800 A.D.?). This would also account for the limited spread of the borrowing in Germanic (for details see Martynov, 1963:181-83).

11) PGermc. *skatta- 'cattle' $\rightarrow$ 'wealth,' see skotz on p. 368.

12) PGermc. *tila- 'soil,' underlying the verb *tiljan 'till' and other derivatives, attested in OE tilian 'cultivate soil, till', OFries. tilia idem, MLG tilen idem, NHG dial. zielen 'grow' (transitive), etc. The source of PGermc. *tila- is PSlav. tblo, attested in the specific agricultural meaning 'soil, cultivated soil' in S-C tlë plur. fem. and Sloven. tlà plur. neut. (OCS tblo 'Boden,' $n a$ tblěxz = Gr. $\chi \alpha \mu \alpha i$ ). It is obvious that Slav. tblo corresponds to Lat. tellüs (transformed from *telnos under the influence of the synonymous rüs) and represents a Balto-Slavic treatment of PIE *tllH-o-. Native Germc. correspondences of Slav. tblo, Lat. tellūs, i.e., PIE *telH-, show regular results of the first consonant shift, e.g., OIc. pel n. 'Grund, Boden,' pilja f. 'Diele, Planke,' OE ðille 'Diele,' ðel 'Schiffsplanke,' OHG dil, dilo 'Bretterwand, Diele, Schiffsdeck,' etc. (for details see Pokorny, 1061, s.v. tel(a)- 'flach, flacher Boden, Brett'). Martynov (1963:140-45) shows that Germc. *tila- is a penetration from Proto-Slavic. It is interesting that the same word was borrowed from Slavic by prehistorical Ossetic (see p. 335). 
13) PGermc. *warga- 'outlaw, criminal' $\rightarrow$ 'devil,' atttested in OHG warg 'Verbrecher,' OE wearg idem, OIc. vargr 'wolf, outlaw' (Martynov quotes for OIc. 'robber, brigand, disgraced person, wolf,' and for other languages 'disgraced person, criminal') and with a secondary meaning 'devil' in Old English and Old High German; Gothic has only a compound launa-wargs adj. ' $\alpha \chi \alpha$ ó derivationally well motivated position of PSlav. *vorgz (OCS vragz) 'outlaw' $\rightarrow$ 'enemy' within Slavic (and Balto-Slavic), where we find its underlying verb *verkti (OCS vrěšti), *vbrgq) 'throw (away),' with respect to criminals 'expell' - there is little doubt that the Germc. word represents a penetration from Proto-Slavic. The underlying PIE root is *ureg- // *uerg-, reconstructed by Pokorny (1181) as 'stoßen, drängen, treiben, feindselig verfolgen' and well represented in IE languages (including Germanic), e.g., Lat. urgēo 'drängen, bedrängen, pressen,' Goth. wrikan 'verfolgen,' OIc. reka 'treiben, jagen, verfolgen, werfen, verwerfen,' OE wrecan 'drängen, treiben, rächen,' etc., with such derivatives as Goth. wraks 'Verfolger,' OE wracu 'Rache, Strafe, Elend,' wræc n. 'Verbannung, Elend,' OHG wreh 'exul,' etc. The Germc. type *wraka- (cf. OE wræc!) corresponds to Balto-Slav. *varga- (PSlav. *vorgz), so the PGermc. *warga- cannot be native in Germanic: it must be a penetration from Slavic, and it must have been borrowed quite early since we have not only the Goth. compound launa-wargs, but also a Germc. derivative *wargipo 'hostility' (in Goth. wargipa 'curse,' Lat.-Germ. wargida 'hostility'), undoubredly imitating PSlav. *vorgbda (OCS vražbda, etc.). For details see Martynov, 1963:153-56.

As we see, we have 11 Proto-Germanic words borrowed from Slavic (hwata- and stubō- are eliminated!). To these we can also add two with a high degree of probability: lěks and lukz (PGermc. *lëkja- and *lauka-), discussed above on pp. 372 and 365, respectively. So for the time being, the sum total of PSlav. borrowings in Germanic would amount to 13. This is not an impressive number, but if we bear in mind that the sum total of Germanic loanwords in Slavic (including also some significant OHG examples) reaches only 44 (or 45 ), then 13 is not a negligible quantity. It acquires its significance in view of the fact that the etymological studies of the Germanic vocabulary from the standpoint of its prehistorical Slavic elements virtually do not exist. The semantics of the PSlav. borrowings in Germanic is rather transparent and self-explanatory: 10 words belong to material culture (farming!), two to social life ('relative,' 'criminal'), and one to nature ('pine wood'). Among the terms referring to material culture the names of 'sheep' (*skāpa-), 'cattle' $\rightarrow$ 'wealth' (*skatta-), 'saddle' (*sadula-), and 'soil' (*tila-) should 
be especially emphasized. In view of the above it seems quite obvious that the contacts between the prehistorical Slavs and the Teutons had a very close socio-economic character, although they did not affect more essential aspects of culture such as religion and mythology. As we have seen, the same, mutatis mutandis, can be said about the Germanic borrowings in prehistorical Slavic.

Now the question arises, how do the Germanic-Slavic relations compare with the Iranian-Slavic relations, both, of course, viewed through lexical exchange. Our extralinguistic knowledge allows us to posit an obvious relative chronology of Slavic-Iranian and Slavic-Germanic relations, the former starting much earlier (at least since about 700 B.C.), the latter much later (since about 300 B.C.). Of course, there was partial overlapping between these two periods, because only the migration of the Goths to the Black Sea and their settlement there seems to have brought about a decisive break in the direct contacts between the Slavs and the Pontic Iranians (the Sarmatians); this happened in the 3rd century A.D. Of course, the geography of those relations was also quite different: the Slavic-Iranian relations were concentrated chiefly in the east (the Ukraine), from where the Iranian borrowings spread westward, although in the oldest period they seem to have directly affected most of the Proto-Slavic tribes; the Slavic-Germanic relations were originally concentrated in the west (the Odra and Lower Vistula basins, i.e., present-day Poland), but later they also affected the eastern part of the prehistorical Slavs because of the movement of the Goths.

We should also emphasize that the span of time during which the prehistorical Slavs were in contact with the Pontic Iranians on the one hand, and with the Teutons (i.e., Germanic tribes) on the other was roughly the same (ca. 700 B.C.-300 A.D. for Slavic-Iranian contacts, ca. 300 B.C.-600 A.D. for Slavic-Germanic contacts). The question is whether the intensity of these contacts was also similar. This question can be answered first of all on the basis of the respective lexical results (borrowings) in Slavic. Here the numbers speak for themselves: the sum total of sure (material) borrowings from Iranian is 27 (I do not count proper names, e.g., theonyms, and words which can be justifiably suspected of Iranian semantic influence, like the well-known pair bogz: divz, etc., and others discussed in the chapter about the stratification of the Proto-Slavic vocabulary); the sum total of sure (material) Germanic borrowings is, as we have seen, 44 (or 45).

But, as any statistical data, these figures should be interpreted in a relative framework. Let us remember the point emphasized by $\mathrm{K}$. Moszyński, that the number of Germanic words available for 
historical-comparative analysis is many times larger than the number of Iranian words, at least in the dictionary of Walde-Pokorny, which basically reflects the situation in comparative-historical IE lexicology, at least in the first half of this century. In this context the above statistical data cannot be compared mechanically, and the 27 sure material borrowings from Iranian have their weight. An additional argument for the intensity of prehistorical Slavic-Iranian contacts is the impressive number of PSlav. borrowings in Scythian (and its descendants), namely 16 as presented and discussed on p. 336.

Part III. Prehistorical Slavic-Altaic Contacts.

When discussing the prehistorical contacts between the Slavs and other neighboring tribes as reflected in the reciprocal lexical borrowings, we cannot omit the problem of the relations between the Slavs and the Altaic peoples. The term Altaic peoples is preferred here over the term Turkic because the former, being broader, includes also possible representatives of non-Turkic peoples with whom the prehistorical Slavs might have been in contact. This point is especially relevant in the case of the Avars, whom some scholars consider a Mongolian tribe (F. Dvorník, 1956:36). Furthermore, a recent Altaistic synthesis (N. Poppe, 1965:147) distinguishes the following genetic groups within Altaic: the Turkic languages, the Chuvash language, the Mongolian languages, the Manchu-Tungus languages, and Korean (questionable). In this context the separation of Chuvash from Turkic should be especially underlined, although both of them earlier formed a prehistorical unity (West Altaic). Of course, the above description operates with the languages still existing today. But for prehistorical Slavic-Altaic contacts, the languages (and $a$ fortiori tribes) which no longer exist are relevant. I have already mentioned the Avars, suspected by some of Mongolian origin; here two other Altaic tribes should be mentioned: the Huns, and the Volga and Danube Bulgars.

As far as the linguistic position of Hunnic within Altaic is concerned, nothing certain can be said. Some scholars have wanted to identify it with Proto-Turkic, but because of the lack of reliable lexical material such a hypothesis seems unjustified. Most probably the Huns spoke a very archaic Turkic dialect (see N. Poppe, 1965:57). The language of the Bulgars, both the Volga Bulgars and the Danube Bulgars (who primarily roamed the present-day south Russian steppes) is closely related to Chuvash, and the common opinion of Altaists is that Bulgarian was the direct or indirect ancestor of Chuvash (see Poppe, loc. cit., 58). So in the framework of the above Altaist concepts it is more reasonable to speak 
about Slavic-Altaic contacts than simply about Slavic-Turkic contacts.

After these general terminological remarks let us review the historical information provided by written sources about the earliest possible contacts between the Slavs and the Altaic peoples. No doubt the first information of this kind refers to the invasion of the Pontic steppes by the Huns. About the year 370 A.D., having previously subjugated the Iranian (Sarmatian) Alans, they attacked the Ostrogoths, at that time the masters of the Lower Dniepr regions, and forced part of them to join their hordes, whereas the other part withdrew beyond the Dniestr River and later to Pannonia. The problem is whether at that time, i.e., after 370 A.D., the Huns, who replaced the Goths as the ruling element on the Pontic steppes, had any direct contacts with the Eastern Proto-Slavs (the Antes). The sources, e.g., Jordanis, who speaks extensively about the Gothic-Slavic relations of that time, are silent on this matter. It is highly probable that the Huns, being interested chiefly in reaching and looting the rich northeastern provinces of the Roman Empire as soon as possible, simply paid no attention to the relatively primitive and poor agricultural peoples dwelling north of the steppe zone, so the Slavs were spared any direct contact with them for the time being.

The situation changed in the next century when Attila (445-453) managed to transform the loose federation of nomadic tribes under the Hunnic hegemony into a kind of empire with its center in Pannonia (along the Tisa River). First of all, it is almost certain that in the first half of the fifth century A.D. the Slavs were already crossing the central and eastern Carpathians and settling to the south in what is now sub-Carpathian Ruthenia and northern Transylvania. Similarly, in the west they began to penetrate the Moravian Gate and the Sudeten passes (Klodzko Pass) south towards Moravia and Bohemia. So, some groups of the Slavic population, the ancestors of the Southern Slavs and of the Czechs and Slovaks, could have been affected directly by the Huns, who at that time extended their political control all over the Danube basin. Whether the Hunnic control reached north of the Carpathians, at least for a time, remains doubtful. The solution of this problem depends on the interpretation of a report by Priskos (taken over from Romulus, the West Roman envoy to Attila in 449), according to which Attila also

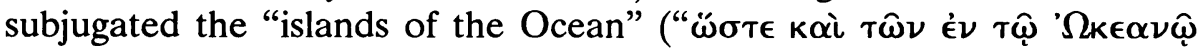

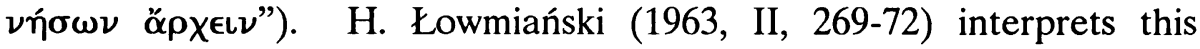
quotation as referring to the Baltic Sea, and suggests on the basis of additional archeological evidence that the Huns, supported by the Goths, at that time their vassals, organized raids for slaves into the Slavic regions north of the Carpathians (probably using the Dukla Pass). It is also probable that there existed some Hunnic-Gothic strongholds on the 
North Slavic territory (see Łowmiański, loc. cit., 273-95).

In the context of the above facts and hypotheses it seems almost certain that within the boundaries of the Hunnic empire (in the Danube basin) there dwelt some groups of Slavic population. Some scholars (e.g., L. Niederle) who accepted this possibility even tried to explain as Slavic the word strava 'funeral feast' (?), ${ }^{26}$ quoted by Jordanis in his description of Attila's funeral (allegedly borrowed from PSl. *sstrava 'meal,' cf. Pol. strawa, ORuss. strava, etc., an old derivative from the verb trovo, truti 'digest,' e.g., OCS natrovo, natruti 'speisen, nähren'; see Vasmer, III, 770, and Sadnik-Aitzetmüller, 62). But first, if this word had been Slavic at that time, it would have sounded *sutrava in its Latinized form because of the prefix sz-; then there is also a more convincing and historically much better justified etymology of strava as a Gothic word (Goth. *strava 'Gerüst, Paradebett' from stráujan 'streuen') already proposed by J. Grimm; see Łowmiański, 1963, II, 254, footnote 769; but Pokorny, 1031, reconstructs Germc. strava as 'Scheiterhaufen zur Siegesfeier'. So the case of strava is irrelevant as a linguistic argument for the presence of the Slavs in Attila's milieu.

As we know, Attila's empire did not survive his death. After the battle on the Nedao River (454 A.D.) between the Huns and some of their Germanic vassals (first of all the Gepids) in which the Huns were defeated, a part of the Huns withdrew from Pannonia to the Pontic (Lower Dniepr) steppes, the rest however remained in the Lower Danube region, where they probably dissoved later within a new nomadic wave, the Bulgars. In any case, after the battle on the Nedao River the Hunnic empire disintegrated. The period which followed then and lasted more than one hundred years (until 558), i.e., until the arrival of a new Altaic wave, the Avars, was very favorable for the expansion of the Southern Slavs towards the Danube-Sava line. At that time they undoubtedly had some contacts with the remnants of the Huns and with the arriving Bulgars in the Lower Danube region, but the invasion of Eastern Europe by the Avars and their subsequent rule in the Danube basin started a new and much more important period of Slavic-Altaic social and linguistic relations.

So we should discuss briefly the historical information about these relations. A recent presentation and analysis of the historical data referring to the invasion of Eastern Europe by the Avars and their relations with the Slavs has been published by H. Łowmiański (1963, II, 340-419). In his account he convincingly distinguishes two stages of the Avar invasion. First, in the yers 558-561 the Avars attacked and managed to subdue the East Slavic Antes, through whose territory they had to pass when proceeding towards the Lower Danube area. It should be noted 
that the Antes resisted the Avar hegemony for some time, but they later had to accept it, although the political-military details of these relations are not known. In this first period of the Avar invasion in Eastern Europe the attention of these Altaic belligerent nomads was directed towards the Frankonian monarchy; they attacked it through the Slavic territories north of the Carpathians, and the decisive battle took place on the Laba (Elbe) River in 562. This fact is very important because it proves that the Avars not only got in touch with the Western Slavs, but also had to have somehow received their support in that military enterprise. Lowmiański argues convincingly that some Slavic tribes participated in the Avar raids against the Frankonian monarchy: these tribes were most probably the ${ }^{*} X ъ$ rvate $/ /{ }^{*} X$ srvati (Croatians) and the $D u(d) l e ̌ b i$, both primarily belonging to the eastern branch of the Proto-Slavs; the warriors of these two tribes probably joined the Avar hordes in their raids westward. This circumstance explains why the ethnicon ${ }^{*} X z r v a t e / i$ is known on the Lusatian territory ${ }^{27}$ in the Latinized form Chruvati attested by Thietmar (present-day German toponym Corbetha) and in the Polonized form Charvaty as a north Bohemian region in the Old Czech Chronicle of Dalimil; similarly, the East Slavic ethnicon Dulěbi (*Dudlěbi), whose original territory was Volynia, reappears in southern Bohemia (OCz. Dudlebi, the present-day toponym Doudleby) and even in Slovenia (Dudlebi).

But the direct contacts between the Avars and the Slavs dwelling north of the Carpathians lasted for only a short time. After the year 567 (the last raid of the Avars against the Frankonian monarchy) the main bulk of these Altaic people crossed the eastern Carpathians and settled in the Danube basin along the Tisa River, gradually extending their control over the Slavic tribes of that region. In this way the second, more important period in Avar-Slavic relations begins.

The second period of Avar-Slavic relations, which lasted until the ultimate dissolution ${ }^{28}$ of the Avar ethnos in the Slavic population of Pannonia (in the ninth century), was characterized by the changing role of the Avars as a kind of hegemon with respect to the Slavs, especially the Sclavini (= Sloverne), the first waves of the Southern Slavs who were already well established along the Danube-Sava line before the arrival of the Avars. It is obvious from the historical evidence that from the end of the sixth century until the year 626, when the Avars were ultimately defeated by the Byzantines at Constantinople, the Slavs played the role of a secondary, dominated element in the alliance of plundering tribes headed by the Avars. We can say that they were under the hegemony of the Avars and participated in the raids they organized in the same way as the Goths and other Germanic tribes participated in the notorious raids 
organized by their Hunnic hegemons about two centuries earlier. However, there was a very significant distinction between the behavior of the Avars and the Slavs in their raids: the former, a typical pastoral-nomadic element, usually withdrew to their strongholds in Pannonia after plundering the Byzantine territories, wheras the Slavs, an agricultural element in need of Lebensraum, usually remained in the overrun and depopulated regions, taking over the land and gradually establishing their own rural settlements. In this way the Slavic raids began to change the ethnic character of the Byzantine provinces south of the Danube-Sava line quite rapidly.

In connection with the second period of Avar-Slavic relations we must answer the following questions: which Slavic tribes (or regions) were under direct Avar control and what was the character of that control, how long did it last, and what were its effects on the socio-cultural life of the respective Slavic peoples?

Since the Avars established the center of their power in Pannonia along the Tisa River, where, as history indicates, all the nomadic tribes that invaded Europe from the East usually came to a final stop and settled down (e.g., the Huns and in more recent times the Hungarians) it is understandable that first of all those Slavs who, having crossed the Carpathians, colonized the Danube basin were subject to their rule; these were the Dacian Slavs, i.e., those dwelling in the medieval provinces of Translyvania and Wallachia, and then the Pannonian Slavs, extending towards the eastern Alps (Carinthia). Here we should also mention the Slavs who at that time, i.e., the turn of the sixth and seventh centuries, managed to settle in the regions of Illyricum and Dalmatia controlled by the Avars until 626, the time of the arrival of the Croats and Serbs (see below). Undoubtedly for geographical reasons, the Slavs of what is now Slovakia and Moravia also belonged here; whether the Slavs of Bohemia were subject to direct Avar control remains questionable.

But we must remember that the Avar empire consisted of two parts: the western part in the Danube basin and the eastern part (the Kutrigur Khaganate) on the steppes between the Dniepr and Don rivers. Communication between these two parts was maintained until 670 through the East Slavic region of Volynia, the country of the $D u(d) l e ̌ b i$ tribe, since this was the shortest way (north of the Upper Tisa through the east Carpathian passes to the Upper Dniestr and the Upper Bug region, and then eastward!). This communication route, convincingly presented by Łowmiański (1963, II, 363-67), also explains the well-known tradition of the Primary Russian Chronicle (Povest'vremennyx let) about the oppression of the Dulěbi by the Avars. This exaggerated tradition of oppression most probably refers to the very burdensome duty of 
providing the travelling Avars with requisitioned wagons. So we can imagine that some representatives of all the main Slavic groups were affected longer by direct contacts with the Avars: the Southern Slavs, from among the Western Slavs the ancestors of the Slovaks and Czechs, and the Eastern Slavs (Antes and Dulëbi). Only the Lusatian and Lekhitic Slavs seem to have been spared direct contacts with the Avars, except for a short time in 562-67, when the first Avar raids were moving through their territories against the Frankonian monarchy.

Now, we should answer the question concerning the character of the Avar control over the Slavic tribes mentioned above. To be sure, the historical sources provide us with no concrete information about that. We can rather hypothesize by analogy to later, historically well described, relations between the Eastern Slavs (Rus') and the Tartars (in the thirteenth century). Two main duties symbolized the political dependence of Rus' with respect to the Tartars: the obligatory participation of auxiliary Slavic troops in the Tartar expeditions, and an annual tribute (cf. Ukr., Pol., S-C harač), which was undoubtedly paid in nature, i.e., in grain and cattle, at the time of the Avars because of the low level of productive forces. We can also assume that they had the additional duty of maintaining some Avar troops stationed temporarily among the Slavic population by providing lodging and food. To what extent the Slavic tribal chieftains ( $k \lesssim n e \varepsilon z i)$ were nominated and imposed by the Avar khagan is not known. Such a practice could have taken place, but it is highly probable that most Slavic kznęzi simply surrendered to the Avar hegemony and were left as the heads of their peoples charged with the responsibility of performing the basic duties defined above. Of course, in view of that it would be unjustified and historically anachronical to imagine the so-called Avar empire in terms of a well-organized state with a central administration, etc. So we should not exaggerate the cultural influence of the Avars upon the Slavs with respect to the organization of statehood.

The next problem here is the terminus ad quem the direct rule of the Avars over the Slavs (as presented above) lasted. Here fortunately we already have exact historical information which concentrates around two important events: the uprising of the Moravian Slavs against the Avars under Samo (623 according to Fredegar's chronicle, but actually in 626, after the defeat of the Avars at Constantinople), ${ }^{29}$ and after its success, because of the support of the Franks, the formation of a kind of Slavic state which consisted of Moravia, Bohemia, Lower Austria, and later also the regions of the Sorbs (so-called White Serbia; see Dvorník, 1956:61-62); the second event, chronologically contemporaneous with the first, the migration of the two belligerent Slavic tribes from the North, the 
Croatians ( ${ }^{*} X$ zrvati) and the Serbs $\left({ }^{*}\right.$ Sъrbi), and their anti-Avar campaign, requires a more detailed presentation.

As we know, in the famous work by Emperor Constantine Porphyrogenitus, De administrando imperio (the original written in Greek), from the tenth century, there is an extensive commentary about

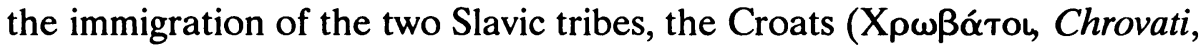

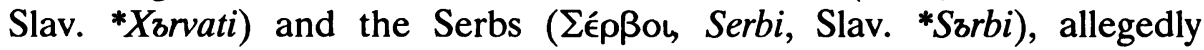
invited from beyond the Carpathians by Emperor Heraclius as allies against the Avars. The movement of these two tribes took place at the time of a general anti-Avar insurrection in the western part of the Danube basin (after 626) and brought about the expulsion of the Avars from Dalmatia, Illyricum, and Carinthia (Dvorník, 1956:62-64). Of course, the newcomers, who represented well-organized warrior clans, settled down in the new territories and became the organizers of the earlier Slavic groups already present there. This is the beginning of the historical South Slavic nationalities of the Croats and Serbs. The question is, however, which route from beyond the Carpathians southward did they use? It seems highly improbable that they used a direct way through Pannonia, the stronghold of the Avars. Most plausible is the hypothesis which accepts the western route: through the Moravian Gate (?), across the Danube River, and then south along the western outskirts of Pannonia. The Moravian Gate did not have to be used. The tribes could have crossed the central Carpathian passes (e.g., the Dukla Pass) and then moved southwest towards the Danube River, etc. In any case, the hypothesis ventured by Łowmiański, according to which the migration took place along an eastern route (through Transylvania and Wallachia, i.e., along the old route of the Sclavini) and then westward (see his map on p. 415 , loc. cit.), seems to be geopolitically unjustified if we recall that the military goal for which these tribes were brought in by the Byzantine diplomats was the liberation of Dalmatia and Illyricum from the Avars. Łowmiański's hypothesis is conditioned by his belief that the primary "trans-Carpathian" habitat of the Croats immediately before their migration south was the Upper Dniestr basin. But this is disputable.

In any case, against the background of the above historical facts the problem of the socio-cultural contacts and undoubtedly reciprocal influences between the Altaic peoples and the Slavs acquires a more concrete character. Of course, in accordance with the principles of my methodological approach, this problem will be discussed on the basis of Altaic loanwords in Late Proto-Slavic, i.e., borrowed by the Slavs in the period between $370-670$, the latter date accepted conventionally as the time when the contacts between the western and the eastern Avar 
Khaganates, maintained through the East Slavic territory (Dulěbi), were broken. We must remember that the oldest Altaic loanwords in Slavic may have been borrowed from the language of the Huns. As the reader observes, I have omitted the problem of Slavic-Bulgarian contacts. I have done so deliberately because these contacts started much later than those with the Avars (officially in 679), and they were limited to one South Slavic group only, namely to those Slavic tribes of Moesia Inferior and Thracia whose dialects later developed into Bulgarian. To be sure, some Turkic elements taken over from the language of the Bulgars (Proto-Bulgars) already appeared in Old Church Slavonic, e.g., bistro 'Perle,' byl'a (Voc.) 'Vornehmster, Grosser,' kapb f. 'Abbild,' kapište 'Götzenbild, Götzentempel,' samъči(ji) 'Präfekt,' sanı 'Würde, Rang, Stand,' synz 'Turm' (for which see Kiparsky, 1975:63-68), and through it later penetrated the literary languages of the Orthodox Slavs, e.g., Russian. But these phenomena do not belong to the framework of our discussion, since they represent the cultural history of separated Slavic nationalities and their languages. So we can and should concentrate on those possible Altaic loanwords which still belong to the Late Proto-Slavic (Common Slavic) period, i.e., which in our case do not transcend the seventh century A.D. It should be noted that at this point I am more generous than in the case of Germanic-Slavic relations reflected in lexical borrowings: for those I have conventionally accepted the year 600 A.D. as terminus ad quem. I have done so deliberately in order to avoid involving myself in the discussion of OHG loanwords, which started at that time and continued to penetrate West Slavic and the northwestern part of South Slavic (Kajkavian) during several centuries of separate historical development of these languages. But in the case of the Avars we must extend our chronology further into the seventh century because of the specific geopolitical conditions of the Avar-Slavic relations presented above.

It is interesting that the invasion of Eastern Europe by the Avars and their first contact with the Slavs left a deep imprint in the historical tradition of the Slavs. This is reflected in the Common Slavic name of that nomadic and belligerent Altaic tribe: Obsre plur., Obzrins sing. (these forms are attested in ORuss., e.g., in the Povest' vremennyx let; there are also Russ. toponyms of the Obrovo type and the S-C Obre, Obrov, Obrovac, undoubtedly derived from the ethnonym $\left.{ }^{*} O b z r-\right)$. It seems certain that PSl. *Obъrъ corresponds to Gr. "A $\beta \alpha \rho$ sing., "A $\beta \alpha \rho \in \iota$, "A $\beta \alpha \rho o$ plur., Lat. plur. Avares, Avari, and somehow reflects Turkic apar // abar 'rebel' from the root $a b a$ - 'oppose.' But there are some problems connected with the alleged continuation of this ethnicon in the historical Slavic languages: namely, the forms continuing PSl. *obzr-inz show only 
the secondary meaning 'giant,' e.g. Cz. obr, OPol. obrzym (NPol. olbrzym), Sloven. óbar. The question is whether we are dealing here with a semantic change of the primary ethnicon, analogical to the Germ. Hüne 'giant' from the ethnicon Hüne 'Hun,' or with a contamination of the ethnicon *Obsr- $\leq$ Turkic abar with the native PSl. *obro 'strong,' corresponding to Goth. abrs idem (for details see Vasmer, III, 107). Whatever the solution of this problem, the name of the Avars has survived in Slavic, which means that the Avar-Slavic relations must have affected important aspects of social life.

Now the question arises, which aspects of the social life of the early historical Slavs were influenced by the Avars, or if we assume Hunnic influences, also by the Huns. On the basis of obvious cultural differences between the basically agricultural Slavs and the pastoral-nomadic Altaic peoples, who also proved to be efficient warriors and organizers of mass military actions, we can hypothesize that it is first of all in matters of cattle breeding, transportation, and military organization where we will observe Altaic loanwords in Slavic.

In order to verify this hypothesis we should make a survey of all the Altaic words in Slavic which are not limited to one Slavic group (e.g., South Slavic) and do not come from later sources such as $\operatorname{Tartar}^{30}$ or Osman Turkish, and can thus be considered borrowings from the period of prehistorical and early historical contacts between the Slavs and the Altaic peoples, i.e., most probably from the time of Slavic-Hunnic, and mainly Slavic-Avar relations. Unfortunately, there is no exhaustive treatment of this problem in any special monograph. Valuable contributions are dispersed in etymological articles devoted to individual words and then used by etymological dictionaries of Slavic languages. Among these dictionaries Vasmer's dictionary of Russian occupies the leading position. In the following paragraphs I will mainly use the data of this dictionary, supplemented with a recent publication by E. N. Sipova: Slovar' tjurkizmov v russkom jazyke (Alma-Ata, 1976). Of course, other sources will be used if they are relevant, primarily articles by K. H. Menges.

The tentative list of Altaic loanwords in Late Proto-Slavic (Common Slavic) can be given as follows:

1) barans // borans 'ram'

2) čekans 'battle-hammer'

3) dostokans 'cup'

4) xaloga 'fence'

5) xomutz 'horsecollar'

6) xorqgy, gen. -zve 'banner'

7) *kolbukъ // klobukъ 'calpac, fur cap' 
8) kolimagz 'covered wagon'

9) *kblbasa 'sausage'

10) kъn'iga 'book'

11) sokači(ji) 'cook'

12) sokals 'kitchen'

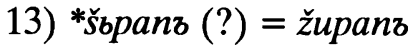

14) tovars 'mobile property' (?), 'cattle' (?)

15) tovarišb 'companion'

16) tzlmačb 'interpreter'

17) tъma (?) ' 10,000 , multitude'

18) županz 'chieftain of a district, etc.' (?)

1) baranz 'ram,' attested in most Slavic languages, e.g., Russ. barán, ORuss. boránz (the same form in OLus.!), Pol. baran, Cz. beran, OCz. baran // beran, S-C baran; quite a disputable word, but most probably borrowed from Altaic: N. K. Dmitriev ( $O$ turskix èlementax russkogo slovarja, 1958) quotes as its source forms from the Turkic languages of the Volga region, e.g., Tatar and Bashkir bärän 'lamb,' Kazakh beren 'ewe,' etc. (see Vasmer, I, 123; Sipova, 59-60, and Kiparsky, 1975, 49). ${ }^{31}$

2) čekanb 'battle-hammer' or 'battle-hatchet' ('Streitaxt'), attested in most Slavic languages, e.g., Russ. čekán (already Russ. Church Slav. in the 12th cent.), Pol. czekan // czakan, Bulg. čékan 'hammer' (sic!), S-C čàkanac, etc. This is a Common Slavic borrowing from Turkic, cf. Chaghatai čakan 'battle-hatchet' and Kazakh čakan idem, which seem to be derived from the verb represented by Turkish čakmak 'beat' (see Vasmer, IV, 381-82; Berneker, 134-35; and Kiparsky, 1975:64).

3) dostokanz 'cup,' attested only in ORuss. and OPol. dostuchan, rostuchan, rostruchan, hostruchan (sic!); cf. also modern Russ. stakán. It is probably an early historical borrowing from Turkic, cf. Chaghatai tostakan, Kazakh tusta yan '(wooden) cup,' etc. (Vasmer, III, 743; Šipova, 289; and Kiparsky, 1975:64). However, because of the geography of the word, it may be simply an East Slavic borrowing of the pre-Tatar period (see Kiparsky, loc. cit.), which then penetrated into Polish.

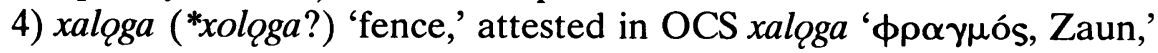
Serb. Church Slav. xoluga, ORuss. xaluga, Russ. xalúga idem, Ukr. xalúha 'alga' (sic!), Bruss. xalúha 'shelter built from withes,' S-C hàluga 'weed; thicket; cleft,' Sloven. halóga 'bushes; seaweed'; in WSlav. only OCz. chalužnık 'Strauchdieb' and Pol. charłężnik idem, with an "unorganic" $r$, belong here. It is quite a disputable word (see Vasmer, IV, 218-19), but highly probable seems to be K. Menges' etymology (Zeitschrift für Slav. Philologie, XXIII, 1955, 333-34) deriving it from a Turkic prototype *qaty-n-ya 'etwas Hervostehendes, Erhöhtes, etc.' with the passage of $q$ - 
$\geq x$ - characteristic of Volga-Bulgar. The verbal stem qaty- 'sich aufwärts bewegen; konvex, hoch sein' which underlies the word under discussion is well-known in all Altaic languages; it is also represented by another Turkic loanword kolimogz, and probably by *kolbukъ // klobukъ (for details see K. Menges, loc. cit., 327-33).

5) xomutz // xomqtz (with a secondary PSl. nasalization of $u \geq Q$ as in *nudja // *nqdja $\geq$ OCS nužda // nqžda, etc.) 'horsecollar,' attested in all Slavic languages, e.g., ORuss. xomutz, Serb. Church Slav. xomotz, Russ. xomút, gen. -á, Pol. chomąt(o), gen. chomata, Cz. chomout, etc.; in S-C xômut the meaning 'yoke' is attested only in older times, now it is 'handful, armful,' also in Sloven. homột 'horsecollar' and secondarily 'dragnet' (sic!). These latter facts seem to prove that the Southern Slavs were not very familiar with this type of harness and the corresponding word. The etymology of xomutz has produced quite a copious literature (see Vasmer, IV, 259-60); among various hypotheses that by M. Räsänen (Finnisch-ugrische Forschungen, XXIX, 200) deriving the Slavic word from Chuvash xomât 'horsecollar' (with many obvious correspondences in Altaic, e.g., Kazakh kamit, Mong. xomūD, etc.) seems to be the most convincing. Vasmer's objection in this respect: "Unconvincing is the reduction of Slavic *xomotz to Chuvash xomatt...because there is no nasal in the latter" is not justified, because the nasal vowel is obviously secondary in Slavic and we should start from an earlier form xomutb. Räsänen's etymology obtains additional important support in the ethnological facts presented by A. G. Haudricourt (Revue de Géographie Humaine et d'Ethnologie I, 1948, 54-64) and by J. Czekanowski (Wstęp do historii Stowian, 2nd ed., 1957, 402-06). It is interesting that the word shows the passage of Turkic $q \geq x$ as in the case of xaloga, which is characteristic of Chuvash, which, as we know is closely related to Volga Bulgar and probably through it to Hunnic (for comparative Altaic material see Sipova, 365-66).

6) xorggy, gen. xorggъve 'banner,' attested in all Slav. languages, e.g., OCS xorggy, gen. xorggъve; ORuss. xorugy, gen. -ъve; Russ. xorúg(o)v'; Pol. choragiew, gen. -gwi; Cz. korouhev; OCz. korúhva ( $k$-instead of $c h$-proves that it is rather a secondary, historical borrowing?); S-C horugva // horuga; Bulg. xorb́gva, etc. In the opinion of most Altaists the word was borrowed through a Turkic intermediary (the prothetic $h$-?) from Mong. orungo // orunga ${ }^{32}$ 'sign, banner' (for details see Vasmer, IV, 268-69, Sipova, 366-67, and N. Poppe, Word, IX, 1953, 98).

7) klobukz primarily 'fur-cap,' attested in all Slavic languages (except for Bulgarian?), e.g., Church Slav. klobukz, ORuss. (1073) klobučbcb and Črnii Klobuci (11th-12th cent.) = Kara Kalpaks (a Turkic tribe), Russ. klobúk 'monk's cap, fur-cap,' Pol. (old and dial.) kłobuk, Cz. klobouk 'hat,' 
S-C klòbuk 'cap, hat,' and even Polab. klüběk, etc. The word must be a PSlav. borrowing from Turkic; as its source Turkic *qały-b-uq (see K. Menges, Zeitschrift für Slav. Philologie, XXIII, 1955, 331) is quoted, whose cognate is the historically attested Turkic qalpaq (e.g., Osman, Crimean Tatar, Kazakh, etc.); *qałybuq, qalpaq have a well-substantiated etymology in Altaic: they are derived from the verbal stem *qaty- 'sich aufwärts bewegen; konvex, hoch sein' (see Menges, loc. cit., 329-30), whose meanings ('aufwärts gehen, hervorstehen') lend themselves to naming a high, pointed, calpac-like cap. There is however a phonemic problem: the Turkic archetype *qałybuq should have given PSlav. *kolsbukz, so we should expect Russ. *kolbúk, etc.; the PSlav. form *klobukz from which we must start in order to account for the historical Slav. forms, cannot be derived directly from the Turkic archetype. Therefore, we have to admit (assume) a prehistorical contamination (through folk etymology) of the expected *kolsbukz with a native Slavic word, probably with the verb kloniti 'bow,' in reflexive forms also 'greet' (by removing one's hat, etc.); see Berneker, 522. Consequently, *kolsbukz kloniti resulted in klobukz, whose continuants are represented in historical Slavic languages. This explanation of the form $k l o b u k b$ is proposed here for the first time (for other details see Vasmer, II, 252; Sipova, 186; Kiparsky, 1975:64; and Menges, loc. cit.).

8) kolymags // kolimagz // kolimogz 'covered (high) wagon' = ORuss. $v \check{z} \check{z} a$, attested in the following Slavic languages: ORuss. kolimagz, kolimogz, kolymagz, kolzmagz, Church Slav. kolimagz, Serb. Church Slav. kolimogz, everywhere with the meaning 'Zelt, Zeltlager, $\sigma \kappa \eta \nu \eta$,' but in other Slavic languages with the meaning 'großer, schwerer Wagen': Russ. kolymága (in the Don region kalamága 'Hochzeitswagen'), Ukr. kolymáha (but kolymáh 'Zelt'), Bruss. kalamažka dimin., OPol. (15th cent.) kolimaga, OCz. kolimah (in the last two 'wagon'). As the above examples indicate, the word seems to be North Slavic (in the South it is known after the 16th cent. only in Serb. Church Slav.). The most convincing etymology of kolymagz, etc., has been proposed by K. Menges (loc. cit., 327-29); here it is worth quoting him:

"Die Grundbedeutung von kolimogъ, etc. muß sowohl die von 'Zelt, Zeltlager' wie die von 'schweren Wagen' gewesen sein, und nichts liegt näher, als daß dieses Wort die großen, hochräderigen Zeltwagen bezeichnet haben muß, mit denen die altajischen Nomadenvölker von den Hunnenstürmen an bis zu den mongolischen Feldzügen die ungeheuren Weiten der Steppen Central-Asiens und Ost-Europas durchquerten. Die "Wagenburgen" der Hunnen und Avaren bestanden aus 
solchen Zeltwagen. Nach den mongolischen Feldzügen scheinen diese großen Zeltwagen mehr und mehr aus dem Gebrauch gekommen zu sein, so daß sie in späteren Zeiten vollkommen unbekannt sind" (loc. cit., 328).

As the source of this borrowing a Turkic prototype *qaty-maq or a Mongol prototype *qali-maq can be reconstructed (the former would account for the Slavic archetype kolymagz // kolzmagz, the latter for kolimagz; both are attested in the oldest sources, although the archetype kolimagz seems to be more common; cf. West Slavic!). However, the Altaic word itself is not attested in any Altaic language, except for the ethnicon of the Mongolian Kalmucks, Xal'mag ( $\leq$ *qali-maq), whose primary meaning was, according to Menges, 'hohe Zeltwagen' (interesting semantic parallels in other Altaic ethnica!), but etymologically it is a transparent formation (an action noun) from the verbal stem *qaty-, whose most basic meaning (Grundbedeutung) is formulated by Menges as 'sich aufwärts bewegen; konvex, hoch sein' (loc. cit., 330). The problem is whether the word in its Mongolian form kolimágz might have been borrowed from the Avars. Menges doubts that because we do not know whether the primary Altaic $y$ had already passed into $i$ so early, but there seems to be little doubt that the word belongs to the early stratum of Altaic borrowings in Late Proto-Slavic (6th-7th cent.); see Vasmer, II, 291, Šipova, 193: kolymága, and Menges, loc. cit.; it is strange that Kiparsky (1975) does not quote kolimagz, etc., in his book.

9) *kblbasa 'sausage,' attested in all Slavic languages, e.g., in ORuss. kolbasa (1280), Russ. kolbasá, Pol. kiełbasa, Bulg. kzlbása, etc. Some languages have forms which cannot be directly derived from PSl. *kzlbasa, e.g., Cz. klobása (but Slovak klbása!), S-C kobàsica, Sloven. klobása. Such cases indicate either a secondary borrowing from another Slavic language, e.g., S-C kobàsica is probably either from East Slavic (?) or the result of folk etymology, e.g., Slovene, Cakavian, and Czech klobása, probably under the influence of PSl. *klobz 'ball,' secondarily also 'bundle' (?). In any case, the PSl. archetype *kzlbasá seems to be certain. Among the etymologies of the word, that which derives it from a Turkic gerund *külbasa, posited on the basis of Turkish külbasty 'grilled meat,' seems to be the most convincing (see Vasmer, II, 286; Sipova, 191; and Sławski, SEJP, II (2), 143-44).

[Remark: In connection with the realia of *kblbasa, it could be noted that a kind of typical Turkish grilled meat, the kebab (S-C ceebab, ćebàpčić) has the shape of small sausages rolled in the hands: so the passage of the meaning 'broiled pieces of meat' $\rightarrow$ 'sausages' seems to be 
justified.]

10) kßn'iga 'book,' primarily used only in the plural, e.g., in OCS kznigy

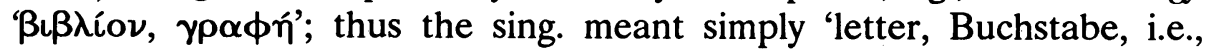
written sign.' It is attested in all Slavic languages, e.g., OCS kzn'iga, Russ. kniga, Pol. księga, S-C knjüga, etc. Räsänen proposed an oriental etymology for this word, from Chinese ćzüan (*kịwan) 'Buchrolle,' through a Turkic intermediary (see Vasmer, II, 262-63, and Menges, UAJ, $31,1959,183-87)$, but as Menges convincingly argues in this article Slav. $k z n$ 'iga, because of the initial $k z-\left({ }^{*} k \breve{u}-\right)$, cannot come from the Chinese archetype, which contains $* k i-$, i.e., palatalized * $k$ '- (in Proto-Slavic at that late time we would expect through a Turkic intermediary ${ }^{*}(b-),{ }^{33}$ in his words:

"Es liegt auch keinerlei Grund vor, anzunehmen, daß $k w j n$, wie vielleicht auch $k i \eta$, $k i$ im Altaischen entpalatalisiert und in solcher Gestalt ins Slavische übernommen worden wäre. Das slav. kzn'iga schließt eine palatale erste Silbe oder zumindest palatalen Vokal in der ersten Silbe - des entlehnten Wortes a priori aus. Deshalb halte ich für die einizig mögliche Quelle der Entlehnung eine Form, die armen. ... knik' 'Siegel' nahesteht, das seinerseits schließlich auf akkad. kunukku 'Siegel,' vielleicht auch kaniku, ptc. pass. 'etwas Versiegeltes' zurückgeht..." (loc. cit., 184), and further (loc. cit., 185):

"Das Ossetische hat im Digorischen k'iunugä (Vasmer, l.c.)... das Ironische $\check{c}$ 'inyg 'Buch.' Diese Formen, besonders die altertümliche digorische, stehen dem assyrischen Prototyp näher als die $k^{\prime}$ art'velischen, sogar auch als das armen. knik', und legen deshalb die Annahme eines anderen Entlehnungsweges nahe, jedenfalls eines solchen, der nicht unmittelbar aus Armenien kommt. Daß das Wort aber bei den Proto-Bulgaren früher Aufnahme gefunden hätte als bei den Alanen und Aorsoi, den späteren Osseten, is nicht anzunehmen; vielleicht war gerade das proto-ossetische Alanische die Sprache, aus der die Proto-Bulgaren das Wort übernahmen? Wichtig ist hier wieder die Bedeutung "Buch," wie im K'art'velischen" (for further details, see Menges, loc. cit., 185-86).

In any case, it should be stressed that the same word - through Causasian and Proto-Bulgar (?) intermediary - appears in Hungarian: köňv (orthographically könyv) 'book,' Chuvash koň (*koňiv), Mordv. koňov 'paper,'34 which proves its cultural character. The source of the 
borrowing must have been a form close to the primary Akkadian trisyllabic *kuni $u$, because only such a form accounts for PSl. kæn'iga and Hung. köňv. An additional argument for the early borrowing of kzn'iga directly from Turkic is OCS kъn'igzči(ji) ' $\gamma \rho \alpha \mu \mu \alpha \tau \epsilon u ́ s, ~ B u c h g e l e h r t e, '$ Russ. knigočéj idem, an obvious Turkic derivative with the suffix -či.

11) sokači(ji) 'cook,' attested only in OCS, ORuss. sokačii, and in Sloven. sokáč. Menges (UAJ, XXXIII, 1961, 107-14) has convincingly proven the Altaic origin of the noun, namely that its source is *soqqat-čy, a nomen professionis 'der mit Geschlachtetem, Schlachtfleisch zu tun hat,' derived from soqqat 'Schlachtfleisch, Geschlachtetes,' a transparent formation containing the Altaic verbal root soq- (e.g., Turkish sokmak) 'schlagen, hauen, stossen, schneiden, stechen, etc.' (see Vasmer, III, 708, s.v. sokal; and Menges, loc. cit.).

12) sokals (?) 'kitchen,' attested only in Church Slavonic (Russ. and Serb. recensions already in the eleventh century), but because of the toponym Sokal (a town on the Upper Bug) and other similar ones (e.g., two villages in northern and southeastern Poland) it can be treated as PSI. It has a variant sokalskb which seems to represent a transparent Turkic formation with the productive suffix -lyq (*soqqattyq, etc.), a nomen actionis from soq-, whereas sokals reflects a less productive Turkic formation in - $t$ : (soq-qa-t 'Zubereitung von Geschlachtetem, Fleisch,' which is, however, quite frequent in older Turkic texts and in Mongolian (for details see Menges, loc. cit., 110).

13) ${ }^{*}$ španz = županz; in my opinion, the former can be reconstructed on the basis on Hung. išpān (orthograph. ispán), ${ }^{35}$ semantically corresponding to Slav. županz, and seems to represent the primary form of the Slavic noun borrowed from Proto-Bulg. *šupan (cf. the passage of Turkic ${ }^{*} \check{c}$ - $\geq s$ - in Chuvash [N. Poppe, 1975:197]); župans is most probably the result of the contamination of the borrowed *šbanz with the native Slav. župa '(Wohn)grube,' then 'Sippe, Gemeinde; Gau, Bezirk, Komitat.' Here it is worth quoting a condensed presentation of the much discussed etymology of županı by Menges (UAJ, XXXI, 1959, 178-79):

"Bei županъ...handelt es sich sicherlich um den von altaischen Völkern - wenn nicht den mongolischen Avaren, so doch bestimmt von den türkischen Pečenegen (diesen ist die Inschrift fon Nagy Szent Miklós zuzuschreiben, nicht den Avaren), oder den Proto-Bulgaren - nach dem Westen geführten Titel čupan $\sim$ *čopan, vgl. mittel-türk. (Kāš.) čupan 'Gehilfe des Dorfvorstehers,' der in slavischer Nachbarschaft und schließlich in slavischem Milieu an das 
slavische župa angelehnt wurde, das wie das urverwandte

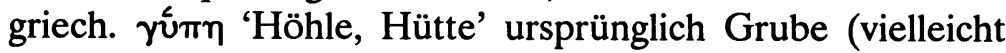
auch "Wohngrube"; "Grube für Wintervorräte" - vgl. Schrader-Nehring, Indogerm. Altertumskunde, unter "Unterirdische Wohnungen") bedeudet hat und aus dem sich sekundär die Bedeutung 'Sippe, Gemeinde' entwickelt hat. Daraus haben sich dann weiterhin und später die Bedeutungen 'Gau, Bezirk, Komitat' ergeben - dies vielleicht schon unter der Wirkung einer rückläufigen Beeinflussung, d. h. Anlehnung an den Title županz. Bei den Proto-Bulgaren kommt er immer mit $Z$ - vor, das auch als $\check{z}$ gelesen werden kann, z. B. Z O У П A N T A P K A N O C. Es wäre auch denkbar, daß die Proto-Bulgaren den Titel ursprünglich nicht besaßen, sondern ihn erst auf dem Balkan in slavischer Nachbarschaft bereits in der slavisierten Form županъ ( $\mathrm{Z}$ O $\mathrm{y} \Pi \mathrm{A} \mathrm{N}$ ) kennengelernt hätten. Vielleicht handelt es sich, wie Vasmer annimmt, um eine und dieselbe indogermanische Wurzel, die župa, županz und dem west-slav. pan 'Herr' (alt. čech. hpán $\leq$ *gzpanz) zugrundeliegt und in einer iranischen Form in eine altaische Sprache Zentral-Asiens entlehnt wurde: čupan. Diese könnte dann ihrerseits später auf dem Balkan unter dem Einfluß des Slavischen modifiziert worden sein, *župan..." (Menges, $U A J$, XXXI, 1959, 178-79).

I think that Menges clarifies the problem of župans (*šbanı (̌̌upa) in a satisfactory way, although we should remember that Trubačev tried to explain WSlav. *gzpanz (OCz. hpán, Pol. pan, etc.) as representing a direct Iranian loanword 'gu-pāna- 'shepherd,' i.e., a primary Iran. compound consisting of $g u$ - (reduced from gou-) 'cattle' and pā- 'protect,' whereas, if Vasmer is right (and for this matter see also M. Rudnicki, Slavia Occidentalis, XX (1), 1960, 93-98) - županz and *gъpanъ would represent two different Ablautsstufen (apophonic grades) of IE *geup- ${ }^{36}$ 'guard,' cf., e.g., OI gōpāyáti 'guard,' etc. (see Vasmer, II, 65, s.v. župa, amd 66, s.v. župán; Rudnicki, loc. cit.; and P. Skok, ERHSJ, III, 1973, 687, s.v. žúpa).

14) tovarb 'cattle' (?), 'mobile goods' (?) $\rightarrow$ 'goods, merchandise,' attested in most Slav. languages, e.g., ORuss. tovar (1229) 'goods, property, merchandise,' Russ. továr 'merchandise,' but Ukr. továr 'merchandise, cattle,' Pol. towar 'merchandise'; in South Slavic, e.g., S-C tòvar 'load' (of a pack-animal), etc. It is an obvious borrowing from Turkic, cf. Uighur tavar 'property, cattle,' Turkish, Chaghatai tavar 
'merchandise, property, cattle,' etc., even Mong. tawar 'merchandise, property.' The primary meaning of the word seems to be 'cattle,' which is well represented by many Turkic languages and preserved in Ukrainian. In view of the above, ORuss. továr 2 'military camp,' which Vasmer separates out and connects with Crimean Tatar tabur 'camp,' can be interpreted as preserving an older meaning of tovarb, namely: "The word tovar in ancient times meant 'cattle, herd, camp,' which meaning has been preserved to this day in Ukrainian; and because cattle served as a valuable market commodity, a new meaning of the word tovar developed - 'object of purchase and sale"' (Melioranskij, cf. Sipova, 322; for details see Vasmer, IV, 67-68, and Sipova, 321-22).

15) tovarišb 'companion,' primarily 'camp-mate' or 'shepherd' (?), attested in most Slavic languages, although in South Slavic it is known only in Slovenian (tovâriš), e.g., Russ. továrišč, Ukr. továryš, Pol. towarzysz, OCz. tovariš, NCz. -yš, ULus. towařs, LLus. towariš. It is most probably a derivative with the Turkic suffix -iš from tovar (cf. above). But there is also another Turkic etymology proposed by Räsänen: Chuvash tavra 'around' + iš 'companion' (see Vasmer, IV, 68; and Šipova, 322-23).

In connection with tovarb and tovarišb it is worth noting that the former is listed by Kiparsky (1975:64) in ORuss. under the so-called vortatarische Lehnwörter (attested before 1240), but the latter is not - it appears only in 1395 and according to Kiparsky (loc. cit., 67) belongs to the Turkic loanwords borrowed during the Tatar rule. However, the spread of the word in Slavic (note the OCzech and Lusatian forms!) makes such a late borrowing questionable, so it is highly probable that tovarišb belongs to the early Turkic elements in Slavic, although it was not attested in ORussian, perhaps by chance.

16) *tzlmačb 'interpreter,' with its derivative *tzlmačiti 'interpret,' attested in all Slavic languages, e.g., ORuss. tzlmačb (in the pre-Tatar epoch), Russ. tolmáč, gen. -á, tolmáčit', Pol. thumacz, thumaczyć, Cz. tlumač, tlumočiti (sic!), Croat. Church Slav. (Glagol.) tlımačb, S-C túmáč, gen. tumáča, tumáčiti, etc. It was borrowed from Turkic, cf., e.g., Kypchak tylmač, Kazakh tilmäži, Turkish dilmač, etc., and it seems to have a transparent etymology in Turkic: it is derived from tyl- // til'tongue, language' (see Vasmer, IV, 72, and Sipova, 324-25). In connection with tzlmačb it should be noted that the word has been borrowed from WSlavic (ULus. totmač) or Slovene (tolmáč) by German: MHG tolmetsche, NHG Dolmetsch.

17) toma 'ten thousand, multitude,' in this form attested in Old Church Slavonic: 'grosse Menge, zehntausend, ungeheuer viel,' tzmami 'zu tausenden' (Sadnik-Aitzetmüller, 139-40); in other languages it is confused with the PSl. *tbma 'darkness,' e.g., Russ. t'ma, Ukr. t'ma, 
Bruss. c'ma, OPol. ćma. Because of the special meaning 'ten thousand' (undoubtedly connected with the military organization of the steppe nomands - cf., e.g., Uzbek tuman 'a military detachment of 10,000 horsemen'), the most probable source of tzma is Turkic tuman (or even Altaic because of Mong. tuman), which in its turn is probably an old borrowing from Tokhar. tuman (for details see Vasmer, IV, 134, s.v. tbma 2, and Sipova, 339). The old Turkic word tuman was rendered by PSI. tzma, and then the word was borrowed for the second time in the form tuman // toman by East Slavic (see Vasmer, IV, 119, s.v. tuman 1, and Sipova, 335; for a recent discussion of tzma see also Vernadskij, For Roman Jakobson, 1956:589ff.).

18) županz 'chieftain of a district,' most probably a result of the "Slavicization" of a Turkic *šupan ( $\geq$ PSl. *šbanz) through contamination with PSl. župa (see above under *šspanz). The word is attested in the following languages: OCS županz, ORuss. *županı (retrieved from place-names of the type Županovo), Russ. župán, OPol. (1242) zupan (strongly supported by place-names of the type Żupanie // Żupany // Żupanówka), Cz. župan, Slovak župan (in Slovak the meaning 'conductor (on a train)' is undoubtedly new), Bulg. župán, S-C žùpân, Sloven. župàn, gen. župána. At first glance the word looks like a derivative with the suffix -anı from the PSl. noun župa 'district' (primarily 'dugout, home; family, commune,' the two latter meanings, e.g., in Serbo-Croatian), but such derivatives are very rare from primary $a$-stems (see, however, A. Vaillant, IV, 1974, 616-18, and Sławski, Słownik prastowiański, I, 1974, 130). In view of the above, the hypothesis about the Turkic source of the word and its secondary Slavicization seems to be quite plausible - but see footnote 36 of this chapter (cf. *španz).

As the above survey of the 17 probable Late PSl. borrowings from the Altaic languages indicates, they can be classified into some semantic groups, reflecting the type of socio-cultural contacts and influences between the Slavs and Altaic tribes (the Huns, Avars, and Bulgars). It is significant that, as I anticipated, many words belong to the three following domains of life: 1) war, 2) transportation, and 3) cattle breeding, namely:

1) čekanz, xorggy, tzma;

2) xomutz, kolimagz;

3) baranz, tovarı (if its primary meaning is 'cattle'), tovarišs (if its primary meaning is 'shepherd').

We also have such important culture words as kъn'iga and *tzlmačb and probably a political term *šspanz // županz. Apart remain terms connected with food (meat!) and its preparation, kzlbasa, sokači(ji), sokals, and with clothing, *kolbukz // klobukz. To be sure, the number of 
Altaic loanwords that could be treated as borrowed in the Late Proto-Slavic period (approx. by the middle of the 7th cent.) is not impressive, but if we compare it with the number of Germanic loanwords (44 [or 45] total!) then this number is not negligible. After all, the period of the contacts between the Slavs and the Altaic peoples taken into consideration here was much shorter (ca. 370-650 A.D.) than the period of the contacts between the Slavs and the Teutons (ca. 300 B.C. -600 A.D.). We should also remember that the subject of Slavic-Germanic linguistic contacts is much better investigated than that of Slavic-Altaic linguistic contacts. All these circumstances must be taken into account in any general conclusions concerning the significance of the cultural exchange between the respective languages and peoples. This latter statement takes us to the problem of possible prehistorical Slavic influences in the Altaic (mainly Turkic) languages.

Of course, the Altaic languages did not develop in isolation: in prehistorical times they had contacts with their western neighbors, the IE languages. In his Introduction to Altaic Linguistics (1965), N. Poppe devotes three pages (167-70) to a short survey of the problem of the ancient IE elements in the Altaic languages, and he distinguishes the following IE languages that have influenced the Altaic vocabulary: Sanskrit, Tokharian, Sogdian, and some other Iranian languages. It should be noted that the active role in the spread of IE elements within the Altaic family was played by the Turkic languages, which were directly affected by the IE languages mentioned above. But Poppe mentions no ancient influences from Slavic. The problem is whether such influences were possible. In view of all the information we could retrieve from history and linguistics about the primary (oldest) habitat of the Slavs in Eastern Europe, it seems highly improbable that the Proto-Slavs might have had any direct contact with the Turkic peoples. But there are some facts which nevertheless deserve attention and discussion. I will quote only one interesting, although highly controversial publication in this field, K. Moszyński's Badania nad pochodzeniem i pierwotnq kultura Stowian, I (PAU, Wydział Filologiczny, Rozprawy LXII, 2, Cracow, 1925). The main thesis of the author, who at that time represented the idea about the eastern (Euro-Asian) origins of the Slavs, is that the impressive number of old Slavic-Turkic lexical correspondences (whatever their linguistic interpretation) decisively proves that the early prehistorical habitat of the Proto-Slavs must have been located more to the east, somewhere on the borders of Europe and Asia, because only there could the cultural and linguistic exchange between the Slavs and the Turkic peoples have taken place.

The list of these correspondences presented and analyzed by 
Moszyński on pp. 108-26 contains 39 words (starting from Slavic). Of course, some of them are obviously wrong, e.g., PSl. *kody/a 'which way,' cf. Pol. kędy (dial. ka(ny)), Russ. kudá, etc. Kazakh kana, kanī (i.e., kany), Uighur, Osm. kany 'where, whither,' etc.; many have been criticized and explained within Turkic by Altaic linguists (see the review of Moszyński's work by W. Kotwicz in Rocznik Orientalistyczny III, 1927, 291-326), but there are undoubtedly some which cannot be discarded so easily. I will quote only the most striking examples:

1) PSl. bykz 'bull' e.g., OTurkish, East Turkest., Taranchi, Kirghiz buka, Osman. boha, etc., even Mong. buxa 'wild bull,' Tungus büka idem, etc. ${ }^{37}$ (Moszyński, loc. cit., 108-09, and Vasmer, I, 258).

2) PSl. gqba 'mushroom, sponge, touchwood,' e.g., OCS gqba 'sponge,' Russ. gubá, Pol. gqbka (only 'sponge'), etc. e.g., Kazakh gömbä // gümbä 'mushroom,' Chuvash komba // kîmba // kumbá 'mushroom, sponge.' The same word is known in Finnic (Moszyński, loc. cit., 109; the word has an IE pedigree; see Vasmer, I, 468).

3) PSl. koza 'goat' e.g., Kazakh, Bashkir käzä, Chuvash kaDźa, etc. It is significant that the relationship koza : *aza (in Church Slav. and ORuss. (j)azbno = koža 'skin, hide') is repeated by Altaic, namely the type käzä, etc., with the initial $k$ - appears in Northwestern Turkic, and the type öškä, etc., without the initial $k$ - (cf. Lith. ožkà!) in Northeastern Turkic and Mongolian, e.g., Soyot öškä, Kirghiz eški, etc. (Moszyński, loc. cit., 110); but see also Trubačev, 1960:87-88.

4) PSl. osa (osika, osina), e.g., Pol., Cz. dial. osa, ULus., LLus. wosa, Russ. osína, Bulg. osíka, etc. 'aspen.' The primary form was *opsa (cf. Latv. apse, OHG aspa) e.g., Teleut, Altai, Lebed apsak, Chuvash ëvës, etc. (Moszyński, loc. cit., 110; see also Vasmer, III, 159, where the hypothesis about the borrowing of the word by Turkic from the East IE languages [Iranian, Armenian, but not Slavic] is expressed).

5) PSl. *tolkzno, e.g., Russ. toloknó 'coarse-grained flour' (i.e., not from ground grain, but from crushed, pestled grain). The PSl. character of the word is supported by Southeast German dial. talken 'meal from coarse-grain oats,' an obvious borrowing from a prehistorical (Proto-Slovene?) *talkъno e.g., Teleut, Altai, Kirghiz, Soyot, Kazakh talkan 'geröstete kleine gestossene Gerste; aus dieser Gerste bereitete Speise,' etc., even Mong. talxa 'Brot, Mehlspeise' and Tungus tâlgâna 'Mehl' (Moszyński, loc. cit., 111-12).

6) PSl. *kopın-, e.g., Russ. dial. kopén' 'stack' (of hay or grain), OCz. kopenec, Sloven. kopanac (derivative from PSl. kopa) e.g., Kuman (Codex Cumanicus) keben 'eine huwte' (sic! - rather huwfe = Haufe), Barabe käbän 'Heuschober,' Kirghiz kebän idem, Chuvash kaBan // kaban 'Ladung, Schober, Heuschober, Getreidehaufen,' etc. It is interesting 
that the word has come back to Russian dialects as a Turkic loanword: kabán (Moszyński, loc. cit., 119; see also Šipova, 146).

7) PSl. koqdělb, e.g., Church Slav. koqělb f., Pol. kqqdziel f., Russ. kudél' f., etc. 'distaff' e.g., Chuvash kandâr 'Hanf,' Koibal kendar idem, Turkish kändir // kendir 'Hanf, Hanfgewebe,' etc. (widespread in most Turkic languages, even in Mongolian). Because of the well-substantiated native etymology of the word in Slavic (Vasmer, II, 399), the Altaic correspondences are obvious borrowings from prehistorical Slavic (note the continuation of the nasal vowel); see Moszyński, loc. cit., 119-20.

8) PSl. kuna, e.g., Russ. kuná, Pol. kuna, S-C kúna, etc., everywhere with the meaning 'marten (Mustela martes et foina); marten's fur' (highly priced in older times and used as a means of exchange; see Vasmer, II, $417)$ e.g., Kirghiz kön 'buntes (gelbes) Leder,' Baraba, Teleut kön 'gegerbtes Leder,' Kazan Tatar kün idem, etc. Because of the obviously secondary meaning in Turkic and the IE origin of the word in Slavic it is a Slavic borrowing in the Turkic languages (Moszyński, loc. cit., 122).

9) PSl. *moltz, e.g., OCS mlatz, Russ. mólot, Pol. młot, etc., everywhere with the meaning 'hammer' e.g., Teleut, Tuba, Sagai, Shor malta 'Beil,' Kirghiz, Turkish baltu, balta, balto 'Beil, Axt,' even Mongol. balta süke idem. It should be noted that the passage of the primary $m-\geq$ $b$ - is regular in Turkic (see Poppe, loc. cit., 196). Because of the transparent IE etymology of Slav. *moltz (from the underlying verb mel' $Q$, *melti 'pound,' etc.; see Vasmer, II, 647) the direction of borrowing seems clearly to be from Slavic to Altaic (Moszyński, loc. cit., 123-24).

10) PSl. *palıka 'mace, club,' e.g., Russ. pálka, Pol. patka, etc. e.g., Chaghatai balha 'Keule mit langem Stiele,' Sart balha 'Hammer,' Kirghiz balha idem, East Turkestan. b'alka idem, Baraba palha idem (Moszyński, loc. cit., 124-25).

11) PSl. tzkati 'weave,' e.g., OCS tъkati (tzko), Russ. tkat', Pol. tkać, etc. e.g., Chaghatai toka- 'weben,' tokuči 'Weber,' Teleut tok- 'weben,' Kirghiz, Tara toku- 'weben' (Moszyński, loc. cit., 125).

The two last examples (palska, tzkati) have an IE pedigree in Slavic (see Vasmer, III, 193, and IV, 64), and tzkati seems to represent a special technical semantic development from 'shove' $\rightarrow$ 'weave' in Slavic only; in view of this, the corresponding words in Turkic seem to be borrowings from Slavic.

The old lexical correspondences between Slavic and Altaic (mainly Turkic) quoted above seem to represent borrowings from Slavic to Altaic in all cases, not vice versa, perhaps with the exception of bykz $\sim b \bar{k} k a$, which may be an accidental independent coincidence in Slavic and Altaic. ${ }^{38}$ The semantics of these borrowings is quite characteristic: we have two (or one) terms belonging to cattle breeding (bykz, koza), two 
connected with agriculture (*tolkъno, *kopsn-), two belonging to weaving terminology (kqdělb, tzkati), two representing the names of tools ( ${ }^{*}$ moltz, palska), and three referring to nature, i.e., names of animals (kuna) and plants $(g q b a, o s a)$. In connection with the latter group I should observe that the word kuna 'marten' was borrowed by Turkic in its secondary, cultural meaning 'leather.' So most of the above borrowings clearly show the cultural contacts and exchange between the prehistorical Slavs and the Turkic peoples. The main question which arises in this context and which is relevant for Moszyński's hypothesis can thus be formulated as follows: when and where did the above borrowings from Slavic into Turkic take place?

Moszyński suggests quite an early period (Proto-Slavic), although he does not specify it exactly, and as the region where the Slavic-Turkic contacts took place he suggests Northern Asia (sic!), in his words: "The hypothesis forces one to the conclusion that Proto-Slavic still prevailed somewhere in Asia about the 7th-6th centuries B.C., neighboring on the west and perhaps on the north the language of the southern Ugrians, especially the ancestors of the contemporary Hungarians (....), on the east the language of the Turkic peoples, and on the south the dialects of the Scythians, who roamed the steppes of western Asia and Europe as nomads and who had direct contacts with the Ugro-Finns in Europe on the northern boundary of the steppes. The (later) shift of the Proto-Slavs would be in principle very similar to that of the Hungarians-Magyars" (Moszyński, loc. cit., 136).

This hypothesis in such a radical form as above was later abandoned by Moszyński himself because of the lack of sufficient linguistic and prehistorical justification (in his book Pierwotny zasiag jezzka prasłowiańskiego, 1957, he locates the Proto-Slavs in the Middle Dniepr basin about the birth of Christ!), but I think that the very idea that old, i.e., prehistorical ethno-linguistic contacts and exchange between the Slavs and the Turkic peoples must have taken place somewhere far to the East, in sub-Uralian regions, is not necessary to account for the above interesting Slavic-Turkic lexical correspondences. First of all, from a purely linguistic standpoint, for such remote prehistorical contact we would have to compare early PSl. forms with corresponding reconstructed Proto-Turkic forms. Inasmuch as this involves a very controversial stage of the historical-comparative Altaic linguistics, such a comparison would be impossible today. On the Slavic side, of course, we are able to operate with quite well reconstructed early PSl. forms, for example, Late PSl. bykz $\leq$ Early PSl. *bükos, etc. Then, the well-known and accepted fact of the close common prehistorical Balto-Slavic development (at least until the beginning of the first millennium B.C.) 
and the old ties of the PSI. lexicon with the West IE languages (especially technical terminology!) preclude locating the oldest habitat of the Proto-Slavs east of the Volga River. To be sure, Moszyński is manifestly aware of all these objections in his later publications. So in order to explain the prehistorical Slavic-Turkic lexical correspondences, which in most cases seem to represent Slavic borrowings in Turkic, we can (and this is perfectly sufficient) operate with the hypothesis that the Slavic loanwords spread into Turkic relatively late.

Here we should emphasize one socio-historical fact: nomadic peoples, particularly such a restless and active element as the Asian horsemen, have been known in history to be very mobile and able to cover vast (steppe) distances in a short period of time, moving back and forth. ${ }^{39} \mathrm{We}$ know this about the Hunns, Avars, Bulgars, etc. Therefore it seems quite understandable that some culture words borrowed, e.g., by the Hunns, Avars, or Bulgars from the early historical Slavs in the Dniepr basin (from the Antes) or in the Dunaj basin (from the Sclavini) could have migrated back to the east to other Turkic peoples in connection with the "back" movements of these Altaic tribes. I think that this circumstance explains satisfactorily the appearance of old, linguistically prehistorical Slavic loanwords in the Turkic languages. Therefore we can draw no conclusions concerning the primary habitat of the Slavs from the above linguistic facts. 


\section{Chapter VII}

\section{Conclusions}

Now let us attempt to formulate concisely the essential conclusions which will answer the questions raised at the beginning of this book: when, where, and how did the Slavs come into existence as a separate ethno-linguistic entity?

The first question can be answered only approximately in connection with the position of Slavic within the gradually disintegrating IE linguistic community. In this respect everything seems to indicate that after the final dissolution of the PIE linguistic comunity, which took place most probably between 3000-2500 B.C., and after a transitional period of Balto-Slavic "community," the linguistic ancestors of the Slavs got separated from the Balts and became an autonomous ethno-linguistic entity sometime about or just after the year 1000 B.C. Therefore after that time we are entitled to speak of Proto-Slavs. The linguistic ancestors of these Proto-Slavs should be referred to as "Pre-Slavs," either as a subgroup within the Balto-Slavic community or earlier as a subgroup within the North European dialectal zone of late Proto-Indo-European. The oldest historical references about the Proto-Slavs thus defined are undoubtedly found in the work by Herodotus (fifth century B.C.) under the ethnica Neupoi ( $\left.{ }^{*} N e r v i\right)$ and Bousivou (*Bydb). These two tribes, the northern neighbors and allies of the Pontic Scythians, must have been well established in their respective regions in the sixth century B.C., which means that their sojourn there was not of a recent date.

The second question has been answered by combining linguistics and geography. As the starting point from which the Pre-Slavs began to move gradually southwest (along the parkland belt), the Upper Don basin is posited. This movement, which must have started about 2500 B.C., brought the Pre-Slavs (all that time in close relations with their more northern neighbors, the Pre-Balts) across the Middle Dniepr (the primary Slavic name of the river is Dunaj!) to the Kiev and Volynia regions, where they ultimately loosened their contacts with the Pre-Balts, becoming in this way a separate Proto-Slavic ethno-linguistic community. So the 
Middle Dniepr basin and the regions south of Kiev and west of Kiev (Volynia) appear to be the crystallization center of the Proto-Slavs. It is significant that the first two Proto-Slavic tribes attested historically, Neupoi and Bousivoo, are, roughly speaking, located by Herodotus in the regions which seem to represent the prehistorical migratory zone of the Pre-Slavs, namely: the Bovoivou between the Upper Donec and the Desna river, the Neupoi in Volynia and the region south of Kiev on the west bank of the Dniepr. This location of the two tribes seems to indicate that in spite of the basic shift of the main bulk of the Pre-Slavs, represented by the Nevpoi, from the Upper Don basin southwest to the Middle Dniepr basin, and particularly to Volynia, a significant portion of the Pre-Slavic population remained east of the Dniepr river and, maintaining close contacts with their western relatives, was involved in the process of the Proto-Slavic ethnogenesis.

But the Proto-Slavs began quite early to expand further westward. The close etymological ties between the Middle Dniepr basin and the Vistula basin hydronyms and the fact that the hydronym Vistula (*Vistla), undoubtedly of Slavic origin, is well established by about the birth of Christ prove quite convincingly that the expansion of the Proto-Slavs westward started much earlier, at least several centuries B.C. It is probable that its beginning could be related with the invasion of the Pontic area by the Scythians (approx. 700 B.C.), who simply blocked the southeastern direction for the Proto-Slavic expansion.

The western expansion of the Proto-Slavs from Volynia across the Bug river to the Vistula basin and further on, as the geography of the trees with original Slavic and borrowed (chiefly Germanic) names indicates, spread first in the central part of this basin (the sub-Carpathian and sub-Baltic zones were primarily omitted). It was carried by the Veneti, originally a social term in Proto-Slavic meaning 'warrior-class,' then secondarily extended by the Teutons to all the Slavs expanding westward. In this way the social term became an ethnicon, but as such it has a clear exogenous character, i.e., it is used about the Slavs only by foreigners. So ultimately by the birth of Christ the Proto-Slavs seem to have occupied quite a long belt of parklands running from the Upper Don basin (?) through the Middle Dniepr basin to the Vistula and Upper and Middle Odra basins, reaching the Baltic coast along the Vistula river in the north. That extended belt of the gradual prehistorical Slavic expansion can be segmented into three chronologically successive parts: the Upper Don basin as the base from which the Pre-Slavs began to spread, the Middle Dniepr basin (Kiev-Volynia) as the nucleus where the Proto-Slavic ethnos crystallized, and the Vistula-Odra basins representing the zone of pre-historical expansion and colonization by the Proto-Slavs. Whether all 
these regions belonged to the Proto-Slavic habitat simultaneously about the time of the birth of Christ, especially the eastern base, is questionable. However, the ethnica Bousivou (PSl. *Bydb), Nevpoi (PSl. *Nervi), and Veneti (PSl. *Venete?) and their location seem to reflect quite clearly the prehistorical process of the Pre-Slavic and Proto-Slavic expansion presented above. In this connection the readers should be reminded that the oldest Proto-Slavic endogenous ethnicon used from time immemorial for the self-identification of the Slavs, Slověne ( $\leq$ *Sloběne // *Svoběne) is attested by Ptolemy (second century A.D.) in two places: east of the Volga (sic!), but on the latitude of the Upper Don (cf. the location of the Bousivou), and south of the Prypeć, i.e., roughly speaking, where the Nevpoi dwelt. This fact cannot be neglected.

Let us now pass to the last question, concerning the causes, particularly the socio-linguistic processes, which brought about the formation of the Slavs. In this respect one can suggest the following conditions that seem to have determined a gradual separation of the Pre-Slavs from other IE groups and their final transformation into a separate ethnos with a separate language, social organization, culture, and, which is indispensable in such cases, a separate self-identity (the latter usually expressed in a general endogenous ethnicon, in our case in the ethnicon *Svoběne // *Sloběne $\geq$ Slověne). These conditions are:

First, the gradual territorial spread of the Pre-Slavs along the parkland belt in a southwestern direction, which enabled them to develop a basically agricultural way of life, in contradistinction to their more northern neighbors and relatives, the Pre-Balts, who were expanding westward in a forest zone: among the latter cattle-breeding seems to have played a more important role. The difference in economy is quite obviously reflected in the respective vocabularies, characterized by the virtual lack of common Balto-Slavic innovations in agricultural terminology.

Second, contacts and cultural-linguistic exchange with other IE groups, which had started in the late PIE period and developed successively. Here one should make some important distinctions: on the one hand, the early contacts with the speakers of various late PIE dialects (3000-2500 B.C.) are to be taken into account; on the other hand, the later contacts with separate IE peoples speaking already separate languages. It is also important to distinguish the contacts taking place between the neighbors (i.e., between coterminous groups) and those between the older conquered and the younger conquering groups, i.e. between the ethnic substratum and the ethnic superstratum. As far as the first type of contacts is concerned, those within the late PIE dialectal zone, there is no question about some ties of the Pre-Slavs and the 
Pre-Aryans, which tended to orient the linguistic ancestors of the Slavs more toward their southeastern neighbors than toward their northwestern neighbors, the Pre-Balts and the Pre-Teutons. This orientation is reflected in the old lexical ties between Proto-Slavic and Aryan, especially Iranian, that cannot be treated as later loanwords. The ties with the Pre-Aryans were then loosened and the ties with the Pre-Balts strengthened (the period of Balto-Slavic lexical innovations), but the geographical orientation of the linguistic ancestors of the Slavs towards the forest-steppe boundary brought them again into closer relations with the Iranian branch of the Aryans roaming the Pontic steppes. This happened, however, at the time when the Pre-Slavs were already linguistically crystallized into the Proto-Slavs, speaking a separate language; the same can be said about the Northern Iranians (the Scythians). It is highly probable, and this is my hypothesis, that the decisive factor in the transformation of the Pre-Slavs into the Proto-Slavs and in their ultimate split from the Pre-Balts (the termination of the so-called Balto-Slavic ethno-linguistic unity) was an additional IE substratum which the linguistic ancestors of the Slavs had encountered and absorbed in the Middle Dniepr area, the center of their crystallization as Proto-Slavs. In this way the basic difference between the Slavs and the Balts in terms of the historical differentiation of the IE languages would lie in that the former had absorbed an additional IE substratum (or substrata) which on the one hand complicated the IE elements in their grammar and lexicon and on the other hand contributed to a relatively more innovative character of Proto-Slavic; the latter (the Balts), on the contrary, free from any additional IE substratum, have preserved a relatively more conservative character of their language. These distinctions can be observed first of all in the conjugations of the respective languages. In this connection some interesting correspondences between Slavic and Armenian should be emphasized, which suggest a possible IE substratum absorbed by the Pre-Slavs in the Ukraine and perhaps representing Pre-Armenian. But the most probable IE substratum absorbed by the linguistic ancestors of the Slavs and then by the Proto-Slavs themselves is a kentum substratum. The analysis of the kentum elements in Balto-Slavic reveals that many of them (e.g., cattle-breeding terms) go back to a remote epoch of late PIE dialects. But others are undoubtedly younger. In this context, by kentum elements I understand not only the PIE words with the kentum treatment in Slavic (i.e., ${ }^{*} \mathrm{k},{ }^{*} \mathrm{~g}(\mathrm{~h}) \geq{ }^{*} \mathrm{k}$, ${ }^{*} \mathrm{~g}$, etc.), but also the old IE lexical elements common to Proto-Slavic and North-West Indo-European, especially Italo-Celtic. A characteristic phenomenon in this respect is the exclusion of Baltic from these correspondences. As Trubačev has convincingly 
pointed out, we are dealing here with the linguistic (lexical) reflection of a kind of prehistorical Central European cultural-linguistic area, which at least partly encompassed some PSI. tribes (undoubtedly the western ones, the Veneti). This area covered today's Poland, and its IE (kentum) population (maybe identical with the tribes of the so-called Lusatian culture, $1300-600$ B.C.) was gradually ousted or absorbed by the Proto-Slavs (the Veneti) expanding from the east. Thus the lexical elements with obvious West IE correspondences and with kentum treatment penetrated Proto-Slavic, strengthening its distinction from Baltic. It is characteristic that these western elements belong mainly to technical terminology (pottery, primitive metallurgy, etc.).

So in the gradual formation of the Proto-Slavs as a separate ethno-linguistic entity, i.e., detached from the Balts, the decisive role should be assigned on the one hand to the contacts with the Pre-Aryans and the Iranians and on the other to the absorption of additional IE substrata, the Pre-Armenian (?) substratum and a West IE (kentum) substratum, the former undoubtedly older (somewhere in the Ukraine), the latter younger (somewhere in today's Poland). Of course, later contacts and lexical exchange between the prehistorical Slavs on the one side, and the Pontic Iranians, the Teutons, and even some Altaic peoples on the other, affected an already clearly individuated Slavic community speaking the separate Proto-Slavic language and representing a separate socio-cultural entity.

The above synthesis is based first of all upon linguistic, then upon geographic and some historical evidence. Archaeology has deliberately been omitted in this presentation. It is the task of the representatives of this latter discipline to compare the above synthesis with the achievements of their own investigations and to accept or reject the results of this synthesis, depending on whether they harmonize or not with the archaeological synthesis about the origins of the Slavs. I am, however, deeply convinced that the decisive vote here belongs to linguistics. 


\section{Notes}

\section{Chapter I}

${ }^{1}$ E.g., the Vallon-Flemish ethnic conflict in Belgium, the Breton nationalism in France, Welsh and Scottish nationalisms in Great Britian, the Basque nationalism in Spain, and last but not least the ethnic movements in the U.S.A.

${ }^{2}$ Of course, unless we apply "genetic engineering" and eugenic practices, phenomena which until recently have been irrelevant in human history.

${ }^{3}$ Including an insignificant percentage of such national minorities as White Ruthenians, Ukrainians, Lithuanians, and some Germans.

${ }^{4}$ Including an insignificant percentage of the Gagauz-Turkish national minority.

${ }^{5}$ Of course, this process affected the upper classes, i.e., the relatively numerous rural gentry and burghers, whereas the peasants remained White Ruthenian or Lithuanian (the latter in the west).

\section{Chapter II}

${ }^{1}$ I mark here only $o$, since it seems to be highly probable that first $e \geq$ $o$ under the influence of the adjacent $H_{24}$, and then after the fall of these $H_{24}$ that secondary $o$ passed into $a$ in South European (cf. J. Kuryłowicz, 1956).

${ }^{2}$ The corresponding Slav. forms are, e.g., OCS bratra, $\emptyset$, sažda.

${ }^{3}$ This innovation seems to be the most controversial one.

${ }^{4}$ In these examples Lith. and PSI. stands for old long falling pitch ("old circumflex"), Lith. and PSl. ' - for old long rising pitch ("old acute").

${ }^{5}$ But in $1978 \mathrm{~W}$. Winter proposed another interpretation of the B-S lengthening of vowels before PIE plain voiced stops $/ b, d, g^{\prime}, g /$ : according to him this was a regular phonemic change/Lautgesetz/. In this connection see W. Winter "The Distribution of Short and Long Vowels in Stems of the Type Lith. ěsti : vàsti : màsti and OCS jasti : vesti : mesti in Baltic and Slavic Languages" in: Recent Developments in Historical Phonology, ed. J. Fisiak, Mouton, 1978, p. 431-46, and H. Birnbaum 
"Winter's Law and the Issue of Balto-Slavic" in: Studia Linguistica Diachronica et Synchronica Werner Winter Sexagerario Anno MCMLXXXIII, eds. Pieper/Stickel, Mouton de Gruyter 1985, p. 41-54.

${ }^{6}$ The phonetic development of this form is not clear; see Stang, 1966:269.

${ }^{7}$ About Baltic-Finnic contacts see P. Hajdu, 1975:72-74; their most intensive period was between 500 B.C. and the birth of Christ.

${ }^{8}$ Literally (in reversed order): 'formation of words of the language of the Lithuanians.'

${ }^{9} \mathrm{Cf}$. also P. Scardigli and T. Gervasi: Avviamento all' etimologia inglese $e$ tedesca, Florence, 1978, p. 15; and E. Schwarz: Germanische Stammeskunde, Heidelberg, 1956, pp. 19-24.

${ }^{10}$ Because of the perfective aspect it was rather an aorist in PIE; thus the example is not instructive. Meillet should have quoted instead forms like veds, etc. (vede in Supr. 435, 22; cf. Dostál, 1954:124).

${ }^{11}$ The starting point seems to have been the 3rd sg.: after the fall of word-final consonants $(t)$ bbra + jaše; then the pattern extended to other persons. Compare the new Polish present of być: jest, jest-eś, jest-em, etc. For the iterative type proposed here, cf. Russ. xodil byvalo, etc.

${ }^{12}$ The latter only in the East of the prehistorical Slavic territory.

${ }^{13}$ For details see Chapter VI.

\section{Chapter III}

${ }^{1}$ Trubačev (1967:76) proposes an Iranian etymology of Av. kä日a'revenge' ("vozmezdie na strašnom sude").

${ }^{2}$ The kentum elements of this stratum are in most cases indistinguishable from the so-called Italic elements, about which see below. The only proof of the latter is the exclusive Slavic-Latin correspondence, e.g. golobb columbus, goser $\sim$ (h)anser, perhaps kostro castrum.

${ }^{3}$ Where $V=$ any vowel, $R=$ any sonorant, $H=$ any laryngeal, $C=$ any consonant.

${ }^{4}$ According to M. Gimbutas (1971:21) the so-called "North Carpathian culture."

${ }^{5}$ Here we can quote W. Porzig (1954:168-69): Arisch, Baltisch, und Slavisch, "Die Übereinstimmungen zwischen dem Gesamtarischen und dem Baltischen unter Ausschluß des Slavischen haben alle den Charakter von Altertümlichkeiten im Randgebieten.” (168)

"Aus den vorstehenden Untersuchungen ergibt es sich, daß die Beziehungen des Arischen zum Baltischen und Slavischen fast immer beide Sprachen zugleich umfassen. Diese müssen also damals, in der 
ersten Hälfte des zweiten Jahrtausends, eng verbunden gewesen sein. Erst viel später, nach Herstellung unmittelbarer Nachbarschaft von Slaven und Iraniern im südlichen Rußland, hat sich zwischen diesen Sprachen ein Austausch entwickelt, an dem das Indische und das Baltische nicht beteiligt waren." (169)

${ }^{6}$ According to Kuryłowicz's reconstruction of the PIE gutturals, *-loiko-.

${ }^{7}$ The difference between the Lith. and Slav. intonations, namely Slav. mésto (old acute) would indicate that the Slav. noun should be interpreted as an old vrddhi-adjective from *moisto, i.e., *mōisto 'which belongs to a dwelling.'

${ }^{8}$ But the alleged Iranian origin of these hydronyms is sharply criticized by P. Arumaa in Baltes et Iraniens, Studi Linguistici in onore di Vittore Pisani, vol. I, Brescia, 1969:73-90.

9'A sacrificial cake cut by a sacrificial knife.'

${ }^{10}$ More probable is the competition between the following pairs: desnz : šujb 'right' : 'left,' and pravъ : krivъ 'straight' : 'crooked,' whereas lěvъ 'left' entered into play later.

${ }^{11}$ Not mentioned by Trautmann, but Fraenkel (I, 194-95) treats it as a Slav. loanword.

${ }^{12}$ But see my interpretation under kentum elements in Slavic.

${ }^{13}$ This is, of course, highly controversial.

${ }^{14} \mathrm{~W}$. Porzig $(1954: 140,143,147)$ presents the problem in the following way:

"Zu Beginn der geschichtlichen Zeit, um die Mitte des ersten vorchristlichen Jarhtausends, war das Germanische vom Baltischen und Slavischen durch das illyrische Sprachgebiet getrennt. Ob diese Trennung von jeher bestand, oder ob sie erst durch geschichtliche Ereignisse eingetreten ist, muß die Prüfung der ausschließlichen Beziehungen des Germanischen zum Baltischen und zum Slavischen ergeben. Entscheidend werden dabei die Fälle sein, in denen das Illyrische positiv abweicht." (140)

"Die gemeinsamen Neuerungen des Germanischen, Baltischen und Slavischen bezeugen eine langandauernde Nachbarschaft von uridg. Zeit (vgl. das Wort für 'Mühle') bis zur frühen Eisenzeit ('Roggen'). Das Illyrische weicht bei den Kasusendungen mit $m$ ab, teilt aber das Wort für 'Gold.' In den übrigen Fällen fehlt uns sein Zeugnis. Daß Germanisch, Baltisch, und Slavisch auch in frühgeschichtlicher Zeit noch im selben Raume zu Hause waren, zeigt der fremde Name für 'Silber,' den alle drei Sprachen aus derselben Quelle, aber jede für sich entlehnt haben: got. silubr an. silfr ahd. silbar lit. sidäbras russ. serebró. Soweit wir wissen, hatte das Illyrische einen anderen Namen dafür (...) Die Beziehungen der drei 
Sprachen haben also wenigstens zum Teil unabhängig vom Illyrischen bestanden. Eine gemeinsame höhere Entwicklung der Wirtschaft läßt sich aus ihnen erkennen." (143)

"Die Beziehungen des Germanischen zum baltisch-slavischen Raum bewegen sich im allgemeinen auf dem Gebiete der natürlichen Umwelt und einfachster Wirtschaftsformen. Nur die gemeinsamen Wörter für 'Gold' 'tausend' und 'herrschen' bekunden eine höhere Entwicklung des wirtschaflichen und staatlichen Lebens... Das Germanische hat engere Beziehungen zum Baltischen und Slavischen als zu irgendeiner andern Sprache außerhalb der Westgruppe. Nur dem Lateinischen steht es offensichtlich näher. Es unterscheidet sich demnach von den anderen Angehörigen der Westgruppe, die alle nur geringe spezielle Beziehungen zu östlichen Sprachen haben.” (147)

${ }^{15}$ Slav. and Germc. vocalisms of the first syllable are reduced, the Baltic vocalism is full: *km- : *kom-.

${ }^{16}$ Isn't it rather a Slav. loanword in Baltic and Germanic?; see Moszyński 1957:122ff., and Trautmann 289, who does not quote Balt. correspondences.

${ }^{17}$ For the development of the meaning 'lure, call' $\rightarrow$ 'summon (to court)' $\rightarrow *$ *'persecute, etc.,' cf. Latv. (from Slavic) vābiti and Lith. (from Slavic) võbyti 'vor Gericht fordern' (Pokorny 1109).

${ }^{18}$ Particularly those which also show traces in Celtic languages, cf., e.g., Pokorny's material corresponding to Slav. *svbrběti (Pokorny 1050), etc.

${ }^{19}$ See S. B. Bernštejn in Slavjanskaja Filologija I (1958), 45-67.

${ }^{20}$ See V. V. Ivanov and V. N. Toporov in Issledovanija po slavjanskomu jazykoznaniju, 1961:273-305.

${ }^{21}$ Jan Rozwadowski in his inspiring article published in Rocznik Slawistyczny, V (1912) under the title "O pierwotnym stosunku wzajemnym języków battyckich $i$ słowiańskich" ("About the primary mutual relation between the Baltic and Slavic languages"), called attention to "paradoxical differences in the vocabulary with simultaneous great similarities" between Baltic and Slavic, and wrote the following: "It is really a striking phenomenon. On the one side there is a long series of words characteristic exclusively of the Baltic and Slavic languages, identical in their form and meaning, and these are not only concrete substantives (Endzelin has recently composed a list of them). On the other side there is also an equally long, or even longer series of words that are completely different, and these are not words for more or less vague psychological or abstract concepts but for concepts from various everyday fields, concrete and clearly determined. I am quoting a list prepared ad hoc" (loc. cit. 106).

From Rozwadowski's list I will quote only the names of plants and 
phenomena related to them: mẽdis : *dervo, lěsъ ('tree'), málka : drъva ('wood' as material), glúoksnis : *vbrba ('willow'), javaĩ : žito ('grain' as cereals), miežeĩ : jęčımy ('barley'), kviečei : pbšenica ('wheat'), ãžuolas : dobъ ('oak'), apyniai : x(ъ)meljb ('hops'), várpa : *kolsъ ('ear of grain'), laükas : polje ('field'), dirvà : njiva ('arable, cultivated field'), píeva : loka ('meadow'), ežẽ : mežda ('(field) boundary'), šaknis : korenb ('root'), šiáudas : stbblo ('stalk')."

These are undoubtedly striking differences, as are, on the other hand, equally striking such identities as rankà 'hand,' galvà 'head,' šeimà 'family' roka, *golva, sěmbja, etc. (see the list compiled by F. Sławski in Donum Balticum, 1970:501-05).

${ }^{22}$ Lith. vẽlès, vẽlès 'geisterhafte Gestalten der Verstorbenen,' sing. vèlẽ, velẽ 'Seele (des Verstorbenen), Geist,' vẽlinas 'Teufel,' abbrev. velnas, vélnias, etc.' Latv. velis, plur. veḷi 'Geister der Verstorbenen,' vel̃ns 'Teufel.' It is compared with OIc. valr 'Toter auf dem Schlachtfeld,' OSax., OHG wal, NHG Walküre, Toch. A. wäl 'sterben,' past part. walu 'tot'; Slav. Veles, a prehistorical deity, according to Vasmer, does not belong here (see Fraenkel II, 1218-19). The semantic development 'ghost of a dead person' $\rightarrow$ 'devil' is similar to that of Ukr. didko (from *děd-ъko).

${ }^{23}$ For the details of this etymology see Z. Gołąb in Prace Językoznawcze III, Wyższa Szkoła Pedagogiczna, Cracow, 1976:21-26.

${ }^{24}$ But cf. also Martynov's etymology in the Italic-Slavic correspondences discussed above.

${ }^{25}$ Incidentally, the same change took place in Gothic, where 'father' is usually rendered by atta.

${ }^{26}$ And some obvious Iranian loanwords in Proto-Slavic, which, however, do not belong to our topic.

${ }^{27}$ See J. Safarewicz in Prace Językoznawcze III, Wyższa Szkoła Pedagogiczna, Cracow 1976:55-65.

${ }^{28}$ It does not mean, however, that some innovations could not originate earlier.

${ }^{29}$ Here we can use the terms Pre-Teutons, Pre-Balts, and Pre-Slavs.

30" According to Stenberger there are many reasons for believing that the original region [of the "battle-axe culture," i.e. IE - ZG] may have been situated in southern Russia, perhaps around the lower course of the Dniepr or even further to the east, in central Asia. As to the Swedish branch of the battle-axe culture, Stenberger adheres to the immigration theory: the seemingly sudden appearance of the new cultural group in the southern Scandinavian stone age environment must be regarded as an immigration of alien groups of people during the early mid-neolithic period. Stenberger is of the opinion that the course of the immigration 
was solely via the Aland Islands from the interior of Russia via the Baltic and southern Finland. On their wanderings to the north and west from the interior of Russia certain tribes reached the southern coast of the Gulf of Finland, where it is possible that they met other related people coming directly from the south. They crossed to the southern coast of Finland, continued to the west, went across the islands between Finland and Sweden, after which they spread rapidly across central and southern Sweden. Here they came into contact with the pit-ware people and later with the scattered megalithic peasants in the west." Quoted after Uesson, Ants-Michael: On linguistic affinity. The Indo-Uralic Problem, Förlags Ab Eesti Post, Malmö, 1970, p. 68; see also Stenberger, M.: Det forntida Sverige (Pre-historic Sweden), 1964.

${ }^{31}$ For these see J. Rozwadowski, 1948:176-82.

${ }^{32}$ See the etymology of this toponym in Chapter V.

\section{Chapter IV}

${ }^{1}$ The reconstructed forms are from Pokorny's dictionary (1959).

${ }^{2}$ The stem is heteroclitic; *ak'-men/mer-.

${ }^{3}$ See Vasmer, III, 697.

${ }^{4}$ See Antiquitates Indogermanicae, 1974, 113-31.

${ }^{5}$ But Pokorny (loc. cit.) quotes OI *sira- n. 'Saatpflug,' sitā 'Furche' (*die Besäte), undoubtedly after M. Mayrhofer's etymological dictionary of Sanskrit (1953 etc.). This etymology, however, seems to be highly improbable because of the innovative or foreign character of $\mathrm{OI}$ agricultural terminology (for this see C. Masica, 1977).

${ }^{6} \mathrm{However}$, the meanings given in the dictionary by Monier-Williams are 'crush, smash, slay, kill, break, destroy; thread, winnow,' i.e., there is no reference to grinding corn.

${ }^{7}$ But Pokorny reconstructs *euk- (Pok. 347).

${ }^{8}$ For the phonemic treatment see W. Merlingen I (1967), 47.

${ }^{9}$ The results of an extensive study by Hančar deserve the attention of those Indo-Europeanists who seem to romanticize the life of the prehistorical Indo-Europeans, ascribing to them, among other things, not only acquaintance with the horse, but also the extensive use of this animal for draft and riding. However, not only is there no linguistic ground for such a picture, but the archaelogical and paleoontological evidence proves quite clealy that the horse was domesticated relatively late and was primarily used as a draft animal.

A transparent chart on page 547 of Hančar's book shows that the domestication of the horse began after the year 3000 B.C. for nutrition ("Pferd als Fleischtier"), and only after the yea 2000 B.C. does the horse 
appear as a draft animal at chariots ("Pferd im Paargespann an der Jochdeichsel des Streitwagens"). For an excellent summary, see Hančar, loc. cit., 552-53.

${ }^{10} \mathrm{~W}$. Krogmann in Das Buchenargument (Zeitschrift für vergleichende Sprachforschung auf dem Gebiete der indogermanischen Sprachen, v. 72 (1955):1-29, v. 73 (1956):1-25), after analyzing the entire available material, posits *bhāug'os, which allows him to include here Slav. *buzz, *bzzz, etc., and derives it from the PIE root *bha- (according to Pokorny, 104: *bhä-, bhō-, bhə-) 'glänzen, leuchten, scheinen,' extended by $u$ : *bhä-u- (for the latter cf. OI vi-bhấva-h, vi-bhấvan- 'strahlend, scheinend,' Gr. Homeric $\phi \alpha ́ \epsilon \epsilon\left({ }^{*} \phi \alpha \digamma \epsilon \epsilon\right)$ 'glänzte, erschien,' etc., Pokorny, loc. cit.). So the etymological meaning of *bhāug'os, etc., accordign to Krogmann would be a tree with 'silberglänzende glatte Rinde,' which actually fits the characteristic feature of the beech-tree in comparison with other species. But Krogmann's etymology, based on the hypothetical and highly controversial *bhāug'os is too much a Wurzeletymologie to be convincing.

${ }^{11}$ We can also add a statement by W. Krogmann (Das Lachsargument, $K Z$ (1960)): "The most important fact emerging at once is that the salmo salar is not the only real salmon. There are other species than those which frequent the rivers emptying into the North Sea and the Baltic, and in particular, there is the salmon trutta caspius, the salmon of the Caucasus region, especially of the rivers which empty into the Caspian Sea from the west and northwest. Likewise a variant of salmo salar, the salmo salar brevipes, is to be found in the White Sea and its tributaries." (quoted after G. Lane, "Tocharian: Indo-European and Non-IndoEuropean Relationships" in Indo-European and Indo-Europeans, 1970, p. 83).

${ }^{12}$ For the discussion of this problem see K. Moszyński, Człowiek (1958), 806-07.

${ }^{13}$ Against Lehr-Spławiński, 1946:75.

${ }^{14} \mathrm{See}$, however, the criticism by P. Arumaa quoted in the next chapter.

${ }^{15}$ Compare the hypothetical route of the Pre-Slavs from the east suggested in the preceding chapter.

${ }^{16}$ It is also supported by the preservation of the main bulk of the PIE tree names just in this branch of Indo-European (see P. Friedrich's synthesis).

${ }^{17}$ See also M. Rudnicki, Prasłowiańszczyzna..., I, 173.

${ }^{18}$ The vestiges of this root may be preserved in Pol. dać drała 'run away,' drałować 'run' (from *dbra-lb), see Brückner, 1927:95, 100.

${ }^{19}$ See P. Hajdu, 1975:36.

${ }^{20}$ Because of the consonant $\mathrm{j}$ in FU instead of $k$, cf. luke- under 9, it is rather an IE borrowing from a satem dialect. 
${ }^{21}$ Or rather *g'hrdho-, supported by Aryan, e.g., OI grhá- 'Haus': then PIE or Aryan * $r$ would be treated in Uralic as ${ }^{*} e r$; in this connection cf. *mertä in Volga Finnic, e.g., Votyak murt, mort 'Mensch; Mann; Fremdling,' an obvious loanword from Iran, *mrta- 'mortalis,' etc. (see Joki, 281).

${ }^{22}$ One item is repeated twice!

${ }^{23}$ But see A. Tovar, 1970:267-78. The author quotes some possible IE loanwords in Basque, e.g., (b)urki 'birch,' (h)artz 'bear,' etc.; also the suffix -ko- (pp. 269-70). But most interesting is the possible Basque origin of the names for 'silver' in North Indo-European and 'lead' in Italic-Celtic-Germanic-Greek (for the latter cf. Lat. plumbum and Gr.

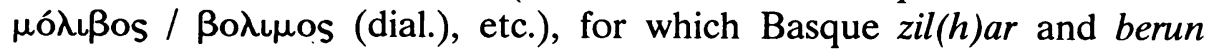
(*plun) are quoted as sources. In any case, these borrowings are not earlier than the late 2 nd millennium B.C.

\section{Chapter V}

${ }^{1}$ More or less the same region, including the eastern part of the middle Dniepr basin (i.e., Volynia and the Kievan district) is accepted by K. Moszyński as the core of the Proto-Slavic habitat about the time of the birth of Christ. It is worth emphasizing that $\mathrm{K}$. Moszyński reached his conclusion on the basis of purely linguistic evidence: old Slavic-Aryan lexical correspondences; old, though highly controversial, Slavic-Turkic correspondences, pointing to prehistorical Slavic loanwords in Turkic langages; tree names, among which there is a characteristic lack of original Slavic names for trees unknown in the Dniepr basin (the central problem here is the name of the beech-tree, 'Fagus silvatica,' about which see below!); and hydronyms of the middle Dniepr basin. For details see the corresponding chapters of K. Moszyński's book: Pierwotny zasiag języka prastowiańskiego (1957) and especially chapter XVII, entitled: “Czy $i$ skąd mógt się przesunqć język protostowiański $w$ zachodnio-środkowe dorzecze Dniepru" ("Whether and whence the Pre-Slavic language could move into the western and central Dniepr basin"), pp. 207-32.

${ }^{2}$ As an additional argument supporting the above etymology one can quote the old tradition transmitted by al-Masudi, an Arab traveller and geographer of the tenth century, which reads: "The Slavs form many 'nations.' And among them there is one with whom from the beginning there was power: its king bore the name Magak. This nation is called Walinjana, and the remaining Slavic tribes used to subordinate themselves to it because it had power and other kings succumbed to it." Most scholars identify the ethnicon Walinjana with the later Volynjane of 
Povest' vremennyx let, although there are some objections to this. For a detailed discussion of the problem see G. Labuda "Okres 'wspólnoty' stowiańskiej $w$ świetle źródet i tradycji historycznej" in Slavia Antiqua 1 (1948), pp. 181-227, and K. Moszyński: "Przyczynek do tzw. etnogenezy Stowian" also in Slavia Antiqua, VIII (1961), pp. 25-35. In any case, whether or not we agree with the identification of al-Masudi's Walinjana with Volynjane, the important role of Volynia in the prehistory of the Slavs seems to be highly probable.

${ }^{3}$ It is significant that in western Volynia we have a concentration of old Slavic hydronyms (see below!).

${ }^{4} \mathrm{~K}$. Moszyński, Kultura Ludowa Stowian, II, 2, 852, has Hreza (sic!).

${ }^{5}$ This general statement should, however, be attenuated after the publication of the book by J. Udolph, Studien $z u$ slavischen Gewässernamen und Gewässerbezeichnungen. Ein Beitrag zur Frage nach der Urheimat der Slaven (Heidelberg 1979). As the author of this extensive linguistic study convincingly proves, most of the hydro- and toponyms considered "Illyrian" and "Thracian" by Trubačev, do not qualify as such: they have well-substantiated Slavic etymologies, e.g., Duklja (a well-known central Carpathian pass, etc.), Sambor (a town), Strypa (a river), etc. (see pp. 600-18). The results of J. Udolph's research, in his own words, can be formulated as follows:

"Eine detaillierte Untersuchung der unter Umständen vorslavischen Namen Galiziens hat meines Erachtens gezeigt, daß die weitaus meisten Namen eher dem Slavischen zuzurechnen sind. Daneben sind einige Reste alteuropäischer Namengebung zu Tage getreten...bei einigen Namen ist eine genauere Bestimmung (zur Zeit) nicht möglich. Eine spezielle Beziehung Galiziens zum Balkan konnte nicht bestätigt werden, wesentlich auffälliger sind dagagen die Verbindungen mit dem Baltischen..." (p. 618).

Similarly we can also quote a strong criticism by P. Arumaa of the Iranian etymologies of some Upper Dniepr basin hydronyms proposed by Toporov and Trubačev. Namely, in his essay Baltes et Iraniens, he writes:

"De la critique présentée ci-dessus ressort clairement que toutes les étymologies iraniennes proposées jusqa'à présent concernant les habitats septentrionaux des Iraniens reposent sur les bases très fragiles. Quand Toporov et Trubačev nous disent qu'ils ont constaté un nombre double des hydronymes iraniens sur le cours supérieur du Dniépr, en comparison avec les résultats antérieurs de Vasmer, an pourrait bien expliquer une telle prétention par le fait que les onomatologues russes ont été dans leur jugement moins circonspects que Vasmer. Même les étymologies conjecturales de Vasmer, bien que mieux fondées, sont difficiles à défendre." (p. 87) 
A good example of the vagueness and low probability of some of Toporov's and Trubačev's etymologies is the alleged Iranian origin of the hydronym Sejm (a big left tributary of the Lower Desna connecting the Middle Dniepr basin with the Don basin). In the book quoted (p. 226) the older forms Semb and Sermb f. (Povest'vremennyx let) are mentioned and the form Sejm is explained as due to a spelling mistake or to a secondary folk etymology. Then the authors write: "The hypothesis that ORuss. Sěmb goes back to Iranian, cf. Avestan syäma- and OI syäma'dark,' is not excluded. In that case it would be the same root as in the names Sev, Sava, but extended in another way." The suggestion of this Iranian etymology is also repeated in the Russian edition of Vasmer's etymological dictionary (III, 600).

However, this intuitive etymology, suggested by the concentration of Iranian hydronyms in the Sejm and Desna basins (loc. cit. 239) turns out to be illusory after closer linguistic scrutiny. Namely: from the Iran. syāma- (the form actually attested in Avesta is syāmaka- m. 'Name eines Bergs oder Gebirgs'; see Bartholomae, 1631) we could only have Slav. $*_{\text {šamo- since }} *_{s j} \geq \check{s}$ in Proto-Slavic. So I see no possibility of deriving Sěmb from Iran. syāma-, unless we start from a variant sāma- adj. 'schwarz' (Bartholomae, 1571), whose irregular relation to syäma-should itself be clarified. Note that the form of the IE root contained in the Aryan adjective syäma- is ${ }^{*} k^{\prime} i \bar{e}$ - (the extension of the root ${ }^{*} k^{\prime} e i$-; see Pokorny, 540-41), so there is no regular possibility for Avestan sāma-.

In view of the above I propose another etymology. I would derive Sermb from the IE verbal root *sem- 'schöpfen, gießen' (Pokorny, 901-2), attested in Gr. ' $\alpha \mu \alpha ́ \alpha \mu \alpha \iota$ 'sammle', OIr. sem- 'ausgießen': to-uks-sem 'zeugen, erzeugen' and first of all in Lith. semiù, sémti 'schöpfen.' Thus the common name *sěmb, underlying this hydronym, could represent the same type of deverbal noun as rěčb from reko, tvarb from tvoriti, etc., i.e. with the lengthening of the root-vowel and the stem-suffix $-i\left(*_{s e m i-s)}\right.$, whatever the intermediary stages of this formation. It is probable that it ultimately represents a Balto-Slavic transformation of a primary deverbal root-noun. Its meaning would be that of a nomen actionis, i.e. in our case 'drawing (water),' then that of nomen loci actionis, i.e. 'the place where water is drawn,' etc. Pokorny (loc. cit.) quotes an Illyrian hydronym Semnus (in Lucania) derived from the root under discussion. Whether there are other hydronyms representing this name on the Slavic territory remains an open question. Moszyński (1957:186-88) quotes Russ. Semka, Semica, Semec in the northeastern Dniepr region, Semi-ryczka (so in Stownik Geograficzny Królestwa Polskiego) in the Boh basin, Lake Siemien and a little river Siemota on the Polish ethnographic territory. Perhaps some hydronyms with the root-vocalism $o$ - (som-) belong here too. 
As far as the semantics of the name is concerned, I can quote some parallels proving that a river can be called after its pragmatic function in people's life, e.g.: Kolodez', eleven rivers of this name are distinguished only by different attributes, e.g., Dobryj Kolodez', Gniloj Kolodez', Germjačij Kolodez', etc. (see Toporov-Trubačev, loc. cit. 255), obviously derived from Russ. kolódec, kolódjaz' (PSl. *koldęzb) 'well' (see also J. Uldoph, 1979:405-10 with a map) or Supoj, a left tributary of the Middle Dniepr mentioned as early as the eleventh century, which undoubtedly represents a compound *sQ-pojb from the verb piti 'drink' and the adverb-preposition *som-/szm- 'together' (see Trubačev, 1968:195).

All of the above facts make the Slavic etymology of Sermb highly probable. The fact that the basic verb has been preserved in Lithuanian, but lost in Slavic, should not surprise us. This is quite a frequent phenomenon in these languages, due to the greater conservatism of Lithuanian. The possibility of a Slavic etymology of Sermb, the largest river constituting a natural water-way from the Upper Don basin to the Middle Dniepr basin, acquires additional significance in connection with my hypothesis about the primary migratory route of the Pre-Slavs from the east westward.

Ultimately, we can also quote critical remarks by A. Žučkevič, expressed in his review of Toporov and Trubačev's book (Sovetskaja Etnografija, 1968, I, 107-13). The main objection of the review is that the factographic material taken from the only source (Maštakov's well-known collection of hydronyms) has not been checked in the field ("na meste"). Then there are among allegedly Baltic names quite many of Slavic origin; e.g. fifteen such names are listed in footnote 5, p. 108. Žučkevič also states clearly, on the basis of his own research, that the southernmost boundary of compact Baltic hydronymy is represented by the line Pružany-Sluck-Rogačev-Kostjukoviči, i.e., it does not reach the Prypeć river. South of this line we have isolated Baltic hydro- and toponyms, e.g. Jasel'da, Motol' and Oresa.

All of the above objections should be taken into account in evaluating Toporov and Trubačev's book.

${ }^{6} \mathrm{~K}$. Moszyński in his Kultura ludowa Stowian (2nd ed., 1968, II, 851-52) gives the most exhaustive and condensed presentation of this phenomenon, which deserves quotation, namely: "And so supplementing to some extent the data of Rozwadowski with new details we find in Poland: Wista, Wistok, Wistoka (Długosz [the XV cent.-ZG] also knows a lake Wistka), Świślina, several Dunaj's, Dunajec, a marsh Dunajki, two Bug's, San, Sanna, Sanica and Sona (Sana with Sanica also occur in Croatia), and in the east [i.e., chiefly but not exclusively in the Dniepr basin-ZG] we find also Wisła, a marsh Wisło, Wiślica, Wisłów Rów, 
Wisłówka, Wisłocz (...), two Świstocz's, several Dunaj's, three Dunajec's, Dunajka, two Bužek's (and Dorohobuža), Sana, Sanica, Sonna and Soninka (...). This striking repetition of names involves in the east among others the Worsklica basin in the steppe region of North Ukraine; in this basin by a strange coincidence Wistok, Sanok and Dunajčyk flow in a very close vicinity."

${ }^{7}$ However, their concentration in Polesie is puzzling (see Rozwadowski, loc. cit., pp. 288-89).

${ }^{8}$ For the variation -tlo $\sim$-slo see F. Specht, 1947:348-39, and K. Brugmann, Grundriss, 2nd ed., II, 1, 242, etc.

9"With the term Venetic we denote here the names which occur in Slavic, Illyrian, and Celtic territories, i.e. everywhere we meet the ancient ethnicon Veneti." (loc. cit. 177, note 131).

${ }^{10}$ For a detailed etymology of these hydronyms see Lehr-Spławiński, loc. cit., 68-72, and Rozwadowski, loc. cit. under the appropriate entry.

${ }^{11}$ It is probable that this substratum was the Lugii, whom most scholars are inclined to assign to the Celts. They might have been the last remnant of a prehistorical West Indo-European people (Veneti), encountered and absorbed by the Slavs in the Upper Odra basin sometime about the birth of Christ (see the discussion of the Lugii by $\mathrm{H}$. Łowmiański, loc. cit., I, 191-96).

${ }^{12}$ See M. Rudnicki, "Cień urojonego narodu," in Slavia Occidentalis, 27 (1968).

${ }^{13}$ Lehr-Spławiński and Rudnicki quote Venet-orum, Venet-i from Tacitus, but M. Plezia in his translation has Wenedowie (sic!). For the discussion of the form used by Tacitus see: C. Taciti De origine et situ Germanorum, edited by J. G. C. Anderson, Oxford, 1938, p. 216.

${ }^{14}$ In the original there is Viscla, a Germanic form based upon Baltic *Visklä.

${ }^{15}$ Those *Uenotói might mean 'beloved, friends' or 'clansmen' according to an etymology by $\mathrm{H}$. Krahe, of course, derived from the same root.

${ }^{16}$ This is Stender Pedersen's hypothesis, but see V. Kiparsky, 1934:285.

${ }^{17}$ See H. Łomiański, Poczqtki Polski, I, 266-67, and note also three Germanic hydronyms in this region (Trubačev, 1968, map 17). Here the Bastarnians can be taken into consideration too.

${ }^{18} \mathrm{Cf}$. Slovak červený smrek 'larch,' literally 'red spruce.'

${ }^{19}$ Why not *tegu-?, should we reconstruct *tēgu-?

${ }^{20}$ The primary IE $\bar{e}$ is represented in Late Proto-Slavic by $\check{e}$, which was $[æ]$, i.e., just the opposite - low.

${ }^{21}$ Only after having established this location of the Bousivou did I have an opportunity to read the excellent book by B. A. Rybakov, Gerodotova Skifija (1979), which seems to have solved the problem of the 
exact geographic location of the tribes of ancient Scythia once and for all.

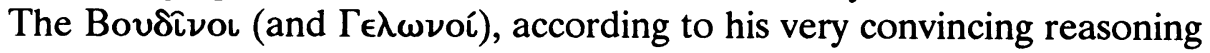
dwelt: the former in the Middle Desna and Sejm basins, which belong to the forest zone, the latter south of them in the parkland (lesostep') with the city Gelonos identified by archaeologists as Bel'skoe Gorodišče on the Vorskla River $530 \mathrm{~km}$. north of the estuary of the Don (see Rybakov, loc. cit., 159-60, and the map on p. 161). So the intuition of the great Lubor Niederle, who located the Bousivo approximately in the same region (see the map between pages 272 and 273 in the first volume of his Slovanské starožitnosti), was correct.

${ }^{22}$ See Moszyński, loc. cit. 186-89, and the etymology of Sejm (Sěmb) presented above in footnote 5 .

${ }^{23}$ Among the IE peoples in Europe there was a Celtic tribe Nervii "populus Galliae Belgicae inter Scaldim et Mosam," whose name is etymologically identical with these East European (Slavic) *Nervi.

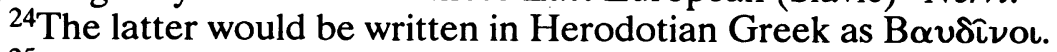

${ }^{25}$ Cf. page 286.

${ }^{26}$ In this connection cf. a typical answer of the Byelorrusian (White Ruthenian) peasants from the prewar Polish Polesie to the question: "Who are you?" - "tutejsi," i.e. 'local people.'

${ }^{27}$ This highly plausible Slavic etymology of the ethnicon Bov8ivou *Bydin- $i$ does not, however, eliminate some other possibilities which should be mentioned. Namely, it is not excluded that we are dealing here with a Finnic name; cf. Votyak bydy- 'wachsen, gross werden,' budem 'Wuchs,' budon 'Gewächs, Geschöpf' and toponyms Body, Bod'a, Bodinopil'ga, A. Joki, 60. The toponyms derived from the root (?) byd-, e.g., Bydanixa, Bydanovskaja, Bydany, etc. are known especially in the Vjatka and one in the Vologda regions of Russia, i.e., in regions still inhabited by Finnic peoples. The toponym Bydina (two villages) is also known in the Orenburg region. (See M. Vasmer, H. Bräuer (ed.): Russisches Geographisches Namenbuch, Wiesbaden, vol. 1, 1964).

${ }^{28} \ddot{\alpha} \pi \alpha \xi \lambda \epsilon \gamma o ́ \mu \epsilon \nu o \nu$ without any convincing etymology, but judging from the context, it most probably referred to the region between the Lower Odra and the Lower Vistula, mistaken by the Roman maritime expeditions for a large island like Scandinavia.

${ }^{29}$ Łowmiański correctly eliminates the comma between Sarmatis and Venedis, and interprets the name as a juxtaposition used to distinguish these Veneti from the Italic (Adriatic) ones.

${ }^{30}$ About a possible Celtic etymology of Kalisz (or rather Helisii, in my opinion) see K. Moszyński, Pierwotny zasiag... 267-68; see also S. Rospond, "Pierwotna nazwa Kalisza," Slavia Occidentalis, v. 20 (1960, pp. 133-38), where Kalisz is interpreted as PSl. *Kališča 'swamps' (cf. 
Ptolemy's K $\left.\alpha \lambda_{\iota} \sigma i \alpha\right)$. This latter etymology seems to be well-substantiated by the primary topography of Kalisz.

${ }^{31}$ Schütte, G., Ptolemy's maps of Northern Europe, Copenhagen, 1917, p. 11.

"Marinus was not gifted with great divination in interpreting the physical outlines of the original maps from which he constructed his own atlas. He often mistakes sea-coasts for rivers, and rivers for mountains, or mountains for tribes and so on. North is changed into west, and west into south, etc. His philological capacity was still weaker. He was completely unable to read and interpret barbarian names from little-known regions. When two of his prototypes had the same name spelt a little differently, he did not recognize the identity. Thus the same name may occur twice, thrice, and even four times on the maps."

We may add that he also had a weak knowledge of Latin, which is reflected in his inconsistent and mistaken transliteration of Latin names into Greek. See a whole chapter in Schütte, p. 16, §6, Misreadings of Latin forms, p. 18, §7, Misreadings of Barbarian names. Schütte, p. 20: "To a great extent, the present Ptolemaic orthography of exotic barbarian names must be regarded simply as a field of ruins. If, therefore, we examine each name separately, it would in many cases lead to nothing. Our chief key of identification must be a survey of the entire milieu.

G. Schütte, Études sur la nomemclature géographique de Ptolémée, p. 18: "Ptolémée, continuateur de Marinos, était un érudit prodigieux et un grand astronome, mais, comme philologue, il n'était pas meilleur que son prédécesseur. Il a accepté les méprises de Marinos et les a transmises aux géographes modernes. L'Atlas antiquus du cartographe allemand déjà cité, Karl von Spruner, accentue souvent les erreurs de Ptolémée au lieu de les corriger, et cela aussi bien dans les rééditions de 1855 et 1867 que dans l'édition originale de 1837. Par example, Ptolémée place les Lakkobardoi dans la région du Bardengau, sur l'Elbe, ce qui est le véritable domicile des Langobardoi. Inversement, il transplante les Langobardoi sur les bords du Rhin. En 1837, von Spruner, qui se pique de méthode scientifique, reporte les Langobardoi à leur domicile véritable, dans la région de l'Elbe, mais il maintien le doublet imaginaire Lakkobardoi dans la région du Rhin.

M. Georg Gerland, professeur à l'Université de Strasbourg, a inséré dans son Atlas der Völkerkunde, paru en 1892, une carte de l'Europe ancienne (p. 175), qui ne vaut pas mieux que celle de von Spruner. Comme Marinos, il confond la côte de la Mer Baltique avec le cours de la Vistule; aussi écarte-t-il de la région balte les Ambrones, les Varini, les Burgondes, les Goths et les Finnois pour les transporter à l'intérieur de la Pologne ou de la Russie." 
${ }^{32}$ As far as the location of the above tribes is concerned, see the map in H. Lowmiański's Poczqtki Polski, I. 176, with a very convincing interpretation of the respective passage from Ptolemy.

${ }^{33}$ Actually, in the aforementioned place in Ptolemy's Geographia (VI,

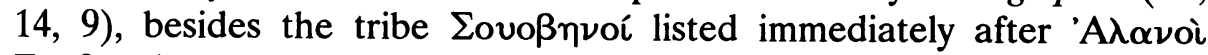
$\Sigma \kappa u ́ \theta \alpha \iota$ (between the Volga and the Ural Mountains) we have another ethnicon which should be quoted here, namely $\Sigma$ únßou, (Latinized Svēbi), separated from $\Sigma o v o \beta \eta \nu o i ́$ by three other, undoubtedly Iranian tribes in Ptolemy's list. These $\Sigma u ́ n \beta o \iota$ seem to have quite an exact Latin parallel in the ethnicon Suavi mentioned by Jordanis (Getica, 250), when he speaks about the war of the Gothic ruler Hunigund "contra Suavorum gente" somewhere in the Dniepr area (see Niederle II, 1, 473). The geographical relation between these Suavi and $\Sigma$ únßor seems to be

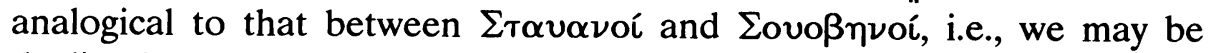
dealing here with the same ethnicon assigned to two related but separate tribes. In any case, it would be unreasonable not to attempt to relate $\Sigma o v o \beta \eta v o i$ and $\Sigma u ̛ \eta \beta o / S u a v i$. If so, then in the latter two forms we would have PSl. *sveb-/*svob- as a simpler form underlying PSl. *svoběn-,

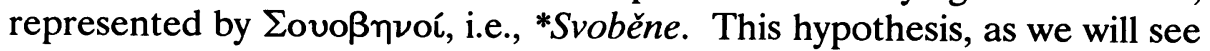
later, opens up quite an interesting and convincing etymological perspective.

${ }^{34}$ See Z. Gołąb: "Nazwa etniczna Serbowie (sch. Srbi, głuż. Serbja/Serbjo) na tle etnonimii słowiańskiej," Akademija Nauka i Umjetnosti Bosne i Hercegovine, Posebna Izdanja, Knjiga XXXIV, Sarajevo, 1977, pp. 109-19, and "About the connection between kinship terms and some ethnica in Slavic (the case of *Sirrbi and Slověne)," International Journal of Slavic Linguistics and Poetics, vol. 25/26 (1982).

${ }^{35}$ Recently (Vopr. Jaz. 1979, 4, p. 41) Trubačev has proposed another, brilliant and quite convincing explanation of the unusual form $\Sigma \tau \alpha v \alpha \nu$ oi (*Stavan-?). Namely, having proven that in the so-called Herodotian Old

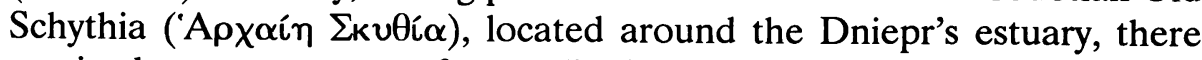
survived some remnants of an earlier Indo-Aryan wave of population (as opposed to a later Iranian wave) - he proposed to interpret the form in question as representing Indo-Aryan *Stávāna- 'the praised' (cf. OI stâuti, stávate 'lobt, preist,' stávāna- 'gepriesen,' Av. staoiti 'lobt, preist, besingt,' stavana- part. praes. med., etc.; cf. Pokorny, 1035, and Bartholomae, 1593-1595). But in his interpretation this Indo-Aryan (or as a matter of fact also Iranian) form would be a translation (loan-translation) of PSl. *Sloverne misunderstood as 'the praised, the famous' because of the association with the Slavic verb slovg, sluti 'nominari, clarum esse,' etc. Of course, such an explanation presupposes a kind of Slavic-Indo-Aryan or Slavic-Iranian bilingualism in the contact area somewhere in the Lower 
Dniepr basin, lasting from Herodotian times to the beginning of the Christian era, which is supported by other facts presented and discussed in Trubačev's article. It also suggests that the transformation of the primary PSI. *Svoběne//*Sloběne into Slověne - through folk-etymology - must have taken place relatively early in the center of the Proto-Slavic habitat if we have the form $\Sigma \tau \alpha v \alpha \nu$ oi based upon the secondary Sloverne (phonetically *Slovæenæ at that time) already in Ptolemy. Here it is worth

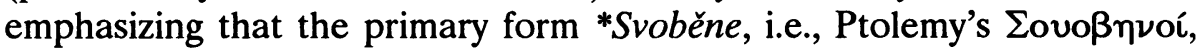
survived beyond the eastern outskirts of the Proto-Slavic habitat, among the foreign non-Slavic tribes.

${ }^{36}$ The name stems from K. Peutinger, an alderman of Augsburg $(+1543)$ who was the owner of the manuscript.

${ }^{37}$ Notice that the ethnicon Sloverne (and its derivatives), which stems from *Svoberne, survived as the endogenous name denoting these historical Slavic peoples (tribes or nationalities), which from an early historical period happened to dwell in direct contact with non-Slavic peoples, e.g., Slověne of Novgorod, Slovenians, Slovaks, etc.

${ }^{38}$ See Stownik Geograficzny Królestwa Polskiego...v. III, pp. 686-86.

${ }^{39}$ In documents: Sclenza (1155), Zlenza (1208), about the river, Slenz (1242), Zlenz (1247), about the mountain see S. Rospond, loc. cit.

${ }^{40}$ See K. Moszyński, $O$ sposobach badania kultury materialnej Prastowian, 1962:257-76.

\section{Chapter VI}

${ }^{1}$ Not accidentally a younger loanword, probably Germanic.

${ }^{2}$ The etymology explaining ${ }^{*} g$ zpanъ as derived from ${ }^{*} g z p a=\check{z} u p a$ 'pit,

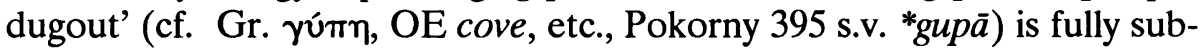
stantiated in my article in Collectanea Linguistica, Prace Komisji Językoznawstwa 53(1986). In the same article županz 'a dignitary, governor of a district' is similarly interpreted as a parallel derivative from župa ( ${ }^{*}$ geupā).

${ }^{3} a$ would require an Iran. long $\bar{a}$; a short Iran. $a$ in this position should be rendered by Slav. $e$.

${ }^{4}$ In the Sogdian glossary (Benveniste, Essai de grammaire sogdienne, II, 1929:209) only the meaning 'fleurir' is quoted!

${ }^{5} \mathrm{His}$ association with war and weaponry seems to be a secondary development, characteristic of the culture and beliefs of the notoriously belligerent Polabian (Baltic) Slavs.

${ }^{6}$ But Pokorny (630) establishes a separate IE * $k$ 'uen- 'feiern, heilig' for Slav. svęţ on the basis of Avesta, Balto-Slavic and Germanic; see also Benveniste, Le vocabulaire...II (1969), 181-84.

${ }^{7}$ E.g., OCS şlękg, szlęšti 'zusammenbiegen, -krümmen, beugen.' 
${ }^{8}$ Here we should also mention a very interesting but controversial article by D. A. Mačinskij and M. A. Tixanova: O mestax obitanija i napravlenijax dviženij slavjan I-VII vv. n. e. (po pis'mennym i arxeologičeskim istočnikam), Acta Archaeologica Carpathica, XVI (1976), Cracow, pp. 58-94. The authors primarily use the well-known and, of course, insufficient method of archaeology that consists of drawing ethnic conclusions from the typical remnants of material cultures. So it is no wonder that the hypothetical results of their essay cannot satisfy those who apply first of all a linguistic method in their search for the clarification of the origins of the Slavs.

${ }^{9}$ One part of them, however, remained in the lower Danube area and was allowed later (270 A.D.) to settle south of this river.

${ }^{10}$ See E. Schwarz, 1956:51.

${ }^{11} \mathrm{~F}$. Kopečný, in Adolfu Kellnerovi, 1954, pp. 158-73.

${ }^{12}$ According to Vasmer (Sitzungberichte der Preuss. Akad. der Wissenschaften, Philosoph.-Hist. Klasse, 1933, IV, 197-206), probable traces of the ethnicon Burgundians (PGermc. *Burgundoz 'highlanders'?) have been preserved in the Polish family name Bargęda or Germanized Bargenda, etc. quite popular in Pomerania and Lower Silesia. This etymology, although criticized by M. Rudnicki (1961, II, 26), is well justified phonemically and morphologically, i.e., PGermc. ${ }^{*}$ Burgunda- $\geq$ PSl. *Bargod- $\geq$ Pol. Bargq/ęd-. There is also a toponym Bargędzino derived from the above name in east Pomerania (Kashubian region).

${ }^{13}$ There is also a basic phonemic difficulty in substituting PSI. *Pblty for the PGermc. *Fuldō!

${ }^{14}$ For a condensed presentation of the Gothic problem in connection with the Slavs, see Stownik starożytności stowiańskich II, 1964, 121-28, and about the Gepids ibid., pp. 94-95.

${ }^{15}$ Perhaps even earlier if the Eastern Goths in the Pontic region were Arians?

${ }^{16} \mathrm{Cf}$. also a recent semantic parallel for $*$ dhuHmo- $\sim * d h o u H m \bar{a}-$, i.e., $\theta \bar{u} \mu o ́ s, d u m a$, namely: Polish puszyć (się) pycha 'give oneself airs' 'haughtiness' (puszyć, Slav. pušiti etymologically means 'blow, breathe,' cf. Vasmer, III, 414).

${ }^{17}$ Although there is the Mac. hydronym Glazna Reka (Martynov, loc. cit. 64).

${ }^{18}$ But see page 321 of this chapter, where the Iranian origin of kotb is accepted.

${ }^{19}$ Where it has a transparent etymology as a derivative from the verb niutan (Gothic) 'brauchen, geniessen.'

${ }^{20}$ The second form, accorcing to Benveniste's theory, would represent

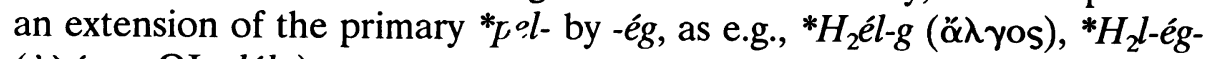
( $\dot{\alpha} \lambda \hat{\gamma} \gamma \omega$, OIc. lákr), etc. 
${ }^{21}$ An alleged variant of the hypothetical *plogo- underlying the Germc. and Slavic names for the plough was attested for the first time by Pliny in a passage describing a kind of colter used in Raetia Galliae "Non pridem inventum in Raetia Galliae duas addere tali rotulas, quod genus vocant plaumorati” (quoted after K. Moszyński, Język Polski, XXXVI, (1956), 1). This strange plaumorati is interpreted as corrupted from *plaumo $(\mathrm{m})$ Raeti by V. Pisani in his Indogermanisch und Europa (Munich, 1974:48-50) and explained as derived from "Palaeo-European" (Krahe's "Alt Europäisch"?) *ploggmo-. Another variant of this noun, attested in 568 A.D. in a Longobard Latin document is plovum, which has survived in the North Italian dialects as pyo, piò, etc., 'plough' (Pisani, loc. cit.). Moszyński, however, (loc. cit.) interprets plaumorati as plaumo-rati, i.e., 'plough-wheels' (meaning 'wheeled plough') which corresonds well to the realia of the tool and Pliny's context. Then he tries to derive plaumofrom PIE ${ }^{*} p(h) l o u-$, an extension of the root ${ }^{*} p(h) e l$ - 'split, cut, etc.' Such an etymology, although semantically plausible, is too much of a Wurzeletymologie to be convincing, but it obviously puts in doubt the connection of plaumo- with the underlying Germc. and Slavic *plogo-.

${ }^{22} \mathrm{Cf}$. Vaillant, Grammaire comparée...IV (1974): pp. 677-78 (adjectives in -tŭ).

${ }^{23}$ But see Martynov, (loc. cit. 161-66), where a hypothesis is ventured about the Slavic origin of this verb (in connection with kopa, kupa) and its penetration into Germanic.

${ }^{24}$ Goth. $\bar{o}$ is regularly rendered in Slavic as $u$, cf., e.g., bōka $\rightarrow b u k-y$, etc.

${ }^{25}$ It must be a very old derivative since it shows a primary short vocalism of the root ${ }^{*}$ sed-, which was otherwise lengthened in Slavic: sěděti, sěsti.

26Jordanes, Getica XLIX (p. 124): Postquam talibus lamentis est defletus (sc. Attila), stravam super tumulum eius quam appellant ipsi ingenti commessatione concelebrant... (cited after Łowniański, 1963, II, 254), trans. "After he (Attila) has been bemoaned with such laments they celebrate with a huge consumption, the strava, as they call it themselves, above his tomb."

${ }^{27}$ On the river Saale!

${ }^{28}$ Some remnants probably survived until the arrival of the Magyars!

${ }^{29}$ Cf. Dvorník, 1956:62 and Łowmiański, 1963, II:416.

${ }^{30} \mathrm{By}$ this I understand various Turkic dialects of the Tartars organized into the Golden Horde and the Crimean Horde after the XIII century.

${ }^{31}$ See also Siatkowska, Ewa: "Na tropach barana" ( $Z$ polskich studiów slawistycznych 1973, 4, 185-97).

32 Kiparsky, 1975:64 quotes a reconstructed Mong. *horongo!

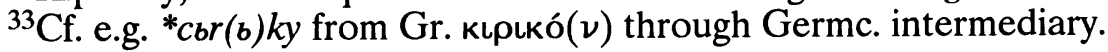


${ }^{34}$ Which reflects a Proto-Turkic *kön̆ig (Menges, loc. cit. 186).

${ }^{35}$ See also the S-C material in P. Skok's dictionary!

${ }^{36}$ For a better substantiation of the native, Slavic etymology of županı and $*_{g z p a n ̋}$ as derived from župa and $*_{g z p a}$, respectively, see my article mentioned in footnote 2 of this chapter.

${ }^{37}$ But see an interesting Slavic etymology of bykz by $\mathrm{Ch}$. Gribble in Linguistics 113 (October 1973), pp. 53-61.

${ }^{38}$ Owing to their onomatopoeic origin?; but cf. the etymology of bykz by Gribble quoted above.

${ }^{39}$ This fact accounts for the high degree of their linguistic uniformity. 


\section{Bibliography}

Abaev, V. J. Istoriko-ètimologičeskij slovar' osetinskogo jazyka. Leningrad, 1958-.

. Skifo-evropejskie izoglossy: Na styke vostoka i zapada. Moscow, 1965.

"K skifo-evropejskim leksičeskim svjazjam.” Ètimologia, 1966, pp. 241-46.

Alekseeva, T. I. and V. P. Alekseev. "Ètnogenez slavjanskix narodov po dannym antropologii." In Meždunarodnyj s"ezd slavistov, Varšava 1973, Doklady sovetskoj delegacii, Moscow, 1973, pp. 211-22.

Allen, W. S. "The PIE Velar Series: Neogrammarian and Other Solutions in the Light of Attested Parallels." Transactions of the Philological Society, 1978, pp. 87-110.

Arntz, H. Sprachliche Beziehungen zwischen Arisch und Baltoslavisch. Heidelberg, 1933.

Arumaa, P. "Baltes et Iraniens." Studi Linguistici in onore di Vittore Pisani 1:73-90. Brescia: Paideia, 1969.

Bańczerowski, J. "Die Suche nach den uralischen Laryngalen." Lingua Posnaniensis XV (1971):81-96.

. "Zum Problem des proto-uralischen Klusilsystems." Lingua Posnaniensis XV (1971):97-112.

Baran, V. D. Ranni slov'jany miž Dnistrom i Pryp'jattju. Kiev, 1972. Bartholomae, Ch. Handbuch der iranischen Dialekte. Leipzig, 1883.

. Altiranisches Wörterbuch. 2nd ed. Berlin: Walter de Gruyter and Co., 1961.

- "Vorgeschichte der iranischen Sprachen: Avestasprache und Altpersisch." Grundriss der iranischen Philologie 1. Strassburg, 1895-1901.

Bednarczuk, L. "Preliminary Observations on the Relations between Finno-Ugric and Balto-Slavonic Languages." Folia Orientalia XI (1969):49-54.

Benveniste, E. Origines de la formation des noms en indo-européen. Paris, 1935.

. Essai de grammaire sogdienne, 2 pte.: Morphologie, syntaxe et glossaire. Paris, 1929.

The continuation of Gautiot's work.

. "La construction passive du parfait transitif." In Problèmes de 
linguistique générale, pp. 176-86. Paris: Gallimard, 1966.

"Les relations lexicales slavo-iraniennes." In To Honor $R$.

Jakobson, pp. 197-202. The Hague: Mouton, 1967.

. Études sur la langue ossète. Paris, 1959.

- Le vocabulaire des institutions indoeuropéennes. 1. économie,

parenté, société. 2. pouvoir, droit, religion. Paris, 1969.

Berneker, E. Slavisches etymologisches Wörterbuch. 2nd ed. Heidelberg:

C. Winter's Universitätsbuchhandlung, 1924.

Bernštejn, S. B. Razyskanija v oblasti bolgarskoj istoričeskoj dialektologii, I:

Jazyk valašskix gramot XIV-XV vekov. Moscow-Leningrad, 1948.

"Balto-slavjanskaja jazykovaja soobščnost'" Slavjanskaja

filologija I (1958):45-67.

Birnbaum, H. "Four Approaches to Balto-Slavic." In Donum Balticum, edited by Velta Rūķe-Draviña, pp. 69-76. Uppsala, 1970.

. "Zur Problematik der zeitlichen Abgrenzung des Urslavischen."

Zeitschrift f. slav. Philologie XXXV, 1, (1970).

- Common Slavic: Progress and Problems in its Reconstruction.

Columbus: Slavica Publishers, 1975.

. "The Original Homeland of the Slavs and the Problem of Early

Slavic Linguistic Contacts." The Journal of Indo-European Studies 1, no. 4, Winter 1973, pp. 407-21.

Brandenstein, W. "Die erste 'indogermanische' Wanderung." Klotho 2 (1936).

. "Die Lebensformen der 'Indogermanen'." Die Indogermanenund Germanenfrage. Neue Wege ihrer Lösung, edited by W. Koppers, Wiener Beiträge zur Kulturgeschichte und Linguistik IV (1936):231-77.

Brückner, A. Słownik etymologiczny języka polskiego. Cracow: Krakowska Spółka Wydawnicza, 1927.

Brugmann, K. Kurze vergleichende Gammatik der indogermanischen Sprachen. Strassburg, 1904.

Bosch-Gimpera, P. "The Migration Route of the Indo-Aryans." The Journal of Indo-European Studies 1, no. 4, Winter 1973, pp. 513-17.

Buck, C. D. A Dictionary of Selected Synonyms in the Principal Indo-European Languages: A Contribution to the History of Ideas. Chicago: University of Chicago Press, 1949.

Cardona, G., H. M. Hoenigswald, A. Senn, editors. Indo-European and Indo-Europeans. University of Pennsylvania Press, 1970.

Chantraine, P. Dictionaire étymologique de la langue grecque. Histoire des mots, vol. 1-4. Paris, 1968-1980.

. La formation des noms en grec ancien. Paris, 1933.

Childe, V. G. The Dawn of European Civilization. 6th ed. New York, 1964. 
"The Diffusion of Wheeled Vehicles." Ethnographisch-Archäologische Forschungen II. Berlin, 1954.

Collinder, B. Sprachverwandschaft und Wahrscheinlichkeit. Uppsala, 1964.

Czarnecki, J. The Goths in Ancient Poland. Coral Gables: University of Miami Press, 1975.

Czekanowski, J. "Syntetyczne szkice V. Kiparsky'ego: Finowie Nadbałtyccy i Bałtowie.” Lud 41 (1952): p. 185, especially pp. 198-201.

. Wstęp do historii Słowian. 2nd ed. Poznań, 1957.

Cemodanov, N. S. Mesto germanskix jazykov sredi drugix indoevropejskix jazykov. In Sravnitel'naja grammatika germanskix jazykov, vol. 1. Edited by Guxman, M. M., V. M. Žirmunskij, E. A. Makaev and V. N. Jarceva. pp. 19-111. Moscow, 1962.

Dal', V. Tolkovyj slovar' živogo velikorusskogo jazyka, vol. 1-4. 3rd ed. Edited by J. Baudouin de Courtenay. Petersburg-Moscow, 1903-1909. Décsy, G. Einführung in die finnisch-ugrische Sprachwissenschaft. Wiesbaden, 1965.

Devoto, G. Origini indoeuropee. Florence: Sansoni, 1962.

Dressler, W. "Methodische Vorfragen bei der Bestimmung der 'Urheimat'." Die Sprache: Zeitschrift für Sprachwissenschaft 11, fascicles 1-2, (1965):25-60.

Ebert, M., editor. Reallexicon der Vorgeschichte. Berlin: W. de Gruyter and Co., 1924-1932.

Ernout, A. and A. Meillet. Dictionnaire étymologique de la langue latine. Histoire des mots. Paris: C. Klincksieck, 1939.

Falk, H. and A. Torp. Norwegisch-dänisches etymologisches Wörterbuch, vol. 1-2. Heidelberg, 1910-1911.

Feist, S. Kultur, Ausbreitung, und Herkunft der Indogermanen. Berlin, 1913.

. Indogermanen und Germanen. Halle, 1924.

Fraenkel, E. Die baltischen Sprachen: Ihre Beziehung zu einander und zu den indogermanischen Schwesteridiomen als Einführung in die baltische Sprachwissenschaft. Heidelberg, 1950.

Litauisches etymologisches Wörterbuch, vol. 1-2. Heidelberg-Göttingen, 1955-1965.

"Syntax der litauischen Kasus." Tauta ir Žodis 4-5, 1926-1928.

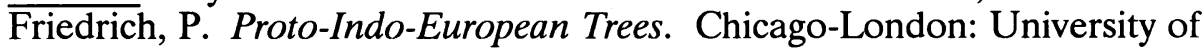
Chicago Press, 1970.

"Semantic structure and social structure: an instance from Russian." In Explorations in Cultural Anthropology: Essays in Honor of G. P. Murdock, pp. 131-66, edited by W. H. Goodenough. McGraw-Hill, 1964. 
. "Proto-Indo-European Kinship." Ethnology 4, no. 1, January 1966 , pp. 1-36.

Gamkrelidze, T. V. and V. V. Ivanov. "Drevnjaja Azija i indoevropejskaja problema. Vremennye i areal'nye xarakteristiki obščeindoevropejskogo jazyka po lingvističeskim i kul'turno-istoričeskim dannym." Vestnik Drevnej Istorii 3 (1980):3-27. The hypothesis about Near Eastern (Transcaucasian) habitat of Proto-Indo-Europeans is proposed on the basis of IE-Semitic and IE"Kartvelian" lexical exchange and typological similarities for 5th-4th mill. B.C.

Gasparini, E. Il matriarcato slavo. Antropologia culturale dei Protoslavi. Florence: Sansoni, 1973.

Gates, H. P. "The Kinship Terminology of Homeric Greek." Supplement to the International Journal of American Linguistics 37 (1971).

Gauthiot, R. Essai de grammaire sogdienne, 1 pte.: Phonetique. Paris, 1914-1923.

Georgiev, V. I. Issledovanija po sravnitel'no-istoričeskomu jazykoznaniju. Moscow, 1958.

See especially chapter 7, "Baltoslavjanskij, germanskij, i indoiranskij."

Gimbutas, M. The Slavs. New York-Washington, 1971.

"Proto-Indoeuropean Culture." In Indo-European and Indo-Europeans, edited by Cordona, G., H. Hoenigswald, and A. Senn., pp. 155 etc. Philadelphia: University of Pennsylvania Press, 1970.

Gołąb, Z. "Etnogenezata na Slovenite vo svetlinata na lingvistikata I." Makedonski Jazik 19 (1968):5-20.

"Etnogenezata na Slovenite vo svetlinata na lingvistikata II." Makedonski Jazik 20 (1969):105-25.

“'Kentum' elements in Slavic." Lingua Posnaniensis 16 (1972):53-82.

"The initial $\chi$ - in Common Slavic: A Contribution to Prehistorical Slavic-Iranian Contacts." In American Contributions to the VII International Congress of Slavists, Warsaw, August 21-27, 1973, vol. 1, pp. 129-56.

"The Oldest Ethnica Referring to the Slavs: Nevpoi and

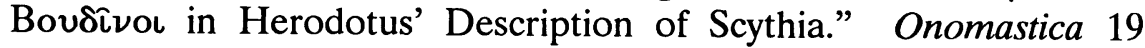
(1974):125-63.

. "Veneti/Venedi - The oldest name of the Slavs." The Journal of Indo-European Studies, vol. 3, no. 4 (Winter 1975), pp. 321-36.

"On the Mechanism of Slavic-Rumanian Linguistic Interference in the Balkans." In Bulgaria. Past and Present, edited by T. Butler, pp. 297-309. Columbus, OH: AAASS, 1976. 
"Stratyfikacja słownictwa prasłowiańskiego a zagadnienie etnogenezy Słowian." Rocznik Slawistyczny 38, 1, (1976), pp. 15-30.

. "SCS. srbdobol'a 'krewny' - ślad indoeuropejskiej terminologii społecznej w słowiańskim?" Rocznik Naukowo-Dydaktyczny WSP w Krakowie, z. 58, Prace Językoznawcze 3 (1976):21-26.

- "Nazwa etniczna Serbowie (sch. Srbi, głuż. Serbja/Serbjo) na tle etnonimii słowiańskiej." Akademija Nauka i Umjetnosti Bosne $i$ Hercegovine, Posebna Izdanja 34, Odeljenje Društvenih Nauka, 6, (1977):109-21.

"About the Connection between Kinship Terms and Some Ethnica in Slavic: The Case of *Šrrbi and Slověne. International Journal of Slavic Linguistics and Poetics 35/36 (1982):165-71.

"Slavic komonb and konb 'equus': An Attempt at Etymology against the Background of the History of Domestication." The Journal of Indo-European Studies, Vol. 13, No. 3 and 4, Fall/Winter 1985, pp. 415-443.

Hajdu, P. Finno-Ugrian Languages and Peoples. London, 1975.

Hall, R. A. Pidgin and Creole Languages. Ithaca, New York: Cornell University Press, 1966.

Hamp, E. "North European '1000'." In Papers of the Ninth Regional Meeting. Chicago Linguistic Society, pp. 172-78. Chicago, 1973.

"OCS věstb." Cohen, G., ed. Comments in Etymology, vol. VIII, 15(1979), pp. 2-3.

Hančar, F. Das Pferd in prähistorischer and früh historischer Zeit. Vienna, 1955.

Harmatta, J. Studies in the History and Language of the Sarmatians. Szeged, 1970.

Haudricourt, A. G. "Contribution à la géographie et l'ethnologie de la voiture." La Revue de Géographie Humaine et d'Ethnologie 1 (1948):54-64.

Hensel, W. "Etnogeneza Słowian." Slavia Orientalis 23, 1 (1974):85-89.

"Etnogeneza Słowian. Niektóre problemy." Slavia Antiqua 20 (1973):1-12.

Hoenigswald, H. M. "The comparative method." Current Trends in Linguistics, edited by T. A. Sebeok, vol. 11, pp. 51-62. The Hague: Mouton, 1973.

and R. E. Longacre, editors. "Diachronic, areal and typological linguistics." Current Trends in Linguistics, vol. 11. The Hague: Mouton, 1973.

Illič-Svityč, V. M. Opyt sravnenija nostratičeskix jazykov (semito-xamitskij, kartvel'skij, indoevropejskij, dravidskij, altajskij). Vvednije-Sravnitel'nyj slovar' (b-K). Moscow, 1971.

Ivanov, V. V. "Social'naja organizacija indoevropejskix plemën po 
lingvističeskim dannym." Vestnik istorii i mirovoj kul'tury 1 (1951).

"K ètimologii russkogo 'pasti'." In Sbornik statej po jazykoznaniju pamjati M. V. Sergievskogo, pp. 111-19. Moscow, 1969.

"Dual'naja organizacija pervobytnyx narodov i proisxoždenie dualističeskix kosmogonij." Review of Rodovoj stroj $i$ pervobytnaja mifologija, by A. M. Zolotarev. In Sovetskaja Arxeologija 4 (1968):276-87.

- "Jazyk kak odin iz istočnikov ètnogenetičeskix issledovanij i problematika slavjanskix drevnostej." Sovetskoe slavjanovedenie 4 (1973):69.

and V. N. Toporov. "K rekonstrukcii praslavjanskogo teksta." Slavjanskoe jazykoznanie (1963).

Slavjanskie jazykovye modelirujuščie semiotičeskie sistemy: Drevnij period. Moscow, 1965.

Issledovanija $v$ oblasti slavjanskix drevnostej: Liksičeskie $i$ frazeologičeskie voprosy rekonstrukcii tekstov. Moscow, 1974.

"Karpaty v svjazi s problemami rasselenija drevnix indo-evropejskix plemën." In Simpozium po problemam karpatskogo jazykoznanija. Tezisy dokladov i soobščenij, pp. 22-25. Moscow, 1973. Jacobsohn, H. Arier und Ugrofinnen. Göttingen, 1922.

Jankuhn, H. "Sprachzeugnisse zur frühesten Geschichte der Landwirtschaft." In Vor- und Frühgeschichte von Neolithikum bis zur Völkerwanderungszeit. Stuttgart, 1969.

Joki, A. Uralier und Indogermanen: Die älteren Berührungen zwischen den uralischen une indogermanischen Sprachen. Helsinki, 1973. Reviewed by T. Burrow in Kratylos 21 (1976-77):53-67.

Jurkowski, M. Ukraińska terminologia hydrograficzna. Wrocław, 1971.

Karstein, H. "Das slav. Imperfekt und der armen. -ace- Aorist (Ein Beitrag zum slavisch-armenischen Verwandschaftsverhältnis)." In Festschrift für Max Vasmer zum 70. Geburtstag, pp. 211-19. 1956.

Kiparsky, V. Russische historische Grammatik. Band III: Entwicklung des Wortschatzes. Heidelberg, 1975.

Die gemeinslavischen Lehnwörter aus dem Germanischen. Helsinki, 1934.

"O xronologii slavjano-finskix leksičeskix otnošenij." Scando-Slavica 4 (1958):127 etc.

. "Gibt es ein finnougrisches Substrat im Slavischen?" Annales Academiae Scientiarum Fennicae, Ser. B, vol. 153, h, (1969):27 etc.

Klimas, A. "Baltic, Slavic, Germanic." In Donum Balticum, edited by Velta Rūķe-Draviņa, pp. 501-6. Uppsala, 1970.

Kluge, F. Etymologisches Wörterbuch der deutschen Sprache. 18th ed. Berlin: Walter de Gruyter and Co., 1960.

Kóčka, W. "Zagadnienie etnogenezy ludów Europy.” In Materiały i Prace 
Antropologiczne. Wrocław: PAN, 1958.

Kopečny, F. "O záhadě iména Beskydy.” In Adolfu Kellnerovi, p. 158-73.

Opava: Slezský Studijní Ústav, 1954.

- Etymologický slovník slovanských jazyků. Slova gramatická a

zájmena. I: Předložky. Koncové particule. Prague: Academia, 1973.

Koppers, W., ed. "Die Indogermanen- und Germanenfrage. Neue Wege

zu ihrer Lösung." Wiener Beiträge zur Kulturgeschichte und Linguistik 4 (1936).

Koppers, W. "Pferdeopfer und Pferdekult der Indogermanen." Die Indogermanen und Germanenfrage. Neue Wege zu ihrer Lösung, edited by W. Koppers, Wiener Beiträge zur Kulturgeschichte und Linguistik 4 (1936):278-411.

Kotwicz, W. A Review of Badania nad pochodzeniem i pierwotna kulturq Stowian by K. Moszyński. Rocznik Orientalistyczny 3 (1927):291-326.

Kowalenko, W., G. Labuda, T. Lehr-Spławiński, editors. Słownik starożytności stowiańskich. Encyklopedyczny zarys kultury Stowian od czasów najdawniejszych. Wrocław: PAN, 1961-.

Krahe, H. Unsere ältesten Flussnamen. Wiesbaden, 1964.

. "Die Struktur der alteuropäischen Hydronymie." Akademie der Wissenschaften und der Literatur in Mainz. Abhandlungen der Geistesund Sozialwissenschaftlichen Klasse 5 (1962):287-341.

. Einleitung in das vergleichende Sprachstudium. Innsbruck, 1970.

Krogmann, W. "Das Buchenargument." Zeitschrift für vergleichende Sprachforschung auf dem Gebiete der indogermanischen Sprachen 72 (1955):1-29, and vol. 73 (1957):1-25.

"Die Lachsargument." Zeitschrift für vergleichende Sprachforschung auf dem Gebiete der indogermanischen Sprachen 76 (1960):83 etc.

Kulišić, S. "Slovenski matrijarhat. (A review of Gasparini's Il matriarcato slavo)." Delo 20, no. 3, March 1974:394-405.

Tragovi arhaične rodovske organizacije $i$ pitanje balkansko-slovenske simbioze. Belgrade, 1963.

Kuryłowicz, J. "Związki językowe słowiańsko-germańskie.” Przeglqd Zachodni 7. Poznań, Institut Zachodni, 1951.

. L'accentuation des langues indo-européennes. Wrocław-Cracow: PAN, 1958.

L'apophonie en indo-européen. Wrocław: PAN, 1956. Especially chapters five, eight and the Appendix.

"O jedności językowej bałto-słowiańskiej." Biuletyn Polskiego Towarzystwa Językoznawczego 16 (1957), pp. 70-114.

. Esquisses linguistiques. Wrocław-Cracow: PAN, 1960.

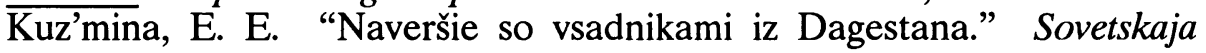
arxeologija, no. 2, 1973, p. 187 etc. 
Labuda, G. "Słowianie, Goci i Hunowie." In Fragmenty dziejów Słowiańszczyzny Zachodniej, vol. 2, pp. 22-106. Poznań, 1964.

"Okres wspólnoty słowiańskiej w świetle źródeł i tradycji historycznej." Slavia Antiqua 1 (1948):186 etc.

Lehr-Spławiński, T. O pochodzeniu i praojczyźnie Stowian. Poznań, 1946.

Zarys gramatyki języka staro-cerkiewno-stowiańskiego na tle

porównawczym. 4th ed. Wrocław-Cracow, 1959.

Linde, S. B. Słownik języka polskiego. 2nd ed. Warsaw, 1854-1861.

Littleton, C. S. The New Comparative Mythology: An anthropological assessment of the theories of Georges Dumézil. University of California Press, 1966.

Locker, E. "Développement et décomposition du type des langues indo-européennes." In Kultur und Sprache, edited by W. Koppers, pp. 415-25. Vienna: Institut für Völkerkunde der Universität Wien, 1952. Löpelmann, M. Etymologisches Wörterbuch der baskischen Sprache, vol. 1-2. Berlin: Walter de Gruyter and Co., 1968.

Lyonnet, S. Le parfait en arménien classique. Paris, 1933.

Łowmiański, H. Poczq̨tki Polski: $Z$ dziejów Stowian w I tysiqcleciu n. e., vol. 1-2. Warszawa, PAN, 1963.

Machek, V. "Zur Vertretung der idg. Palatale." Indogermanische Forschungen 53 (1935):89-96. 1957.

Etymologický slovník jazyka českého a slovenského. Prague,

Mačinskij, D. A. and M. A. Tixanova. "O mestax obitanija i napravlenijax dviženij slavjan 1-3 vv. n. è. (po pis'mennym i arxeologičeskim istočnikam)." Acta Archaeologica Carpathica 16 (1976):59-94.

Makaev, E. A. Problemy indoevropejskoj areal'noj lingvistiki. Moscow, 1964.

"Armjano-indoevropejskie leksičeskie izoglossy i areal'naja lingvistika." Zeitschrift für Phonetik, Sprachwissenschaft und Kommunikationsforschung 20, 5-6 (1967).

Mallory, J. "A Short History of the Indo-European Problem." The Journal of Indo-European Studies 1, no. 1 (Spring 1973), pp. 21-65.

Mańczak, W. "Gocki, litewski i staro-cerkiewno-słowiański a praojczyzna Słowian." In $Z$ polskich studiów slawistycznych, Seria 5, Literaturoznawstwo, folklorystyka, problematyka historyczna, pp. 385-90. Warsaw, 1978.

Martynov, V. V. Slavjano-germanskoe leksičeskoe vzaimodejstvie drevnejšej pory. Minsk, 1963. Minsk, 1978.

Balto-slavjano-italijskie izoglossy: Leksičeskaja sinonimija.

Marvan, J. "On the Morphological Disintegration of Slavic Unity (Morphological Development of Contraction)." In The Slavic Word: 
Proceedings of the International Slavistic Colloquium at UCLA, pp. 311-29. Mouton, 1972.

Masica, Colin P. "Aryan and Non-Aryan Elements in North Indian Agriculture" in Aryan and Non-Aryan in India, edited by Madhav M. Deshpande and P. E. Hook, Ann Arbor, 1979, pp. 55-156.

Mayrhofer, M., W. Meid, B. Schlerath, and R. Schmitt, editors. Antiquitates Indogermanicae. Studien zur indogermanischen Altertumskunde und zur Sprach- und Kulturgeschichte der indogermanischen Völker. Gedenkschrift für Hermann Güntert. Innsbruck, 1974.

Mažjulis, V. "Lingvističeskie zametki po baltijskomu ètnogenezu." In VII Meždunarodnyj Kongress Antropologičeskix i Ėtnografičeskix Nauk, pp. 3-4. Moscow, 1964.

Meillet, A. Le slave commun. 2nd ed. Paris, 1934.

. Esquisse d'une grammaire comparée de l'arménien classique. 2nd ed. Vienna, 1936.

- Introduction à l'étude comparative des langues indo-européennes. 8th ed. Paris, 1937.

"Vocabulary of the Northwest." In The Indo-European Dialects, pp. 33-39 (the translation of Meillet's 2nd edition of 1922). University of Alabama Press, 1967.

Mel'nyčuk, O. S., editor. Vstup do porivnjal'no-istoryčnoho vyvčennja slov"jans'kyx mov. Kiev, 1966.

Menges, K. "Slavo-altaische Wortforschungen." In Festschrift für Dmytro Cyževskyj zum 60. Geburtstag, pp. 179-95. Berlin, 1954.

. "Altaische Lehnwörter im Slavischen." Zeitschrift für Slavische Philologie 23 (1955):327-34.

. "Influences altaïques en slave." Académie Royale de Belgique. Bulletin de la Classe des Lettres et des Sciences Morales et Politiques. 5e Série, Tome 44 (1958):518-41.

"Schwierige slavisch-orientalische Lehnbeziehungen." Ural-Altaische Jahrbücher 31 (1959):177-90.

"Altaische Kulturwörter im Slavischen." Ural-Altaische Jahrbücher 33 (1961):107-16.

- The Turkic Languages and Peoples: An Introduction to Turkic Studies. Wiesbaden, 1968.

Merlingen, W. "Eine ältere Lehnwörterschicht im Griechischen." Österreichische Akademie der Wissenschaften. Schriftern der Balkankommission. Linguistische Abteilung. Part I: Vienna, 1963. Part II: ibidem, 1967.

Meyer, H. "Zur frühen Sonderstellung des Slavischen." Zeitschrift für slavische Philologie 47 (1981):300-14.

Mierow, Ch. The Gothic History of Jordanes - In English Version with an Introduction and Commentary. New York, 1966. 
von Miklosich, F. Lexicon Palaeoslovenico-Graeco-Latinum. Aalen: Scientia Verlag, 1963. Reprint of the first edition, Vienna, 1862-1865. Milewski, T. "Nazwy z obszaru Polski podejrzane o pochodzenie wenetyjskie lub iliryjskie." Slavia Antiqua 11 (1964):37-86.

. "Die Differenzierung der indoeuropäischen Sprachen." Lingua

Posnaniensis 12-13 (1968):37-54.

. Indoeuropejskie imiona osobowe. Wrocław-Warsaw-Cracow, 1969.

Miller, V. F. Jazyk osetin. Moscow, 1962.

Moszyński, K. "Badania nad pochodzeniem i pierwotną kulturą

Słowian.” PAU: Wydziat Filologiczny. Rozprawy 42, no. 2, 1925.

. Pierwotny zasiag języka prasłowiańskiego. Wrocław, 1957.

Człowiek. Wstęp do etnografii powszechnej $i$ etnologii.

Wrocław-Cracow-Warsaw, 1958.

$O$ sposobach badania kultury materialnej Prastowian.

Wrocław-Cracow-Warsaw: PAN, 1962.

- Kultura ludowa Stowian. Vol. 1: Kultura materialna, vol. 2, part

1: Kultura duchowa, vol. 2, part 2: Kultura duchowa. 2nd ed. Warsaw, 1967-1968.

Müller, C. Géographie de Ptolémée. Paris, 1883-1901. Contains maps.

Nalepa, J. Stowiańszczyzna pótnocno-zachodnia. Podstawy jedności $i$ jej rozpad. Poznań, 1968.

Nehring, A. "Studien zur indogermanischen Kultur und Urheimat." Die Indogermanen- und Germanenfrage. Neue Wege ihrer Lösung, edited by W. Koppers, Wiener Beiträge zur Kulturgeschichte und Linguistik 4 (1936):7-229.

Niederle, L. Slovanské starožitnosti. Díl I: Pưvod a počátky národa slovanského. Prague, 1902.

Oranskij, I. M. Vvedenie v iranskuju filologiju. Moscow, 1960. . Iranskie jazyki. Moscow, 1963.

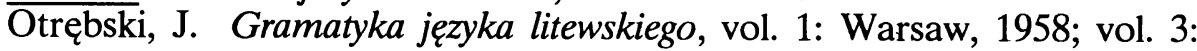
Warsaw, 1956.

Palomé, E. "Germanic and the other Indo-European Languages." In Toward a Grammar of Proto-Germanic, edited by Van Coetsem, F. and H. L. Kufner, pp. 43-69. Tübingen, 1972.

Pellegrini, G. B. and A. L. Prosdocimi. La lingua venetica II: Studi. A cura di A. L. Prosdocimi. Padova, 1967.

Perwolf, J. "Slavische Völkernamen." Archiv für slavische Philologie 7 (1884).

Piggott, S. "The earliest wheeled vehicles and the Caucasian evidence." In Proceedings of the Prehistoric Society, vol. 34., pp. 266-318. London, 1969.

Pisani, V. Indogermanisch und Europa. Munich, 1974.

Plezia, M. Najstarsze świadectwa o Stowianach. Biblioteka Źródet 
Historycznych 8. Poznań, 1947.

Polák, V. "Die Entstehung des Urslavischen im Lichte der neueren Forschung." In Acta II Congressus Internationalis Historiae Slavicae Salisburgo-Ratisbonensis anno 1967, pp. 26-33. Wiesbaden, 1970.

Pokorny, J. Indogermanisches etymologisches Wörterbuch. Vol. 1: Bern-Munich, 1959; vol. 2: Bern-Munich, 1969.

Poppe, N. Introduction to Altaic Linguistics. Wiesbaden: Otto Harrassowitz, 1965.

"Studies of Turkic Loan Words in Russian." Asiatische Forschungen 34 (1971).

Porzig, W. Die Gliederung des indogermanischen Sprachgebiets. Heidelberg, 1954.

Ptolemy: Claudii Ptolemaei Geographia. Edidit Carolus Fridericus Augustus Nobbe, vol. 1-3 (with indices). Leipzig, 1843-1845.

Pulgram, E. "Linguistic Expansion and Diversification." In Studies presented to Joshua Whatmough on His Sixtieth Birthday, edited by E. Pulgram, pp. 239-52. Mouton, 1957.

Reichelt, H. Avestisches Elementarbuch. Heidelberg, 1909.

Rospond, S. "Miscellanea onomastica slavogermanica." In Onomastica Slavogermanica, vol. 2, edited by S. Rospond, pp. 63-81. Wrocław, 1966.

"Słowiańskie imiona w źródłach antycznych." Lingua Posnaniensis 12-13 (1968):99-117.

Rostafiński, J. O pierwotnych siedzibach $i$ gospodarstwie Stowian $w$ przedhistorycznych czasach. Cracow, 1908.

Rozwadowski, J. "O pierwotnym stosunku wzajemnym języków bałtyckich i słowiańskich.” Rocznik Slawistyczny 5 (1912):1-36.

"Stosunki leksykalne między językami słowiańskimi a irańskimi." Rocznik Orientalistyczny 1 (1914-1915):95-110. . Studia nad nazwami wód stowiańskich. Cracow, 1948.

"Beskidy." Język Polski 2 (1914):162-64; also in Wybór Pism, Vol. 1, pp. 318-19, Warsaw, 1959.

1961.

Rudnicki, M. Prasłowiańszczyzna-Lechia-Polska. Vol. 1; Poznań, 1959; vol. 2: ibid., 1961.

(1937).

"Dyskusja na temat nazwy Sląska." Slavia Occidentalis 16

"Wartość nazw drzewa bukowego, łososia i rdzenia lendh- dla wyznaczenia prakolebki (praojczyzny) indoeuropejskiej i słowiańskiej.” Biuletyn Polskiego Towarzystwa Językoznawczego 15 (1956):127-37.

. “Cień urojonego narodu." Slavia Occidentalis 27 (1968). 
. “Jeszcze o Odrze.” Lingua Posnaniensis 14 (1969):99-107.

"Resztki językowe wróżdy i pokory." Slavia Occidentalis 31 (1974):97-105.

Rudnyc'kyj, J. B. An Etymological Dictionary of the Ukrainian Language, 2. Winnipeg, 1963.

Russu, I. I. Illiri. Istoria - Limba și Onomastica - Romanizarea. Bucharest, 1969.

Rybakov, B. A. Gerodotova Skifija. Moscow, 1979.

Rygier, J. "W sprawie wpływów germańskich na toponomastykę w dorzeczu Sanu, górnego Bugu i górnego Dniestru." Rocznik Slawistyczny 31, no. 1, (1970):13-25.

Sadnik, L. and R. Aitzetmüller. Handwörterbuch $z u$ den altkirchenslavischen Texten. 'S-Gravenhage: Mouton and Co., and Heidelberg: C. Winter Universitätsverlag, 1955.

Safarewicz, J. "Przedhistoryczne związki językowe italsko-słowiańskie" in his Studia językoznawcze, 1967, pp. 267-73.

"Archaizm słowotwórczy w języku litewskim." Prace językoznawcze, vol. 3, pp. 55-65. Cracow: Wyższa Szkoła Pedagogiczna w Krakowie, 1976.

Scardigli, P. Elementi non indoeuropei nel germanico. Florence, 1960.

. Filologia Germanica. Florence: Sansoni, 1964.

and T. Gervasi. Avviamento all'etimologia inglese e tedesca. Dizionario comparativo dell'elemento germanico comune ad entrambe le lingue. Florence, 1978.

Scherer, A. "Die Urheimat der Indogermanen." Wege der Forschung 166 (1968).

Schlerath, B. "Los Indoeuropeos: sociología y religión." Estudios Orientales 5 (1970).

. "Die Indogermanen. Das Problem der Expansion eines Volkes im Lichte seiner sozialen Struktur." Innsbrucker Beiträge zur Sprachwissenschaft, Vorträge 8 (1973).

Schmidt, W. Rassen und Völker in der Vorgeschichte und Geschichte des Abendlandes, vol. 1-2. 3rd ed. Lucerne, 1946-1949.

Schmid, W. P. "Alteuropa und der Osten im Spiegel der Sprachgeschichte." Innsbrucker Beiträge zur Kulturwissenschaft, Sonderheft 22. Innsbruck, 1966.

"Alteuropäisch und Indogermanisch." Akademie der Wissenschaften und der Literatur in Mainz, Abhandlungen der Geistesund Sozialwissenschaftlichen Klasse 6 (1968):244-58.

. "Baltische Gewässernamen und das vorgeschichtliche Europa." Indogermanische Forschungen 77, no. 1, (1972):1-18.

"Indogermanische Modelle und osteuropäische Frühgeschichte." Akademie der Wissenschaften und der Literatur in 
Mainz. Abhandlungen der Geistes- und Sozialwissenschaftichen Klasse, 1978, no. 1, pp. 3-24.

Schmitt-Brandt, R. "Die Herausbildung der slavischen Sprachgemeinschaft." In Donum Indogermanicum. Festgabe für Anton Scherer, edited by R. Schmitt-Brandt. Heidelberg, 1971.

Scholz, F. Slavische Etymologie. Eine Anleitung zur Benutzung etymologischer Wörterbücher. Wiesbaden, 1966.

Schrader, O. Reallexikon der indogermanischen Altertumskunde. Grundzüge einer Kultur- und Völkergeschichte Alteuropas. Strassburg, 1901.

Schramm, G. Namenschatz und Dichtersprache. Studien zu den zweigliedrigen Personennamen der Germanen. Göttingen, 1957.

"Alteuropas nordpontische Namenlandschaft." Indogermanische Forschungen 84 (1979):62-78.

Schütte, G. Ptolemy's Maps of Northern Europe: A reconstruction of the prototypes. Copenhagen, 1917.

"Études sur la nomenclature géographique de Ptolémée." Revue Internationale d'Onomastíque 8 (1956):17-28.

Schwarz, E. Germanische Stammeskunde. Heidelberg, 1956.

Semkowicz, W. "Historyczno-geograficzne podstawy Sląska." In Historja Ślq̨sk, edited by S. Kutrzeba, pp. 1-71. Cracow, 1933.

Senn, A. "Slavic and Baltic Linguistic Relations." In Donum Balticum, edited by Velta Rūḳe-Dravinia, pp. 485-94. Uppsala, 1970.

Sędzik, W. Prasłowiańska terminologia rolnicza. Rośliny uprawne. Użytki rolne. PAN, Prace Slawistyczne 3. Wrocław, 1977.

Shevelov, G. A Prehistory of Slavic. The Historical Phonology of Common Slavic. New York: Columbia University Press, 1965.

Shields, Jr., K. "A New Look at the Centum/Satem Isogloss." Zeitschrift für vergleichende Sprachforschung, vol. 95, fascicle 2 (1981).

Skok, P. Etimologijski rječnik hrvatskoga ili srpskoga jezika, vol. 1-4. Zagreb: Jugoslavenska Akademija Znanosti i Umjetnosti, 1971-1974.

Sławski, F. Słownik etymologiczny języka polskiego. Cracow: Towarzystwo Miłośników Języka Polskiego, 1952-.

. "Lexikalische Neuerungen im Baltisch-Slavischen." In Donum

Balticum, edited by Velta Rūķe-Dravinna, pp. 501-6. Uppsala, 1970.

, editor. Słownik prastowiański. PAN: Wrocław-Warsaw-

Cracow-Gdańsk, 1974-.

Specht, F. Der Ursprung der indogermanischen Deklination. Göttingen, 1947.

Solta, G. R. Die Stellung des Armenischen im Kreise der indogermanischen Sprachen. Vienna, 1960.

Stang, Ch. Lexikalische Sonderübereinstimmungen zwischen dem Slavischen, Baltischen und Germanischen. Oslo-Bergen-Troms $\emptyset$ : 
Universitetforlaget, 1972.

Vergleichende Grammatik der baltischen Sprachen. OsloBergen-Troms $\emptyset, 1966$.

Stankiewicz, E. "The etymology of Common Slavic skotò 'cattle' and Related Terms." In Studies in Slavic Linguistics and Poetics in Honor of Boris O. Unbegaun, pp. 219-26. New York-London, 1968.

Szemerényi, O. "The Problem of Balto-Slav Unity: A Critical Survey." Kratylos 2 (1957):97-123.

1970 .

Einführung in die vergleichende Sprachwissenschaft. Darmstadt,

"Studies in the Kinship Terminology of the Indo-European Languages." Acta Iranica 17, Textes et Mémoires 7, Varia 1977. Teheran-Liège.

Šaur, V. "K voprosu o rekonstrukcii praslavjanskix nazvanij mesjacev." Ètimologija, 1971, pp. 93-101.

Tacitus. Cornelii Taciti De origine et situ Germanorum, edited by J. G. C. Anderson. Oxford, 1938.

Thieme, P. "Die Heimat der indogermanischen Gemeinsprache." Akademie der Wissenschaften und der Literatur in Mainz. Abhandlungen der Geistes- und Sozialwissenschaftlichen Klasse 11 (1953):539-613.

. "The comparative method for reconstruction." In Language in Culture and Society: A Reader in Linguistics and Anthropology, edited by D. H. Hymes, pp. 585-97. New York, 1964.

Thomas, W. Die tocharischen Verbaladjektive auf -l.: Eine syntaktische Untersuchung. Berlin: Akademie Verlag, 1952.

Toporov, V. N. "K voprosu ob èvolucii slav. i balt. glagola." Voprosy Slavjanskogo Jazykoznanija 5 (1961):35-70.

“O proisxoždenii neskol'kix russkix slov (K svjazjam s indo-iranskimi istočnikami)." Ėtimilogia 8 (1970):21-45. 3-15.

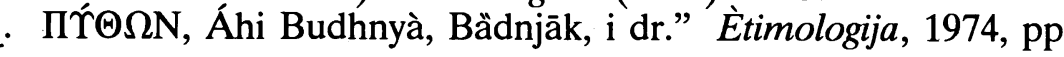

and O. N. Trubačev. Lingvističeskij analiz gidronimov Verxnego Podneprov'ja. Moscow, 1962.

Tovar, A. "The Basque Language and the Indo-European Spread to the West." In Indo-European and Indo-Europeans, edited by G. Cardona, H. M. Hoenigswald, and A. Senn, pp. 267-78. University of Pennsylvania Press, 1970.

"L'indoeuropeo e la teoria del sostrato. Uno squardo panoramico" (in German). In Le lingue dell' Europa. Atti de V Convegno internazionale di linguisti tenuto a Milano 1969, pp. 109-23. Brescia, 1972.

. “Die späte Bildung des Germanischen.” Rix, 1975, pp. 346-57. 
"Krahes alteuropäische Hydronymie und die westindogermanischen Sprachen." In Sitzungsberichte der Heidelberger Akademie der Wissenschaften, Philosophisch-historische Klasse, Jahrgang 1977, Abhandlung 2.

Trager, G. L. and H. L. Smith. "A chronology of Indo-Hittite." Studies in Linguistics 8 (1950), no. 3, pp. 61-70.

Trautmann, R. Baltisch-slavisches Wörterbuch. 2nd ed. Göttingen: Vandenhoeck and Ruprecht, 1970.

Trost, K. Perfekt und Konditional im Altkirchenslavischen. Wiesbaden, 1972.

Trubačev, O. N. Istorija slavjanskix terminov rodstva i nekotoryx drevnejšix terminov obščestvennogo stroja. Moscow, 1959.

- Proisxoždenie nazvanij domašnix životnyx $v$ slavjanskix jazykax. (Étimologičeskie issledovanija). Moscow, 1960. pp. 3-81.

"Iz slavjano-iranskix leksičeskix otnošenij." Ètimologija, 1965,

. Remeslennaja terminologija v slavjanskix jazykax. Moscow, 1966. . Nazvanija rek pravoberežnoj Ukrainy. Moscow, 1968.

"Rannie slavjanskie ètnonimy - svideteli migracii slavjan." Voprosy Jazykoznanija, 1974, no. 6, pp. 48-67.

. "Lingvističeskaja periferija drevnejšego slavjanstva. Indoarijcy v severnom Pričernomor'e.” Voprosy Jazykoznanija, 1977, no. 6, pp. 13-29.

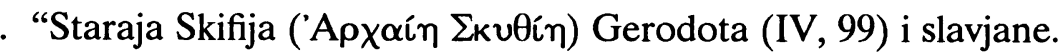
Lingvističeskij aspekt.” Voprosy Jazykoznanija 1979, no. 4, pp. 27-45.

. "Indoarica v severnom Pričernomor'e. Istočniki. Interpretacija. Rekonstrukcija." Voprosy Jazykoznanija, 1981, no. 2, pp. 5-21.

"Jazykoznanie i ètnogenez slavjan. Drevnie slavjane po dannym ètymologii i onomastiki." Voprosy Jazykoznznija 1982, no. 4, pp. 10-26, and no. 5, pp. 3-17.

, editor. Ėtimologičeskij slovar' slavjanskix jazykov. Praslavjanskij leksičeskij fond. Moscow, 1974-.

Udolph, J. "Studien zu slavischen Gewässernamen und Gewässerbezeichnungen. Ein Beitrag zur Frage nach der Urheimat cier Slaven." In Beiträge zur Namenforschung. Neue Folge, Beiheft 17. Heidelberg, 1979.

Uesson, A.-M. On Linguistic Affinity. The Indo-Uralic Problem. Malmö, Sweden, 1970.

Vaillant, A. Grammaire comparée des langues slaves. Vol. 1: Phonétique, Paris 1950. Vol. 2: Morphologie, 1. Flexion nominale, 2. Flexion pronominale, Paris 1958. Vol. 3: Le Verbe, Paris 1966. Vol. 4: La formation des noms, Paris 1974.

Vasmer, M. Untersuchungen über die ältesten Wohnsitze der Slaven I: Die 
Iranier in Südrussland. Leipzig, 1923.

. "Die Urheimat der Slawen." In Der ostdeutsche Volksboden, edited by W. Th. Volz, p. 118 etc. Breslau (Wrocław), 1926.

. "Der Burgundername bei den Westslaven." Sitzungsberichte der

Preussischen Akademie der Wissenschaften, Philosophisch-historische Klasse 4 (1933):197-206.

"Die alten Bevölkerungsverhältnisse Russlands im Lichte der Sprachforschung." Preussische Akademie der Wissenschaften. Vorträge und Schriften 5. Berlin, 1941.

. Ėtimologičeskij slovar' russkogo jazyka. Perevod s nemeckogo $i$ dopolnenija O. N. Trubačeva. Moscow, 1964-1975.

Wackernagel, J. "Genetiv und Adjektiv." In Mélanges de linguistique offerts à M. Ferdinand de Saussure, pp. 125-52. Paris, 1908.

Walde, A. and J. Pokorny. Vergleichendes Wörterbuch der indogermanischen Sprachen, vol. 1-3. Berlin-Leipzig, 1927-1932.

Wierciński, A. "Aktualny stan badań nad etnogenezą Słowian w antropologii." Slavia Antiqua 20 (1973):15-27.

Van Windekens, A. J. Lexique étimologique des dialects tokhariens. Louvain, 1941.

. Morphologie comparée du tokharien. Louvain, 1944.

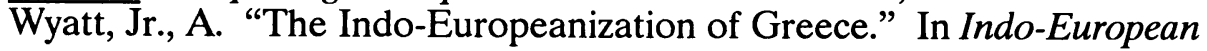
and Indo-Europeans, edited by G. Cardona, H. M. Hoenigswald, and A. Senn, pp. 89-111. University of Pennsylvania Press, 1970.

Xaburgaev, G. A. Ėtnonimija "Povesti vremennyx let." Moscow, 1979.

Zaliznjak, A. A. "Problemy slavjano-iranskix jazykovyx otnošenij drevnejšego perioda." Voprosy Jazykoznanija 6 (1962):28-45.

Żak, J. "Słowianie i Germanie w prahistorii polskiej i niemieckiej." In Stosunki polsko-niemieckie $w$ historiografii, I: Studia $z$ dziejów historiografii polskiej i niemieckiej, edited by J. Krasucki, G. Labuda, and A. Walczak, pp. 21-149. Poznań, 1974.

Žučkevič, A. "K voprosu o baltijskom substrate $\mathrm{v}$ ètnogeneze belorussov." Sovetskaja Ėtnografija 1 (1968):107-13. 